\title{
URÂNIO NOS HIDROTERMALITOS POTÁSSICOS ("ROCHA POTÁSSICA") DA MINA OSAMU UTSUMI, COMPLEXO ALCALINO DE POÇOS DE CALDAS, MG
}

\author{
MARIA MANUELA GALVÃO MONTEIRO CAPOVILLA
}

Orientador: Prof. Dr. Johann Hans Daniel Schorscher

TESE DE DOUTORAMENTO

COMISSÃO JULGADORA

Nome
Presidente: $\quad$ Prof. Dr. Johann Hans Daniel Schorscher
Examinadores: Prof. Dr. Horstpeter Herberto G. J. Ulbrich
Prof. Dr. Jean Michel Legrand
Prof. Dr. Milton Luiz Laquintinie Formoso
Prof. Dr. Othon Henry Leonardos 


\section{ERRATA}

ÍNDICE GERAL, linha 5: ...Laboratoriais...

ÍNDICE GERAL, linha 22: ...Frentes Redox e....

ÍNDICE GERAL, linha 30: ..._Geoquímica...

ÍNDICE DE FIGURAS, $1^{a}$ página, linha $4:$... $\underline{e}$ Gomes...

ÍNDICE DE FIGURAS, $2^{\mathrm{a}}$ página, linha $1:$... $\underline{\text { da mina } . . .}$

ÍNDICE DE FIGURAS, $2^{a}$ página, linha $2:$... da mina...

ÍNDICE DE FIGURAS, $2^{a}$ página, linha $19:$... Os pontos...

ÍNDICE DE FOTOS, $1^{a}$ página, linha $4:$... mineralizações...

ÍNDICE DE TABELAS (Anexo I), $2^{\mathrm{a}}$ página, linha 3 ; ... Poços...

ÍNDICE DE TABELAS (Anexo I), $2^{\mathrm{a}}$ página, linha 7 ; ...Poços...

RESUMO, $1^{a}$ página, linha $5:$... em brechas...

RESUMO, $1^{a}$ página, linha 13: ... ex explosões...

RESUMO, $1^{a}$ página, linha 28 : ... à todas...

Pág. 2, linha 22: ... . maior_e $\mathrm{e}_{2} \ldots$

Pág.2, linha 23: ... preferencialmente íons complexos_de uranila...

Pág. 10, linha 11: ... neste trabalho ${ }_{2} \ldots$

Pág. 11, linha 11: ... a elas...

Pág. 12, linha 8: ...defesa_da Tese...

Pág. 19, linha 6: ... então $o_{2}$ desenvolveram-se as frentes redox e com $\operatorname{estas}_{2} \ldots$

Pág. 19, linha 22: ...principalmente ${ }_{2} \ldots$

Pág. 20, linha 2: ...permeabilidade_que portanto $_{2} \ldots$

Pág. 20, linha 4: ... A todas...

Pág.20, linha 19: ... da mina_indicaram...

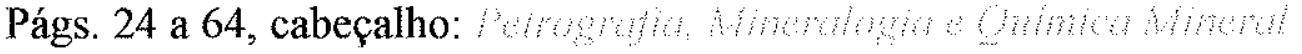

Pág. 25, linha 13: ... a pequenas...

Pág. 26, linha 13: ...illita/sericita...

Pág. 26, linha 28: ...é de brechas...

Pág. 27, linha 23: ... leucitas com preservação magmática $_{2} \ldots$

Pág. 27, linha 28: ... não identificados...

Pág. 31, linha 20: ...Ph e NeS, ...

Pág.33, linha 10: ...illita/sericitas...

Pág.33, linha 13: ...As illita/sericitas...

Pág. 34, linha 21: ... propiciaram $_{2}$ nas rochas afetadas ${ }_{2} \ldots$

Pág. 36, linha 3: ... entretanto ${ }_{2}$ ativas,...

Pág. 37, linha 18: ...uraninita/pithblenda...

Pág. 37, linha 23: ....caolinita_da...

Pág. 38, linha $3: \ldots$ científica ${ }_{2} \ldots$

Pág. 38, linha 8: ...reduzidos ${ }_{2} \ldots$

Pág. 38, linha 29: ... (cf.pág. 20; ...

Pág. 39, linha 3: ... enriquecimentos...

Pág. 39, linha 13: ... foto $\underline{30 b}$....

Pág. 39, linha 25: ... indígenos ${ }_{2} \ldots$

Pág. 40, linha 15: .... $\mathrm{SiO}_{2}(2.09-2.96 \% \ldots$

Pág.55, linha 3 da legenda Foto 30 : ...(amostra $\underline{\mathrm{SN} / 24) \ldots}$

Pág.63, Tabela 1, linha 37, coluna 1: greenockita

Pág. 65, linha 23: ...uraníferos_em... 
Pág. 65 , linha $25: \ldots$, adequadas às finalidades...

Pág. 66, linha 4: ...não-hidrotermalizados...

Pág. 66, linha 12: ...destacar_que...

Pág. 66, linha 13: ... rochas $_{2}$ por técnicas...

Pág. 66, linha 14: ....absolutos ${ }_{2} \ldots$

Pág.66, linha 19: ...interferências inter-elementares...

Pág. 72, legenda Figura 9: Distribuição dos $\mathrm{Ph}$ e NeS como peralcalinos metaluminosos a peraluminosos no diagrama de Maniar e Piccoli (1989) (parâmetros de Shand (1943)).

Pág. 73, linha 25: ... Por fim fim $_{2} \ldots$

Pág.74, Legenda Figura 10, linha 8: ...MedFon2. A simbologia utilizada para amostras individuais e médias está representada na Pág. 71.

Pág. 76, linha 21: ...oxidados) $)_{2} \ldots$

Pág. 78, linha 18: ... feitos ${ }_{2} \ldots$

Pág. 78, linha 19: ...reduzidos ${ }_{2} \ldots$

Pág. 79, linha 15: ...(Pb como anglesita $).$.

Pág. 79, legenda Figura 12: ...elementos traço. Legenda: - -AltaMin-Th, omedRed-mi, +-AltaMin-U.

Pág.80, Tabela 4, legenda, linha 1: ...(Ph e NeS) regionais (MedAlcR)...

Pág. 82, linha13: ...pirita $e_{2}$ subordinadamente $_{2} \ldots$

Pág. 83, linha 15: ... amostragem ${ }_{2} \ldots$

Pág. 84, linha 11: ...normalização com valores do manto primordial.

Pág. 86, linha 2: ... oxidada_demonstra $a_{2} \ldots$

Pág. 86, linha 5: ... à FR $\mathrm{FR}_{2}$ apresentam_menor...

Pág. 87, linha 2: ..2,2 $\mathrm{ppm}_{2}$ ficam próximos à média, sendo Mo...

Pág. 87, linha $3: \ldots 1,3 \mathrm{ppm}_{2} \ldots$

Pág. 87, linha 11: ...reduzidas_das...

Pág. 87, linha 14: ... Similarmente, também é reprecipitada...

Pág. 87, linha 15: ...própria, ilsemanita (azul de molibdênio: um óxi-hidróxido ou óxi-sulfato hidratado de $\mathrm{Mo}$ ), de cor azul escuro forte e típica expressão visual em afloramentos e amostras de mão, estável...

Pág. 87, linha 19: ... pirita ${ }_{2}$ são disponibilizados ainda ${ }_{2} .$.

Pág. 87, linha 20: ...hidrólise...

Pág. 88, linha2: ....específicos.

Pág. 88, linha 3: ...: Apresenta-se, na zona reduzida, em concentrações...

Pág. 88, linha 4: ... e com enriquecimento...

Pág. 88, linha 5: ... oxidada ${ }_{2} \ldots$

Pág. 88 , linha 15 ; ... (paládio $). .$.

Pág. 88, linha 21: ...Fe/ $\underline{\mathrm{OHF}} .$.

Pág. 89, linha 3: ...em status...

Pág. 89, linha 13: ... à média...

Pág. 89, linha 14: ... apresenta ${ }_{2}$ na...

Pág. 89, linha 16: ...(foto 24)...

Pág. 89, linha 21: ....absolutos ${ }_{2} \ldots$

Pág. 89 , linha 22 : ...textural) ${ }_{2}$ preservado...

Pág. 89, linha 24: ... Desta forma ${ }_{2} \ldots$

Pág. 92, linha 19: ...e illita/sericita)...

Pág. 93, linha 4: ...pela illita/sericita... 
Pág. 93, linha 24: ...(cromo)..

Pág. 94, linha 15: ... supergênica) $)_{2} \ldots$

Pág. 94, linha 16: ... isomorfia, e se...

Pág. 95, linha 12: ...ETRL, do La...

Pág. 95, linha 15: ...ERTP, do Dy...

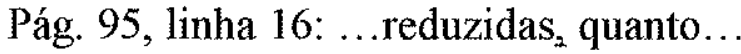

Pág. 95, linha 27: ...oxidadas ${ }_{2} \ldots$

Pág. 96, linha 13: ...irregularidades (...

Pág. 98, linha 6: ... OHF ocorreriam...

Pág.98, linha 18: ... eqüidistantes, a ...

Pág. 102, linha 20: .. 300x) ao Sm...

Pág. 104, linha 29: ... amostra 32 da...

Pág. 105, linha 5: ... hipogênicos ${ }_{2} \ldots$

Pág. 106, linha 2: ...oxidada ${ }_{2}$ essas...

Pág. 106, linha 24: ...próximas à...

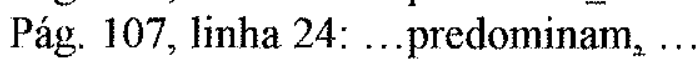

Pág. 107, linha $25 \ldots$ frentes $_{2}$ os controles geoquímicos globais dos hidrotermalitos, ...

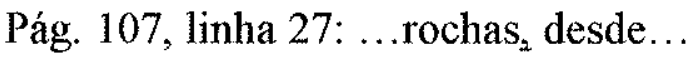

Pág. 107, linha 28: ...magmáticas ${ }_{2}$ ou...

Pág. 112, linha 3: ...Foto 27) $\ldots$

Pág. 112, linha 4: ...heterogênea ${ }_{2} \ldots$

Pág. 112, linha 20: ...oxidada ${ }_{2}$ indicando...

Pág. $112,2^{\circ}$ parágrafo: ... A geoquímica global das duas frentes redox de tipo 3 heterogêneas mostra sua ocorrência em hidrotermalitos de fraca mineralização hipogênica. Mostra ainda a seletividade e variabilidade muito fraca da mineralização supergênica, que é restrita na zona reduzida, ao $U$ associado com $\mathrm{Cd}$. Na zona oxidada, a mineralização supergênica de U também é restrita, e associada ao $\mathrm{Cd}$.

Pág. 112, linha 28: ...Cd,_a outros..

Pág. 113, linha 1: ...reduzidos, que são também oportunisticamente...

Pág. 113, linha 13: ... Notam-se_ainda,...

Pág. 113, linha 28:...U, Th, Zr...

Pág. 114, linha 7: ...ETRP ${ }_{2}$ sem que se note...

Pág. 115, linha 14: Entre estas ${ }_{2} \ldots$

Pág. 115, linhal6: ... cita-se o .....do $\mathrm{Cd}_{2} \ldots \ldots$. . zona oxidada ${ }_{2} \ldots$

Pág. 119, linha 18: ... seculares_associadas...

Pág. 119, linha 20: ...regionais _e,...

Pág. 120, linha 13: ...OHF_caracterizados...

Pág. 120, linha18: ...repetindo__ virtualmente...

Pág. 126, linha 12: ...observada ${ }_{2}$ desta forma, na população...

Pág. 127 , linha 12:...FR, ou_ainda,...

Pág. 127, linha 23: ...FR $\mathrm{FR}_{2}$ ocorreu a ...

Pág. 127, linha 25: ...em ilsemanita)...

Pág. 128, linha 21: ... U, mas...

Pág. 128, linha 22: ...Assim ${ }_{2}$ resultam padrões de $\mathrm{ETR}_{2} \ldots$

Pág. 128, linha 25: ...,1992)_dos processos...

Pág. 128, linha $30: \ldots$ definidos ${ }_{2}$ do... 
Pág. 128, linha 32: ... integrado ${ }_{2}$ todos...

Pág. 130, linha 3: ...que_são constituintes...

Pág. 132, linha 3: ...principalmente como micro...

Pág. 133, linha 8: ... cristalina ${ }_{2}$ com...

Pág. 133, linha 10: ...coprecipitados...

Pág. 133, linha 14: ...1992)_revelaram...

Pág. 135, linha 25: ... disseminada $a_{2} \ldots$

Pág. 136, linha 6: ... baddeleyta ${ }_{2}$ de...

Pág. 136, linha 9: ... geoquímica ${ }_{2} .$.

Pág. 136, linha 13: ...geoquímica); a mineralização...

Pág. 136, linha 19: ...entretanto ${ }_{2} \ldots$

Pág. 136, linha 21: ...hoje_e responsável...

Pág. 136, linha 23: ... ciclo...

Pág. 137, linha 6: ...rica de $\mathrm{U}_{2} \ldots$

Pág. 137, linha 11: ....in situ $_{2}$ por...

Pág. 137, linha 28: ... mineralização...

Pág. 138, linha 12: ... supergênica de $U_{2} \ldots$

Pág. 138, linha14: ... ocorreu...

Pág. 138, linha 21: ...típico ${ }_{2}$ pode ser citado o $\mathrm{Pd}_{2} \ldots$

Pág. 138, linha 24: ...detalhes ${ }_{2} \ldots$

Anexo III, pág.5: retirar análise da amostra $\mathrm{A} 2-\mathrm{P} .85 / \mathrm{C} 5$ matriz

Anexo III, pág.6: retirar análise da amostra A5-P.113/C1 matriz 
UNIVERSIDADE DE SÃO PAULO

INSTITUTO DE GEOCIÊNCIAS

\section{URÂNIO NOS HIDROTERMALITOS POTÁSSICOS ("ROCHA} POTÁSSICA") DA MINA OSAMU UTSUMI, COMPLEXO ALCALINO DE POÇOS DE CALDAS, MG

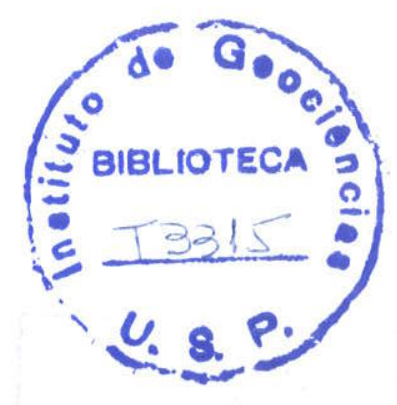

MARIA MANUELA GALVÃO MONTEIRO CAPOVILLA

Orientador: Prof. Dr. JOHANN HANS DANIEL SCHORSCHER

TESE DE DOUTORAMENTO

Programa de Pós-Graduação em Mineralogia e Petrologia

SÃO PAULO

2001

DEDALUS - Acervo - IGC

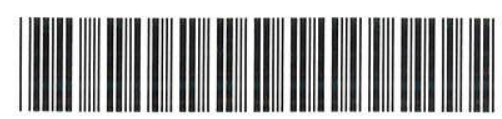

30900006849 


\section{ÍNDICE GERAL}

1. INTRODUÇÃO E OBJETIVOS ........................................

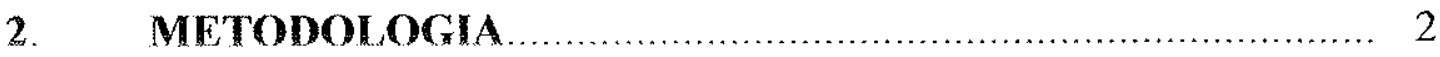

2.1. Trabalhos Preliminares.............................................................. 4

2.2. Trabalhos de Campo ............................................................... 4

2.3. Trabalhos Laboratorias.............................................................. 4

2.3.1. Tratamentos Preliminares..................................................... 5

2.3.2. Microscopia Petrográfica e de Minérios................................... 5

2.3.3. Litogeoquímica.................................................................. 6

2.3.4. Microscopia Eletrônica de Varredura (MEV).......................... 9

2.3.5. Microssonda Eletrônica (MSE) .............................................. 10

2.3.6. Mineralogia das Piritas e Isótopos Estáveis de $\delta^{3 .} S \ldots \ldots \ldots \ldots \ldots \ldots . . .11$

2.4. Trabalhos Finais.................................................................. 12

3. ESTUDOS GEOLÓGICOS ............................................. 13

3.1. Geologia Regional............................................................... 13

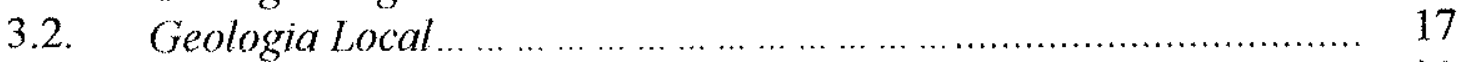

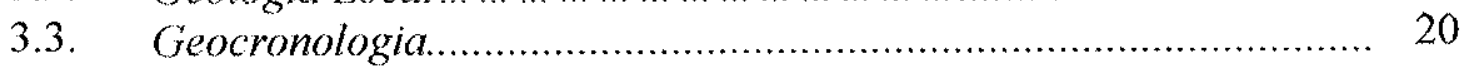

4. PETROgRAFIA E MINERALOGIA E QUíMICA MINERAL 24

4.1. Fonolitos e Nefelina Sienitos Não-Hidrotermalizados..................... 25

4.2. Hidrotermalitos e Frentes Redox da Mina de Urânio Osamu

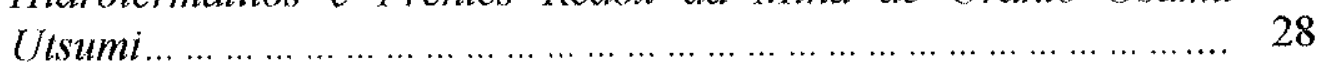

4.2.1. Hidrotermalitos .......................................... 28

4.2.2. Frented Redoxe Mineralização Supergênica de U................... 34

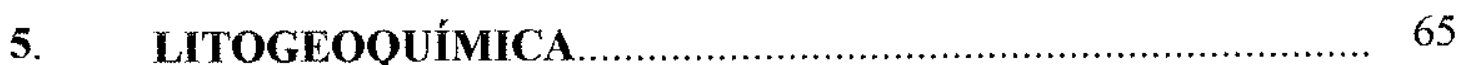

5.1. Rochas Näo-Hidrotermalizadas da Mina Osamu Utsumi e Regionais ........................................................ 65

5.2. Rochas Hidrotermais da Mina de Urânio: Fonolitos (PH), Nefelina Sienitos (NeS) e Brechas (Br) Reduzidos e Oxidados........ 76

5.3. Firentes Redox.................................................................... 81

5.3.1. Resultados Analíticos e Tratamentos dos Dados.......................... 83

5.3.2. ...... Geoquímica das Frentes Redox ................................. 84

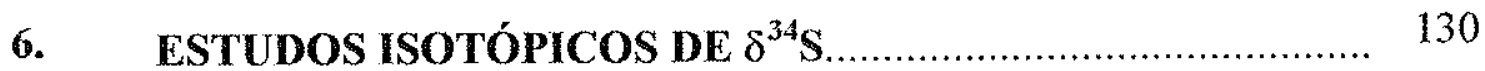

7. CONCLUSÃo E DISCUSSÃo FINAL .......................... 135

8. REFERÊNCIAS BIBLIOGRÁFICAS ................................... 140

ANEXO I (Dados geoquímicos)

ANEXO II (Listagem de amostras)

ANEXO III (Dados de microssonda eletrônica-análises de WDS) 


\section{ÍNDICE DE FIGURAS}

Figura 1: Esboço geológico da parte centro-leste do Brasil (modificado de Almeida, 1977), mostrando a localização do Complexo Alcalino de Poços de Caldas e outras intrusões alcalinas e de carbonatitos (segundo Ulbrich \& Gomes, 1981). Subdivisões tectônicas: (1)-Maciço de Guaxupé; Cinturões Móveis (2)-Ribeira e (3)-Brasilia; (4)-Bacia do Paraná (sedimentar com basaltos); (5)-Cráton do Sâo Francisco. Símbolos e abreviações: PdC-Complexo Alcalino de Poços de Caldas, -complexos alcalinos e -complexos alcalinos com carbonatitos, I-infracambrianos,

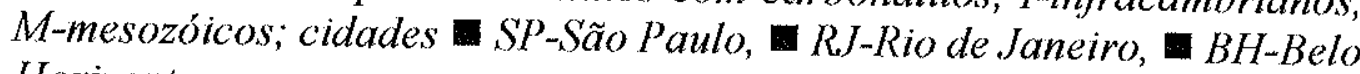
Horizonte

Figura 2: Mapa geológico do Complexo Alcalino de Poços de Caldas (modificado de Ellert, 1959, e Fraenkel et al., 1985). A principal área de alteração hidrotermal inclui a mina de Urânio Osamu Utsumi........................15

Figura 3: Mapa geológico e de amostragem da mina de urânio Osamu Utsumi, na parte $S E$ do Complexo Alcalino de Poços de Caldas, $M G$.

Figura 4: Perfil esquemático e modelo metalogenético da Mina de Urânio Osamu Utsumi, na parte SE do Complexo Alcalino de Poços de Caldas, $M G$

Figura 5: Distribuição dos Ph e NeS no campo dos fonolitos, em diagrama de Le Maitre (1989)

Figura 6: Distribuição dos Ph e NeS no campo dos fonolitos, em diagrama de Coxetal. (1979)

Figura 7: Distribuiçấo dos Ph e NeS no campo dos fonolitos em gráfico de Winchester e Floyd (1977) 72

Figura 8: Distribuição dos Ph e NeS no campo dos fonolitos e traquitos em gráfico de Winchester e Floyd (1977)

Figura 9: Distribuição dos Ph e NeS no campo dos fonolitos no diagrama de Maniar e Piccoli (1989) (parâmetros de Shand (1943))...

Figura 10 a-h: Variogramas expandidos dos Ph menos alterados da borda $N W d a$ mina de U e dos Ph e NeS regionais (Anexo I, Tabela 1.4): (a)-todas as 
amostras e médias; (b)-todas as médias; (c)-Ph menos alterados a mina (análises FRX) e média MMFRX; (d) Ph menos alterados a mina (análises ICP-AES) e média MMICP; (e)-NeS regionais -... NSI (Schumann, 1994) e média MedNS1; (f)-Ph reginais NS1 (Schumann, 1994) e média MedFonl; (g)-NeS regionais - NS2 (Schorscher e Shea, 1992) e média MedNS2; (h)Ph regionais - Ph2 (Schorscher e Shea, 1992) e média MedFon2......... 74

Figura 11 a-b: Variogramas multielementares da composição média dos $P h$ menos alterados da borda $N W$ da mina de $U$ normalizados pela composição média dos $\mathrm{Ph}$ e NeS regionais: (a)-óxidos maiores; (b)elementos traço

Figura 12: Variogramas multielementares da composição média dos hidrotermalitos reduzidos e de mineralizaçồs ricas hipogênicas (reduzidas) de U e Th, respectivamente, normalizados pela composição média dos Ph e NeS regionais: (a)-óxidos maiores; (b)-elementos traço... 79

Figura 13: Variogramas multielementares da composição média dos hidrotermalitos oxidados normalizados pela média dos hidrotermalitos reduzidos: (a)-óxidos maiores; (b)-elementos traço.

Figura 14: Gráficos binários multielementares dos microperfis da amostra PDCPH 028 (frente redox de tipo 1). O pontos amostrados estão dispostos eqüidistantemente na abcissa, segundo a seqüencia de alteração (da zona reduzida para oxidada) : (a)-perfil 1, (b)-perfil 2, (c)-perfil 1-detalhe $e$ (d) - perfil $2 \cdots$ detalhe.

Figura 15: Variograma dos ETR da amostra PDC-PH-028 (perfil l) da frente redox de tipo 1 , normalizados pelo manto primitivo (PRIM), com os respectivos teores de $U$, Th, Zre Fe...

Figura 16: Variograma dos ETR da amostra PDC-PH-028 (perfil 2) da frente redox de tipo 1 , normalizados pelo manto primitivo (PRIM), com os respectivos teores de $U, T$, Zh $\mathrm{Zr}$ Fe.

Figura 17: Gráficos binários multielementares dos microperfis da amostra M2b (frente redox de tipo 2). O pontos amostrados estão dispostos eqüidistantemente na abcissa, segundo a seqüência de alteração (da zona reduzida para oxidada) : (a)-perfil 1, (b)-perfil 2, (c)-perfil 1 --detalhe $e$ (d) - perfil 2 -- detalhe. 
Figura 18: Variograma dos ETR da amostra $M 2 b$ (perfil l) da frente redox de tipo 2, normalizados pelo manto primitivo (PRIM), com os respectivos teores de U, Th, Zre Fe...

Figura 19: Variograma dos ETR da amostra M2b (perfil 2) da frente redox de tipo 2, normalizados pelo manto primitivo (PRIM), com os respectivos teores de U, Th, Zre Fe

Figura 20: Gráficos binários multielementares dos microperfis da amostra $S N / 15$ (frente redox de tipo 3 , heterogênea). O pontos amostrados estão dispostos eqüidistantemente na abcissa, segundo a seqüencia de alteraçäo (da zona reduzida para oxidada): (a) - perfil, (b)- detalhe

Figura 21: Gráficos binários multielementares dos microperfis da amostra U3c (frente redox de tipo 3, heterogênea). O pontos amostrados estão dispostos equiidistantemente na abcissa, segundo a seqüência de alteração (da zona reduzida para oxidada): (a)-perfil, (b)-detalhe. 108

Figura 22: Variograma dos ETR da amostra U3c da frente redox de tipo 3 , normalizados pelo manto primitivo (PRIM), com os respectivos teores de U, Th, Zre Fe

Figura 23: Variograma dos ETR da amostra $S N / 15$, da frente redox de tipo 3, normalizados pelo manto primitivo (PRIM), com os respectivos teores de $U, T h, \mathrm{ZreFe}$

Figura 24: Gráficos binários multielementares dos microperfis da amostra M2c (frente redox de tipo 4). O pontos amostrados estão dispostos eqüidistantemente na abcissa, segundo a seqüencia de alteração (da zona reduzida para oxidada): (a)-perfil, (b)-detalhe

Figura 25: Variograma dos ETR da amostra $M 2 c$ da frente redox de tipo 4, normalizados pelo manto primitivo (PRIM), com os respectivos teores de U, Th, Zre Fe

Figura 26: Gráficos binários multielementares dos microperfis da amostra IARF (frente redox complexa). O pontos amostrados estão dispostos eqüidistantemente na abcissa, segundo a seqüencia de alteração (da zona reduzida para oxidada) : (a)-perfil 1, (b)-perfil 2, (c)-perfil 1 -... detalhe $e$ (d)-perfil 2 - detalhe 
Figura 27: Variograma dos ETR da amostra IARF (perfil I) da frente complexa, normalizados pelo manto primitivo (PRIM), com os respectivos teores de $U, T h, Z$ re Fe.

Figura 28: Variograma dos ETR da amostra IARF (perfil 2) da frente redox complexa, normalizados pelo manto primitivo (PRIM), com os respectivos teores de U, Th, Zre Fé.

Figura 29: Diagramas binários, segundo Bau (1996), das amostras de frentes redox: $\square$ - reduzida, O- oxidada, - oxidada rica em Fe, 点 - zona branca. (a) - Y/Ho versus $Z$ r/Hf, (b) - Y versus Y/Ho..........................129

Figura 30 : Histograma dos resultados das análises isotópicas do $S$ de piritas hidrotermais, supergênicas e sulfatos supergênicos em $\delta^{34} S$ relativo
$C D T$................. 133 


\section{ÍNDICE DE TABELAS (texto)}

Tabela 1: Síntese da mineralogia dos nefelina sienitos (NeS) e fonolitos (Ph) regionais e hidrotermalitos equivalentes reduzidos (HiRed) e oxidados (HiOx) da mina de urânio ( $m$ - constituinte maior $>10 \%$ vol.; e - constituinte essencial $\geq 1 \%$ sl0\%-vol; tr-constituintes em traços: $<1 \%$-vol) $\ldots \ldots \ldots \ldots \ldots \ldots \ldots \ldots \ldots \ldots .63$

Tabela 2: Análises semiquantitativas por MEV-EDS em associações de minerais hidrotermais de urânio de uma amostra de brecha reduzida/piritizada de alta radioatividade da mina Osamu Utsumi (Amostra F4/243-1A, Fotos 8-19) .....64

Tabela 3: Dados litogeoquímicos dos fonolitos menos alterados da borda NW da mina de U (ph-mi) por FRX e ICP-AES e respectivas médias (MMFRX e MMICP), e composições médias de fonolitos e nefelina sienitos regionais (ph-reg e ns-reg) calculadas de dados de FRX de: 1-Schumann (1994), 2-Schorscher e Shea (1992)

Tabela 4: Composições médias integradas dos fonolitos não ou pouco alterados da borda $N W$ da mina de $U$, em comparação às médias das rochas alcalinas regionais e dos hidrotermalitos reduzidos e oxidados predominantes da mina (dados deste trabalho e de Schorscher e Shea, 1992; Schumann, 1994; Waber et al., 1992) ...................................................... 80

Tabela 5: Microperfil geoquímico via ICP-MS da frente redox PDC-PH-(1)28 90

Tabela 6: Microperfil geoquímico via ICP-MS da frente redox $\mathbf{M 2 b}$ 100

Tabela 7: Microperfil geoquímico via ICP-MS da frente redox $\boldsymbol{S}_{\mathrm{N} / 15}$ 109

Tabela 8: Microperfil geoquímico via ICP-MS da frente redox U3c 110

Tabela 9: Microperfil geoquímico via ICP-MS da frente redox M2c.... 116

Tabela 10: Microperfil geoquímico via ICP-MS da frente redox IARF 122

Tabela 11: Resultados das análises isotópicas de $S$ de piritas hidrotermais e supergênicas e sulfatos supergênicos 


\section{ÍNDICE DE FOTOS}

Foto 1: Frentes redox principal e secundárias da mina de urânio Osamu Utsumi. Observamos rochas reduzidas: azuis e oxidadas: marrom alaranjadas e o processo de formação de macronódulos supergênicos a partir de frentes

Foto 2: Detalhe do processo de formação de macronódulos supergenicos ricos em U, por "implosão", isto é, oxidação in situ de volumes de rochas reduzidas mineralizadas e isoladas por frentes redox secundárias em ambiente

Foto 3: Fonolito não-hidrotermalizado da mina de urânio (amostra AlHT, lâmina Al-1) com microfenocristal de clinopiroxênio zonado, em matriz fina de sanidina, nefelina, aegirina e giannetita (polarizadores $X$, lado maior da foto $=7 \mathrm{~mm}$ ). Nota-se o núcleo sódi-augítico arredondado por corrosão magmática e supercrescimentos de aegirina-augita a aegirina na borda externa subidiomórfica rica em inclusões poiquiliticas. ...................41

Foto 4: Fonolito não-hidrotermalizado da mina de urânio (amostra AIHH, lâmina Al-homo-2). Detalhe de microfenocristal de sanidina com zona de borda rica em inclusões poiquilíticas (polarizadores $X$, lado maior da foto $=$

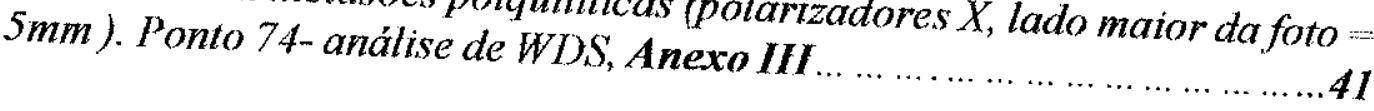

Foto 5: Fonolito fracamente hidrotermalizado da mina de urânio (amostra AIM, lâmina A1-2) com microfratura preenchida de fluorita hidrotermal de cristalização grossa (incolor a azul), também fraturada e carbonatos $\mathrm{em}$ impregnações disseminadas cripto a microcristalinos (polarizadores X, lado
maior da foto $=7 \mathrm{~mm}$ )

Foto 6: Brechas vulcanicas hidrotermalizadas na parte centro-leste (corpo B) da mina Osamu Utsumi (altura da bancada é de $\pm 3 m$ ) ....................42

Foto 7: Mineralização uranifera hidrotermal rica na matriz (cimento) de brecha vulcânica, indicada por medidas cintilométricas (valores em cps) e cortada por fraturamento tectônico posterior (linhas tracejadas com setas de

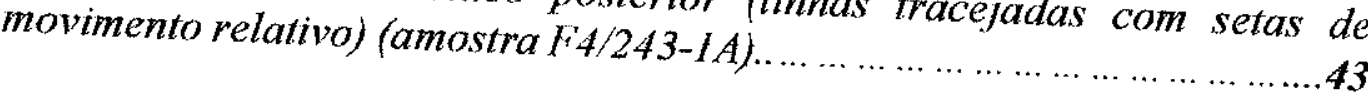

Foto 8: Imagem $n^{\circ}$ MI-001 de MEV de cimento de brecha hidrotermalizada reduzida mineralizada em $U$. Os números representam as fases com anátises semiquantitativas pontuais por EDS, representadas na Tabela 2 (amostra 
F4/243-1A).Os pontos de análise 4 e 5 representam silicatos de $\mathrm{Zr}$ com teores de $U$ de até $5,14 \%$

Foto 9: Imagem $n^{\circ} \mathrm{M2-00I}$ de $\mathrm{MEV}$ de cimento de brecha hidrotermalizada reduzida mineralizada em $U$. Os números representam as fases com análises semiquantitativas pontuais por EDS, representadas na Tabela 2 (amostra ( 4/243-IA). O ponto de análise 9 representa sulfeto de Fe com $\mathrm{Zn}$ e $\mathrm{Zr}$ e teores de U de até 17,17\%

Foto 10: Imagem $n^{\circ}$ M3-001 de MEV de cimento de brecha hidrotermalizada reduzida mineralizada em U. Os números representam as fases com análises semiquantitativas pontuais por EDS, representadas na Tabela 2 (amostra FA/243-1A). O ponto de análise I representa sulfeto de Zn com $\mathrm{Zr}$ e fie e teores de U de até $15,49 \%$

Foto 11: Imagem $n^{\circ}$ M4-002 de MEV de cimento de brecha hidrotermalizada reduzida mineralizada em $U$. Os números representam as fases com análises semiquantitativas pontuais por EDS, representadas na Tabela 2 (amostra $F 4 / 243-1 A)$. Trata-se de silicato de $\mathrm{Zr}$ com Fe e de teores de $U$ de até
$16 \% \ldots \ldots \ldots \ldots \ldots \ldots \ldots \ldots \ldots \ldots$

Foto 12: Imagem $n^{\circ} \mathrm{J}_{-002}$ de $\mathrm{MEV}$ de cimento de brecha hidrotermalizada reduzida mineralizada em $U$. Os números representam as fases com análises semiquantitativas pontuais por EDS, representadas na Tabela 2 (amostra (F4/243-1A). Os pontos de análises 1 e 2 representam sulfetos de Zn com Fie com teores de Ude 21,24 a $38,69 \%$. .45

Foto 13: Imagem $n^{\circ} \mathrm{U}-003$ de $M E V$ de cimento de brecha hidrotermalizada reduzida mineralizada em $U$. Os números representam as fases com análises semiquantitativas pontuais por EDS, representadas na Tabela 2 (amostra F 4/243-IA). O ponto de análise I representa silicato de Ca com inclusóes de sulfeto de Zne fie com teores de $U$ de $26,69 \% \ldots \ldots \ldots \ldots \ldots \ldots \ldots \ldots \ldots \ldots . . \ldots 6$

Foto 14: Imagem $n^{\circ} \mathrm{U}-004$ de $M E V$ de cimento de brecha hidrotermalizada reduzida mineralizada em $U$. Os números representam as fases com análises semiquantitativas pontuais por EDS, representadas na Tabela 2 (amostra F 4/243-IA). O ponto de análise I representa um sulfeto de Zn com Fe com teores de U muito baixo de 0,65\%.

Foto 15: Imagem $n^{\circ}$ U-005 de MEV de cimento de brecha hidrotermalizada reduzida mineralizada em $U$. Os números representam as fases com análises semiquantitativas pontuais por EDS, representadas na Tabela 2 (amostra F4/243-1A). O ponto de análise I representa sulfeto de fe com $\mathrm{Zn}$ com 

teores de $U$ de 21,24 a $38,69 \% .0$ s pontos 2 e 3 representam sulfetos de $Z n$
com $Z$ re Fe com teores de $U$ de $0,44 \% \ldots \ldots \ldots \ldots \ldots \ldots \ldots \ldots \ldots \ldots \ldots \ldots \ldots \ldots$

Foto 16: Imagem $n^{\circ}$ U-006 de MEV de cimento de brecha hidrotermalizada reduzida mineralizada em $U$. Os números representam as fases com análises semiquantitativas pontuais por EDSS, representadas na Tabela 2 (amostra $+4 / 243-(A)$. Os pontos de análises 1,2 e 3 representam sulfetos Mo com fie com teores de $U$ de 0,72 a $12,02 \%$. O ponto 4 representa um sulfeto de Fie com Z $\mathrm{r}$ com teores de $U$ de até 2,76\% ...............................47

Foto 17: Imagem $n^{\circ}$ U-007 de MEV de cimento de brecha hidrotermalizada reduzida mineralizada em $U$. Os números representam as fases com análises semiquantitativas pontuais por EDS, representadas na Tabela 2 (amostra F4/243-1A). Os pontos de análises 1,2 e 3 representam silicatos de $Z \mathrm{r}$ com Mo e Fe com teores de $U$ de 4,54 a 6,9\% .............................48

Foto 18: Imagem $n^{\circ}$ U-009 de MEV de cimento de brecha hidrotermalizada reduzida mineralizada em $U$. Os números representam as fases com análises semiquantitativas pontuais por EDS, representadas na Tabela 2 (amostra F 4/243-1A). Os pontos de análises 1,2 e 3 representam sulfetos Fe com Mo

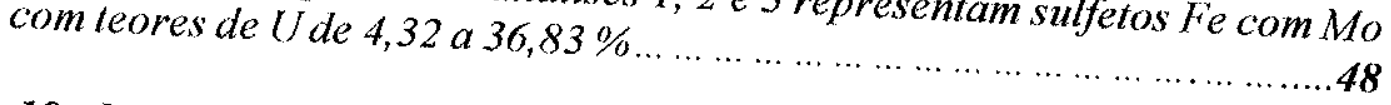

Foto 19: Imagem $n^{\circ} U-010$ de MEV de cimento de brecha hidrotermalizada reduzida mineralizada em $U$. Os números representam as fases com análises semiquantitativas pontuais por EDS, representadas na Tabela 2 (amostra F $4 / 243-1 A)$. Os pontos de análises l e 3 representam sulfetos $\mathrm{Fe}$ com $\mathrm{Mo}, \mathrm{Zr}$

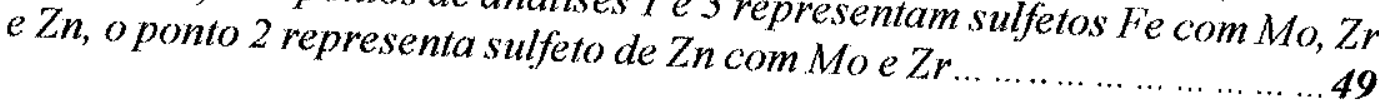

Foto 20: Ph porfiritico hidrotermalizado reduzido da mina Osamu Utsumi, com fenocristais de sanidina, nefelina e pseudoleucita em matriz fina piritizada ............................49

Foto 21: Ph porfirítico hidrotermalizado oxidado, com caolinizaçâo mais forte dos feldspatos e pigmentação da rocha por OHF (amostra Fil/-1.30m). Concentrações maiores de OHF indicam oxidação das piritas em condições

de pseudoleucita de morfologia irregular em Ph porfirítico com fenocristais (prismática cinza escura) separa), sanidina (prismática branca) e nefelina azulados) e Ph hidrotermalizados oxidadormalizados reduzidos (cinza (amostraf 1-47) ................. 

Foto 23: Frente redox com mineralização secundária de U em brecha magmática
Os micronódulos finos e pretos de pitchblenda ocorrem somente na parte (amostra do corpo $B$ de minério de até $20 \mathrm{~mm}$ de largura adjacente à frente

Foto 24: Amostra PDC-PH-028, frente redox de tipo 1 , com forte enriquecimento

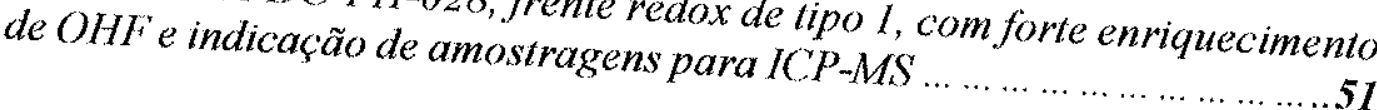

Foto 25: Amostra $M 2 b$, frente redox de tipo 2, com zona branca de contato $e$ indicação de amostragens para ICP-MS.

Foto 26: Amostra $S N / 15$, frente redox de tipo 3, com zonas rítmicas ricas em $O H H^{\prime}$ e indicação de amostragens para ICP-MS ... .........................

Foto 27: Amostra U3c, frente redox de tipo 3, com zonas rítmicas ricas em OHFe indicação de amostragens para $I_{C P}-M S \ldots \ldots$ Foto 28 a: Amostra $M 2 c$, frente redox de tipo 4 , com contato nítido e indicação de
amostragens para $I C P-M S \ldots \ldots \ldots \ldots \ldots \ldots \ldots \ldots \ldots \ldots \ldots \ldots \ldots \ldots \ldots \ldots \ldots \ldots \ldots .53$

Foto 28 b: Frente redox de tipo 4 em fonolito microxenolitico (amostra $S N / 21$ ). 54

Foto 29: Amostra IARF, frente redox complexa e indicação de amostragens para ICP-MS. Ocorrem 2 frentes caracterizadas por zonas enriquecidas em $O H F$, uma recente na interface com a rocha reduzida e outra fóssil na zona oxidada, separadas por avanço de frente de tipo 4, em condições saturadas e

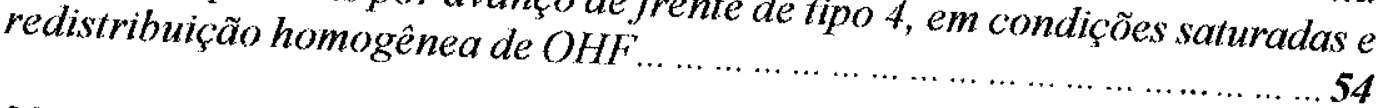

Foto 30: a-Detalhe de uma frente redox com forte enriquecimento supérgeno de $U$ na forma de micronódulos (pretos) e disseminações finas (tingimentos cinza claros a médios) (amostra $\$ N / 21$ ) b -Micronódulos concentricos homogêneos (amostra RFI)(tamanho natural)............ concêntricos e de U (diâmetro de $10 \mathrm{~mm}$ ), emitida (polarizadores /) de micronódulo crescimento periférico interstical $\mathrm{Ph}$ com textura fluidal, mostrando silicáticos (polarizadores nódulo em pirita supergênica em relaça mostrando o enriquecimento do da rocha (amostra $S^{S} N / 21$, lâmina $S N / 21$ ) às piritas hidrotermais na matriz 
Foto 32: a-Macronódulo de uraninita/pitchblenda maciça em amostra de mão com piritas supergênicas em cristais de $0,2-1 \mathrm{~mm}$ idiomórficos, e núcleo silicático de rocha reduzida (amostra VII); b-Microfotografia de seção sobrecrescida às piritas macronódulo com uraninita/pitchblenda botrioidal hidrotermais finas arredondadas por cortomórficas e raros restos de piritas SN/24; pol. //, lado maior da $10 \mathrm{~mm}$ ) corrosãoldissolução parcial (amostra

Foto 33: Imagem de microscopia eletrônica de mineralização supergênica de $U$, mostrando pitchblenda botrioidal e vermiforme, crescendo sobre minerais silicáticos da matriz e piritas da $2^{a}$ geração (amostra $S N / 24$, lamina
sn/24) ........................

Foto 34: Imagem de microscopia eletrônica, mostrando detalhe da foto 33 de superficie de uma pirita de $2^{a}$ geração, com início do crescimento de pitchblenda botrioidal, em arranjos finamente zonados. Esta estrutura sugere atividade biogênica (colônia de bactérias) que causam a precipitação $e$ crescimento de pitchblenda botrioidal famostra $\$ N / 24, \quad$ lamina
sn/24) $\ldots \ldots \ldots \ldots \ldots \ldots \ldots \ldots \ldots \ldots \ldots \ldots \ldots \ldots \ldots \ldots \ldots \ldots \ldots \ldots \ldots \ldots \ldots \ldots \ldots \ldots \ldots \ldots \ldots$

Foto 35: Imagem de microscopia eletrônica mostrando outro detalhe da foto 33 , com pitchblenda botroidal, evidenciando a criptocristalinidade de seus grãos $e$ as estruturas de crescimento zonado (amostra $\$ N / 24$, lamina
sn/24)...

Foto 36: Imagem de microscopia eletrônica que mostra detalhe de mineralização supergênica de U com pitchblenda criptocristalina vermiforme, crescendo sobre superficies (fraturas e bordas de grãos) de minerais silicáticos

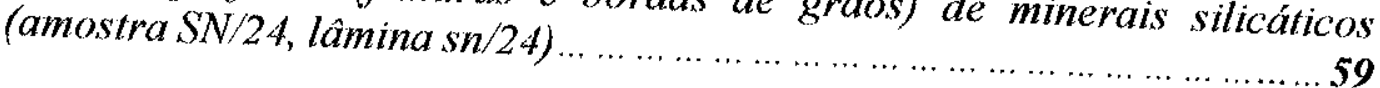

Foto 37: Imagem de microscopia eletrônica de OHF exógenos, a partir da oxidação da pirita sob sistema de saturação, finamente disseminados na matriz do hidrotermalito potássico (amostra M2c, lâmina M2c) ... ........60

Foto 38: Imagem de microscopia eletrônica, mostrando cristal idiomórfico de pirita hidrotermal (amostra $M 2 c$, parte reduzida, lâmina $M 2 c$ )............60

Foto 39: Imagem de microscopia eletrônica de OHF indígeno, pseudomorfizando um cristal idiomórfico de py. A falta de OHF fora da pirita indica um sistema de insaturação durante a oxidação da mesma (amostra F1/1-1.30m, 
Foto 40: Imagem de microscopia eletrônica de feldspato potássico da rocha
reduzida reduzida em estágio inicial de substituição incompleta, por caolinita hidrotermal bem cristalizada (amostra F4/243-1 A, lamina F4/243-1A)..... 61

Fotos 41: Detalhe da foto 40, imagem de microscopia eletronica mostrando caolinita hidrotermal bem cristalizada (amostra F $4 / 243-1$ A, lâmina $F 4 / 243$
IA) $\ldots \ldots \ldots \ldots \ldots \ldots \ldots \ldots \ldots \ldots \ldots \ldots \ldots \ldots \ldots \ldots \ldots \ldots \ldots \ldots \ldots \ldots \ldots \ldots \ldots \ldots \ldots \ldots$

Foto 42: Imagem de microscopia eletrônica de feldspato alcalino com inclusões
de minerais radioativo hidrotermais eno de minerais radioativos hidrotermais envolvidos por auréolas de corrosão (amostra Fi4/243-1A, lamina F4/243-1A) ...........................62 


\section{ÍNDICE DE TABELAS (Anexo I)}

Tabela I-1: Análises por FRX (IGC-USP) de fonolitos da borda NW da Mina de Urânio: (ph-mi) - não a fracamente hidrotermalizados e composição Média, e (ph-mi-alt) - variável e fortemente alterados. L.D. e L.Q. Limites de Detecção e Quantificação, ${ }^{\prime}$-. carbonatização fraca: ${ }_{\dot{2}}$ carbonatização forte e piritização; ${ }^{3}$ - carbonatização, fluoritização e piritização fortes; ${ }^{11}$-seritização forte; ${ }^{12}$-. argilização intempérica. ........1

Tabela I-2: Análises por FRX de Fonolitos da borda NW da Mina de Urânio: (phmi) - não a fracamente hidrotermalizados e composição Média, e (ph-mialt) - variável a fortemente alterados, analisados no Laboratório de FRX do Instituto de Mineralogia Aplicada e Geoquímica da T.U. Munique, Alemanha. L.D. - Limites de Deteç̧ão; ${ }^{\prime}$ - carbonatização fraca; ${ }^{2}$ carbonatização forte e piritização; ${ }^{3} \ldots$ carbonatização, fluoritização e piritização fortes; ${ }^{11}$-seritização forte, ${ }^{12}$ argilizaçâo intempérica $\ldots \ldots \ldots . . .3$

Tabela I-3: Análises por ICP-AES (IGc-USP) de Fonolitos da borda NW da Mina de Urânio: (ph-mi) - não a fracamente hidrotermalizados e composição Média, e (ph-mi-alt) - variável a fortemente alterados, analisados no Laboratório de FRX do Instituto de Mineralogia Aplicada e Geoquímica da T.U. Munique, Alemanha. L.D. - Limites de Deteç̧ão, ' - carbonatização fraca; ${ }^{2}$ - carbonatização forte e piritização; ${ }^{3}$ - carbonatização,

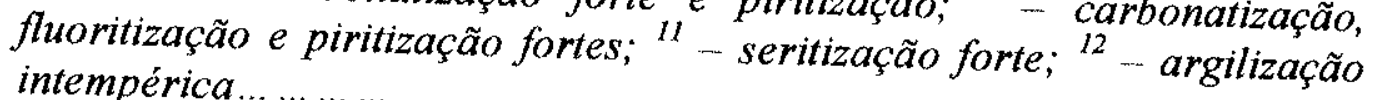

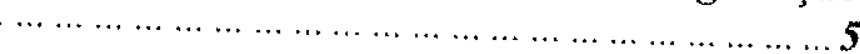

Tabela I-4: Dados litogeoquímicos comparativos de Fonolitos nãohidrotermalizados selecionados da borda NW da Mina de Urânio (ph-mi) por FRX e ICP AES e médias (MMXRF e MMICP), assim como de fonolitos e nefelina sienitos regionais (ph-reg e ns-reg): I- segundo Schumann (1994), 2- segundo Schorscher e Shea (1992) e respectivas

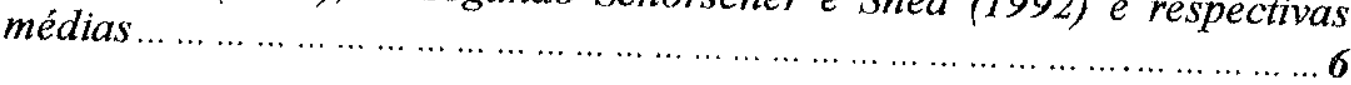

Tabela 1-5: Índice de alcalinidadelagpaicidade de Fonolitos nãohidrotermalizados selecionados da borda NW da Mina de Urânio (ph-mi) por FRX e ICP-AES e médias (MMXRF e MMICP), assim como de fonolitos e nefelina sienitos regionais (ph-reg e ns-reg): 1- segundo Schumann (1994), 2- segundo Schorscher e Shea (1992) e respectivas
médias............... 
Tabela I-6 A: Análises por FRX de rochas reduzidas (hidrotermalitos reduzidos) com pirita da mina de U Osamu Utsumi, Complexo Alcalino de Poços de Caldas (Projeto Internacional Pónços de Caldas; dados extraídos de Waber et al., 1991; 1992)...

Tabela I-6 B: Análises por FRX de rochas oxidadas (hidrotermalitos oxidados) com OHF da mina de U Osamu Utsumi, Complexo Alcalino de Poços de Caldas (Projeto Internacional Poços de Caldas; dados extraídos de Waber et al., 1991; 1992) 17

Tabela 1-7 A: Geoquímica via ICP-MS dos microperfis das frentes redox nas zonas reduzidas.

Tabela I- 7 B: Geoquímica via ICP-MS dos microperfis das frentes redox nas zonas oxidadas.

Tabela I-8: Reanálise via ICP-MS e AES* de amostras maiores das frentes redox dos microperfis 


\section{ÍNDICE DE TABELAS (Anexo II)}

Tabela II-1: Listagem de amostras... .1 


\section{ÍNDICE DE TABELAS (Anexo III)}

Feldspatos Alcalinos.

Clinopiroxênios. 1

(n)

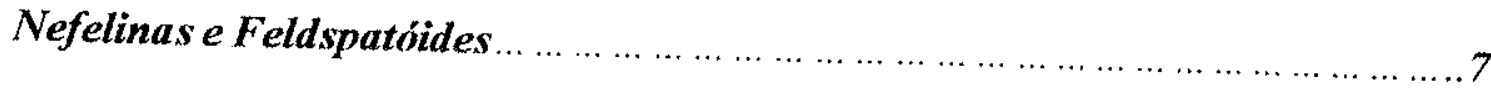

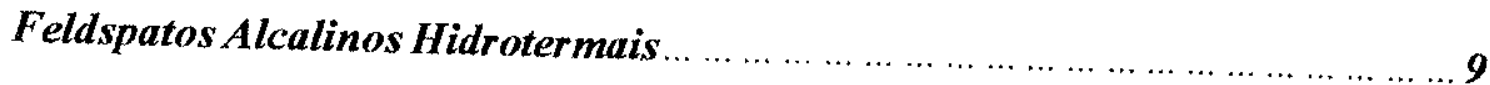

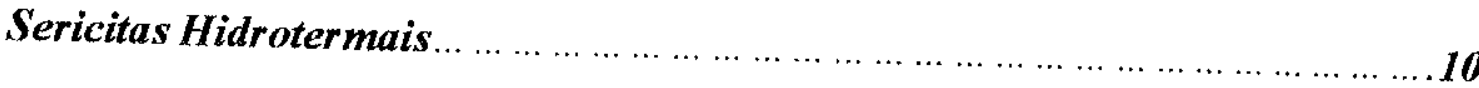




\section{RESUMO}

A mineralização de $U$ da mina Osamu Utsumi, no sudeste do Complexo Alcalino de Poços de Caldas, MG, de idade mesozóica, foi estudada com métodos geológicos de campo e laboratoriais mineralógico-petrográficos e geoquímicos. É uma mineralização poligenética, formada em fonolitos e nefelina sienitos leuco a hololeucocráticos e brechas magmáticas destes, por processos superimpostos hidrotermais específicos e supergênicos. Os processos hidrotermais mineralizantes ocorreram de forma localizada e causaram a potassificação, argilização e piritização das rochas nefelínicas, transformando-as em hidrotermalitos reduzidos, junto com sua mineralização pobre em $U, T h, Z$ r, $\mathrm{ETR}, \mathrm{F}, \mathrm{Mo}, \mathrm{Zn}, \mathrm{Pb}, \mathrm{Ba}$, removendo principalmente $\mathrm{Na}, \mathrm{Ca}, \mathrm{Mg}$ e Sr. A mineralização complexa de tipo impregnação disseminada e stockwork superimposto é bastante variável, indica fluidos heterogêneos e foi relacionada a explosões magmato-freáticas e à formação de brechas de conduto subvulcânicas. A assinatura geoquímica, incluindo os ETR, relaciona estes processos como pós-magmáticos consangǘneos finais ao magmatismo nefelínico. A mineralização de tipo impregnação disseminada é, em geral, pobre (anomalia geoquímica); mineralização mais rica ocorre nas matrizes e como cimentos das brechas e em fraturas da mineralização stockwork. Aí, foram encontradas fases individuais e suas misturas, incluindo sulfetos, óxidos, silicatos e molibdatos, entre outros, com $U$ variando entre 0,65 e $39 \%$-peso; entretanto, um mineral específico de U não pôde ser definido, ocorrendo, provavelmente, uraninita criptocristalina.

Há cerca de 76 Ma cessaram, segundo outros autores, os processos magmáticos na área da mina, iniciando-se o ciclo supergênico, em andamento até hoje, e responsável pela formação do perfil de intemperismo. Os agentes desse ciclo, principalmente águas oxidantes descendentes, sob condições ambientais, promoveram a dissolução oxidante de pirita e demais sulfetos, liberação de ácido sulfúrico e ataques variáveis e específicos a todas as fases minerais dos hidrotermalitos reduzidos/piritizados pré-existentes, transformando-os em hidrotermalitos oxidados com OHF (isentos de pirita e demais sulfetos). Originaram-se assim, frentes redox típicas, separando os hidrotermalitos reduzidos dos oxidados, por interfaces nítidas muito bem definidas. As zonas de frentes redox compreendem faixas de $10-20 \mathrm{~cm}$ de largura dos hidrotermalitos reduzidos e oxidados adjacentes às interfaces e são os principais sítios da mineralização supergênica rica de U. Cinco tipos de frentes redox foram definidos por critérios geológicos, mineralógicos e geoquímicos, todos com atividade de tipo frentes rolantes. Os metais disponibilizados em solução nos processos de frentes redox de ataque ácido (desencadeado pela dissolução da pirita) são redistribuídos nas zonas da frente redox, de acordo com suas afinidades geoquímicas. U e Cd (como greenockita), principalmente, são enriquecidos na mineralização supergênica rica, em micro e macronódulos concrecionários de pitchblenda/uraninita criptocristalina; a grande maioria dos demais metais pesados e parte do $\mathrm{U}$ e $\mathrm{Cd}$, além de outros metais mais raros e de 
origens problemáticas como $\mathrm{Pd}$ e $\mathrm{W}$, são enriquecidos e co-precipitados com OHF na zona oxidada da frente; outros metais pesados mais móveis como, por exemplo, $\mathrm{Zn}$, são em parte removidos em solução nas águas do freático e superficiais. Os ETRL fortemente fracionados preservam padrões típicos de rochas e hidrotermalitos alcalinos; os ETR intermediários e ETRP mostram comportamento próprio característico das zonas de frentes redox, incluindo enriquecimentos consideráveis e efeitos tetrádicos, típicos de especiação como íns complexos com ligantes aniônicos em meio aquoso supergênico. Estudos isotópicos do $\mathrm{S}$ de piritas hidrotermais e de uma segunda geração de piritas, que ocorrem exclusivamente no interior de nódulos de pitchblenda supergênicos, mostram, para as primeiras, origens de magmas máficos do manto superior e para as segundas, processos biogeoquímicos de fracionamento isotópico por bactérias redutoras de sulfato. Sob aspectos de aplicação, destaca-se o comportamento geoquímico-supergênico conservador de rápida reprecipitação e/ou imóvel de U, Th, ETR, Zr e demais metais pesados, tanto em ambiente redutor quanto oxidante, sendo, no ambiente oxidante, os OHF de baixa cristalinidade as principais fases imobilizantes. 


\section{ABSTRACT}

The U-mineralization of Osamu Utsumi Mine in the SE part of the Poços de Caldas Alkaline Complex, MG, of Mesozoic age, was studied with field geological and laboratory mineralogical, petrographical and geochemical methods. It is a polygenetic mineralization hosted in leucocratic to hololeucocratic phonolites, nepheline syenites and their magmatic breccias, formed by superimposed processes of a specific hydrothermal event and supergenic alteration. The hydrothermal mineralizing processes occurred on a local scale and caused potassification, argillation and pyritization of the nephelinic rocks, transforming them into reduced hydrothermalites, along with their low-grade mineralization in $\mathrm{U}, \mathrm{Th}, \mathrm{Zr}, \mathrm{REE}, \mathrm{F}, \mathrm{Mo}, \mathrm{Zn}, \mathrm{Pb}, \mathrm{Ba}$, and removal of mainly $\mathrm{Na}, \mathrm{Ca}, \mathrm{Mg}$ and $\mathrm{Sr}$. The complex mineralization consists of disseminated impregnation and superimposed stockwork types; it is quite variable, thus indicating heterogeneous fluids and is genetically related to magmato-phreatic explosions and to the formation of subvolcanic conduit breccias. The chemical signature, including REE, indicates these processes as of post-magmatic consanguineous origin of final stages of the nephelinic magmatism. The mineralization of the disseminated impregnation type is generally low-grade (geochemical anomaly); a higher-grade mineralization occurs in the stockwork type in the breccias as matrices and cements, as well as fracture fillings. There were identified individual mineral phases and mixtures, including sulphides, oxides, silicates and molybdates, among others, with U-contents varying from 0.6 to 39 weight- $\%$; nevertheless, a specific U-mineral could not be defined, probably there occurs cryptocrystalline uraninite. 76 my ago, according to some authors, the magmatic processes ceased in the area of the mine, the supergenic cycle, responsible for the weathering profile, started and is still going on today. The main agents of this cycle were oxidizing descending waters under environmental conditions, causing the dissolution of pyrite and other sulphides, the liberation of sulphuric acid as well as variable and specific attacks of all the mineral phases of the reduced pyritized hydrothermalites, transforming them into oxidized hydrous ferric oxides (HFO)-bearing hydrothermalites (without pyrite and other sulphides). Thus, typical redox fronts formed, separating the reduced and oxidized hydrothernalites by very well defined interfaces. The redox fronts comprise 10-20 cm-wide zones of the reduced and oxidized hydrothermalites adjacent to the interfaces and they are the main sites of the supergenic rich U-mineralization. Five types of redox fronts could be defined, using geological, mineralogical and geochemical evidence, all acting in a roll front way. The metals released into solution by the roll front processes of acid attack (caused by the pyrite dissolution) are redistributed in the redox front zones, according to their geochemical affinities. Mainly $\mathrm{U}$ and $\mathrm{Cd}$ (as greenockite) are enriched in the high-grade supergenic mineralization in the reduced front zone as concretionary micro and macronodules of pitchblende/cryptocrystalline uraninite; most of the other heavy metals and part of the $U$ and $\mathrm{Cd}$ as well as more rare metals of problematic origins, such as $\mathrm{Pd}$ and $\mathrm{W}$, are enriched and co-precipitated 
with HFO in the oxidized zone of the redox front; still other more mobile metals, as for instance $\mathrm{Zn}$, are removed in solution in ground and surface waters. The strongly fractionated LREE preserve typical patterns of alkaline rocks and hydrothermalites; intermediate and HREE show distinct behaviour, characteristic of the redox front zones, including considerable enrichments and tetrad-effects, typical of a speciation as complex ions with anionic ligants in aqueous supergenic environment. $S$ isotope studies of hydrothermal pyrites and of pyrites of a second generation that occur exclusively inside the supergenic pitchblende nodules show, for the former, origins of mafic upper mantle derived magmas and for the latter, isotopically light $\mathrm{S}$, indicating biogeochemical fractionation by sulphate reducing bacteria. Under aspects of practical application, the conservative geochemical behaviour of rapid reprecipitation or immobility of $U, T h, R E E, Z r$ and other heavy metals in the supergenic reducing and oxidizing environment seems important. HFO are the most efficient metal immobilizing phases in the oxidizing
environment. 


\section{AGRADECIMENTOS}

Ao concluir esta Tese de Doutorado, ora apresentada ao Programa de Mineralogia e Petrologia do IGc-USP, aproveito para expressar os meus mais sinceros agradecimentos a diversas pessoas e instituições, cujas colaborações foram
decisivas para conclusão deste trabalho.

Agradeço ao Prof. Dr. Hans D. Schorscher, de maneira especial, pela orientação desta tese de doutorado, que me proporcionou uma conduta científica e ética de
inestimável valia.

Agradeço também aos meus colegas de pós-graduação, em especial a Peter Davies, pela importante ajuda na edição gráfica desta tese.

Agradeço aos responsáveis técnicos e funcionários dos laboratórios do IGc-USP de Microscopia Eletrônica, FRX, ICP-AES e Microssonda Eletrônica, pela ajuda
na obtenção de dados para esta tese.

Agradeço, ainda, ao Prof. Dr. Norbert F. Miekeley e Dra. Carmen C. Porto da Silveira, do Laboratório de Espectrometria Atômica e Nuclear Aplicada - EANA do Departamento de Química da PUC do Rio de Janeiro, pelas análises de ICP. MS, parte importante do acervo de dados desta tese de doutorado. Agradecimentos são devidos ao CNPq, pela concessão de bolsa de estudo que
viabilizou esta pesquisa.

À minha família, agradeço a presença sempre decisiva, nos momentos mais dificeis, não permitindo meu esmorecimento.

À todos, o meu mais sincero obrigado. 


\section{INTRODUÇAOO E OBJETIVOS}

Este projeto de doutorado tem sua área de estudo localizada no Sul do Estado de Minas Gerais, mais especificamente na mina de urânio Osamu Utsumi pertencente à INB - Indústrias Nucleares do Brasil, no Sudeste do Complexo Alcalino de Poços de Caldas (Figuras 1 e 2).

O Complexo possui forma circular com aproximadamente $30 \mathrm{~km}$ de diâmetro, e é composto predominantemente por nefelina sienitos e fonolitos leucocráticos de idade Mesozóica. Sua evolução é caracterizada por vários estágios magmáticos. Três deles são bem caracterizados: (1)-o magmatismo máfico básico-ultrabásico inicial incluindo ankaratritos (Ellert, 1959); (2)-o magmatismo alcalino intermediário nefelínico, vulcânico a plutônico, que originou as rochas que sustentam o Complexo e (3)-o magmatismo alcalino ultramáfico subvulcânico em enxames de diques, localmente freqüentes, de biotita lamprófiros que cortam o Complexo. Um quarto evento magmático carbonatítico, evidenciado apenas indiretamente por fenômenos de fenitização, brechas magmáticas e pela mineralização de elementos terras raras leves (ETRL), Th e U do Morro do Ferro, em rochas argilizadas sustentadas por um stockwork de veios de magnetita e suas possíveis relações genéticas com os estágios anteriores, é ainda assunto de pesquisas.

Este projeto estuda o estágio final do magmatismo nefelínico na região da mina de urânio Osamu Utsumi, representado por um evento hidrotermalmetassomático, que causou mineralizações de baixo teor de U-Th-Zr-ETR-FMo-Zn, assim como os processos de alteração supérgena que atuaram sobre as associações hidrotermais. A mineralização hidrotermal foi associada à piritização, transformação potássica e argilização intensa das rochas nefelínicas regionais. A alteração supérgena provocou a oxidação das piritas e o desenvolvimento de frentes redox por processos do tipo roll-front, responsáveis pelo enriquecimento secundário forte e localizado de $U$, iniciado há cerca de 76 
Ma, conforme indicam as idades dos diques ultramáficos da mina (Schorscher et al., 1991; Shea, 1992).

O elemento urânio (número atômico 92, peso atômico 128.03 e raio iônico $0.97 \AA$ ), que é foco dos estudos desta pesquisa, apresenta valências que variam entre $+2 \mathrm{e}+6$. Entretanto, somente as valências $+4,+5 \mathrm{e}+6$ são conhecidas em minerais, com predomínio dos estados de oxidação tetravalente e hexavalente. Em processos hipogênicos, prevalece o urânio tetravalente, e sua geoquímica em magmas, rochas ígneas e seus minerais está intimamente associada à geoquímica do tório (Goldschmidt, 1954; Ahrens, 1965; Taylor, 1979). Segundo Rogers e Adams (1969), o urânio ocorre num grande número de minerais, mas se concentra, caracteristicamente, em poucas espécies de menor abundância, como por exemplo torianita, torita, allanita, monazita, zircão, fluorita, apatita, epídoto e barita, pela facilidade de substituição, na estrutura desses minerais, do Th (r.i. $1.02 \AA$ ), Ca (r.i. $1.06 \AA$ ), ETR (r.i. 1.13 a $0.94 \AA$ ), Y (r.i. $1.06 \AA$ ), Zr (r.i. $0.8 \AA$ ), F (r.i. $0.8 \AA$ ) e Ba (1.44 $\AA$ ) (Wittaker e Munts, 1970). O mineral de urânio mais frequente é a uraninita, com variedade de menor cristalinidade pitchblenda. Sua fórmula varia de $\mathrm{UO}_{2}$ a $\mathrm{U}_{3} \mathrm{O}_{8}$ em função da oxidação parcial do $U^{4+}$ para $U^{6+}$ durante ou depois da deposição, (proporcionando a transição para pitchblenda), podendo ser encontradas todas as composições intermediárias entre estes dois termos finais.

O urânio, em processos supergênicos, é oxidado para o estado hexavalente, apresentando um grau de mobilidade geoquímica muito maior, e em solução, forma preferencialmente complexos anionicos de uranila $\left(\mathrm{UO}_{2}{ }^{2+}\right)$. Este íon é facilmente mobilizado em águas de superfície e sub-superficie, e incorporado nos minerais supérgenos como carbonatos, fosfatos, vanadatos, silicatos, sulfatos, uranomicas e uranatos (Rogers e Adams, 1969; Dyck, 1978; Mackenzie et al., 1991).

A mina de urânio Osamu Otsumi nos permite, desta maneira, estudar a geologia, mineralogia, petrografia e geoquímica dos processos metalogenéticos e de migração do urânio nas condições hipogênicas - na mineralização 
hidrotermal-metassomática - e supergênicas - nas frentes redox e mineralizações secundárias associadas. Pesquisas desta natureza têm relevância não só na área de metalogênese do urânio, mas são muito importantes também nas áreas de ciência e tecnologia ambiental, no que se refere à mineração e meio ambiente, uso e ocupação do solo e como análogos naturais na projeção e análise de riscos de repositórios de rejeitos nucleares em meios geológicos.

Este trabalho tem como objetivo geral a caracterização da metalogênese hipogênica e principalmente supergênica de $U$, Th, ETR e demais elementos associados e suas características sistemáticas de migração. Os objetivos específicos são contribuições à:

(1)-pesquisa fundamental sobre a mineralogia, petrografia e geoquímica das reações fluidos-rochas em sistemas abertos uraniferos naturais de temperaturas contrastantes hidrotermais e ambientais, e

(2)-pesquisa aplicada nas áreas de metalogênese do urânio, mineração e meio ambiente e análogos naturais. 


\section{METODOLOGLA}

\subsection{Trabalhos Preliminares}

Os estudos preliminares compreenderam levantamentos bibliográficos regionais, locais e temáticos. Incluíram ainda, a revisão das coleções de amostras, lâminas e dos resultados das etapas anteriores dessa pesquisa, assim como a elaboração do plano específico deste trabalho e a preparação das etapas de campo.

\subsection{Trabalhos de Campo}

Os levantamentos geológicos de campo tiveram como enfoque principal a mina de urânio Osamu Utsumi. Foram realizados em várias etapas e incluíram amostragens sistemáticas de rochas na cava da mina a céu aberto e de testemunhos de sondagens cedidos pela Nuclebrás (atual INB-Indústrias Nucleares do Brasil), além de minérios e produtos de intemperismo. Em afloramentos e perfis regionais de reconhecimento, foram realizados estudos e amostragens de fonolitos $(\mathrm{Ph})$ e nefelina sienitos (NeS) não afetados pelos processos mineralizantes uraníferos hidrotermais da mina Osamu Utsumi, para fins de comparação.

\subsection{TRABALhOS LABORATORIAIS}


Os estudos laboratoriais efetuados com métodos analítico-experimentais multidisciplinares e entre si complementares, representaram a parte principal de aquisição de dados deste projeto.

\subsubsection{Tratamentos E EStudos Preliminares}

Esta etapa incluiu:

* Catalogação, descrição macroscópica e de lupa binocular e seleção das amostras para as demais etapas;

* Definição dos roteiros analíticos individuais e/ou por grupos de amostras;

* Serragem das amostras em placas para descrições complementares e documentação fotográfica e posterior: (1)-confecção de lâminas delgadas, seções polidas, lâminas delgadas polidas para microssonda, (2)-preparação de fragmentos para microscopia eletrônica de varredura, (3)-preparação de pósanalíticos para estudos geoquímicos múltiplos, e (4)-separações granulométricas e de minerais em grãos para estudos específicos mineralógicos por difração de raios $\mathrm{X}$ e de isótopos estáveis.

\subsubsection{Microscopia Petrográfica e de Minérios}

Estudos petrográficos qualitativos e semiquantitativos de luz transmitida e refletida foram realizados em lâminas petrográficas, lâminas delgadas polidas, seções polidas, montagens de minerais em grãos e compreenderam também trabalhos microfotográficos de documentação. Incluíram amostras coletadas para este projeto e do Projeto Internacional Poços de Caldas, do qual a doutoranda participou como estagiária em pesquisa. 
Estes estudos foram subdivididos em duas etapas: (a) preliminar, para completar e confirmar a seleção das amostras e as etapas laboratoriais, e (b) de detalhe, para caracterização mineralógica, petrográfica e metalogenética pormenorizada dos litotipos de interesse.

\subsubsection{LITOGEOQUímICA}

Estudos litogeoquímicos multielementares por fluorescência de raios $X(F R X)$, espectrometria de emissão atômica e espectrometria de massa com fontes de plasma indutivamente acoplado (ICP-AES e ICP-MS) foram realizados em amostras representativas dos litotipos de interesse: rochas não hidrotermalizadas regionais e da mina de urânio, rochas e minérios hidrotermais, além das expressivas frentes redox de diferentes tipos da mina de urânio.

Os pós-analíticos foram obtidos mediante britagem, homogeneização, quarteamento e moagem (em moinho de bolas de ágata) até a granulometria $-200 \#$ das amostras previamente selecionadas.

\section{* FLUORESCÊNCIA DE RAIOS X (FRX)}

Estes estudos foram realizados no laboratório de FRX do DMP-IGc-USP, com equipamento Phillips, seqüencial automático, modelo PW 2400, utilizando-se o programa analítico Uniquant(B). Foram analisados, em média, 32 elementos/variáveis químicos por amostras, em pastilhas de pó prensadas, em 10 amostras de $\mathrm{Ph}$ não-hidrotermalizados e em 11 hidrotermalitos reduzidos e oxidados da mina. Em função de problemas analíticos, principalmente nos elementos maiores, decorrentes da rotina laboratorial de preparação de pastilhas de pó prensadas, outras alíquotas das mesmas amostras de $\mathrm{Ph}$ não- 
hidrotermalizados da mina de urânio foram reanalisadas no laboratório de FRX do Instituto de Mineralogia Aplicada e Geoquímica da TU-Munique, Alemanha, com espectrômetro Siemens SRS303, após preparação de pastilhas fundidas e usando-se o programa de quantificação específico do equipamento. Os demais dados de FRX utilizados nesta pesquisa foram analisados em cooperação internacional no Instituto de Mineralogia e Petrografia da Universidade de Berna, Suíça, durante o Projeto Internacional Poços de Caldas, com a participação da doutoranda, usando-se, segundo metodologia internacionalmente convencional, pastilhas fundidas para os elementos maiores e pastilhas de pó prensadas para os elementos traço (Tertian e Claisse, 1982; Gomes e Dutra, 1984; Williams, 1987; Ahmedali, 1989). Dados de comparação foram extraídos da literatura (Schorscher e Shea, 1992; Schumann, 1994).

\section{* Espectrometria de Emissão Atômica com fonte de Plasma INDUTIVAMENTE ACOPLADO (ICP-AES)}

Estudos de ICP-AES foram realizados no Laboratório de DMP-IGc-USP, determinando-se 24 elementos/variáveis químicas por amostra, em 4 amostras de $\mathrm{Ph}$ não-hidrotermalizados e 13 hidrotermalitos reduzidos e oxidados da mina. Estes estudos foram efetuados para complementação dos dados de amostras disponíveis em pequena quantidade e para comparação e verificação da confiabilidade analítica dos métodos por FRX e ICP-AES, uma vez que várias amostras foram analisadas pelos dois métodos.

A rotina laboratorial de ICP-AES adotada no laboratório de IGc-USP foi descrita por Janasi et al. (1995). Consiste basicamente na abertura das amostras por fusão alcalina com mistura de meta e tetraborato de lítio, e diluição final das soluções a 1:1000. Estas são então analisadas em espectrômetro seqüencial ARL-3410. 


\section{* Espectrometria de Massa com fonte de Plasma Indutivamente ACOPLADO (ICP-MS)}

Análises de ICP-MS foram efetuadas, em cooperação científica no laboratório do grupo de pesquisa de Espectrometria Atômica e Nuclear Aplicada - EANA, sob orientação do Prof. Dr. Norbert F. Miekeley e Dra. Carmen C. Porto da Silveira, do Departamento de Química da PUC do Rio de Janeiro, inicialmente em 49 amostras de frentes redox da mina de urânio, onde foram analisados, em média, 71 elementos por amostra, incluindo todos os ETR, elementos de alta força iônica (HFSE), litófilos de raio iônico grande (LILE), metais nobres e platinóides, $U$, Th, entre outros. Os pós-analíticos destas amostras foram preparados/extraídos com broca dentária visando as propriedades geoquímicas de detalhe das frentes redox selecionadas. Os resultados foram obtidos por análises com fatores de diluição $(\mathrm{Fd})$ diferentes, baixo (5.000) e alto (50.000), uma vez que a amostragem com esta metodologia muitas vezes produziu material apenas em quantidade limite ou mesmo insuficiente para análise com Fd alto $(\sim 100 \mathrm{mg})$. Em decorrência deste fato, pós-analíticos de 22 amostras complementares, das mesmas frentes redox, foram preparados em maiores quantidades (de aproximadamente $10 \mathrm{~g}$ ) e reanalisados, também com dois fatores de diluição, baixo (1.000) e alto (10.000). Desta maneira, eliminou-se também uma possível interferência do "efeito pepita" e contaminação pelos metais constituintes da broca dentária.

A metodologia aplicada se resume a abertura triácida das amostras (com ácidos fluorídrico, nítrico e perclórico), avolumando-as ao final para $25 \mathrm{ml}$ com ácido nítrico a 1\%. Esta solução foi então analisada em equipamento Elan 5000A da Perkin Elmer Sciex, usando-se o programa analítico TotalQuant ${ }^{\circledR}$ (Perkin Elmer). Uma solução de calibração com 54 elementos de concentração conhecida (incluindo todos ETR, platinóides e os mais relevantes elementos principais e traço), foi utilizada para atualização dos fatores de resposta 
(cps/ppm). Como padrões internos foram utilizados o In e $\mathrm{Tl}$, e a incerteza dos resultados analíticos dos elementos traço é tipicamente entre 10-30\%.

\subsubsection{MICROSCOPIA ELETRÔNICA DE VARREDURA (MEV)}

Estudos de microscopia eletrônica de varredura foram divididos em duas etapas. A primeira foi realizada pelo orientador nos laboratórios da Fábrica da Carl Zeiss, Oberkochen, Alemanha, com o microscópio Gemini DSM 982, de tipo thermal field emission (emissão de campo térmico) (Martin et al., 1995), em amostras de frentes redox mineralizadas da mina de urânio.

A segunda etapa foi realizada pela doutoranda, no Laboratório de Microscopia Eletrônica do DPE-IGc-USP, com o microscópio LEO 440i, com canhão eletrônico convencional de filamento de tungstênio, analisador energiadispersiva (EDS) com detetor de estado sólido silício-lítio (marca Oxford), em amostras de brechas vulcânicas com mineralizações uraniferas hidrotermais de alta radioatividade distantes das frentes redox. As propriedades destas amostras, metalizadas com carbono, permitiram visualização com aumentos de até 10.000 vezes, nas condições de corrente de feixe de $1.0 \mathrm{nA}$ para as imagens e de $4.5 \mathrm{nA}$ para as análises EDS, corrente de filamento de $4.5 \mathrm{~A}$, tensão de aceleração de elétrons (EHT) de $20 \mathrm{kV}$, distância de trabalho (WD) de $25 \mathrm{~mm}$ e detetor de elétrons retroespalhados (QBSD). As análises pontuais EDS permitiram a caracterização química semiquantitativa de diversos minerais uraníferos de interesse do protominério. 


\subsubsection{MicrosSONdA EleTrốniCA (MSE)}

Os estudos de química mineral por microssonda eletrônica foram realizados no Laboratório de Microssonda Eletrônica do Departamento de Mineralogia e Petrologia do IGc-USP, utilizando-se equipamento JXA - 8600 Superprobe (JEOL) com automação NORAN. Incluíram: (a) análises quantitativas por dispersão de comprimentos de ondas (WDS) com correções de máquina (ruído de fundo/background - $\mathrm{BG}$, deriva do filamento/filament drift e tempo morto/dead time dos contadores) e $\mathrm{ZAF}\left(\mathrm{Z}-\mathrm{n}^{\circ}\right.$ atômico, $\mathrm{A}$ - absorção, $\mathrm{F}$ fluorescência secundária), sendo nessas condições o erro analítico máximo estimado de $\pm 3 \%$ para elementos maiores $e$, (b) análises qualitativas e semiquantitativas por sistema energia dispersivo (EDS).

Foram analisados, por WDS, neste trabalho o total de 137 pontos em fases minerais magmáticas (feldspatos alcalinos, nefelinas, leucitas, analcitas e clinopiroxênios) e hidrotermais (feldspatos alcalinos e illitas/sericitas) de 10 amostras de $\mathrm{Ph}$ não-hidrotermalizados a incipientemente hidrotermalizados, aflorantes na parte $\mathrm{NW}$ da mina de urânio Osamu Utsumi (figura 3), considerando, sempre que possível, as diferentes gerações texturais e genéticas para cada qual desses minerais (principalmente clinopiroxênios e feldspatos alcalinos) e 43 pontos em fases minerais hidrotermais (caolinitas, rutilos, óxidos de $U$, piritas, zircões e fluoritas). Análises por EDS (qualitativas e semiquantitativas) foram feitas em 3 amostras de $\mathrm{Ph}$ hidrotermalizados reduzidos da mina para auxiliar na identificação de algumas fases minerais.

Dados complementares e de comparação, de estudos WDS e EDS quantitativos anteriores, realizados pelo orientador para o Projeto Internacional Poços de Caldas, no Instituto de Mineralogia e Petrografia da Universidade de Berna, Suíça, utilizando uma microssonda automática ARL-SEMQ (Schorscher, 1991) também foram incluídos neste trabalho. 


\subsubsection{Mineralogia das PIRITas E Isótopos EStáveis de $\delta^{34} S$}

Estudos mineralógicos específicos das piritas foram desenvolvidos, tendo em vista a constante associação pirita-mineralização de urânio, caracterizando-se gerações texturais e paragenéticas distintas, hidrotermais e supergênicas, além de alterações para sulfatos.

Compreenderam descrições macroscópicas de amostras, microscopia de luz transmitida e refletida, e separações dos minerais de interesse (piritas e sulfatos) em concentrados puros para as análises isotópicas. As amostras selecionadas foram testemunhos de sondagem e amostras de mão da cava da mina com mineralizações hidrotermais de tipo impregnações disseminadas, e stockwork concentradas em micro e macro-veios, além de matrizes de brechas, afastadas das frentes redox e próximas à elas, assim como de mineralizações supergênicas de urânio em micronódulos e macronódulos.

Dessas amostras, as piritas foram preparadas/separadas em cristais individuais por catação manual em lupa binocular, após liberação por processos de moagem, peneiramento e separação por líquidos densos (bromofórmio). Assim, foram obtidos concentrados puros (de 95-99\%) em várias frações granulométricas (diâmetros de: <0.1, 0.1 a $0.5,0.5$ a 1.0 e 1.0 a $2.0 \mathrm{~mm}$ ).

Estes concentrados foram analisados, em cooperação científica internacional, pelo Prof. A. E. Fallick e colaboradores no Scottish Universities Research and Reactor Center - SURCC (East Kilbride/Glasgow, Grã Bretanha), e seguiram metodologias convencionais, internacionalmente em uso, que se encontram detalhadamente descritas na literatura (por exemplo Hall et al., 1987). Constam, de uma maneira geral, na liberação de $\mathrm{S}$ na forma de gás $\mathrm{SO}_{2}$ pela reação do sulfeto com $\mathrm{Cu}_{2} \mathrm{O}$ a $1070{ }^{\circ} \mathrm{C}$ (Robinson e Kusakbe, 1975); num forno de $\mathrm{Cu}$, que mantém a temperatura a $600{ }^{\circ} \mathrm{C}$, qualquer $\mathrm{SO}_{3}$, eventualmente formado, é reduzido para $\mathrm{SO}_{2}$. Seguem-se a purificação e determinação/quantificação do $\mathrm{SO}_{2}$ obtido $\mathrm{e}$, finalmente, a análise isotópica que foi efetuada num espectrômetro de massa modelo ISOSPEC 44 - modificado para $\mathrm{SO}_{2}$. $\mathrm{O}$ 


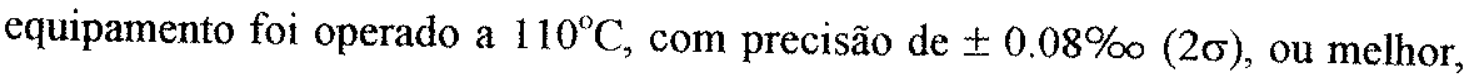
reprodutibilidade de $\pm 0.25 \%$ e todos os resultados de $\delta^{34} \mathrm{~S}$ expressos como diferença em $\%$ relativos ao padrão de Trolilita do Meteorito Canyon Diablo (CDT).

\subsection{TRABalhos FinAIS}

Os trabalhos finais desenvolvidos neste projeto compreenderam todas as atividades necessárias para a integração final dos dados, redação, ilustração e apresentação, na forma definitiva para a defesa, da Tese de Doutorado. 


\section{ESTUDOS GEOLÓGICOS}

\subsection{GeOlogia Regional}

O Complexo Alcalino de Poços de Caldas situa-se entre a bacia sedimentar do Paraná a W e a serra de Mantiqueira a S, na porção sudeste do Brasil (Figura 1), limítrofe entre os estados de Minas Gerais e São Paulo. Intrude e encobre rochas pré-cambrianas do embasamento cristalino, constituído por biotitagnaisses que passam localmente para anatexitos e encontram-se cortados por diques de dolerito (Fraenkel et al., 1985). Possui idade Mesozóica e forma circular com diâmetro de aproximadamente $30 \mathrm{~km}$ (Figura 2), estando associado à separação das placas Sul Americana e Africana (Almeida, 1977). Foi geologicamente estudado e mapeado por Ellert (1959) e Ellert et al. (1959), estruturalmente analisado por sensoriamento remoto por Almeida e Paradella (1977) e investigado geofisicamente por Araújo (1980), Hamza (1982) e Montes-Lauar (1988). Detalhamentos, principalmente dos NeS, devem-se a Ulbrich, M. (1983), Ulbrich, M. et al. (1984) e Ulbrich, H. (1984).

O Complexo é composto essencialmente por rochas alcalinas intermediárias vulcânicas, subvulcânicas e plutônicas, representadas por $\mathrm{Ph}$ e NeS, predominando tipos leucocráticos; subordinadamente ocorrem rochas ultramáficas e ultrabásicas, ankaratritos e biotita lamprófiros em diques e prováveis carbonatitos (Ellert, 1959; Ellert et al., 1959; Bushee, 1971; Schorscher et al., 1991; Schorscher e Shea, 1992, e outros). Sob aspectos geológicos, Ellert (1959) desenvolveu um modelo de evolução tectonomagmática em seis estágios. Neste trabalho será adotado um modelo simplificado de apenas três estágios magmáticos principais, sendo:

(1)-Vulcanismo básico-ultrabásico máfico, incluindo ankaratritos, tidos como as lavas mais antigas do Complexo Alcalino (Ellert, 1959), sendo cortadas pelos $\mathrm{Ph}$ e NeS do magmatismo alcalino intermediário nefelínico principal; 


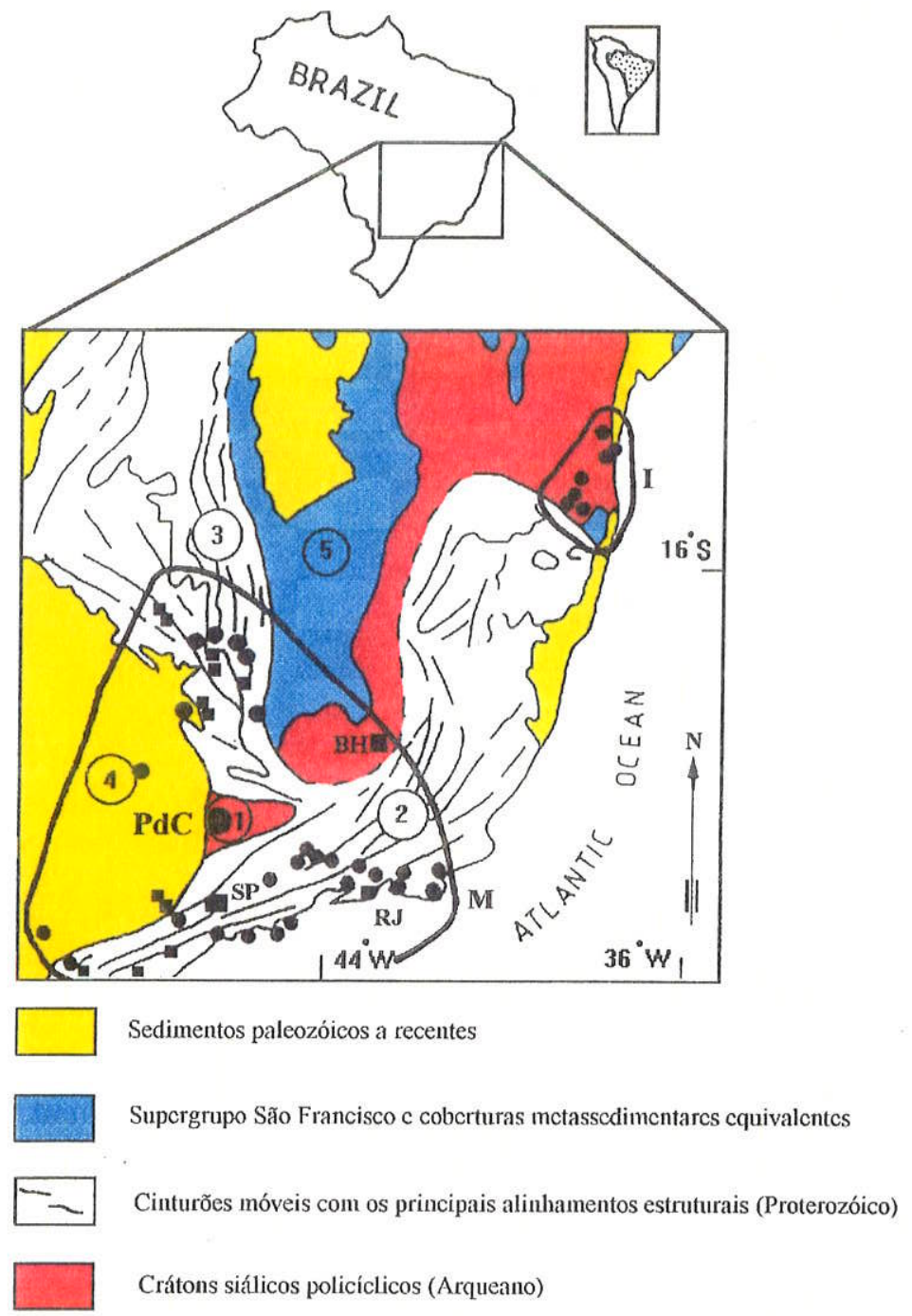

Figura 1: Esboço geológico da parte centro-leste do Brasil (modificado de Almeida, 1977), mostrando a localização do Complexo Alcalino de Poços de Caldas e outras intrusões alcalinas e de carbonatitos (segundo Ulbrich \& Gomes, 1981). Subdivisões tectônicas: (1)-Maciço de Guaxupé; Cinturões Móveis (2)-Ribeira e (3)-Brasília; (4)-Bacia do Paraná (sedimentar com basaltos); (5)-Cráton do São Francisco. Símbolos e abreviações: - PdCComplexo Alcalino de Poços de Caldas, -complexos alcalinos e $\mathbf{\text { 日⿱ }}$-complexos alcalinos com carbonatitos, I-infracambrianos, M-mesozóicos; cidades São Paulo, 지-Rio de Janeiro, $\mathbf{B}$ BH-Belo Horizonte. 

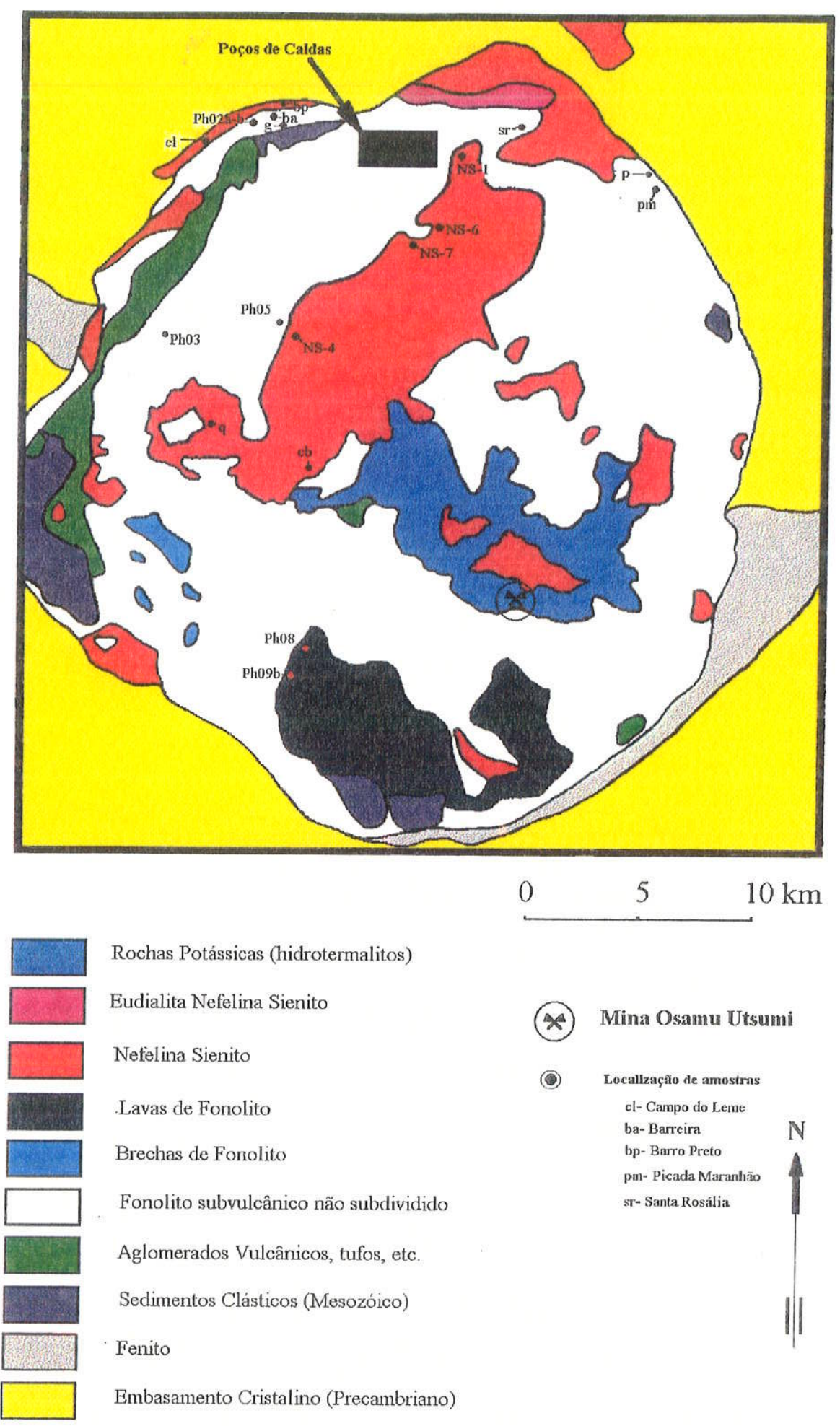

Rochas Potássicas (hidrotermalitos)

Eudialita Nefelina Sienito

Nefelina Sienito

Lavas de Fonolito

Brechas de Fonolito

Fonolito subvulcânico não subdividido

(x) Mina Osamu Utsumi

(C) Localização de amostras cl- Campo do Leme ba- Barreira

bp- Barro Preto pm- Picada Maranhāo sr- Santa Rosália

Aglomerados Vulcânicos, tufos, etc.

Sedimentos Clásticos (Mesozóico)

Fenito

Embasamento Cristalino (Precambriano)

Figura 2: Mapa geológico do Complexo Alcalino de Poços de Caldas (modificado de Ellert, 1959, e Fraenkel et al., 1985). A principal área de alteração hidrotermal inclui a mina de Urânio Osamu Utsumi. 
(2)-Magmatismo alcalino intermediário nefelínico principal vulcânico e subvulcânico, em três estágios:

- Vulcanismo fonolítico inicial, incluindo tufos, lavas e intrusões fonolíticas subvulcânicas, da fase generativa do edifício vulcânico.

- Intrusões dos $\mathrm{NeS}$ principais (tipo Pedreira da Prefeitura) freqüentemente com veios pegmatíticos e hidrotermais, moderadamente peralcalinos, portadores de xenólitos dos $\mathrm{Ph}$ anteriores e de raros enclaves ultramáficos de piroxenitos alcalinos, formação dos diques anelares descontínuos de $\mathrm{Ph}$ subvulcânicos e abatimento fraco a moderado da caldeira, e colocação de diques de $\mathrm{Ph}$ subvulcânicos rasos afaníticos microporfiríticos, que cortam os $\mathrm{NeS}$ principais, inclusive seus veios pegmatíticos e hidrotermais (por exemplo no local tipo da Pedreira da Prefeitura).

- Intrusões de NeS agpaíticos (com abundante eudialita) altamente peralcalinos, de expressão apenas local (Ulbrich, H., 1984) (p.ex.: Pedra Balão, Morro do Serrote e arredores da mina de urânio Osamu Utsumi) e $\mathrm{Ph}$ equivalentes, sendo que nos lujauritos da Pedra Balão foram encontrados xenólitos dos $\mathrm{Ph}$ do dique anelar do Anel Norte.

(3)-Evento magmático subvulcânico final ultramáfico-alcalino, representado pelos enxames de diques de biotita lamprófiros da mina de urânio, entre outros. Um quarto evento magmático, ultrabásico carbonatítico (tipo Morro do Ferro) associado, eventualmente com brechas carbonatíticas (tipo Areião) da parte NW e central do Complexo Alcalino e zonas de fenitização (cf.: Ellert, 1959 e Ellert et al., 1959), e suas relações genéticas e temporais com os demais estágios magmáticos do complexo, continuam assuntos de pesquisas.

A evolução magmática do Complexo incluiu ainda, importantes processos pósmagmáticos. Estes apontam para uma considerável riqueza em voláteis dos magmas de $\mathrm{NeS}$ e $\mathrm{Ph}$ e podem ser agrupados em duas associações de eventos genetica e temporariamente distintas. A primeira é diretamente relacionada ao 
magmatismo nefelínico, sendo sempre mais expressiva nos NeS (Figura 2), e resultou na formação de veios e mineralizações miarolíticas pegmatíticas a pneumatolíticas e hidrotermais, que ocorrem por todo o Complexo. Causou, entre outros, a precipitação de silicatos de metais raros como, por exemplo, giannettita ou eudialita, além de aegirina fibrosa e reações incipientes de troca de álcalis em feldspatos (no estágio pegmatítico a pneumatolítico), assim como a precipitação de zeólitas, fluorita, hematita e carbonatos (no estágio hidrotermal). A segunda associação de eventos pós-magmáticos, de característica tipicamente hidrotermal e de ocorrência mais restrita, foi responsável pela alteração potássica e pela mineralização de $U$ hipotermal da mina Osamu Utsumi e ocorrências similares em vários outros locais do Complexo, sendo que os principais estudos se devem a Tolbert (1966); Gorsky e Gorsky (1974) e Garda (1990). Este evento causou fortes enriquecimentos principalmente de $\mathrm{K}, \mathrm{U}, \mathrm{Th}, \mathrm{Zr}$, ETR, Mo, Zn, F e S, transformando os NeS e $\mathrm{Ph}$ regionais em hidrotermalitos específicos denominados de rochas potássicas (Frayha, 1962; Tolbert, 1966; Garda, 1990; Schorscher e Shea, 1992). Suas características geoquímicas apontam origens consangüíneas com o magmatismo nefelínico regional. Por essas relações geoquímicas e, sendo cortadas por diques de biotita lamprófiros não afetados pelos processos hidrotermais, foram atribuídos à fase final do magmatismo nefelínico, posteriores aos eudialita $\mathrm{NeS}$ e anteriores a colocação dos diques de biotita lamprófiros datados em $76 \mathrm{Ma}$ (Shea, 1991, 1982; Schorscher et al., 1991).

\subsection{GEOLOGIA LOCAL}

A jazida de $U$ da mina Osamu Utsumi é um produto de processos superimpostos magmáticos, de alteração hidrotermal e supérgena (NUCLEBRÁS/INB - Relatórios Internos; Fraenkel et al., 1985; Waber et al., 1992; entre outros), constituindo-se numa associação de intrusões mútuas de $\mathrm{Ph}$ 
subvulcânicos e NeS hipoabissais, cortados por diques de $\mathrm{Ph}$ e corpos tabulares de brechas vulcânicas, todos hidrotermalmente transformados em rochas potássicas com mineralizações de U-Th-Zr-ETR-Mo-F principalmente (Figuras 3 e 4). No contexto maior do Complexo Alcalino de Poços de Caldas, os eventos hidrotermais uraníferos foram superimpostos aos eventos hidrotermais regionais de forma sempre localizada, mais fortes e com características físico-químicas distintas, afetando indiscriminadamente e com intensidade igual todos os $\mathrm{Ph}$ e/ou NeS do local (Tolbert, 1966; Gorsky e Gorsky, 1974; Garda, 1990, entre outros). Na mina, estas mineralizações hidrotermais, mineralógica e quimicamente análogas em $\mathrm{Ph}, \mathrm{NeS}$ e brechas, são mais ricas nas brechas, concentrando-se na matriz. A alteração hidrotermal potássica, piritização e mineralização de $\mathrm{U}$ de baixo teor disseminada nos $\mathrm{Ph}$ e $\mathrm{NeS}$, assim como a formação e mineralização das brechas são cogenéticas, sendo as brechas produtos de explosões magmato-freáticas tardias do evento hidrotermal. A alteração hidrotermal das rochas alcalinas nefelínicas regionais para rochas potássicas causou a transformação dos álcali-feldspatos magmáticos (ortoclásios pertíticos, sanidinas) em feldspatos potássicos (triclínicos) puros, da nefelina em pseudomorfos de illita e caolinita e do clinopiroxênio em misturas de minerais finos incluindo fases titaníferas semiopacas, argilominerais e pirita, além da piritização generalizada fina e disseminada, e da precipitação intergranular/intersticial de zircão - às vezes intercrescido com baddeleyita, de monazita e outros minerais de ETR, esfalerita, molibdenita, jordisita e fluorita, entre outros (Garda, 1990; Schorscher e Shea, 1992).

À segunda associação de processos hidrotermais, seguiu-se na mina de urânio Osamu Utsumi, um evento magmático final subvulcânico de enxames de diques de biotita lamprófiros ultramáficos ultrapotássicos. Estes representam uma mudança drástica do magmatismo nefelínico, cortando todas as litologias locais; incluem xenólitos destas e não sofreram a alteração hidrotermalmineralizante uranífera. Um destes diques foi datado em $76 \mathrm{Ma}$ por Ar-Ar em 
flogopitas de fenocristais e da matriz (Shea, 1992) e apresenta, ainda, apatitas com idades de traços de fissão concordantes (Schorscher et al., 1991), indicando resfriamento rápido para temperaturas abaixo de $100^{\circ} \mathrm{C}$, mesmo no nível hoje exposto na mina, ou seja, que na superfície do Complexo Alcalino há $76 \mathrm{Ma}$, as condições ambientais já eram de intemperismo.

Desde então se desenvolveram as frentes redox e com estas a mineralização secundária de tipo roll front de $\mathrm{U}$, essencialmente pura - no que difere da mineralização hidrotermal rica em $\mathrm{Zr}$, Th e ETR principalmente - por processos de intemperismo e alteração supergênica (de baixas temperaturas) e com a participação de processos biogeoquímicos bacterianos, estando relacionada à oxidação da pirita e à formação de OHF (Schorscher et al., 1991, 1997; Schorscher e Osmond, 1992; Waber et al., 1992). Sob aspectos geológicos extremos distinguem-se dois tipos genéticos principais de frentes redox:

- Frentes redox estruturalmente controladas (ou advectivas) seguem sistemas de falhas e fraturas de alto ângulo e penetram profundamente dentro da zona dos hidrotermalitos reduzidos/piritizados, formando corpos de rochas oxidadas de tipo quilhas, afinando com a profundidade até o desaparecimento (Figura 4) e, seguem também, sistemas de juntas de alívio, horizontais a subhorizontais, originando então, zonas estreitas e irregulares de rochas oxidadas correspondentes.

- Frentes redox litologicamente controladas dependem, face à similaridade químico-mineralógica dos hidrotermalitos reduzidos, principalmente dos parâmetros físicos de porosidade e permeabilidade dessas rochas e avançam de cima para baixo com a infiltração dos fluidos intempéricos oxidantes seguindo as bordas dos grãos.

A realidade geológica da mina de urânio resultou da interação desses fatores controladores: (1)-uma frente redox principal e contínua por toda a área da jazida de morfologia fortemente irregular dada por avanços diferenciais mais fortes em zonas mais fraturadas e/ou de rochas mais porosas e permeáveis, e (2)-várias frentes redox secundárias, locais, sendo superfícies de oxi-redução 
que envolvem e isolam volumes de rochas hidrotermais reduzidas/piritizadas de baixa porosidade e permeabilidade, que, portanto sobreviveram temporariamente em condį̧ões instáveis de dissolução mais lenta, em meio à zona de rochas já oxidadas (Fotos 1 e 2, pág. 23). À todas essas frentes redox, associam-se mineralizações secundárias supergênicas de $U$ de desenvolvimento e teores variáveis.

$O$ avanço médio da frente redox principal foi estudado e estimado/datado com métodos de desequilíbrios radioativos em poucos $\mathrm{mm} / 1.000$ anos, por Schorscher e Osmond (1992), usando um modelo de progressão contínua. Entretanto, resta a questão da influência das variações climáticas nos últimos 76 Ma do Terciário e Quaternário, sobre a migração e propagação desta e das demais frentes redox da mina.

\subsection{GEOCRONOLOGIA}

Datações geocronológicas indicam que a atividade ígnea no Complexo deve ter começado por volta de 89 Ma com ankaratritos (Bushee, 1971), ou antes, produzindo NeS já há $92 \mathrm{Ma}$ (Kawashita et al., 1984). Shea (1992) determinou idades Sm-Nd de 78 Ma para NeS regionais e idades $\mathrm{Rb}-\mathrm{Sr}$ de 76 Ma para NeS hidrotermalmente alterados da mina de urânio; as razões iniciais do Sr e Nd dos $\mathrm{NeS}$ e $\mathrm{Ph}$ regionais e equivalentes hidrotermalmente alterados da mina, indicaram ainda a derivação astenosférica de seus magmas parentais e dos fluidos hidrotermais.

Shea (1992) datou ainda diques de biotita lamprofiros ultramáficos ultrapotássicos, também da mina de urânio, que cortam a mineralização hidrotermal e representam, regionalmente, a manifestação magmática mais recente, com idade Ar-Ar de $76 \mathrm{Ma}$.

Os trabalhos de datação sugerem, em geral, que o magmatismo alcalino nefelínico principal (de $\mathrm{Ph}$ e $\mathrm{NeS}$ ) persistiu regionalmente por mais de $10 \mathrm{Ma}$ e 
que terminou, na região da mina de urânio, com hidrotermalismo e mineralização uranífera hipogênica, mais provavelmente no intervalo de 78 a $76 \mathrm{Ma}$, entretanto, antes do magmatismo subvulcânico dos diques de biotita lamprófiros, também datados em 76 Ma (Shea, 1992). Em comparação, a mineralização supergênica aparentemente foi muito mais lenta e pode ter perdurado desde o magmatismo dos diques de biotita lamprófiros até o presente.

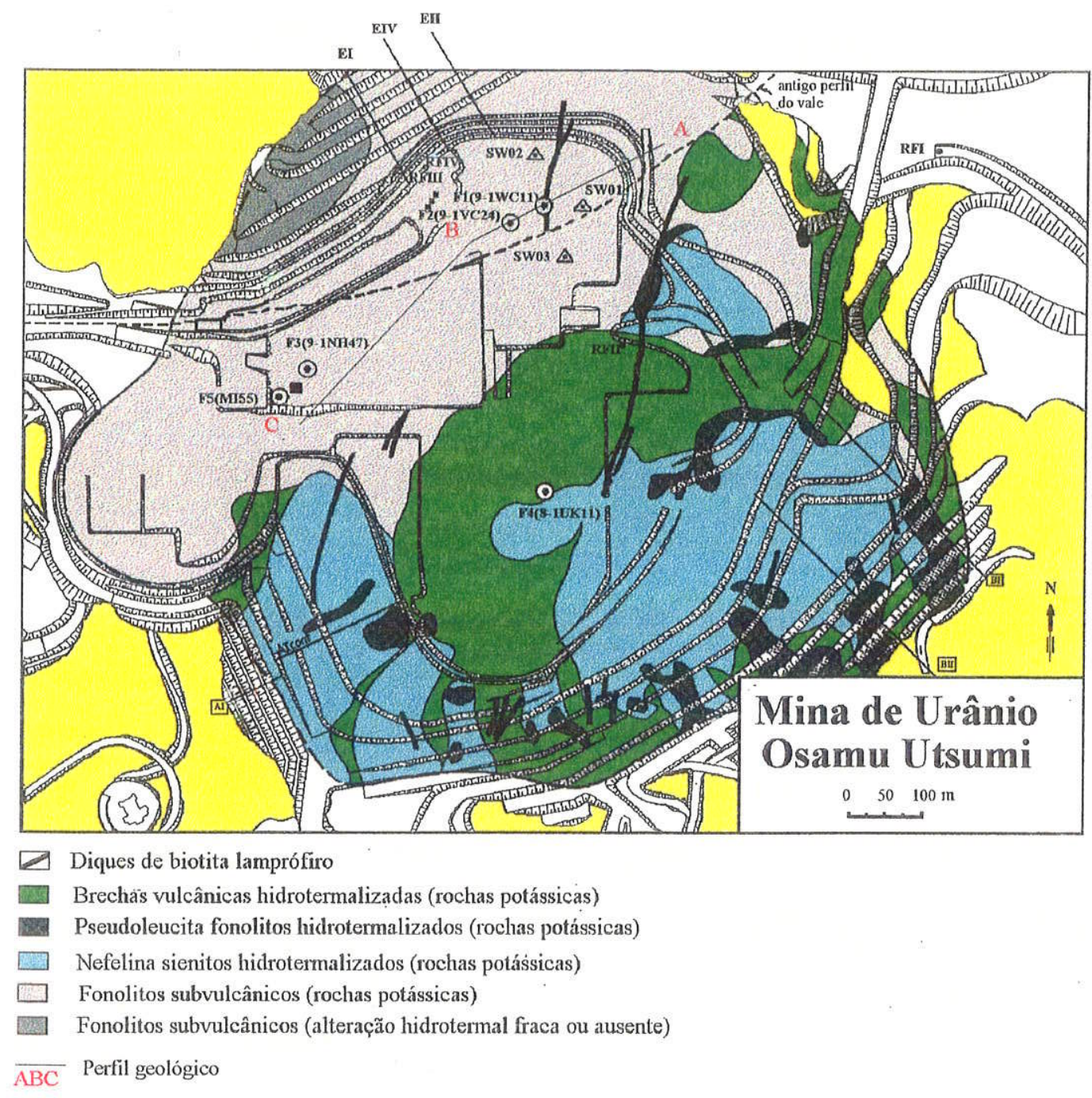

Figura 3: Mapa geológico e de amostragem da mina de urânio Osamu Utsumi, na parte SE do Complexo Alcalino de Poços de Caldas, $M G$. 


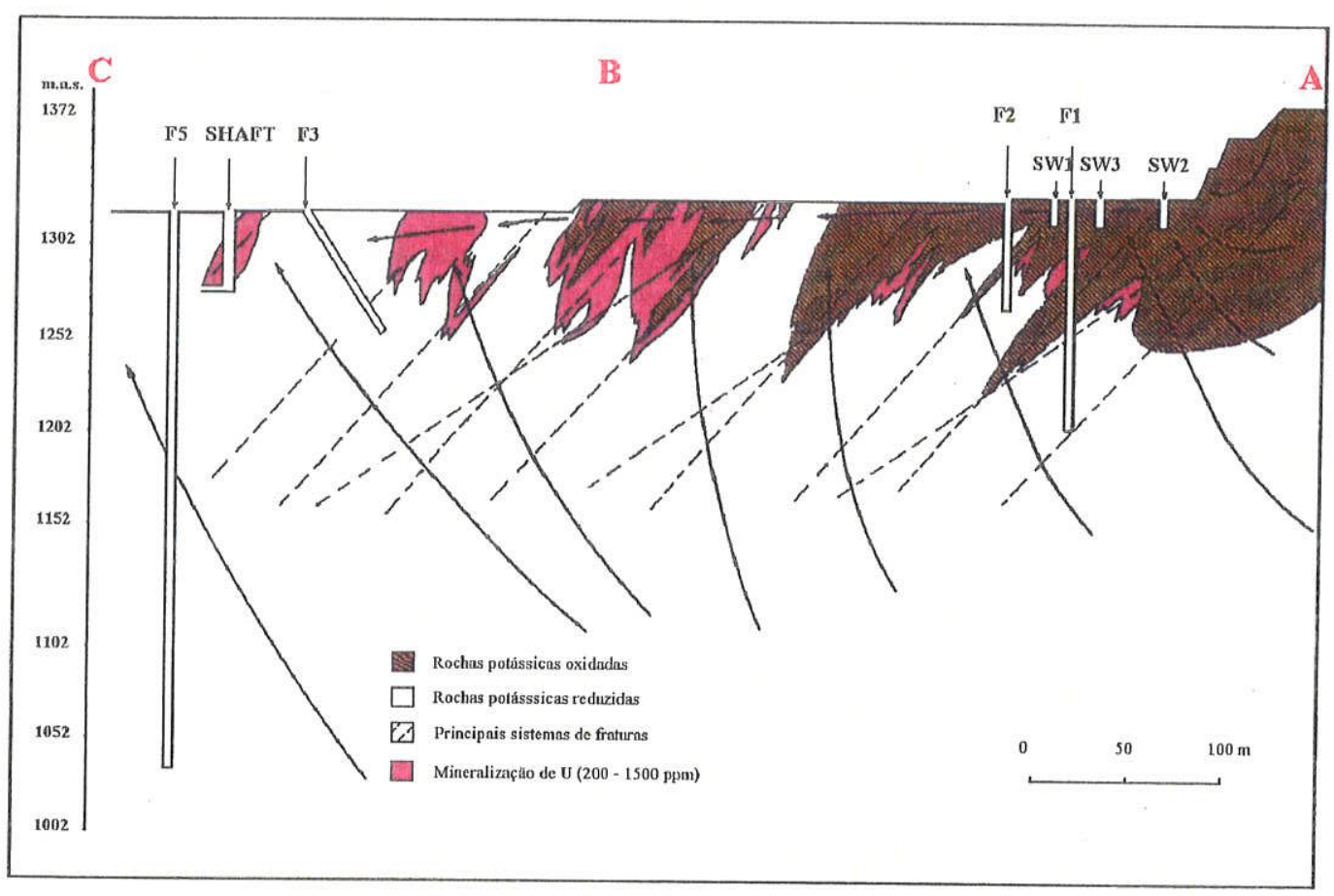

Figura 4: Perfil esquemático e modelo metalogenético da Mina de Urânio Osamu Utsumi, na parte SE do Complexo Alcalino de Poços de Caldas, MG. 


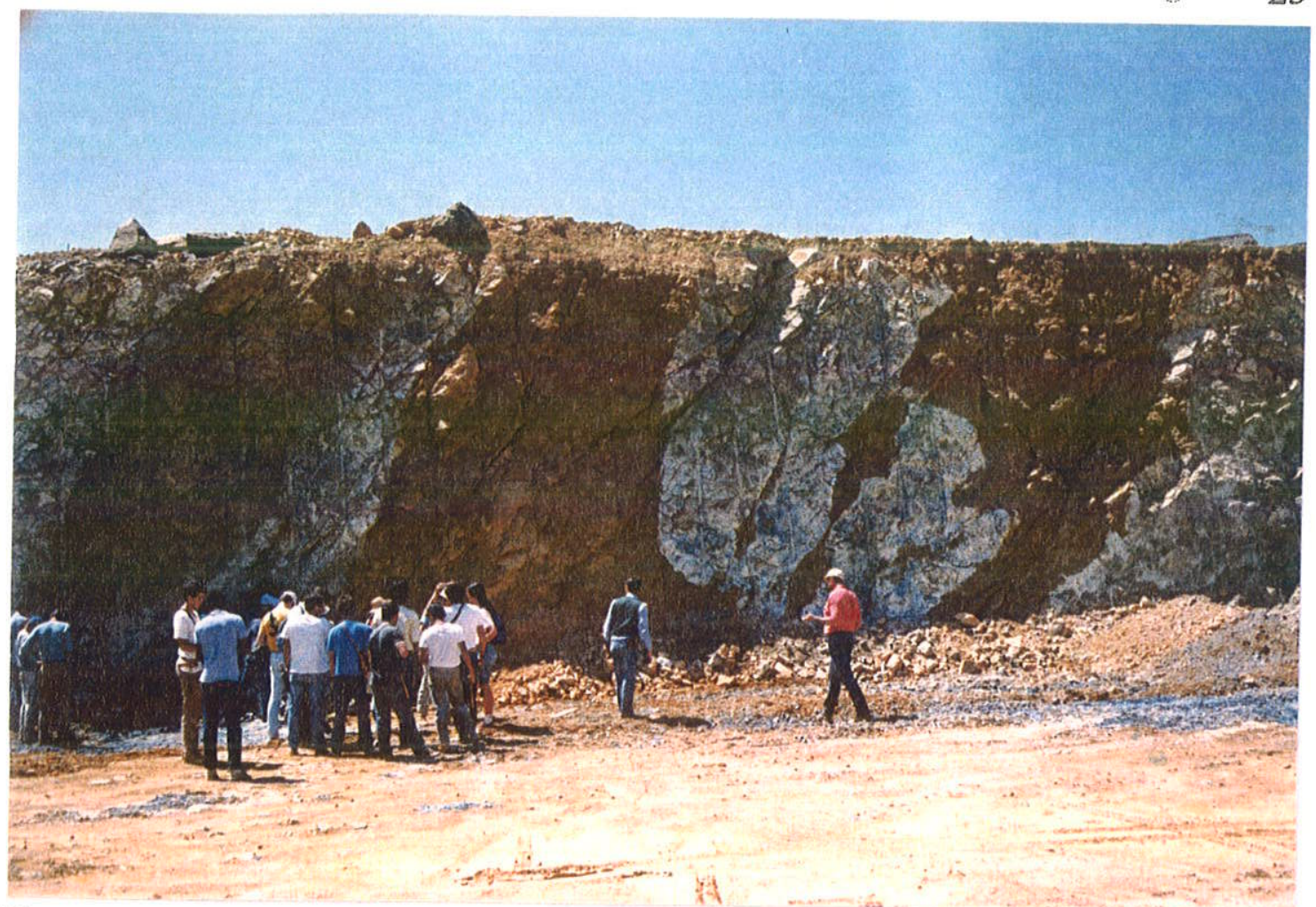

Foto 1: Frentes redox principal e secundárias da mina de urânio Osamu Utsumi. Observamos rochas reduzidas: azuis e oxidadas: marrom alaranjados e o processo de formação de macronódulos supergênicos a partir de frentes redox secundárias com mineralizacões ricas em U.

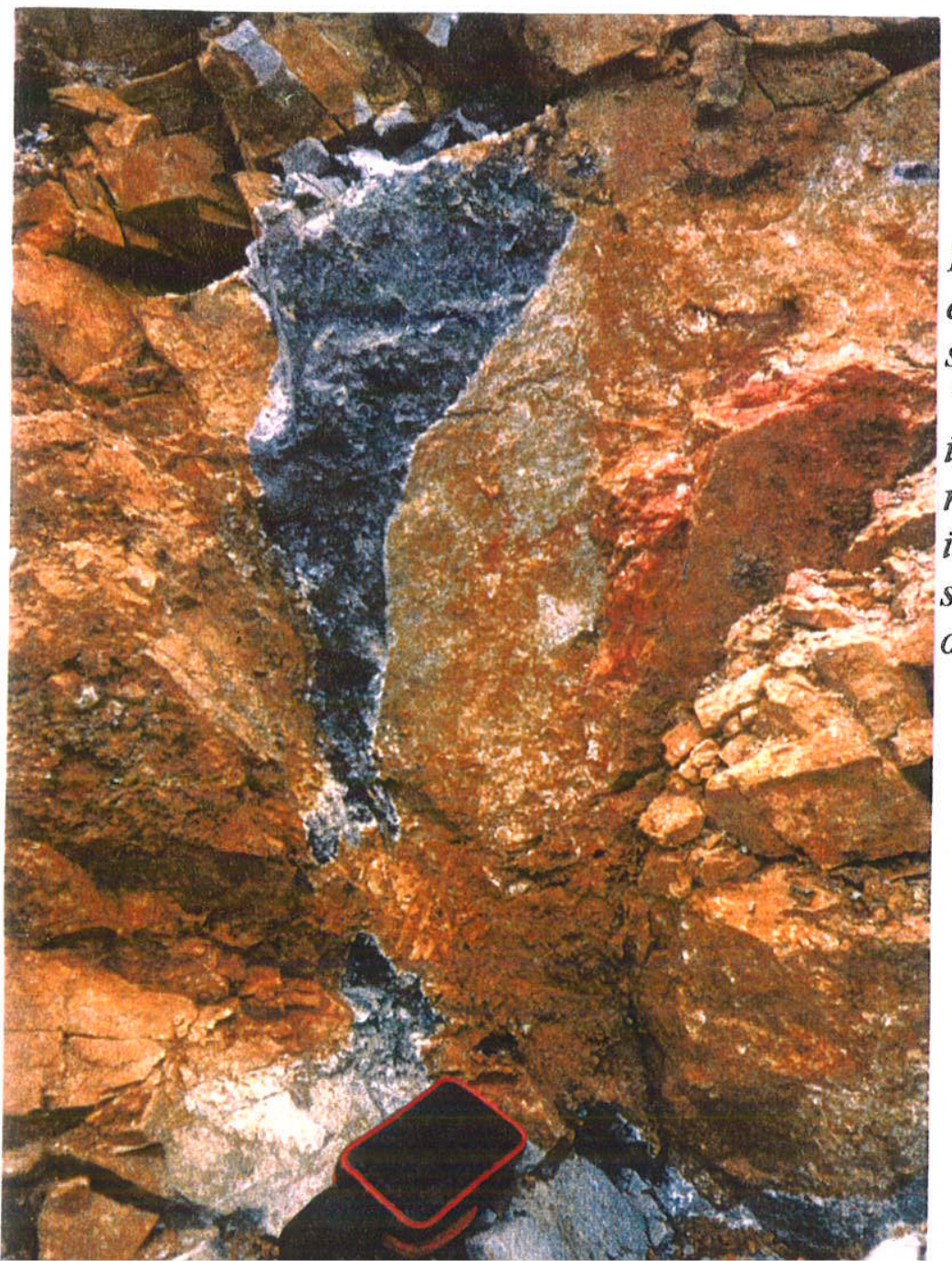

Foto 2: Detalhe do processo de formação de macronódulos supergênicos ricos em $U$, por "implosão", isto é, oxidação in situ de volumes de rochos reduzidas mineralizadas $e$ isoladas por frentes redox secundórias em ambiente oxidado. 


\section{PETROGRAFIA, MINERALOGLA E QUÍMICA}

\section{MINERAL}

Foram estudados os principais grupos litológicos e as mineralizações uraníferas da mina Osamu Utsumi (Figura 3): fonolitos $(\mathrm{Ph})$ e nefelina sienitos $(\mathrm{NeS})$ diversos, brechas vulcânicas $(\mathrm{Br})$, mineralizações hidrotermais e frentes redox. Sendo na mina de urânio, as rochas nefelínicas não-hidrotermalizadas restritas à um único tipo de $\mathrm{Ph}$ porfirítico e, portanto, sub-representadas em relação às variedades hidrotermalizadas, foram incluídos em estudos comparativos diversos tipos de $\mathrm{NeS}$ e $\mathrm{Ph}$ regionais e dados da literatura (Figura 2 e Anexo II).

$\mathrm{Na}$ lavra, predominam amplamente $\mathrm{Ph}, \mathrm{NeS}$ e $\mathrm{Br}$ hidrotermalizados, genericamente denominados de rochas potássicas. São preservados como hidrotermalitos reduzidos/piritizados mineralizados em $U$ (protominérios) nas partes mais profundas da cava e como hidrotermalitos oxidados/com OHF (saprolitos de intemperismo incipiente) depauperados em $U$, nas partes superficiais. As frentes redox separam os hidrotermalitos oxidados/com $\mathrm{OHF}$ dos equivalentes reduzidos/piritizados $\mathrm{e}$ compreendem, em suas partes oxidadas, as zonas de mobilização do U solúvel e nas partes reduzidas as zonas de reprecipitação e principal enriquecimento supergênico de U.

Certo destaque foi dado aos $\mathrm{Ph}$ porfiríticos não hidrotermalizados da borda $\mathrm{NW}$ da cava da mina (Figura 3), que apresentam a única transição contínua conhecida para equivalentes hidrotermalizados. Esta transição é bastante brusca, passando, num intervalo de cerca de 1 metro, de rochas de preservação magmática para hidrotermalitos reduzidos, totalmente transformados mineralogicamente, entretanto, com perfeita conservação estrutural e textural. A observação específica desse caso é confirmada pelos demais hidrotermalitos da mina que também preservaram suas características estruturais e texturais magmáticas, a despeito das transformações mineralógicas hidrotermais, o que permite correlações confiáveis com litotipos regionais equivalentes não hidrotermalizados. 


\subsection{FONOLITOS E NEFELINA SIENITOS NÃO-HIDROTERMALIZADOS}

\section{Petrografia e Mineralogia}

Os dados mineralógicos e petrográficos de $\mathrm{Ph}$ e $\mathrm{NeS}$ regionais e da mina Osamu Utsumi são resumidos na Tabela 1. De um modo geral, ressaltam sua variabilidade bastante restrita. Os $\mathrm{Ph}$ não-hidrotermalizados da mina foram ainda estudados por microssonda eletrônica, com análises WDS (Anexo III).

Entre os NeS e Ph predominam tipos hololeucocráticos a leucocráticos, sendo raros os tipos mesocráticos. Rochas máficas e ultramáficas ocorrem apenas como xenólitos nos $\mathrm{NeS}, \mathrm{Ph}$ e fragmentos nas $\mathrm{Br}$, sendo piroxenitos alcalinos variavelmente arredondados por resorção magmática. Sua composição é de $\geq 95 \%$ modais de aegirinamaugita e aegirina, além de minerais de minérios e apatita.

As diferenças mineralógicas qualitativas das rochas regionais consistem essencialmente nos tipos de feldspato alcalino, sanidina nos $\mathrm{Ph}$ e ortoclásio pertítico $\operatorname{nos} \mathrm{NeS}$, e nos constituintes menores típicos das rochas agpaíticas e miasquíticas. As diferenças quantitativas são limitadas à pequenas variações percentuais nas composições modais (Tabela 1). As principais diferenças petrográficas são de natureza estrutural/textural, distinguindo-se nos $\mathrm{Ph}$ tipos desde afaníticos (vulcânicos a subvulcânicos rasos) a faneríticos médios ('tinguaítos') equigranulares, de outros, fortemente porfiríticos a xenolíticos (transicionais para brechas magmáticas). Os $\mathrm{NeS}$ variam de tipos médios a grossos equigranulares a inequigranulares, às vezes xenolíticos, até tipos muito grossos pegmatíticos em veios e mobilizados miarolíticos, homogêneos ou zonados.

Os $\mathrm{Ph}$ não-hidrotermalizados da mina de urânio são tipos microporfiriticos leucocráticos de matriz muito fina, que perfaz 80 a $90 \%$ modais, sendo constituída por feldspato alcalino - sanidina $(0.01$ a $0.1 \mathrm{~mm})$, clinopiroxênio aegerina-augita $(0.05$ a $0.1 \mathrm{~mm})$, nefelina $(0.01$ a $0.03 \mathrm{~mm})$ parcialmente alterada para cancrinita, cada qual com 10 a $15 \%$ modais. Como minerais raros e acessórios ocorrem giannettita (1-3\% modais), aenigmatita $(<1 \%)$ e outras espécies menos comuns não identificadas, além de titanita, zircão e apatita. Os microfenocristais são de clinopiroxênios zonados $(0.3$ a $3 \mathrm{~mm})$, feldspato alcalino-sanidina $(0.5$ a $2 \mathrm{~mm})$, nefelina $(0.5$ a $2 \mathrm{~mm})$ parcialmente 
alterada para cancrinita e outros minerais criptocristalinos e, mais raramente, pseudoleucita, que, porém, pode apresentar granulação muito grossa (de até $10 \mathrm{~mm}$ ). Os clinopiroxênios zonados (Foto 3) variam de núcleos sódi-augíticos a bordas de aegirina-augita e aegirina, e como os microfenocristais de sanidina (Foto 4 ), também apresentam zonas de crescimento externas heteradcumuláticas muito ricas em inclusões poiquilíticas. Argilominerais, principalmente caolinita em quantidades diminutas, fluorita, carbonatos e zeolitas (natrolita entre outras) em microfraturas e veios são produtos de alteração autohidrotermal (Foto 5).

Nas zonas de transição para os hidrotermalitos reduzidos adjacentes e encaixantes, desaparecem, inicialmente, os minerais raros giannettita, aenigmatita e outros, por transformação em misturas criptocristalinas de argilominerais e óxi-hidróxidos de Fe e Mn; as nefelinas são transformadas progressivamente, até a substituição total, em pseudomorfos de ilita/sericita e caolinita; os clinopiroxênios são substituídos por misturas de argilominerais e minerais opacos e semiopacos (óxi-hidróxidos de $\mathrm{Fe} \mathrm{e}$ $\mathrm{Mn}$ ), e os feldspatos alcalinos são reequilibrados cristaloquimicamente para espécies triclínicas potássicas puras com argilização/caolinização incipiente associada. As pseudoleucitas sofreram transformações equivalentes aos feldspatos alcalinos e nefelinas magmáticos livres. Os minerais opacos, predominando hematita nas rochas de preservação magmática, são substituídos por pirita. Os minerais magmáticos mais resistentes às transformações hidrotermais são os feldspatos alcalinos, em primeiro lugar, e os clinopiroxênios, em segundo. Dos acessórios, apenas o zircão não sofre transformações, ocorrendo inclusive a neoformação de zircão hidrotermal intercrescido com baddeleyita.

Além dos $\mathrm{Ph}$ e $\mathrm{NeS}$, foram estudadas ainda brechas magmáticas regionais nãohidrotermalizadas. Estas pertencem a dois tipos distintos. As brechas de tipo mais comum são constituídas como matriz de $\mathrm{Ph}$ finos a afaníticos microporfiríticos e microxenolíticos e contém fragmentos, em geral, angulosos de $\mathrm{NeS}$ e demais $\mathrm{Ph}$ regionais. O segundo tipo é brechas especiais, de ocorrência mais restrita e, em geral, ricas em fragmentos ultramáficos. Por vezes, ocorrem fragmentos de rochas carbonáticas, incluindo possivelmente carbonatitos. Mais comuns e freqüentes são xenocristais idiomórficos até centimétricos de flogopitas individuais ou em 'livrinhos'. 
Às brechas deste tipo, associam-se aureólas de fenitização, que são consideradas de origens carbonatíticas e não serão mais aqui tratadas.

\section{Química Mineral}

As fases minerais magmáticas (feldspatos alcalinos, clinopiroxênios, nefelinas, leucitas, analcitas) dos $\mathrm{Ph}$ não-hidrotermalizados da mina de urânio foram estudadas por microssonda eletrônica-WDS (Anexo III). Foram consideradas as características texturais, distinguindo-se fenocristais de cristais da matriz, e as características cristaloquímicas de cristais individuais, como por exemplo, o zoneamento composicional do centro para a borda, principalmente de feldspatos alcalinos e clinopiroxênios.

Os feldspatos alcalinos apresentam composições pouco variáveis. Nos fenocristais, o zoneamento composicional é fraco e não-sistemático; em poucos casos foram observados fenocristais e/ou porções de fenocristais/exsoluções(?) albíticas. Em comparação, os feldspatos alcalinos da matriz apresentam tendência clara de enriquecimento em ortoclásio e também em $\mathrm{Fe}_{2} \mathrm{O}_{3}$.

Os fenocristais de clinopiroxênios, com zoneamento microscópico mais freqüente e nítido (Foto 3), apresentam núcleos que variam de augita sódica, com teores mais altos de $\mathrm{Ti}, \mathrm{Al}, \mathrm{Mg}$, $\mathrm{Ca}$ e mais baixos de $\mathrm{Si}, \mathrm{Fe}, \mathrm{Na}, \mathrm{Zr}$, à aegirina-augitas (com teores intermediários de todos esses elementos), e bordas de aegirina-augitas a aegirinas virtualmente puras com os teores mais elevados de $\mathrm{Si}, \mathrm{Fe}, \mathrm{Na}, \mathrm{Zr}$ e mais baixos de $\mathrm{Ti}$, $\mathrm{Al}, \mathrm{Mg}$ e Ca.

As nefelinas apresentam-se pouco variáveis com em torno de 16 e $6 \%$-de peso, respectivamente, de $\mathrm{Na}_{2} \mathrm{O}$ e $\mathrm{K}_{2} \mathrm{O}$, e cerca de $1 \%$-de peso de $\mathrm{Fe}_{2} \mathrm{O}_{3}$. As leucitas com preservação magmática homogêneas são mais raras e variam de 8-8,5\%-de peso de $\mathrm{Na}_{2} \mathrm{O}$, com 9,5\%-de peso de $\mathrm{K}_{2} \mathrm{O}$ e cerca de $1,5 \%$-de peso de $\mathrm{Fe}_{2} \mathrm{O}_{3}$. As analcitas são raras e virtualmente puras.

As demais fases analisadas foram:

- minerais opacos e semi-opacos não-identificados microscopicamente, que ocorrem livres na matriz e em inclusões diminutas nos clinopiroxênios;

- produtos de alteração da nefelina; 
- fluorita e outros minerais hidrotermais em massas criptocristalinas preenchendo fraturas.

São todas análises semiquantitativas a qualitativas, de valor apenas para uma primeira orientação cristaloquímica e /ou geoquímica.

\subsection{HIDROTERMALITOS E FRENTES REDOX DA MINA DE URÂNIO OSAMU UTSUMI}

\subsubsection{HIDROTERMALITOS}

\section{Petrografia e Mineralogia}

Os $\mathrm{Ph}, \mathrm{NeS}$ e as $\mathrm{Br}$ hidrotermalizados da mina de urânio apresentam a mesma variabilidade estrutural/textural observada nos equivalentes regionais nãohidotermalizados, permitindo reconstruir a mineralogia magmática original das rochas transformadas. Analogamente às rochas não-hidrotermalizadas, apresentam entre si, também, grande similaridade mineralógica. Desta maneira, serão aqui tratadas em conjunto, distinguindo-se apenas entre hidrotermalitos reduzidos/piritizados e oxidados/com OHF.

Os $\mathrm{Ph}$ hidrotemalizados, reduzidos/piritizados e oxidados/com OHF, são as rochas mais abundantes na mina Osamu Utsumi, formando corpos subvulcânicos de gerações estruturais, texturais, composicionais-mineralógicas e de idades diferentes (Figura 3). $\mathrm{Na}$ ordem da abundância e idade relativa decrescente, ocorrem: (1)-Ph faneríticos de granulação média equigranulares a subequigranulares ('tinguaítos') subvulcânicos, em sua maioria hololeucocráticos, sendo que subtipos algo mais máficos foram denominados de clinopiroxênio fonolitos por Waber et al. (1992); (2)-pseudoleucita (Plc) $\mathrm{Ph}$ fortemente porfiríticos com abundantes fenocristais de Plc muito grossos ( $>2$ - $\geq 10 \mathrm{~cm}$ ) que chegam até a predominar em volume sobre a matriz de granulação média, também subvulcânicos, e (3)- $\mathrm{Ph}$ afaníticos a faneríticos muito finos fracamente porfiríticos (com fenocristais esparsos de Plc até centimétricos) comumente com estrutura fluidal, vulcânicos a subvulcânicos rasos. Variedades subordinadas destes $\mathrm{Ph}$ incluem tipos tufisíticos a ultra-fluidais fortemente microvesiculares e ricos em 
xenólitos angulosos (de $\mathrm{Ph}$ e NeS), que por vezes, gradam para os corpos de brechas magmáticas. A mineralogia global dos $\mathrm{Ph}$ hidrotermalizados reduzidos e oxidados é sumarizada na Tabela 1, em comparação às rochas equivalentes de preservação magmática (não-hidrotermalizadas).

Os hidrotermalitos reduzidos e oxidados de NeS são subordinados em abundância, e

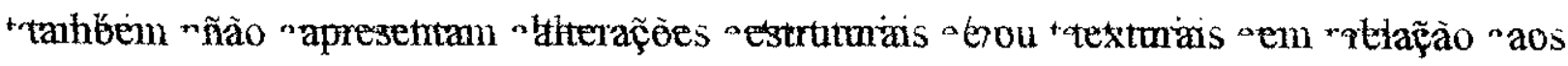
equivalentes regionais, exceção feita às microtexturas de pseudomorfização hidrotermal (Tabela 1). São rochas hololeucocráticas a, mais raramente, leucocráticas, grossas, por vezes algo inequigranulares até com megacristais de feldspato alcalino (ortoclásio variavelmente pertítico reequilibrado estrutural e quimicamente para feldspato potássico puro triclínico). São ainda xenolíticas, com fragmentos de $\mathrm{Ph}$ subvulcânicos e vulcânicos, dos estágios magmáticos anteriores, arredondados por resorção magmática, sendo que, no local da mina de urânio, os NeS seguiram-se aos $\mathrm{Ph}$ subvulcânicos da primeira geração ('tinguaitos') e foram sucedidos pelos $\mathrm{PlcPh}$ (com Plc muito grossas) e pelos $\mathrm{Ph}$ afaníticos a faneríticos muito finos finais.

As brechas hidrotermalizadas (Br) são o terceiro grupo em abundância (Foto 6), sendo as brechas reduzidas o principal sítio da mineralização uranífera hidrotermal. Os fragmentos observados são de $\mathrm{Ph}$ e NeS diversos, além de brechas. Esses fragmentos não se distinguem quanto ao tipo de alteração hidrotermal das rochas não-brechadas da mina, entretanto, é geneticamente notável que a intensidade da alteração hidrotermal de fragmentos associados possa variar. Dessa forma, ocorrem, inclusive em uma única amostra de mão, fragmentos de $\mathrm{Ph}$ e/ou NeS totalmente hidrotermalizados junto com outros incipientemente transformados ou mesmo isentos de alteração hidrotermal (com nefelina e/ou aegirina preservada). A mineralização uranifera hipogênica ocorre principalmente na matriz das $\mathrm{Br}$ cimentando os fragmentos (Foto 7).

As principais transformações mineralógicas hidrotermais e supergênicas depreendemse da Tabela 1. A seguir são dados alguns detalhamentos dos processos petrometalogenéticos hidrotermais.

$\rightarrow$ A substituição drástica envolvendo modificação composicional e estrutural dos feldspatos alcalinos magmáticos predominantes, sanidinas nos $\mathrm{Ph}$ e ortoclásios pertíticos nos NeS, para microclínios virtualmente puros de triclinicidade máxima (Waber et al., 1992). Nesse processo de interação fluido-rochas, a troca de álcalis de 
$\mathrm{Na}^{+}$do retículo cristalino dos feldspatos por $\mathrm{K}^{+}$da solução é acompanhada, ainda, pela formação de inclusões fluidas, caolinização incipiente e piritização interna fina e esparsa, provavelmente a partir dos teores de Fe originais dos feldspatos alcalinos magmáticos (Anexo III; cf. M. Ulbrich et al., 1984) e $\mathrm{S}^{2-} / \mathrm{HS}^{-}$do fluido hidrotermal redutor.

$\rightarrow$ A substituição completa da nefelina por caolinita, illita/sericita e pirita disseminada gera pseudomorfos com zoneamento mineralógico nem sempre muito regular, compostos, no centro das antigas nefelinas, de caolinita e pirita, com illitas/sericitas micro-idioblásticas esparsas a abundantes como constituinte adicional apenas nas bordas. A caolinita apresenta tipicamente granulometria média $\leq 2 \mu \mathrm{m}$ (cristais em 'livrinhos' mais grossos são muito raros), enquanto que a illita/sericita é microidioblástica e sempre consideravelmente mais grossa, na faixa de 15-50 $\mu \mathrm{m}$, crescendo sobre a pirita (que permanece como inclusões) e substituindo a caolinita.

Illita/sericita forma-se pela substituição progressiva da caolinita, sob atividade crescente de $\mathrm{K}^{+}$no fluido; a pirita é originada a partir dos teores originais de $\mathrm{Fe}$ da nefelina magmática (Anexo III; cf. M. Ulbrich et al., 1984), em analogia ao que ocorre nos feldspatos alcalinos.

$\rightarrow$ A substituição das pseudoleucitas (Plc) ocorre pelos dois processos supradescritos, participando proporcionalmente em função da composição das Plc.

$\rightarrow$ O clinopiroxênio idiomórfico a hipidiomórfico é pseudomorfizado por agregados criptocristalinos de óxidos e/ou silicatos de $\mathrm{Ti}$ e eventualmente $\mathrm{Fe}$ associados a argilominerais, caolinita, esmectita e pirita.

$\rightarrow$ Como minerais acessórios mais comuns dos $\mathrm{Ph}$ e $\mathrm{NeS}$ regionais, ocorrem em proporções variáveis, totalizando até $1.5-2 \%$ vol., titanita, zircões e apatitas euedrais. Destes, a titanita e a apatita desaparecem no processo hidrotermal; o zircão magmático nada sofre, sendo afetado apenas por supercrescimentos hidrotermais de zircão intercrescido com baddeleyita; essa associação ocorre também como fase independente de precipitação hidrotermal intersticial, sendo sempre e tipicamente relacionada aos processos mineralizantes uraniferos.

$\rightarrow$ Os minerais raros magmáticos e pós-magmáticos, como giannettita, eventualmente eudialita e todos os demais (lamprofilita, goetzenita, aenigmatita, etc.) (Atencio et al., 
1996, 1999; Gualda e Vlach, 1996, 1998) desaparecem por dissolução nos processos hidrotermais, restando apenas óxi-hidróxidos de Fe e Mn com altos teores de ETR, Zr, U e Th co-precipitados e em solução.

$\rightarrow$ A fluorita ocorre como preenchimento intersticial na matriz, em fraturas e cavidades, intercrescida com carbonatos, pirita, zircão e microclínio. Sua granulação varia de $<0.2 \mathrm{~mm} \mathrm{a}>10 \mathrm{~mm}$. É, em geral, incolor a amarelada, entretanto, comumente apresenta centros de cor azul-lilás, que podem ser abundantes tingindo cristais inteiros. $\rightarrow$ A barita aparece como um mineral raro, em cristais finos preenchendo fraturas ou interstícios; as evidências texturais apontam para uma origem hidrotermal tardia.

$\rightarrow$ Carbonato varia de fase muito rara a abundante formada nos processos hidrotermais tardios. Ocorre principalmente nas matrizes/cimentos das $\mathrm{Br}$ e, eventualmente, nos $\mathrm{Ph}$ e NeS em fraturas, veios e impregnações laterais decorrentes, relacionadas aos processos finais das brechas. Acompanha sempre a fluorita como constituinte em geral subordinado, porém, típico.

$\rightarrow$ As piritas são os principais minerais opacos-metálicos, e ocorrem finamente disseminadas por toda rocha, na matriz, nas bordas dos grãos e no interior dos minerais magmáticos pseudomorfizados (feldspatos alcalinos, nefelinas e clinopiroxênios); ocorrem também como preenchimento de cavidades miarolíticas e em fraturas, nesses casos em cristais maiores idiomórficos até centimétricos.

$\rightarrow$ Nos $\mathrm{Ph}$ e N, os minerais de urânio e uraníferos formaram-se junto com outras fases da mineralização, durante todo o evento hidrotermal, e aparecem disseminados e enriquecidos em fraturas, veios, porosidades e micromiárolos. São associados a sulfetos, principalmente pirita, subordinadamente esfalerita, molibdenita, jordisita (MoS amorfo) e mais raramente, galena, calcopirita, pirrotita, pentlandita, fluorita roxa, minerais complexos de U, Th, ETR, Ti e $\mathrm{Zr}$, entre estes zircão hidrotermal intercrescido com baddeleyita ('caldasito'), monazita, cheralita, crandalita, florencita, gorceixita, goyazita, brannerita. Um mineral específico de $U$, indicado em autorradiografias, provavelmente uraninita micro a criptocristalina, não foi confirmado oticamente pela granulação muito fina $(<1 \mu \mathrm{m})$.

$\rightarrow$ Nas brechas, como principal sítio da mineralização uranífera hidrotermal, todos esses minerais ocorrem em diferentes gerações texturais e cronológicas com variações 
composicionais. Distinguem-se assembléias 'pré-brechas' nos fragmentos de $\mathrm{Ph}$ e NeS, variavelmente hidrotermalizados; 'sin-brecha' e 'pós-brecha' como veios de piritização e argilização, cortando as brechas (matriz e fragmentos). Os cimentos 'sinbrecha' apresentam as mais elevadas concentrações de minerais uraniferos/radioativos (Foto 7). Algumas das amostras mineralizadas mais ricas foram selecionadas para estudos por MEV - EDS (Fotos 8 a 19, Tabela 2).

Os hidrotermalitos oxidados (de $\mathrm{Ph}$, NeS e $\mathrm{Br}$ ) da mina de urânio apresentam essencialmente a mesma mineralogia principal dos equivalentes reduzidos, quanto às fases silicáticas. Certa exceção diz respeito ao feldspato potássico hidrotermal, que se apresenta algo mais fortemente caolinizado e pigmentado por OHF da oxidação das inclusões de piritas (Fotos 20 e 21). Entretanto, o seu desaparecimento abrupto ocorre tão somente na transição das rochas oxidadas para a zona de 'solos lateríticos', excluída desta pesquisa. As principais características dos processos supergênicos e dos hidrotermalitos oxidados residem nos constituintes menores, sendo:

- oxidação e dissolução até o desaparecimento total da pirita e demais sulfetos;

- formação abundante de OHF pela oxidação das piritas e outros sulfetos de Fe;

- formação subordinada e mais irregular de minerais secundários de Mo, por exemplo ilsemanita, pela oxidação da molibdenita e jordisita;

- desaparecimento por dissolução da fluorita;

- desaparecimento por dissolução dos carbonatos;

- dissolução parcial dos minerais uraníferos, sendo a radioatividade residual relacionada a minerais resistentes aos processos supergênicos com $U$ em pequenas concentrações (p.ex. zircão, baddeleyita, minerais de ETR), assim como aos OHF por adsorção e/ou coprecipitação.

As observações mineralógico-petrográficas desse trabalho complementam e confirmam no essencial as descrições da literatura (cf. Ellert, 1959; Ulbrich, M., 1983; Ulbrich, M. et al., 1984; Ulbrich, H., 1984; Garda, 1990; Schorscher e Shea, 1992; Waber et al., 1992; entre outros). 


\section{Química Mineral}

Estudos de MEV-EDS semiquantitativos foram realizados para caracterizar os minerais de urânio e uraníferos primários hidrotermais, ainda não definidos na literatura. Os resultados identificaram diversas fases individuais e misturas dessas,

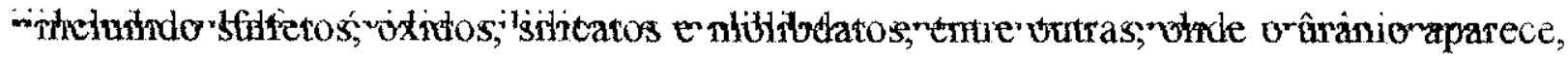
em muitos casos, como elemento maior, com teores (de U) de 0.65 - 39\%-peso (Fotos 8 a 19; Tabela 2). Entretanto, um mineral específico de U, embora indicado, não pode ser definido por limitações operacionais, podendo tratar-se de uraninita e/ou pitchblenda micro a criptocristalinas.

As fases minerais hidrotermais representadas por feldspatos alcalinos reequilibrados $\mathrm{e}$ ilitas/sericitas da matriz e que pseudomorfizam nefelinas, foram analisadas por microssonda eletrônica-WDS (Anexo III). Os feldspatos alcalinos (matriz e fenocristais, centros a bordas) apresentam-se virtualmente homogêneos, com teores de $\mathrm{K}_{2} \mathrm{O}$ de $15.5-16.1 \%$, e de $\mathrm{Na}_{2} \mathrm{O}$ de $0.2-1 \%$. As ilitas/sericitas que pseudomorfizam fenocristais de nefelina são algo mais ricas em $\mathrm{Fe}_{2} \mathrm{O}_{3}(1.9-3.2 \%$ em peso) em relação aos cristais da matriz (0.8-3.9\% em peso), o inverso acontecendo com os teores de $\mathrm{K}_{2} \mathrm{O}$ e $\mathrm{MgO}$.

Outras fases hidrotermais, como caolinitas, zircões, fluoritas, rutilos, piritas e minerais de $\mathrm{U}$ foram estudadas pelo orientador (Schorscher, 1991); alguns destes dados encontram-se reproduzidos no Anexo IIII e abaixo comentados.

As caolinitas apresentaram dificuldades e alguns problemas analíticos em decorrência de sua granulometria muito fina e instabilidade sob o feixe de elétrons, além de contaminações com $\mathrm{Pb}$ dos discos de polimento. As análises obtidas nos cristais em 'livrinhos' mais grossos $(10-30 \mu \mathrm{m})$ apresentaram como única impureza química mais freqüente e sistemática teores de $\mathrm{FeO}$ de 0.4-0.6\%-peso; valores eventuais de $\mathrm{Na}_{2} \mathrm{O}$ (<0.1\%-peso) e MgO (<0.3\%-peso) podem ser desconsiderados. Os zircões hidrotermais, tipicamente associados às mineralizações uraníferas hipógenas, indicaram teores de $\mathrm{U}$ e Th apenas esporadicamente. As fluoritas apresentam composições virtualmente puras, com teores de $\mathrm{K}_{2} \mathrm{O}$ e $\mathrm{Na}_{2} \mathrm{O}$ sempre < $1 \%$-peso, podendo estar correlacionados aos fluidos de inclusões fluidas; $U$ e Th não foram detectados, e a presença de $\mathrm{Y}$ está relacionada mais tipicamente às variedades com 
centros de cores azuis (violetas a roxas). Os rutilos, prováveis produtos de alteração dos clinopiroxênios (aegirina-augitas), apresentam teores de $\mathrm{Si}, \mathrm{Al}$ e Fe, além de $\mathrm{Nb}$ e $\mathrm{Y}$. Por fim, as piritas são minerais muito puros, apenas com traços de $\mathrm{As}$ e $\mathrm{Pb}$, este último, por contaminação com os discos de polimento.

\subsubsection{FRENTES REDOX E MINERALIZAÇÃo SUPERGÊNICA dE U}

\section{Petrografia e Mineralogia: Frentes Redox}

As frentes redox são feições de destaque, resultantes dos processos supergênicos relacionados ao lençol freático, e enfoque principal dessa pesquisa. São zonas estreitas, em geral não excedendo aos $20-30 \mathrm{~cm}$, excepcionalmente atingindo até 2 metros de largura, bem definidas, e evidenciadas no campo pela mudança drástica na coloração das rochas, de cinza azuladas para marrom avermelhadas (Fotos 22, 23). Nessas frentes ocorre, geologicamente, a transformação, por oxidação, dos hidrotermalitos reduzidos/piritizados para oxidados/com OHF associada à formação da principal mineralização uranífera, em conjunto com o desaparecimento das piritas e demais sulfetos e a liberação de ácido sulfúrico. A oxidação das piritas ocorre em geral intervalo de poucos milímetros na zona de saturação do lençol freático. Todavia, algumas piritas em dissolução persistem ainda por vários centímetros na rocha oxidada, mais freqüentemente em frentes redox desenvolvidas em zonas insaturadas. Assim, a disposição em relação ao lençol freático, as variações do nível do lençol freático e as condições de oxi-redução (Eh) em função da difusão de $\mathrm{O}_{2}$ nas águas da zona de saturação e nas respectivas reações fluídos-rochas, propiciaram nas rochas afetadas frentes redox com propriedades mineralógicas e expressão macroscópicafisiográfica variáveis em função das condições supra locais.

A petrografia macroscópica de detalhe, em amostras de mão, permitiu identificar cinco tipos principais de frentes redox, além de combinações destes em frentes complexas: (1)-no primeiro tipo ocorrem na rocha oxidada, no contato com a rocha reduzida, fortes enriquecimentos de OHF em zonas ferruginosas sem restos de pirita, de espessuras variáveis, nilimétricas a centimétricas, sendo lateralmente contínuas 
acompanhando a frente redox; essas zonas tem contato brusco com as rochas reduzidas na interface da frente redox e gradacional, por diminuição de OHF, com a continuação das rochas oxidadas (Foto 24);

(2)-o segundo tipo é caracterizado por uma zona branca milimétrica (até $1-2 \mathrm{~cm}$ ) sem OHF e com apenas algumas piritas metaestáveis em restos corroídos de dissolução incompleta, que separa as rochas oxidada (homogênea quanto à distribuição de OHF, sem pirita) e reduzida (não-alterada quanto ao teor e a distribuição de piritas hidrotermais) (Foto 25);

(3)-o terceiro tipo é definido pela precipitação/distribuição dos OHF na rocha oxidada em alternâncias rítmicas de zonas finas milimétricas mais e menos ferruginosas, podendo ocorrer restos de pequenos cristais de pirita corroídos, metaestáveis, de dissolução incompleta, em diminutas quantidades nas bandas menos ferruginosas (Fotos 26 e 27);

(4)-o quarto tipo é representado por um contato direto por interface nítida muito bem definida, separando as rochas reduzidas (inalteradas) e oxidadas (homogêneas quanto a distribuição e tingimento por OHF) sem qualquer zoneamento e/ou outra irregularidade adicional nova relacionada ao desenvolvimento dessas frentes (Foto 28).

(5)-o quinto tipo é mais variável quanto às distribuições/tingimentos de OHF nas rochas oxidadas, que podem ser homogêneas até heterogêneas-irregulares; é caracterizado principalmente pela ocorrência associada (nas rochas oxidadas) de OHF concentrados em agregados virtualmente puros, de tamanhos e estruturas diferentes, ora preenchendo pequenos cubos, que são pseudomorfos de piritas hidrotermais pretéritas, idiomórficas em cristais individuais esparsos, ora pseudomorfizando concreções maiores policristalinas de pirita, de formas irregulares e tamanhos variáveis, milimétricos a centimétricos, comumente ainda com alguma pirita metaestável preservada em restos de oxidação incompleta (Foto 21).

Esses tipos representam:

(1)-Frentes redox imersas na zona de saturação, estagnadas (inativas e imóveis) por redução/defíciência do potencial redox na água desta zona, aliado, ainda, ao rebaixamento do nível do lençol freático. Assim, ocorreria, ao longo da interface da frente redox estagnada e imóvel, a concentração dos colóides de OHF em suspensão na 
parte oxidada do freático, acima da frente redox, por efeitos combinados de decantação e filtração acompanhando o rebaixamento do nível do freático;

(2)-Frentes redox também imersas na zona de saturação, entretanto ativas, ainda que em progressão lenta, retardada pelo rebaixamento do lençol e redução do volume do freático, aliado à redução moderada do potencial de oxi-redução nas águas do freático. Essas condições causariam, na zona da frente, simultaneamente Eh menor e maiores concentrações de $\mathrm{H}_{2} \mathrm{SO}_{4}$, que impediriam a formação de $\mathrm{OHF}$, originando assim a zona branca fina, virtualmente isenta de pirita e demais sulfetos, uraninita/pitchblenda, e sem OHF, onde estariam presentes essencialmente sulfatos di e trivalentes de Fe em equilibrio e em solução bastante concentrada (na água do freático). A formação e precipitação de OHF ocorreria apenas após diluição e hidrólise dos sulfatos trivalentes de Fe, à certa distância da interface com as rochas reduzidas, definindo a largura da zona branca (de 1-2 $\mathrm{mm}$ a $1-2 \mathrm{~cm}$ ) e condicionando a sua passagem para as rochas oxidadas típicas com OHF.

ntes redox imersas no freático com zona de saturação pouco espessa, ativas sob aniwiancias cíclicas e rítmicas das condições dos tipos 1 e 2 , ou 2 e 4, eventualmente, retratando mudanças sazonais das condições climáticas.

(4)-Frentes redox mais ativas, imersas no freático, com zona de saturação de volume expressivo, atenuando, assim, as influências de eventuais variações de curta duração sobre as condições de Eh e pH do lençol. Portanto, em progressão sob condições de equilíbrio/desequilíbrio de constância secular considerando: avanço da frente, potencial redox, acidez, rebaixamento e alimentação/recarga do freático.

(5)-Frentes redox caracterizadas na rocha oxidada pela substituição pseudomórfica direta das piritas pretéritas, por precipitação in situ de OHF indígenos, comumente com a preservação metaestável de piritas corroídas em restos de substituição incompleta, indicando, claramente, condições predominantes de oxidação das piritas ao ar, na zona de insaturação acima do nível médio do freático. A escassez de fluídos (água do freático) temporária a permanente, neste horizonte do perfil de alteração supergênica por oxi-redução, impediu a dissolução das piritas e decorrente exportação e redistribuição do $\mathrm{Fe}$ na forma de OHF dispersos, condicionando a substituição pseudomórfica das piritas sur place. 
Varią̧ões seculares nas condições físico-químicas, durante o desenvolvimento geológico do perfil de alteração supergênica por oxi-redução e variações associadas do lençol freático, durante os últimos 76 Ma (Schorscher e Shea, 1992; Shea, 1992; Schorscher e Osmond, 1992), reforçadas por processos/condições locais da evolução estrutural e morfológica, deixaram seus registros em intervalos por vezes restritos, centimétricos a decimétricos, desse perfil, na forma de frentes redox denominadas de frentes complexas (Foto 29). Trata-se, de fato, de sucessões temporais de frentes redox de tipos distintos desenvolvidas, ora em sucessões espaciais estreitas, ora mesmo em superposição espacial, quando a tectônica local de blocos e/ou subidas mais duradouras do lençol freático causaram a reinundação de frentes redox anteriores/fósseis pela zona de saturação do lençol freático.

De um modo geral, constatou-se que as zonas reduzidas das frentes redox resumem-se aos próprios hidrotermalitos reduzidos, com algumas particularidades quanto à formação e distribuição da mineralização supergênica rica de $U$ com pirita associada, também supergênica (ver ítem a seguir). Essas peculiaridades, assim como heterogeneidades hidrotermais-primárias, que também consistiam, via de regra, em concentrações locais maiores, principalmente de pirita, além de outros sulfetos e uraninita/pitchhblenda, causaram efeitos locais, como maiores concentrações de $\mathrm{H}_{2} \mathrm{SO}_{4}$ que inibiam a precipitação de OHF na zona saturada, ou ainda, proporcionavam a preservação de pirita metaestável na zona insaturada, superimpostos a qualquer tipo de frente redox, simples ou complexa.

Na zona oxidada, os OHF formados da oxidação da pirita são, além de argilominerais - principalmente caolinita, da decomposição intempérica dos feldspatos alcalinos - os principais minerais neoformados. Os OHF apresentam uma seqüência progressiva de alteração e desidratação para espécies de maior cristalinidade, de OHF amorfos $\rightarrow$ OHF de cristalinidade baixa e irregular $\rightarrow$ goethita (e eventualmente lepidocrocita) $\rightarrow$ hematita, o que ocorre ao longo do perfil geológico, onde os OHF de mais baixa cristalinidade se encontram próximos às frentes (principalmente quando de desenvolvimento mais recente), e goethita e hematita predominam nos solos lateríticos superficiais (Waber et al., 1992). Os OHF de baixa cristalinidade são fases geoquimicamente muito ativas e fixam, por adsorção e/ou co-precipitação, metais pesados como Cu (Veiga et al., 1991), Cd, Zn (Spark et al., 1995) e, principalmente, U 
e seus radionuclídeos (Edghill, 1991; Waite et al., 1994; Bruno et al., 1995; Murakami et al., 1997; Bruno et al., 1998; De Putter et al., 1999; entre outros). Os OHF representam assim, um grupo de minerais de eminente importância científica fundamental e de aplicação em metalogênese, tecnologia e ciências ambientais.

\section{Petrografia e Mineralogia: Mineralização supergênica rica de $U$}

A mineralização supergênica rica de $U$ é restrita à uma faixa centimétrica, em média de 10-15 cm, eventualmente mais larga, ou mesmo ausente, na zona de hidrotermalitos reduzidos imediatamente adjacente à frente redox. Uma largura máxima de até $2 \mathrm{~m}$ foi observada numa frente redox da parte NW da cava da mina (Figura 3). Entretanto, mesmo na ausência de uma mineralização de qualquer significado econômico, sempre em anomalias geoquímicas típicas do enriquecimento supergênico de $U$ nessas zonas.

A mineralização supergênica rica predominante ocorre em micronódulos de diâmetro milimétrico a centimétrico, ora homogêneos, ora com estruturas concêntricas de cor preta, dada pelas altas concentrações de uraninita/pitchblenda associada às disseminações finas também de uraninita/pitchblenda criptocristalina (Fotos 30 a, b). A formação desses nódulos inicia-se ao longo das bordas dos grãos, na continuidade do crescimento intergranular, envolvendo e dissolvendo todos os minerais silicáticos e gerando porosidades preenchidas em seqüência, progressivamente, pela precipitação principalmente de uraninita/pitchblenda (Fotos 31 a, b). Um segundo tipo de mineralização supergênica rica é representado por concreções macronodulares arredondadas a botrioidais, com dimensão máxima observada de $\sim 20 \mathrm{~cm}$ e peso de até $\geq 1 \mathrm{~kg}$ de pitchblenda/uraninita maciça que envolvem sempre um núcleo silicático das rocha reduzidas (Fotos 32 a, b). Essas concreções resultaram da oxidação e colapso in situ ("implosão"), por frentes redox secundárias, de volumes maiores (dezenas de $\mathrm{m}^{3}$ ) de rochas reduzidas com mineralização hipogênica de $U$, isoladas, por suas propriedades estruturais, de porosidade e permeabilidade especificas e de maior resistência a alteração supergênica, em meio às rochas predominantes já oxidadas pelo avanço da frente redox principal (cf. pág. 19; Fotos 1 e 2, pág. 23). Tanto nos micro 
quanto nos macronódulos observou-se ainda, a formação de uma segunda geração de piritas (Fotos 31 a, b e 32 a, b) assim como do sulfeto de Cd-greenockita.

Um outro tipo de enriquecimentos supergênico de $U$ é observado ainda, nas frentes redox de tipo 1, que têm como característica principal o forte enriquecimento de OHF, originando verdadeiras zonas ferruginosas na rocha oxidada, no contato com a frente (Foto 24). Estas zonas ferruginosas também são caracterizadas por altos teores de $U$, acima de 1000 ppm (tabela 5, pontos 028-3, 028-4, 028-5 e 028-8).

\section{Microscopia Eletrônica e Química Mineral}

Esses estudos complementam as informações e ilustram com detalhes os processos supra descritos. A foto 33 mostra a mineralização supergênica rica de $U$, com pitchblenda botrioidal e vermiforme crescendo sobre os minerais silicáticos da matriz e piritas da segunda geração, no caso de um macronódulo de uraninita/pitchblenda maciça, sendo uma visão geral de MEV da amostra da foto $21 \mathrm{~b}$. A foto 34 detalha a superficie e o início do crescimento da pitchblenda sobre uma face da pirita da segunda geração, em arranjos finamente zonados e ornamentados, sugerindo a atuação de atividade biogênica. A foto 35 evidencia, na mesma amostra, a criptocristalinidade da pitchblenda botrioidal e seu crescimento zonado. Uma outra forma de mineralização supergênica rica é representada por uraninita/pitchblenda criptocristalina, finamente disseminada, crescida com textura vermiforme intersticial, sobre fraturas e bordas de grãos dos minerais silicáticos da matriz (Foto 36).

Os OHF exógenos disseminados na rocha oxidada (Foto 37) são provenientes da dissolução oxidante das piritas hidrotermais (Foto 38), em ambiente de saturação do lençol freático, com decorrente homogeneização e diluição do $\mathrm{Fe}^{3+}$ em solução, até a sua precipitação dispersa como OHF exógenos por toda a rocha. Já a precipitação de OHF indígenos que pseudomorfizam o cristal de pirita (Foto 39), acontece sob condições de insaturação em relação ao lençol freático, predominando a oxidação ao ar, face à falta de fluidos (i.e. água do freático).

Os estudos de MEV incluíram ainda, algumas observações complementares das fases silicáticas e radioativas nas rochas reduzidas. A foto $\mathbf{4 0}$ mostra um feldspato potássico da rocha reduzida em estágio inicial de substituição, ainda incompleta, por caolinita 
hidrotermal bem cristalizada (Fotos 40 e 41), contendo inclusões de minerais radioativos hidrotermais envolvidos por auréolas de corrosão (Foto 42). Tais auréolas se devem à radiação $\alpha$ (alpha) de $U$ e/ou Th e subseqüente dissolução do mineral silicático (feldspato potássico) nas partes onde o seu retículo cristalino foi danificado pela radiação. Os minerais radioativos, neste caso, não foram identificados com precisão em função de suas dimensões pequenas (foto 42); em geral predominam zircão por vezes intercrescido com baddeleyita e monazita (cf. Waber, 1990).

Estudos de microssonda eletrônica-EDS e WDS (Schorscher, 1991) foram efetuados para caracterizar as fases minerais supergênicas características e mais importantes das frentes redox: os minerais de U nas mineralizações supergênicas em nódulos maciços e disseminadas nas partes reduzidas das frentes e, tentativamente, os OHF, nas partes das das frentes, visando verificar possíveis concentrações de $U$, Th, ETR e demais metais pesados. As análises dos minerais de $\mathrm{U}$ foram feitas em nódulos supergênicos maciços de pitchblenda/uraninita, e revelaram tratar-se de óxidos quase puros de $\mathrm{U}$, com pequenos teores de $\mathrm{SiO}_{2}\left(12.09-2.96 \%\right.$ peso), $\mathrm{K}_{2} \mathrm{O}$ ( $0.84-1.39 \%$ peso) e $\mathrm{Al}_{2} \mathrm{O}_{3}(0.15-0.53 \%$ peso). Dos elementos traço notou-se a presença esporádica de Ce e Y; Th não foi detectado (Anexo III).

As análises dos OHF de baixa cristalinidade, entretanto, foram mal sucedidas em decorrência da instabilidade destes OHF sob o feixe de elétrons. As espécies mais estáveis de $\mathrm{Fe}$ demonstraram ser óxidos puros de Fe. As análises de OHF de baixa cristalinidade necessitam de técnicas específicas adicionais (Veiga et al., 1991), que não foram disponíveis no presente trabalho. Os estudos microanalíticos revelaram também a presença de óxidos hidratados de Ti nas rochas oxidadas próximo às frentes redox, derivados dos minerais de $\mathrm{Ti}$ e $\mathrm{Nb}$ hidrotermais pretéritos das rochas reduzidas (Anexo III), mas o número de observações e análises não foi suficiente para verificar se estes óxidos eram produtos de substituição/alteração sur place das fases hidrotermais de seus equivalentes reduzidos, ou se eles representam fases neoformadas por precipitação das soluções supergênicas. 


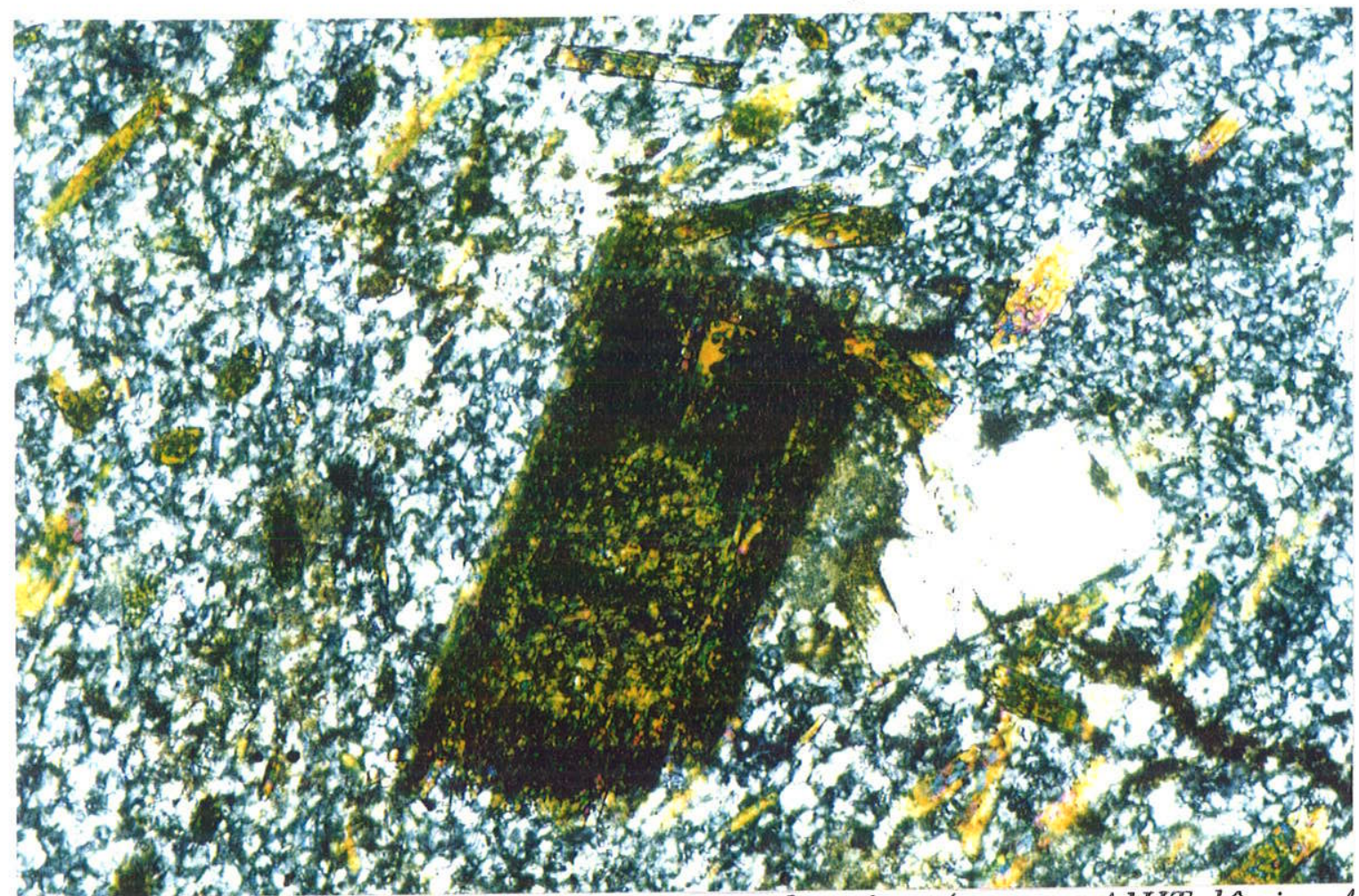

Foto 3: Fonolito não-hidrotermalizado da mina de urânio (amostra AlHT, lâmina Al-

1) com microfenocristal de clinopiroxênio zonado, em matriz fina de sanidina, nefelina, aegirina e giannetita (polarizadores $X$, lado maior da foto $=7 \mathrm{~mm}$ ). Nota-se o núcleo sódi-augítico arredondado por corrosão magmática e supercrescimentos de aegirina-augita a aegirina na borda externa subidiomórfica rica em inclusões poiquilíticas.

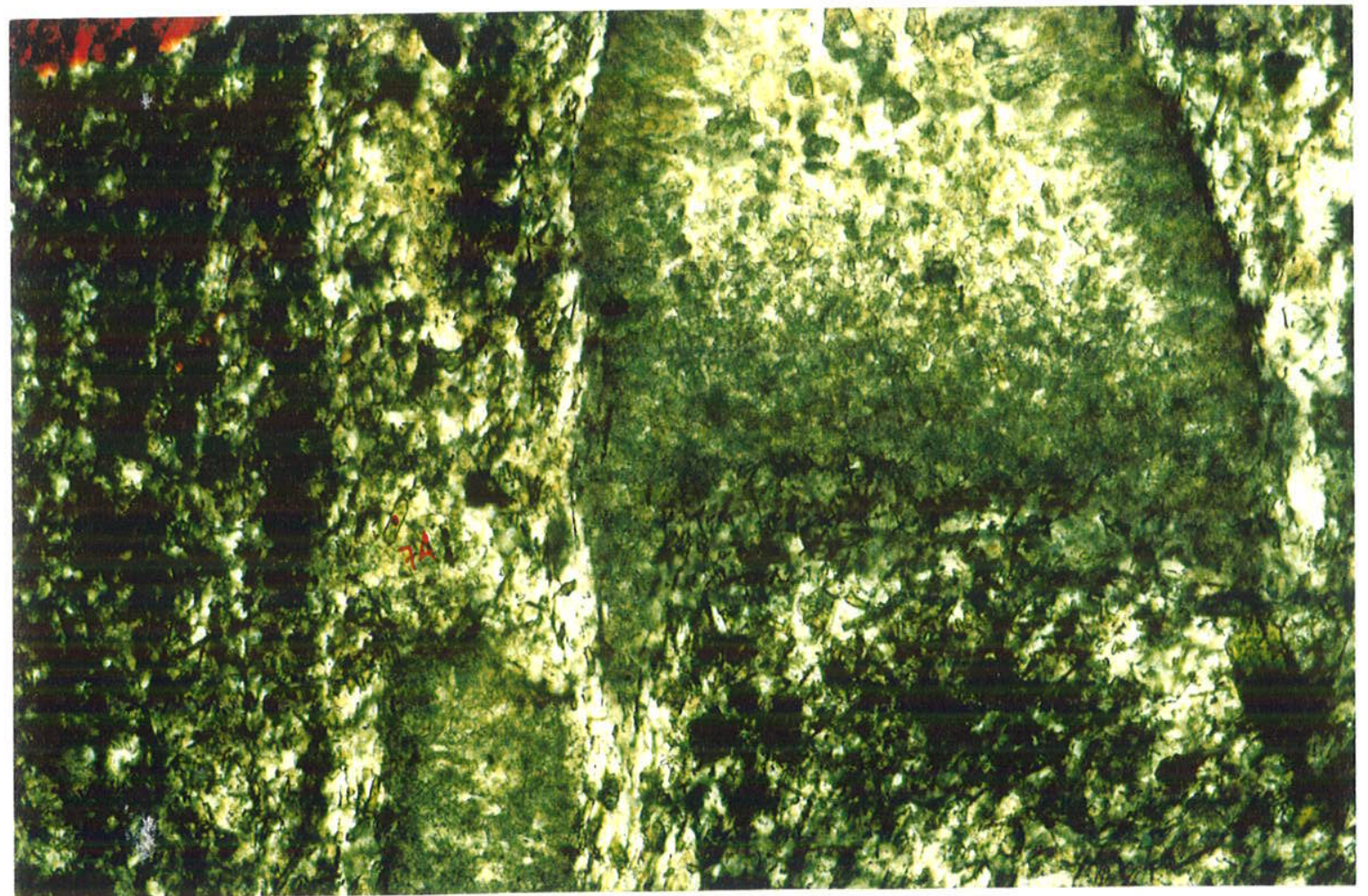

Foto 4: Fonolito não-hidrotermalizado da mina de urânio (amostra AlHH, lâmina A1-homo-2). Detalhe de microfenocristal de sanidina com zona de borda rica em inclusões poiquilíticas (polarizadores $X$, lado maior da foto $=5 \mathrm{~mm}$ ). Ponto 74 análise de WDS, Anexo III. 


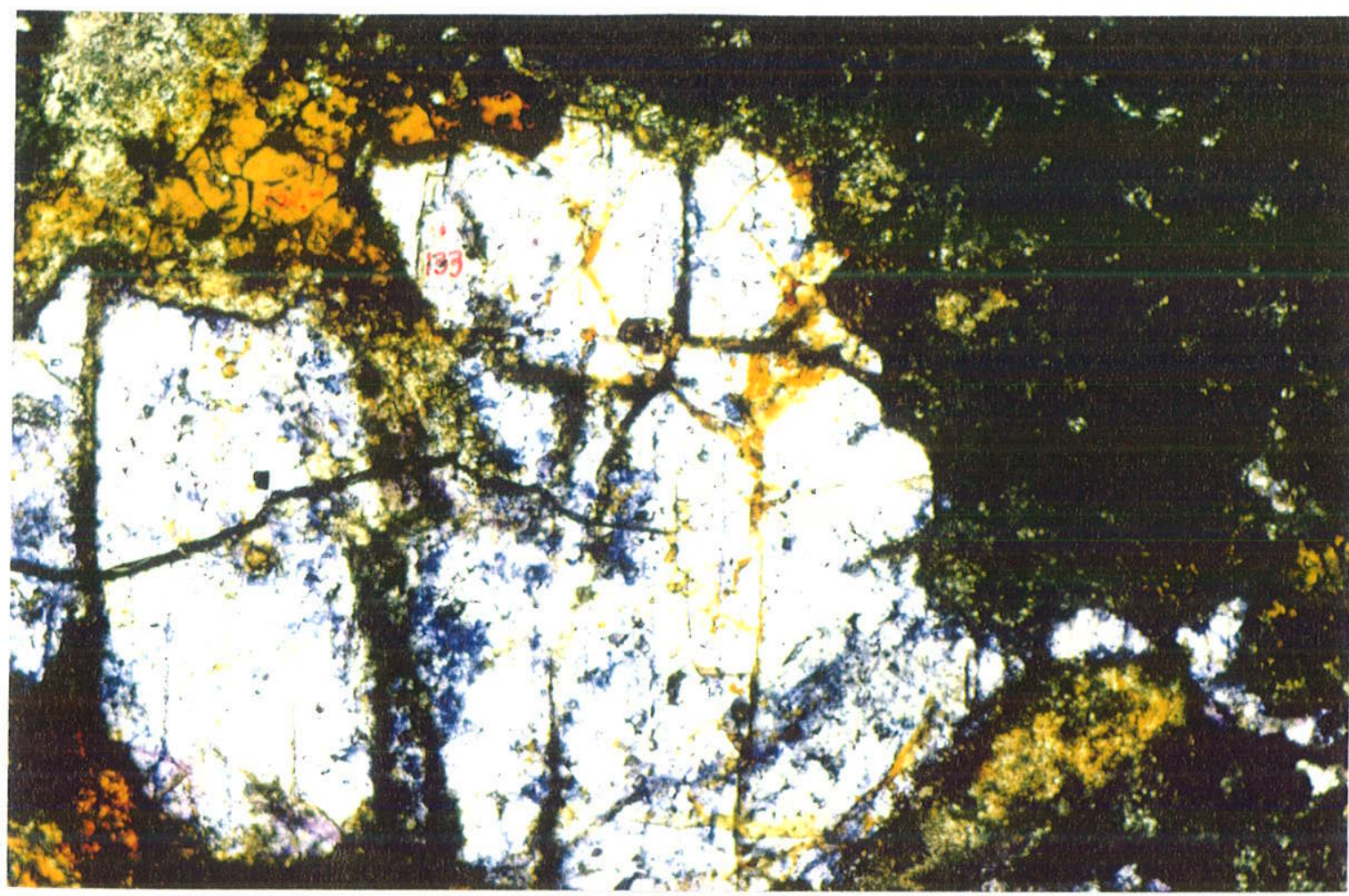

Foto 5: Fonolito fracamente hidrotermalizado da mina de uranio (amostra AlM, lâmina A1-2) com microfratura preenchida de fluorita hidrotermal de cristalização grossa (incolor a azul), também fraturada $e$ carbonatos em impregnações disseminadas cripto a microcristalinos (polarizadores $X$, lado maior da foto $=7 \mathrm{~mm}$ ).

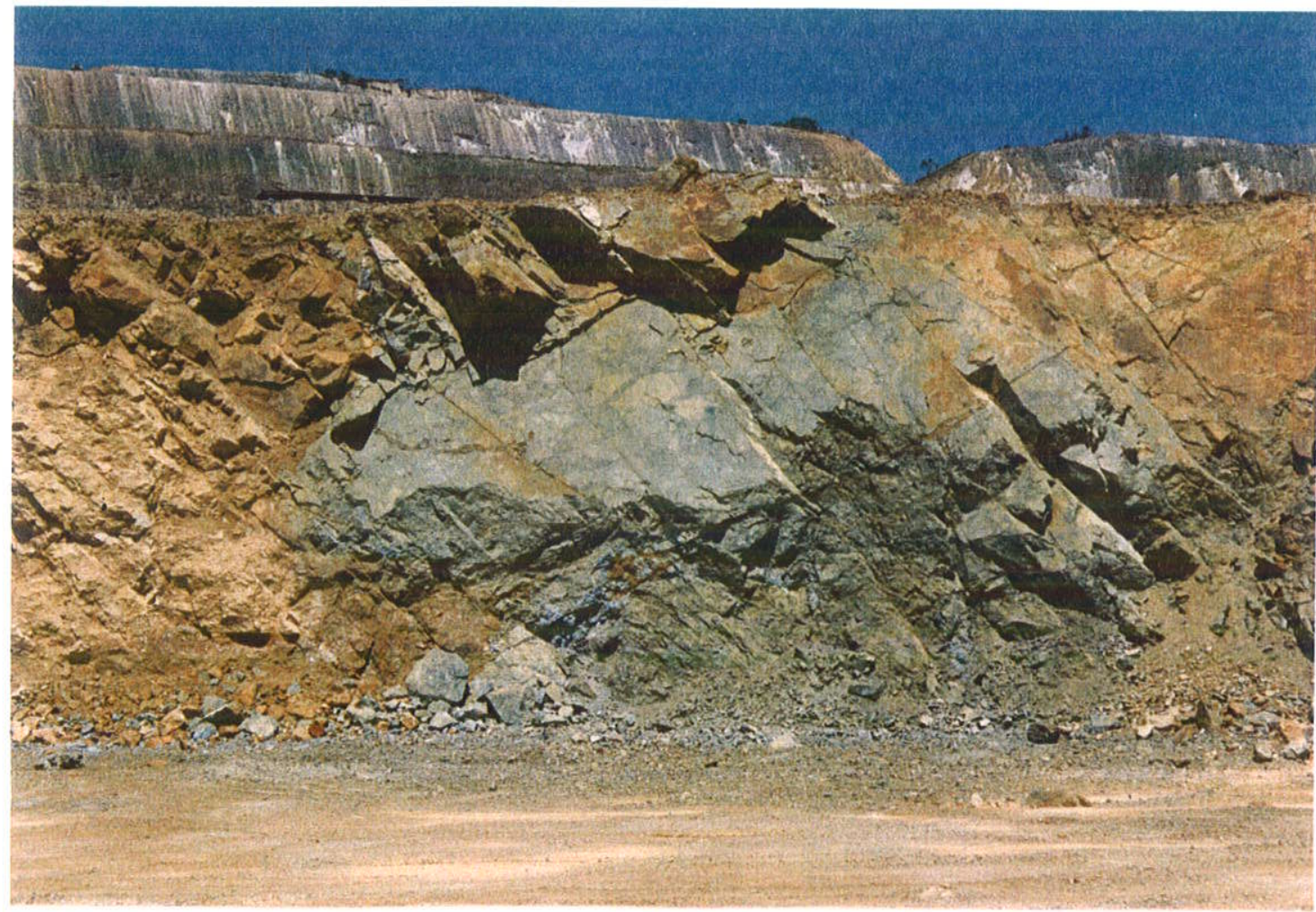

Foto 6: Brechas vulcânicas hidrotermalizadas na parte centro-leste (corpo B) da mina Osamu Utsumi (altura da bancada é de $\pm 3 m$ ). 

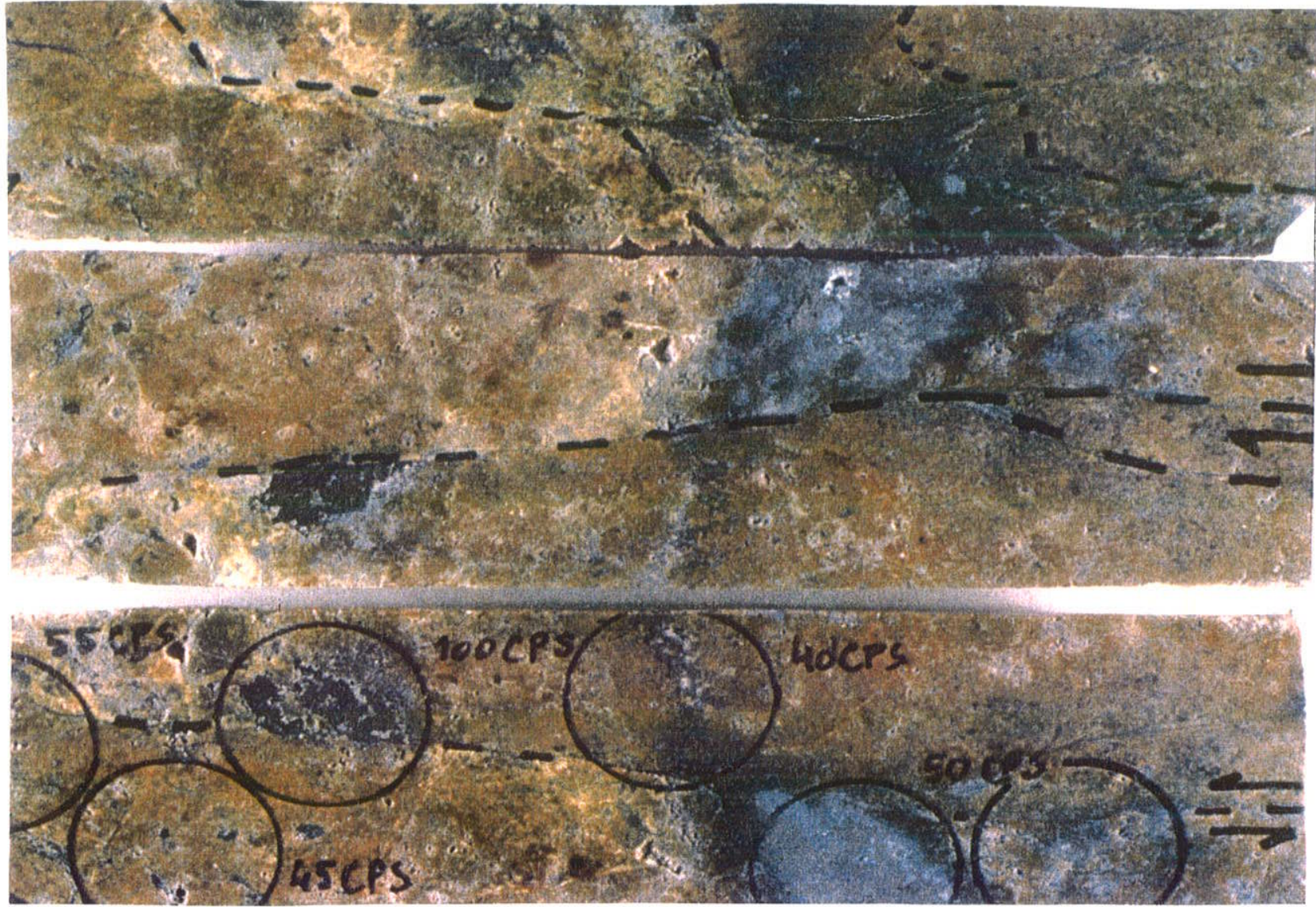

Foto 7: Mineralização uranífera hidrotermal rica na matriz (cimento) de brecha vulcânica, indicada por medidas cintilométricas (valores em cps) e cortada por fraturamento tectônico posterior (linhas tracejadas com setas de movimento relativo) (amostra F4/243-1A).

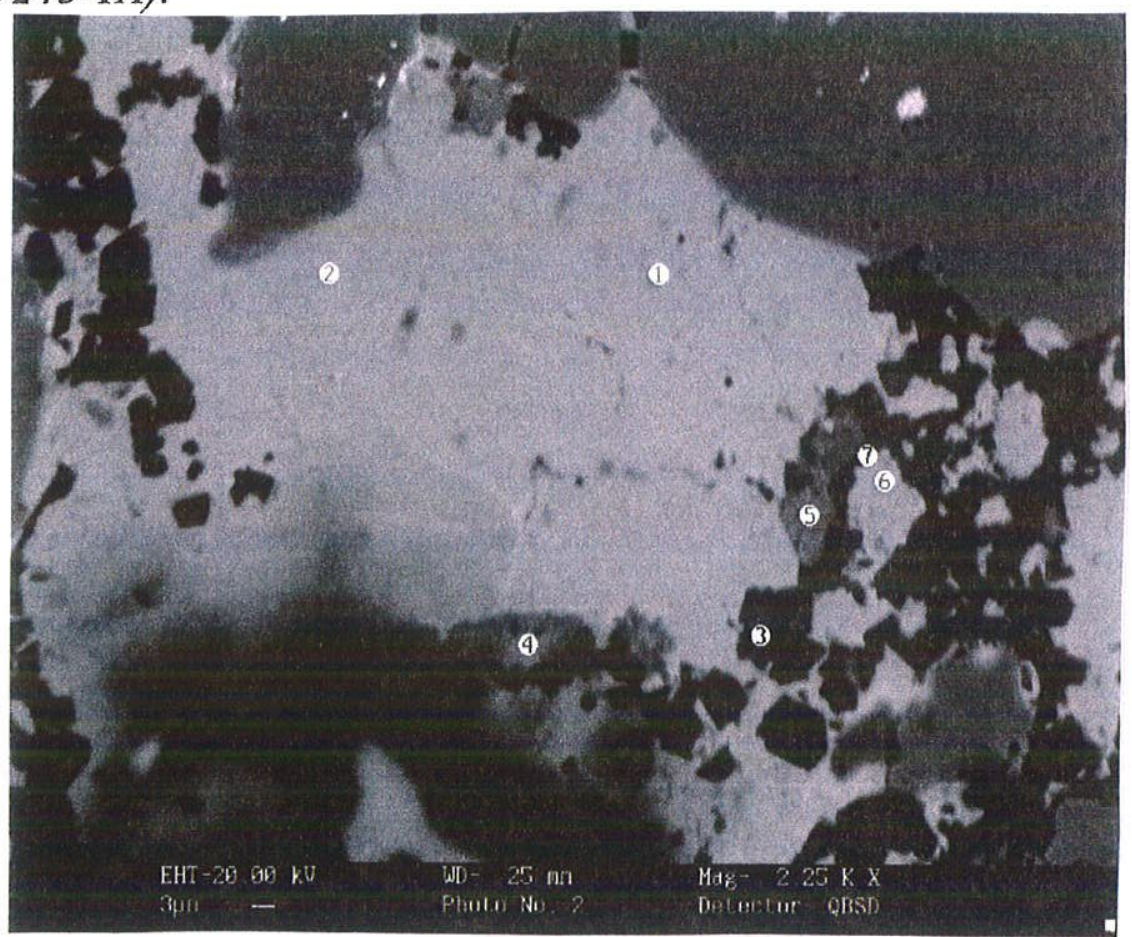

Foto 8: Imagem $n^{\circ}$ M1-001 de MEV de cimento de brecha hidrotermalizada reduzida mineralizada em U. Os números representam as fases com análises semiquantitativas pontuais por EDS, representadas na Tabela 2 (amostra F4/243-1A). Os pontos de análise 4 e 5 representam silicatos de $\mathrm{Zr}$ com teores de $U$ de até 5,14\%. 

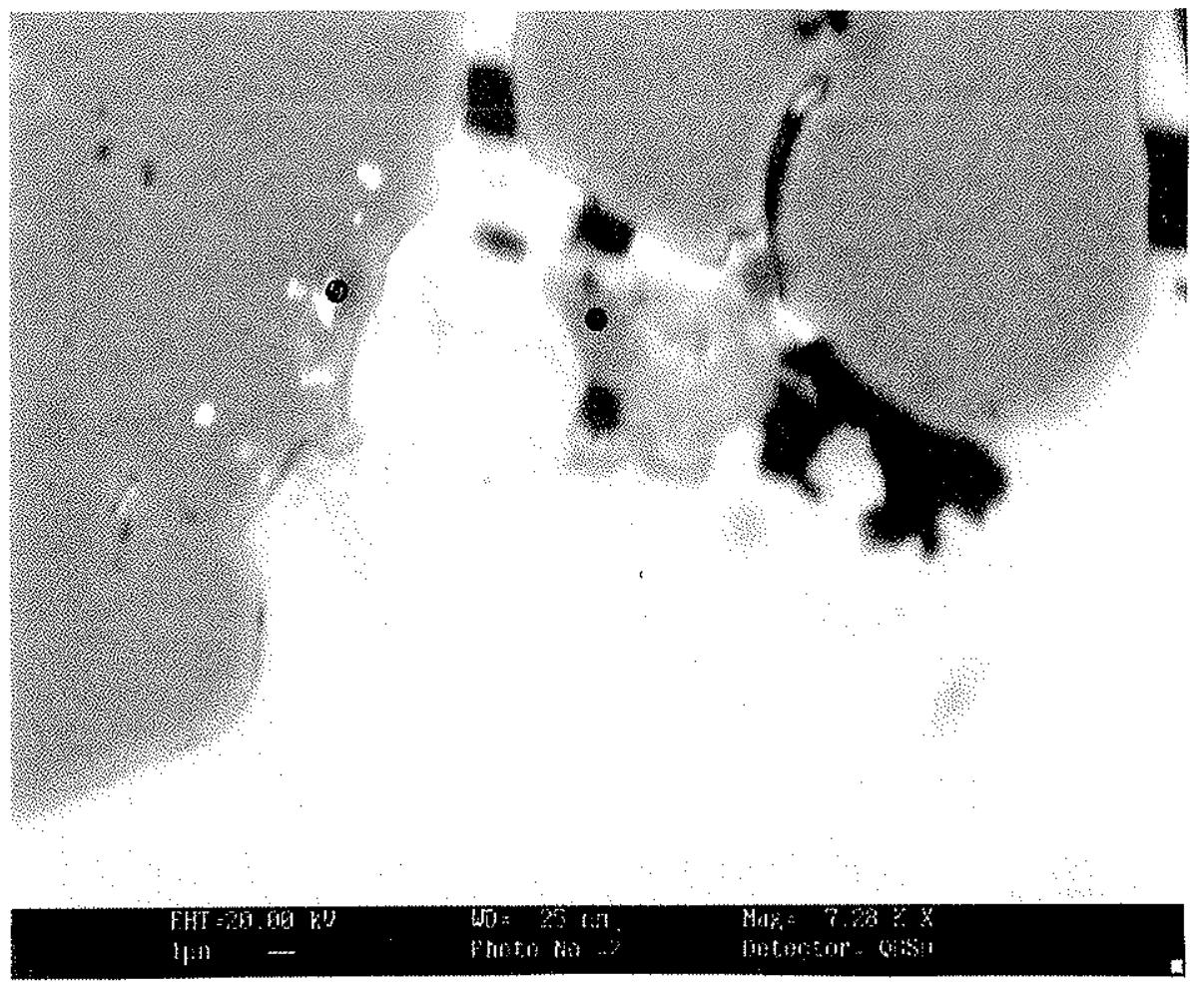

Foto 9: Imagem $n^{\circ}$ M2-001 de MEV de cimento de brecha hidrotemalizada reduzida mineralizada em U. Os numeros representam as fases com análises semiquantitativas pontuais por EDS, representadas na Tabela 2 (amostra F4/243m1A). O ponto de análise 9 representa sulfeto de Fe com Zn e Zre teores de U de até 17,17\%.

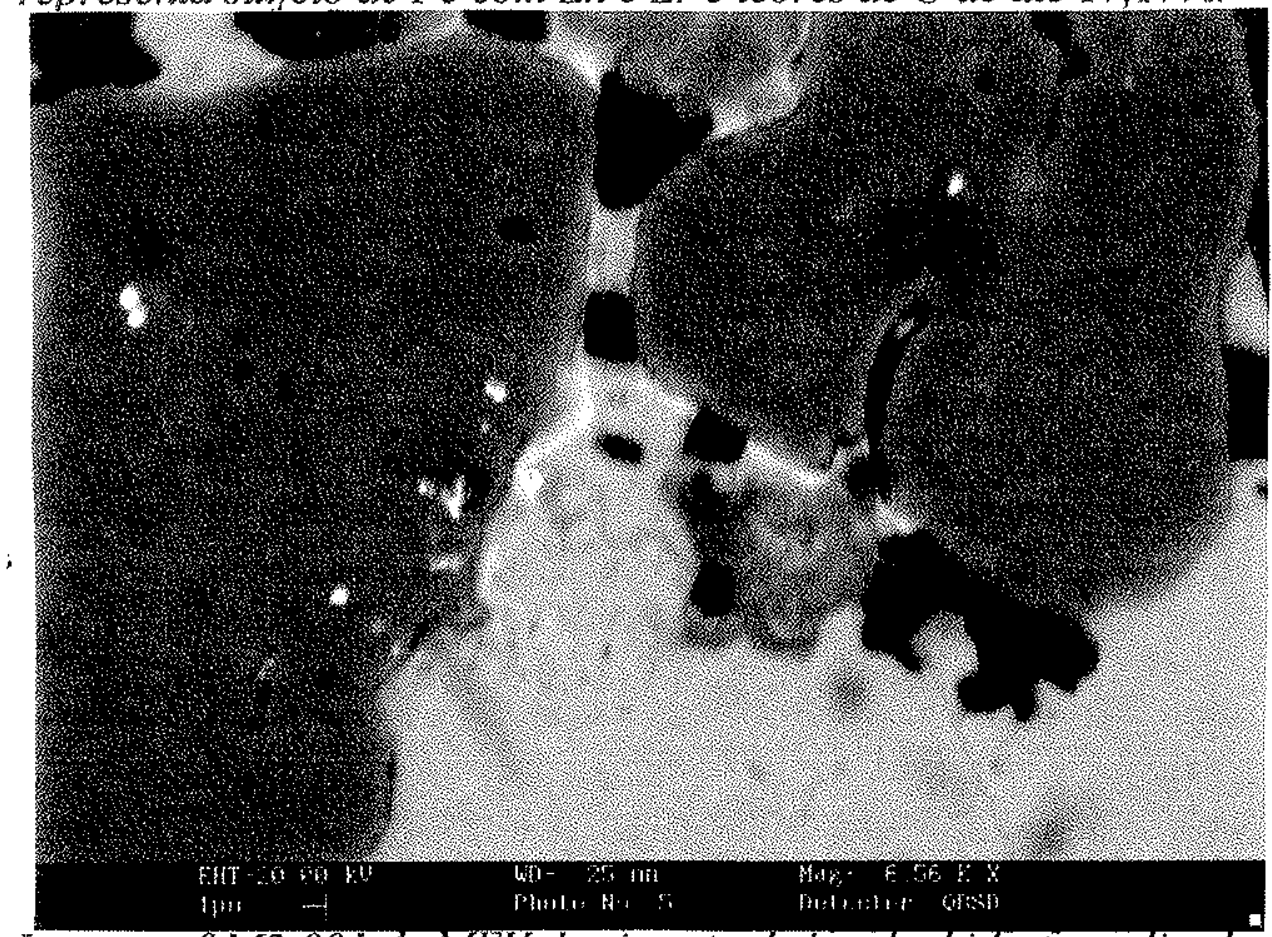

Foto 10: Imagem ${ }^{\circ}$ M3-001 de MEV de cimento de brecha hidrotermalizada reduzida mineralizada em $U$. Os numeros representam as fases com análises semiquantilativas ponnas por EDS, representadas na Tabela 2 (amostra FA/243-1A). O ponto de arílise I representa silfeto de Zn com Zn e Fe e teores de U de até 15,49\%. 


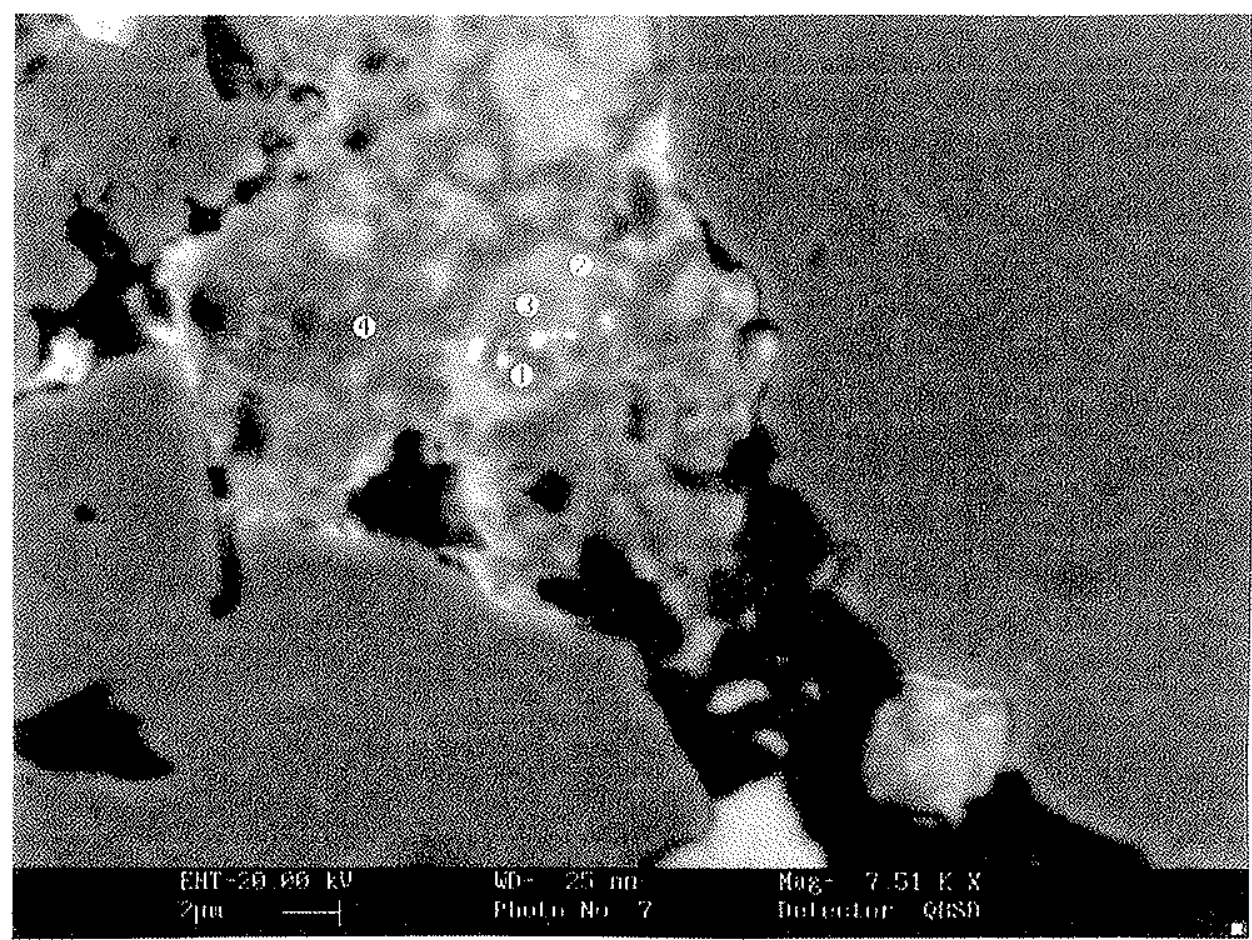

Foto 11: Imagem $n^{\circ}$ M4 002 de MEV de cimento de brecha hidrotermalizada reduzida mineralizada em U. Os números representam as fases com análises semiquantitativas pontuais por EDS, representadas na Tabela 2 (amostra F4/243-1A). Trata-se de silicato de $\mathrm{Zr}$ com $\mathrm{Fe}$ e de teores de U de até $16 \%$.

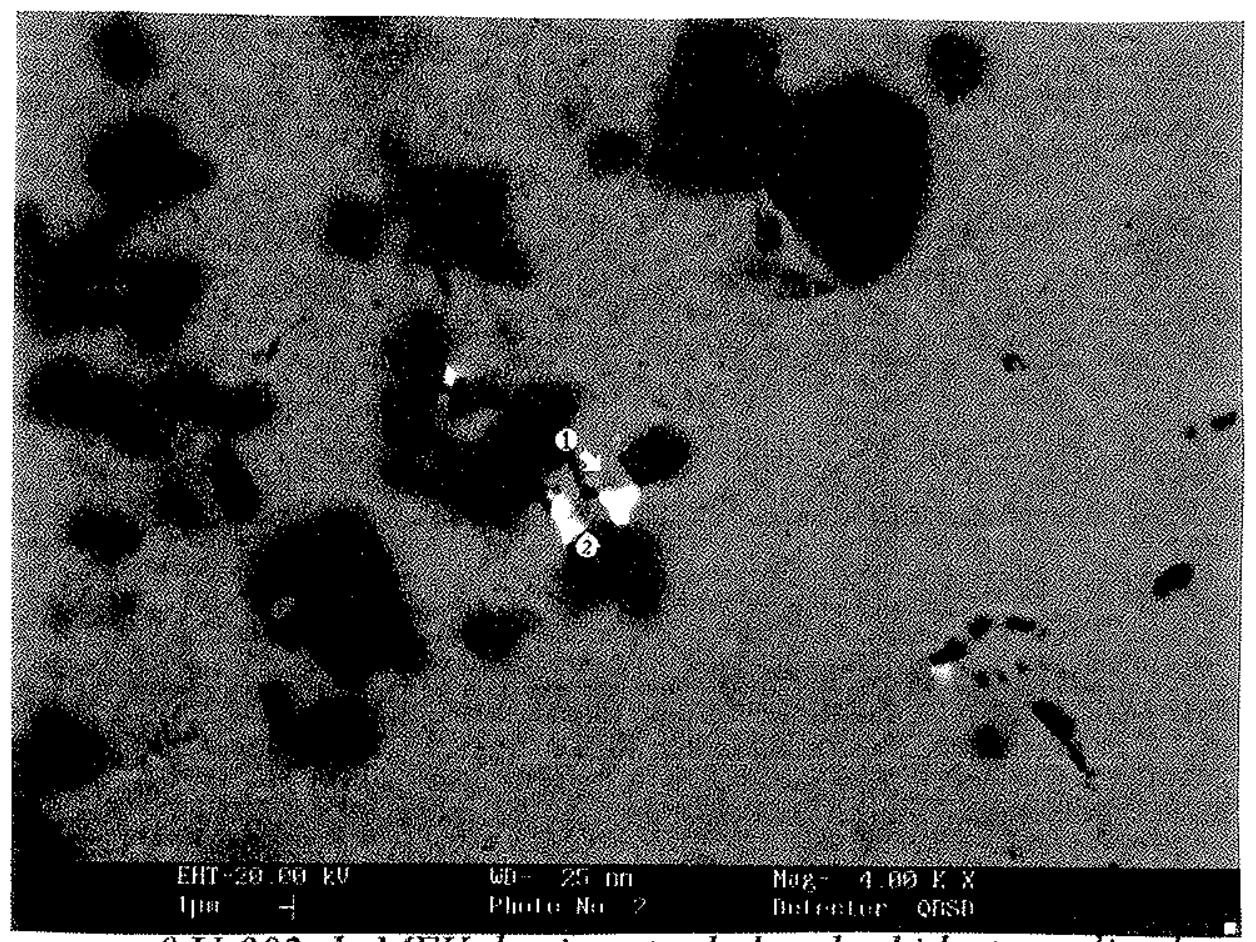

Folo 12: Imagem no Un002 de MEV de cimento de brecha hidrotermalizada reduzida mineralizada em $U$. Os números representam as fases com análises semidquantitativass pontuais por EDS, representodas na Trabella 2 (amostra F4/243-1A). Os pontos de análises 1 e 2 representom sulfetos de Zn com fe com teores de $U$ de 21,24 a 38,69\%. 


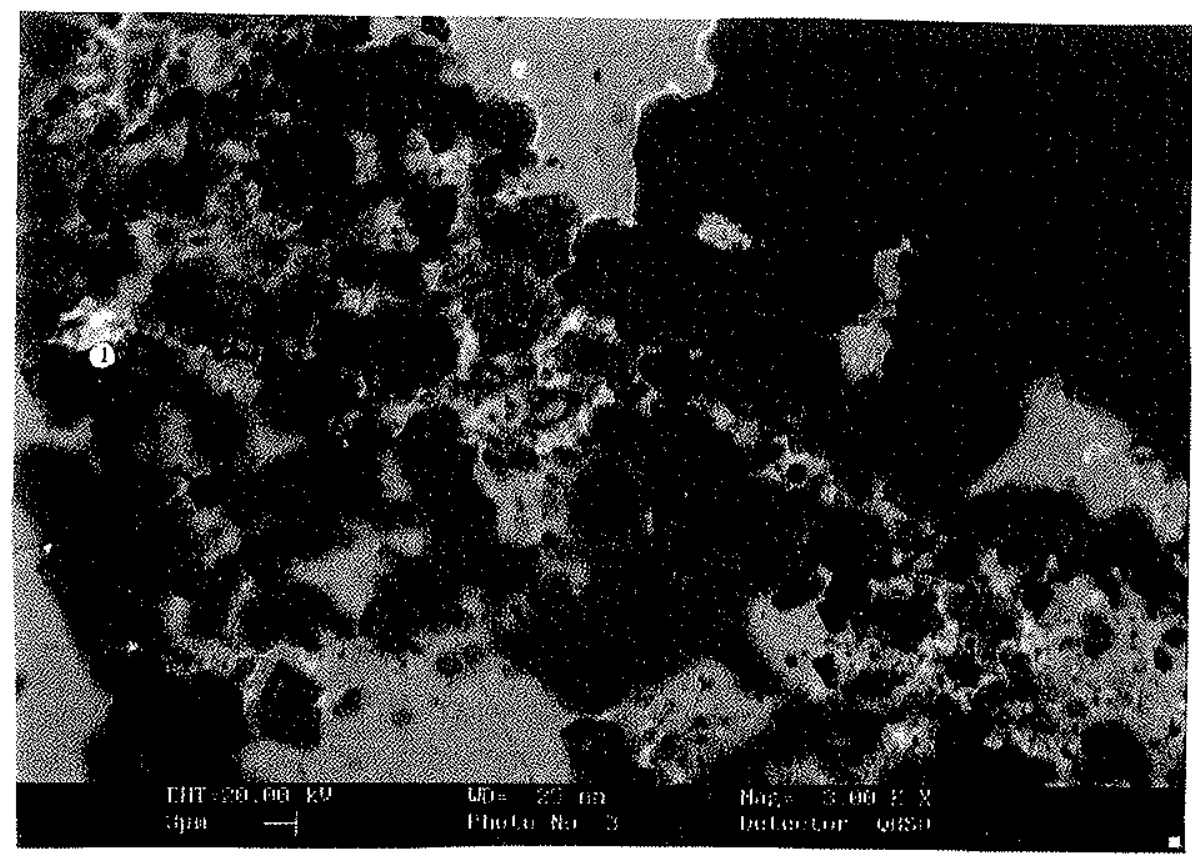

Foto 13: Imagem $n^{\circ} \mathrm{U}-003$ de MEV de cimento de brecha hidrotermalizada reduzida mineralizada em $U$. Os números representam as fases com análises semiquantitativas pontuais por EDS, representadas na Tabela 2 (amostra F4/243-1A). O ponto de análise 1 representa silicato de Ca com inclusões de sulfeto de Zn e Fe com teores de $U$ de $26,69 \%$.

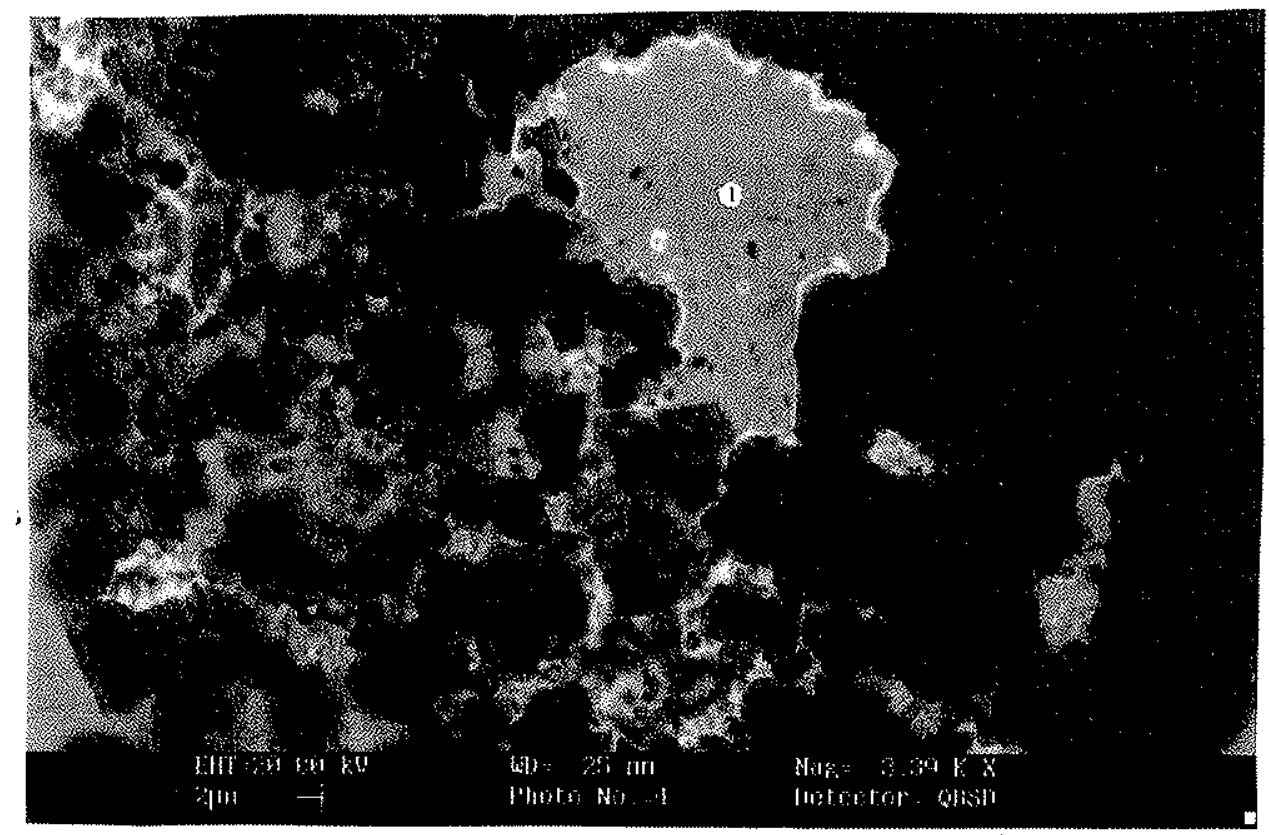

Foto 14: Imagem $n^{\circ}$ U-004 de MEV de cimento de brecha hidrotermalizada reduzida mineralizada em $U$. Os números representam as fases com análises semiquantitativas pontuais por EDS, representadas na Tabela 2 (amostra F4/243-1A). O ponto de análise 1 representa um sulfeto de Zn com Fe com teores de U muito baixo de $0,65 \%$. 


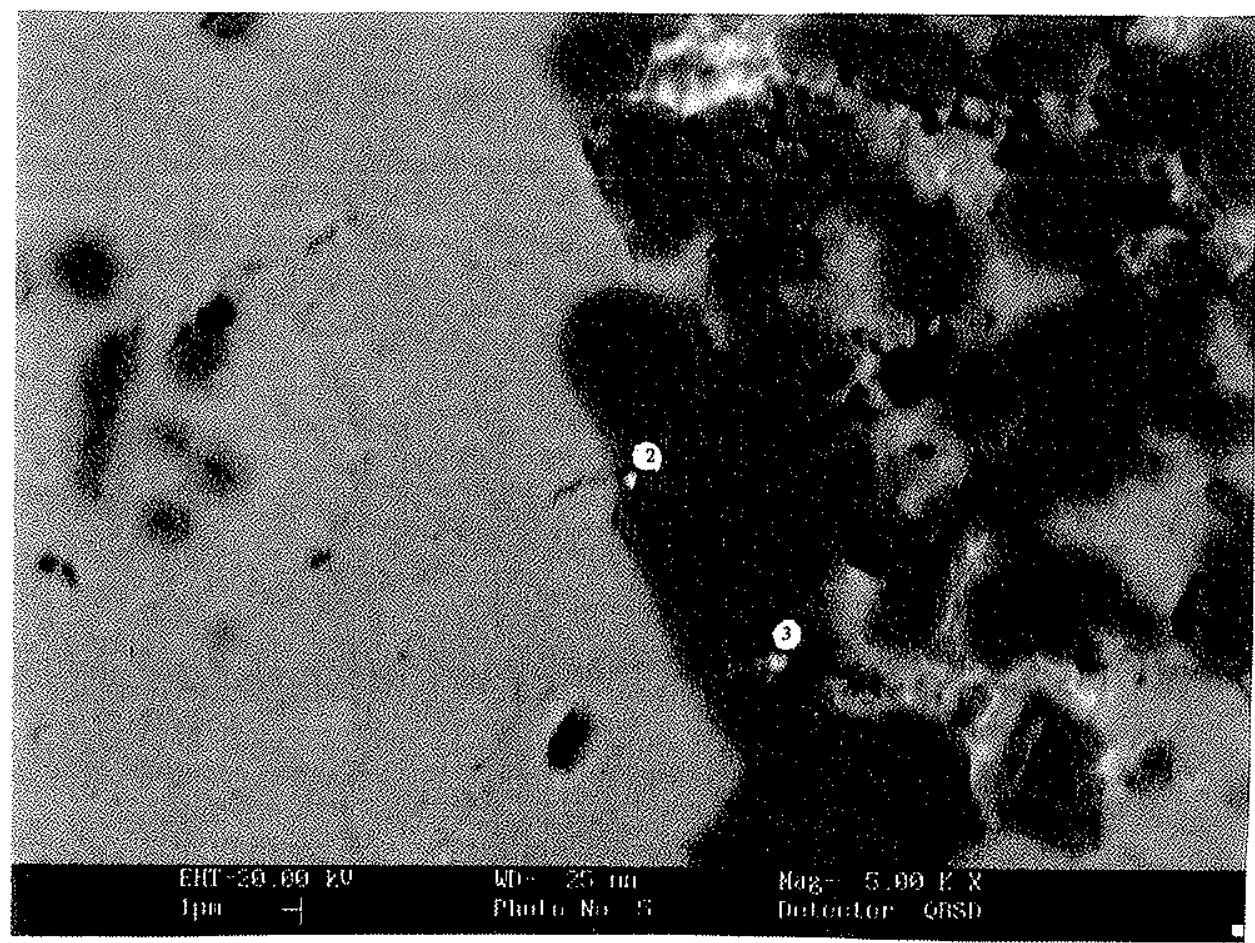

Foto 15: Imagem $n^{\circ}$ U-005 de MEV de cimento de brecha hidrotermalizada reduzida mineralizada em $U$. Os números representam as fases com análises semiquantitativas pontuais por EDS, representadas na Tabela 2 (amostra F4/243-1A). O ponto de análise 1 representa sulfeto de Fe com $Z$ n com teores de $U$ de 21,24 a 38,69\%. Os pontos 2 e 3 representam sulfetos de Zn com Zre Fe com teores de U de 0,44\%.

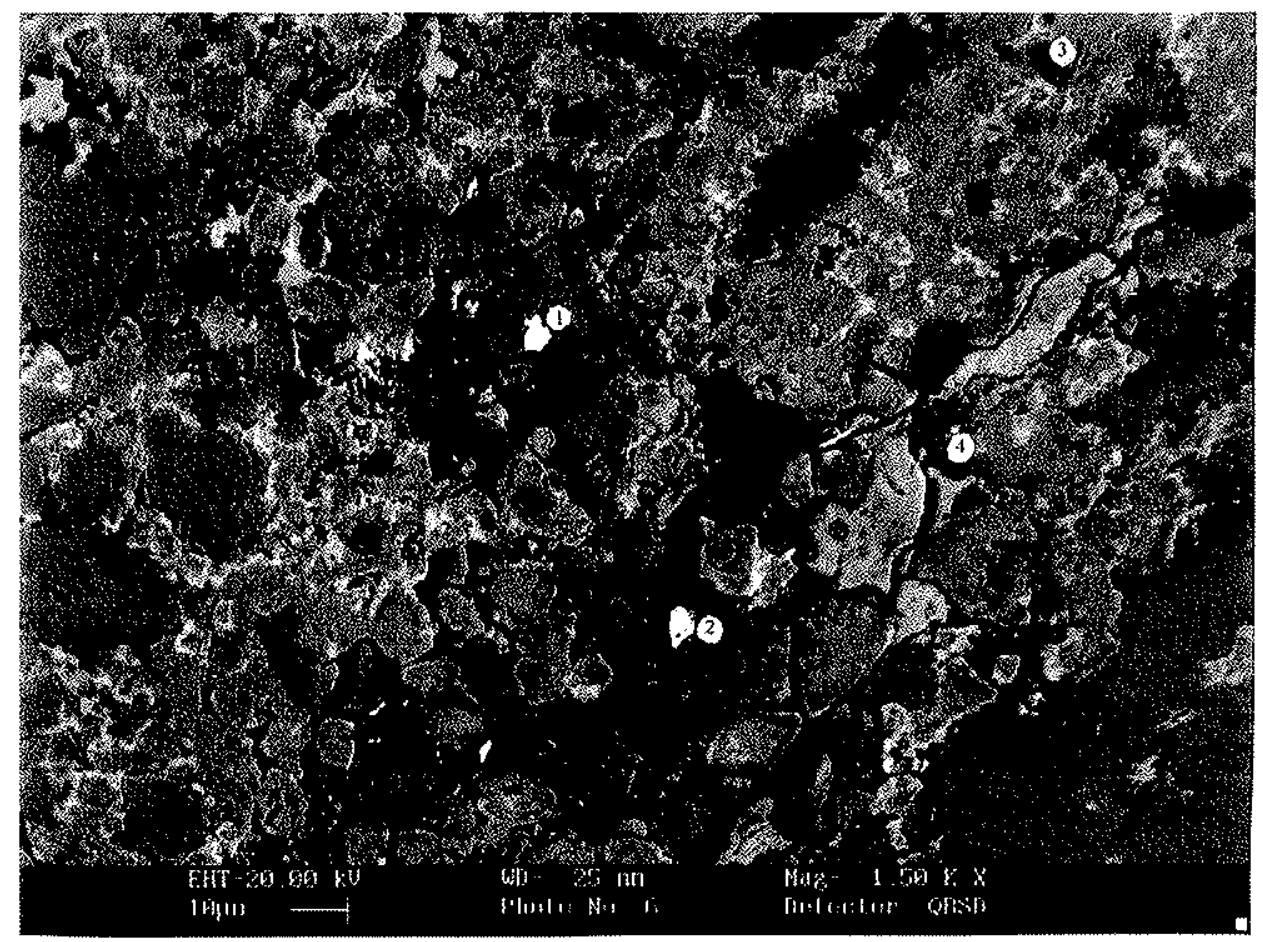

Foto 16: Imagem $n^{\circ}$ U-006 de $\mathrm{MEV}$ de cimento de brecha hidrotermalizada reduzida mineralizada em $U$. Os números representam as fases com anólises semiquantitativas pontuais por EDS, representadas na Tabela 2 (amostra FA/243-1A). Os pontos de análises 1,2 e 3 representam sulfetos Mo com $F$ e com teores de $U$ de 0,72 a 12,02\%. O ponto 4 representa um sulfeto de Fe com $\mathrm{Zr}$ com teores de $U$ de até $2,76 \%$. 


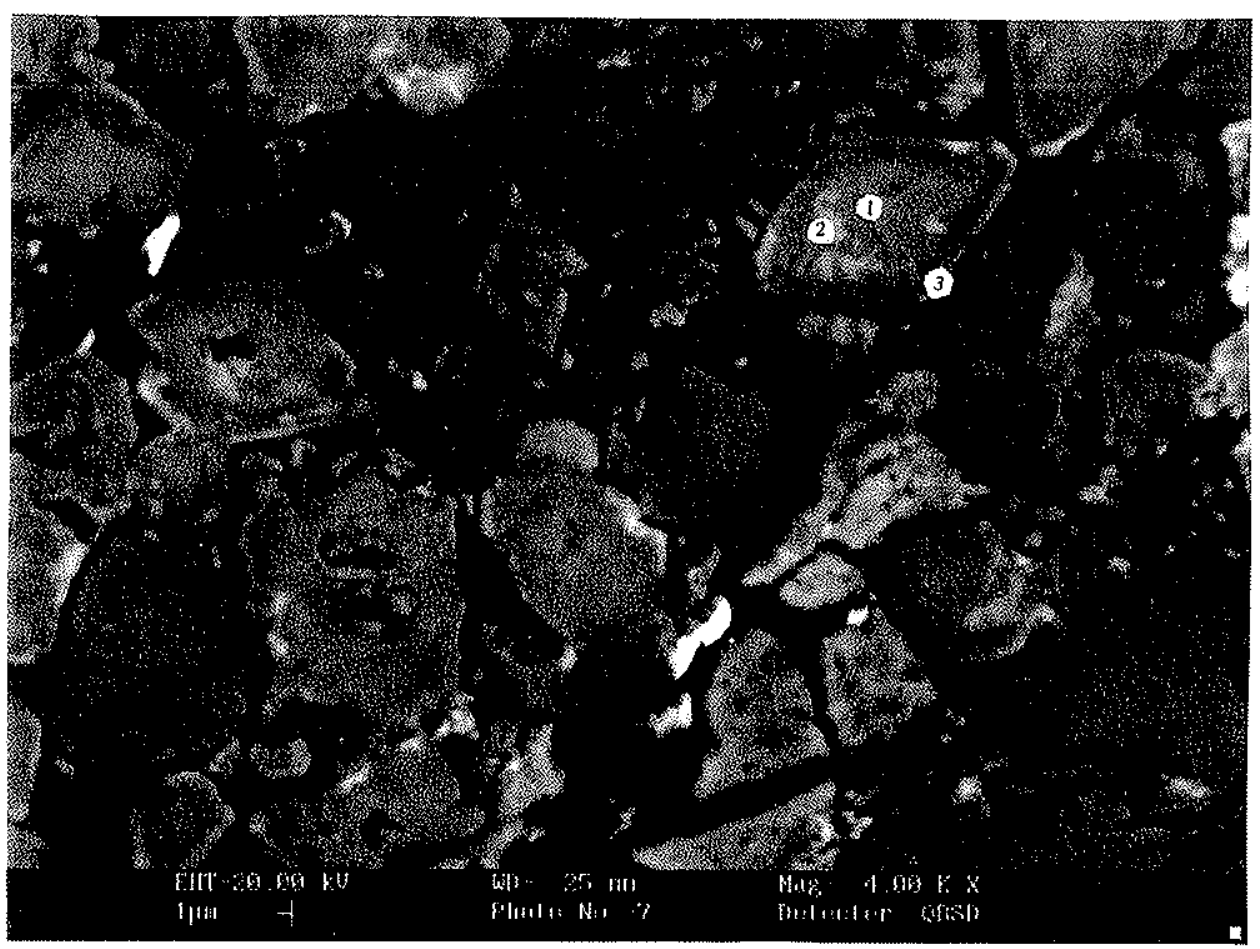

Foto 17: Imagem $n^{\circ} U-007$ de MEV de cimento de brecha hidrotermalizada reduzida mineralizada em $U$. Os números representam as fases com análises semiquantitativas pontuais por EDS, representadas na Tabela 2 (amostra F4/243-1A). Os pontos de análises 1,2 e 3 representam silicatos de $\mathrm{Zr}$ com Mo e Fe com teores de U de 4,54 a $6,9 \%$

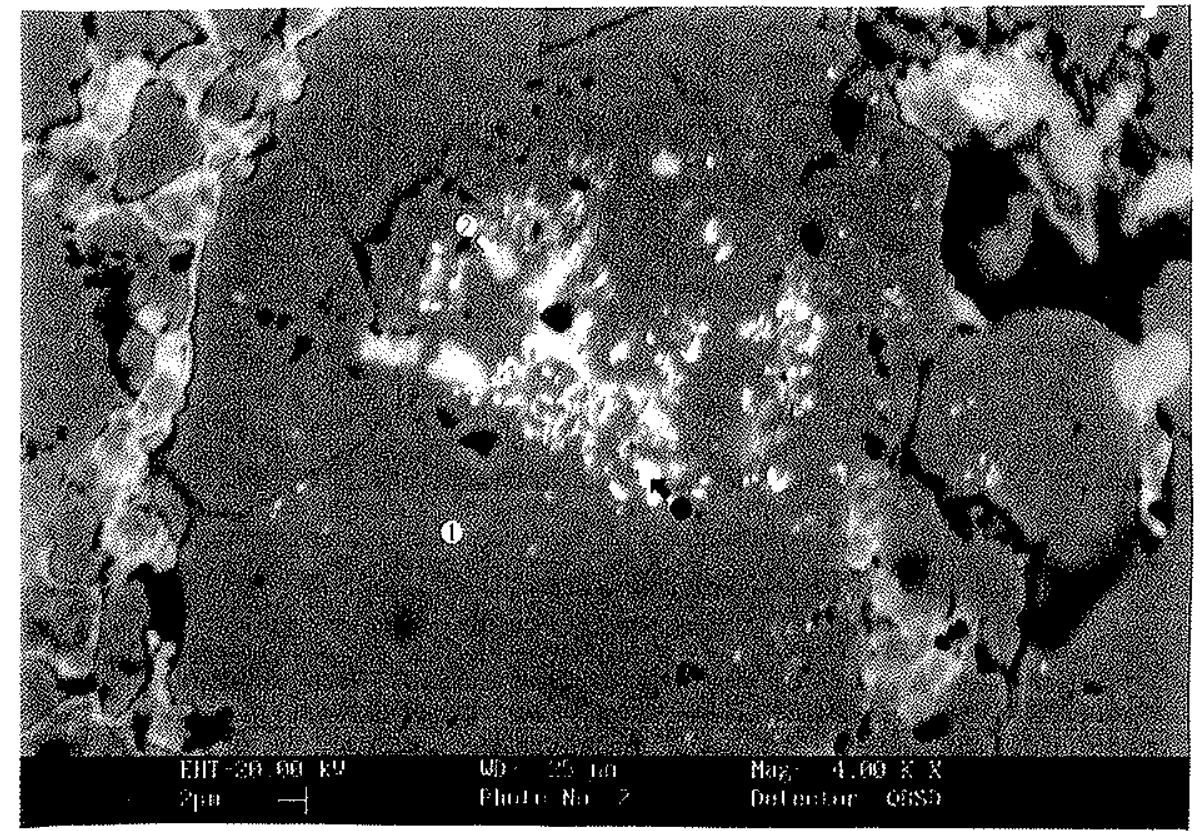

Foto 18: Imagem $n^{\circ} U-009$ de $M E V$ de cimento de brecha hidrotermalizada reduzida mineralizada em $U$. Os números representam as fases com análises semiquantitativas pontuais por EDS, representadas na Tabela 2 (amostra F4/243-1A). Os pontos de análises $l, 2$ e 3 representam sulfetos Fe com Mo com teores de $U$ de 4,32 a 36,83\%. 


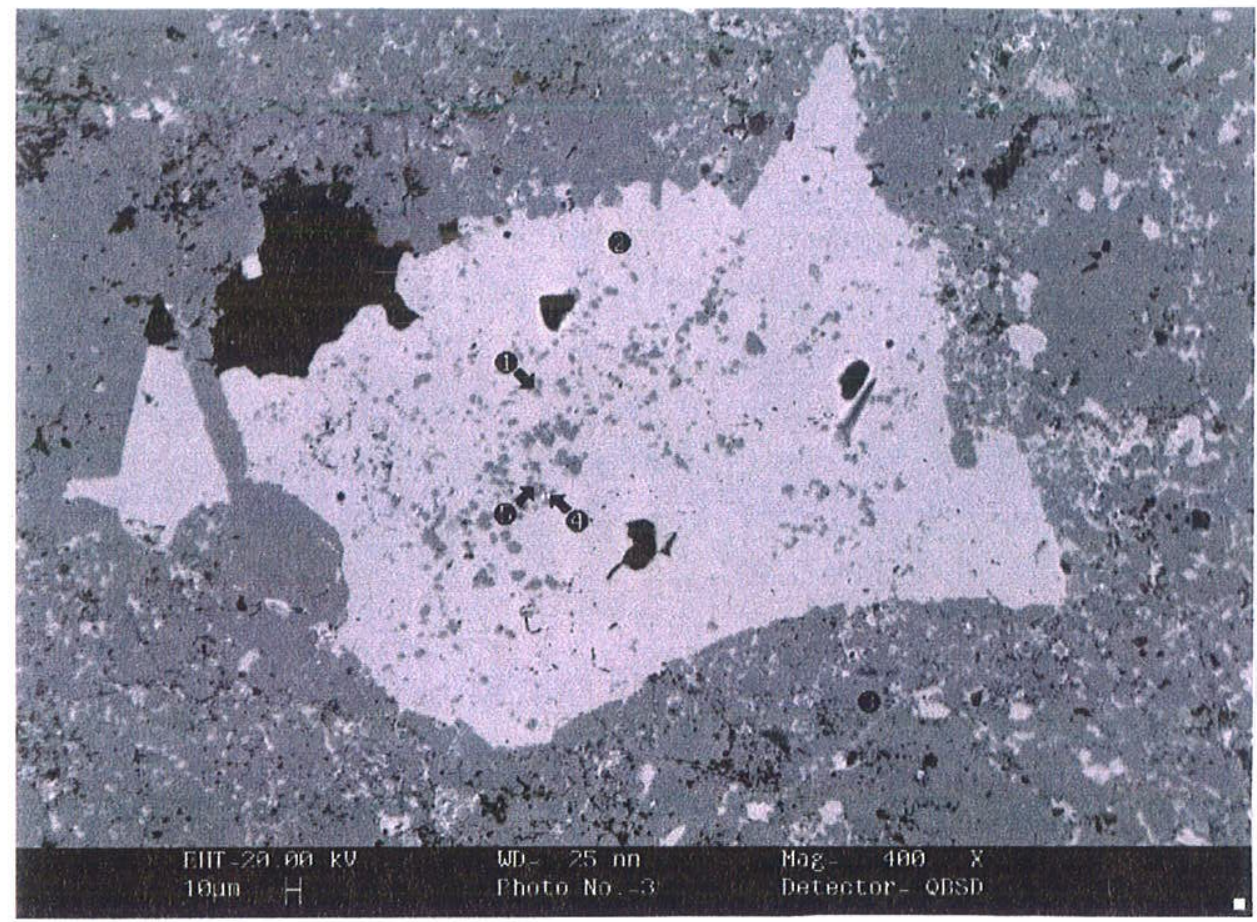

Foto 19: Imagem $n^{\circ}$ U-010 de MEV de cimento de brecha hidrotermalizada reduzida mineralizada em $U$. Os números representam as fases com análises semiquantitativas pontuais por EDS, representadas na Tabela 2 (amostra F4/243-1A). Os pontos de análises 1 e 3 representam sulfetos $\mathrm{Fe}$ com $\mathrm{Mo}, \mathrm{Zr}$ e $\mathrm{Zn}$, o ponto 2 representa sulfeto de Zn com Mo e Zr.

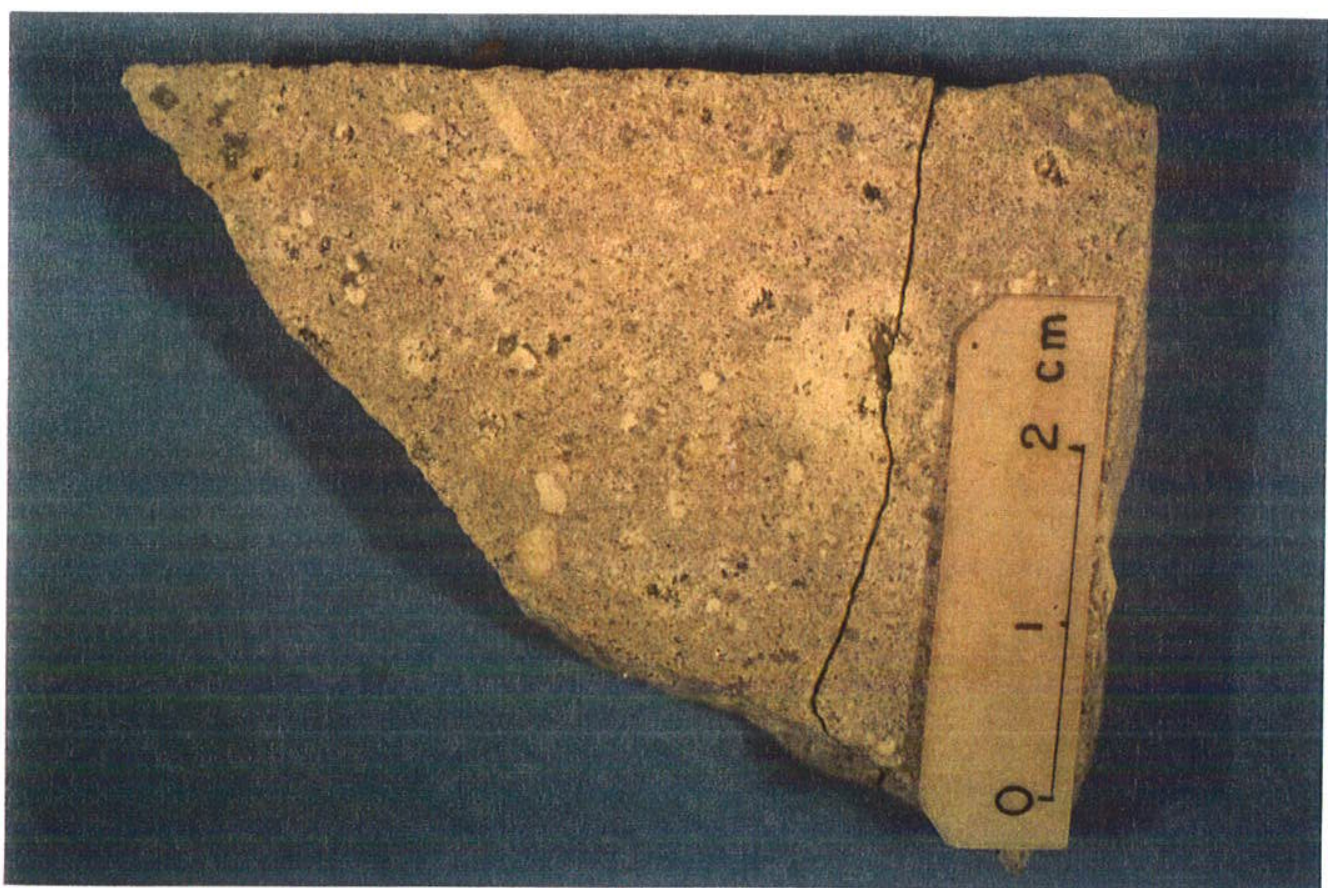

Foto 20: Ph porfirítico hidrotermalizado reduzido da mina Osamu Utsumi, com fenocristais de sanidina, nefelina e pseudoleucita em matriz fina piritizada (amostra F1/69-1A). 


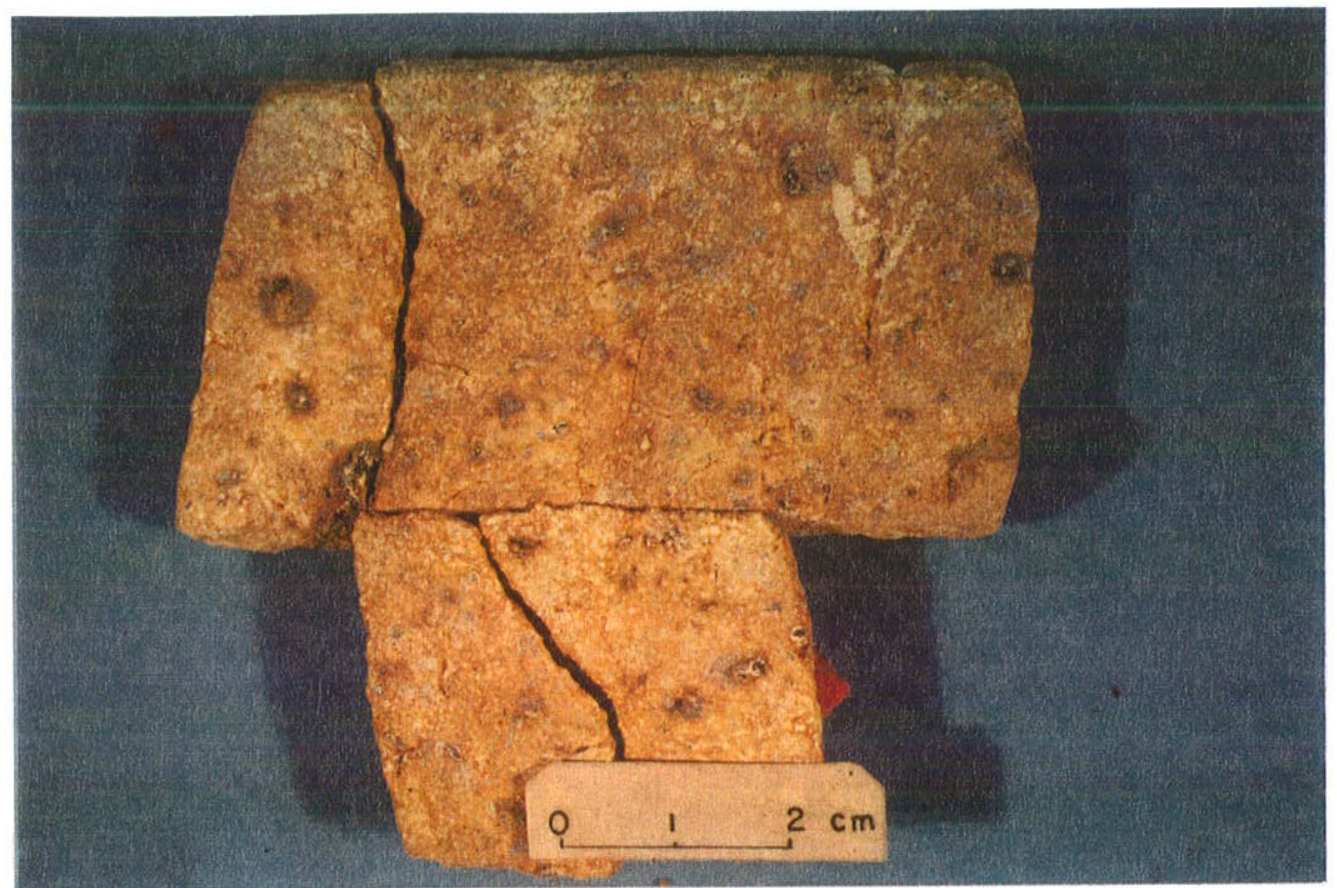

Foto 21: Ph porfirítico hidrotermalizado oxidado, com caolinização mais forte dos feldspatos e pigmentação da rocha por OHF (amostra F1/1-1.30m). Concentrações maiores de OHF indicam oxidação das piritas em condições insaturadas.

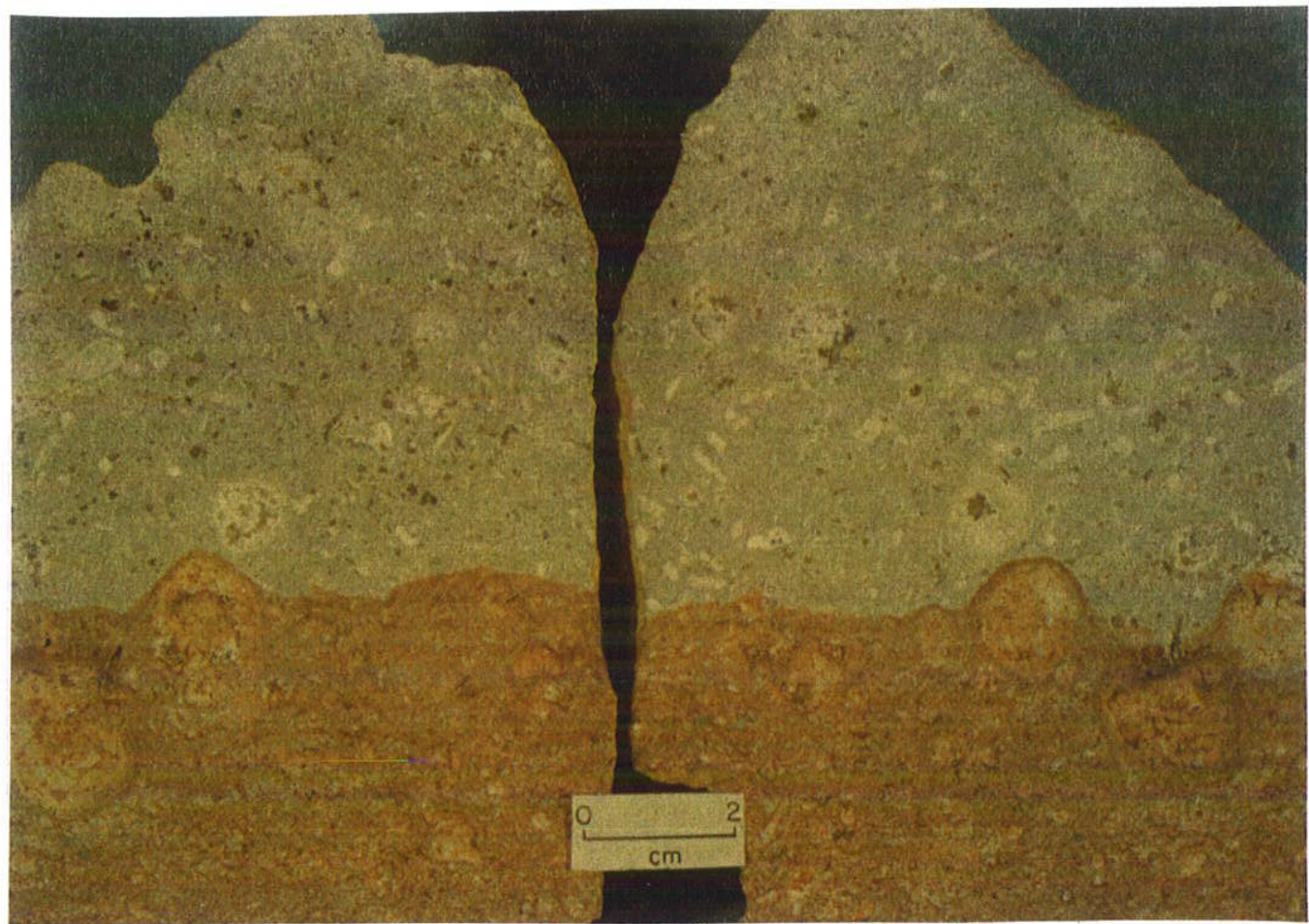

Foto 22: Firente redox de morfologia irregular em $\mathrm{Ph}$ porfirítico com fenocristais de pseudoleucita (redonda branca), sanidina (prismática branca) e nefelina (prismática cinza escura), separando $\mathrm{Ph}$ hidrotermalizados reduzidos (cinza azulados) e Ph hidrotermalizados oxidados (marrom avermelhados) (amostra $n^{\circ}$ F1-47). 


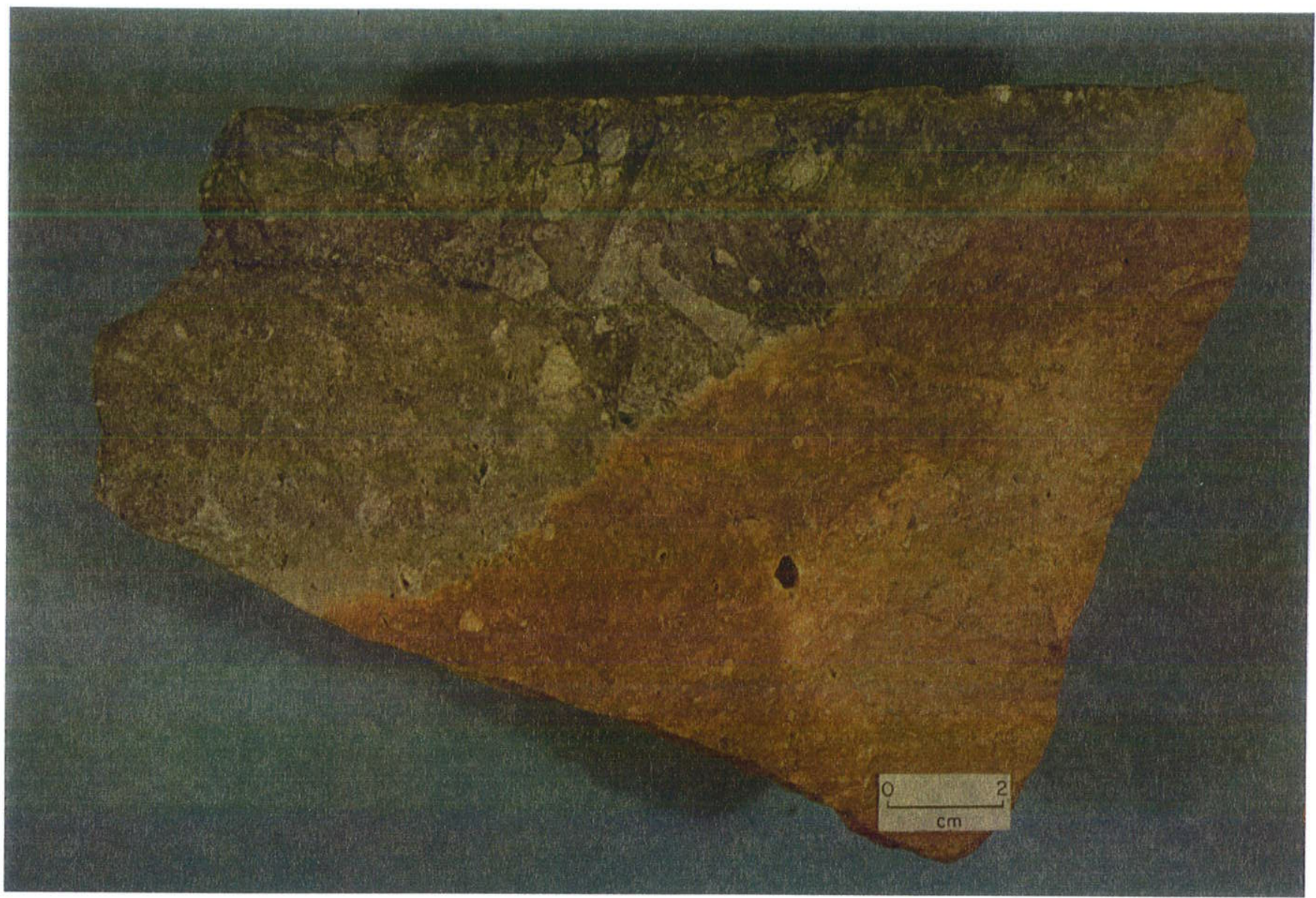

Foto 23: Frente redox com mineralização secundária de U em brecha magmática. Os micronódulos finos e pretos de pitchblenda ocorrem somente na parte reduzida da rocha, numa zona de até $20 \mathrm{~mm}$ de largura adjacente à frente (amostra do corpo B de minério, próximo às coordenadas J/1Z).

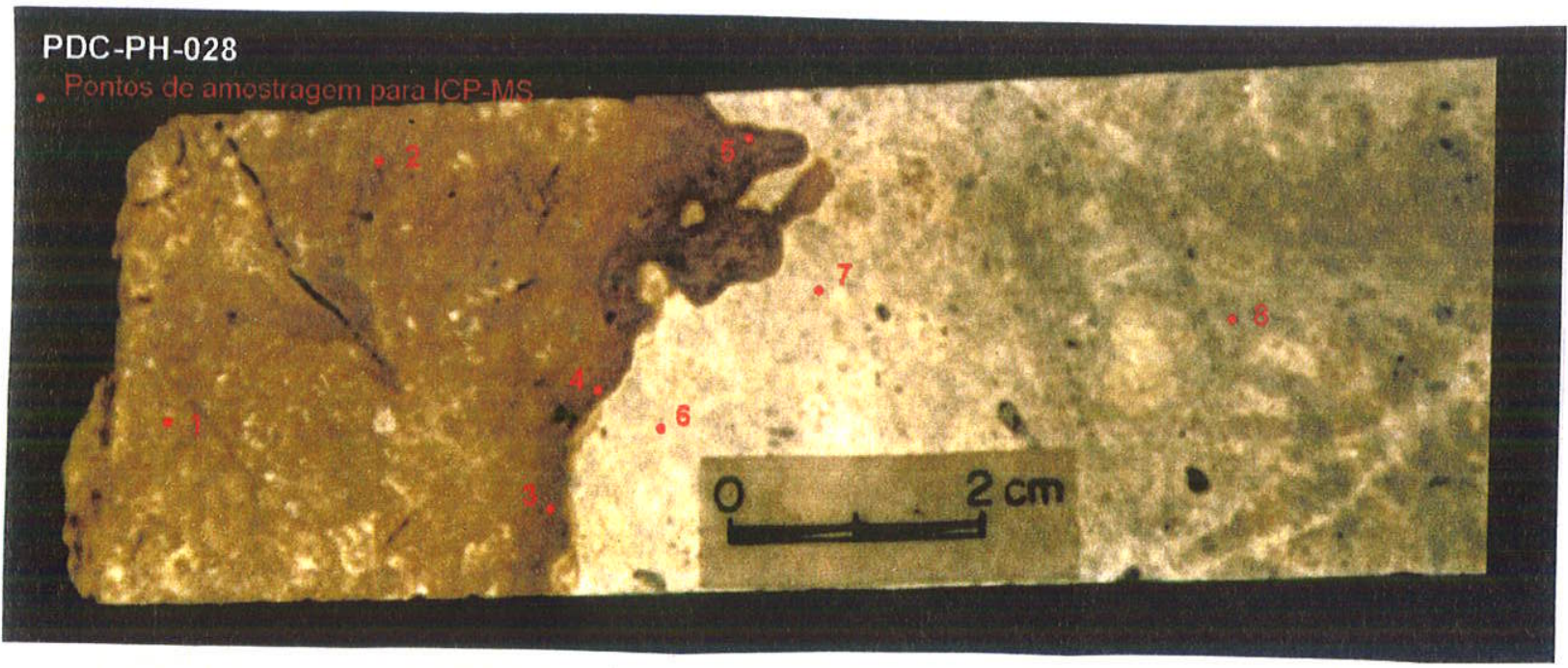

Foto 24: Amostra PDC-PH-028, frente redox de tipo 1, com forte enriquecimento de OHF e indicação de amostragens para ICP-MS. 


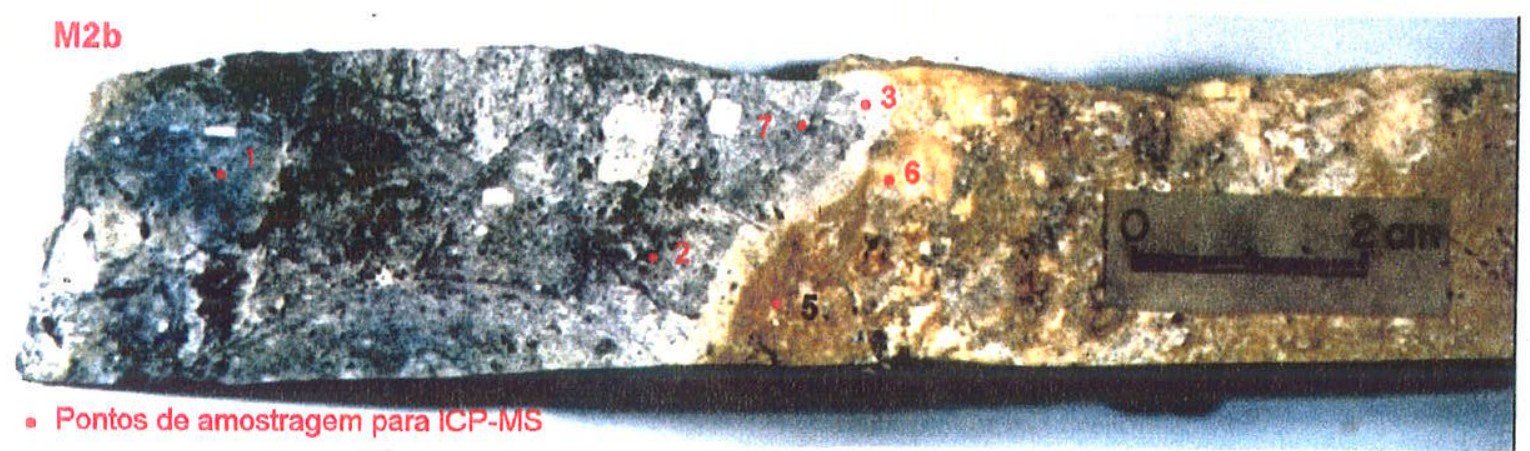

Foto 25: Amostra M2b, frente redox de tipo 2, com zona branca de contato $e$ indicação de amostragens para ICP-MS.

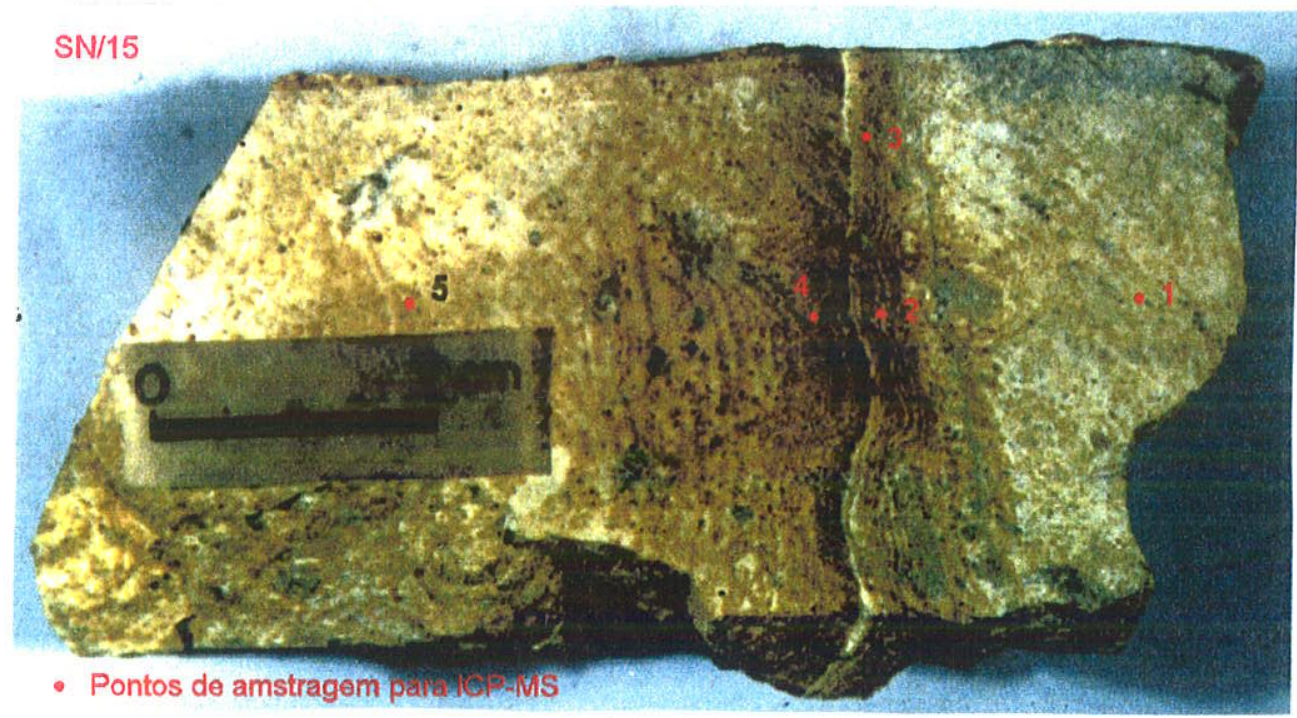

Foto 26: Amostra $S N / 15$, frente redox de tipo 3, com zonas rítmicas ricas em $\mathrm{OHF} e$ indicação de amostragens para ICP-MS. 


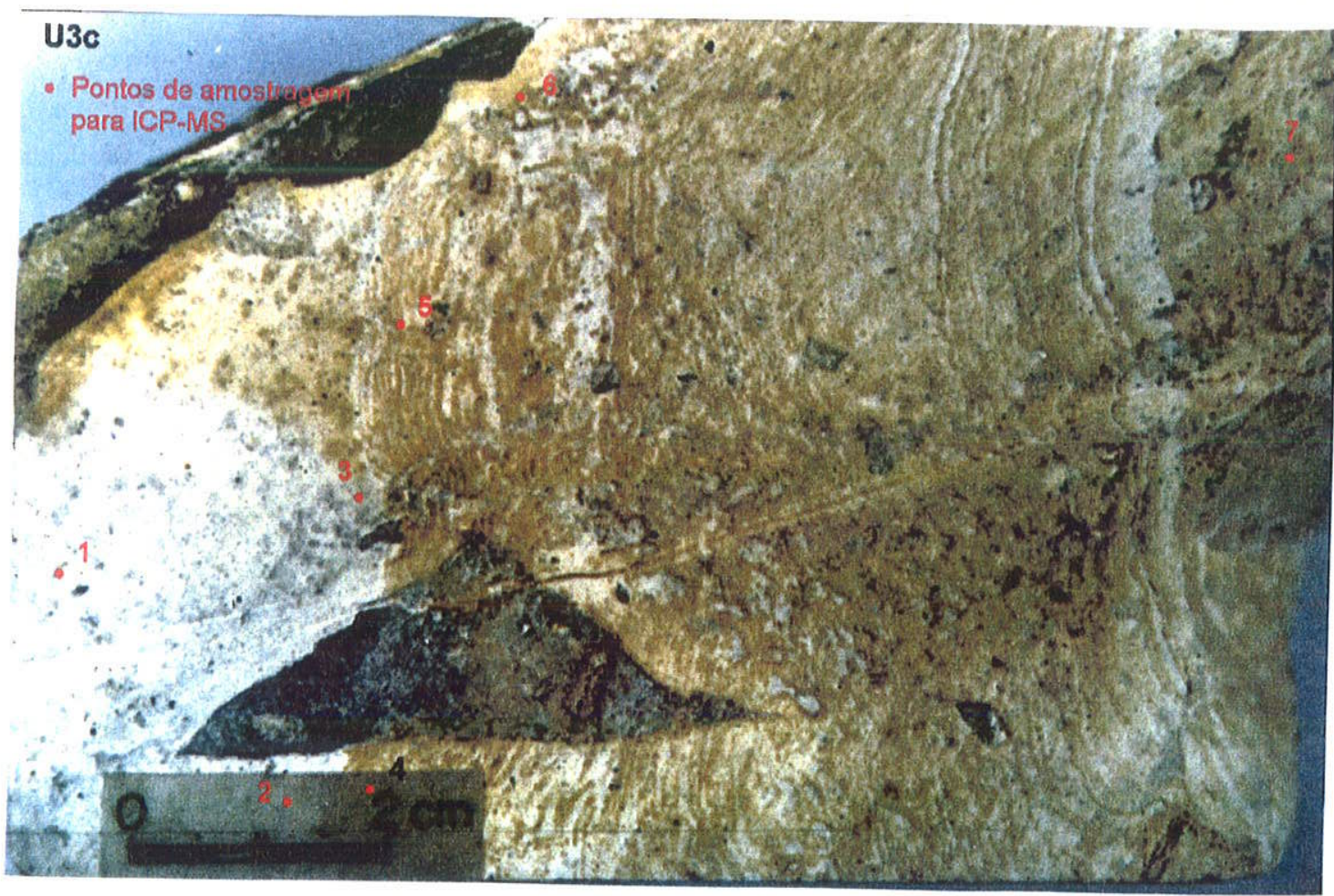

Foto 27: Amostra U3c, frente redox de tipo 3, com zonas rítmicas ricas em OHF e indicação de amostragens para ICP-MS.

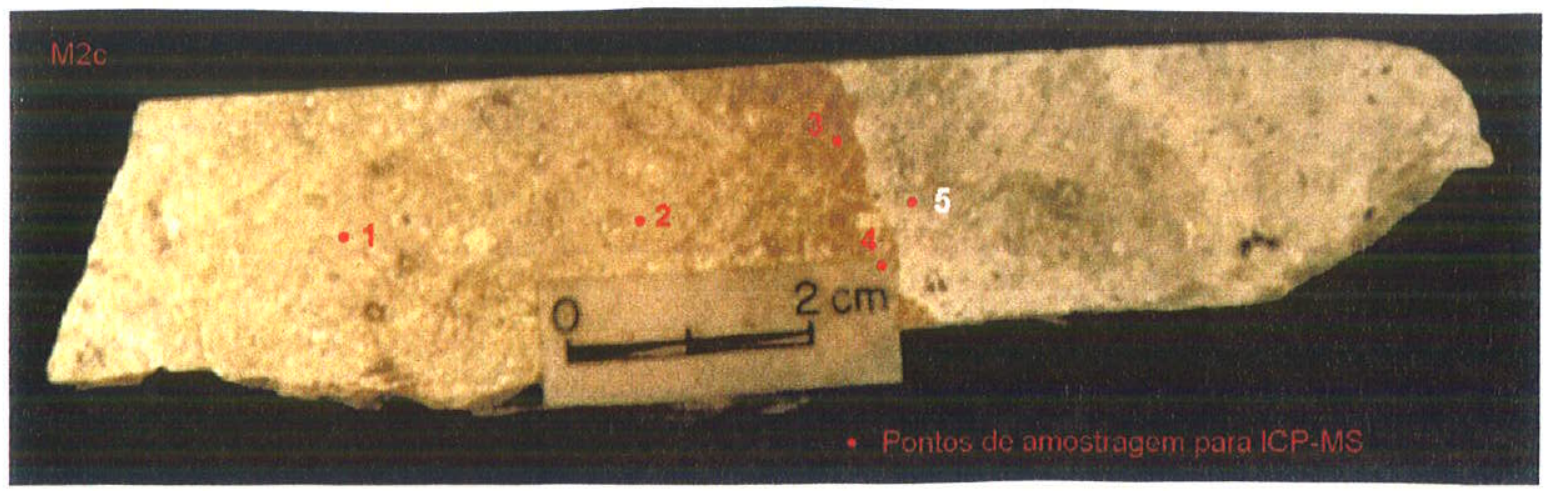

Foto 28 a: Amostra M2c, frente redox de tipo 4, com contato nítido e indicação de amostragens para ICP-MS. 


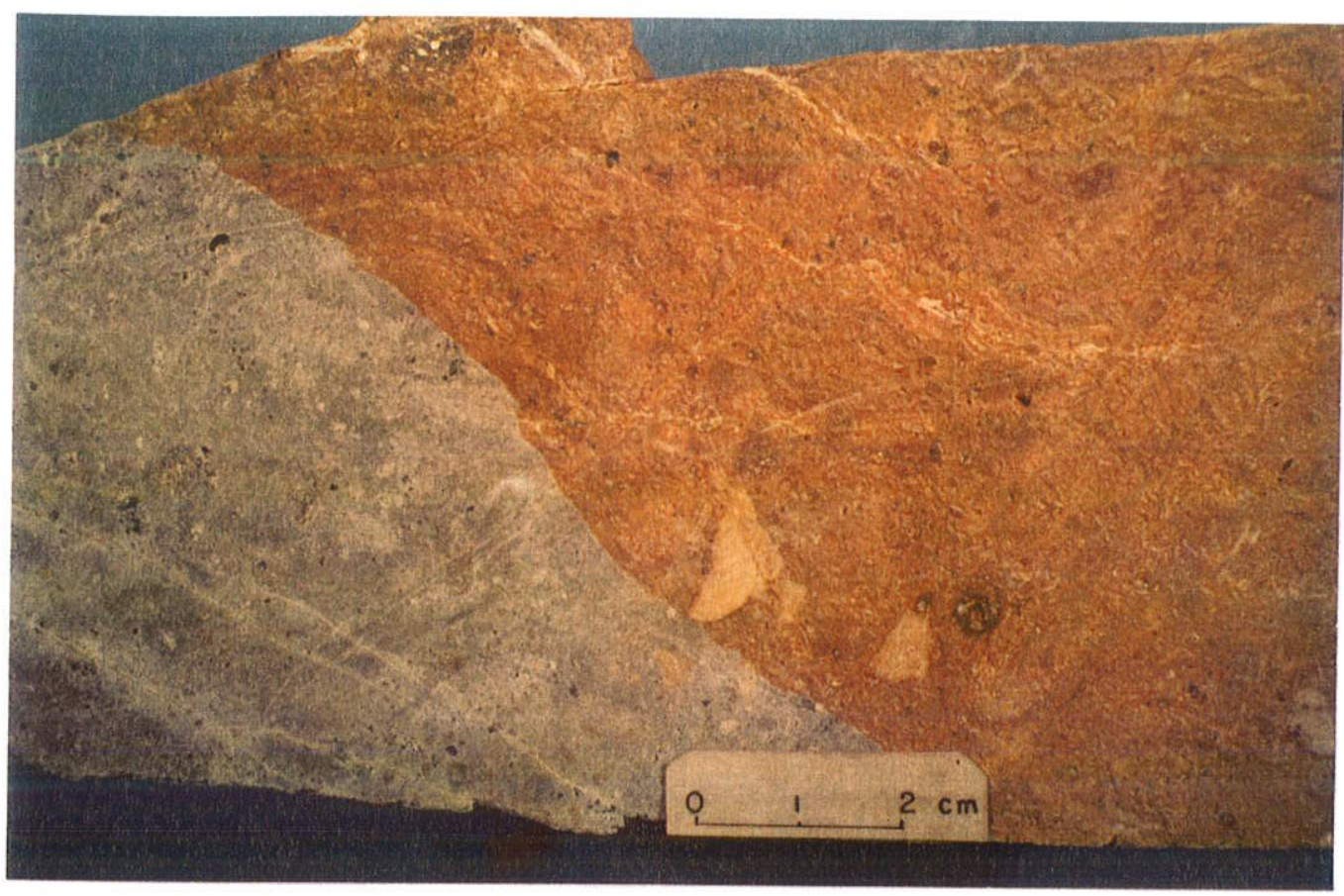

Foto 28 b: Frente redox de tipo 4 em fonolito microxenolítico (amostra $S N / 21$ ).

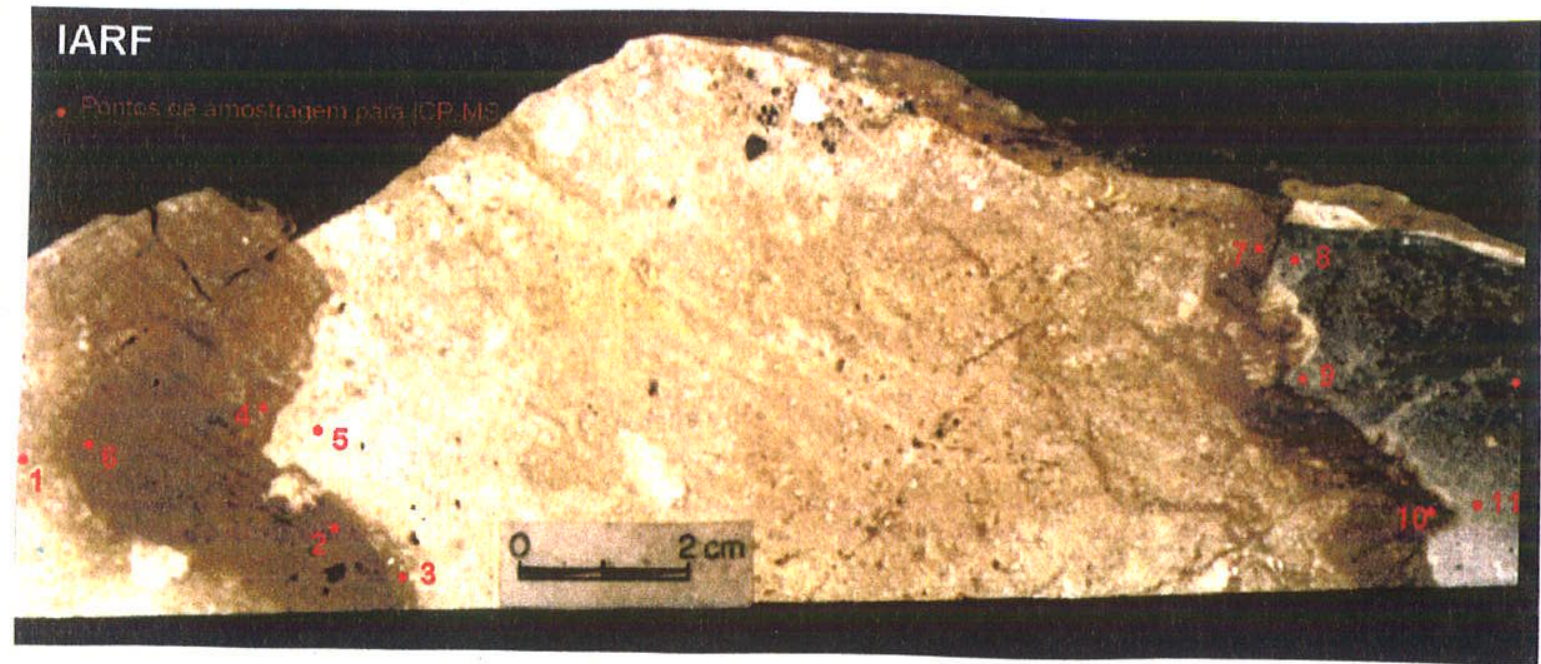

Foto 29: Amostra IARF, frente redox complexa e indicação de amostragens para ICPMS. Ocorrem 2 frentes caracterizadas por zonas enriquecidas em OHF, uma recente na interface com a rocha reduzida e outra fóssil na zona oxidada, separadas por avanço de frente de tipo 4 , em condições saturadas e redistribuição homogênea de $O H F$. 


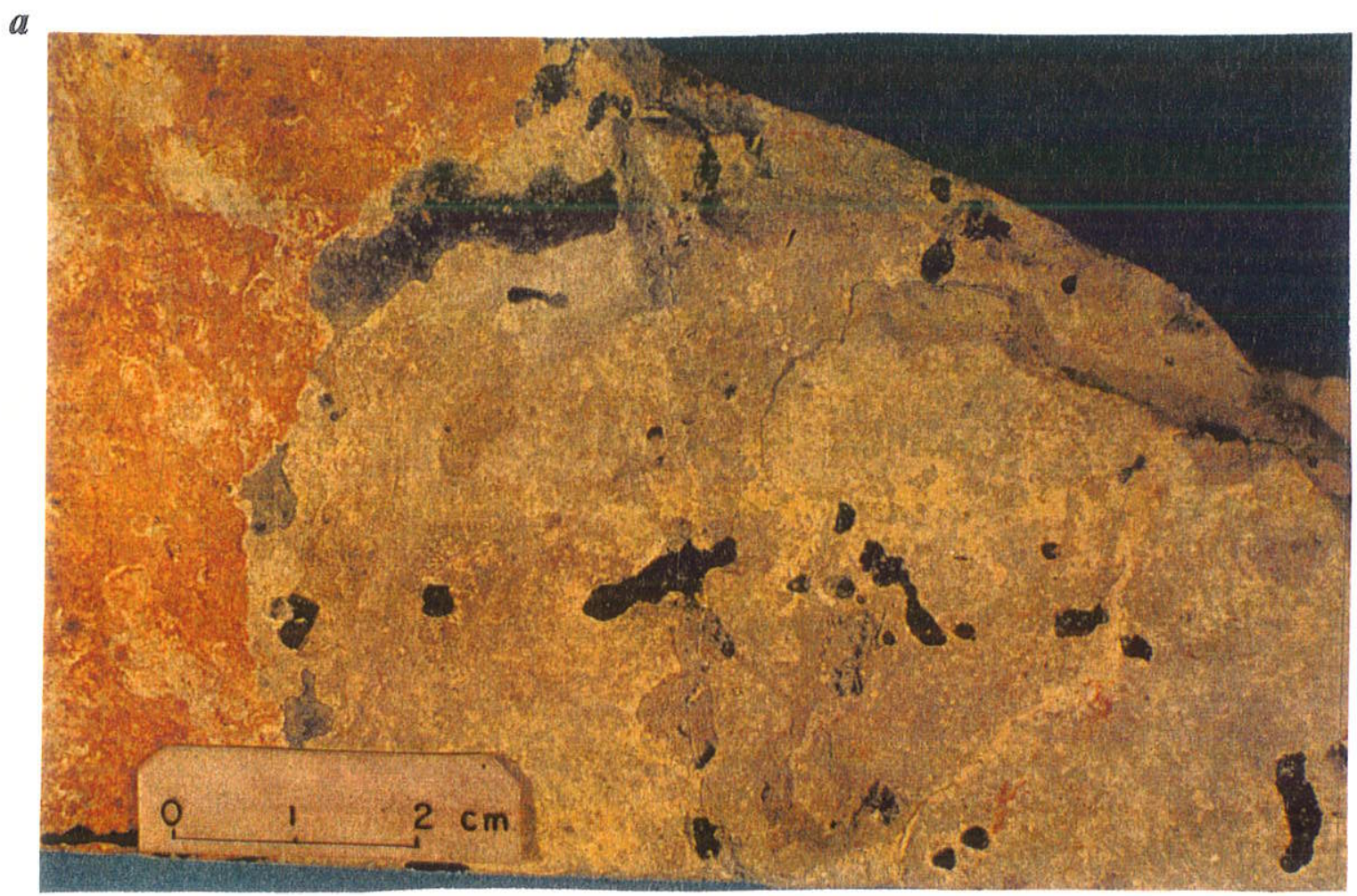

b

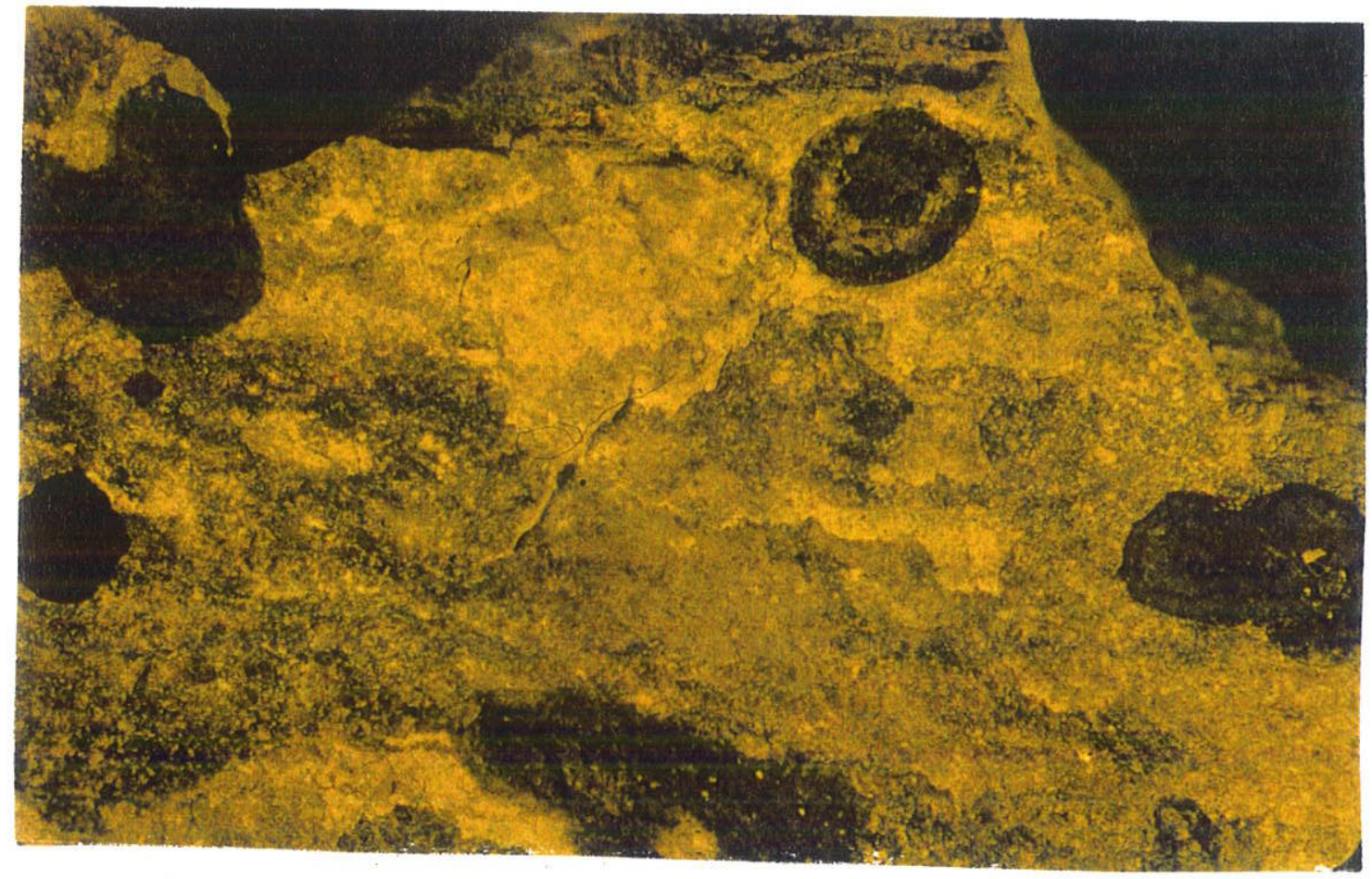

Foto 30: a-Detalhe de uma frente redox com forte enriquecimento supérgeno de $U$ na forma de micronódulos (pretos) e disseminações finas (tingimentos cinza claros a médios) (amostra SN/21); b-Micronódulos concêntricos e homogêneos (amostra RFI)(tamanho natural). 
a

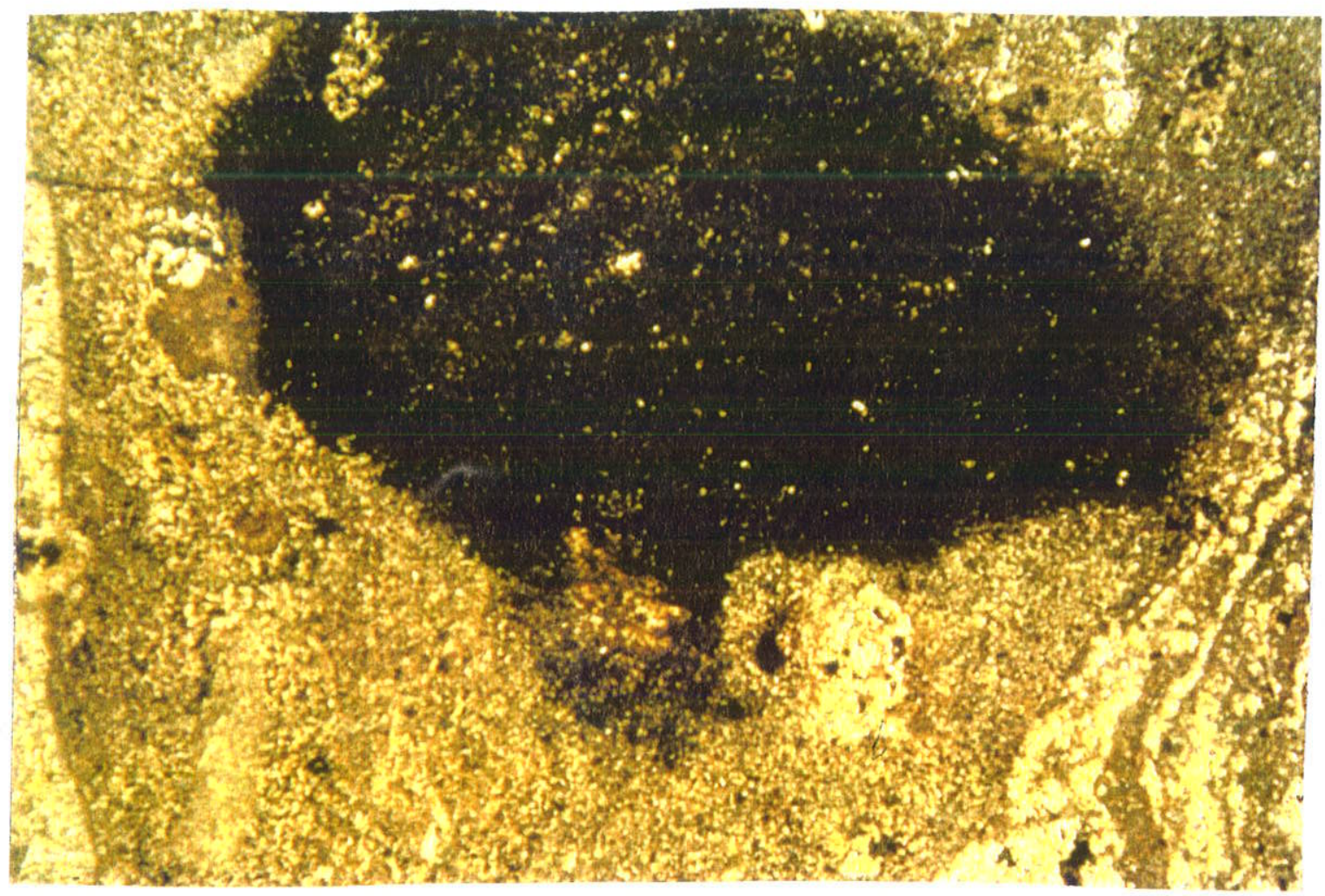

b

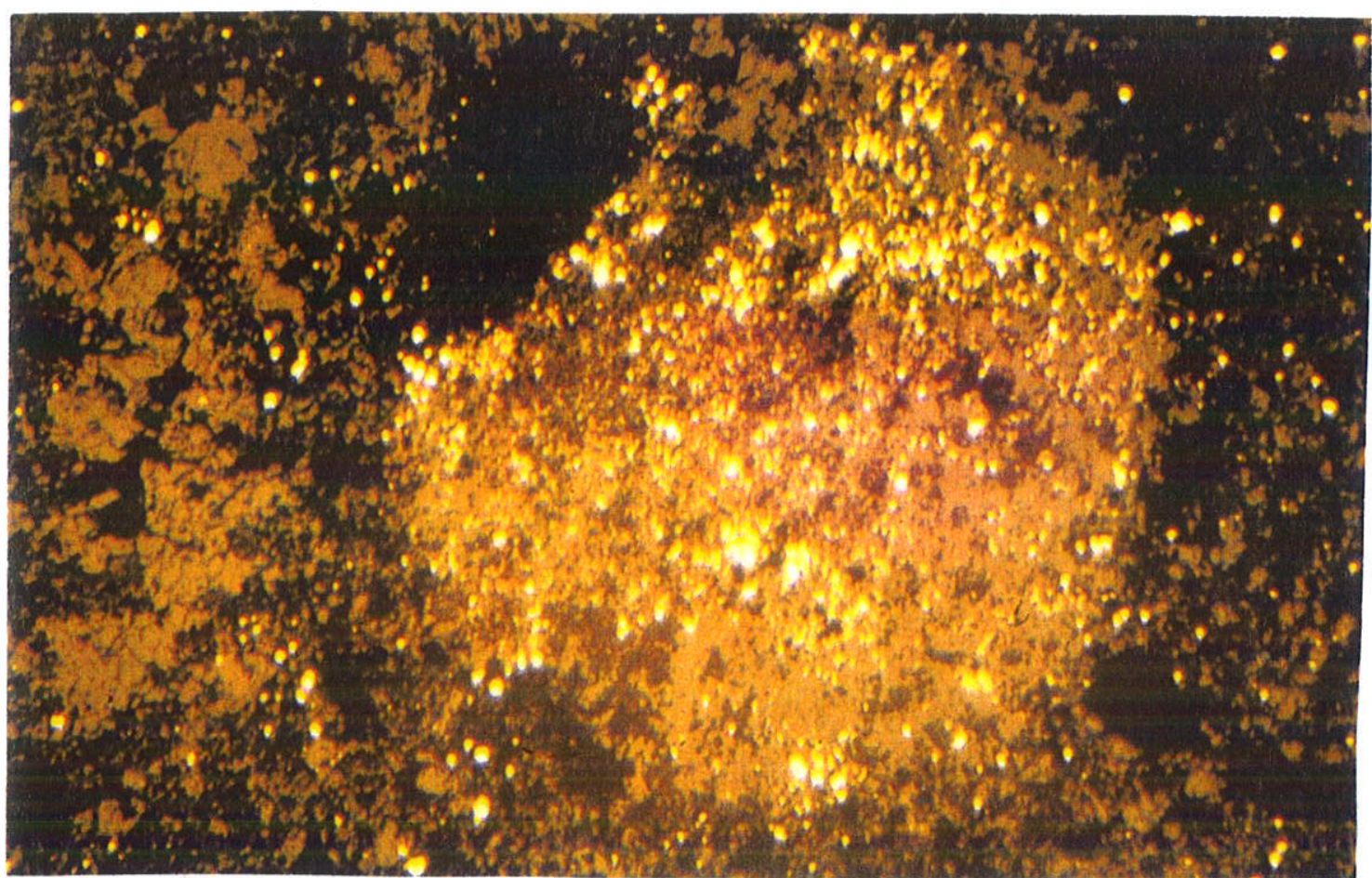

Foto 31: a-Microfotografia de luz transmitida (polarizadores //) de micronódulo de $U$ (diâmetro de $10 \mathrm{~mm}$ ), em $\mathrm{Ph}$ com textura fluidal, mostrando crescimento periférico intersticial e a substituição interna dos minerais silicáticos (polarizadores //, lado maior da foto $15 \mathrm{~mm}$ ) (amostra SN/15, lâmina SN/15); b-Microfotografia de seção polida (luz refletida) de micronódulo de $U$ (diâmetro de $3 \mathrm{~mm}$ ) mostrando o enriquecimento do nódulo em pirita supergênica em relação às piritas hidrotermais na matriz da rocha (amostra SN/21, lâmina SN/21). 


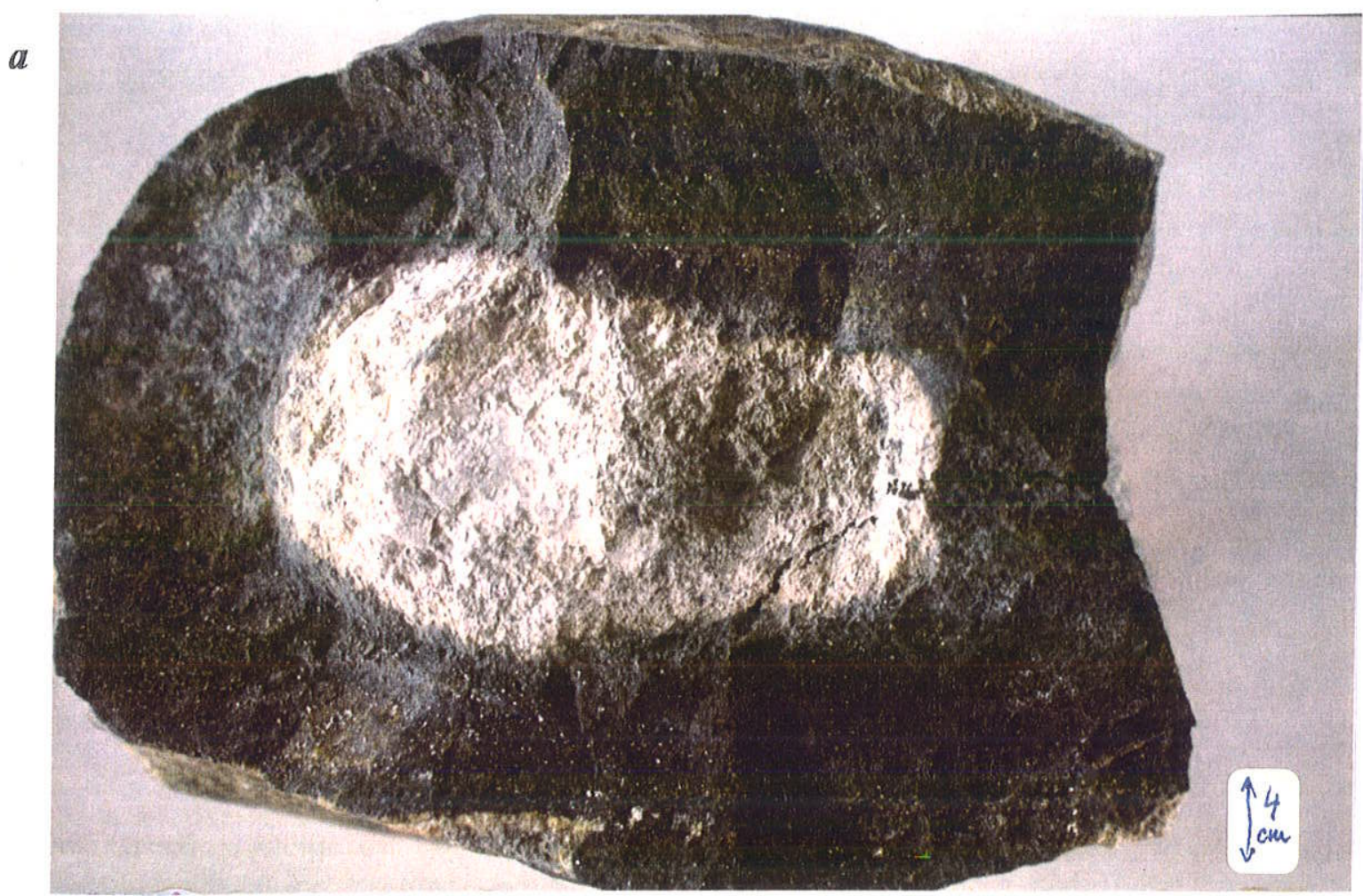

$b$

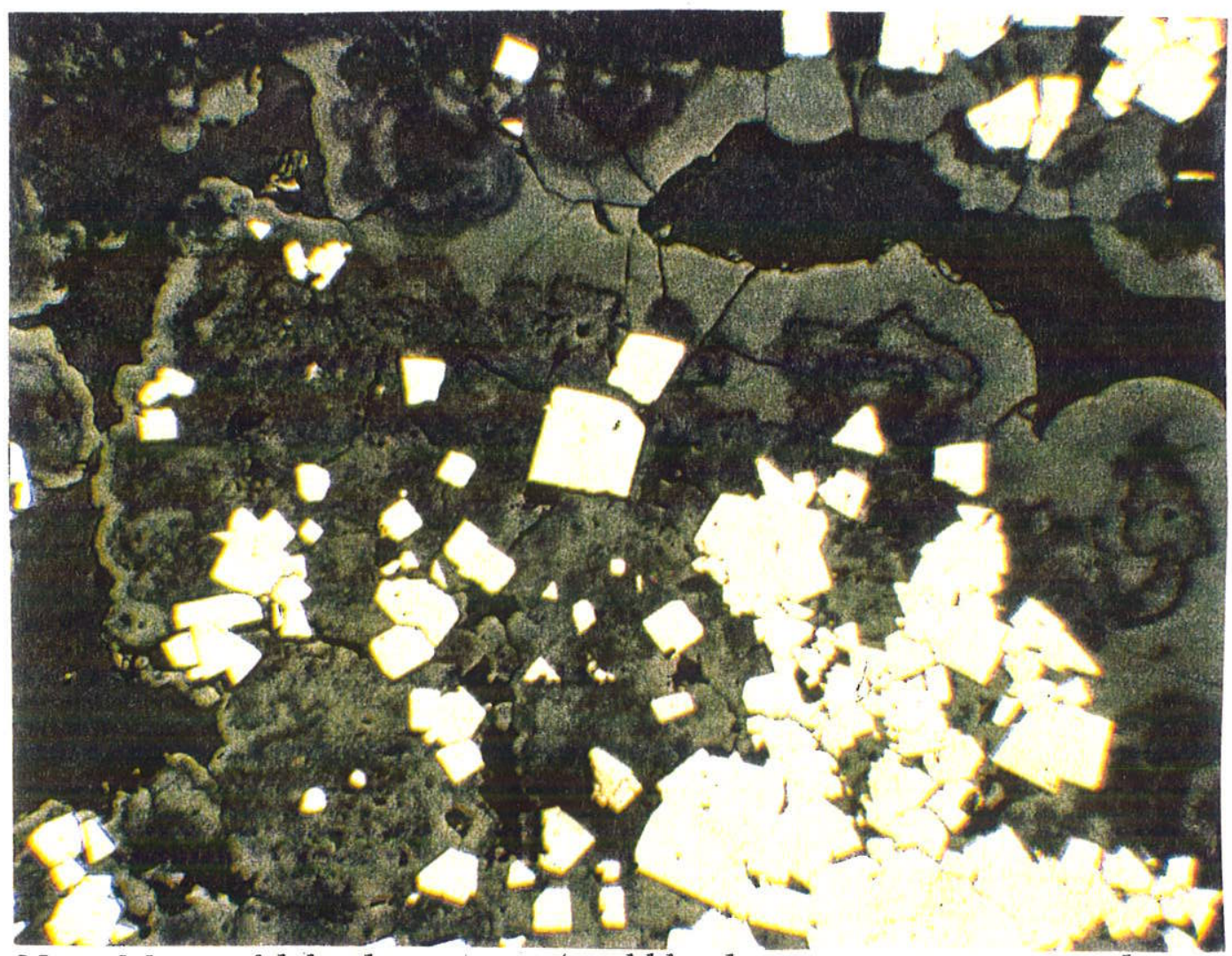

Foto 32: a-Macronódulo de uraninita/pitchblenda maciça em amostra de mão com piritas supergênicas em cristais de 0,2-1 mm idiomórficos, e núcleo silicático de rocha reduzida (amostra VII); b-Microfotografia de seção polida (luz refletida) de macronódulo com uraninita/pitchblenda botrioidal sobrecrescida às piritas supergênicas idiomórficas e raros restos de piritas hidrotermais finas arredondadas por corrosão/dissolução parcial (amostra SN/24; pol. //, lado maior da $10 \mathrm{~mm}$ ). 


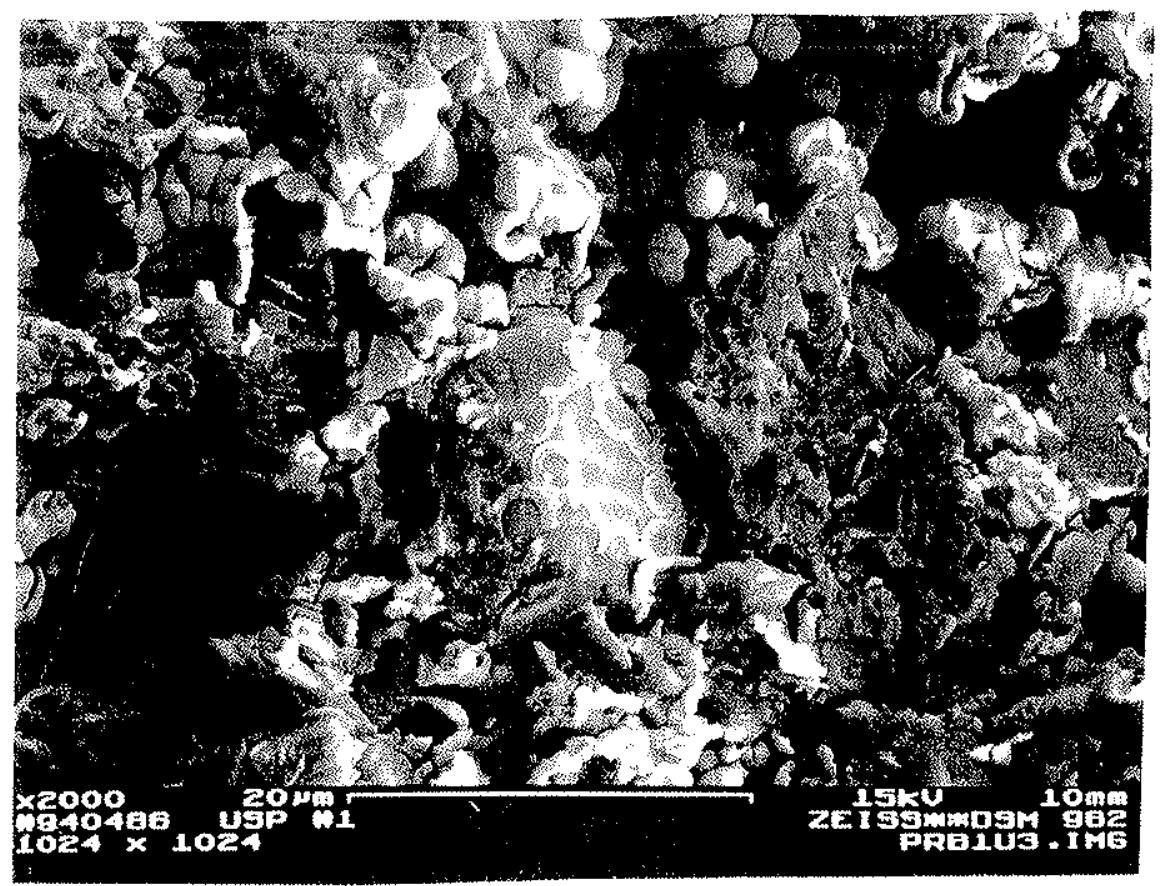

Foto 33: Imagem de microscopia eletrônica de mineralização supergênica de $U$, mostrando pitchblenda botrioidal e verniforme, crescendo sobre minerais silicáticos da matriz e piritas da $2^{\alpha}$ geração (amostra $\$ N / 24$, lamina sn/24).

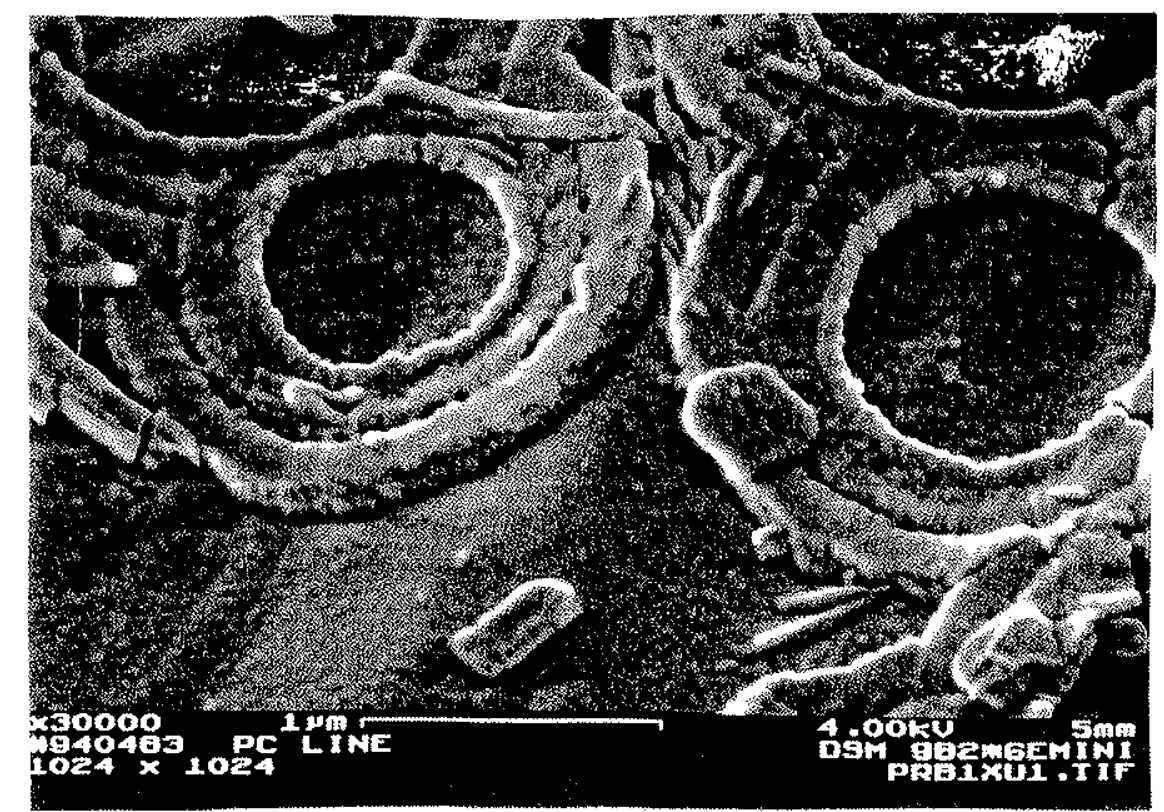

For 34: Imagem de microscopia eletrônica, mostrando detalhe da foto 33 de superficie de uma pirita de $2^{a}$ geração, com inicio do crescimento de pitchblenda botrioidal, em arranjos finamente zonados. Esta estrutura sugere atividade biogentica (colônia de bactérias) que causam a precipitaça e o crescimento de pitchblenda botrioidal (amostra $\$ N / 24$, lamina sn/24). 


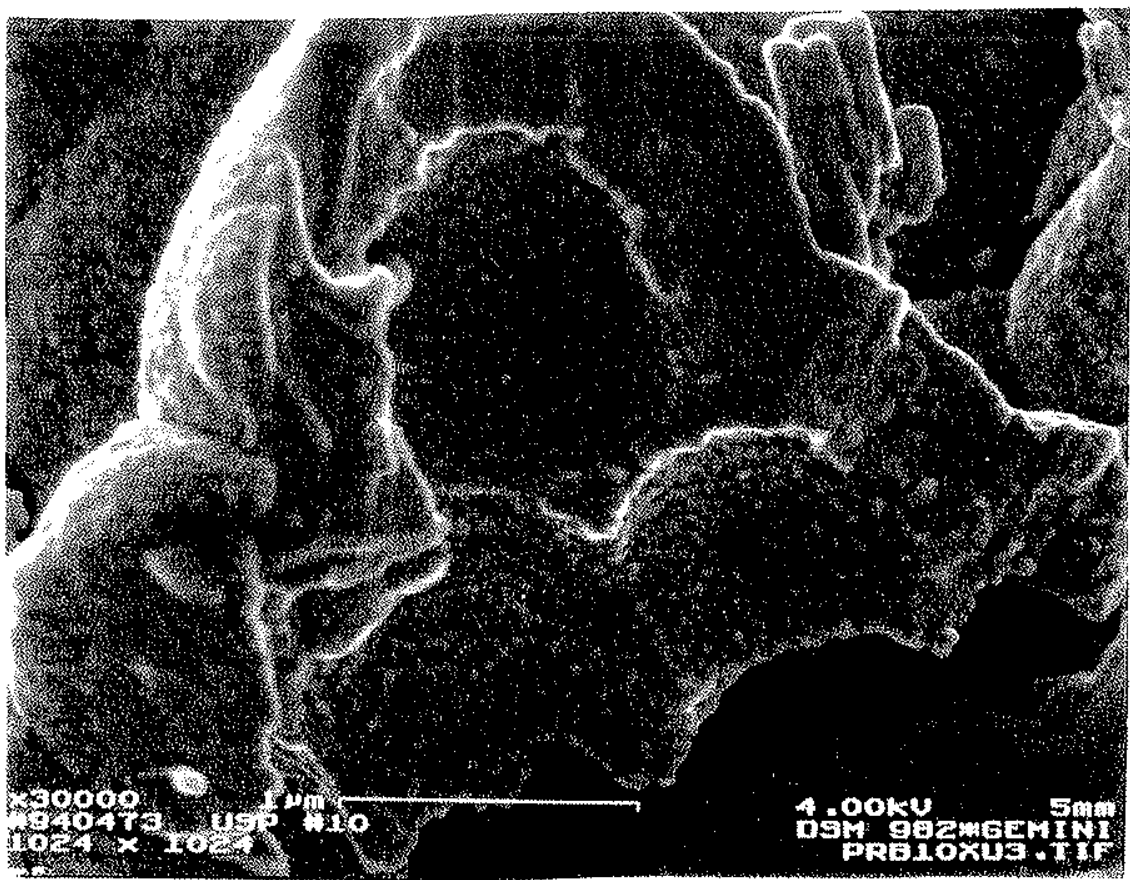

Fon 35: Imagem de microscopia eletronica mostrando outro detalhe da foto 33, com pitchblenda botroidal, evidenciando a criptocristalinidode de seus gróas $e$ as estmuturas de crescimento zonado (amostra $\$ N / 24$, lâmina $5 n / 24$ ).

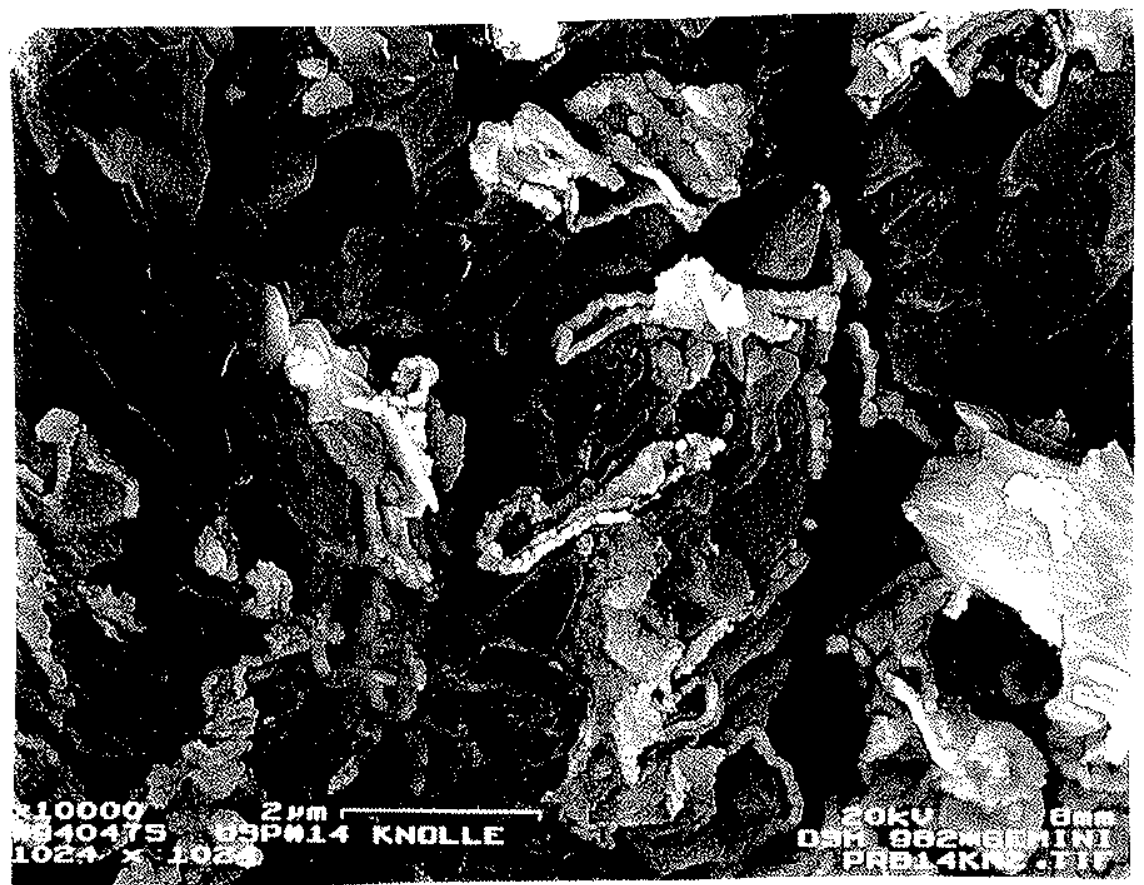

Fota 36: Imagem de microscopia eletrônica que mostra detalhe de mineralizaçán supergentica de $U$ com pitchblenda criptocristalina vermifome, crescendo sobre superficies (fraturas e bordas de gräos) de minerais silicáticos (amostra $5 N / 24$, lâmina sn/24). 


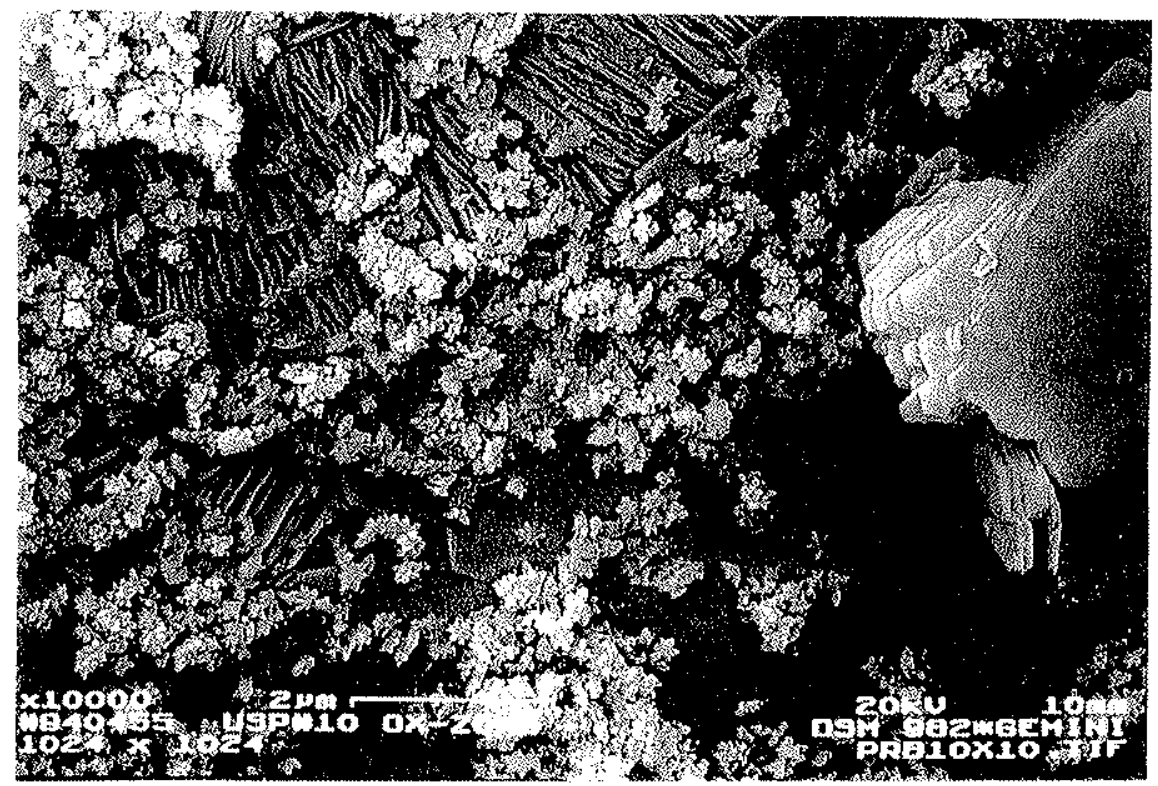

Fớ 37: Imagem de microscopia eletrônica de OHF exógenos, a partir da oxidação da pirita sob sistema de saturação, finamente disseminados na matriz do hidrotermalito potássico (amostra M2c, lâmina M2c).

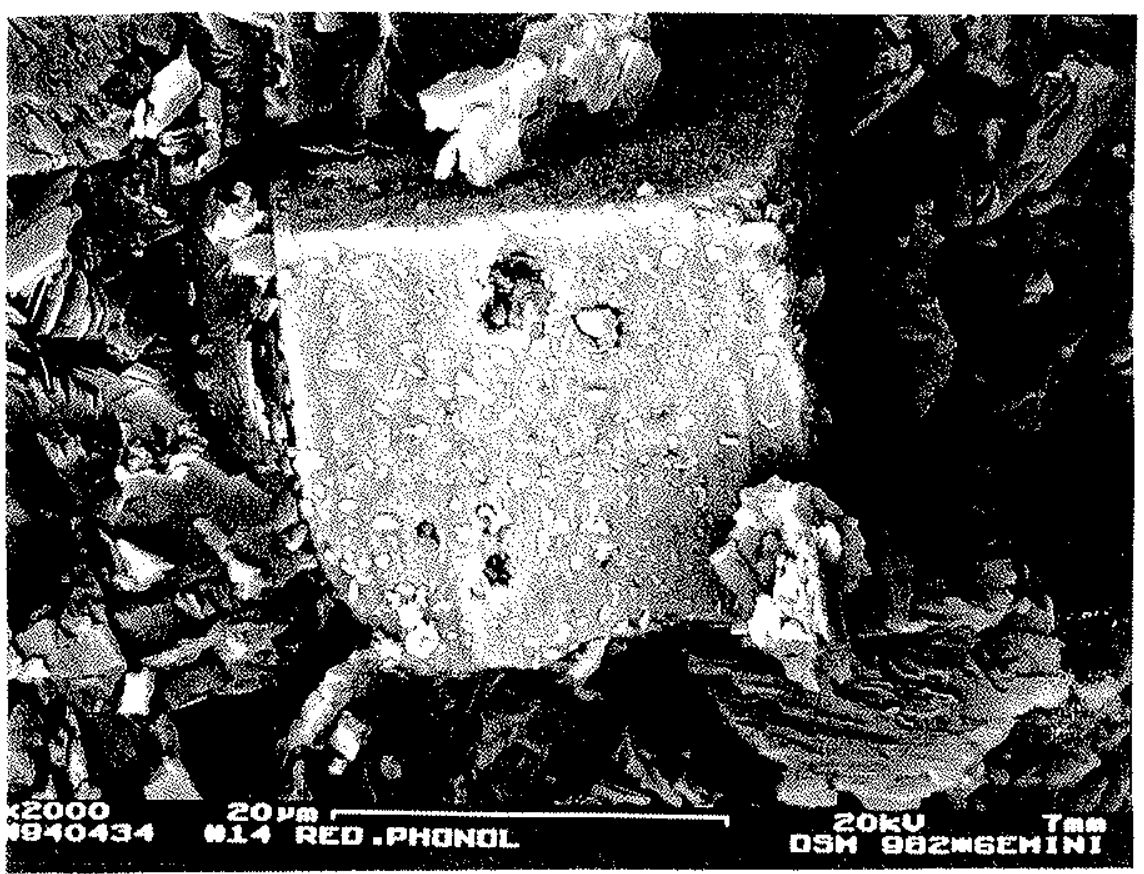

IF (1) 319: Imagem de microscopia eletrônica, mostrando cristal idiomónfico de pirita hidroternal (amostra $M 2$, parte reduzido, lamina $M 2 \mathrm{c}$ ). 


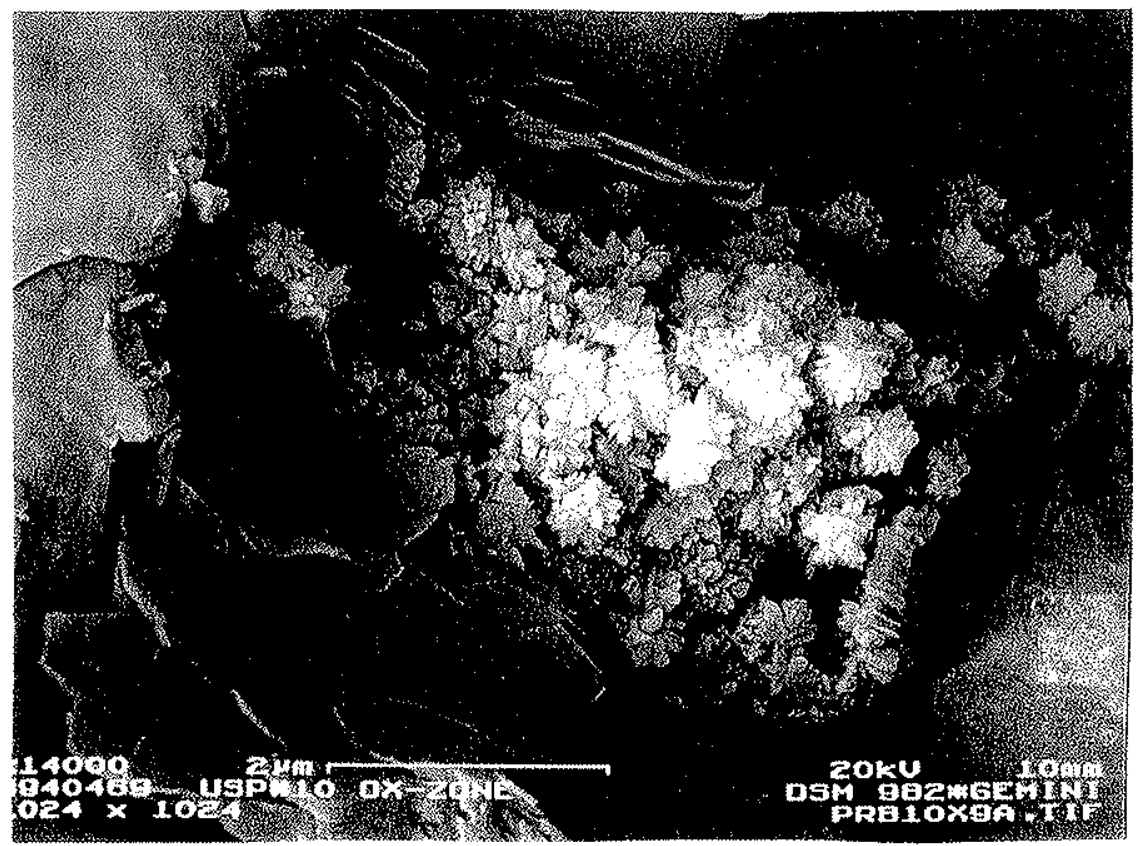

IF 39: Imagem de microscopia eletrônica de OHF indigeno, pseudomorfizando um cristal idiomórfico de pirita. A falta de OHF fora da pirita indica um sistema de insaturação durante a oxidação da mesma (amostra Fl/1-1.30m, lamina Fl/l).

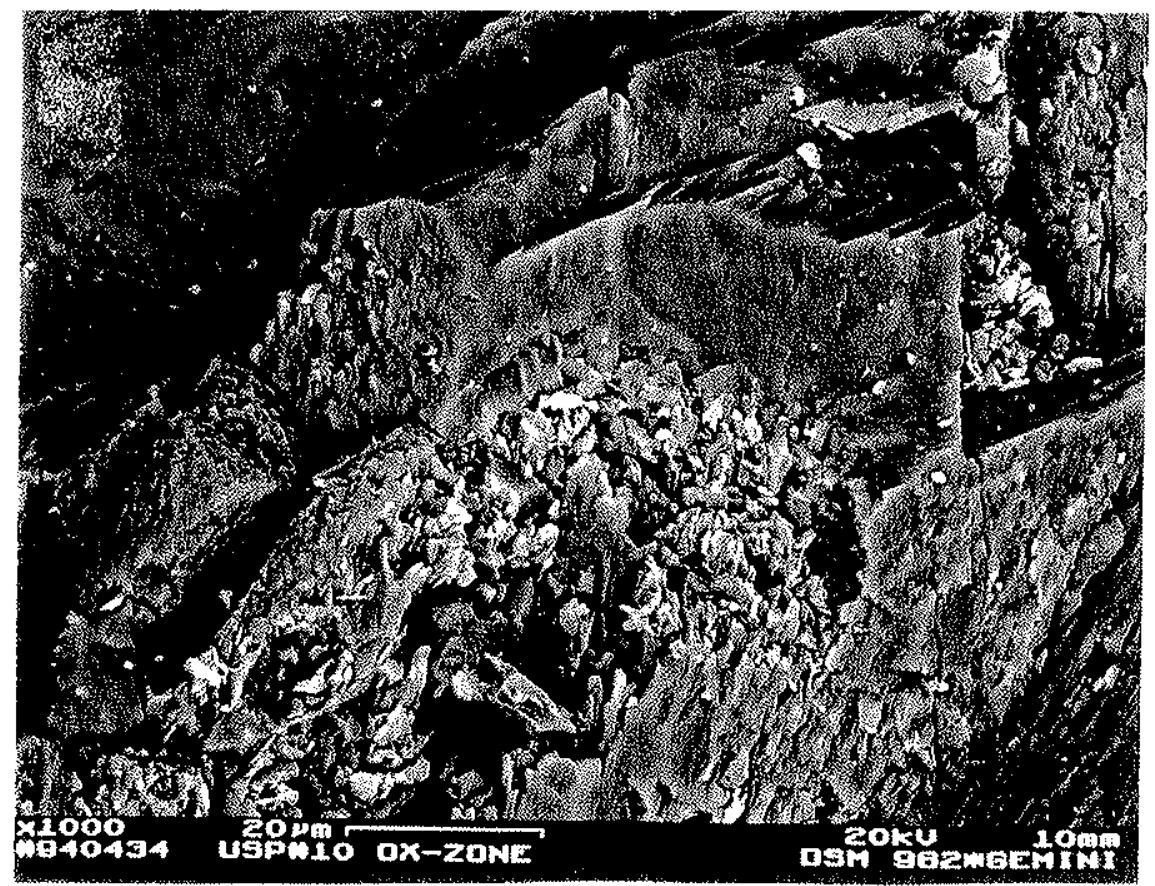

Ifoto 40: Imagem de microscopia eletrônica de feldspato potóssico da rocha reduzida em estágio inicial de substituição incompleta, por caolinita hidroterwal bem cristalizada (amostra F4/243-1A, lânina F4/243-1A). 


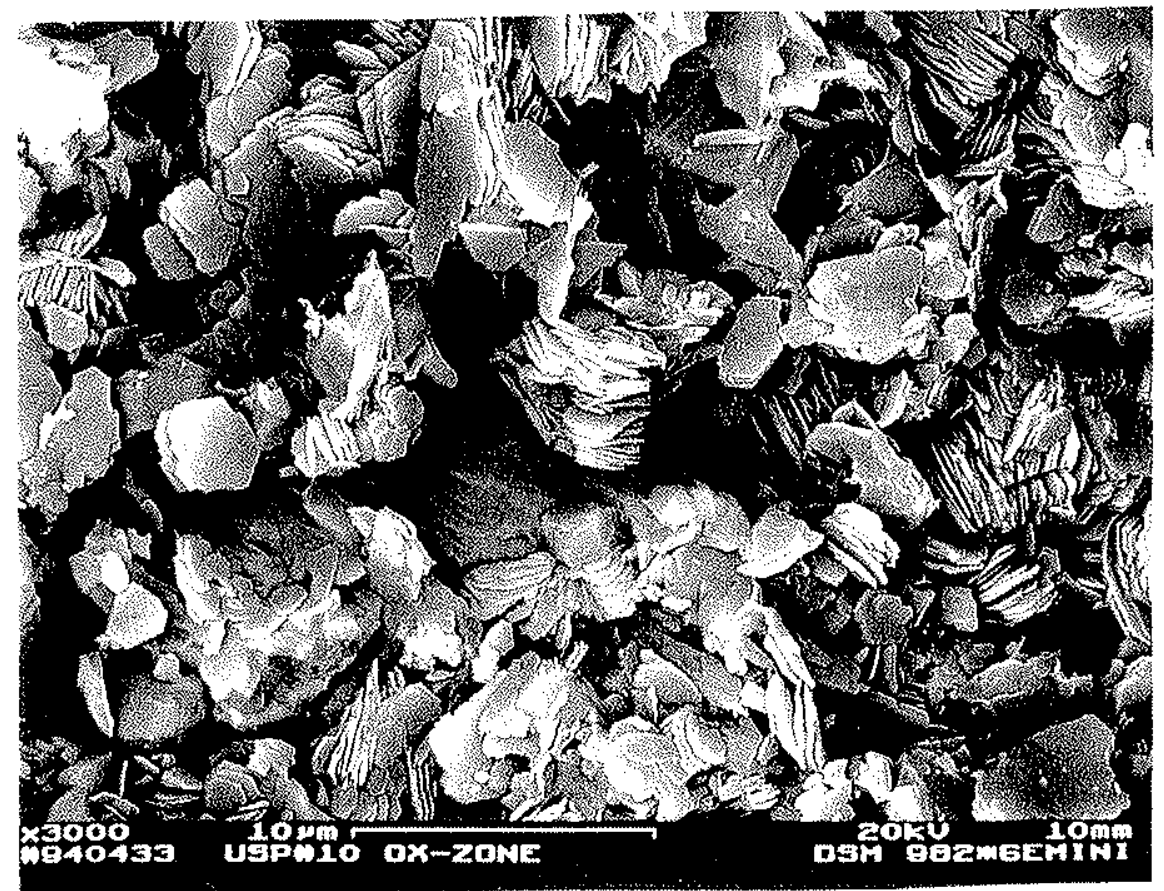

Fotos 41: Detalhe da foto 40, imagem de microscopia eletrônica mostrando caolinita hidroternal bem cristalizada (amostra F4/243-1A, lamina F4/243-1A).

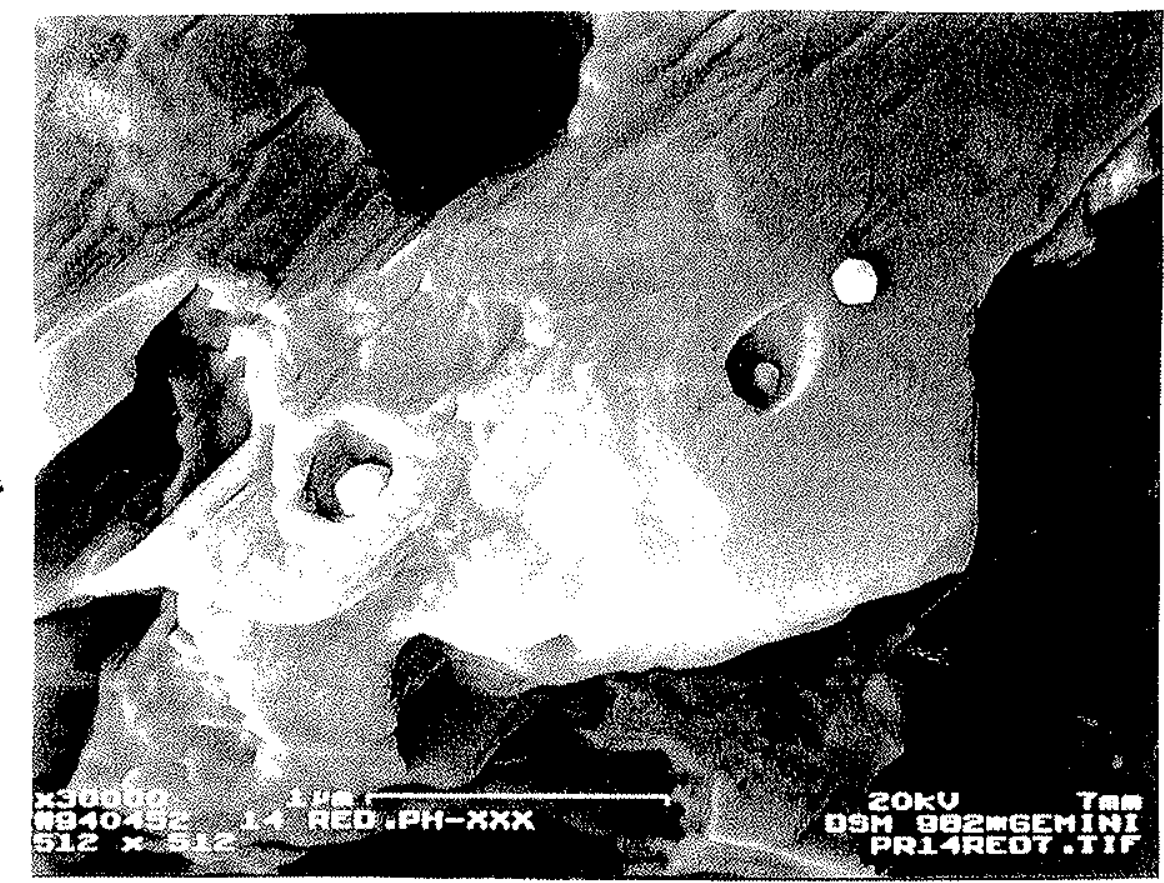

Foto 12: Imagem de microscopia eletrônica de feldspato alcalino com inclusöes de minerais radioativos hidrotermais envolvidos por auréolas de corrosão (anostra FA/243-1A, lamina FA/243 1A). 


\begin{tabular}{|c|c|c|c|c|c|}
\hline Mineraogia & NeS & $\mathrm{Ph}$ & HiRed & HiOx & $\begin{array}{l}\text { Frentes } \\
\text { Redox }\end{array}$ \\
\hline Sanidina & - & $\mathrm{m}$ & - & - & - \\
\hline Ortoclásio pertítico & $m$ & - & - & - & - \\
\hline K-feldspato baixa T & - & - & $m$ & $m$ & $m$ \\
\hline Nefelina & $m$ & $m$ & - & - & - \\
\hline Cancrinita & $\operatorname{tr}$ & tr & - & - & - \\
\hline Pseudoleucita & $\mathrm{e}$ & $\mathrm{e}$ & - & - & - \\
\hline Aegirina-augita & $\operatorname{tr}$ & $\mathrm{tr}$ & - & - & - \\
\hline Natrolita & $m$ & $m$ & - & - & - \\
\hline Illita/sericita & - & - & $\mathrm{e}-\mathrm{m}$ & $e-m$ & $e-m$ \\
\hline Caolinita & - & - & $e-m$ & $e-m$ & $e-m$ \\
\hline Smectita/(clorita?) & - & - & tree & tr-e & trme \\
\hline Apatita & tr & tr & - & - & - \\
\hline Titanita & tr & $\operatorname{tr}$ & - & - & - \\
\hline Zircão & $\operatorname{tr}$ & $\mathrm{tr}$ & tr-e & tr-e & tr-e \\
\hline Baddeleyita & - & - & tr-e & tr-e & tr-e \\
\hline Giannettita & $\mathrm{e}$ & $\mathrm{e}$ & - & - & - \\
\hline Monazita & - & - & $\operatorname{tr}$ & tr & - \\
\hline Fluorita & $\operatorname{tr}$ & $\mathrm{tr}$ & $\mathrm{e}$ & - & - \\
\hline Carbonato & - & - & tr & - & - \\
\hline Magnetita & $\operatorname{tr}$ & $\operatorname{tr}$ & - & - & - \\
\hline Hematita & $\operatorname{tr}$ & $\mathrm{tr}$ & - & tr-e & tr-e \\
\hline Pirita & $\operatorname{tr}$ & tr & $\mathrm{m}$ & - & $e-t r$ \\
\hline Uraninita/pitchblenda & - & - & $\operatorname{tr}(?)$ & - & $e-m$ \\
\hline Mos (crist. E/ou amorfo) & - & - & tr-e & - & $\operatorname{tr}$ \\
\hline Galena & - & - & $\operatorname{tr}$ & - & $\operatorname{tr}$ \\
\hline Esfalerita & - & 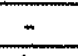 & $\operatorname{tr}$ & - & $\operatorname{tr}$ \\
\hline Calcopirita & $\operatorname{tr}$ & tr & $\operatorname{tr}$ & - & $\operatorname{tr}$ \\
\hline $\mathrm{OHF}$ & - & - & - & $m$ & $m$ \\
\hline TiO2 criptocristalino & - & - & $\operatorname{tr}$ & $\operatorname{tr}$ & $\operatorname{tr}$ \\
\hline IIsemanita & - & 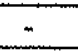 & - & tr-e & $\operatorname{tr}$ \\
\hline Jarosita & - & - & - & $\operatorname{tr}(?)$ & $\operatorname{tr}(?)$ \\
\hline Eudialita & true & $\operatorname{tr}$ & - & - & - \\
\hline Outros silicatos de ETR magmáticos & tr & $\operatorname{tr}$ & - & - & - \\
\hline Pirrotita & $\operatorname{tr}$ & $\operatorname{tr}$ & - & - & - \\
\hline Pentlandita & $\mathrm{tr}$ & $\operatorname{tr}$ & - & - & - \\
\hline Greenailita & - & - & - & - & $\operatorname{Tr}$ \\
\hline Outros fosfatos de ETR hidrotemais & - & - & $\operatorname{tr}$ & $\operatorname{tr}$ & $\operatorname{Tr}$ \\
\hline Barita & - & - & $\operatorname{tr}$ & $\operatorname{tr}(?)$ & $\operatorname{tr}(?)$ \\
\hline
\end{tabular}

Tabela 1: Síntese da mineralogia dos nefelina sienitos (NeS) e fonolitos (Ph) regionais e hidrotermalitos equivalentes reduzidos (HiRed) e oxidados (HiOx) da mina de urânio ( $m$ - constituinte maior > 10\%-vol.; e - contituinte essencial $\geq 1 \%-\leq 10 \%$ vol; tr - constituintes em traços: <1\%-vol). 


\begin{tabular}{|c|c|c|c|c|c|c|c|c|c|}
\hline Imagem & M1-Do1 & $M 1-\infty 01$ & $M 2-\infty 01$ & M3-DO1 & $M 3-\infty 01$ & M4-002 & $\mathrm{M} 4002$ & $M 4002$ & $\mathrm{M} 4002$ \\
\hline Ponto Análise & 4 & 5 & 9 & 1 & 2 & 1 & 2 & 3 & 4 \\
\hline $\mathrm{Si}$ & 7.72 & 9.8 & - & 2.56 & 0.9 & 11.27 & 13.32 & 13.32 & 11.76 \\
\hline 5 & 0.95 & - & 40.3 & 19.58 & 42 & - & - & - & - \\
\hline$P$ & 0.89 & $=$ & - & $=$ & $=$ & 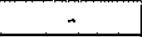 & - & - & - \\
\hline $\mathrm{K}$ & 1.17 & - & 0.27 & 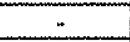 & 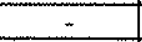 & - & - & - & $\sim$ \\
\hline $\mathrm{Ca}$ & 1.38 & 1.16 & 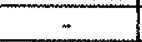 & 0.76 & 0.59 & 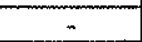 & $\because$ & - & 0.32 \\
\hline $\mathrm{Ti}$ & $=$ & - & 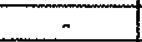 & 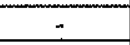 & 1.12 & $=$ & $=$ & - & $=$ \\
\hline $\mathrm{Fe}$ & 0.53 & 0.82 & 27.61 & 2.91 & 2,96 & 0.54 & 0.59 & 0.64 & 1.35 \\
\hline $\mathrm{Zn}$ & 2.29 & 1.93 & 2.64 & 24.96 & - & 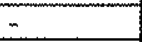 & 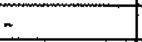 & - & - \\
\hline $\mathrm{Zr}$ & 40.51 & 43.51 & 2.96 & 10.69 & 53.25 & 37.7 & 44.43 & 44.5 & 42.07 \\
\hline $\mathrm{Mn}$ & $\therefore$ & 0.29 & $\approx$ & $=$ & 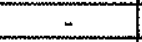 & - & - & 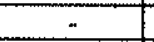 & - \\
\hline $\mathrm{Nd}$ & - & 0.38 & - & - & $\sim$ & $=$ & - & $=$ & 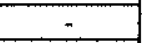 \\
\hline $\mathbf{U}$ & 5.14 & 4.79 & 17.17 & 15.49 & 10.35 & 15.66 & 5.93 & 5.38 & 3.41 \\
\hline
\end{tabular}

\begin{tabular}{|c|c|c|c|c|c|c|c|c|c|c|}
\hline Imagem & 0.002 & 4.002 & U.002 & U-ODO & U.004 & $U-\infty) 4$ & $U-004$ & U.005 & U.006 & U.006 \\
\hline Ponto Análise & $0002-1$ & $0002-1 b$ & U002-2 & U0003-1 & $\mathrm{U} 0041$ & UoO4-2 & U0O43 & U005-1 & U006-1 & U006.2 \\
\hline Si & 3.46 & 3.73 & 2.11 & 6.78 & 0.12 & 2.15 & 2.64 & & 0.12 & 0.1 \\
\hline$S$ & 14.76 & 10.52 & 28.77 & 4.4 & 35.96 & 21.2 & 19.13 & 42.01 & 5.71 & 4.23 \\
\hline $\mathrm{Al}$ & - & - & - & $=$ & - & 0.16 & 0.34 & 0.06 & - & - \\
\hline $\mathrm{Ca}$ & 0.88 & 1.05 & 0.71 & 1.22 & 0 & 0.69 & 0.92 & 0.02 & - & 0.19 \\
\hline $\mathrm{Ti}$ & - & - & - & 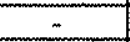 & $\sim$ & 0.05 & 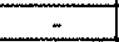 & 0.18 & 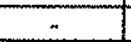 & $\sim$ \\
\hline $\mathrm{Mo}$ & - & - & $=$ & - & - & - & - & $=$ & 9.72 & 15.5 \\
\hline $\mathrm{Fe}$ & 6.04 & 1.74 & 14.45 & 6.4 & 1.15 & 1.18 & 2.37 & 27.27 & 1.4 & 1.15 \\
\hline $\mathrm{Zn}$ & 11.88 & 13.86 & 13.14 & 2.29 & 61.34 & 31.44 & 25.67 & 6.3 & 0.35 & 0.26 \\
\hline $\mathrm{Zr}$ & - & 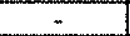 & - & - & 1.56 & 9.37 & 11.08 & 1.36 & - & - \\
\hline $\mathrm{Pr}$ & 0.6 & - & - & 0.29 & 0.08 & - & 0.83 & - & 0.33 & 0.13 \\
\hline $\mathrm{Ce}$ & 0.22 & 0.21 & 0.26 & 0.21 & 0.01 & $=$ & 0.8 & $=$ & 0.54 & 0.05 \\
\hline$A C$ & 0.23 & 0.77 & 0.86 & $=$ & 0.45 & 0.21 & 0.63 & 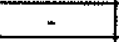 & $=$ & 0.18 \\
\hline $\mathrm{Nd}$ & 0.3 & - & 0.15 & 0.33 & 0.05 & $=$ & - & - & 0.07 & 0.21 \\
\hline $\mathrm{Pb}$ & &. & - & - & 4.06 & 3.86 & 2.56 & 13.13 & 50.9 & 47.94 \\
\hline Th & 0.58 & - & 0.26 & 0.05 & 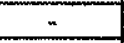 & $\approx$ & 0.68 & 0.59 & - & 0.26 \\
\hline $\mathbf{U}$ & 38.69 & 39.63 & 21.24 & 26.69 & 0.65 & 18.77 & 21.51 & 0.44 & 1.28 & 0.72 \\
\hline
\end{tabular}

\begin{tabular}{|c|c|c|c|c|c|c|c|c|c|c|c|}
\hline Imagem & $\mathrm{U}-006$ & U.006 & U-007 & U.007 & U.007 & U-009 & 4009 & U-009 & $\mathrm{U}-010$ & $0-010$ & U-010 \\
\hline Ponto Análise & U0063 & $4006-4$ & U007-1 & $0007-2$ & 0007.3 & $0009-1$ & U009-2 & 00003 & $0010-1$ & $4010-2$ & $0010-3$ \\
\hline $\mathrm{Si}$ & 1.85 & 0.42 & 9.44 & 13.54 & 10.81 & & 0.39 & 0.56 & & 0.02 & 0.01 \\
\hline$s$ & 12.97 & 33.86 & & 0.61 & & 50.38 & 25.32 & 19.63 & 48.36 & 32.53 & 46.88 \\
\hline Al & 0.56 & 0.04 & 1.22 & 0.22 & 0.43 & & 0.17 & & & & \\
\hline $\mathrm{Ca}$ & 0.34 & 0.12 & 0.84 & 0.08 & 0.43 & 0.21 & 0.23 & 0.07 & & - & \\
\hline $\mathrm{Ti}$ & & 0.08 & 0.25 & - & 0.13 & & 0.61 & 0.4 & 0.15 & $=$ & 0.03 \\
\hline Mo & 11.36 & & 2.4 & & 4.11 & 12.84 & 0.05 & 4.36 & 13.32 & 4.43 & 14.57 \\
\hline $\mathrm{Fe}$ & 3.25 & 20.38 & 1.53 & 0.65 & 1.2 & 38.05 & 15.00 & 12.99 & 38.17 & 0.34 & 37.22 \\
\hline $\mathrm{Zn}$ & 0.22 & 0.29 & 0.2 & 0.3 & 0.38 & $=0$ & 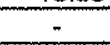 & & 2.01 & 60.79 & 0.1 \\
\hline$Z_{r}$ & 6.36 & 2.49 & 41.43 & 48.05 & 39.85 & 4.13 & 37.86 & 7.08 & 2.89 & 2.16 & 3.29 \\
\hline $\mathrm{Pr}$ & 0.01 & 0.17 & 0.12 & - & $=$ & - & 0.34 & & & $=$ & 0.23 \\
\hline $\mathrm{Ce}$ & 0.02 & 0.12 & 0.48 & 0.6 & 0.68 & & 0.4 & 0.29 & 0.25 & & 0.15 \\
\hline$A C$ & & 0.08 & 0.41 & - & $=$ & - & 0.53 & 0.2 & $=$ & 0.09 & 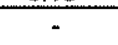 \\
\hline $\mathrm{Nd}$ & & 0.19 & 0.31 & 0.46 & 0.05 & 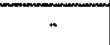 & . & - & 0.27 & - & 0.19 \\
\hline $\mathrm{Pb}$ & 20.45 & 25.23 & & $\pi$ & 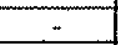 & - & $\approx$ & - & - & $=$ & 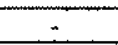 \\
\hline$T h$ & & & 0.12 & 0.48 & & - & - & & - & - & - \\
\hline U & 12.02 & 2.76 & 7.33 & 8.9 & 4.54 & & 4.3 & 36.83 & & & \\
\hline
\end{tabular}

Tabela 2: Análises semiquantitativas por MEV-EDS em associações de minerais hidrotermais de urânio de uma amostra de brecha reduzida/piritizada de alta radioatividade da mina Osamu Utsumi (Amostra F4/243-1A, Fotos 8-19). 


\section{LITOGEOQUÍMICA}

Foram estudados, por métodos geoquímicos multielementares de fluorêscencia de raios $X(F R X)$, espectrometrias de emissão atômica e de massa com fontes de plasma indutivamente acoplado (ICP-AES e ICP-MS) os seguintes litotipos ta mina de urânio:

- Ph não hidrotermalizados preservados numa ocorrência restrita na parte limítrofe NW da cava da mina (Figura 3);

- $\mathrm{Ph}$ e NeS hidrotermalizados reduzidos incluindo mineralizações hipogênicas ricas de U-Th-ETR-Zr,

- frentes redox e mineralizações supergênicas ricas de $U, \mathrm{e}$

- Ph e NeS hidrotermalizados oxidados.

Para comparações foram incluidos ainda dados compilados da literatura (Schorscher e Shea, 1992, e Schumann, 1994). Estes estudos objetivaram caracterizar os processos petro-metalogenéticos fundamentais envolvidos na gênese das mineralizações de urânio hidrotermal e supergênica com enfoque nas migrações e transportes geoquímicos, desde os litotipos do magmatismo alcalino regional a protominérios e minérios.

\subsection{ROCHAS NÃO HIDROTERMALIZADAS DA MINA OSAMU UTSUMI E REGIONAIS}

$\mathrm{Ph}$ não-hidrotermalizados da mina Osamu Utsumi, foram estudados $\mathrm{e}$ comparados com $\mathrm{Ph}$ e NeS regionais selecionados da caldeira alcalina (Figuras 2 e 3), na tentativa de se definir a variabilidade composicional inicial (préhidrotermal), uma vez que representariam os protolitos e as eventuais fontes magmáticas dos processos hidrotermais uraníferos, em estudo nesta tese. Efetuadas em paralelo com as preparações litogeoquímcas, as revisões microscópicas mineralógico-petrográficas minuciosas, adequadas as finalidades 
geoquímico-petrológicas da etapa do trabalho em curso revelaram que os $\mathrm{Ph}$ da borda NW da cava da mina de urânio, considerados previamente, sob aspectos geológico-petrográficos gerais macro e mesoscópicos de campo e laboratoriais, como não-hidrotermalizadas, de fato se subdividem em dois grupos: o primeiro, de rochas não ou pouco alteradas e o segundo de rochas hidrotermalizadas, inclusive mineralizadas e/ou, em geral, alteradas por processos específicos, entre si, diferentes. Neste grupo foram identificadas alterações de tipos e intensidades variáveis, associadas ou independentes, de carbonatização; carbonatização e piritização; carbonatização, piritização e fluoritização; sericitização/ilitização, além de argilização hidrotermal e intempérica (Anexo I, Tabelas I.1, I.2 e 1.3).

Sob aspectos analíticos geoquímicos, há de se destacar, que as análises globais destas rochas por técnicas rotineiras de FRX seqüencial automática, anresentaram-se bastante complicadas, tanto em função dos teores absolutos das combinações de elementos maiores e principalmente traço. Assim, ucstacam-se os elementos $\mathrm{Ce}, \mathrm{La}, \mathrm{Nd}, \mathrm{Zr}, \mathrm{F}, \mathrm{Sr}, \mathrm{Ba}$, entre outros, por suas elevadas concentrações, além das faixas de calibrações e dos padrões certificados usados na análise de rochas ígneas comuns. Daí resultam problemas adicionais para o cálculo das interferências elementares na ređução dos dados analíticos brutos e, por final, também para a confiabilidade das concentrações quantificadas dos elementos dosados. Outros problemas resultaram da preparação de amostras como então usada no Laboratório de FRX do IGc-USP, na forma de pastilhas em pó prensadas, inadequada para a análise mais confiável de elementos maiores via FRX em amostras de rochas. Portanto, as análises deste trabalho, foram realizadas em três laboratórios diferentes e com métodos entre si complementares.

Os respectivos dados geoquímicos são apresentados no Anexo I nas tabelas I.1 e I.2: análises por FRX de $\mathrm{Ph}$ não-hidrotermalizados da mina (feitas em dois laboratórios independentes); tabela 1.3: análises por ICP-AES de parte das mesmas rochas/amostras, e tabela I.4: análises comparativas deste trabalho dos 
Ph não ou pouco alterados da borda NW da Mina de Urânio (por FRX e ICPAES) e de $\mathrm{Ph}$ e NeS regionais (por FRX) selecionadas da literatura (Schorscher e Shea, 1992, e Schumann, 1994).

Para os Ph da parte NW da cava da mina de $U$, não ou pouco alterados, foram calculadas composições médias (Anexo I, tabelas I.1 e 1.2). De mesma forma procedeu-se com os dados (das mesmas rochas) de ICP-AES e de comparação da literatura (Anexo I, tabelas 1.3 1.4). Para todas as rochas regionais e os $\mathrm{Ph}$ não ou pouco alterados da mina (Anexo I, Tabela 1.4) foram ainda calculados os parâmetros de Shand (1943) $\mathrm{ACNK}$ e $\mathrm{ANK}, \mathrm{Fe}_{2} \mathrm{O}_{3}$ e $\mathrm{FeO}$ (razão 0,5) e os Índices de Agpaicidade (Anexo I, Tabela 1.5).

Após cuidadosa análise dos dados das diversas populações analíticas do Anexo I, foram integrados na tabela 3 deste capítulo, arquivos litogeoquímicos para os Ph não ou pouco alterados da borda NW da cava da Mina de $U$, considerados mais completos e corretos possíveis, a partir dos dados de FRX de elementos maiores e traço (da TUM) complementados com dados (FRX do IGc-USP) dos elementos traço F e Sc e, com alguns dados de Be (via ICP-AES, IGc-USP). Para fins de comparação foram ainda incluídos (na tabela 3), os resultados obtidos via ICP-AES em partes das mesmas amostras, com as respectivas médias, e as composições médias dos $\mathrm{Ph}$ e NeS regionais calculadas a partir de dados de XRF selecionados da literatura.

Da Tabela 3 (e Anexo I, tabelas 1.1, 1.2 e 1.3) depreende-se a correspondência boa a tolerável entre os dados integrados de FRX e respectivas médias, com os resultados equivalentes de ICP-AES (e respectivas médias). Divergências maiores dizem respeito à tendência sistemática via ICP-AES para valores maiores de $\mathrm{SiO}_{2}$ (em até $1 \%$ de peso absoluto), $\mathrm{Fe}_{2} \mathrm{O}_{3}, \mathrm{Ni}$, e valores menores de $\mathrm{Al}_{2} \mathrm{O}_{3}, \mathrm{CaO}, \mathrm{K}_{2} \mathrm{O}$ e $\mathrm{Ba}$. Exceção deve ser feita para a média via ICP-AES de $\mathrm{Na}_{2} \mathrm{O}$, sendo que as duas amostras analisadas, A4B e A5, foram as mais ricas neste óxido de todos $\mathrm{OS} \mathrm{Ph}$ da parte $\mathrm{NW}$ da mina de $\mathrm{U}$.

De um modo geral confirma-se para a íntegra das amostras alcalinas regionais e os $\mathrm{Ph}$ menos alterados da mina, a grande similaridade geoquímica de todos os 
litotipos estudados, com variações locais e regionais apenas menores, inclusive entre rochas texturalmente tão contrastantes quanto nefelina sienitos grossos a muito grossos, tipicamente intrusivos abissais e fonolitos vulcânicos a subvulcânicos rasos, conforme já constatado anteriormente (Schorscher e Shea, $1991 ; 1992)$.

Os dados geoquímicos (elementos maiores e traço) dos $\mathrm{Ph}$ menos alterados da parte NW da mina de $\mathrm{U}$ e dos $\mathrm{Ph}$ e NeS regionais da caldeira alcalina foram ainda representados em alguns gráficos já tradicionais de classificação de rochas ígneas (principalmente vulcânicas). Em todos estes diagramas, independentemente se baseados em óxidos maiores e/ou elementos traço, todas as rochas alcalinas regionais, $\mathrm{NeS}$ e $\mathrm{Ph}$, e os $\mathrm{Ph}$ menos alterados da mina de $\mathrm{U}$, mostram comportamento conjunto, caracterizando uma população litogeoquímica única e inseparável, posicionada ou no campo dos fonolitos (Figuras 5, 6 e 7) ou na transição dos campos de fonolitos para traquitos (Figura 8). Quanto aos parâmetros de Shand (1943), utilizando-se a representação de Maniar e Piccoli (1989), observa-se um certo espalhamento, desde composições fortemente peralcalinas a metalumínicas e até mesmo peralumínicas; os $\mathrm{Ph}$ menos alterados da parte $\mathrm{NW}$ da cava da mina de $\mathrm{U}$ apresentam-se neste contexto desde fracamente peralcalinos a peralumínicos (Figura 9).

Sem a intenção de um maior envolvimento com a litogeoquímica primária e a petrogênese e petrologia magmática das rochas alcalinas nefelínicas do Complexo de Poços de Caldas, que fogem dos objetivos deste trabalho, os dados, tanto dos NeS e $\mathrm{Ph}$ regionais quanto dos $\mathrm{Ph}$ menos alterados do limite NW da cava da mina de $U$, foram tratados em diagramas binários dos álcalis $\mathrm{K}_{2} \mathrm{O}, \mathrm{Na}_{2} \mathrm{O}$ e da soma de $\mathrm{Fe}_{2} \mathrm{O}_{3}+\mathrm{MnO}+\mathrm{MgO}+\mathrm{TiO}_{2}$ magmáticos versus todos os demais óxidos maiores e elementos traço, na tentativa de se caracterizar eventuais correlações e variabilidades. 
TABELA 3 - Dados litogeoquímicos dos fonolitos menos-alterados da borda NW da mina de U (ph-mi) por FRX e ICP-AES e respectivas médias (MMFRX e MMICP), e composiçסes médias de fonolitos e ne-felina sienitos regionais (ph-reg e ns-reg) calculadas de dados de FRX de: 1 -Schumann (1994), 2 -

Schorscher e Shea (1992).

\begin{tabular}{|c|c|c|c|c|c|c|c|c|c|c|}
\hline $\begin{array}{c}\text { Amostra } \\
\text { Rocha } \\
\text { \%-peso }\end{array}$ & $\begin{array}{l}\text { A1HT } \\
\text { ph-mi }\end{array}$ & $\begin{array}{l}\text { A4B } \\
\text { ph-mi }\end{array}$ & $\begin{array}{c}\text { A5 } \\
\text { ph-mi }\end{array}$ & $\begin{array}{l}\text { A10BH } \\
\text { ph-mi }\end{array}$ & $\begin{array}{l}\text { A10BT } \\
\text { ph-mi }\end{array}$ & $\begin{array}{c}\text { MMFRX } \\
\text { ph-mi }\end{array}$ & $\begin{array}{l}\mathrm{A} 4 \mathrm{BICP} \\
\mathrm{ph}-\mathrm{mi}\end{array}$ & $\begin{array}{l}\text { A5ICP } \\
\text { ph-mi }\end{array}$ & $\begin{array}{l}\text { MMICP } \\
\text { ph-mi }\end{array}$ & $\begin{array}{c}\text { MedNS1 } \\
\text { ns-reg1 }\end{array}$ \\
\hline $\mathrm{SiO} 2$ & 53.30 & 53.40 & 52.70 & 54.57 & 54.92 & 53.78 & 54.35 & 54.84 & 54.60 & 51.96 \\
\hline $\mathrm{TiO} 2$ & 0.38 & 0.42 & 0.39 & 0.37 & 0.37 & 0.39 & 0.40 & 0.37 & 0.39 & 0.37 \\
\hline $\mathrm{Al} 2 \mathrm{O} 3$ & 20.72 & 20.83 & 20.29 & 20.04 & 20.11 & 20.40 & 20.50 & 19.99 & 20.25 & 20.78 \\
\hline $\mathrm{Fe} 2 \mathrm{O} 3$ & 4.23 & 4.02 & 4.09 & 4.74 & 4.78 & 4.37 & 4.21 & 4.16 & 4.19 & 3.75 \\
\hline MnO & 0.49 & 0.31 & 0.33 & 0.63 & 0.61 & 0.47 & 0.31 & 0.33 & 0.32 & 0.21 \\
\hline $\mathrm{MgO}$ & 0.16 & 0.14 & 0.12 & 0.17 & 0.19 & 0.16 & 0.20 & 0.18 & 0.19 & 0.16 \\
\hline $\mathrm{CaO}$ & 2.08 & 1.34 & 1.49 & 1.81 & 1.54 & 1.65 & 1.15 & 1.27 & 1.21 & 1.34 \\
\hline$n$ & 5.22 & 7.94 & 8.35 & 4.89 & 4.93 & 6.27 & 7.59 & 7.96 & 7.78 & 7.97 \\
\hline & 10.01 & 8.25 & 9.06 & 7.93 & 7.92 & 8.63 & 7.23 & 7.93 & 7.58 & 8.87 \\
\hline & 0.05 & 0.01 & 0.01 & 0.01 & 0.01 & 0.02 & 0.02 & 0.02 & 0.02 & 0.00 \\
\hline$w$ & 2.90 & 4.00 & 2.30 & 4.40 & 4.20 & 3.56 & 3.33 & 1.72 & 2.53 & 2.22 \\
\hline total & 99.54 & 100.66 & 99.13 & 99.56 & 99.58 & 99.69 & 99.29 & 98.77 & 99.03 & 97.63 \\
\hline $\mathrm{H} 2 \mathrm{O}-$ & & & & & & & 0.66 & 0.10 & 0.38 & 0.48 \\
\hline
\end{tabular}

\begin{tabular}{|c|c|c|c|c|c|c|c|c|c|c|}
\hline As & 3.00 & 6.00 & 14.00 & 10.00 & 8.00 & 8.20 & & & & \\
\hline $\mathrm{Ba}$ & 797.00 & 110.00 & 69.00 & 579.00 & 559.00 & 422.80 & 54.00 & 30.00 & 42.00 & 145.57 \\
\hline $\mathrm{Be}$ & & 11.00 & 10.00 & & & 10.00 & 11.00 & 10.00 & 10.50 & \\
\hline $\mathrm{Ce}$ & 451.00 & 365.00 & 208.00 & 482.00 & 371.00 & 375.40 & & & & 384.29 \\
\hline $\mathrm{Cl}$ & 194.00 & 791.00 & 808.00 & & & 597.67 & & & & \\
\hline Co & 2.00 & 4.00 & 4.00 & 3.00 & 3.00 & 3.20 & & & & 13.00 \\
\hline $\mathrm{Cr}$ & 30.00 & 6.00 & 7.00 & 16.00 & 19.00 & 15.60 & & & & 17.71 \\
\hline Cs & 14.00 & 5.00 & 12.00 & 181.00 & 93.00 & 61.00 & & & & \\
\hline $\mathrm{Cu}$ & 11.00 & 17.00 & 6.00 & 16.00 & 2.00 & 10.40 & & & & 2.43 \\
\hline$F$ & 12035.00 & 3254.00 & 8645.00 & 3611.00 & 2750.00 & 6059.00 & & & & \\
\hline $\begin{array}{l}\mathrm{Ga} \\
\mathrm{Hf}\end{array}$ & 38.00 & 48.00 & 49.00 & 45.00 & 47.00 & 45.40 & & & & 41.43 \\
\hline La & 333.00 & 345.00 & 115.00 & 430.00 & 303.00 & 305.20 & 331.00 & 105.00 & 218.00 & 266.57 \\
\hline $\mathrm{Nb}$ & 237.00 & 267.00 & 248.00 & 261.00 & 258.00 & 254.20 & & & & 201.57 \\
\hline $\mathrm{Nd}$ & 93.00 & 75.00 & 59.00 & 143.00 & 14.00 & 76.80 & & & & 72.14 \\
\hline $\mathrm{Ni}$ & 5.00 & 1.00 & 3.00 & 2.00 & 4,00 & 3.00 & 20.00 & 16.00 & 18.00 & 0.43 \\
\hline $\mathrm{Pb}$ & 36.00 & 50.00 & 47.00 & 54.00 & 49.00 & 47.20 & & & & 47.00 \\
\hline $\mathrm{Rb}$ & 342.00 & 126.00 & 141.00 & 550.00 & 626.00 & 357.00 & & & & 242.57 \\
\hline$S$ & 300.00 & 461.00 & 202.00 & 367.00 & 401.00 & 346.20 & & & & 509.21 \\
\hline Sc & 12.00 & 7.00 & 6.00 & 9.00 & 7.00 & 8.20 & & & & \\
\hline Sn & 11.00 & 1.00 & 1.00 & 4.00 & 1.00 & 3.60 & & & & \\
\hline $\mathrm{Sr}$ & 2241.00 & 1083.00 & 1202.00 & 1516.00 & 1121.00 & 1432.60 & 1019.00 & 1125.00 & 1072.00 & 1031.71 \\
\hline $\mathrm{Ta}$ & 3.00 & 10.00 & 6.00 & 1.00 & 19.00 & 7.80 & & & & \\
\hline Th & 37.00 & 57.00 & 17.00 & 64.00 & 63.00 & 47.60 & & & & 37.71 \\
\hline$U$ & 1.00 & 6.00 & 4.00 & 10.00 & 10.00 & 6.20 & & & & 9.57 \\
\hline V & 85.00 & 70.00 & 59.00 & 59.00 & 63.00 & 67.20 & 59.00 & 59.00 & 59.00 & 55.57 \\
\hline W & 1.00 & 1.00 & 1.00 & 3.00 & 1.00 & 1.40 & & & & \\
\hline$Y$ & 45.00 & 40.00 & 32.00 & 53.00 & 45.00 & 43.00 & 42.00 & 30.00 & 36.00 & 59.71 \\
\hline $\mathrm{Zn}$ & 251.00 & 260.00 & 295.00 & 470.00 & 421.00 & 339.40 & 275.00 & 310.00 & 292.50 & 165.00 \\
\hline $\mathrm{Zr}$ & 1124.00 & 1721.00 & 1749.00 & 1728.00 & 1686.00 & 1601.60 & 1654.00 & 1674.00 & 1664.00 & 1118.71 \\
\hline
\end{tabular}


TABELA 3 - Continuação.

Amostra MedFon1 MedNS2 MedFon2 MedNSR MedPhR MedAlcR

Rocha ph-reg1 ns-reg2 ph-reg2 ns-reg ph-reg alc-reg

\%-peso

$\begin{array}{lrrrrrr}\mathrm{SiO} 2 & 52.54 & 54.18 & 54.11 & 52.76 & 53.12 & 52.98 \\ \mathrm{TiO} 2 & 0.52 & 0.82 & 0.56 & 0.53 & 0.54 & 0.54 \\ \mathrm{Al} 2 \mathrm{O} 3 & 20.46 & 19.99 & 20.01 & 20.49 & 20.29 & 20.37 \\ \mathrm{Fe} 2 \mathrm{O} 3 & 4.18 & 4.22 & 3.92 & 3.92 & 4.08 & 4.02 \\ \mathrm{MnO} & 0.22 & 0.27 & 0.24 & 0.23 & 0.23 & 0.23 \\ \mathrm{MgO} & 0.26 & 0.44 & 0.24 & 0.26 & 0.25 & 0.25 \\ \mathrm{CaO} & 1.87 & 1.84 & 1.64 & 1.52 & 1.79 & 1.68 \\ \mathrm{Na2O} & 8.41 & 6.56 & 7.38 & 7.45 & 8.03 & 7.79 \\ \mathrm{~K} 2 \mathrm{O} & 8.39 & 8.04 & 8.38 & 8.57 & 8.39 & 8.46 \\ \mathrm{P} 2 \mathrm{O} 5 & 0.03 & 0.12 & 0.06 & 0.04 & 0.04 & 0.04 \\ \mathrm{LOI} / \mathrm{PF} & 1.49 & 2.44 & 1.38 & 2.30 & 1.45 & 1.80 \\ \text { total } & 98.37 & 98.89 & 97.91 & 98.09 & 98.20 & 98.15 \\ \mathrm{H} 2 \mathrm{O} & 0.26 & & & 0.48 & 0.26 & 0.35\end{array}$

ppm

As

$\mathrm{Ba}$

$\mathrm{Be}$

$\mathrm{Ce}$

$\mathrm{Cl}$

Co

$\mathrm{Cr}$

Cs

$\mathrm{Cu}$

$\mathrm{Ga}$

$\mathrm{Hf}$

La

$\mathrm{Nb}$

$\mathrm{Nd}$

$\mathrm{Ni}$

$\mathrm{Pb}$

$\mathrm{Rb}$

$S$

$\mathrm{Sc}$

Sn

$\mathrm{Sr}$

Ta

Th

U

W

Y

$\mathrm{Zn}$

$\begin{array}{rrrrrr}343.80 & 395.25 & 131.17 & 236.36 & 264.06 & 252.78 \\ & & & & & \\ 394.40 & 363.75 & 342.67 & 376.82 & 375.00 & 375.74 \\ & & & & & \\ 11.90 & 8.00 & 9.17 & 11.18 & 10.88 & 11.00 \\ 15.20 & & 9.00 & 17.71 & 14.64 & 15.83 \\ & & & & & \\ 5.50 & & & 2.43 & 5.50 & 4.24 \\ & 1746.75 & 1688.40 & 1746.75 & 1688.40 & 1714.33 \\ 35.60 & & & 41.43 & 35.60 & 38.00 \\ & & 1.00 & & 1.00 & 1.00 \\ 198.10 & 268.75 & 254.00 & 267.36 & 219.06 & 238.74 \\ 180.80 & 269.00 & 237.00 & 226.09 & 201.88 & 211.74 \\ 88.20 & 103.50 & 88.17 & 83.55 & 88.19 & 86.30 \\ 0.90 & & 3.00 & 0.43 & 1.09 & 0.83 \\ 41.60 & 9.50 & 6.60 & 33.36 & 29.93 & 31.38 \\ 180.90 & 144.75 & 160.67 & 207.00 & 173.31 & 187.04 \\ 480.60 & 793.50 & 1089.33 & 612.59 & 708.88 & 669.65 \\ & & & & & \\ 1929.10 & 2393.50 & 1600.17 & 1526.91 & 1805.75 & 1692.15 \\ & & & & & \\ 17.50 & 15.50 & 9.00 & 29.64 & 14.31 & 20.56 \\ 0.00 & & 6.00 & 9.57 & 0.55 & 4.06 \\ 71.20 & 58.00 & 71.50 & 56.45 & 71.31 & 65.26 \\ & & & & & \\ 41.80 & 48.25 & 38.00 & 55.55 & 40.38 & 46.56 \\ 167.40 & 181.75 & 165.83 & 171.09 & 166.81 & 168.56 \\ 891.20 & 1102.00 & 895.00 & 1112.64 & 892.63 & 982.26\end{array}$


Legenda adotada para representação, em diagramas de classificação e variogramas, dos $\mathrm{Ph}$ e NeS regionais e menos alterados da mina de urânio:

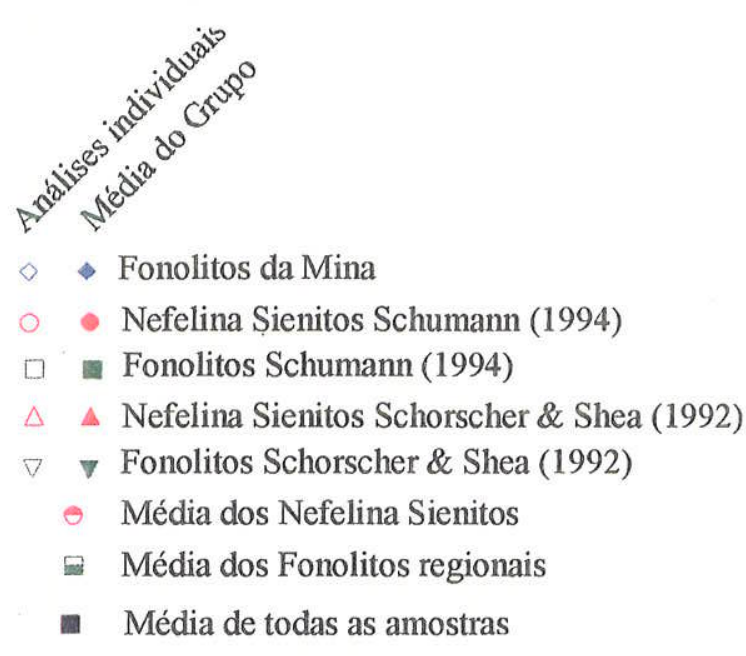

Le Maitre 1989

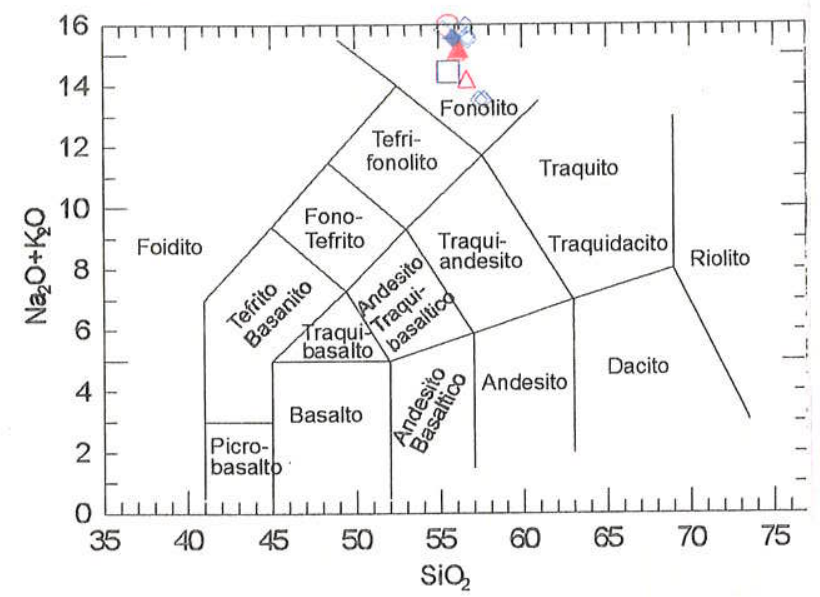

Figura 5: Distribuição dos Ph e NeS no campo dos fonolitos, em diagrama de Le Maitre (1989).

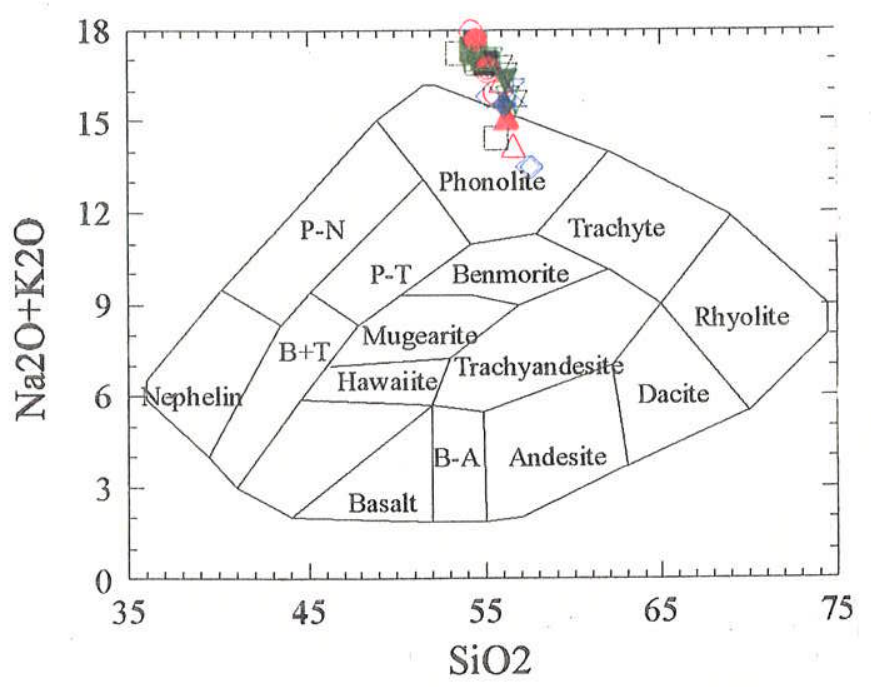

Figura 6: Distribuição dos Ph e NeS no campo dos fonolitos, em diagrama de Cox et al. (1979). 


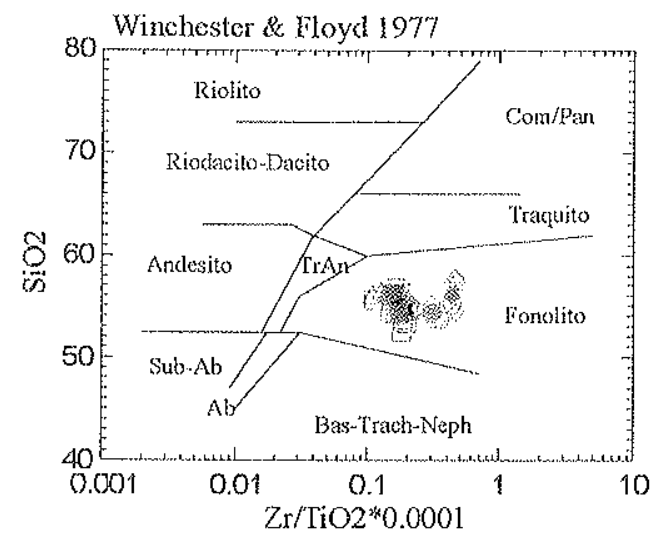

Winchester \& Floyd 1977
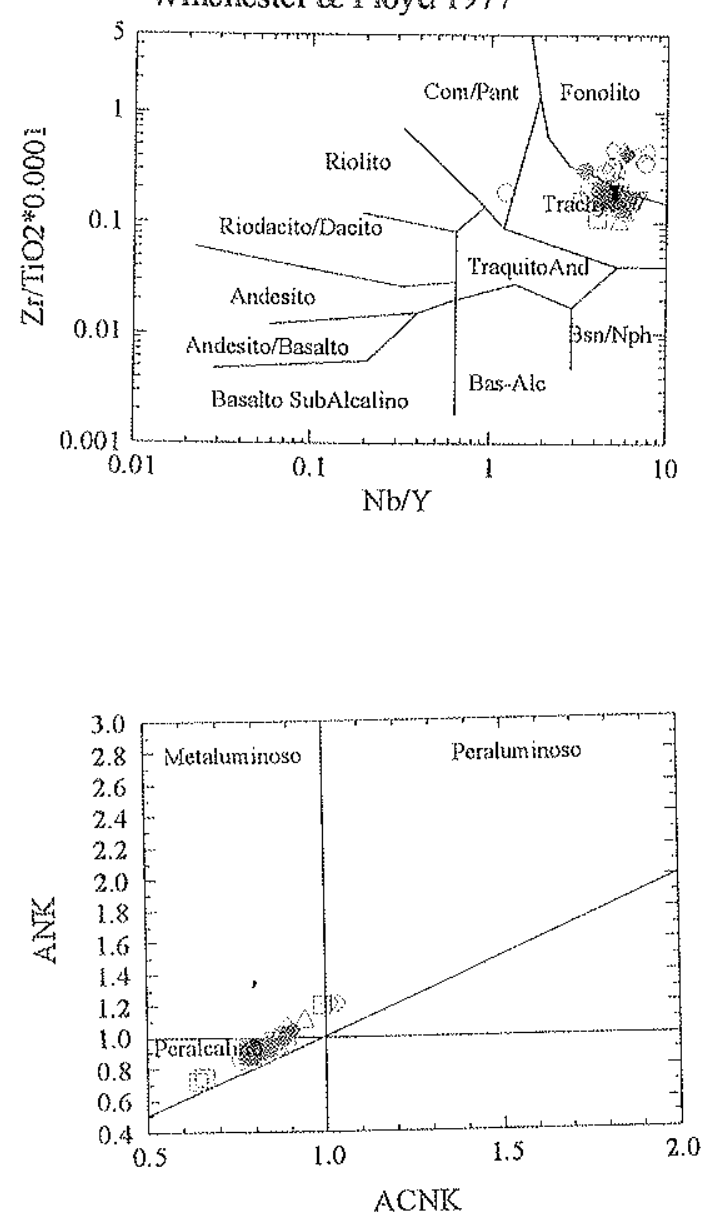

Frgarm 7: Distribuiço dos Ph e NeS no campo dos fonolitos em gráfico de Winchester e Floyd (1977).

Fighugura 8: Distribuição dos Ph e NeS no campo dos fonolitos e traquitos em grófico de Winchester e Floyd (1977).

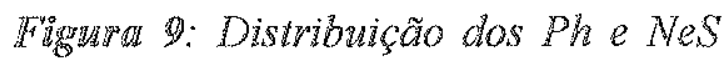
no campo dos fonolitos no diagrama de Maniar e Piccoli (1989) (porânetros de Shand (1943)). 
Desses diagramas binários das rochas alcalinas regionais e dos $\mathrm{Ph}$ menos alterados da mina resultam, para a população integral, comportamento geoquímico muito similar, fortemente anômalo de virtualmente todos os elementos traço, com enriquecimentos dos elementos incompativeis, contrastando com os compatíveis, imóveis a depauperados. Correlações específicas, entretanto, não podem ser delineadas, e considera-se o conjunto das anomalias geoquímicas como uma característica intrínseca de todos os magmas nefelínicos dos $\mathrm{Ph}$ e NeS de Poços de Caldas, independentemente das variações, em geral, muito restritas dos óxidos maiores considerados.

As rochas alcalinas regionais e os $\mathrm{Ph}$ menos alterados da mina (dados da Tabela I.4 do Anexo I), foram tratados ainda em variogramas multielementares (spidergrams) expandidos, normalizados em valores do manto primitivo (Taylor e McLennan, 1985) usando-se o pacote de programas MINPET2. De uma maneira geral, confirma-se o comportamento geoquímico como população única de variabilidade muito restrita, de todas as rochas consideradas do complexo Alcalino de Poços de Caldas, com enriquecimentos fortes, variáveis até muito fortes, de todos os elementos representados, com exceção do Sc- que não desvia do padrão, $\mathrm{V}$ e $\mathrm{Cu}$ - fracamente depauperados e $\mathrm{Cr}$ e principalmente $\mathrm{Ni}$ - fortemente depauperados. Observa-se, ainda, o fracionamento normal decrescente dos elementos incompatíveis, enriquecidos, para os compativeis, depauperados, com anomalias fortes positivas de $\mathrm{Cs}$, e negativas de $\mathrm{Pb}$ e $\mathrm{Ba}$, assim como os enriquecimentos típicos e fortes de $U$ e Th em geral com $U>T h$ - de significado metalogenético - e de $\mathrm{Nb}$ em relação ao $\mathrm{Ti}$ - característico das rochas alcalinas intermediárias e ultrabásicas/carbonatíticas (Figura 10 a - h).

Por fim foram comparados os $\mathrm{Ph}$ menos alterados da parte $\mathrm{NW}$ da mina de $\mathrm{U}$ com as rochas alcalinas regionais em representações normalizadas de suas respectivas composições médias (Tabela 3 ), apresentando-se os $\mathrm{Ph}$ da mina algo mais ricos em $\mathrm{SiO}_{2}, \mathrm{Fe}_{2} \mathrm{O}_{3}, \mathrm{MnO}, \mathrm{LOU} / \mathrm{PF}$ e em virtualmente todos os elementos traço, por vezes com fortes enriquecimentos, e mais pobres em $\mathrm{TiO}_{2}$, $\mathrm{MgO}, \mathrm{Na}_{2} \mathrm{O}, \mathrm{Co}, \mathrm{Nd}$ e Sr (Figura 11 a e b). 
a

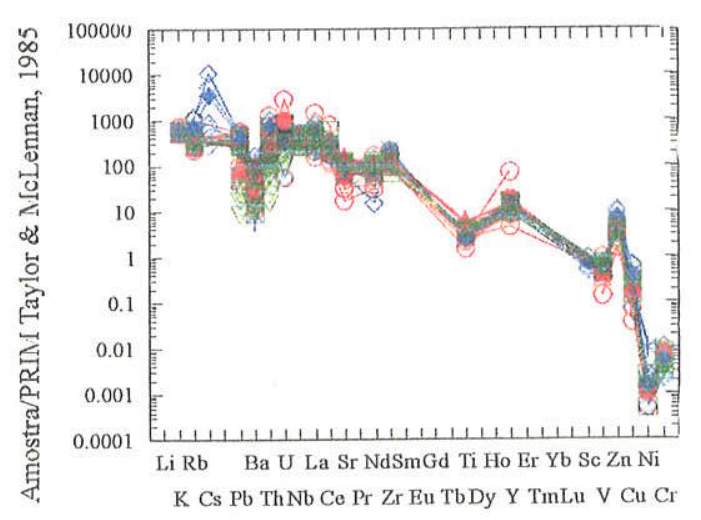

c

告

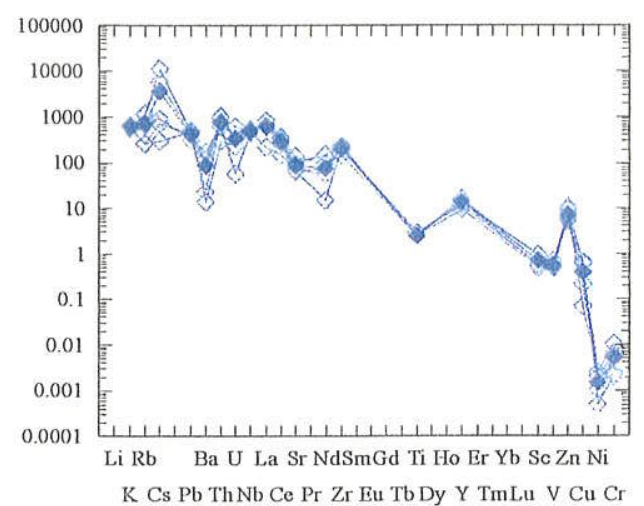

e

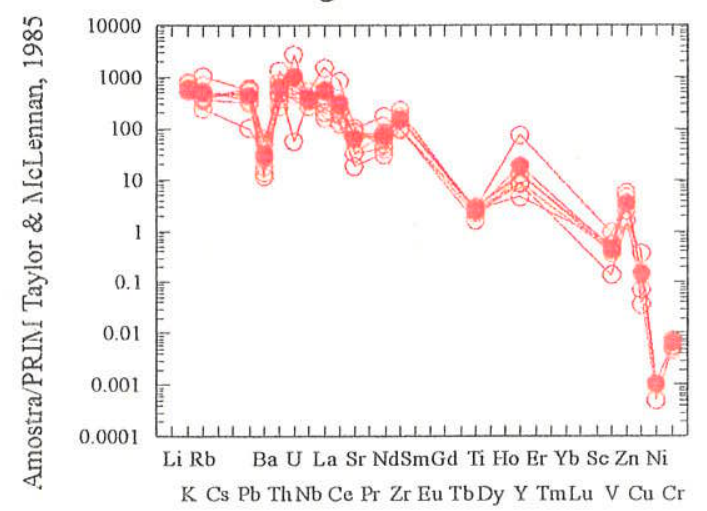

b

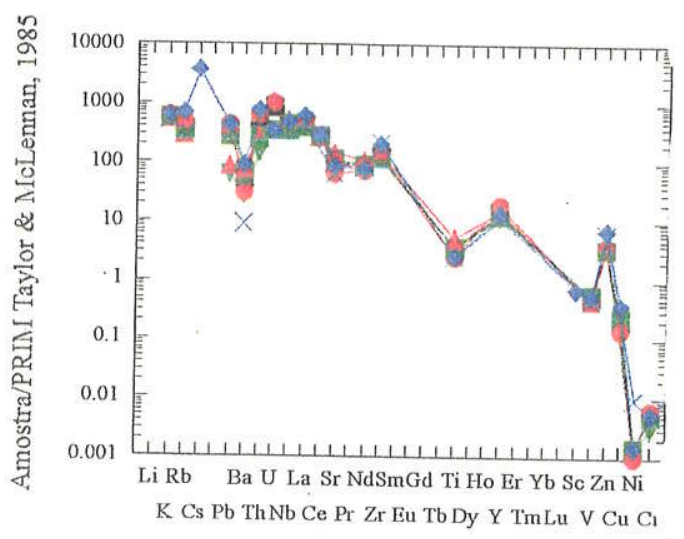

d
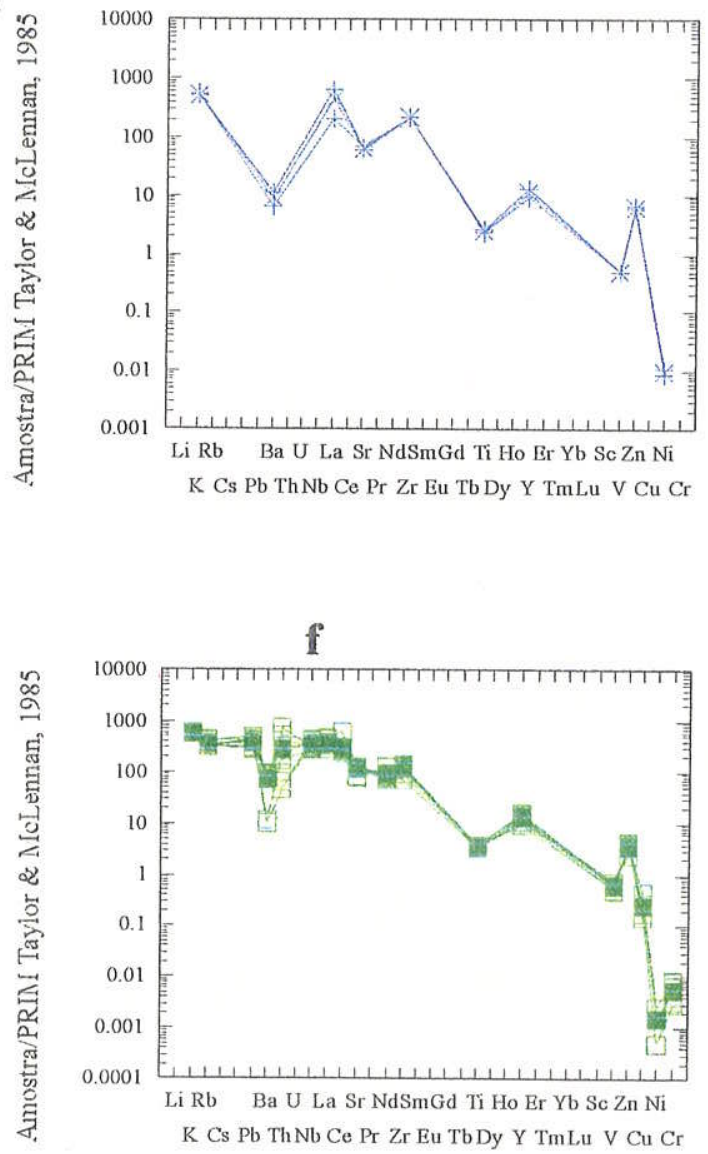

Figura 10: Variogramas expandidos dos Ph menos alterados da borda NW da mina de $U$ e dos Ph e NeS regionais (Anexo I, Tabela 1.4): (a)-todas as amostras e médias; (b)-todas as médias; (c)-Ph menos alterados a mina (análises FRX) e média MMFRX; (d)- Ph menos alterados a mina (análises ICP-AES) e média MMICP; (e)- NeS regionais - NS1 (Schumann, 1994) e média MedNS1; (f)- Ph reginais NS1 (Schumann, 1994) e média MedFon1; (g)NeS regionais - NS2 (Schorscher e Shea, 1992) e média MedNS2; (h)-Ph regionais - Ph2 (Schorscher e Shea, 1992) e média MedFon2. 
g

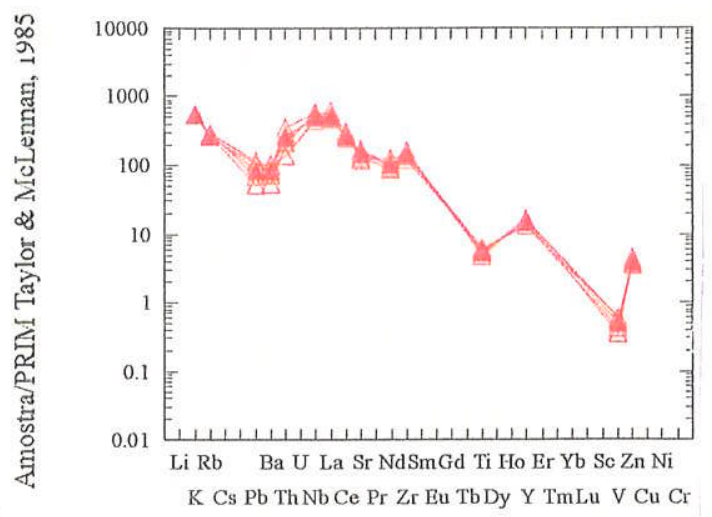

Figura 10:Continuação.

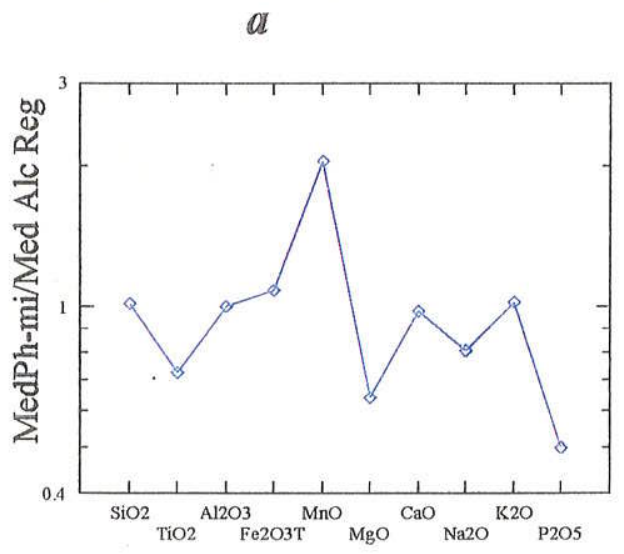

h
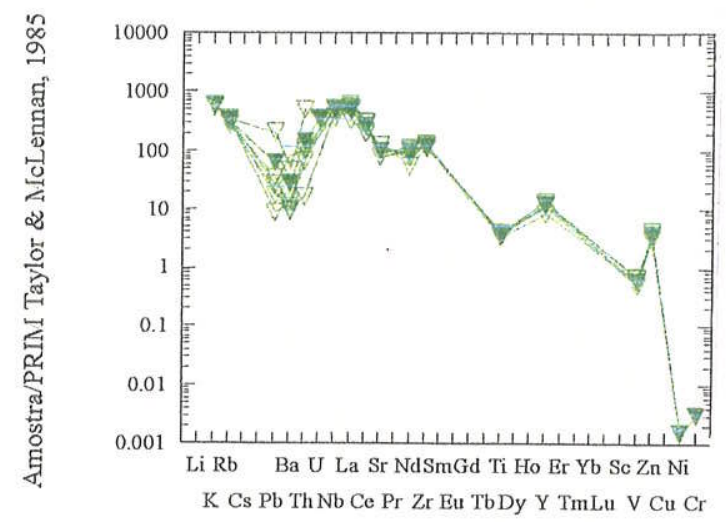

b

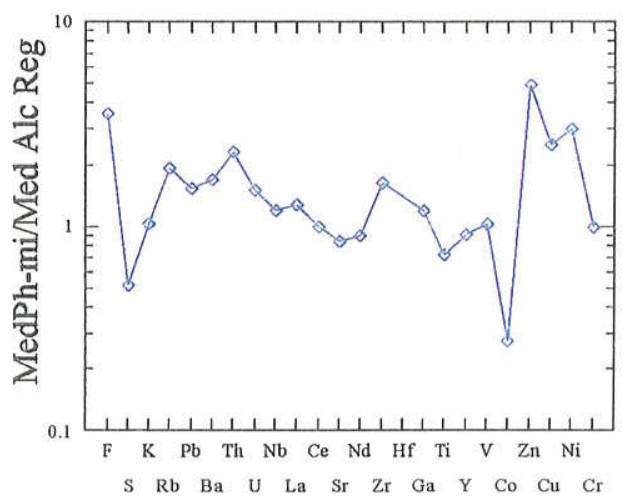

Figura 11: Variogramas multielementares da composição média dos Ph menos alterados da borda NW da mina de U normalizados pela composição média dos Ph e NeS regionais: (a)-óxidos maiores; (b)-elementos traço.

Principalmente os mais fortes enriquecimentos em alguns elementos traço típicos, como $\mathrm{Zr}$, Th, U, La, Ce, Rb, entre outros, mais provavelmente se devem ao início dos processos de alteração hidrotermal mineralizante; possivelmente ocorreu ainda um evento hidrotermal anterior, diferente da mineralização hipogênica típica de $U$, como sugere o forte enriquecimento de $F$ 
(indicado por venulitizações de fluorita nesses $\mathrm{Ph}$ ). Também não pode ser descartada uma tendência magmática primária, nos $\mathrm{Ph}$ da mina, para rochas mais peralcalinas (agpaíticas); tendência essa, não mais preservada, mas possível, vistos os índices de agpaicidade que variam de 0,83 até 1,16 com médias de 0,96 e 1,04 (Anexo I, Tabela I.5).

\subsection{Rochas hidrotermais da Mina de URÂnio: fonolitos (PH), NEFELINA SIENITOS (NES) E BRECHAS (BR) REDUZIDOS E OXIDADOS}

A maioria absoluta das rochas da mina de urânio Osamu Utsumi, incluindo $\mathrm{Ph}$, $\mathrm{NeS}$ e $\mathrm{Br}$, foram afetadas por processos hidrotermais mineralizantes uranotoríferos específicos (Figura 3) fortes e fortemente variáveis, e agrupadas segundo sua preservação hidrotermal ou intempérica-saprolítica, como rochas hidrotermais/hidrotermalitos reduzidos com piritas/piritizados ou oxidados com OHF. Dependendo da intensidade local da alteração hidrotermal mineralizante, distinguem-se, ainda, protominérios de baixo teor e mineralizações ricas de UTh-ETRL-Zr. Essa distinção é mais dificil no caso dos hidrotermalitos já oxidados por processos intempéricos, sendo que os processos envolvidos causaram tanto obliterações das características pretéritas hidrotermais, quanto novas mineralizações uraníferas supergênicas também variáveis.

Análises por FRX do Projeto Internacional Poços de Caldas (Waber et al., 1992) destes grupos litológicos são apresentadas no Anexo I nas tabelas I.6A (rochas/hidrotermalitos reduzidos) e $\mathbf{l . 6 B}$ (rochas/hidrotermalitos oxidados) junto com as respectivas composições médias.

Para definir a composição média mais representativa dos hidrotermalitos de $\mathrm{Ph}$, $\mathrm{NeS}$ e $\mathrm{Br}$ reduzidos da mina, que são os protominérios de $\mathrm{U}$, utilizaram-se apenas dados de amostras de testemunhos de sondagens, com ocorrência mais afastada das frentes redox, para evitar possíveis interferências dos processos mineralizantes supergênicos (ligados às partes redutoras dessas frentes). 
Tambem excluiram-se dessa média (Tabela 4) quaisquer amostras e valores fortemente anômalos representativos da mineralização hidrotermal rica de UTh-ETRL-Zr.

A definição da composição média mais representativa dos hidrotermalitos oxidadas da mina, que são os produtos de alteração incipiente saprolítica dos protominérios de $U$, mostrou-se mais difícil e problemática, pela interferência dos processos mineralizantes, tanto hipogênicos - hidrotermais, quanto supergênicos - intempéricos, e pelo fato de que as melhores amostras desse tipo são provenientes do Furo F1 (Figura 3) localizado na parte centro-norte da cava da mina em meio do corpo $\mathrm{E}$ da mineralização hipogênica mais rica da jazida.

Na Tabela 4 (texto) são mostradas as composições médias dos hidrotermalitos reduzidos e oxidados, em comparação com as médias dos $\mathrm{Ph}$ menos alterados da parte NW da cava da mina de $U$ e das rochas alcalinas regionais; para ilustrar os efeitos e a variabilidade da mineralização hidrotermal rica de U-ThETRL-Zr, foram incluídos ainda dois exemplos contrastantes, um uranífero e o outro torífero dessa mineralização, representados por análises individuais. Os dados da tabela 4 foram usados como valores absolutos quando em diagramas binários, em variogramas multielementares, na análise comparativa dos processos de alteração hidrotermal e da mineralização hipogênica associada mais rica de $U$ e $\mathrm{Th}$, assim como nos processos de intemperismo nas rochas oxidadas.

Assim ficam evidentes, nos hidrotermalitos reduzidos e oxidados em relação às composições médias das rochas alcalinas regionais e dos $\mathrm{Ph}$ menos alterados da parte NW da mina de $U$ :

- enriquecimentos fracos a moderados de $\mathrm{SiO}_{2}, \mathrm{Al}_{2} \mathrm{O}_{3}$ e $\mathrm{P}_{2} \mathrm{O}_{5}$;

- enriquecimento forte de $\mathrm{K}_{2} \mathrm{O}$;

- empobrecimentos fracos a moderados de $\mathrm{Fe}_{2} \mathrm{O}_{3}, \mathrm{MnO}$ e $\mathrm{MgO}$;

- empobrecimentos fortes de $\mathrm{CaO}$ e $\mathrm{Na}_{2} \mathrm{O}$; 
- dos elementos traço são enriquecidos principalmente $\mathrm{Ba}, \mathrm{Ce}, \mathrm{Hf}, \mathrm{La}, \mathrm{Nd}$, $\mathrm{U}, \mathrm{V}$ e $\mathrm{Y}$, sendo o principal elemento depauperado o $\mathrm{Sr}$.

Dos hidrotermalitos reduzidos para os oxidados as principais diferenças sistemáticas são:

- enriquecimentos fracos a moderados de $\mathrm{TiO}_{2}, \mathrm{Al}_{2} \mathrm{O}_{3}, \mathrm{Na}_{2} \mathrm{O}, \mathrm{Ba}, \mathrm{Ce}, \mathrm{Cr}$, Th, Ve Y, e

- empobrecimentos fracos a fortes de $\mathrm{Fe}_{2} \mathrm{O}_{3}, \mathrm{MnO}, \mathrm{MgO}, \mathrm{CaO}, \mathrm{F}, \mathrm{Hf}, \mathrm{La}$, $\mathrm{Nb}, \mathrm{Nd}, \mathrm{S}, \mathrm{Sr}, \mathrm{U}, \mathrm{Zn}$ e Zr.

As mineralizações hipogênicas (hidrotermais) ricas de $\mathrm{U}$ e $\mathrm{Th}$, respectivamente, mostram comportamentos de elementos maiores e $\mathrm{S}$ similares entre si, típicos dos hidrotermalitos reduzidos, dos quais representam um subgrupo. $O$ enriquecimento de $\mathrm{P}_{2} \mathrm{O}_{5}$ indica a importância crescente das fases fosfáticas nessas mineralizações, notando-se ainda enriquecimentos conjuntos e similares de $\mathrm{Co}, \mathrm{Cr}$, Ni e V. As principais diferenças entre os dois tipos contrastantes de mineralizações são representadas por enriquecimentos fortes, principalmente de $\mathrm{Hf}, \mathrm{Nb}, \mathrm{Rb}, \mathrm{Sr}, \mathrm{U}$ e $\mathrm{Zr}$ na mineralização hipogênica rica uranífera, e de $\mathrm{Ba}$, ETRL ( $\mathrm{Ce}, \mathrm{La}, \mathrm{Nd}), \mathrm{Cu}, \mathrm{Pb}, \mathrm{Th}, \mathrm{Y}$ e $\mathrm{Zn}$ na mineralização equivalente torífera. Como no caso dos $\mathrm{Ph}$ menos alterados da parte $\mathrm{NW}$ da mina de $\mathrm{U}$, foram feitos também para os hidrotermalitos reduzidos diagramas binários para análise das variações geoquímicas impostas pelo processo hidrotermal mineralizante e suas possíveis correlações com as principais reações de elementos maiores, representadas pela troca de $\mathrm{CaO}+\mathrm{Na}_{2} \mathrm{O}+\mathrm{K}_{2} \mathrm{O}$ magmáticos por $\mathrm{K}_{2} \mathrm{O}$ hidrotermal. Nestes diagramas binários $\mathrm{K}_{2} \mathrm{O}$ versus os demais óxidos maiores e elementos traço não se observam correlações diretas específicas e/ou variações geoquímicas sistemáticas representativas do processo hidrotermal mineralizante.

Os transportes geoquímicos envolvidos nos processos de formação dos hidrotermalitos reduzidos foram analisados em variogramas das composições médias normalizadas pelas composições médias das rochas alcalinas regionais, incluindo as mineralizações hipogênicas ricas uranífera e torifera (Tabela 4). 
Para os óxidos maiores e os elementos traço observaram-se enriquecimentos fortes a muito fortes e mobilizações/remoções também amplamente variáveis, entretanto, consangüíneos, ou seja de uma mesma tendência e assinatura geoquímica, tanto nos hidrotermalitos reduzidos que são os protominérios de $U$, quanto nas mineralizações uranífera e torífera hidrotermais ricas, guardadas suas especificidades (Figura $\mathbf{1 2}$ a e b).

A análise dos transportes geoquímicos nos hidrotermalitos oxidados foi feita, em analogia, a partir das composições médias, usando-se como valores de normalização a composição média dos hidrotermalitos reduzidos (Tabela 4). Os respectivos gráficos (Figura 13 a e b) mostraram a remoção forte principalmente de $\mathrm{CaO}$ e $\mathrm{MnO}$ - de carbonatos, $\mathrm{F}$ - de fluorita, e $\mathrm{Zn}$ e $\mathrm{S}$ - de esfalerita e outros sulfetos hidrotermais, sendo fases solúveis em ambiente supergênico oxidante acido-sulfúrico, assim como o enriquecimento fraco a moderado dos elementos $\mathrm{Pb}, \mathrm{Th}, \mathrm{Ce}, \mathrm{Ti}, \mathrm{Cu}, \mathrm{Ni}$ e $\mathrm{Cr}$, residual ( $\mathrm{Th}, \mathrm{Ti}, \mathrm{Cr}, \mathrm{Ce}$ ), por precipitação como fase própria ( $\mathrm{Pb}$ como cerussita), e/ou por coprecipitação com $\mathrm{OHF}(\mathrm{Ce}, \mathrm{Co}, \mathrm{Ni})$.

a

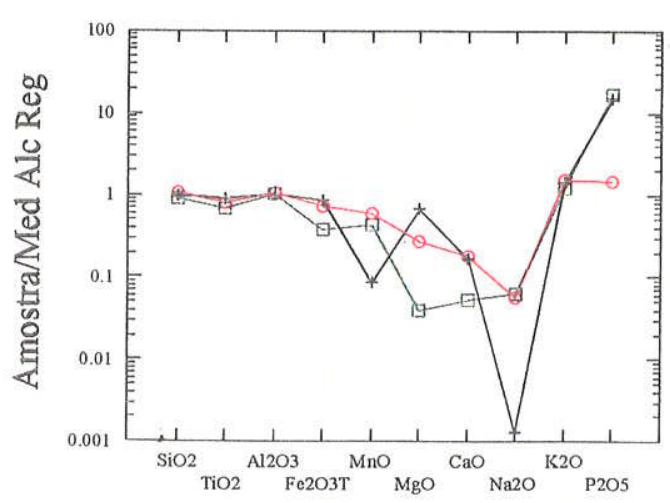

b

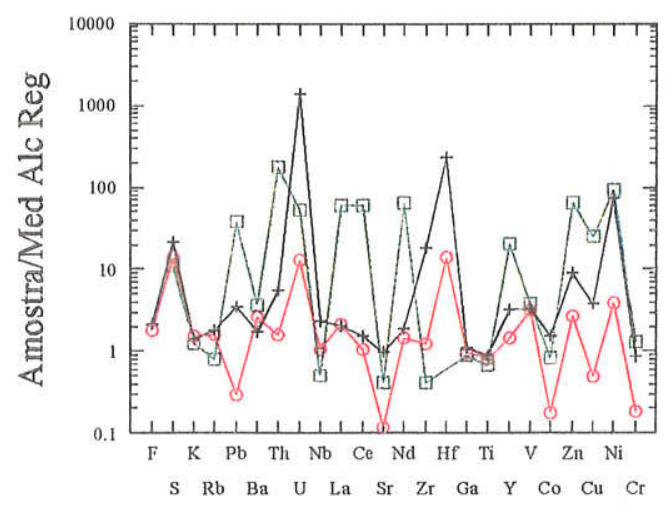

Figura 12: Variogramas multielementares da composição média dos hidrotermalitos reduzidos e de mineralizações ricas hipogênicas (reduzidas) de $U$ e Th, respectivamente, normalizados pela composição média dos Ph e NeS regionais: (a)-óxidos maiores; (b)-elementos traço. 
Tabela 4: Composiçסes médias das rochas alcalinas (Ph e NeS) regionais, dos Ph menos alterados da parte NW da mina de U (MedPh-mi), dos hidrotermalitos reduzidos (MedRed-mi) e oxidados (MedOx-mi), assim como de mineralizaçסes hipogenicas (reduzidas) ricas de $U \mathrm{e}$ Th (AltaMin-U e AltaMin-Th), respectivamente.

MedAlcR MedPh-mi MedRed-mi MedOxi-mi

\begin{tabular}{|c|c|c|c|c|}
\hline $\begin{array}{l}\text { Amostras } \\
\% \text {-peso }\end{array}$ & $s / n$ & $s / n$ & $\overline{s / n}$ & $s / n$ \\
\hline $\mathrm{SiO} 2$ & 52.98 & 53.78 & 55.85 & 55.5 \\
\hline $\mathrm{TiO}_{2}$ & 0.54 & 0.39 & 0.44 & 0.5 \\
\hline $\mathrm{A} 12 \mathrm{O} 3$ & 20.37 & 20.4 & 21.80 & 23.3 \\
\hline $\mathrm{Fe} 2 \mathrm{O} 3$ & 4.02 & 4.37 & 2.96 & 2.7 \\
\hline $\mathrm{MnO}$ & 0.23 & 0.47 & 0.14 & 0.0 \\
\hline $\mathrm{MgO}$ & 0.25 & 0.16 & 0.07 & 0.0 \\
\hline $\mathrm{CaO}$ & 1.68 & 1.65 & 0.31 & 0.0 \\
\hline $\mathrm{Na} 2 \mathrm{O}$ & 7.79 & 6.27 & 0.44 & 0.6 \\
\hline $\mathrm{K} 2 \mathrm{O}$ & 8.46 & 8.63 & 13.16 & 12.9 \\
\hline P2O5 & 0.04 & 0.02 & 0.06 & 0.0 \\
\hline LOI/PF & 1.8 & 3.56 & 3.56 & 3.0 \\
\hline total & 98.16 & 99.7 & 98.64 & 98. \\
\hline $\mathrm{H} 2 \mathrm{O}$ & 0.35 & 0.38 & & \\
\hline \multicolumn{5}{|l|}{ ppm } \\
\hline As & & 8 & 10.25 & \\
\hline $\mathrm{Ba}$ & 253 & 423 & 648.69 & 7 \\
\hline $\mathrm{Be}$ & & 10 & & \\
\hline $\mathrm{Ce}$ & 376 & 375 & 403.77 & 479.3 \\
\hline $\mathrm{Cl}$ & & 598 & & \\
\hline Co & 11 & 3 & 1.67 & 1.8 \\
\hline $\mathrm{Cr}$ & 16 & 16 & 2.60 & 5.5 \\
\hline Cs & & 61 & & \\
\hline $\mathrm{Cu}$ & 4 & 10 & 2.23 & 3.1 \\
\hline $\mathrm{F}$ & 1714 & 6059 & 3116.42 & 1388.2 \\
\hline Ga & 38 & 45 & 37.27 & 35.54 \\
\hline $\mathrm{Hf}$ & 1 & & 14.00 & 11.1 \\
\hline La & 239 & 305 & 507.51 & 447.8 \\
\hline $\mathrm{Nb}$ & 212 & 254 & 225.80 & 193.25 \\
\hline $\mathrm{Nd}$ & 86 & 77 & 126.14 & 107.3 \\
\hline $\mathrm{Ni}$ & 1 & 3 & 4.19 & 5.55 \\
\hline $\mathrm{Pb}$ & 31 & 47 & 8.79 & 29.3 \\
\hline $\mathrm{Rb}$ & 187 & 357 & 298.56 & 330. \\
\hline$S$ & 670 & 346 & 9316.00 & 37. \\
\hline Sc & & 8 & 3.24 & 3. \\
\hline $\mathrm{Sn}$ & & 4 & & \\
\hline $\mathrm{Sr}$ & 1692 & 1433 & 198.28 & 174.15 \\
\hline Ta & & 8 & & \\
\hline Th & 21 & 48 & 32.61 & 50.6 \\
\hline$U$ & 4 & 6 & 51.95 & 48.78 \\
\hline V & 65 & 67 & 213.00 & 229.85 \\
\hline w & & 1 & & \\
\hline Y & 47 & 43 & 69.00 & 75.5 \\
\hline $\mathrm{Zn}$ & 69 & 339 & 185.84 & 23.45 \\
\hline $\mathrm{Zr}$ & 982 & 1602 & 1202.93 & 1043.5 \\
\hline
\end{tabular}

\begin{tabular}{|c|c|}
\hline AltaMin-U & AltaMin-Th \\
\hline$F 4: 243-A 3$ & F1: 105-1A \\
\hline 52.31 & 48.4 \\
\hline 0.48 & 0.37 \\
\hline 21.03 & 20.48 \\
\hline 3.52 & 1.56 \\
\hline 0.02 & 0.1 \\
\hline 0.17 & 0.01 \\
\hline 0.28 & 0.09 \\
\hline 0.01 & 0.49 \\
\hline 12.17 & 10.4 \\
\hline 0.6 & 0.68 \\
\hline 5.13 & 5.33 \\
\hline 95.72 & 87.91 \\
\hline
\end{tabular}



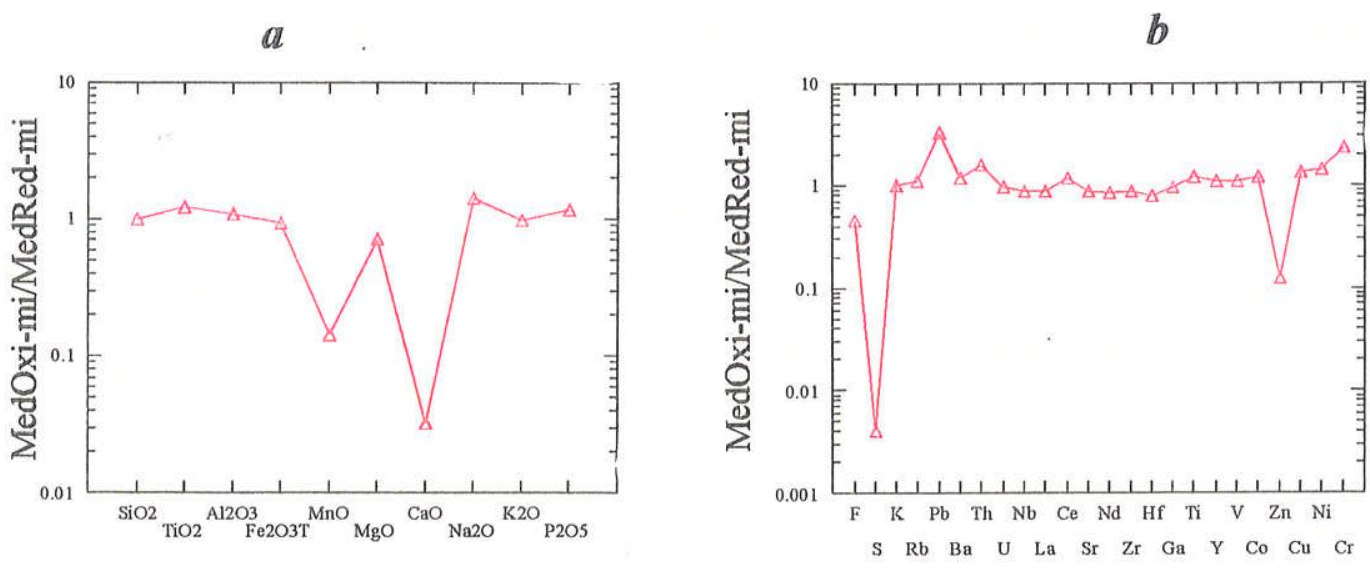

Figurara 13: Variogramas multielementares da composição média dos hidrotermalitos oxidados normalizados pela média dos hidrotermalitos reduzidos: (a)-óxidos maiores; (b)-elementos traço.

\subsection{FRENTES REDOX}

As frentes redox, alvo central dessa pesquisa, consistem numa interface nítida, muito bem definida em afloramentos e amostras de mão, que separa as zonas justapostas, bastante estreitas, de rochas reduzidas e oxidadas, que se apresentam com características mineralógicas e geoquímicas distintas entre si e dos hidrotermalitos adjacentes reduzidos e oxidados normais, que predominam por toda a mina de $U$, com excessão dessas frentes. As frentes redox são o resultado do avanço dos processos intempéricos de tipo frente rolante, impostos aos hidrotermalitos reduzidos. As interfaces são caracterizadas pela mudança drástica na coloração das rochas de cinza-azulado médio a escuro dos hidrotermalitos reduzidos/piritizados, para marrom avermelhado dos hidrotermalitos oxidados/com OHF. São, de fato, interfaces de reações fluidosrochas supergênicas diversas, que ocorrem conjuntamente num intervalo restrito de tempo, espaço e condições físico-químicas por ação de águas oxidantes do freático sobre as rochas piritizadas e mineralizadas em $U$ de baixo teor. Sob aspectos visuais, macroscópicos, entretanto, predomina a transformação oxidante da pirita, finamente disseminada nas rochas reduzidas 
escuras, para OHF (óxi-hidróxidos de Fe) marrom avermelhados nas rochas oxidadas.

As zonas das frentes redox de rochas reduzidas e oxidadas, adjacentes à interface em justaposição, são os reservatórios geológicos de reações geoquímicas específicas com destaque para lixiviação e enriquecimento residual na zona oxidada e de redeposições seletivas na zona reduzida. Essas zonas tem contato brusco entre si, dado pela interface de reação da frente redox, e contatos gradativos com os reservatórios geológicos maiores adjacentes em continuação física dos hidrotermalitos reduzidos, respectivamente, oxidados normais da mina. As zonas reduzidas das frentes redox, resumem-se aos próprios hidrotermalitos reduzidos, com algumas particularidades quanto à presença e distribição da mineralização supergênica rica de urânio que ocorre disseminada e como micronódulos, de pirita e subordinadamente greenockita. As zonas reduzidas mineralizadas em $U$ por processos supergênicos, de reprecipitação e concentração por frentes rolantes descendentes acompanhando o avanço do perfil de intemperismo, se restringem em geral, a uma faixa com largura média de cerca de $15-20 \mathrm{~cm}$, a partir da frente redox (fotos $\mathbf{3 0}$ a, b) dentro da zona dos hidrotermalitos reduzidos; exepcionalmente essa zona de mineralização rica supergênica, atinge até 2 metros de largura.

As zonas oxidadas das frentes redox, distinguem-se menos ainda dos hidrotermalitos oxidados normais adjacentes. Notam-se apenas pequenas particularidades mineralógico-químicas, como a eventual persistência de piritas, seja em cristais individuais ou agregados, ainda que corroídos, por estreitas faixas, em geral não excedendo poucos centímetros de largura, até a total oxidação, e anomalias geoquímicas, na forma de gradientes de concentração em processo de diluição e dissipação progressiva, variáveis para os diferentes elementos, com o afastamento da frente para as rochas oxidadas normais.

Particularidades locais e variações temporais na evolução geológica, durante os últimos $76 \mathrm{Ma}$, dos perfis de intemperismo, tectônicas, morfológicas, 
paleoclimáticas e mineralógico-petrográficas, principalmente, causaram variações nas condições de recarga do lençol freático e nas propriedades físicoquímicas de suas águas, de concentração/diluição/salinidade e pH, temperatura, difusão de $\mathrm{O}_{2}$ e Eh. Estas, por sua vez, controlaram e influenciaram as reações fluidos-rochas supergênicas e originaram tipos distintos de frentes redox, sendo que, cinco tipos principais e combinações destes em frentes complexas, foram definidos e estudados nesta pesquisa (cf. Item 4.2.2., p: 32-36).

Para os estudos geoquímicos de detalhe foram realizadas análises multielementares por ICP-MS em amostras selecionadas dos diferentes tipos de frentes redox, na forma de microperfis amostrados com espaçamento mili a centimétrico (fotos 24 a 29). As tabelas I-7A e B do Anexo I apresentam os dados obtidos com um ou dois fatores de diluição (FD alto: 50.000 e FD baixo: 5.000), dependendo da quantidade de amostra em cada caso. Para suprimir e controlar o "efeito pepita" nas microamostras, numa segunda amostragem foram extraídas quantidades maiores de material, sempre quando possivel, de partes mais homogêneas das mesmas frentes e amostras e reanalisadas, também por ICP-MS usando um FD 10.000 (Anexo I, Tabela I8).

\subsubsection{Resultados Analíticos e Tratamentos dos DadoS}

Os resultados analíticos por ICP-MS integrais das amostras dos microperfis de frentes redox (Fotos 24 a 29), com os dois fatores de diluição, foram compreendidos e representados em dois grandes grupos, referentes às zonas reduzidas e oxidadas dessas frentes (Anexo I, Tabelas I-7A e B). Os resultados das reanálises de amostras selecionadas maiores dessas mesmas frentes encontram-se no Anexo I, Tabela 8. Os tratamentos dos dados e discussões no texto, a seguir, baseiam-se na análise individual das frentes redox por tipo 
genético, separando elementos traço convencionais e ETR. Para cada uma das frentes redox são apresentadas tabelas com os dados dos microperfis organizados de acordo com a disposição das amostras no perfil: da zona reduzida, para a interface e a zona oxidada da frente. Elementos de interesse específico, que permitem correlações com observações mineralógicoparagenéticas foram selecionados e serão discutidos em valores absolutos. Adicionalmente foram representados em gráficos binários multielementares, perfis geoquímicos esquemáticos das frentes redox, mostrando na abscissa (eixo $\mathrm{x}$ ), como pontos eqüidistantes, a disposição das microamostras no perfil da frente redox e na ordenada (eixo y) a concentração elementar. Os dados de ETR foram representados e discutidos a partir de padrões com normalização condrítica.

Pela importância petro-metalogenética no contexto do trabalho, cabe ainda ressaltar, que todas as análises dos microperfis das zonas reduzidas das frentes redox com teores de $U>3.000 \mathrm{ppm}$ e de $\mathrm{Th}<150 \mathrm{ppm}$ representam mineralização supergênica rica de U em micronódulos.

\subsubsection{GEOQUímica dAS FRENTES REDOX}

\section{FRENTE REDOX PDC-PH-028 (Foto 24)}

Tipologia: Frente Redox Tipo 1(simples)

É caracterizada pela formação de uma zona de alta concentração de OHF na parte da zona oxidada imediatamente adjacente a interface da frente, apresentando concentração máxima de OHF e contato brusco com a rocha reduzida na interface, e decrescência gradativa de OHF com o afastamento da interface adentro à zona oxidada. Geneticamente, trata-se de uma frente estagnada, praticamente inativa e imóvel, ainda que imersa na zona de saturação, por redução temporária do potencial redox aliado ao rebaixamento 
do nível do freático e a decantação e filtração de colóides de OHF da suspensão. $\mathrm{O}$ avanço dessa frentes foi controlado predominantemente por critérios texturais (bordas de grãos, porosidade e permeabilidade), embora efeitos estruturais de microfraturas também sejam observados (Foto 24).

\section{Geoquímica multielementar}

Dessa frente foram analisadas um perfil de 8 microamostras (Foto 24), sendo as amostras 1 e 2 da zona oxidada, com a aproximação da interface progressivamente mais ricas em OHF; os pontos 3 , 4 e 5 da zona oxidada de concentração máxima de OHF imediatamente adjacente a interface da frente; os pontos 6 e 7 eqüidistantes, a cerca de $0,5 \mathrm{~cm}$ da interface na zona reduzida, e $o$ ponto 8 , a cerca de $4 \mathrm{~cm}$ da interface também na zona reduzida da frente redox. Os dados analíticos deste perfil são apresentados na Tabela 5 (texto). Adicionalmente foram ainda reanalisadas 4 amostras maiores, 2 da zona oxidada e 2 da reduzida (Anexo I, Tabela I-8).

Nas figuras 14 a-d são plotados os gráficos binários multielementares dos elementos de maior relevância nos microperfis, como U, Tu, Hf, As, Cd, $\mathrm{Zr}$, $\mathrm{Zn}, \mathrm{Mo}, \mathrm{Pd}, \mathrm{Pb}$, abaixo discutidos, onde no eixo (x) estão dispostos os pontos amostrados segundo os microperfis, e no eixo (y) as concentrações em ppm.

$U$ (urânio): Apresenta valor mais elevado ( $\sim 5500 \mathrm{ppm})$ na zona reduzida, no ponto ( 8 do microperfil) mais afastado a $\sim 4 \mathrm{~cm}$ da interface (I) da frente redox (FR) (foto 24) representativo de um micronódulo de uraninita/pitchblenda da mineralização supergênica rica. Os outros dois pontos (7 e 6 do microperfil) da zona reduzida apresentam teor de $\sim 300 \mathrm{ppm}$ (que era o teor de corte operacional da empresa mineradora), lembrando ainda o teor médio dos hidrotermalitos reduzidos normais da mina mais afastados das FR, de $\sim 50 \mathrm{ppm}$ (Tabela 4). Na zona oxidada, o $U$ apresenta clara correlação positiva com o Fe, na forma férrica, sendo mais concentrado ( $\sim 1000-1500 \mathrm{ppm})$ nas zonas mais ricas em OHF junto a IFR e decrescendo com o afastamento da FR para as rochas oxidadas normais da mina, porém, mais rapidamente e até certo ponto 
independentemente dos teores totais de Fe. Isto é bem observado na seqüência dos pontos 3, 2 e 1 do microperfil (foto 24, tabela 5). O U na zona oxidada, demonstra desta forma dependência e correlação não apenas com os teores totais de $\mathrm{Fe}$, mas também e principalmente com a especiação do Fe férrico, sendo que os OHF diretamente adjacentes à FR apresentam-se de menor cristalinidade (com maior teor de amorfos: limonitas) do que aqueles mais envelhecidos/cristalinos, milímetros a poucos centímetros adentro da zona oxidada (com mais goetita e hematita).

Th (tório): Ocorre em teores baixos em todo o microperfil, dentro da variabilidade das médias dos hidrotermalitos reduzidos e oxidados normais da mina (Tabela 4). Na zona reduzida é algo mais concentrado ( $\sim 55 \mathrm{ppm}$ ) no micronódulo de $U$ (ponto 8 do microperfil) em relação aos pontos 7 e $6(\sim 15$ ppm), e na zona oxidada mostra fraca concentração e correlação positiva com $\mathrm{Fe} / \mathrm{OHF}$ (pontos 5 e 3 do microperfil). O fraco enriquecimento no micronódulo de $\mathrm{U}$ e na zona oxidada junto ao Fe dos $\mathrm{OHF}$, com valores dentro da média dos hidrotermalitos normais, apontam para o controle essencialmente hidrotermal do Th e seu pouco envolvimento nos processos supergênicos.

Zr (zircônio) e Hf (háfnio): Confirmam no seu comportamento as relações de análogos geoquímicos de origens hidrotermais, pouco envolvidos nos processos supergênicos. Na zona reduzida os teores mais elevados ocorrem no micronódulo de U (ponto 8 do microperfil); na zona oxidada os teores são em geral algo superiores, correlacionados com o Fe excedem nos pontos 5 e 3 , mais ricos em $\mathrm{Fe} / \mathrm{OHF}$, os valores médios dos hidrotermalitos oxidados (Tabelas 5 e 4 ).

Zn (zinco), Cd (cádmio), Mo (molibdênio) e As (arsênio): Estes metais pesados tem sua origem na mineralização hidrotermal, $\mathrm{Cd}$ substituindo $\mathrm{Zn}$ na estrutura da esfalerita, Mo ocorrendo em fases próprias nos sulfetos cristalino e amorfo, molibdenita e jordisita, e o As, mais provavelmente, como impureza na pirita. No microperfil estudado, na parte reduzida, o $\mathrm{Zn}$ ocorre com valor máximo $(85 \mathrm{ppm})$, bem abaixo da média dos hidrotermalitos reduzidos normais 
(Tabela 4), enquanto que o Mo, As e Cd, com valores máximos de 30, 8,4 e 2,2 ppm ficam próximos, Mo e As algo abaixo e $\mathrm{Cd}$ acima, das respectivas médias, de 40,10,3 e 1,3 ppm de hidrotermalitos reduzidos normais (as médias de Mo e Cd foram calculadas de dados do Projeto Internacional Poços de Caldas extraídos de Waber et al., 1991). Nos pontos do microperfil na zona oxidada observa-se o enriquecimento de todos os metais pesados em correlação positiva muito boa com os teores de Fe/OHF (Tabela 5). Isto complementa e esclarece os processos mineralógicos de frentes redox observados, indicando que a esfalerita e os sulfetos de Mo sofrem dissolução oxidante antes da pirita, disponibilizando em solução $\mathrm{Zn}, \mathrm{Cd}$ e $\mathrm{Mo}$. A reprecipitação de parte do $\mathrm{Cd}$ na zona reduzidas das frentes, como greenockita (CdS), principalmente em inclusões nos micro (e macro) nódulos de $U$ já foi observada (Schorscher, 1991; Waber et al., 1992) e confirmada nesse trabalho em estudos de microscopia de minérios. Similarmente é reprecipitada também uma parte do Mo numa fase supergênica própria, estável na zona reduzida no campo limitrofe superior de estabilidade da pirita, a ilsemannita (azul de molibdênio: um óxi-hidróxido ou oxisulfato hidratado de Mo), de cor azul escuro forte e típica expressão visual em afloramentos e amostras de mão. Na dissolução oxidante da pirita são disponibilizados ainda sulfatos de $\mathrm{Fe}$ (di e trivalentes) e As em solução. A diluição e hidrolise dos sulfatos de Fe causou, em conjunto, a liberação da principal parte do ácido sulfúrico (Blanchard, 1968), dissolução da ilsemannita e disponibilização do Mo e a reprecipitação do Fe como OHF na zona oxidada, que, muito efetivamente, coprecipitaram os quatro metais pesados ainda disponíveis em solução, em correlação com os teores totais de $\mathrm{Fe} / \mathrm{OHF}$ (tabela 5). O avanço da FR e o envelhecimento dos OHF, novamente disponibilizaram parte dos metais pesados em solução, o que levou ao seu empobrecimento nas rochas oxidadas normais, entretanto, por processos diferenciados: o $\mathrm{Cd}$ foi enriquecido na zona reduzida nos processos de frente rolante, e o $\mathrm{Zn}$ parcialmente removido em solução oxidante e por fim nas águas 
superficiais; o comportamento do As e Mo nas rochas oxidadas normais ainda continua obscuro por falta de dados específico.

$P b$ (chumbo): Apresenta na zona reduzida concentrações acima da respectiva média (Tabelas 4 e 5 ) e enriquecimento extremo $(850 \mathrm{ppm})$ no micronódulo de pitchblenda (ponto 8 do microperfil). Na zona oxidada apresenta valores também acima da média das rochas oxidadas normais e concentração maior $(152 \mathrm{ppm})$ no primeiro ponto adjacente a interface na zona oxidada da frente (pto. 5 do microperfil), entretanto sem correlação direta com os teores de Fe/OHF. O enriquecimento extremo $(850 \mathrm{ppm})$ no micronódulo de pitchblenda deve ser considerado como de origem radiogênica. $O$ avanço da frente redox remobilizou o $\mathrm{Pb}$ pela dissolução da mineralização supergênica rica de $\mathrm{U}$ da zona reduzida. Na zona oxidada foi rapidamente reprecipitado, provavelmente como fase própria anglesita ( $\mathrm{PbSO} 4)$ e, eventualmente, em menor proporção, coprecipitado em OHF.

Pd (palládio): Foi inicialmente observado como enriquecimento isolado numa das FR da mina de U Osamu Utsumi nos trabalhos do Projeto Internacional Poços de Caldas (McKenzie et al. 1991; cf. Waber et al., 1992) e estudado mais detalhadamente nesta pesquisa. Apresenta concentração máxima de 14 ppm no micronódulo de $U$ (ponto 8 do microperfil; Tabela 5) e de $\sim 2$ ppm, nos demais pontos da zona reduzida; na zona oxidada os teores variam de $\sim 3$ a 6,6 ppm, em boa correlação com os teores de Fe/HFO (Tabela 5), confirmando a afinidade geoquímica do $\mathrm{Pd}$ com Fe em meio oxidante. Para Pd inexistem valores médios de referência das rochas reduzidas e/ou oxidada normais.

$\mathrm{Fe}$ (ferro): Ocorre, na zona reduzida da FR quase que na totalidade como pirita e na zona oxidada como OHF (óxi-hidróxidos de Fe férrico) diversos, amorfos como limonitas a perfeitamente cristalinos como hematita, sendo constituintes maiores essenciais dos sistemas naturais de FR aqui estudados. Seu comportamento geoquímico é controlado pelas reações de oxi-redução da pirita para OHF, bem estudadas em condições supergênicas naturais, experimentais e teóricas (por ex.: Blanchard, 1968; Garrels e Christ, 1965; Nordstroem et al., 
1992). Estas reações controlam, pela liberação de ácido sulfúrico, a mobilização de todos os demais elementos nos processos de FR, seguida pela coprecipitação/imobilização seletiva de metais afins nos OHF em estatus nascendi na zona oxidada. Por fim, o envelhecimento (aging) dos OHF amorfos e de baixa cristalinidade, incluindo sua desidratação e cristalização progressiva até a formação de hematita, liberam novamente os metais coprecipitados, em processos que ainda carecem de estudos mais detalhados, principalmente experimentais e teóricos em sistemas mais puros. Dessa forma o $\mathrm{Fe}$ é, sem dúvida, o elemento mais importante para a compreensão dos processos de frente redox considerados, controlando o comportamento geoquímico de virtualmente todos os demais elementos presentes.

$\mathrm{Na}$ FR considerada apresenta teores de $\sim 2 \%$-peso nos pontos analíticos da zona reduzida, que correspondem a média dos hidrotermalitos reduzidos normais (Tabelas 4 e 5). Ocorrendo como pirita, não apresenta na zona reduzida correlações nítidas com nenhum dos outros elementos. Na zona oxidada, fortemente enriquecida em OHF (foto 15) pela evolução específica desta FR (de tipo estagnante), os teores de $\mathrm{Fe}$ sobem forte e bruscamente, atingindo o valor máximo de $\sim 6 \%$-peso (no ponto 3 do microperfil); com o afastamento da FR na zona oxidada os valores decrescem gradativamente (pontos 2 e 1 do microperfil). Observa-se assim o comportamento geoquímico conservador/inerte do Fe férrico, ficando, tanto em valores absolutos quanto na sua distribuição fisiográfica (estrutural e textural) preservado nos hidrotermalitos oxidados, conforme depositado pela frente redox específica, quando ativa. Desta forma é um excelente indicador para o tipo de FR fósseis, a evolução do perfil de intemperismo e das condições do lençol freático e, implicitamente, das condições paleoclimáticas. Na zona oxidada o Fe férrico, na forma de $\mathrm{OHF}$, apresenta-se altamente correlacionado com a grande maioria dos demais elementos estudados, pelos processos acima descritos de coprecipitação até as transformações posteriores de envelhecimento e cristalização. 
Tabela 5: Microperfil geoquímico via ICP-MS da frente redox PDC-PH-028.

\begin{tabular}{|c|c|c|c|c|c|c|c|c|}
\hline $\begin{array}{l}\text { Amostra } \\
\text { ppmiTipo }\end{array}$ & $\begin{array}{c}028-8 \\
\text { red }\end{array}$ & $\begin{array}{c}028-7 \\
\text { red }\end{array}$ & $\begin{array}{c}028-6 \\
\text { red }\end{array}$ & $\begin{array}{c}028-5 \\
\text { fr. ox-Fe } \\
\end{array}$ & $\begin{array}{c}028-4 \\
\text { fr. } 0 x-F e \\
\end{array}$ & $\begin{array}{r}028-3 \\
\text { fr. } \mathrm{ox}-\mathrm{Fe} \\
\end{array}$ & $\begin{array}{c}028-2 \\
0 x \\
\end{array}$ & $\begin{array}{c}028-1 \\
0 \times\end{array}$ \\
\hline As & 8.38 & 4.59 & 5.27 & 14.62 & 8.20 & 25.28 & 10.73 & 23.84 \\
\hline $\mathrm{Ba}$ & 458.20 & 508.40 & 497.40 & 497.60 & 507.70 & 835.00 & 518.40 & 700.00 \\
\hline $\mathrm{Be}$ & 5.99 & 4.41 & 3.22 & 1.27 & 4.59 & 3.49 & 2.24 & 2.89 \\
\hline $\mathrm{Bi}$ & 0.04 & 1.18 & 0.02 & 0.08 & 0.04 & 0.02 & 0.03 & 0.03 \\
\hline $\mathrm{Ca}$ & 445.60 & 443.80 & 164.70 & 270.90 & 456.40 & 663.80 & 70.75 & 384.70 \\
\hline $\mathrm{Cd}$ & 1.80 & 2.21 & 1.20 & 2.88 & 2.19 & 4.12 & 2.41 & 1.66 \\
\hline $\mathrm{Ce}$ & 743.90 & 106.50 & 73.90 & 382.60 & 187.60 & 336.70 & 125.00 & 361.70 \\
\hline Co & 4.43 & 20.61 & 1.30 & 9.03 & 6.12 & 8.91 & 1.71 & 2.19 \\
\hline $\mathrm{Cr}$ & 13.44 & 12.85 & 17.46 & 13.26 & 6.98 & 25.52 & 42.79 & 28.37 \\
\hline Cs & 0.31 & 1.36 & 0.22 & 0.36 & 0.31 & 0.54 & 0.32 & 0.35 \\
\hline $\mathrm{Cu}$ & 4.96 & 5.60 & 31.66 & 7.38 & 8.33 & 10.43 & 122.60 & 5.14 \\
\hline Dy & 40.12 & 3.50 & 4.46 & 12.61 & 5.63 & 14.78 & 7.01 & 7.25 \\
\hline Er & 20.77 & 2.24 & 3.37 & 8.89 & 4.24 & 10.20 & 5.37 & 4.75 \\
\hline $\mathrm{Eu}$ & 15.37 & 1.40 & 1.48 & 4.08 & 2.17 & 4.20 & 2.27 & 2.80 \\
\hline $\mathrm{Fe}$ & 19660.00 & 20120.00 & 20130.00 & 47230.00 & 42320.00 & 62030.00 & 28650.00 & 28350.00 \\
\hline $\mathrm{Ga}$ & 55.65 & 52.31 & 42.90 & 26.17 & 66.91 & 76.94 & 43.84 & 43.89 \\
\hline Gd & 49.68 & 4.68 & 4.17 & 17.07 & 8.32 & 15.37 & 9.83 & 12.82 \\
\hline $\mathrm{Ge}$ & 4.76 & 1.82 & 1.51 & 3.85 & 2.98 & 4.31 & 3.17 & 2.19 \\
\hline$H f$ & 14.87 & 9.23 & 13.32 & 19.28 & 13.60 & 31.09 & 17.75 & 14.71 \\
\hline Ho & 7.77 & 0.79 & 1.03 & 2.94 & 1.35 & 3.28 & 1.70 & 1.56 \\
\hline La & 460.40 & 88.50 & 73.21 & 264.70 & 148.30 & 271.30 & 99.75 & 266.30 \\
\hline $\mathrm{Li}$ & 94.22 & 94.81 & 79.54 & 23.88 & 108.90 & 110.10 & 69.98 & 67.43 \\
\hline Lu & 1.85 & 0.36 & 0.55 & 1.21 & 0.59 & 1.33 & 0.73 & 0.56 \\
\hline $\mathrm{Mg}$ & 455.40 & 521.90 & 416.80 & 151.40 & 561.10 & 550.30 & 357.10 & 260.90 \\
\hline $\mathrm{Mn}$ & 56.51 & 52.72 & 27.25 & 96.46 & 92.75 & 135.70 & 54.63 & 48.35 \\
\hline Mo & 30.12 & 13.60 & 16.03 & 254.90 & 192.90 & 385.40 & 180.40 & 182.00 \\
\hline $\mathrm{Nb}$ & 34.50 & 25.52 & 39.53 & 50.02 & 16.40 & 21.79 & 18.79 & 13.00 \\
\hline $\mathrm{Nd}$ & 253.80 & 22.68 & 19.64 & 91.36 & 44.01 & 87.54 & 32.88 & 76.54 \\
\hline $\mathrm{Ni}$ & 14.60 & 17.96 & 37.65 & 15.11 & 46.34 & 92.61 & 38.93 & 342.20 \\
\hline $\mathrm{Pb}$ & 849.70 & 26.53 & 21.69 & 152.40 & 34.94 & 58.16 & 33.54 & 89.53 \\
\hline$P d$ & 14.07 & 1.80 & 2.17 & 6.60 & 2.98 & 6.81 & 5.99 & 3.38 \\
\hline $\mathrm{Pr}$ & 87.05 & 8.69 & 6.38 & 36.69 & 17.66 & 32.40 & 11.71 & 32.54 \\
\hline $\mathrm{Rb}$ & 239.10 & 270.40 & 244.30 & 234.00 & 290.20 & 431.90 & 242.60 & 274.30 \\
\hline$s$ & 57140.00 & 69540.00 & 61580.00 & 11310.00 & 18160.00 & 0.00 & 20910.00 & 1583.00 \\
\hline $\mathrm{Sb}$ & 0.87 & 1.98 & 0.69 & 2.98 & 2.14 & 5.14 & 2.28 & 3.32 \\
\hline $\mathrm{Sc}$ & 1.80 & 1.58 & 0.94 & 2.07 & 1.39 & 1.79 & 1.47 & 1.39 \\
\hline Se & 2.88 & 0.86 & 6.09 & 1.75 & 1.59 & 0.64 & 1.32 & 1.13 \\
\hline $\mathrm{Sm}$ & 44.14 & 3.55 & 3.46 & 11.84 & 5.77 & 11.62 & 5.97 & 7.59 \\
\hline Sr & 245.60 & 216.30 & 179.70 & 257.50 & 239.40 & 416.10 & 210.80 & 310.40 \\
\hline Ta & 0.33 & 0.33 & 0.73 & 0.88 & 0.17 & 0.22 & 0.09 & 0.08 \\
\hline $\mathrm{Tb}$ & 7.78 & 0.68 & 0.73 & 2.32 & 1.17 & 2.54 & 1.28 & 1.50 \\
\hline Th & 53.65 & 13.57 & 16.04 & 59.93 & 29.08 & 50.61 & 21.20 & 25.28 \\
\hline Ti & 1737.00 & 2113.00 & 2434.00 & 2552.00 & 2177.00 & 2012.00 & 3136.00 & 809.50 \\
\hline $\mathrm{Tm}$ & 2.40 & 0.40 & 0.55 & 1.45 & 0.64 & 1.38 & 0.84 & 0.65 \\
\hline U & 5495.00 & 278.90 & 341,80 & 1608.00 & 1077.00 & 1472.00 & 436.70 & 278.90 \\
\hline v & 270.60 & 257.90 & 223.40 & 132.60 & 331.10 & 357.60 & 263.70 & 178.60 \\
\hline W & 3.49 & 2.51 & 3.37 & 6.08 & 2.35 & 4.52 & 2.49 & 2.24 \\
\hline Y & 237.80 & 29.99 & 34.87 & 105.60 & 52.22 & 112.40 & 53.67 & 55.50 \\
\hline$Y b$ & 12.95 & 3.61 & 3.48 & 8.16 & 4.01 & 7.67 & 5.48 & 3.97 \\
\hline $\mathrm{Zn}$ & 86.62 & 37.76 & 68.67 & 327.60 & 428.70 & 413.70 & 245.40 & 157.40 \\
\hline $\mathrm{Zr}$ & 890.00 & 518.90 & 794.40 & 1281.00 & 807.70 & 1813.00 & 1034.00 & 1030.00 \\
\hline
\end{tabular}


\&

PDC-PH-028 - perfil 1

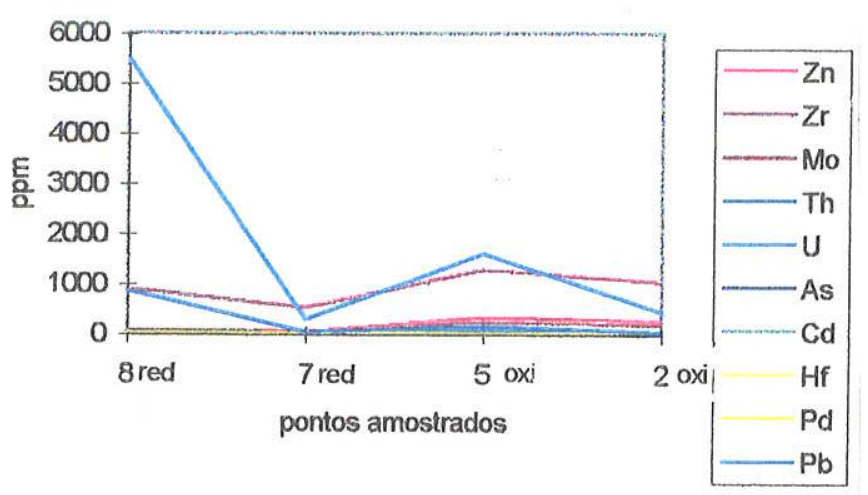

c

PDC-PH-028 - perfil 1

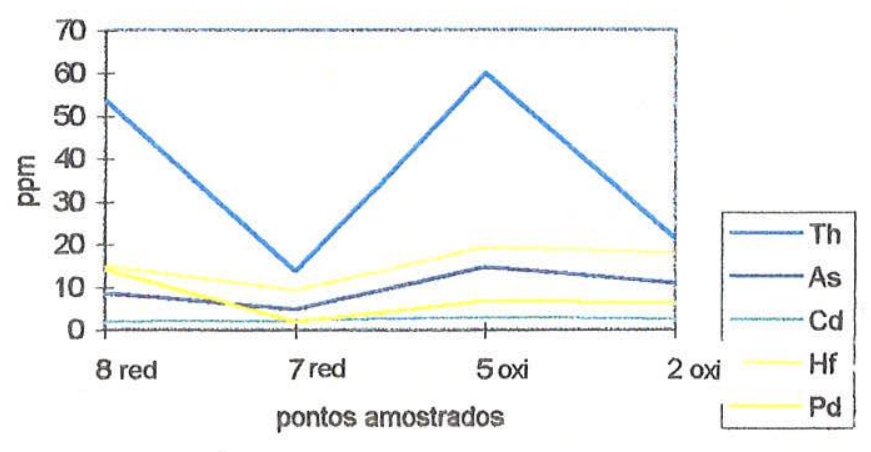

b

PDC-PH-028 - perfil 2

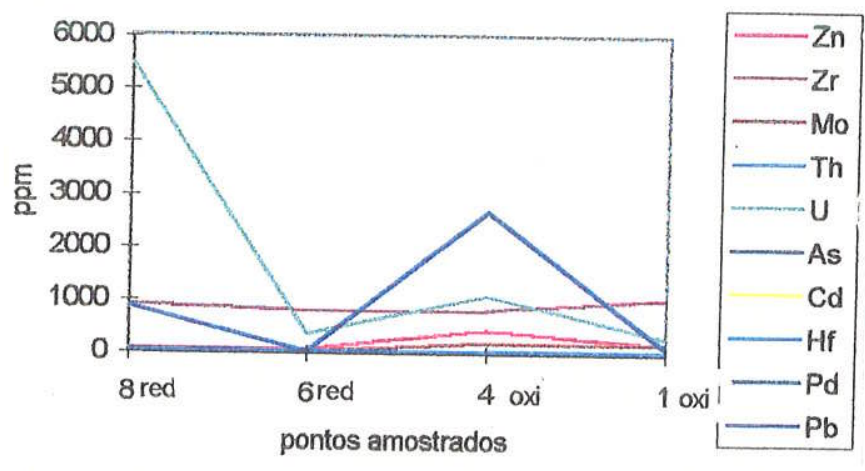

d

PDC-PH-028 - perfil 2

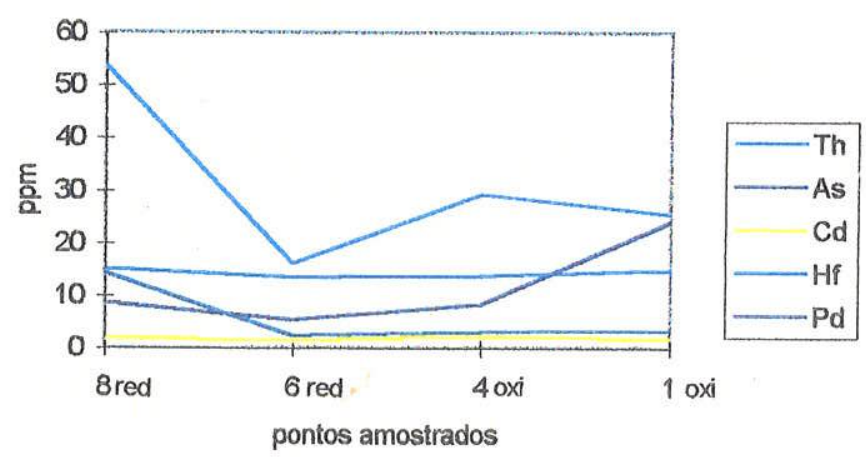

Figura 14: Gráficos binários multielementares dos microperfis da amostra PDC-PH-028 (frente redox de tipo 1). O pontos amostrados estão dispostos eqüidistantemente na abcissa, segundo a seqüência de alteração (da zona reduzida para oxidada) : (a)-perfil 1, (b)-perfil 2, (c)-perfil 1-detalhe e (d)perfil 2 - detalhe. 
Mn (manganês): É um elemento também muito susceptivel a reações de oxiredução por suas múltiplas valências possíveis em sistemas supergênicos, que, similarmente ao $\mathrm{Fe}$ férrico, forma, em ambiente oxidante, óxi-hidróxidos de $\mathrm{Mn}$, muito ativos na co-precipitação de outros metais. Entretanto, como constituinte menor, não propiciou quaisquer efeitos notáveis no sistema estudado. Apresenta em geral teores abaixo das respectivas médias dos hidrotermalitos reduzidos e oxidados (tabelas 4 e 5). Na zona reduzida apresenta variações menores, independentes do $\mathrm{Fe}$, e não pode ser associado a um determinado mineral. Não é isomórfico com o Fe na pirita, mas, mais provavelmente ocorre como impureza nos demais minerais hidrotermais (feldspato alcalino, ilita/sericita, caolinita, esmectitas, etc.). Na zona oxidada seu comportamento é análogo ao Fe férrico, com enriquecimentos máximos acompanhando os mais elevados teores de Fe/OHF e decrescendo com o afastamento da FR para as rochas oxidadas normais. Óxi-hidróxidos de Mn não foram observados.

Ba (bário), Rb (rubídio) e Cs (césio): São os principais elementos traço litófilos de grande raio iônico e, como tais, não apresentam maior envolvimento nos processos de FR, sendo ligados principalmente nas estruturas dos minerais potássicos hidrotermais (feldspato alcalino e ilita/sericita) estáveis nesses processos. Ba e $\mathrm{Rb}$ apresentam, tanto na zona reduzida, quanto na oxidada, teores algo abaixo das respectivas médias; Cs está em geral presente em teores muito baixos ( $<2$ ppm), não se dispondo de valores médios (tabelas 4 e 5 ). Os três elementos apresentam comportamento geoquímico análogo, nas respectivas proporções, sendo que $\mathrm{Ba}$ e $\mathrm{Rb}$ apresentam concentrações máximas no ponto analítico 3 de maior concentração de Fe/OHF do microperfil; outras correlações com o Fe, entretanto, não se percebem.

Ca (cálcio), Mg (magnésio) e Sr (estrôncio): Esses elementos presentes em concentrações de poucas centenas de ppm, também mostram pouca participação nos processos de FR. Apresentam comportamento similar entre si e, até certo ponto, também com os elementos acima descritos ( $\mathrm{Ba}, \mathrm{Rb}$ e $\mathrm{Cs}$ ), entretanto, 
pela natureza global potássica do sistema estudado, sua relação com os principais minerais hidrotermais é menos aparente. Ca e $\mathrm{Sr}$ são controlados principalmente pelos feldspatos alcalinos hidrotermais, como impurezas, e $\mathrm{Mg}$ pela ilita/sericita, como foi confirmado nos estudos de química mineral via microssonda eletrônica (cf: Schorscher, 1991; Waber et al., 1992). Os três elementos também ocorrem com concentrações máximas no ponto analítico 3 de maior concentração de $\mathrm{Fe} / \mathrm{OHF}$, sem outras correlações diretas com o Fe férrico (Tabela 5).

Demais elementos analisados (Tabela 5): Entre esses há de se mencionar o $\boldsymbol{S}$ (enxôfre) cujos valores, embora semiquantitativos, proporcionam um bom controle da passagem da zona oxidada com OHF para a zona reduzida piritizada, dessa e todas as demais FR. Ti (titânio) e $N b$ (nióbio) apresentam-se ambos inertes nos processos de FR, inclusive com comportamentos entre si bastante discordantes, embora sejam análogos geoquímicos. Foi verificada, por estudos via microssonda eletrônica, sua ocorrência conjunta em óxidos de Ti, mas com $\mathrm{Nb}$ associado em proporções amplamente variáveis (Schorscher, 1991). Confirmou-se ainda, a similaridade geoquímica fundamental de alguns elementos como Ga (gálio) e $V$ (vanádio); Ge (germânio) e $U$; Sb (antimônio) e $C d ; L i$ (lítio) e Be (berílio), apesar de não terem sido encontradas bases interpretativas específicas nos estudos mineralógico-petrográficos. Principalmente Ge e Sb e em menor proporção Ga e V, mostraram também enriquecimentos na zona oxidada nos microamostras mais ricas em $\mathrm{Fe} / \mathrm{OHF}$ (Tabela 5). Outros elementos, entretanto, mostraram ou comportamento pouco regular e assistemático como $\mathrm{Ni}$ (níquel), $\mathrm{Cr}$ (crômio), Co (cobalto), Cu (cobre), ou então comportamento irregular, aliado à presença em concentrações muito baixas como $W$ (volfrâmio, tungstênio), Se (selênio), Ta (tântalo) e Bi (bismuto), não permitindo quaisquer inferências sobre os processos de FR estudados. Vários desses elementos, citados como de comportamento geoquímico geral irregular, entretanto, também apresentam enriquecimentos bastante significativos na zona oxidada, principalmente nos pontos analíticos 3 , 
4 e 5 do microperfil com os mais altos teores de Fe/OHF, podendo se citar como exemplos Ni, Co e W (Tabela 5).

\section{Elementos Terras Raras (ETR), Sc (escândio) e Y (ítrio)}

Os ETR, Sc e Y serão tratados em conjunto, sendo o Sc e o Y elementos com comportamento geoquímico análogo aos ETRL e ETRP, respectivamente. Para melhor representação e análise dos ETR em diagramas de distribuição normalizados, os pontos analíticos dos microperfis foram reagrupados de forma a representar dois perfis completos, compreendendo cada um duas rochas reduzidas e duas rochas oxidadas. Para normalização utilizou-se o padrão de manto primordial (Taylor e McLennan, 1985). Os espectros dos ETR da frente redox PDC-PH-028 são representados nas figuras 15 e 16. Para cada uma das microamostras representadas, foram ainda informadas, nas figuras, os teores (absolutos) de $\mathrm{U}, \mathrm{Th}, \mathrm{Zr}$ e Fe, em ppm, sendo estes os principais elementos que, em ambiente hipo e supergênico (Fe principalmente na forma férrica supergênica) apresentam propriedades cristaloquímicas similares e de isomorfia, se correlacionam e controlam o comportamento dos ETR e seus análogos Sc e Y.

Na figura 15 são representados os perfis de ETR das microamostras 8, 5, 2 e 7 (listados na ordem decrescente dos seus teores de ETR) e, na figura 16, na mesma forma e ordem, as microamostras 8, 1, 4 e 6 . A amostra 8, de um micronódulo de $U$ da mineralização rica supergênica da zona reduzida da $\mathrm{FR}$, foi incluída nas duas figuras pelos seus teores mais elevados de ETR (individuais e totais) e de $\mathrm{U}$.

$\mathrm{Na}$ figura 15 observam-se as amostras 8 e 7 da zona reduzida, respectivamente com mais altos e baixos teores totais de ETR, e as amostras 5 e 2 da zona oxidada com teores intermediários de ETR. A amostra 8 reduzida de um micronódulo de $U$ e com os mais elevados teores de ETR e U (5500 ppm), apresenta um padrão fracionado normal, caindo quase que linear e constantemente, dos ETRL fortemente enriquecidos, do La (cerca de 1000x 
enriquecido) para os ETRP, até o Lu (cerca de 30x enriquecido). Nítidos efeitos tetrádicos são marcados por leves anomalias negativas de Sm e Dy, nesta e em todas as demais amostras dessa frente. A amostra 7, também reduzida, de mais baixos teores de ETR e U (279 ppm) apresenta um padrão similar, sendo as principais diferenças a queda quase linear e mais íngreme dos teores (normalizados) de ETRL, do La ao Sm, o leve enriquecimento linear dos ETRP, de Dy ao Lu, e sua interrupção por uma anomalia positiva brusca do $\mathrm{Yb}$. Esta anomalia, entretanto, é algo duvidosa, sendo um caso único em todas as amostras e, portanto, sugerindo a possibilidade de tratar-se de um problema analitico. As amostras da zona oxidada apresentam padrões muito similares entre si, distinguindo-se apenas nos perfis a queda e nitidez relacionada dos efeitos tetrádicos dos ETRL, de La ao Sm. Do Sm ao $\mathrm{Lu}$, estes perfis são réplicas fiéis entre si, distinguindo-se das rochas reduzidas por uma anomalia positiva do Gd e pelo leve enriquecimento, e mais nítido efeito tetrádico dos ETRP, de Dy ao Lu. Na figura 16 observam-se relações análogas, tanto nas amostras reduzidas quanto oxidadas, exceção feita para uma muito leve anomalia negativa do $\mathrm{Gd}$ na amostra 6 reduzida de mais baixos teores de ETR totais e U (342 ppm). Anomalias similares foram observadas apenas em duas outras amostras (4 e 7) da frente redox IARF tratando-se de rochas oxidadas de zonas ricas em Fe/OHF, totalmente diferentes e sem relação direta ou indireta com o caso acima, para o qual não se tem explicação, a não ser por tratar-se, possivelmente, de um erro analítico.

Analisando-se ainda, a relação dos ETR com os principais elementos geneticamente correlacionados e mais significativos das frentes redox $\mathrm{U}, \mathrm{Th}, \mathrm{Zr}$ e $\mathrm{Fe}$, depreende-se, para as rochas reduzidas e as mineralizações uraniferas supergênicas em micronódulos, o controle principal e direto dos teores totais e dos padrões de ETR pelos teores de U. Já no caso das rochas oxidadas destacase o $\mathrm{Zr}$, como diretamente correlacionado com os teores de ETR totais, Fe, U, Th podendo variar aleatoriamente; entretanto, enriquecimentos de $\mathrm{Fe}$ e U, 
conjuntos e separados, parecem exercer um controle mais específico sobre o enriquecimento correlacionado dos ETR intermediários e/ou pesados.

Sc e Y, elementos com comportamento geoquímico análogo aos ETRL e ETRP, respectivamente, apresentam certa diferença em relação ao esperado. Para o Sc observam-se duas progressões distintas, uma para as amostras reduzidas incluindo o micronódulo de $U$ supergênico, na sequeência dos pontos analíticos 6,7 e 8 (com Sc de 0,$9 ; 1,6$ e 1,8 ppm) e a outra para as amostras oxidadas na seqüência dos pontos $1,4,2,3$ e 5 (com $S c$ de 1,$4 ; 1,4 ; 1,5 ; 1,8$ e 2,1 ppm), ambas acompanhando teores crescentes de ETRL (e ETR totais) mas sem correlação com $U$, Th, e $\mathrm{Zr}$ (Tabela 5). Já o $\mathrm{Y}$ cresce continuamente mais bem correlacionado com os ETR intermediários, a exemplo do $\mathrm{Tb}$; também existe correlação com os ETRP, por exemplo Yb e Lu mas com algumas pequenas irregularidade (dentro dos limites dos erros analíticos) (Tabela 5).

\section{Frente Redox M2b (foto 25)}

Tipologia: Frente Redox Tipo 2 (simples)

Essa frente ocorre em fonolito fortemente xenolítico transicional para brecha magmática e não apresenta mineralização supergênica rica na forma de micronódulos de uraninita/pitchblenda. É caracterizada por uma zona branca milimétrica (variando de 3 até $8 \mathrm{~mm}$ de largura), portanto, isenta de OHF e mineralização de $\mathrm{U}$, que apresenta apenas algumas piritas metaestáveis em restos corroídos de dissolução incompleta. Essa zona branca separa as rochas oxidada marrom avermelhada homogênea quanto à distribuição de OHF (sem pirita), e reduzida cinza azulada com piritas hidrotermais inalteradas e alguma mineralização supergênica pobre de U finamente disseminada (Foto 25). 
Nonn Prity

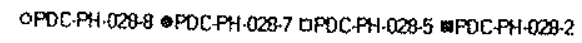

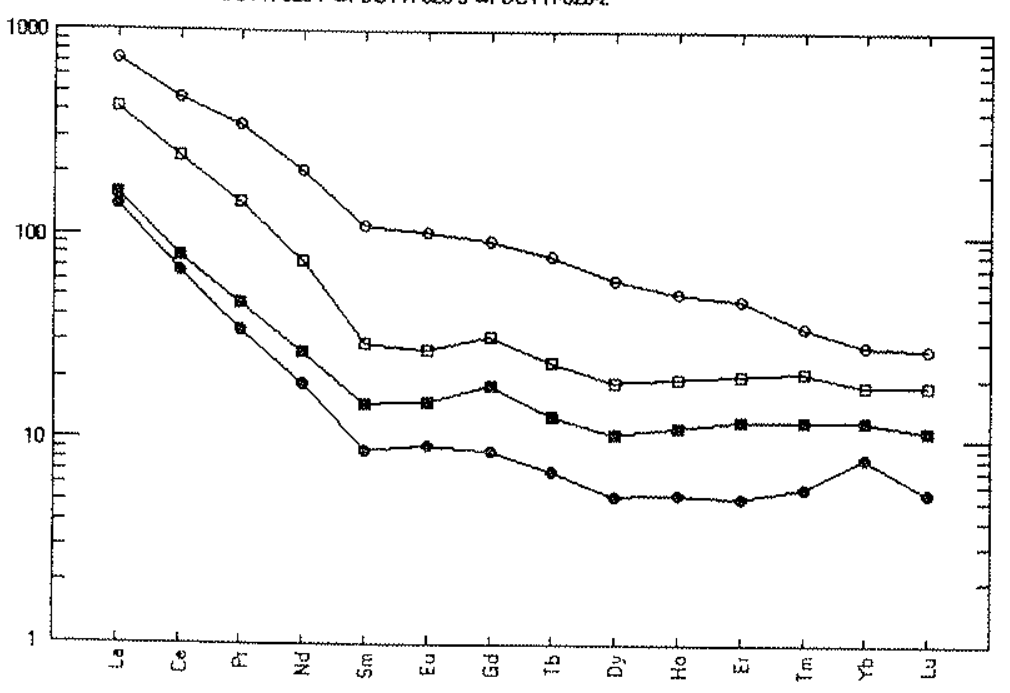

U Th $\mathbf{Z r} \quad \mathbf{F e}$

$\begin{array}{lllll}O \text {-red } & 5495.00 & 53.65 & 890.00 & 19660.00\end{array}$

-red

$278.90 \quad 13.57$

$518.90 \quad 20120.00$

a-fr.ox.Fé

1608.0059 .93

1281.0047230 .00

ㄴ. $-\mathrm{ox}$

$436.70 \quad 21.20$

1034.0028650 .00

Figura 15: Variograma dos ETR da amostra PDC-PH-028 (perfil l) da frente redox de tipo $l$, normalizados pelo manto primitivo (PRIM), com os respectivos teores de U, Th, Zre Fe.

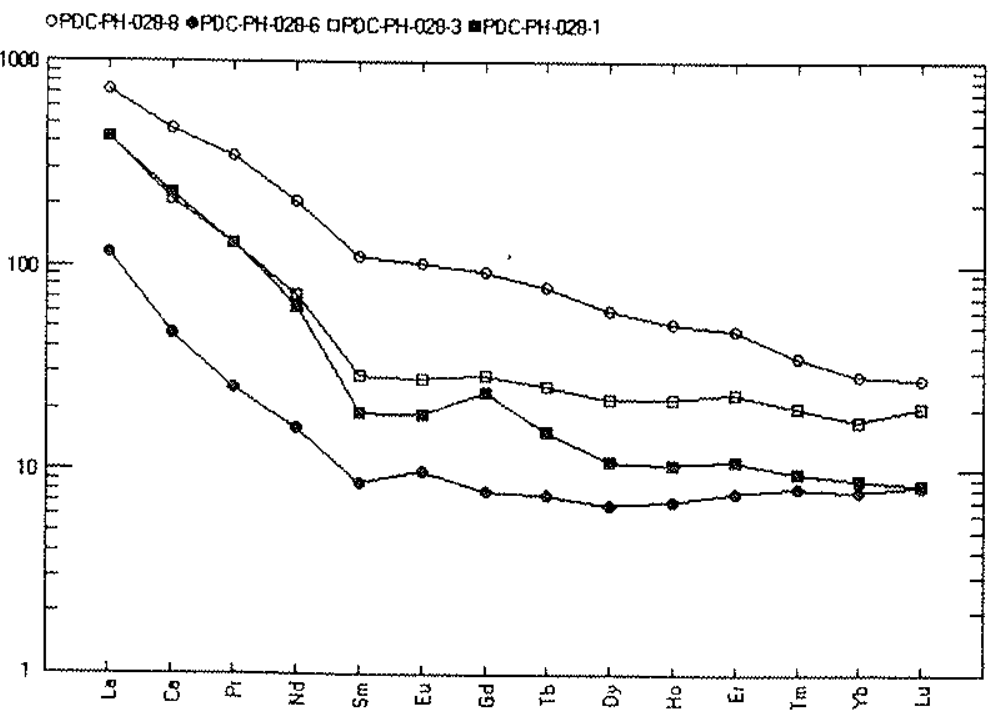

U Th $\quad$ Tr $\quad$ Fe $\begin{array}{llll}5495.00 & 53.65 & 890.00 & 19660.00\end{array}$

O-red $341.80 \quad 16.04$

$794.40 \quad 20130.00$

-red

$1472.00 \quad 50.61$

$1813.00 \quad 62030.00$

-ox

$278.90 \quad 25.28$

1030.0028350 .00

Figura 16: Variograma dos ETR da amostra PDC-PH-028 (perfil 2) da frente redox de tipo 1 , normalizados pelo manto primitivo (PRIM), com os respectivos teores de U, Th, Zre Fe. 
Essa frente formou-se imersa na zona de saturação, como frente de baixa atividade em progressão lenta, por rebaixamento do nível, redução do volume, diminuição do $\mathrm{Eh}$ e aumento da acidez $\left(\mathrm{H}_{2} \mathrm{SO}_{4}\right)$ nas águas do lençol freático (cf. item 4.2.2., p. 34). Na zona branca, típica de máxima concentração de ácido e lixiviação, estariam presentes essencialmente sulfatos di e trivalentes de Fe. A formação e precipitação de OHF ocorreria apenas após diluição e hidrólise dos sulfatos trivalentes de $\mathrm{Fe}$, a certa distância da interface com as rochas reduzidas, definindo a largura da zona branca (de $1-2 \mathrm{~mm}$ a $1-2 \mathrm{~cm}$ ) e a sua passagem para as rochas oxidadas típicas com OHF. O avanço dessa frentes foi controlado predominantemente por desequilíbrios geoquímicos; critérios estruturais e texturais foram secundários, como mostra a transposição discordante da frente redox por bordas de grãos, de fragmentos e matriz independentemente de suas porosidades e permeabilidades diferentes (Foto 25).

\section{Geoquímica multielementar}

Dessa frente foram analisadas um perfil de 6 microamostras (Foto 25), sendo as amostras 1,2 e 7 da zona reduzida, distando, respectivamente $\sim 5, \sim 0,8$ e $\sim 0,5$ cm da zona branca, amostra 3, e as amostras 5 e 6 da zona oxidada, ambas quase eqüidistantes à $\sim 0,3-0,5 \mathrm{~cm}$ da interface com a zona branca.

Os dados analíticos deste perfil são apresentados na Tabela 6 (texto) e a figura 17 a-d representa gráficos binários de alguns elementos de maior relevância (em ppm) versus os pontos amostrados segundo os microperfis. Adicionalmente foram ainda reanalisadas 4 amostras maiores, 2 da zona reduzida, 1 da zona branca e 1 da oxidada (Anexo I, Tabela I-8). 
๕

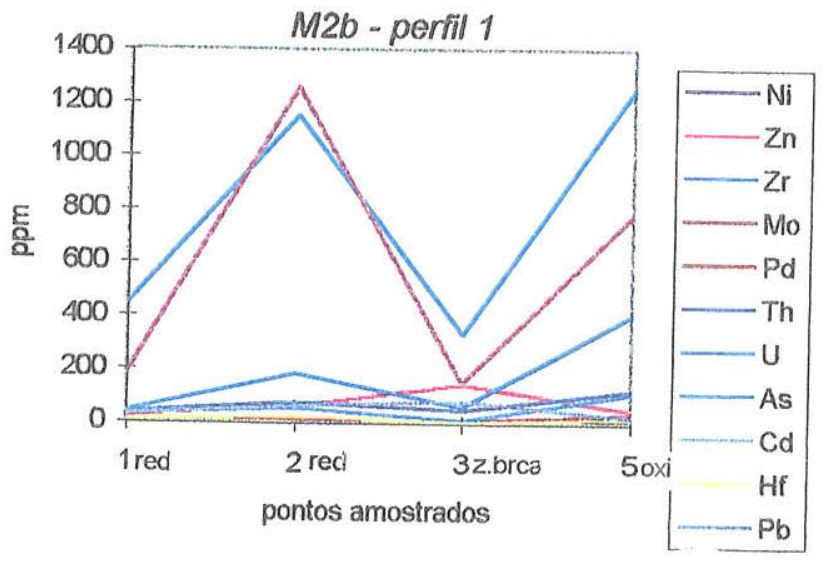

$\mathfrak{C}$

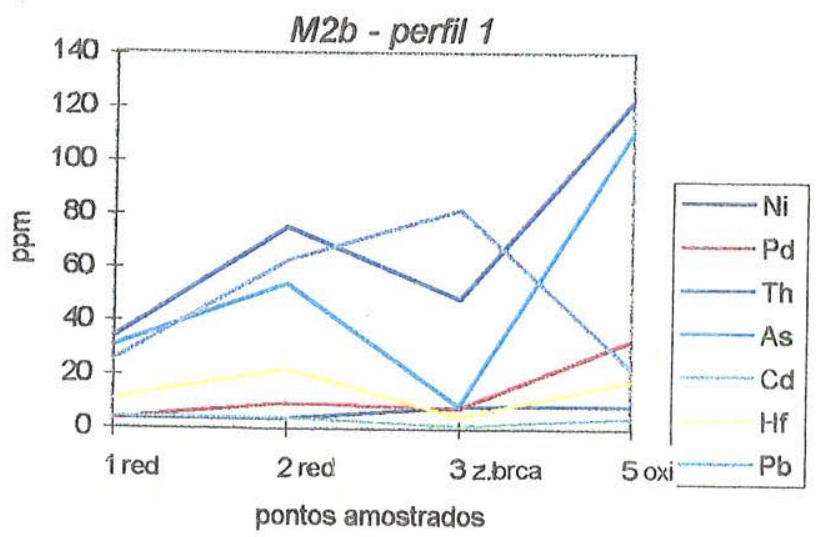

b

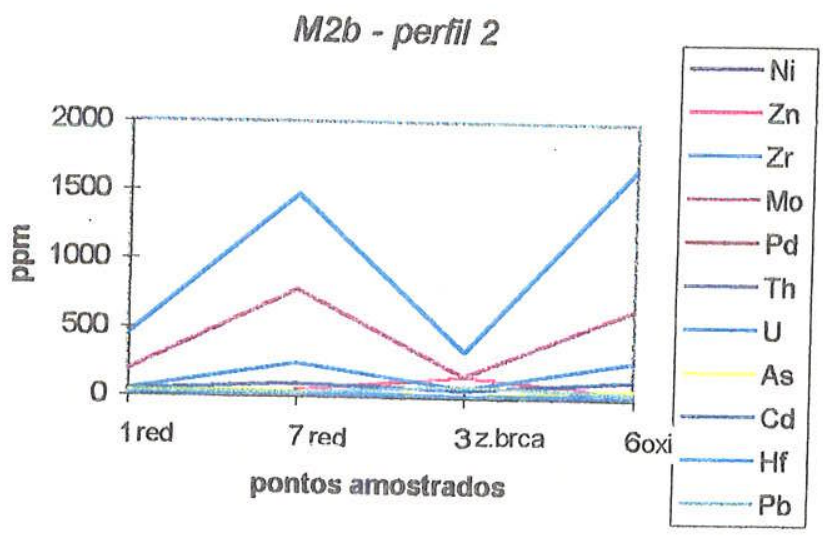

d

M2b - perfill 2

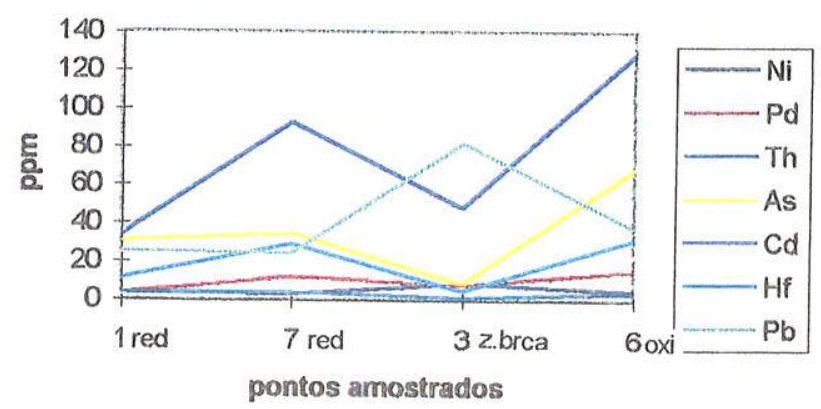

Figura 17: Gráficos binários multielementares dos microperfis da amostra $M 2 b$ (frente redox de tipo 2). $O$ pontos amostrados estão dispostos eqüidistantemente na abcissa, segundo a seqüência de alteração (da zona reduzida para oxidada) : (a)-perfil 1, (b)-perfil 2, (c)-perfil 1 -detalhe e (d)perfil 2 - detalhe. 
Tabela 6: Microperfil geoquímico via ICP-MS da frente redox M2b.

\begin{tabular}{|c|c|c|c|c|c|c|}
\hline $\begin{array}{l}\text { Amostra } \\
\text { ppmiTipo }\end{array}$ & $\begin{array}{c}\text { M2b-1 } \\
\text { red }\end{array}$ & $\begin{array}{c}\text { M2b-2 } \\
\text { red }\end{array}$ & $\begin{array}{c}\text { M2b-7 } \\
\text { red }\end{array}$ & $\begin{array}{c}\text { M2b-3 } \\
\text { zo.branca }\end{array}$ & $\begin{array}{c}\text { M2b-5 } \\
\text { fr.ox }\end{array}$ & $\begin{array}{c}\text { M2b-6 } \\
\text { fr.ox }\end{array}$ \\
\hline As & 30.60 & 53.92 & 34.41 & 8.43 & 111.00 & 68.03 \\
\hline $\mathrm{Ba}$ & 809.30 & 951.40 & 805.90 & 966.40 & 1845.00 & 996.80 \\
\hline $\mathrm{Be}$ & 1.39 & 4.60 & 4.23 & 4.27 & 8.79 & 4.68 \\
\hline $\mathrm{Bi}$ & 0.07 & 0.19 & 0.13 & 0.31 & 0.14 & 0.09 \\
\hline $\mathrm{Ca}$ & 301.90 & 607.50 & 404.80 & 1553.00 & 263.90 & 376.20 \\
\hline $\mathrm{Cd}$ & 4.10 & 3.81 & 3.47 & 0.89 & 4.03 & 3.58 \\
\hline $\mathrm{Ce}$ & 230.80 & 92.79 & 59.63 & 265.10 & 104.60 & 109.00 \\
\hline Co & 9.09 & 3.79 & 2.74 & 1.22 & 13.58 & 1.04 \\
\hline $\mathrm{Cr}$ & 16.12 & 17.90 & 12.91 & 28.82 & 43.41 & 9.60 \\
\hline Cs & 0.21 & 0.23 & 0.24 & 0.32 & 0.24 & 0.26 \\
\hline $\mathrm{Cu}$ & 2.52 & 4.44 & 9.19 & 21.96 & 22.45 & 3.48 \\
\hline Dy & 8.29 & 20.71 & 25.12 & 10.90 & 44.60 & 33.04 \\
\hline Er & 5.30 & 15.14 & 19.84 & 7.85 & 31.60 & 26.55 \\
\hline $\mathrm{Eu}$ & 2.35 & 2.69 & 2.96 & 2.99 & 5.48 & 3.63 \\
\hline $\mathrm{Fe}$ & 12520.00 & 16260.00 & 8606.00 & 21430.00 & 21920.00 & 13940.00 \\
\hline $\mathrm{Ga}$ & 33.09 & 30.75 & 49.67 & 37.36 & 26.88 & 71.41 \\
\hline Gd & 8.36 & 7.88 & 8.93 & 14.60 & 14.98 & 11.98 \\
\hline $\mathrm{Ge}$ & 1.44 & 1.28 & 1.21 & 2.27 & 2.50 & 1.27 \\
\hline $\mathrm{Hf}$ & 10.73 & 22.21 & 28.70 & 4.35 & 17.67 & 31.23 \\
\hline Ho & 1.73 & 5.07 & 6.61 & 2.69 & 11.11 & 8.53 \\
\hline La & 148.60 & 72.12 & 45.06 & 184.70 & 45.40 & 87.43 \\
\hline $\mathrm{Li}$ & 18.21 & 17.01 & 38.78 & 27.65 & 29.82 & 41.71 \\
\hline Lu & 0.73 & 2.21 & 2.92 & 0.95 & 4.87 & 4.12 \\
\hline $\mathrm{Mg}$ & 200.80 & 241.70 & 302.20 & 348.20 & 170.20 & 457.30 \\
\hline $\mathrm{Mn}$ & 14.87 & 18.29 & 22.32 & 127.60 & 42.80 & 32.06 \\
\hline Mo & 180.20 & 1256.00 & 771.60 & 151.70 & 778.90 & 647.60 \\
\hline $\mathrm{Nb}$ & 23.00 & 41.84 & 41.58 & 11.79 & 8.26 & 26.57 \\
\hline $\mathrm{Nd}$ & 50.25 & 20.33 & 16.60 & 57.42 & 23.25 & 25.56 \\
\hline $\mathrm{Ni}$ & 3.41 & 3.49 & 2.79 & 8.21 & 8.77 & 4.22 \\
\hline $\mathrm{Pb}$ & 25.26 & 62.68 & 24.11 & 81.62 & 22.42 & 37.37 \\
\hline Pd & 3.05 & 9.28 & 11.72 & 7.41 & 33.07 & 15.22 \\
\hline $\mathrm{Pr}$ & 19.80 & 7.29 & 5.45 & 22.18 & 7.16 & 9.31 \\
\hline $\mathrm{Rb}$ & 214.70 & 216.40 & 244.10 & 190.80 & 199.60 & 201.40 \\
\hline$S$ & 39830.00 & 53360.00 & 24740.00 & 14970.00 & 19370.00 & 10200.00 \\
\hline $\mathrm{Sb}$ & 0.56 & 3.05 & 2.06 & 1.20 & 0.86 & 1.19 \\
\hline $\mathrm{Sc}$ & 1.10 & 3.84 & 5.37 & 1.47 & 8.01 & 6.32 \\
\hline $\mathrm{Se}$ & 0.00 & 2.24 & 1.05 & 1.11 & 3.49 & 2.31 \\
\hline Sm & 6.09 & 5.21 & 5.63 & 7.98 & 8.96 & 7.25 \\
\hline Sr & 327.30 & 413.70 & 299.00 & 487.80 & 128.90 & 591.30 \\
\hline Ta & 0.11 & 0.95 & 0.61 & 0.10 & 0.22 & 0.32 \\
\hline $\mathrm{Tb}$ & 1.28 & 2.40 & 2.98 & 1.92 & 5.23 & 3.74 \\
\hline Th & 33.55 & 74.99 & 92.38 & 48.19 & 122.60 & 128.50 \\
\hline $\mathrm{Ti}$ & 2501.00 & 2067.00 & 2884.00 & 1529.00 & 3864.00 & 2928.00 \\
\hline $\mathrm{Tm}$ & 0.77 & 2.25 & 3.28 & 1.10 & 5.06 & 4.29 \\
\hline$U$ & 41.48 & 182.10 & 240.50 & 60.22 & 405.10 & 265.70 \\
\hline V & 214.20 & 208.50 & 368.70 & 302.90 & 242.60 & 504.00 \\
\hline W & 5.66 & 8.83 & 9.04 & 111.20 & 5.11 & 7.29 \\
\hline Y & 55.27 & 165.80 & 219.40 & 78.26 & 304.70 & 266.20 \\
\hline $\mathrm{Yb}$ & 4.86 & 14.39 & 18.87 & 6.96 & 32.18 & 26.64 \\
\hline $\mathrm{Zn}$ & 21.92 & 59.32 & 44.11 & 144.50 & 46.53 & 30.24 \\
\hline $\mathrm{Zr}$ & 443.50 & 1148.00 & 1467.00 & 331.00 & 1252.00 & 1669.00 \\
\hline
\end{tabular}


Essa frente, em relação a FR de tipo 1 acima discutida, é tipicamente de pobre mineralização, tanto hipo, quanto supergênica, apresentando teores dos principais elementos de interesse central dessa pesquisa $\mathrm{U}, \mathrm{Th}, \mathrm{Zr}, \mathrm{ETR}, \mathrm{Fe}$, $\mathrm{Zn}, \mathrm{Cd}$, e Pd na microamostra reduzida mais afastada da FR (ponto 1), mais típica da mineralização hidrotermal, abaixo daqueles do ponto equivalente de comparação (Tabela 6, pto. 1 e Tabela 5, pto. 8). Por outro lado, seus teores de alguns elementos como $\mathrm{As}, \mathrm{Ba}, \mathrm{Co}, \mathrm{Cr}, \mathrm{Mo}, \mathrm{Sr}$ e W, são, em parte, nitidamente superiores, indicando, possivelmente, certa heterogeneidade dos fluidos hidrotermais. No geral, entretanto, destacam-se nessa frente, para as zonas reduzidas e oxidadas, respectivamente, muitas características análogas aos processos já descritos da frente tipo 1 (Tabela 6, cf. Tabela 5):

$U$ (urânio) sobe na zona reduzida com a aproximação da FR, indicando a atuação da mineralização supergênica, fraca, de tipo frente rolante, e também apresenta-se enriquecido, atingindo os valores mais altos na zona oxidada em correlação direta com os teores de Fe/OHF (Tabela 6, ptos. 5 e 6).

Comportamento análogo de enriquecimento na zona oxidada, relacionado aos teores de Fe-férrico nos OHF, é mostrado por virtualmente todos os elementos já discutidos nesse contexto da frente tipo 1, como: $\mathbf{A s}, \mathbf{B a}, \mathbf{C d}, \mathbf{M n}, \mathbf{M o}, \mathrm{Pd}$, $\boldsymbol{C o}, S e$, entre outros. Também confirmam-se as tendências de inércia face aos processos de FR e de certo enriquecimento residual na zona oxidada, entretanto sem correlações com Fe/OHF dos elementos $\mathrm{Th}, \mathrm{Ti}, \mathrm{Nb}, \mathrm{Zr}, \mathrm{Hf}, \mathrm{Cr}$, $\mathrm{Ni}, V$ principalmente. Nas microamostras da zona reduzida, os teores de todos os elementos são fortemente influenciados pelo efeito pepita, evidenciando muito bem a heterogeneidade textural e composicional na distribuição da mineralização hipogênica; em comparação, as amostras maiores reanalisadas desta mesma zona caracterizam-se por valores de maior constância (Anexo I, Tabela I-8).

A zona branca representa a grande particularidade desta FR e foi identificada genericamente, por mineralogia e petrografia, como uma zona de lixiviação. Os resultados geoquímicos considerando a microamostra 3 (Tabela 6) e a reanálise 
(Anexo I, Tabela I-8), confirmam este resultado para alguns dos elementos de maior interesse como $\mathrm{U}, \mathrm{Zr}$, $\mathrm{Hf}$, As, $\mathrm{Cd}$, Mo, Pd e S; o único elemento de enriquecimento substancial (confirmado pela reanálise) é o W. Outros elementos, apresentaram resultados ambíguos, indicando até fortes enriquecimentos na microamostra que, entretanto, não foram confirmados na reanálise (ex.: $\mathrm{Ca}, \mathrm{Fe}, \mathrm{Mn}, \mathrm{Pb}$, e $\mathrm{Zn}$ ). Já os ETR, $\mathrm{Sc}$ e $\mathrm{Y}$ apresentam comportamentos diferenciados, (confirmados pela reanálise) que serão discutidos à seguir, no contexto integral do microperfil.

\section{Elementos Terras Raras (ETR), Sc (escândio) e Y (ítrio)}

Os ETR das 6 microamostras foram tratados em conjunto, reagrupados em dois variogramas normalizados (manto primordial) para representar dois perfis completos através da FR. Para tanto, as microamostras dos pontos 1 e 3, respectivamente, da zona reduzida mais afastado da FR e da zona branca, foram repetidos nos dois gráficos, que também apresentam os teores de $U, T h, \mathrm{Zr}$ e Fe correlacionados geneticamente aos ETR (Figuras 18 e 19).

As duas figuras (18 e 19) ressaltam o comportamento similar por um lado das microamostras 1 e 3 (reduzida mais afastada da FR e da zona branca) e por outro lado das microamostras 5,2,6 e 7, com padrões muito diferentes. As amostras 1 e 3 têm os mais fortes enriquecimentos de ETRL, com forte queda (em padrão convexo) de La (enriquecido $\sim 300 \mathrm{x})$ a Sm $(\sim 20 \mathrm{x})$. Eu continua constante no patamar do Sm; Gd mostra anomalias positivas muito fraca (amostra 1) a acentuada (amostra 3), seguindo-se quedas para patamares baixos, sem fracionamento notável, entretanto com leve efeito tetrádico (amostra 3), de Tb a Lu (enriquecidos entre $\sim 20-10 x$ ). 


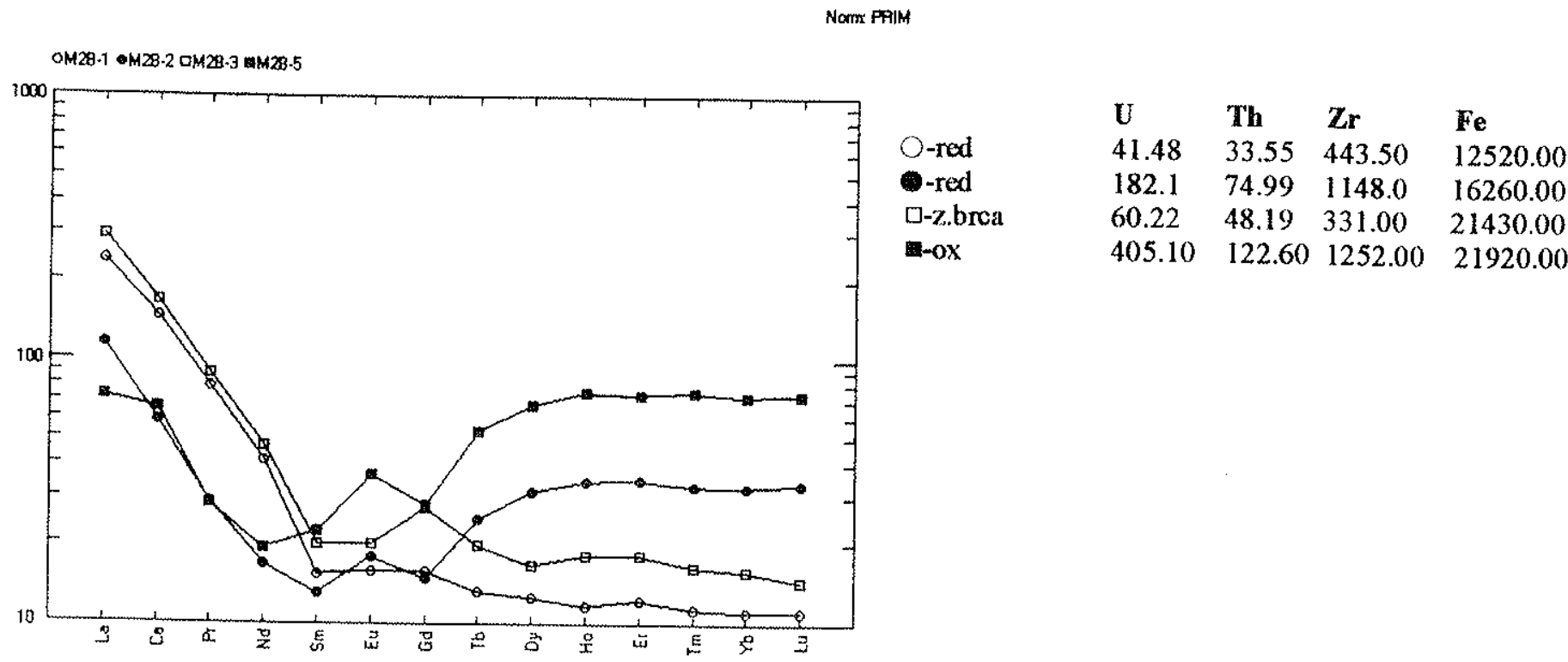

Figura 18: Variograma dos ETR da amostra $M 2 b$ (perfil 1) da frente redox de tipo 2, normalizados pelo manto primitivo (PRIM), com os respectivos teores de U, Th, Zre Fe.

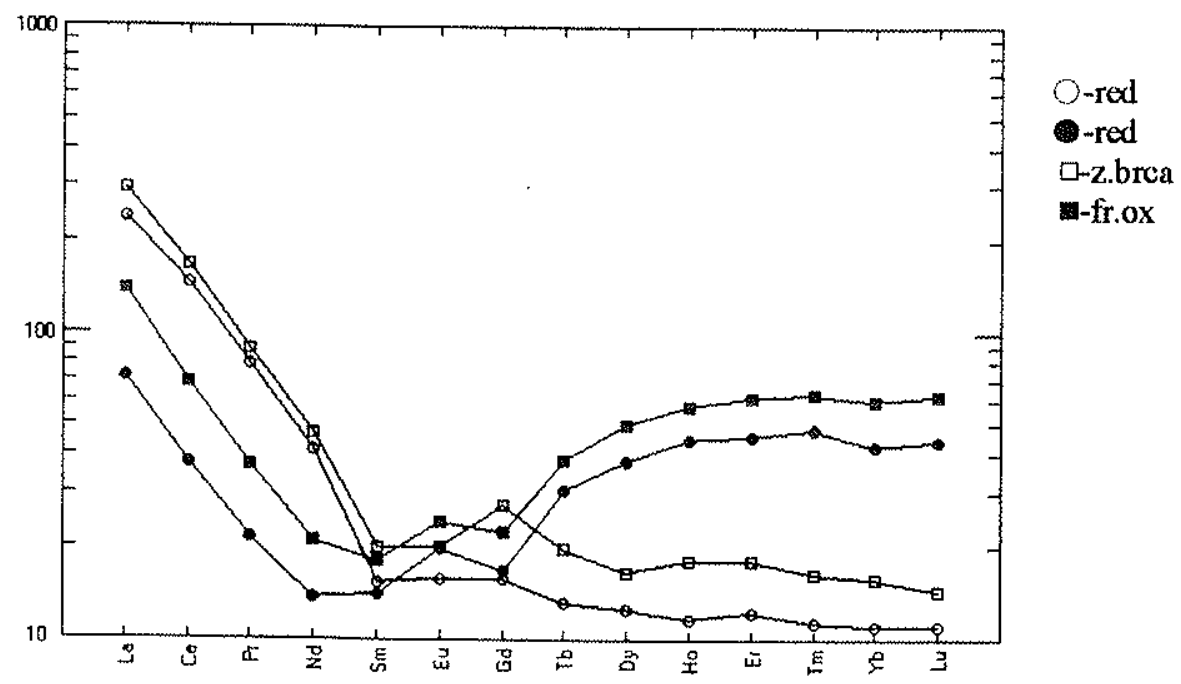

$\begin{array}{llll}\mathbf{T} & \mathbf{T h} & \mathbf{Z r} & \mathbf{F e}\end{array}$

$\begin{array}{llll}41.48 & 33.55 & 443.50 & 12520.00\end{array}$

$\begin{array}{lll}240.50 & 92.38 & 1467.00 \quad 860600\end{array}$

$\begin{array}{llll}60.22 & 48.19 & 331.00 & 21430.00\end{array}$

$\begin{array}{llllll}265.70 & 128.50 & 1669.00 & 13940.00\end{array}$

Figura 19: Variograma dos ETR da amostra $M 2 b$ (perfil 2) da frente redox de tipo 2 , normalizados pelo manto primitivo (PRIM), com os respectivos teores de $U$, Th, Zre Fe. 
O padrões das microamostras 5, 2, 6 e 7 são muito similares entre si (e drasticamente diferentes das amostras 1 e 3). Apresentam, tipicamente, enriquecimentos mais baixos de ETRL, com quedas (em padrão côncavo) de La (enriquecido $\sim 100 \mathrm{x})$ para $\mathrm{Nd}(\sim 15-20 \mathrm{x})$. Sm mostra, em relação ao $\mathrm{Nd}$ e Eu, sempre anomalia negativa, podendo variar em relação ao $\mathrm{Sm}$, de empobrecido (amostras 2 e 6) a enriquecido (amostras 7 e 5). Eu e Gd sempre apresentam expressivas anomalias, respectivamente positiva e negativa, seguindo-se fortes enriquecimentos (em padrão convexo) de Gd a Ho e daí patamares horizontais até Lu (entre si paralelos), com enriquecimentos por amostra constantes de $\sim 30 \mathrm{x}(\operatorname{amostra} 2), \sim 45 \mathrm{x}(\operatorname{amostra} 7), \sim 60 \mathrm{x}(\operatorname{amostra} 6)$ e $\sim 70 \mathrm{x}$ (amostra 5). É notável que neste grupo muito homogêneo, as amostras 2 e 7 representam a zona reduzida próxima a interface com a zona branca e, analogamente, as amostras 5 e 6 representam a zona oxidada próxima a interface, enquanto que a zona branca (amostra 3), com padrão totalmente distinto, é similar aos hidrotermalitos reduzidos mais afastados da FR (amostra 1), e separa, na natureza, os dois subgrupos (das interfaces reduzida e oxidada). Uma interpretação possível seria que a elevada concentração de ácido na interface, representada pela zona branca, lixiviaria dessa zona os ETR ligados junto com a mineralização supergênica de $\mathrm{U}$ de pitchblenda/uraninita, anteriormente existente, reprecipitando-os, com padrões similares, num processo único e contínuo junto com $\mathrm{U}$ imediatamente à frente da interface reduzida e junto com U e OHF atrás da interface oxidada da zona branca (considerando-se como referencial de movimento o sentido do avanço geológico da FR). De fato, observa-se que todas as seis amostras têm seus teores de todos os ETR correlacionados com $\mathrm{U}$, exceto $\mathrm{Eu}$ nas amostras 1 e 3 . A amostra 1, de hidrotermalito reduzido mais distante e sem efeito da frente redox (de atividade fraca), não apresenta qualquer anomalia de Eu. A amostra 3, da zona branca, tem padrão de ETR idêntico, apenas em geral algo enriquecido, e com anomalia negativa de Eu em relação a amostra 1. A amostra 3 da zona branca representaria uma parte do hidrotermalito algo mais enriquecido em ETR desde 
a mineralização hipogênica (ou mesmo do fonolito magmático original), lixiviada de mineralização supergênica de U e ETR solúveis e de parte do Eu hipogênico (divalente) por ataque supergênico oxidante de ácido sulfúrico mais concentrado. Daí, resultaria, na zona branca novamente, um hidrotermalito apenas com os teores originais hipogênicos de U e ETR insolúveis hipogênicos idêntico proporcionalmente a amostra 1, exceção feita para uma pequena parte do Eu divalente, oxidado e removido na solução ácida concentrada. A quantia do $\mathrm{Eu}$, removido em solução, causaria reprecipitação nas zonas adjacentes às interfaces, tanto reduzida, quanto oxidada, das anomalias positivas observadas de Eu (oxidado trivalente) supergênicas. Observa-se também, que as amostras das interfaces da FR, 5 e 6 oxidadas e 2 e 7 reduzidas, correlacionam-se, quanto aos ETR totais e sua distribuição, todas perfeitamente com os teores de $U$; entretanto as amostras 2 e 7 apresentam, adicionalmente, correlação similar com $\mathrm{Th}$ e $\mathrm{Zr}$ (sem incluir o Fe), enquanto que nas amostras 5 e 6 (oxidadas) a correlação adicional análoga é restrita ao $\mathrm{Fe}$ (sem incluir $\mathrm{Th}$ e $\mathrm{Zr}$ ).

Sc e $\mathrm{Y}$, análogos dos ETRL e ETRP respectivamente, deveriam mostrar comportamentos entre si diferenciados, entretanto, não é o que ocorre; ambos apresentam comportamento correlacionado com os ETRP com teores crescentes (cada qual), na seqüência das amostras 1, 3, 2, 7, 6, 5 (Tabela 6).

\section{Frentes Redox SN/15 e U3c (Fotos 26 e 27)}

Tipologia: Frentes Redox Tipo 3 (heterogêneas)

Essas frentes ocorrem, respectivamente, em fonolitos vulcânico fino (U3c) e subvulcânico fino/médio (tingüaito) ( $\mathrm{SN} / 15)$ microporfíríticos e fracamente microxenolíticos. Na zona reduzida são constituídas tipicamente de hidrotermalitos reduzidos normais, com mineralizção supergênica de $U$ em micronódulos e disseminada variável, em geral, pobre, conforme prevalece na mina. A frente $U 3 \mathrm{c}$ apresenta fraca mineralização supergênica de $U$, inclusive 
micronódulos na zona reduzida da FR (Foto 27), o que não foi observado na FR S/N15 (Foto 26). Na zona oxidada essas frentes são caracterizadas e definidas pela precipitação/distribuição peculiar dos OHF, formando hidrotermalitos oxidados com alternâncias rítmicas de zonas finas milimétricas ferruginosas e menos ferruginosas a brancas isentas de OHF, podendo ocorrer pequenos cristais de pirita corroídos, metaestáveis, como restos de dissolução incompleta, em diminutas quantidades nas bandas menos ferruginosas a brancas e, também, alguma variação na espessura e concentração de OHF nas zonas ferruginosas (Fotos 26 e 27). Frentes desse tipo são melhor desenvolvidas em rochas de granulometria fina e muito fina, de menor porosidade $\mathrm{e}$ permeabilidade, dada a natureza filigrana de suas estruturas rítmicas. Quando bem formadas, como é o caso da FR U3c (Foto 27), fica clara, macro e microscopicamente, a analogia de suas zonas brancas rítmicas com as zonas brancas de lixiviação que ocorrem nas interfaces das FR de tipo 2 (acima descritas). Assim, as frentes de tipo 3 heterogêneas são constituídas de hidrotermalitos reduzidos normais típicos da mina com mineralização supergênica de $U$ variável e em geral pobre nas zonas reduzidas, em contato nítido na interface da frente, sem qualquer concentração anômala de OHF e/ou outras feições notáveis, com hidrotermalitos da zona oxidada heterogêneos, apresentando alternâncias milimétricas rítmicas de zonas brancas de lixiviação por alta concentração de ácido com outras de precipitação e concentração algo variável de OHF.

Essas FR originaram-se imersas no freático com zona de saturação pouco espessa ou próximas a superfície do lençol, como frentes ativas e sensíveis à alternâncias cíclicas e rítmicas de relativamente curta duração nas condições ambientais, que retratam, mais provavelmente, efeitos de repetidas mudanças climáticas sazonais, entre condições de frentes simples dos tipos 2 e 4 e eventualmente 1 e 2 (cf. item 4.2.2., p.34). O avanço dessas frentes foi controlado por parâmetros texturais da rocha de porosidade e permeabilidade, 
assim como pelas condições físicomquímicas no lençol freático; fraturas exerceram pouco ou nenhum efeito (Foto 27 ).

\section{Geoquímica multielementar}

Dessas frentes foram analisados perfis de 7 (FR U3c) e 5 (FR S/N15) microamostras (Fotos 27 e 26), sendo os dados analíticos apresentados nas Tabelas 7 e 8 (texto). Adicionalmente foram ainda reanalisadas 3 amostras maiores, todas da FR S/N15, 2 da zona reduzida e 1 da oxidada (Anexo I, Tabela 1-8). Quanto à amostragem das rochas oxidadas com zoneamento rítmico, há de se destacar que mesmo as microacroamostras representam amostras globais, não tendo sido possível amostrar separadamente as zonas ferruginosas e brancas. A disposição das microamostras nos perfis das frentes redox são mostrados nas Fotos 27 para a FR U3c e 26 para a FR S/N15. Para esta última, deve ser mencionado que a amostra 4 representa uma zona ferruginosa de frente redox tipo 1 fóssil e a amostra 5 a rocha oxidada homogênea, fora da zona de frente redox zonada heterogênea de tipo 3 (representando a rocha oxidada formada num estágio anterior/fóssil de FR tipo 4).

Sob aspectos geoquímicos globais as frentes U3c e S/N15, em relação às duas frentes anteriomente tratadas, apresentam-se ainda mais pobremente mineralizadas, considerando tanto as fases hipogênicas quanto supergênicas, conforme é claramente evidenciado pelos baixos teores nos principais elementos de interesse central da pesquisa $\mathrm{U}, \mathrm{Th}, \mathrm{Zr}, \mathrm{ETR}, \mathrm{Y}, \mathrm{Sc}, \mathrm{Fe}, \mathrm{Mo}, \mathrm{Zn}$, $\mathrm{Cd}$, e Pd, entre outros (Tabelas 5-8, e figuras 20 a e 21 am). Comparadas entre si a FR SN/15 é a mais pobre (Tabelas 7 e 8). Desta forma, predominam em ambas as frentes os controles geoquímicos globais dos hidrotermalitos respectivamente reduzidos e oxidados normais da mina, impostos pelos elementos litófilos maiores e traço comuns formadores dessas rochas desde as suas origens magmáticas ou mesmo empobrecidos por lixiviação no estágio hidrotermal. 
SN/15 - perfil 1

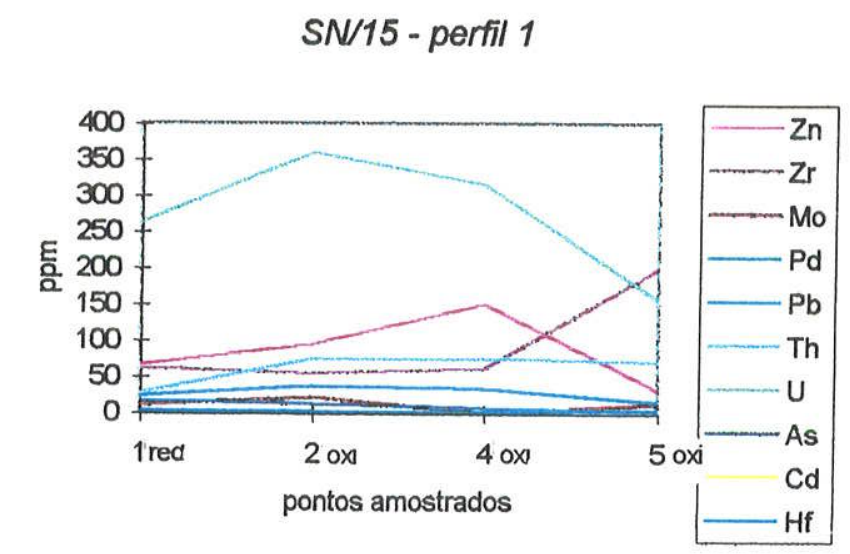

b
SN/15 - perfil 1

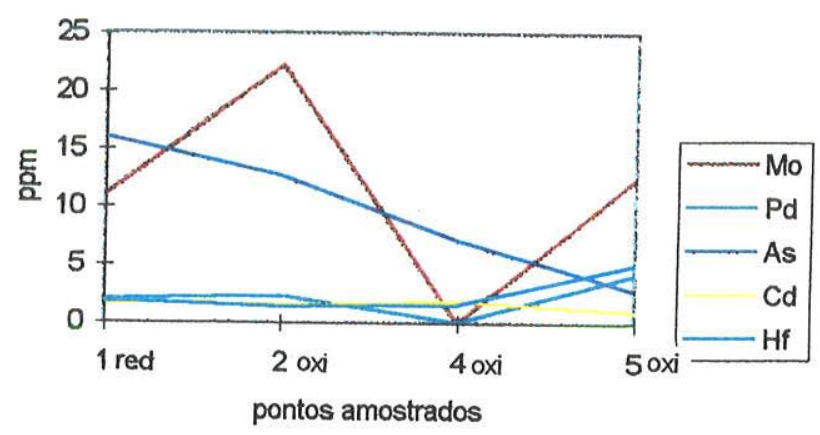

Figura 20: Gráficos binários multielementares dos microperfis da amostra SN/15 (frente redox de tipo 3, heterogênea). O pontos amostrados estão dispostos eqüidistantemente na abcissa, segundo a seqüência de alteração (da zona reduzida para oxidada) : (a)-perfil, (b)- detalhe.

a

U3c-perfil 1

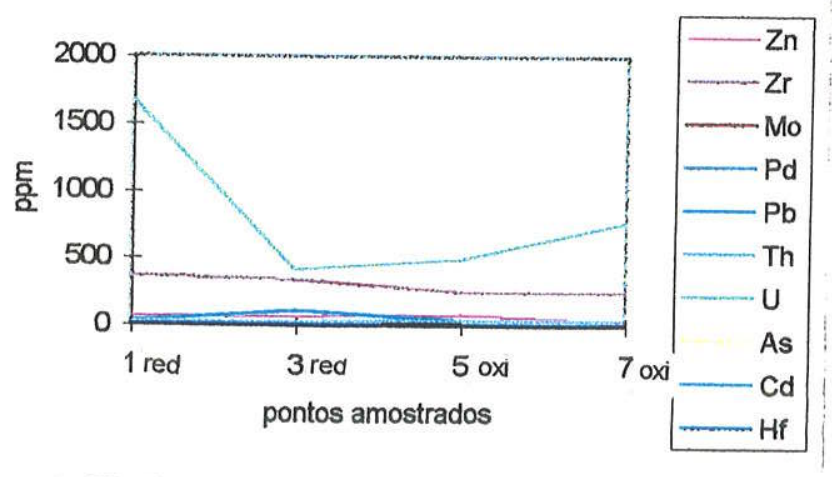

b

U3c-perfil 1

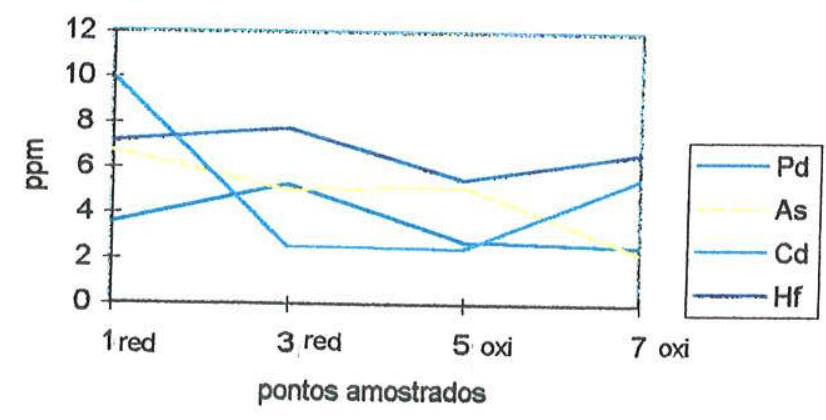

Figura 21: Gráficos binários multielementares dos microperfis da amostra U3c (frente redox de tipo 3, heterogênea). O pontos amostrados estão dispostos eqüidistantemente na abcissa, segundo a seqüência de alteração (da zona reduzida para oxidada) : (a)-perfil, (b)- detalhe. 
Tabela 7: Microperfil geoquímico via ICP-MS da frente redox S/N15.

\begin{tabular}{|c|c|c|c|c|c|}
\hline $\begin{array}{l}\text { Amostra } \\
\text { ppmitipo }\end{array}$ & $\begin{array}{c}\text { SN/15-1 } \\
\text { red }\end{array}$ & $\begin{array}{c}\text { SN/15-2 } \\
\text { Ox-Fe } \\
\end{array}$ & $\begin{array}{c}\text { SN/15-3 } \\
\text { Ox-Fe } \\
\end{array}$ & $\begin{array}{c}\mathrm{SN} / 15-4 \\
\mathrm{Ox}-\mathrm{Fe} \\
\end{array}$ & $\begin{array}{c}\text { SN/15-5 } \\
0 \times \\
\end{array}$ \\
\hline As & 15.97 & 12.66 & 5.30 & 7.10 & 2.75 \\
\hline $\mathrm{Ba}$ & 539.40 & 522.80 & 428.60 & 430.80 & 471.20 \\
\hline $\mathrm{Be}$ & 2.26 & 1.42 & 2.03 & 2.34 & 0.58 \\
\hline $\mathrm{Bi}$ & 0.53 & 0.26 & 0.21 & 0.07 & 0.07 \\
\hline $\mathrm{Ca}$ & 1293.00 & 333.40 & 74.23 & 225.60 & 82.11 \\
\hline $\mathrm{Cd}$ & 1.72 & 1.43 & 1.22 & 1.83 & 0.96 \\
\hline $\mathrm{Ce}$ & 73.81 & 77.42 & 66.69 & 88.49 & 52.55 \\
\hline Co & 0.54 & 0.44 & 0.34 & 0.70 & 0.46 \\
\hline $\mathrm{Cr}$ & 32.60 & 13,22 & 23.67 & 12.94 & 14.51 \\
\hline Cs & 0.29 & 0.28 & 0.21 & 0.28 & 0.22 \\
\hline $\mathrm{Cu}$ & 10.24 & 5.94 & 1.76 & 1.55 & 2.16 \\
\hline Dy & 3.11 & 3.01 & 4.27 & 2.96 & 5.99 \\
\hline Er & 1.79 & 1.92 & 0.72 & 1.77 & 4.37 \\
\hline Eu & 0.80 & 0.66 & 0.75 & 0.72 & 0.75 \\
\hline $\mathrm{Fe}$ & 4309.00 & 20430.00 & 18270.00 & 32420.00 & 6594.00 \\
\hline $\mathrm{Ga}$ & 36.98 & 41.25 & 26.38 & 34.51 & 11.91 \\
\hline$G d$ & 3.49 & 3.43 & 3.22 & 3.07 & 3.03 \\
\hline $\mathrm{Ge}$ & 1.01 & 2.06 & 1.93 & 1.69 & 1.01 \\
\hline$H f$ & 1.81 & 1.28 & 2.05 & 1.53 & 4.99 \\
\hline Ho & 0.68 & 0.71 & 0.94 & 0.60 & 1.53 \\
\hline La & 42.62 & 76.80 & 71.85 & 84.23 & 49.17 \\
\hline $\mathrm{Li}$ & 35.12 & 35.59 & 17.82 & 23.95 & 13.79 \\
\hline $\mathrm{Lu}$ & 0.28 & 0.28 & 0.34 & 0.24 & 0.69 \\
\hline $\mathrm{Mg}$ & 360.20 & 199.10 & 54.71 & 122.20 & 57.45 \\
\hline $\mathrm{Mn}$ & 28.50 & 27.03 & 12.30 & 19.35 & 15.71 \\
\hline Mo & 10.96 & 22.23 & 22.68 & 0.02 & 12.48 \\
\hline $\mathrm{Nb}$ & 15.60 & 14.71 & 19.06 & 13.13 & 18.29 \\
\hline $\mathrm{Nd}$ & 11.54 & 12.29 & 9.45 & 14.81 & 8.21 \\
\hline $\mathrm{Ni}$ & 41.86 & 22.86 & 16.31 & 7.17 & 14.14 \\
\hline $\mathrm{Pb}$ & 23.39 & 37.33 & 38.76 & 33.31 & 15.44 \\
\hline $\mathrm{Pd}$ & 1.97 & 2.23 & 3.46 & 0.00 & 4.13 \\
\hline Pr & 5.62 & 5.88 & 4.72 & 7.16 & 3.95 \\
\hline $\mathrm{Rb}$ & 229.40 & 239.20 & 203.70 & 230.90 & 203.10 \\
\hline$s$ & 12200.00 & 15480.00 & 19110.00 & 5990.00 & 10420.00 \\
\hline $\mathrm{sb}$ & 0.40 & 0.33 & 0.31 & 0.36 & 0.16 \\
\hline Sc & 0.28 & 0.59 & 0.58 & 0.70 & 0.95 \\
\hline $\mathrm{Se}$ & 0.77 & 3.24 & 5.22 & 2.67 & 1.03 \\
\hline $\mathrm{Sm}$ & 1.23 & 1.13 & 1.10 & 1.50 & 1.32 \\
\hline $\mathrm{Sr}$ & 267.30 & 292.10 & 351.20 & 274.30 & 198.90 \\
\hline Ta & 0.15 & 0.05 & 0.12 & 0.11 & 0.06 \\
\hline TD & 0.50 & 0.53 & 0.64 & 0.50 & 0.68 \\
\hline Th & 26.21 & 74.78 & 75.96 & 75.38 & 70.58 \\
\hline $\mathrm{Ti}$ & 1096.00 & 987.20 & 1753.00 & 996.60 & 1125.00 \\
\hline $\operatorname{Tr}$ & 0.30 & 0.28 & 0.42 & 0.26 & 0.73 \\
\hline U & 262.60 & 360.20 & 262.80 & 315.80 & 156.40 \\
\hline V & 194.60 & 226.50 & 147.40 & 153.40 & 40.36 \\
\hline W & 3.84 & 3.64 & 3.57 & 3.16 & 3.16 \\
\hline Y & 19.65 & 20.49 & 29.80 & 22.01 & 41.29 \\
\hline$Y b$ & 1.89 & 1.61 & 2.73 & 1.61 & 4.41 \\
\hline $\mathrm{Zn}$ & 66.86 & 95.86 & 93.11 & 150.70 & 31.76 \\
\hline $\mathrm{Zr}$ & 61.70 & 54.28 & 81.58 & 61.58 & 199.70 \\
\hline
\end{tabular}


Tabela 8: Micropenfil geoquimico via ICP-MS da frente redox U3c.

\begin{tabular}{|c|c|c|c|c|c|c|c|}
\hline $\begin{array}{l}\text { Amostra } \\
\text { ppmitipo } \\
\end{array}$ & $\begin{array}{c}\text { U3c-1 } \\
\text { red }\end{array}$ & $\begin{array}{l}\text { U3c-2 } \\
\text { fr. red } \\
\end{array}$ & $\begin{array}{r}\text { U3c-3 } \\
\text { fr. red } \\
\end{array}$ & $\begin{array}{l}\text { U3c-4 } \\
\text { fr. ox } \\
\end{array}$ & $\begin{array}{l}\text { U3c-5 } \\
\mathrm{fr} . \mathrm{ox} \\
\end{array}$ & $\begin{array}{l}\text { U3c-6 } \\
\text { fr. ox } \\
\end{array}$ & $\begin{array}{c}\text { U3c-7 } \\
\text { ox } \\
\end{array}$ \\
\hline As & 6.74 & 4.04 & 5.02 & 3.78 & 5.18 & 3.23 & 2.23 \\
\hline Ba & 350.90 & 265.40 & 369.20 & 303.20 & 380.80 & 387.10 & 338.00 \\
\hline $\mathrm{Be}$ & 4.96 & 3.54 & 3.72 & 3.00 & 5.01 & 3.56 & 1.45 \\
\hline $\mathrm{Bi}$ & 1.48 & 0.11 & 0.07 & 0.11 & 0.07 & 0.14 & 0.09 \\
\hline $\mathrm{Ca}$ & 431.50 & 378.00 & 68.79 & 524.30 & 316.80 & 24.92 & 414.60 \\
\hline $\mathrm{Cd}$ & 10.06 & 5.60 & 2.55 & 2.07 & 2.43 & 9.79 & 5.51 \\
\hline $\mathrm{Ce}$ & 95.32 & 74.70 & 51.31 & 60.55 & 70.05 & 82.35 & 93.52 \\
\hline Co & 0.90 & $0.61^{\circ}$ & 0.58 & 0.46 & 0.90 & 1.88 & 1.23 \\
\hline $\mathrm{Cr}$ & 14.66 & 7.21 & 25.77 & 18.17 & 28.39 & 30.61 & 12.39 \\
\hline Cs & 0.25 & 0.26 & 0.25 & 0.26 & 0.25 & 0.17 & 0.29 \\
\hline $\mathrm{Cu}$ & 4.22 & 4.38 & 4.06 & 6.03 & 9.57 & 16.36 & 65.01 \\
\hline Dy & 7.38 & 3.79 & 7.21 & 2.80 & 4.86 & 4.44 & 4.19 \\
\hline Er & 5.64 & 2.91 & 6.32 & 2.45 & 4.05 & 3.58 & 3.65 \\
\hline Eu & 1.16 & 0.62 & 0.73 & 0.52 & 0.79 & 0.85 & 0.95 \\
\hline $\mathrm{Fe}$ & 4921.00 & 5615.00 & 8785.00 & 8026.00 & 11540.00 & 14230.00 & 12860.00 \\
\hline Ga & 42.27 & 43.11 & 40.12 & 36.76 & 44.76 & 76.59 & 20.88 \\
\hline $\mathrm{Gd}$ & 4.69 & 2.64 & 3.21 & 2.20 & 3.02 & 4.17 & 3.39 \\
\hline $\mathrm{Ge}$ & 1.29 & 0.88 & 1.09 & 1.15 & 1.03 & 1.34 & 1.49 \\
\hline Hf & 7.14 & 3.85 & 7.74 & 2.66 & 5.49 & 4.72 & 6.67 \\
\hline Ho & 1.77 & 0.88 & 2.00 & 0.70 & 1.31 & 1.02 & 1.03 \\
\hline La & 74.82 & 65.48 & 51.75 & 58.18 & 62.80 & 59.06 & 80.34 \\
\hline $\mathrm{Li}$ & 47.83 & 38.25 & 35.31 & 24.73 & 38.31 & 70.52 & 10,58 \\
\hline Lu & 1.04 & 0.56 & 1.08 & 0.36 & 0.74 & 0.64 & 0.67 \\
\hline $\mathrm{Mg}$ & 326.00 & 240.60 & 259.10 & 186.10 & 191.70 & 151.00 & 97.00 \\
\hline $\mathrm{Mn}$ & 20.88 & 14.46 & 39.08 & 23.49 & 52.02 & 97.30 & 71.78 \\
\hline Mo & 7.89 & 6.00 & 10.79 & 62.90 & 13.65 & 8.65 & 6.54 \\
\hline $\mathrm{Nb}$ & 22.51 & 20.34 & 19.29 & 11.28 & 16.84 & 16.99 & 37.45 \\
\hline $\mathrm{Nd}$ & 21.48 & 14.48 & 9.00 & 11.10 & 13.10 & 16.91 & 16.90 \\
\hline $\mathrm{Ni}$ & 3.22 & 1.95 & 9.91 & 3.70 & 6.81 & 13.16 & 10.01 \\
\hline $\mathrm{Pb}$ & 27.70 & 43.20 & 111.90 & 50.11 & 39.99 & 168.20 & 34.70 \\
\hline $\mathrm{Pd}$ & 3.55 & 2.13 & 5.27 & 1.37 & 2.77 & 2.36 & 2.53 \\
\hline $\mathrm{Pr}$ & 9.90 & 6.70 & 4.53 & 5.03 & 6.15 & 8.36 & 7.76 \\
\hline $\mathrm{Rb}$ & 217.50 & 206.50 & 12.40 & 206.60 & 224.30 & 169.10 & 229.50 \\
\hline$S$ & 19480.00 & 18000.00 & 17410.00 & 11900.00 & 9382.00 & 7155.00 & 6647.00 \\
\hline $\mathrm{Sb}$ & 0.41 & 0.28 & 0.25 & 0.72 & 0.34 & 0.63 & 0.31 \\
\hline Sc & 0.94 & 0.25 & 0.68 & 0.31 & 0.87 & 0.65 & 0.68 \\
\hline $\mathrm{Se}$ & 1.14 & 0.54 & 1.34 & 1.06 & 1.31 & 1.90 & 1.09 \\
\hline $\mathrm{Sm}$ & 2.88 & 1.51 & 1.27 & 1.06 & 1.51 & 1.96 & 1.81 \\
\hline $\mathrm{Sr}$ & 244.80 & 285.00 & 294.40 & 339.10 & 328.60 & 106.50 & 292.60 \\
\hline Ta & 9.34 & 0.06 & 0.02 & 0.03 & 0.12 & 0.05 & 0.47 \\
\hline Tb & 0.98 & 0.53 & 0.76 & 0.39 & 0.62 & 0.75 & 0.65 \\
\hline Th & 25.35 & 12.86 & 24.21 & 42.16 & 44.35 & 36.57 & 39.20 \\
\hline $\mathrm{Ti}$ & 1923.00 & 1286.00 & 1448.00 & 602.40 & 1357.00 & 1022.00 & 2403.00 \\
\hline Tm & 1.01 & 0.52 & 1.11 & 0.37 & 0.70 & 0.59 & 0.69 \\
\hline U & 1677.00 & 890.50 & 2.80 & 392.00 & 492.80 & 2076.00 & 769.80 \\
\hline & 157.60 & 136.70 & 163.50 & 112.30 & 153.10 & 235.70 & 63.41 \\
\hline N & 9.08 & 8.24 & 18.68 & 15.54 & 29.85 & 75.01 & 29.23 \\
\hline Y & 55.44 & 29.80 & 54.74 & 21.69 & 44.90 & 29.99 & 38.97 \\
\hline$b$ & 6.30 & 3.28 & 7.59 & 2.44 & 4.84 & 4.14 & 4.05 \\
\hline-1 & 69.73 & 78.40 & 70.91 & 54.59 & 86.69 & 89.47 & 25.80 \\
\hline & 364.40 & 160.90 & 338.70 & 103.00 & 254.70 & 180.10 & 261.80 \\
\hline
\end{tabular}




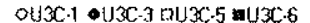

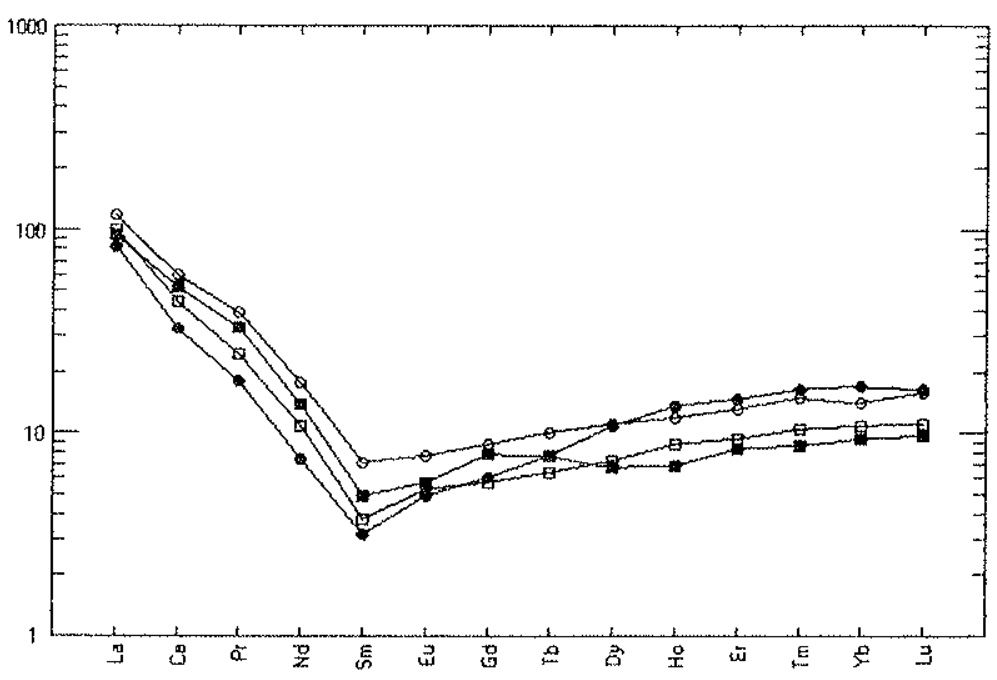

U Th $\mathrm{zr}$ Fe $1677.00 \quad 25.35 \quad 364.40 \quad 4921.00$ $\begin{array}{llll}412.80 & 24.21 & 338.70 & 8785.00\end{array}$ $\begin{array}{llll}492.80 & 44.35 & 254.70 & 11540.00\end{array}$ $\begin{array}{llll}2076.00 & 36.57 & 180.10 \quad 14230.00\end{array}$

Figura 22: Variograma dos ETR da amostra U3c da frente redox de tipo 3, normalizados pelo manto primitivo (PRIM), com os respectivos teores de $U$, Th, Zre Fe.

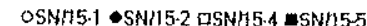

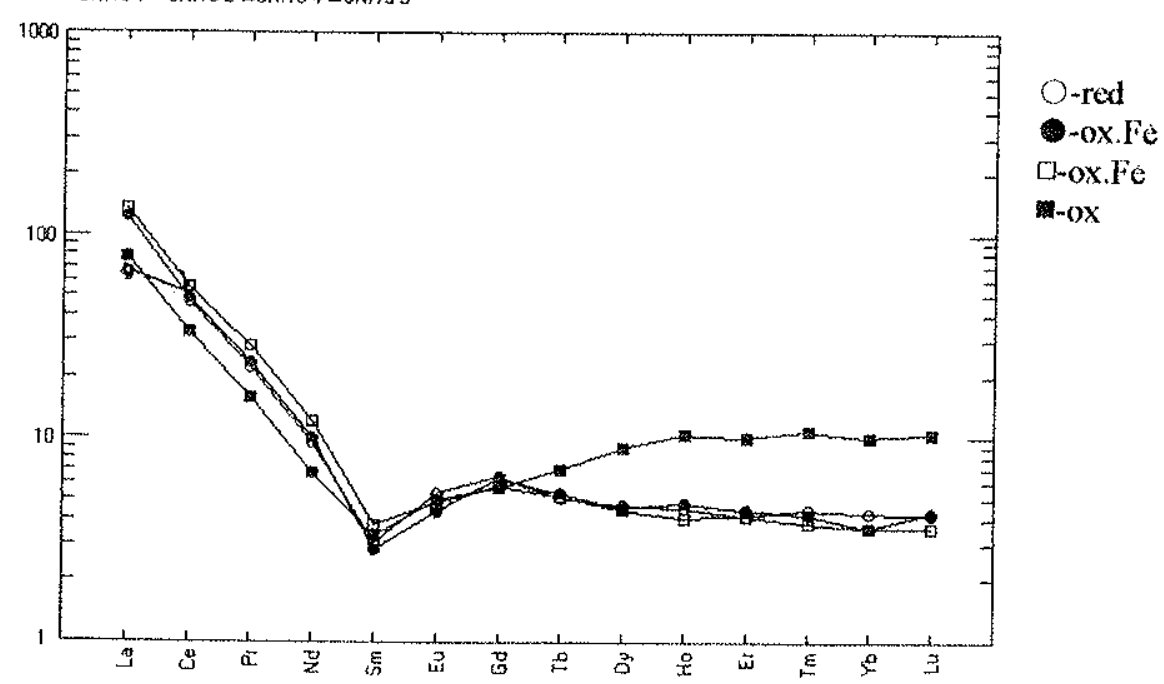

$\begin{array}{llll}\mathbf{U} & \mathbf{T h} & \mathbf{Z r} & \mathbf{F e}\end{array}$ $\begin{array}{llll}262.60 & 26.21 & 61.70 & 4309.00\end{array}$ $\begin{array}{llll}360.20 & 74.78 & 54.28 & 20430.00\end{array}$ $\begin{array}{llll}315.80 & 75.38 & 61.58 & 34420.00\end{array}$ $\begin{array}{llll}156.40 & 70.58 & 199.70 & 659400\end{array}$

Figura 23: Variograma dos ETR da amostra $S N / 15$, da frente redox de tipo 3, normalizados pelo manto primitivo (PRIM), com os respectivos teores de $U$, Th, Zre Fie. 
Do processo supergênico, notam-se na FR U3c apenas enriquecimentos de $U$ $(\sim 1700 \mathrm{ppm}) \operatorname{com} C d(\sim 10 \mathrm{ppm})$ associado, na amostra 1 , reduzida, à cerca de $2 \mathrm{~cm}$ da frente (Foto 27) como típico efeito da mineralização supergênica de U (Figura 21). A forte variabilidade dessa mineralização de distribuição heterogênea em micronódulos é bem evidenciada pela amostra 2 , a poucos $\mathrm{cm}$ de distância, com teores muito menores (U $\sim 900$ ppm e Cd $\sim 6$ ppm). Já na amostra 3 da interface reduzida dessa frente, notam-se os efeitos de lixiviação ácida, também notados na interface oxidada e a poucos $\mathrm{cm}$ na zona oxidada (amostras 4 e 5). A amostra 6 oxidada apresenta os mais elevados teores de U $(\sim 2080 \mathrm{ppm}) \mathrm{Fe}(\sim 1,4 \%)$ e Mn $(\sim 100 \mathrm{ppm})$, associados com Cd ( 10 ppm) e enriquecimentos algo mais variáveis de $\mathrm{Ba}, \mathrm{Cr}, \mathrm{Cu}, \mathrm{Ni}, \mathrm{V}, \mathrm{Zn}, \mathrm{Se}$, entre outros, indicando coprecipitação com OHF, aliada, eventualmente, com a dissolução incompleta de um micronódulo supergênico de $U$.

Sobre a FR S/N15, de mais fraca mineralização hidrotermal e supergênica, menos ainda pode ser comentado. Apenas os teores de $U$ são claramente acima das médias dos $\mathrm{Ph}$ e $\mathrm{NeS}$ magmáticos regionais e da mina, bem como dos hidrotermalitos reduzidos e oxidados normais, entretanto, sem variações sistemáticas mais significantes no perfil da FR (Tabelas 4 e 7 e Figura 20 a-b). Também não se notam variações sistemáticas mais significantes na zona oxidada indicando a coprecipitação mais expressiva de outros metais nos $\mathrm{OHF}$, nem sequer na amostra 4, mais rica em $\mathrm{OHF}$, pelo que tudo indica por deficiência desses outros metais.

A geoquímica global das duas frentes redox de tipo 3 heterogêneas mostra sua ocorrência em hidrotermalitos de fraca mineralização hipogênica, eventualmente por fases de lixiviação hidrotermal; mostra ainda a seletividade e variabilidade até muito fraca da mineralização supergênica restrita, na zona reduzida, ao $\mathrm{U}$ associado com $\mathrm{Cd}$. Na zona oxidada, a mineralização supergênica de $\mathrm{U}$ também é restrita, além do $\mathrm{Cd}$, mas a outros metais mobilizados por ataque e lixiviação/dissolução ácida oxidante parcial dos 
hidrotermalitos reduzidos, são oportunisticamente coprecipitados nos OHF dependendo de sua disponibilidade.

\section{Elementos Terras Raras (ETR), Sc (escândio) e Y (ítrio)}

Os ETR, Sc e Y, nas duas frentes, são baixos (U3c) e muito baixos (SN/15) quando comparados com as demais FR estudadas e entre si (Tabelas 5-8). Dois gráficos de espectros de ETR normalizados (manto primordial) foram representados na figuras 22 da FR U3c e 23 da FR S/N15, cada qual com 4 microamostras.

Os 4 espectros da FR U3c (Figura 22) são todos entre si muito similares, caracterizados por forte fracionamento dos ETR leves (La-Sm), nítida a forte anomalia negativa de $\mathrm{Sm}$ e leve e sistemática crescença dos ETR intermediários a pesados, até atingir patamares de enriquecimentos máximos e constantes de Tm a Lu (de 10 a 20x PRIM). Notam-se, ainda, os teores de ETRL mais elevados e a anomalia negativa de Sm mais fraca na amostra 1 reduzida, de mais elevado teor de $\mathrm{U}$ (1677 ppm, de mineralização de tipo micronódulo supergênica), e os mais baixos teores de ETR intermediários e pesados, mas com claros efeitos tetrádicos, na amostra 6 oxidada, de mais elevados teores de U (2076 ppm) e OHF/ Fe-férrico $(\sim 1,4 \%)$.

As amostras da FR S/N15 (Figura 23) também apresentam padrões de ETRL entre si muito similares e perfeitamente análogos às amostras da FR U3c, fortemente fracionados de $\mathrm{La}$ a $\mathrm{Sm}$ e com forte anomalia negativa do $\mathrm{Sm}$. De Sm a Lu surgem duas tendências, as amostras 1,2 e 4 , reduzida e oxidadas, continuam entre si muito similares; apresentam leve enriquecimento de ETR intermediárias (Sm-Dy), seguido de decréscimo, para um patamar constante, dos ETRP (Ho-Lu), com enriquecimento de 4 x PRIM. A amostra 5, oxidada, diverge deste padrão mostrando enriquecimento de Sm-Lu como ocorre em todas as amostras da FR U3c (Figura 22). Comparando-se esses padrões com os teores dos elementos potencialmente correlacionados $\mathrm{U}, \mathrm{Yh}, \mathrm{Zr}$ e Fe, nota-se claramente que o controle entre os dois padrões, no intervalo incluindo os ETR 
intermediários e ETRP, é exercido, no caso das duas FR, pelo Zr, abaixo de $100 \mathrm{ppm}$ em todas as amostras com enriquecimento leve apenas dos ETR intermediários, e acima de $180 \mathrm{ppm}$ em todas as amostras com enriquecimento contínuo dos ETR intermediários, até um patamar máximo de ETRP (Figuras 22 e 23).

Sc e Y mostram comportamento variável, ora mais similar aos ETRL, ora aos ETRP sem que se notou um contole ou explicações específicas em cada caso.

\section{Frente Redox M2c (Foto 28 a)}

Tipologia: Frentes Redox Tipo 4 (simples)

Essa frente ocorre em fonolito vulcânico fino microporfirítico e fracamente microxenolítico. É constituída por hidrotermalitos normais reduzidos e oxidados separados por uma interface nítida muito bem definida sem qualquer efeito adicional de enriquecimento e/ou zoneamento de OHF ou outra heterogeneidade nova relacionada ao desenvolvimento da frentes, a não ser a mudança de cor, de cinza médio da rocha reduzida para marrom avermelhado da rocha oxidada. Na zona reduzida ocorre mineralização supergênica de $\mathrm{U}$ em micronódulos e disseminada pobre. A distribuição e tingimento de OHF na zona oxidada são homogêneos exceção feita a eventuais microxenolitos e fenocristais.

Essa frente formou-se imersa no freático com zona de saturação de volume expressivo, assim, capaz de atenuar as influências de eventuais variações climáticas de curta duração sobre as condições de Eh e pH do lençol; representa, portanto, um tipo de frente ativa, sob condições de equilíbrio/desequilíbrio de constância secular considerando: avanço da frente, potencial redox, acidez, rebaixamento e alimentação/recarga do freático. Essas frentes produziram as principais e mais ricas mineralizções supergênicas de $U$ da mina. 


\section{Geoquímica multielementar e ETR}

Dessa frente foram analisadas 5 microamostras cuja disposição no perfil da frentes redox é indicada na foto 28 a. Os dados analíticos são apresentados na tabela 9 (texto). Adicionalmente foram ainda reanalisadas 4 amostras maiores, 2 da zona reduzida e 2 da oxidada (Anexo I, Tabela I-8).

Essa frente apresenta alguma mineralização supergênica de $\mathrm{U}$ com $\mathrm{Cd}$ associado, entretanto, quanto a mineralização hipogênica hidrotermal, o hidrotermalito hospedeiro é, em geral, algo mais pobre em relação às respectivas médias dos hidrotermalitos reduzidos e oxidados normais da mina, considerando-se os elementos mais típicos dos processos hidrotermais $(\mathrm{Zr}$ e os ETRL La, Ce, Nd, entre outros) e excetuando-se a microamostra 5 reduzida, portadora de mineralização supergênica de U.

Quanto a geoquímica dos principais elementos traço nos processos de FR, apenas pouquíssimas redistribuições sistemáticas se observam. Entre estas citam-se o caso, já destacado, do $\mathrm{Cd}$ de empobrecimento na zona oxidada excessão feita para a sua coprecipitação nas amostras com teor maior de OHF (Figura 24 a-b). Observam-se ainda depauperações também na zona oxidada de $\mathrm{Ge}, \mathrm{Nb}, \mathrm{Pb}, \mathrm{Sb}, \mathrm{Sr}$ e, não por último, do $\mathrm{U}$, nas amostras mais afastadas da FR, assim como, certo enriquecimento do Pd (Figura 24 a-b). Variações dos demais elementos representam mais provavelmente heterogeneidades das próprias rochas e o efeito pepita da amostragem.

Quatro das microamostras foram representadas em espectros de distribuição dos ETR normalizados (manto primordial) na figura 25. Destaca-se a amostra 5 , reduzida, localizada a poucos milímetros da interface da $\mathrm{FR}$, pelos mais altos teores de ETRL (La-Sm) e intermediários (Sm-Dy), e decréscimos até os mais baixos teores de Tm-Lu, além de efeitos tetrádicos nítidos. Seu padrão de ETRL e intermediários é controlado pela especiação e os elevados teores destes na mineralização supergênica, junto com U e Th. A depauperação dos ETRP parece estar controlada adicionalmente pelo baixo teor de $\mathrm{Zr}$. No geral o padrão 
Tabela 9: Microperfil geoquímico via ICP-MS da frente redox M2c.

\begin{tabular}{|c|c|c|c|c|c|}
\hline $\begin{array}{l}\text { Amostra } \\
\text { ppmiTipo } \\
\end{array}$ & $\begin{array}{c}\text { M2c-5 } \\
\text { red }\end{array}$ & $\begin{array}{l}M 2 c-4 \\
\text { fr. ox } \\
\end{array}$ & $\begin{array}{l}\text { M2c-3 } \\
\text { fr. ox } \\
\end{array}$ & $\begin{array}{c}M 2 c 2 \\
O X\end{array}$ & $\begin{array}{c}\text { M2c-1 } \\
\mathrm{Ox}\end{array}$ \\
\hline$\overline{\mathrm{As}}$ & 6.77 & 10.99 & 7.56 & 6.81 & 8.30 \\
\hline $\mathrm{Ba}$ & 658.30 & 599.80 & 598.60 & 486.40 & 692.40 \\
\hline $\mathrm{Be}$ & 3.30 & 2.13 & 2.45 & 1.81 & 3.01 \\
\hline $\mathrm{Bi}$ & 0.06 & 0.05 & 0.05 & 0.04 & 0.07 \\
\hline $\mathrm{Ca}$ & 430.90 & 86.75 & 396.10 & 117.80 & 399.70 \\
\hline $\mathrm{Cd}$ & 7.46 & 1.75 & 5.11 & 1.98 & 2.35 \\
\hline $\mathrm{Ce}$ & 738.80 & 189.10 & 165.60 & 138.90 & 131.90 \\
\hline Co & 1.65 & 0.59 & 1.33 & 6.46 & 11.36 \\
\hline $\mathrm{Cr}$ & 3.65 & 33.34 & 9.81 & 28.96 & 15.54 \\
\hline $\mathrm{Cs}$ & 0.51 & 0.40 & 0.57 & 0.48 & 0.55 \\
\hline $\mathrm{Cu}$ & 5.53 & 0.00 & 3.03 & 1.65 & 3.23 \\
\hline Dy & 25.98 & 11.87 & 23.14 & 18.99 & 20.80 \\
\hline Er & 12.96 & 6.56 & 15.06 & 11.78 & 11.75 \\
\hline Eu & 11.48 & 3.87 & 6.35 & 5.17 & 5.41 \\
\hline $\mathrm{Fe}$ & 26990.00 & 11900.00 & 19840.00 & 15350.00 & 21520.00 \\
\hline Ga & 45.59 & 33.45 & 50.45 & 35.28 & 53.52 \\
\hline $\mathrm{Gd}$ & 42.21 & 16.20 & 19.44 & 18.63 & 16.07 \\
\hline Ge & 4.08 & 2.19 & 2.15 & 2.37 & 2.03 \\
\hline$H f$ & 11.39 & 8.36 & 15.02 & 18.54 & 25.83 \\
\hline Ho & 5.08 & 2.41 & 4.94 & 4.30 & 4.20 \\
\hline La & 565.00 & 221.20 & 168.90 & 160.60 & 149.80 \\
\hline Li & 68.87 & 60.20 & 106.40 & 72.75 & 99.46 \\
\hline Lu & 1.27 & 0.69 & 1.95 & 1.62 & 1.52 \\
\hline $\mathrm{Mg}$ & 350.80 & 280.30 & 445.40 & 331.00 & 543.80 \\
\hline $\mathrm{Mn}$ & 46.25 & 50.81 & 49.87 & 26.50 & 73.87 \\
\hline Mo & 157.90 & 163.00 & 231.50 & 80.73 & 187.20 \\
\hline $\mathrm{Nb}$ & 39.15 & 15.45 & 16.03 & 7.85 & 19.48 \\
\hline $\mathrm{Nd}$ & 183.20 & 51.47 & 56.14 & 41.93 & 46.60 \\
\hline $\mathrm{Ni}$ & 1.96 & 0.27 & 1.58 & 2.66 & 7.65 \\
\hline $\mathrm{Pb}$ & 58.06 & 21.71 & 17.86 & 17.63 & 21.72 \\
\hline $\mathrm{Pd}$ & 9.83 & 9.12 & 11.27 & 16.05 & 9.86 \\
\hline $\mathrm{Pr}$ & 75.57 & 20.61 & 19.69 & 16.27 & 17.09 \\
\hline $\mathrm{Rb}$ & 216.30 & 188.80 & 223.20 & 189.30 & 260.60 \\
\hline $\mathrm{s}$ & 76990.00 & 23030.00 & 11850.00 & 17100.00 & 10140.00 \\
\hline $\mathrm{Sb}$ & 1.26 & 0.38 & 0.90 & 0.37 & 0.97 \\
\hline Sc & 1.81 & 1.06 & 2.44 & 2.04 & 2.56 \\
\hline Se & 4.20 & 3.31 & 5,56 & 3.96 & 3.27 \\
\hline $\mathrm{Sm}$ & 28.57 & 9.76 & 14.08 & 11.71 & 11.66 \\
\hline $\mathrm{Sr}$ & 610.50 & 469.70 & 444.60 & 370.20 & 367.80 \\
\hline $\mathrm{Ta}$ & 0.57 & 0.05 & 0.17 & 0.12 & 0.28 \\
\hline $\mathrm{Tb}$ & 5.96 & 2.29 & 3.88 & 3.10 & 3.33 \\
\hline Th & 100.30 & 33.65 & 53.33 & 39.28 & 44.24 \\
\hline Ti & 2708.00 & 1292.00 & 1448.00 & 1445.00 & 1967.00 \\
\hline $\mathrm{Tm}$ & 1.58 & 0.91 & 2.24 & 1.73 & 1.74 \\
\hline$U$ & 1257.00 & 1105.00 & 1469.00 & 765.10 & 849.00 \\
\hline V & 224.20 & 174.20 & 246.00 & 199.50 & 295.20 \\
\hline$W$ & 6.80 & 3.43 & 3.40 & 2.27 & 3.08 \\
\hline$Y$ & 158.70 & 73.89 & 171.10 & 125.10 & 143.60 \\
\hline $\mathrm{Yb}$ & 8.52 & 5.01 & 12.78 & 10.54 & 10.58 \\
\hline $\mathrm{Zn}$ & 104.70 & 29.41 & 99.69 & 61.42 & 100.10 \\
\hline$Z r$ & 624.30 & 393.30 & 1109.00 & 1013.00 & 1201.00 \\
\hline
\end{tabular}


$\mathbf{a}$

M2c - perfil 1

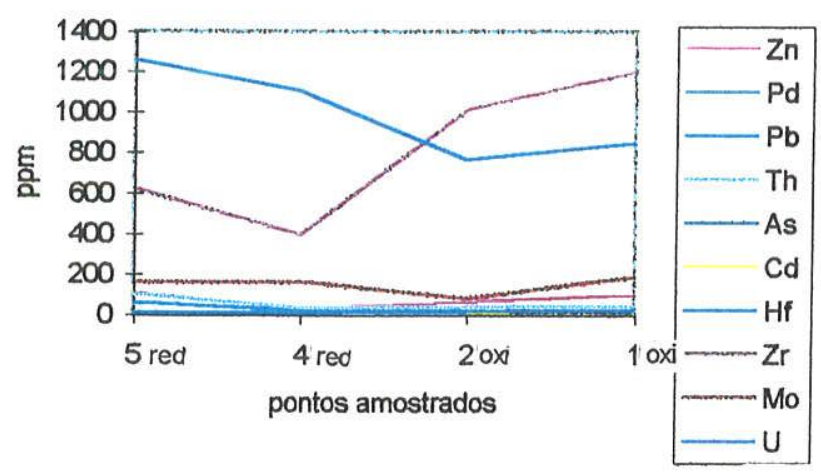

b

M2c - perfil 1

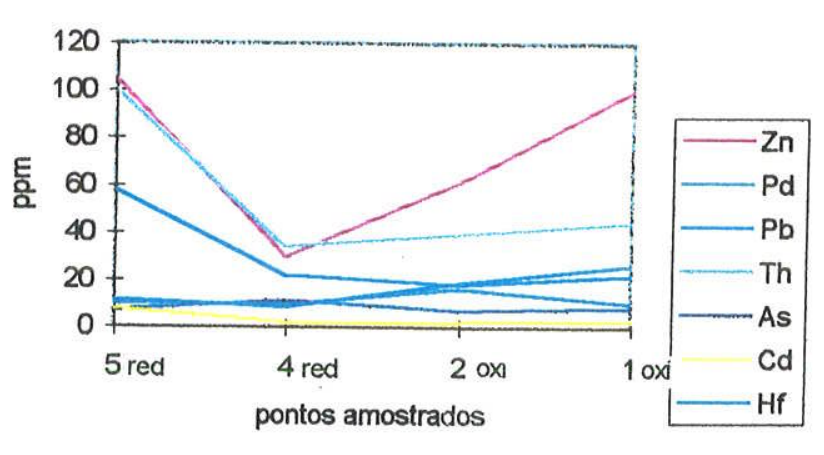

Figura 24: Gráficos binários multielementares dos microperfis da amostra M2c (frente redox de tipo 4). $O$ pontos amostrados estão dispostos eqüidistantemente na abcissa, segundo a seqüência de alteração (da zona reduzida para oxidada) : (a)-perfil, (b)- detalhe.

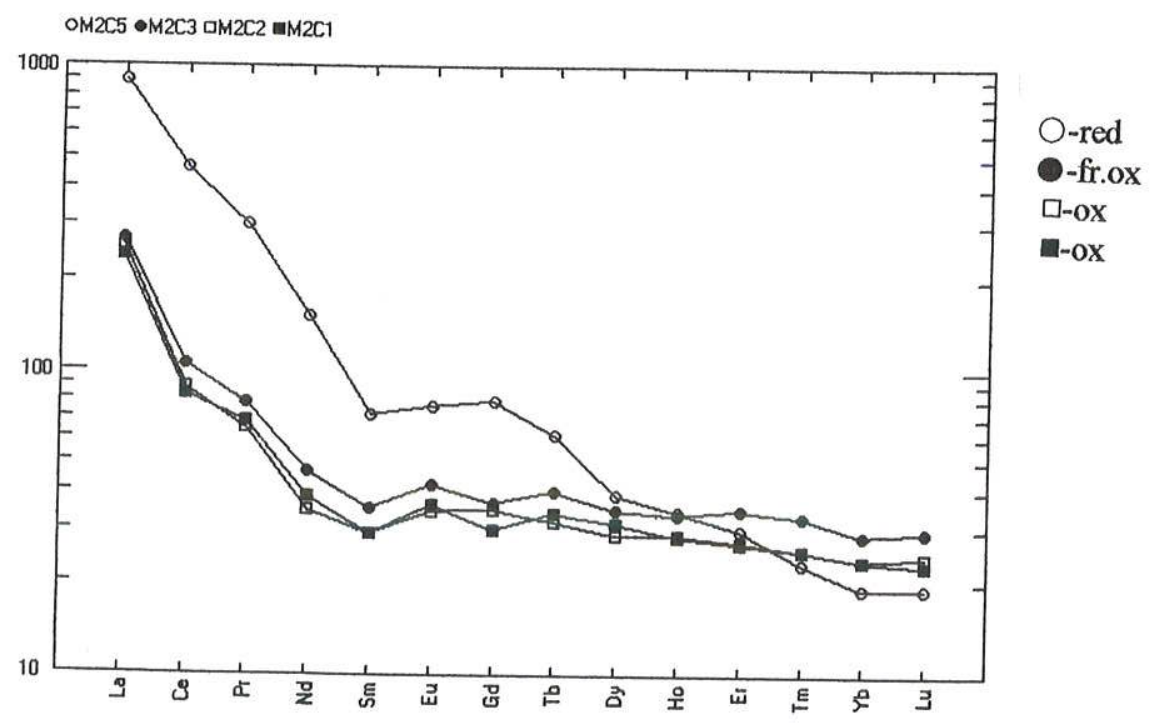

$\begin{array}{llll}\text { U Th } & \mathbf{Z r} \quad \text { Fe }\end{array}$

$\begin{array}{llll}1257.00 & 100.30 & 624.30 & 26990.00\end{array}$

$\begin{array}{lllll}1469.00 & 53.33 & 1109.00 & 19840.00\end{array}$

$\begin{array}{lllll}765.10 & 39.28 & 1013.00 & 15350.00\end{array}$

$\begin{array}{lllll}849.00 & 44.24 & 1201.00 & 21520.00\end{array}$

Figura 25: Variograma dos ETR da amostra $M 2 c$ da frente redox de tipo 4, normalizados pelo manto primitivo (PRIM), com os respectivos teores de $U$, Th, $\mathrm{Zr}$ e Fe. 
de ETR desta amostra é similar às outras com mineralizações supergênica de $U$ (por ex.: amostra 8 da FR PDC-PH-028 e amostra 1 da FR U3c), principalmente quando comparados com base na proporcionalidade das ETRL. Já os padrões de ETR das outras amostras oxidadas dessa FR se assemelham muito com os padrões de hidrotermalitos reduzidos e oxidados normais das outras frentes já descritas.

\section{Frentes e Processos Redox da Zona Insaturada \\ Tipologia: Frentes Redox Tipo 5 (heterogêneas)}

Essas frentes e processos redox ocorrem em qualquer tipo de hidrotermalito reduzido (de $\mathrm{Ph}, \mathrm{NeS}$ e $\mathrm{Br}$ ). São representados por hidrotermalitos normais reduzidos que passam a oxidados com estruturas irregulares e mais variáveis quanto às distribuições/tingimentos de OHF. Estes ocorrem em manchas de dimensões muito variáveis (de milimétricas a decimétricas). São caracterizadas pela ocorrência associada de OHF concentrados em agregados virtualmente puros, também de tamanhos e estruturas diferentes. Ora preenchem pequenos cubos, pseudomorfos de piritas hidrotermais pretéritas, idiomórficas, em cristais individuais esparsos, ora pseudomorfizam concreções maiores policristalinas de pirita de formas irregulares e tamanhos variáveis, milimétricos a centimétricos. Comumente ocorre ainda alguma pirita preservada em restos de oxidação incompleta. As manchas com OHF alternam-se com porções ainda preservadas de hidrotermalitos reduzidos com piritas (e outros sulfetos hidrotermais) também metaestáveis, conforme indicam sulfatos supergênicos principalmente de $\mathrm{Fe}, \mathrm{Al}$ e $\mathrm{K}$ (por ex.: Halotrichita e Kalinita, entre outros sulfatos hidratados do grupo dos alumnos) em poros e fraturas, evidenciando fortes desequilíbrios locais.

Essas frentes e processo são originados pela oxidação e substituição pseudomórfica direta das piritas pretéritas, in situ, por OHF indígenos, comumente com a preservação metaestável de piritas corroídas em restos de 
substituição incompleta, indicando, condições predominantes de oxidação das piritas ao ar, na zona de insaturação acima do nível médio do freático. A escassez de fluídos (água do freático) temporária a permanente, neste horizonte do perfil de alteração, impediu a dissolução das piritas e decorrente exportação e redistribuição do $\mathrm{Fe}$ em solução com reprecipitação posterior na forma de OHF dispersos, condicionando a substituição pseudomórfica das piritas sur place. Entretanto, na medida da disponibilidade de fluidos, por exemplo, promovido pela umidade fixada às rochas, e/ou por inundações de curta duração da zona insaturada, formaram-se as manchas de OHF de maior ou menor tamanho, dependendo também da abundância de pirita no local. Essas frentes não foram estudadas com métodos químicos multielementares, apenas mineralógicos. As imagens de MEV das duas situações contrastantes, de OHF indígenos pseudomorfizando uma pirita idiomórfica, por oxidação in situ, em condições de insaturação e a mobilização, exportação e redistribuição em solução, com reprecipitação final de OHF finamente distribuídos no hidrotermalito oxidado em condições de saturação são mostradas na foto 21 .

\section{Frentes e Processos Redox Complexos}

Variações climáticas sazonais a seculares, associadas e, eventualmente, reforçadas por processos tectônicos e geomorfológicos regionais, e principalmente, as particularidades locais da evolução estrutural e morfológica, modificaram repetidamente as condições do lençol freático, tanto de carga e recarga/nível e volume, quanto físico-químicas, durante os últimos $76 \mathrm{Ma}$, período estimado para o desenvolvimento geológico do perfil de alteração supergênica na área da mina de urânio Osamu Utsumi (Schorscher e Shea, 1992; Shea, 1992; Schorscher e Osmond, 1992). Estas variações deixaram seus registros mineralógico-petrográficos e geoquímicos em intervalos por vezes restritos, centimétricos a decimétricos, do perfil de alteração, na forma de frentes redox complexas. Trata-se, de fato, de sucessões temporais de frentes 
redox de tipos distintos, desenvolvidas, ora em sucessões espaciais estreitas, ora mesmo em superposição espacial, quando a tectônica local de blocos e/ou mudanças climáticas causaram subidas mais duradouras do nível do lençol freático e a reinundação de frentes redox anteriores/fósseis, ou mesmo quando apenas as condições de temperatura, Eh e pH na zona de saturação foram alteradas. Um exemplo de frente redox complexa será brevemente descrito a seguir.

\section{Frente Redox IARF (Foto 29)}

Tipologia: Frente Redox Complexa Tipo 1 e 4

Essa frente ocorre em fonolito vulcânico fino microporfirítico e microxenolítico. Compreende dois estágios de frentes estagnadas (tipo 1) praticamente imóveis, por redução do potencial redox, aliado ao rebaixamento do nível do freático e OHF, caracterizados por duas zonas ferruginosas de forte enriquecimento de OHF. Uma representa a frente recente, estando em contato brusco com a rocha reduzida na interface da frente atual e em contato gradativo por decrescência de OHF com a rocha oxidada adjacente. A segunda zona ferruginosa representa uma frente tipo 1 fóssil (dentro da zona oxidada), distando cerca de $10 \mathrm{~cm}$ da primeira, porém repetindo como uma réplica virtualmente as mesmas características morfológicas e mineralógicas, por exemplo, o gradiente de concentração de OHF. As duas zonas representativas de estágios de frentes estagnadas são separadas por um zona de rocha oxidada normal com disseminação fina pobre mas homogênea de OHF (de cerca de 10 $\mathrm{cm}$ de largura). Esta zona representa um intervalo de tempo-espaço em que a frente redox progrediu efetivamente como frente de tipo 4 , sob condições de elevada recarga e potencial redox constantes do freático.

$O$ avanço dessa frente complexa foi controlado predominantemente por critérios texturais (bordas de grãos, porosidade e permeabilidade), embora efeitos estruturais de microfraturas também sejam observados. O sentido 
direcional da progressão da frente é bem documentado pelos gradientes de concentração dos $\mathrm{OHF}$, gerados por efeitos associados de decantação e filtração dos colóides de OHF, nos periodos de estagnação das frentes.

\section{Geoquímica multielementar e ETR}

Dessa frente foram analisados 12 microamostras representativas de:

Amostra 12 - zona reduzida $\sim 2 \mathrm{~cm}$ da FR tipo1 atual;

Amostras 8, 9, 11 - zona reduzida $\sim 2-4 \mathrm{~mm}$ da interface da FR tipo 1 atual;

Amostras 7, 10 - zona ferruginosa da FR tipo 1 atual;

Amostra 5 - rocha oxidada normal a $\sim 8 \mathrm{~mm}$ da interface da FR tipo 1 fóssil;

Amostra 3 - rocha oxidada da interface da FR tipo 1 fóssil;

Amostras 1, 2, 4 e 6 - várias partes da zona ferruginosa da FR tipo 1 fóssil,

e reanalisadas 7 amostras maiores, 2 reduzidas, 3 oxidadas e 2 das zona ferruginosas. Os resultados analíticos das microamostras são representados na Tabela 10 (texto) e as reanálises no Anexo I, Tabela I-8. As microamostras foram agrupadas em 2 perfis analíticos que atravessam (ambas) todas as zonas da frente complexa, da rocha reduzida para a zona oxidada nas seqüências (foto 29):

PERFIL 1, pontos $12 \Rightarrow 11 \Rightarrow 10 \Rightarrow 3 \Rightarrow 2 \Rightarrow 6 \Rightarrow 1$, onde ponto 12 = rocha reduzida mais distante da FR tipo 1 atual; ponto 11 = rocha reduzida da interface da FR tipo 1 atual; ponto $10=$ parte da zona ferruginosa limitrofe à interface da FR tipo 1 atual; ponto 3 = rocha oxidada próxima à $2^{\mathrm{a}} \mathrm{FR}$ tipo 1 fóssil; ponto 2 = parte limítrofe profunda da $2^{a}$ zona ferruginosa da FR tipo 1 fóssil, e pontos 6 e 1 = partes limítrofes rasas da $2^{\text {a }}$ zona ferruginosa da FR tipo 1 fóssil (referindo-se as designações raso e profundo ao sentido de progressão descendente da FR),

PERFIL 2, pontos $12 \Rightarrow 9 \Rightarrow 7 \Rightarrow 5 \Rightarrow 4 \Rightarrow 6 \Rightarrow 1$, onde ponto 12 = rocha reduzida mais distante da FR tipo 1 atual; ponto 9 = rocha reduzida da interface da FR tipo 1 atual; 
Tabela 10: Micropentil geoquímico via ICP-MS da frente redox IARF.

\begin{tabular}{|c|c|c|c|c|c|c|c|c|c|}
\hline $\begin{array}{l}\text { Amostra } \\
\text { ppmlTipo }\end{array}$ & $\begin{array}{c}\text { IARF-12 } \\
\text { red } \\
\end{array}$ & $\begin{array}{c}\text { IARF-11 } \\
\text { red } \\
\end{array}$ & $\begin{array}{c}\text { IARF -8 } \\
\text { fr. red } \\
\end{array}$ & $\begin{array}{c}\text { IARF-9 } \\
\text { fr. red } \\
\end{array}$ & $\begin{array}{l}\text { IARF-10 } \\
\text { fr. Ox-Fe } \\
\end{array}$ & $\begin{array}{r}\text { IARF-7 } \\
\text { fr. OX-Fe } \\
\end{array}$ & $\begin{array}{c}\text { IARF-5 } \\
\text { OX } \\
\end{array}$ & $\begin{array}{c}\text { IARF -3 } \\
\text { OX } \\
\end{array}$ & $\begin{array}{l}\text { IARF-4 } \\
\text { OX Fe } \\
\end{array}$ \\
\hline As & 6.59 & 22.02 & 8.82 & 5.45 & 8.62 & 10.00 & 6.83 & 17.50 & 25.83 \\
\hline $\mathrm{Ba}$ & 739.30 & 623.30 & 1461.00 & 562.60 & 450.70 & 879.60 & 499.30 & 474.90 & 372.80 \\
\hline $\mathrm{Be}$ & 5.18 & 5.82 & 15.56 & 4.39 & 3.68 & 12.79 & 5.11 & 5.20 & 7.14 \\
\hline $\mathrm{Bi}$ & 0.06 & 0.06 & 0.03 & 0.05 & 0.06 & 0.00 & 0.02 & 0.03 & 0.03 \\
\hline $\mathrm{Ca}$ & 842.30 & 77.40 & 453.20 & 424.10 & 1525.00 & 302.50 & 58.67 & 176.40 & 712.40 \\
\hline $\mathrm{Cd}$ & 3.18 & 2.02 & 3.38 & 1.40 & 1.80 & 1.83 & 0.72 & 0.66 & 1.16 \\
\hline $\mathrm{Ce}$ & 372.50 & 328.70 & 130.40 & 133.50 & 388.70 & 93.29 & 71.61 & 760.30 & 47.66 \\
\hline Co & 7.85 & 21.12 & 6.03 & 8.67 & 40.39 & 9.51 & 3.45 & 0.15 & 1.52 \\
\hline $\mathrm{Cr}$ & 16.63 & 31.15 & 14.13 & 26.23 & 60.80 & 78.13 & 82.56 & 10.53 & 10.43 \\
\hline $\mathrm{Cs}$ & 0.52 & 0.57 & 0.42 & 0.39 & 0.55 & 0.23 & 0.34 & 0.28 & 0.46 \\
\hline $\mathrm{Cu}$ & 3.35 & 8.71 & 7.97 & 2.93 & 17.21 & 3.10 & 7.26 & 0.56 & 14.26 \\
\hline Dy & 34.36 & 15.37 & 14.06 & 7.74 & 20.65 & 10.03 & 5.06 & 39.93 & 4.87 \\
\hline Er & 25.88 & 9.90 & 10.92 & 4.94 & 12.94 & 7.07 & 3.93 & 15.61 & 3.56 \\
\hline $\mathrm{Eu}$ & 5.30 & 2.75 & 3.08 & 1.55 & 3.60 & 1.96 & 1.12 & 13.37 & 1.01 \\
\hline $\mathrm{Fe}$ & 13230.00 & 33080.00 & 24970.00 & 15080.00 & 42510.00 & 47370.00 & 10980.00 & 27550.00 & 64500.00 \\
\hline $\mathrm{Ga}$ & 44.40 & 51.39 & 101.20 & 39.67 & 25.78 & 78.38 & 33.27 & 32.60 & 49.82 \\
\hline $\mathrm{Gd}$ & 20.21 & 12.04 & 8.03 & 6.92 & 19.93 & 5.76 & 4.32 & 61.76 & 3.22 \\
\hline $\mathrm{Ge}$ & 1.58 & 2.43 & 1.99 & 1.27 & 3.10 & 2.98 & 1.91 & 4.24 & 3.27 \\
\hline $\mathrm{Hf}$ & 12.00 & 9.45 & 24.21 & 5.95 & 0.90 & 16.19 & 8.14 & 5.84 & 7.79 \\
\hline Ho & 8.48 & 3.52 & 3.49 & 1.75 & 4.72 & 2.36 & 1.36 & 6.68 & 1.17 \\
\hline $\mathrm{La}$ & 381.30 & 341.30 & 129.60 & 142.50 & 338.20 & 110.40 & 89.30 & 454.00 & 57.15 \\
\hline $\mathrm{Li}$ & 21.93 & 35.50 & 76.48 & 39.60 & 13.88 & 69.42 & 40.59 & 37.56 & 77.07 \\
\hline Lu & 3.56 & 1.14 & 1.67 & 0.62 & 1.42 & 1.13 & 0.57 & 1.05 & 0.51 \\
\hline $\mathrm{Mg}$ & 147.50 & 199.10 & 399.90 & 174.70 & 140.20 & 257.60 & 138.00 & 112.90 & 301.40 \\
\hline $\mathrm{Mn}$ & 38.45 & 47.69 & 108.30 & 50.89 & 81.46 & 92.26 & 36.68 & 40.31 & 44.53 \\
\hline Mo & 654.00 & 408.00 & 257.60 & 180.70 & 294.20 & 217.80 & 53.31 & 151.00 & 284.70 \\
\hline $\mathrm{Nb}$ & 21.62 & 26.31 & 90.12 & 15.55 & 10.06 & 20.75 & 17.60 & 17.29 & 24.36 \\
\hline Nd & 56.98 & 39.02 & 23.48 & 17.30 & 50.34 & 16.77 & 11.71 & 195.50 & 11.01 \\
\hline $\mathrm{Ni}$ & 2.57 & 9.45 & 1447.00 & 51.63 & 6.98 & 2529.00 & 901.80 & 13.93 & 314.90 \\
\hline $\mathrm{Pb}$ & 46.94 & 41.68 & 30.71 & 28.57 & 37.38 & 16.14 & 17.33 & 26.17 & 33.78 \\
\hline $\mathrm{Pd}$ & 18.95 & 8.04 & 6.87 & 5.57 & 17.79 & 4.90 & 4.65 & 13.13 & 2.41 \\
\hline $\mathrm{Pr}$ & 27.08 & 21.08 & 9.87 & 9.20 & 23.05 & 7.64 & 5.30 & 80.16 & 4.68 \\
\hline $\mathrm{Rb}$ & 226.50 & 215.90 & 358.20 & 178.10 & 150.00 & 228.20 & 192.10 & 179.50 & 189.60 \\
\hline$S$ & 36810.00 & 47850.00 & 61940.00 & 35210.00 & 25360.00 & 15150.00 & 18350.00 & 6814.00 & 5407.00 \\
\hline $\mathrm{Sb}$ & 1.95 & 1.64 & 1.84 & 1.24 & 0.62 & 1.44 & 0.39 & 0.71 & 1.21 \\
\hline Sc & 12.19 & 4.42 & 5.16 & 2.14 & 4.63 & 4.19 & 1.62 & 2.92 & 2.36 \\
\hline Se & 2.94 & 1.56 & 1.00 & 0.86 & 2.71 & 0.75 & 1.77 & 3.04 & 0.71 \\
\hline $\mathrm{Sm}$ & 11.13 & 5.87 & 5.07 & 2.99 & 8.83 & 3.67 & 1.82 & 3.46 & 1.88 \\
\hline $\mathrm{Sr}$ & 1478.00 & 1502.00 & 590.70 & 744.40 & 1592.00 & 507.00 & 482.30 & 423.10 & 319.10 \\
\hline Ta & 0.17 & 0.26 & 0.91 & 0.02 & 0.10 & 0.12 & 0.05 & 0.11 & 2993.00 \\
\hline $\mathrm{Tb}$ & 4.98 & 2.36 & 1.90 & 1.20 & 3.06 & 1.43 & 0.74 & 8.37 & 0.70 \\
\hline Th & 124.40 & 54.42 & 70.64 & 30.50 & 93.34 & 108.10 & 30.73 & 55.26 & 31.13 \\
\hline Ti & 1280.00 & 1826.00 & 4126.00 & 1113.00 & 1558.00 & 1993.00 & 1819.00 & 1549.00 & 2514.00 \\
\hline $\mathrm{Tm}$ & 4.05 & 1.46 & 1.90 & 0.74 & 1.85 & 1.19 & 0.61 & 1.67 & 0.60 \\
\hline U & 256.30 & 155.90 & 283.60 & 146.70 & 563.90 & 323.30 & 91.57 & 199.50 & 265.30 \\
\hline V & 260.90 & 345.90 & 601.50 & 258.60 & 165.40 & 452.60 & 210.30 & 216.20 & 369.30 \\
\hline W & 9.28 & 6.46 & 8.96 & 3.97 & 4.70 & 3.88 & 2.84 & 4.67 & 1.81 \\
\hline$Y$ & 291.60 & 125.30 & 122.10 & 57.05 & 144.80 & 85.22 & 39.38 & 146.30 & 40.29 \\
\hline$Y b$ & 24.43 & 8.44 & 11.30 & 4.20 & 10.31 & 7.49 & 3.83 & 8.43 & 3.33 \\
\hline $\mathrm{Zn}$ & 71.91 & 80.95 & 114.00 & 115.40 & 286.10 & 100.80 & 60.62 & 84.48 & 201.30 \\
\hline $\mathrm{Zr}$ & 1195.00 & 591.30 & 1222.00 & 320.50 & 51.09 & 823.40 & 296.70 & 201.80 & 294.80 \\
\hline
\end{tabular}




\begin{tabular}{|c|c|c|c|}
\hline $\begin{array}{l}\text { Amostra } \\
\text { ppmiTipo }\end{array}$ & $\begin{array}{c}\text { IARF-2 } \\
\text { OX-Fe }\end{array}$ & $\begin{array}{c}\text { IARF-6 } \\
\text { ox-Fe }\end{array}$ & $\begin{array}{c}\text { IARF-1 } \\
\text { OX-Fe } \\
\end{array}$ \\
\hline As & 14.14 & 27.15 & 78.24 \\
\hline $\mathrm{Ba}$ & 517.00 & 427.10 & 567.50 \\
\hline $\mathrm{Be}$ & 4.98 & 1.93 & 3.63 \\
\hline $\mathrm{Bi}$ & 0.04 & 0.04 & 0.11 \\
\hline $\mathrm{Ca}$ & 839.20 & 423.90 & 670.10 \\
\hline $\mathrm{Cd}$ & 1.38 & 2.26 & 2.42 \\
\hline $\mathrm{Ce}$ & 77.80 & 69.16 & 1017.00 \\
\hline Co & 0.60 & 0.37 & 1.06 \\
\hline $\mathrm{Cr}$ & 7.30 & 22.21 & 53.37 \\
\hline Cs & 0.93 & 0.69 & 0.39 \\
\hline $\mathrm{Cu}$ & 4.93 & 0.00 & 9.32 \\
\hline Dy & 4.53 & 10.11 & 54.08 \\
\hline Er & 3.19 & 6.79 & 21.45 \\
\hline Eu & 1.22 & 2.05 & 19.73 \\
\hline $\mathrm{Fe}$ & 77670.00 & 66260.00 & 62580.00 \\
\hline $\mathrm{Ga}$ & 30.77 & 32.52 & 44.83 \\
\hline $\mathrm{Gd}$ & 3.99 & 8.03 & 66.98 \\
\hline $\mathrm{Ge}$ & 3.60 & 3.46 & 7.32 \\
\hline$H f$ & 4.82 & 9.20 & 12.12 \\
\hline Ho & 1.08 & 2.28 & 8.97 \\
\hline La & 88.19 & 80.61 & 714.20 \\
\hline $\mathrm{Li}$ & 22.99 & 58.12 & 45.99 \\
\hline Lu & 0.40 & 0.98 & 1.80 \\
\hline $\mathrm{Mg}$ & 213.80 & 218.40 & 210.90 \\
\hline $\mathrm{Mn}$ & 55.06 & 54.92 & 117.30 \\
\hline Mo & 327.40 & 263.90 & 325.90 \\
\hline $\mathrm{Nb}$ & 21.90 & 16.08 & 17.35 \\
\hline $\mathrm{Nd}$ & 12.71 & 20.49 & 293.60 \\
\hline $\mathrm{Ni}$ & 12.03 & 9.74 & 65.72 \\
\hline $\mathrm{Pb}$ & 35.39 & 33.66 & 52.67 \\
\hline $\mathrm{Pd}$ & 2.44 & 7.39 & 14.63 \\
\hline $\mathrm{Pr}$ & 6.01 & 8.49 & 116.00 \\
\hline $\mathrm{Rb}$ & 197.80 & 162.10 & 203.40 \\
\hline$S$ & 9264.00 & 14060.00 & 5400.00 \\
\hline $\mathrm{Sb}$ & 1.15 & 0.41 & 2.39 \\
\hline Sc & 1.67 & 2.67 & 5.88 \\
\hline $\mathrm{Se}$ & 5397.00 & 0.78 & 4.21 \\
\hline Sm & 2.31 & 4.20 & 48.98 \\
\hline $\mathrm{Sr}$ & 424.60 & 491.10 & 1097.00 \\
\hline $\mathrm{Ta}$ & 0.11 & 0.15 & 0.33 \\
\hline $\mathrm{Tb}$ & 0.73 & 1.59 & 10.88 \\
\hline Th & 33.43 & 36.20 & 130.10 \\
\hline $\mathrm{Ti}$ & 1704.00 & 2072.00 & 1128.00 \\
\hline $\mathrm{Tm}$ & 0.48 & 0.98 & 2.43 \\
\hline$U$ & 133.30 & 196.30 & 520.10 \\
\hline V & 180.30 & 211.60 & 178.50 \\
\hline W & 3.93 & 2.13 & 29.93 \\
\hline$Y$ & 39.33 & 70.34 & 232.70 \\
\hline$Y \mathrm{~b}$ & 2.89 & 6.55 & 12.71 \\
\hline $\mathrm{Zn}$ & 253.90 & 279.00 & 280.80 \\
\hline $\mathrm{Zr}$ & 183.40 & 356.10 & 543.00 \\
\hline
\end{tabular}


$\mathbf{a}$

IARF - perfil 1

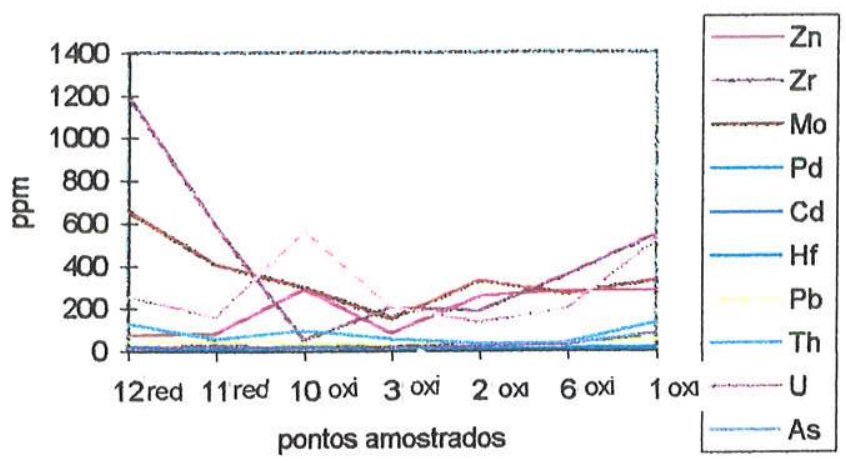

c

IARF - perfil 1

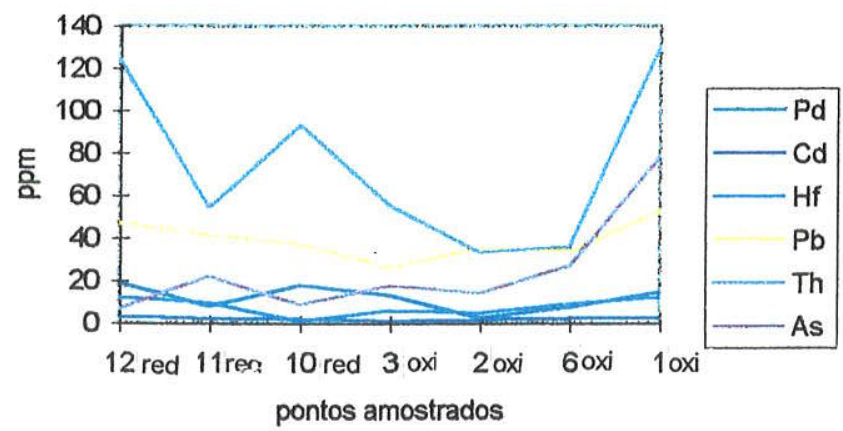

b

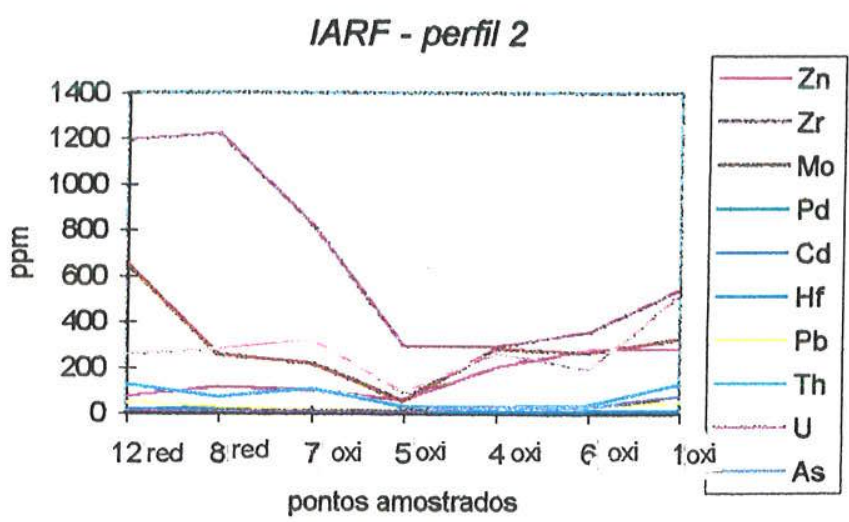

d

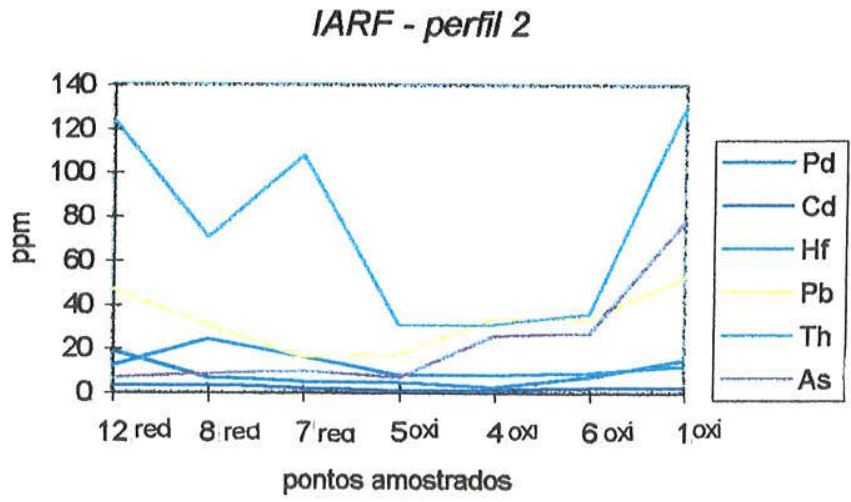

Figura 26: Gráficos binários multielementares dos microperfis da amostra IARF (frente redox complexa). $O$ pontos amostrados estão dispostos eqüidistantemente na abcissa, segundo a seqüência de alteração fda zona reduzida para oxidada) : (a)-perfil 1, (b)-perfil 2, (c)-perfil 1 -detalhe e (d)perfil 2 - detathe. 


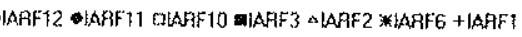

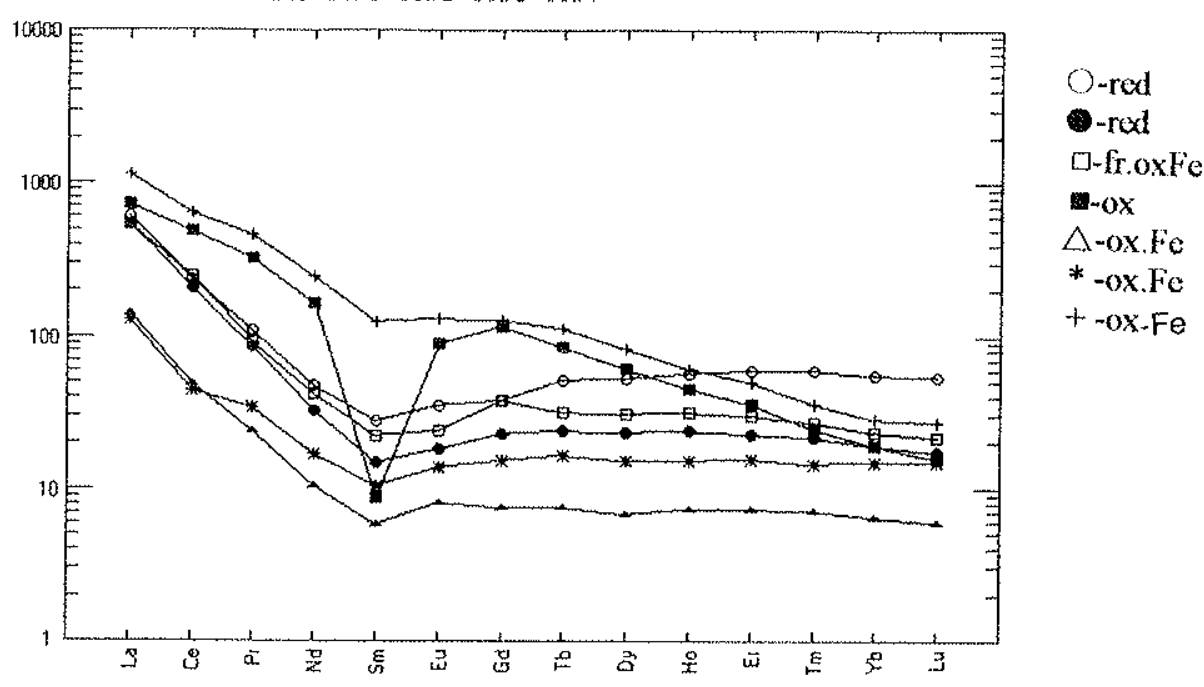

U Th $\quad \mathbf{Z r} \quad \mathrm{Fe}$

$256.30 \quad 124.40 \quad 1195.0013230 .00$

$\begin{array}{llll}155.90 & 54.42 & 591.30 & 33080.00\end{array}$

$\begin{array}{llll}563.90 & 93.34 & 51.09 & 42510.00\end{array}$

$\begin{array}{llll}199.50 & 55.26 & 201.80 & 27550.00\end{array}$

$\begin{array}{llll}133.30 & 33.43 & 183.40 & 77670.00\end{array}$

$\begin{array}{llll}196.30 & 36.20 & 256.10 & 66260.00\end{array}$

$\begin{array}{llll}520.10 & 130.10 & 543.00 & 62580.00\end{array}$

Figura 27: Variograma dos ETR da amostra LARF (perfil 1) da frente complexa, normalizados pelo manto primitivo (PRIM), com os respectivos teores de U, Th, Zre Fe.

OLABF 12 - IARF8 DLARF7 MIARFS AIARFA *IAAF6 XIARF1

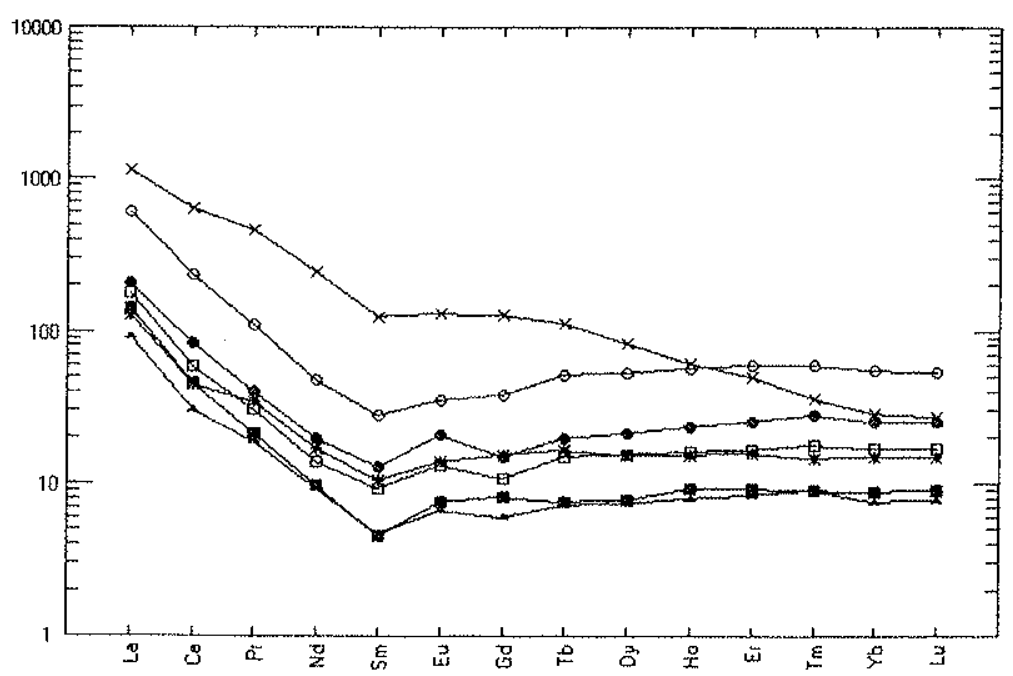

U Th $Z$ r Fe

$\begin{array}{lllll}256.30 & 124.40 & 1195.00 & 13230.00\end{array}$

$\begin{array}{llll}146.70 & 70.64 & 1222.00 & 24970.00\end{array}$

$\begin{array}{llll}323.30 & 108.10 & 823.40 & 47370.00\end{array}$

$\begin{array}{llll}91.57 & 30.73 & 296.70 & 10980.00\end{array}$

$\begin{array}{llll}265.30 & 31.13 & 294.80 & 64500.00\end{array}$

$\begin{array}{llll}196.30 & 36.20 & 256.10 & 66260.00\end{array}$

$\begin{array}{llll}520.10 & 130.10 & 543.00 & 62580.00\end{array}$

Figura 28: Variograma dos ETR da amostra IARF (perfil 2) da frente redox complexa, normalizados pelo manto primitivo (PRIM), com os respectivos teores de $U$, Th, Zre Fe. 
ponto 7 = parte da zona ferruginosa limítrofe à interface da FR tipo 1 atual;

ponto 5 = rocha oxidada próximo à $2^{\mathrm{a}}$ FR tipo 1 fóssil;

ponto 4 = parte limítrofe profunda da $2^{\mathrm{a}}$ zona ferruginosa da FR tipo 1 fóssil, e pontos 6 e 1 = partes limítrofes rasas da $2^{a}$ zona ferruginosa da FR tipo 1 fóssil. Os resultados de elementos traço comuns foram representados em gráficos binários autoexplicativos (Figura 26 a-d) e não serão discutidos aqui em maiores detalhes.

Os perfis normalizados (manto primordial) de ETR referentes aos dois perfis de microamostras são representados nas Figuras 27 e 28. Estes também confirmam em geral os resultados já verificados e discutidos das frentes análogas simples. Uma anomalia negativa muito forte do Sm na microamostra 3 (Figura 28) não foi observada desta forma em toda a população de amostras analisadas e não tem explicação. Trata-se de uma amostra de rocha oxidada normal, diferindo da amostra 1 (de padrão muito similar apenas sem a anomalia de $\mathrm{Sm}$ ) principalmente nos teores de $\mathrm{Fe}, \mathrm{U}$, Th e $\mathrm{Zr}$ muito mais baixos; com as demais amostras oxidadas compara-se bem nos teores de $\mathrm{Fe}, \mathrm{U}$, Th e $\mathrm{Zr}$, entretanto, é drasticamente diferente em todos os demais ETR, exceto o Sm.

\section{CONSIDERAÇões geOQuíMICAS FINAIS dAS FRENTES REDOX}

Os processos associados de FR e mineralização supergênica de $U$ da mina Osamu Utsumi sobrepõem-se aos protolitos alcalinos hidrotermalizados, ou seja, dependem e são diretamente influenciados pelas características mineralógico-geoquímicas do somatório destes estágios evolutivos anteriores. $\mathrm{Os} \mathrm{Ph}, \mathrm{NeS}$ e $\mathrm{Br}$ magmáticos são ricos em álcalis e elementos traço incompatíveis, em particular litófilos, e pobres em $\mathrm{Ca}, \mathrm{Mg}, \mathrm{Fe}$, metais base e elementos traço compativeis. O processo hidrotermal específico da região da mina de $U$ causou, principalmente, remoção do $\mathrm{Na}$ e aporte forte de $\mathrm{K}$, piritização sem aporte de $\mathrm{Fe}$ (apenas de S/HS), e enriquecimentos 
principalmente de $\mathrm{U}, \mathrm{Th}, \mathrm{ETR}, \mathrm{Sc}, \mathrm{Y}, \mathrm{Zr}, \mathrm{F}, \mathrm{Mo}, \mathrm{Zn}$, em proporções variáveis, indicando fluidos heterogêneos, mas consangüíneos. Originaram-se assim, os hidrotermalitos piritizados/reduzidos com mineralizações de teor de protominérios de $U$ ricos em $T h, E T R, Z r, F$, etc., e variáveis em pequena escala na mina e principalmente na escala de amostras de mão.

Os processos de frentes redox proporcionaram, em condições ambientais supergênicas, a dissolução oxidante da pirita, liberação de ácido sulfúrico e ataques variáveis, segundo a sua susceptibilidade específica a todos os minerais presentes nos hidrotermalitos piritizados. Os metais, assim disponibilizados em solução, distribuiram-se de acordo com as suas afinidades específicas entre fases reprecipitadas na zona reduzida da FR, e foram precipitados em fases específicas e/ou coprecipitados nos OHF na zona oxidada da FR, ou, ainda, foram levados embora em solução pelas águas do lençol freático e/ou superficiais.

Os estudos geoquímicos mostraram a baixa atividade dos elementos litófilos nos processos de FR. Na zona reduzida das FR foram enriquecidos por processos de tipo frente rolante, principalmente $\mathrm{U}$ com $\mathrm{Cd}$ (em greenockita) subordinadamente associado e, eventualmente outros elementos chalcófilos presentes em quantidades muito pequenas como $\mathrm{As}, \mathrm{Sb}, \mathrm{Se}$, entre outros, eventualmente incorporados como impurezas numa segunda geração de piritas supergênicas formadas em conjunto com a mineralização supergênica de U nos micronódulos de pitchblenda/uraninita criptocristalina.

Na zona oxidada da FR ocorreram a precipitação eventual de alguns metais pesados como fases próprias supergênicas $(\mathrm{Pb}$ em anglesita, $\mathrm{Ba}$ em barita, Mo em Ilsemannita), e principalmente a coprecipitação, aparentemente pouco específica conforme disponíveis, de virtualmente todos os metais pesados nos OHF, também com variações conforme o tipo de frente redox e os teores de OHF. Ocorreram assim, com bastante freqüência, concentrações altas de metais específicos, mas sem delinear correlações cristaloquímicas sistemáticas e 
regulares. Como caso típico, pode ser citado o Pd, presente em teores de até 40 ppm, sem fontes evidentes.

Os ETR mostraram-se particularmente sensiveis nos processos de frentes redox, embora com variações nem sempre, e em todos os detalhes, explicáveis. As amostras/microperfis dos quatro tipos de frentes redox simples e de uma frente redox complexa, tratadas em diagramas normalizados (manto primordial) de Elementos Terras Raras (Figuras 15, 16, 18, 19, 22, 23, 25, 27 e 28), com o auxílio do programa Newpet (Clarke, 1994) apresentaram:

1) Para os hidrotermalitos reduzidos não enriquecidos em $U$ (com teores de $U \leq$ $50 \mathrm{ppm}$ ), que ocorrem nos pontos analíticos mais afastados das frentes, perfis fortemente fracionados com rápido decréscimo dos ETR leves (ETRL), de La a $\mathrm{Sm}$; evolução plana, sem anomalias de $\mathrm{Eu}$, do Sm ao Gd; e decréscimo suave e contínuo das ETR pesadas (ETRP), do Gd ao Lu.

2-) Para todos os demais pontos dos perfis, quando influenciados por processos supérgenos, sejam em ambiente redutor ou oxidante, aparecem, junto com o fracionamento dos ETRL (La-Sm), efeitos tetrádicos (Masuda et al., 1987; Kawabe et al., 1991; Kawabe, 1992; Hidata et al., 1992; Akagi et al., 1993; McLennan, 1994; Bau, 1996), frequentemente associados ao desenvolvimento de anomalias positivas de Eu, e fortes enriquecimentos dos ETRP, do Gd ao $\mathrm{Lu}$, relacionados com enriquecimento supérgeno (redutor e oxidante) principalmente de $U$ mas também e em proporções variáveis de $\mathrm{Th}, \mathrm{Zr}$, e Feférrico nos OHF. Assim resultam padrões de ETR que embora genericamente similares, apresentam uma variabilidade maior nos detalhes. Essas variabilidades podem ter controles entre si diferentes, herdados desde as origens magmáticas (cf.: Schorscher e Shea, 1992), dos processos hidrotermais (cf.: este trabalho e Waber et al., 1992) ou gerados por detalhes especificos ainda não definidos do próprio enriquecimento supergênico ativo nos processos de frente redox ou do enriquecimento residual.

Num tratamento integrado todos os dados de ETR das FR foram representados em diagramas binários $\mathrm{Y}$ versus $\mathrm{Y} / \mathrm{Ho}$ e $\mathrm{Y} / \mathrm{Ho}$ versus $\mathrm{Zr} / \mathrm{Hf}$, segundo Bau 
(1996), para verificar o seu comportamento cristaloquímico definido por íons simples (controle charac: charge and radius cantrol), típico dos processos hipogênicos de alta temperatura versus tetrádico característico de íons complexos, típico com diversos ligantes aniônicos de sistemas aquosos supergênicos oxidantes e/ou redutores (Figura 29 a-b). Essas representações confirmam o comportamento tetrádico, situando-se uma grande parte dos pontos analíticos fora dos campos charac.

a

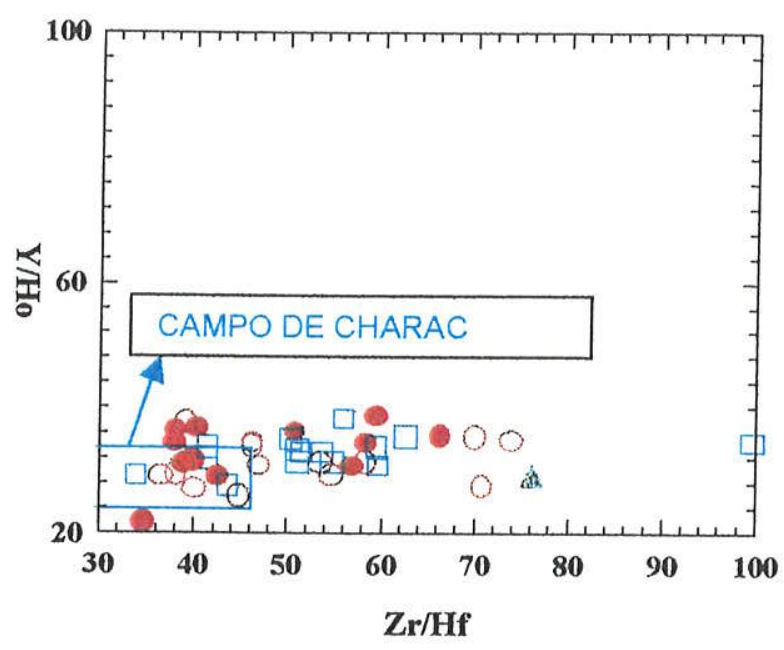

b

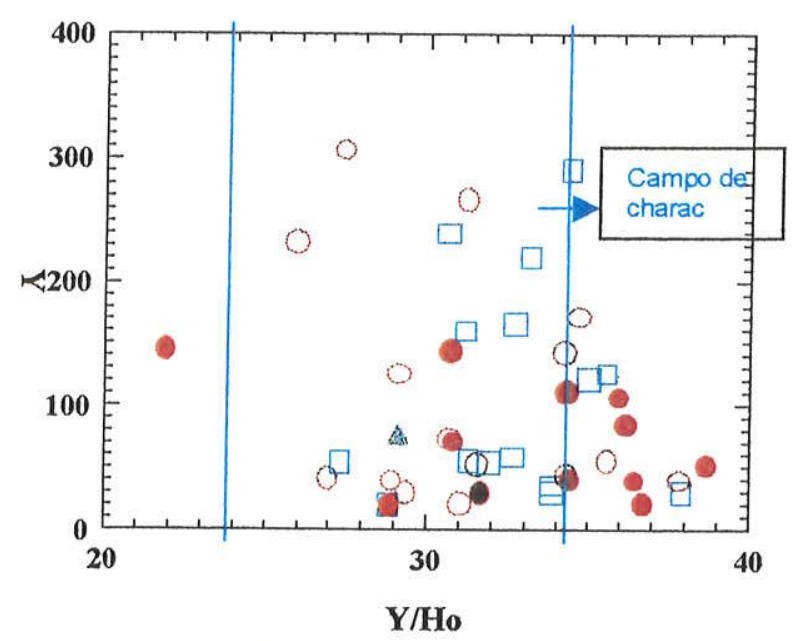

Figura 29: Diagramas binários, segundo Bau (1996), das amostras de frentes

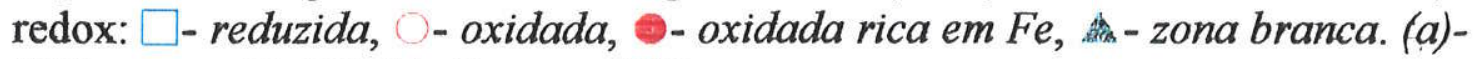
Y/Ho versus $\mathrm{Zr} / \mathrm{Hf}$, (b)- $\mathrm{Y}$ versus $\mathrm{Y} / \mathrm{Ho}$. 


\section{ESTUDOS ISOTÓPICOS DE $\delta^{34} S$}

Estudos de isótopos estáveis representam hoje uma ferramenta muito importante na compreensão de processos de interação fluidos-rochas, uma vez que, são constituintes freqüentemente controladores destes fluidos e seus efeitos geológicos. O seu estudo, em depósitos minerais, permite a caracterização da natureza destes fluidos e de sua participação nos processos petro-metalogenéticos envolvidos.

Neste trabalho são apresentados estudos de isótopos de $\delta^{34} \mathrm{~S}$ de diferentes gerações de piritas $\mathrm{e}$ sulfatos relacionados às mineralizações uraníferas hipógenas hidrotermais e supérgenas da mina Osamu Utsumi, que contribuíram para a melhor compreensão da metalogênese hipo e supergênica do urânio e seu contexto sistemático de migração.

Estudos mineralógicos e petrográficos revelaram diferenças entre as associações de $\mathrm{U}$ e piritas nas mineralizações primárias hidrotermais e supergênicas, que permitiram a caracterização textural e separação física de piritas das diferentes gerações em concentrados puros.

Nas associações hidrotermais de $\mathrm{U}$-piritas nos hidrotermalitos reduzidos (Ph, $\mathrm{NeS}$ e $\mathrm{Br}$ ) foram identificadas duas formas de ocorrência: (1)-de piritas disseminada homogeneamente nas rochas ou em fragmentos das $\mathrm{Br}$ com teores de $U$ (hidrotermal) de protominérios e, (2)-em fraturas nas rochas e nos cimentos e matrizes das $\mathrm{Br}$ com mineralizações de $\mathrm{U}$ fortemente enriquecidas (Foto 7). As piritas hidrotermais são idiomórficas e predominantemente de granulação fina $(<1 \mathrm{~mm})$, entretanto, alguns raros cristais podem atingir 10 a 15 mm. Nas zonas reduzidas, sob influência das frentes redox, as piritas hidrotermais se apresentam arredondadas e corroídas, devido ao início da dissolução/oxidação e conseqüente saída inicial do Fe em soluções sulfatadas. 


\begin{tabular}{|c|c|c|}
\hline Amostra & $8^{34} S x_{0}$ CDT & Caracteristicas texturais e genéticas \\
\hline $1170-1 \mathrm{C}-1$ & +1.24 & Py de fonolito hidrotermalizado muito poroso \\
\hline IF $70-1 \mathrm{C}-2$ & +0.80 & Fdem \\
\hline $1170-1 \mathrm{C}-3$ & +1.04 & Idern \\
\hline $1 \% 1114-1 \mathrm{~A}-1$ & -2.30 & Py de fonolito hidrotermatizado \\
\hline (1) $114-1 \mathrm{~A}-2$ & +0.36 & Idem \\
\hline FI $126-1 \mathrm{~A}$ & -0.86 & Idem \\
\hline $14243-1 \mathrm{~A}$ & +0.27 & Py de mineralização de U hidroternal profunda em matriz de brecha \\
\hline F4 277-1A-1 & -14.77 & Py em fratura (pós-brecha), associada com argilas \\
\hline $14383-1 \mathrm{~A}-1$ & -3.61 & Py em fratura (pós-brecha) \\
\hline F4 $383-1 A-2$ & -4.66 & Py en fratura (pós-brecha), com cotertura escura Mn? \\
\hline F4 386-1A-1 & +3.04 & Py em tratura (pós-brecha) \\
\hline $14386-1 \mathrm{~A}-1.1$ & -2.18 & Idem \\
\hline F4 386-1A-1.2 & -2.38 & Idem \\
\hline $14386-1 A-2$ & +4.60 & Py em fratura (pós-brecha), con cobertura escura Mn? \\
\hline $14386-1 \mathrm{~A}-2.1$ & +0.46 & 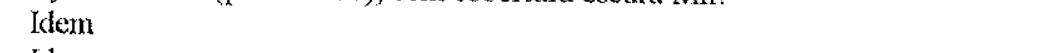 \\
\hline F4 386-1A-3 & -2.29 & Idem \\
\hline $14386-1 \mathrm{~A}-4$ & -1.89 & Py em fratura (pósmbrecha) \\
\hline F4 394-IA-1 & -2.29 & Idem \\
\hline $14394-1 A-2$ & -3.31 & Py em fratura (pós-brecha), com cobertura escura $\mathrm{Mn}$ ? \\
\hline F4 397-1A-1 & -0.57 & By de fragmento de fonolito pouco poroso (pré-brecha) \\
\hline $14397-1 \mathrm{~A}-2$ & -0.68 & Idem \\
\hline $\mathrm{F} 4397-\mathrm{IA-3}$ & -0.83 & Idem \\
\hline I.4 397-1A-4 & -0.74 & Idem \\
\hline $\mathrm{F} 4408-1 \mathrm{~A}-1$ & -1.67 & Py de fragmento muito anguloso de fonolito (pré-brecha) \\
\hline F4 408-1A-2 & -1.55 & Idem \\
\hline F4 414 1B-1 & -1.02 & Py da matriz da brecha (sin-brecha) \\
\hline $\mathrm{F} 44141 \mathrm{~B}-2$ & -1.15 & Idem \\
\hline F44141B-3 & -1.30 & flem \\
\hline F4 $4141 B-4$ & -0.95 & Idem \\
\hline F4 414 1B-5 & $\sim 1.27$ & Idem \\
\hline Fi4 $4141 \mathrm{~B}-6$ & $\sim 1.13$ & KAem \\
\hline U-4A & -0.49 & Py fina, de fonolito com mineralização de Mo e avançada argilização \\
\hline $0-4 B$ & -2.40 & Py média de fonolito com argilização avançada \\
\hline$(\mathrm{U}-4 \mathrm{Y})$ & -2.05 & Py grossa de fonolito com argilização avançada (altos teores de caolinita) \\
\hline $\mathrm{U}-7 \mathrm{E}$ & -0.54 & Py fina de frente redox com mineralização de $U$ \\
\hline$U-7 G$ & -3.63 & ldem \\
\hline OUM 102 & -3.26 & Py de fonolito hidrotermalizado \\
\hline $\mathrm{SN} / 24-1$ & -8.85 & Py, mistura de 2 gerações, de núcleo silicático de nódulo de U maciço \\
\hline $\mathrm{SN} / 24-2$ & -12.20 & Py de zona de pitchblenda de nódulo de U maciço \\
\hline $\mathrm{SN} / 24-3$ & -13.31 & Idem, mais fina \\
\hline $\mathrm{SN} / 244$ & -13.11 & Idem, mais tina \\
\hline $\mathrm{SN} / 24-5$ & -8.13 & Py da cobertura externa silicética de nódulo de U maciço \\
\hline $\mathrm{KU}-3-1$ & -2.20 & Idem \\
\hline$K U-3-2$ & -2.40 & Py da zona de pitchblenta de nódulo de $U$ maciço \\
\hline$K U-6-1$ & -3.14 & Py com leve oxidação da zona de pitchblenda de nódulo de U maciço \\
\hline$K U \sim 6-1.1$ & -12.39 & Py da zona de pitchblenda de nódulo de U maciço \\
\hline $\mathrm{KU}-6-1.2$ & -11.83 & ldem \\
\hline VH 1.1 & -3.78 & Py do núcleo silicático de nódulo de U maciço \\
\hline VIl-1.2 & -3.81 & Idem \\
\hline VIL 2 & -5.16 & Py da zona de pitchblenda de nódulo de U maciço \\
\hline VII -3 & -7.25 & Py da cobertura externa de nódulo de U maciço \\
\hline $04 / 02$ & +0.53 & Sulfatos recentes (placas e agulhas) incolores sobre FR com mineralização de $U$ \\
\hline $\mathrm{M}-1$ & +0.52 & Sulfatos recentes (placas e agulhas) azais sobre FR com mineralização de Mo \\
\hline$U_{-1 A}$ & -2.60 & Sulfatos recentes, massas botrioidais amarelas em cavidades de brechas \\
\hline
\end{tabular}

Tabela 11: Resultados das análises isotópicas de $S$ de piritas (Py) hidrotermais $e$ supergênicas $e$ de sulfatos supergênicos (em $\delta^{34} S$ relativo CDT) $e$ caracterização paragenética e textural Como já discutido nos itens anteriores 4 e 5 , as mineralizações supergênicas de U estão restritas ao desenvolvimento das frentes redox, como disseminações 
muito finas e principalmente micro e macronódulos de pitchblenda/uraninita criptocristalina. Nos micro e macronódulos, o principal mineral de $\mathrm{U}$ é a pitchblenda amorfa ou de baixa cristalinidade, transicionando para uraninita criptocristalina, formando concreções e agregados botrioidais (Fotos 34 e 35). Somente nessas mineralizações formam-se, dentro dos nódulos de pitchblenda, as piritas secundárias supergênicas que são idiomórficas e de granulação mais grossa do que as piritas primárias hidrotermais corroídas (Foto 32).

Cinqüenta e quatro concentrados de piritas hidrotermais e de piritas e sulfatos supergênicos foram separados a partir de amostras de mão (SN/24, VII, 04/02, M1), de testemunhos de sondagens (F1, F4) e nódulos maciços de U (U1, U-4, U-7, OUM, KU-3, KU-6). Os sulfatos recentes (halotrichita e kalinita foram identificados por DRX) formavam abundantes cristais individuais ou ainda massas botrioidais cobrindo planos de fraturas e superfícies expostas. Os concentrados de piritas apresentaram uma pureza bastante elevada, em torno de $95 \%$ a $99 \%$, entretanto, algumas impurezas, eventualmente presentes, eram representadas por minerais silicáticos, que não influenciaram os resultados isotópicos do $\mathrm{S}$.

Os resultados das 54 análises isotópicas realizadas em cooperação internacional pelo Prof. Dr. A. E. Fallick nos laboratórios da Unidade de Pesquisas Isotópicos (Isotope Research Unit) do Scottish Universities Research and Reactor Centre-SURRC, são apresentados na tabela 11, juntamente com algumas observações pertinentes, sobre a tipologia das piritas e das rochas mãe, de onde foram separadas. A representação gráfica no histograma da figura 31 mostra de uma maneira geral, que as piritas hidrotermais relacionadas às mineralizações hipogênicas de $U$ de alta temperatura têm composiçôes isotópicas do $\mathrm{S}$ próximas ao padrão meteorítico, compatíveis com origens de magmas máficos de derivação do manto superior. Seu intervalo composicional corresponde ainda àquele dos sulfetos de depósitos porfiríticos de cobre. 


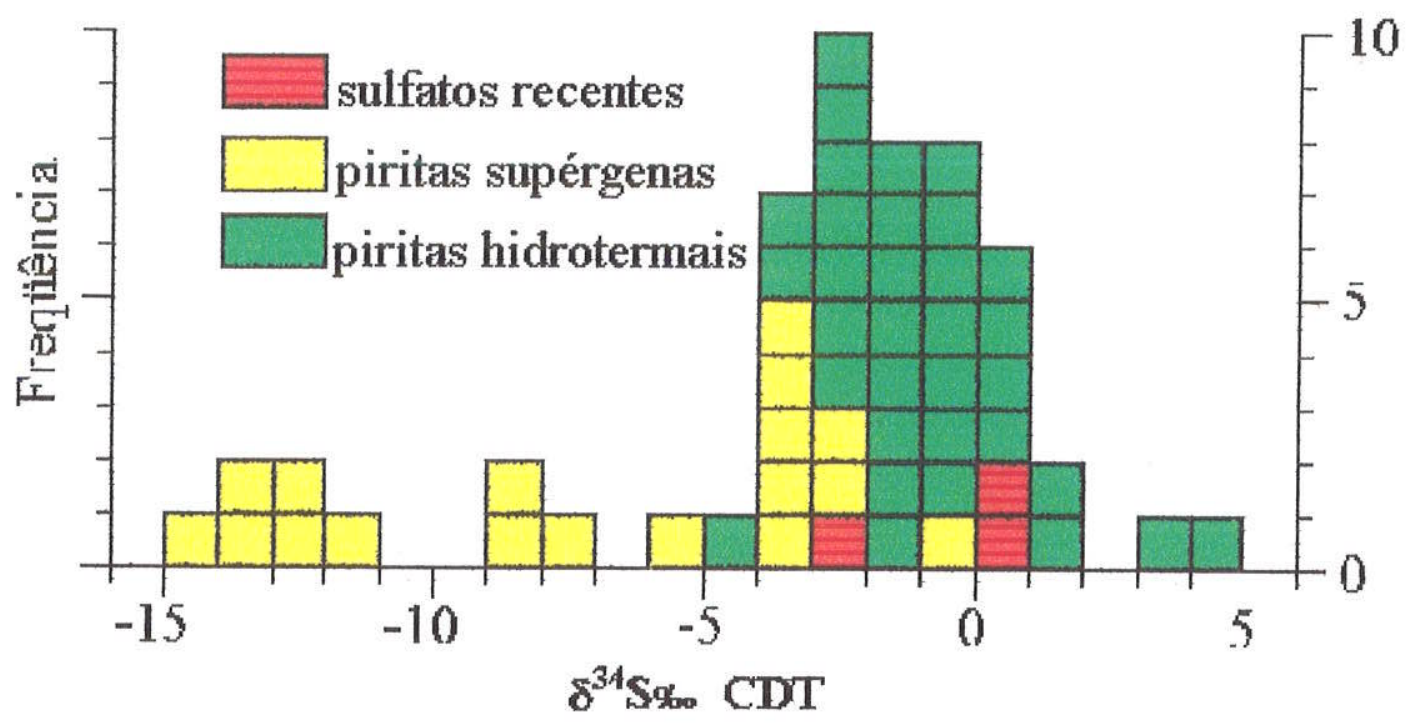

Figura 30 : Histograma dos resultados das análises isotópicas do $S$ de piritas hidrotermais, supergênicas e sulfatos supergênicos em $\delta^{34} \mathrm{~S}$ relativo CDT.

As piritas secundárias dos nódulos supergênicos de $U$, apresentam $S$ de composições isotópicas mais leves, sugerindo, de acordo com as evidências texturais, retrabalhamento biológico durante a redução de sulfatos originados pela dissolução oxidante das piritas hidrotermais. Este processo e a formação das piritas secundárias supergênicas ocorreu exclusivamente no interior durante o crescimento dos nódulos de pitchblenda relacionados aos processos de frentes redox. Dessa forma, as precipitações concrecionárias e nodulares de pitchblenda/uraninita criptocristalina com piritas supergênicas no seu interior, mais provavelmente, representam, como um todo, produtos da atividade biogeoquímica de colônias de bactérias redutoras de sulfatos, coprecipitando no ambiente redutor que geraram inclusive a pitchblenda/uraninita criptocristalina. Estudos de desequilíbrio de U/Th (Schorscher e Omond, 1992), revelaram que as taxas de crescimento dos nódulos de $U$ estariam em torno de $0.02 \mathrm{~mm} / \mathrm{ka}$, podendo ser até 100 vezes mais lentas, quando comparadas às taxas de migração de frentes redox de tipo 4, mais ativas em processos de frentes rolantes (roll fronts). Já a coincidência do intervalo de variação da composição isotópica do $\mathrm{S}$ dos sulfatos supergênicos com a composição das piritas hidrotermais metaestáveis, das quais se formaram, indica que a oxidação das 
piritas foi completa, na presença de oxigênio abundante e que não houve qualquer fracionamento isotópico. 


\section{CONCLUSÕES E DISCUSSÃO FINAL}

A mina de urânio Osama Utsumi foi estudada com métodos geológicos de campo e laboratoriais mineralógicos, petrográficos e geoquímicos globais multielementares e de química mineral, com os objetivos específicos de contribuir à:

- pesquisa fundamental do ciclo do $U$ em sistemas naturais abertos, hidrotermal e supergênico e respectivas reações fluidos-rochas de temperaturas contrastantes, $\mathrm{c}$

- pesquisa aplicada nas áreas de metalogênese do U, mineração e meio ambiente e análogos naturais.

A mineralização de U é poligenética e foi formada por processos superimpostos hipogênico-hidrotermais especificos de altas temperaturas e supergênicos intempéricos sob condições ambientais. Encontra-se hospedada em fonolitos e nefelina sienitos leucocráticos a hololeucocráticos e brechas subvulcânicas destes, na parte SE do Complexo Alcalino de Poços de Caldas, MG, de idade mesozóica.

Os processos hidrotermais mineralizantes ocorreram de forma localizada e causaram a potassificação, argilização e piritização das rochas nefelínicas magmáticas da região da mina, transformando-as em hidrotermalitos reduzidos, junto com sua mineralização pobre em U, Th, Zr, ETR, F, Mo, Zn, Pb, Ba, removendo principalmente $\mathrm{Na}, \mathrm{Ca}, \mathrm{Mg}$ e $\mathrm{Sr}$. A alteração hidrotemal mineralizante transformou os álcali-feldspatos magmáticos (ortoclásios pertíticos, sanidinas) em feldspatos potássicos (triclínicos) puros, as nefelinas em pseudomorfos de illita e caolinita e os clinopiroxênio em misturas de minerais finos, incluindo fases titaniferas semiopacas, argilominerais e pirita. A piritização generalizada, finamente disseminada ocorreu sem aporte de $\mathrm{Fe}$, apenas de $\mathrm{S} / \mathrm{HS}$. 
A mineralização uranífera hidrotermal é complexa e compreendeu um estágio inicial de impregnação disseminada pobre (com teores de anomalia geoquímica) e um estágio de stockwork superimposto, relacionado às explosões magnato-freáticas, que também formaram as brechas subvulcânicas. Composicionalmente é bastante variável, compreendendo, além de fases uranotoríferas, zircão - às vezes intercrescido com baddeleyita de precipitação intergranular/intersticial, monazita e outros minerais de ETR, esfalerita, molibdenita, jordisita e fluorita, entre outros, em proporções e associações variáveis, indicando fluidos heterogêneos. A assinatura geoquímica incluindo os ETR, entretanto, relaciona os processos hidrotermais-mineralizantes uraníferos como pós-magmáticos finais e consangǘneos ao magmatismo nefelínico. A mineralização de tipo impregnação disseminada é, em geral, pobre (anomalia geoquímica); mineralização mais rica ocorre nas matrizes e como cimentos das brechas e em fraturas da mineralização stockwork nos hidrotermalitos reduzidos adjacentes aos corpos de brechas. Nas brechas hidrotermais mineralizadas foram encontradas, com métodos microanalíticos (MEV-EDS e MSE), fases minerais individuais e suas misturas, incluindo sulfetos, óxidos, silicatos e molibdatos com teores de $U$ de até $\sim 40 \%$ de peso. Um mineral de $U$, entretanto não foi definido, embora seja provável a ocorrência de uraninita criptocristalina.

Há cerca de 76 Ma cessaram os processos magmáticos na área da mina, iniciando-se o cíclo supergênico, em andamento até hoje, e responsável pela formação do perfil de intemperismo (Schoscher e Shea, 1992; Shea, 1992; Schorscher e Osmond, 1992). Os agentes desse cíclo, principalmente águas oxidantes descendentes, sob condições ambientais, promoveram a dissolução de pirita e demais sulfetos, liberação de ácido sulfúrico e ataques variáveis e especificos à todas as fases minerais dos hidrotermalitos reduzidos/piritizados pré-existentes, transformando-os em hidrotermalitos oxidados com OHF (isentos de pirita e demais sulfetos). Originaram-se assim, frentes redox típicas, separando os hidrotermalitos reduzidos dos oxidados por interfaces nítidas 
muito bem definidas. As zonas de frentes redox compreendem faixas de 10-20 $\mathrm{cm}$ de largura dos hidrotermalitos reduzidos e oxidados adjacentes às interfaces e são os principais sítios da mineralização supergênica rica de $U$. Cinco tipos de frentes redox simples, além de frentes complexas, foram definidos por critérios geológicos, mineralógicos e geoquímicos, todos com atividade de tipo frentes rolantes. Essa atividade gerou a mineralização supergênica rica de $U$ dissolvendo o $U$ na zona oxidada, redepositando e concentrando-o progressivamente nas zonas reduzidas das frentes redox, finamente disseminado e em micro e macronódulos concrecionários de pitchblenda/uraninita criptocristalina, com estruturas botrioidais. Os macronódulos representam um caso especial de dissolução in situ por colapso contrativo de hidrotermalitos mineralizados, isolados na zona oxidada. Apenas no interior dos nódulos supergênicos de $\mathrm{U}$ ocorrem o sulfeto de $\mathrm{Cd}$ greenockita e uma segunda geração de piritas. As fases mineralógicas características das zonas oxidadas das frentes redox são os OHF formados por processos e principalmente em quantidades muito variáveis, dependendo do tipo de frente redox.

Estudos isotópicos do $\mathrm{S}$ de piritas hidrotermais e de uma segunda geração de piritas, que ocorrem exclusivamente no interior dos nódulos de pitchblenda supergênicos, além de sulfatos supergênicos, foram realizados em 54 concentrados puros obtidos por separação instrumental, com apuração final manual. Os resultados mostraram, para as primeiras, composições isotópicas do $S$ próximas ao padrão meteorítico $\mathrm{CDT}$, indicando origens de magmas máficos do manto superior; diferentemente do $\mathrm{S}$ das piritas incluidas em nódulos supergênicos de $U$, que é isotopicamente mais leve, sugerindo processos biogeoquímicos de fracionamento isotópico por bactérias redutoras de sulfato.

Os estudos geoquímicos multielementares por FRX, ICP-AES e ICP-MS mostraram que os processos de FR e mineralizção supergênica de $U$ dependem e são diretamente influenciados pelas características mineralógico-geoquímicas 
da somatória dos estágios evolutivos anteriores magmático e hidrotermal dos protolitos. Estes, desde o estágio magmático, foram ricos em álcalis e elementos traço incompatíveis, em particular litófilos, e pobres em $\mathrm{Ca}, \mathrm{Mg}, \mathrm{Fe}$, metais base e elementos traço compatíveis. O processo hidrotermal mineralizante uranífero específico da região da mina, acentuou ainda mais essas características (ver acima). Os elementos litófilos mostraram-se, nos processos de $F R$, de muito baixa atividade. Na zona reduzida das FR foram enriquecidos por processos de tipo frente rolante, principalmente $\mathrm{U}$ com $\mathrm{Cd}$ subordinadamente associado e, eventualmente outros elementos chalcófilos presentes em quantidades muito pequenas, como $\mathrm{As}, \mathrm{Sb}, \mathrm{Se}$, entre outros, possivelmente incorporados como impurezas nas piritas formadas em conjunto com a mineralização supergênica de $\mathrm{U}$ em nódulos de pitchblenda/uraninita criptocristalina.

Na zona oxidada da FR ocorreram a precipitação eventual de alguns metais pesados como fases próprias supergênicas ( $\mathrm{Pb}$ em anglesita, $\mathrm{Ba}$ em barita, Mo em Ilsemannita) e, principalmente a coprecipitação nos $\mathrm{OHF}$, aparentemente pouco específica, conforme disponíveis, de virtualmente todos os metais pesados. Variações adicionais foram causadas pelo tipo de frente redox e os teores de OHF. Ocorreram assim, com bastante freqüência, concentrações altas de metais especificos, entretanto, sem delinear correlações cristaloquímicas sistemáticas e regulares. Como caso típico pode ser citado o Pd presente em teores de até $40 \mathrm{ppm}$, sem fontes evidentes.

Os ETR mostraram-se particularmente sensíveis nos processos de frentes redox, embora com variações nem sempre, e em todos os detalhes explicáveis. Os dados dos microperfis de frentes redox (4 simples e 1 complexa), tratados em diagramas normalizados (manto primordial) apresentaram:

1) Para os hidrotermalitos reduzidos não enriquecidos ( $U \leq 50 \mathrm{ppm}$ ) mais afastados das frentes, forte fracionamento dos ETRL de La a Sm; evolução plana, sem anomalias de Eu, do Sm ao Gd; e decréscimo suave e contínuo das 
ETR pesadas (ETRP), do Gd ao Lu, típicos das rochas alcalinas em geral e de Poços de Caldas em particular (Schorscher e Shea, 1992).

2-) Em todas as rochas influenciados por processos redox supérgenos, sejam de ambiente redutor ou oxidante, aparecem, junto com o fracionamento dos ETRL (La-Sm), efeitos tetrádicos frequentemente associados à anomalias positivas de $\mathrm{Eu}$, e fortes enriquecimentos dos ETRP, do Gd ao Lu, relacionados com o enriquecimento supérgeno (redutor e oxidante), principalmente de $U$, mas também e em proporções variáveis de Th, $\mathrm{Zr}$, e Fe-férrico nos OHF.

Sob aspectos de aplicação, destaca-se o comportamento geoquímicosupergênico conservador de rápida reprecipitação e/ou imóvel de U, Th, ETR, $\mathrm{Zr}$ e demais metais pesados, tanto em ambiente redutor quanto oxidante, sendo, no ambiente oxidante, os OHF de baixa cristalinidade as principais fases imobilizantes. 


\section{REFERÊNCIAS BIBLIOGRÁFICAS}

AHMEDALI, S.T. (ed), 1989. X-ray fluorescence analysis in the geological sciences: Advances in methodology. Geol. Assn. Canada: Short course 7.

AHRENS, L.H., 1965. Distribution of the elements in our planet. McGrawHill, 110pp.

AKAGI, T.; SHABANI, M.B. e MASUDA, A., 1993. Lanthanide tetrad effect in kimuraite (CaY2(CO3)4.6H2O): Implication for a new geochemical index. Geochimica et Cosmochimica Acta, 57: 2899-2905.

ALMEIDA, F.F.M. de, 1977. O Cráton do São Francisco. Rev. Bras. Geociênc., 7 (4): 349-364.

ALMEIDA FILHO, R. e PARANDELLA, W.R., 1977. Estudo do Maciço de Poços de Caldas Através de imagens Landsat com ênfase em mineralizações radioativas. INPE, 11/2-TPT/065.

ARAÚJJ, R.L.C., 1980. Pesquisa geotermal na chaminé alcalina de Poços de Caldas. 31 st Cong. Bras. Geol., Camboriú, Anais, 2: 1059-1074.

ATENCIO, D..; COUTINHO, J.M.V.; ULBRICH, M.N.C.; VLACH, S.R.F.; RASTSVETAEVA, R.K. e PUSHCHAROVSKY, D.Y., 1999. Hainite from Poços de Caldas, Minas Gerais, Brazil. Can. Mineral., v.37: 8.

ATENCIO, D.; ULBRICH, M.N.C.; COUTINHO, J.M.V.; MATIOLI, P.A., ULBRICH, H.H.G.J., 1996. Minerais raros do maciço alcalino de Poços de Caldas, Minas Gerais e São Paulo. Cong. Bras. Geol., 39. Anais. Salvador, BA, v.3: 19-21. 
BAU, M., 1996. Controls on the fractionation of isovalent trace elements in magmatic and aqueous systems: evidence from $\mathrm{Y} / \mathrm{Ho}, \mathrm{Zr} / \mathrm{Hf}$, and lanthanide tetrad effect. Contributions to Mineralogy and Petrology, v. 123: 323-333.

BLANCHARD, R., 1968. Interpretation of leached outcrops. Nevada Bureau of Mines, Bull. 66, 196pp.

BRUNO, J.; PABLO, J. de; DURO, L. e FIGUEROLA, E., 1995. Experimental study and modeling of the $\mathrm{U}(\mathrm{VI})-\mathrm{Fe}(\mathrm{OH})_{3}$ surface precipitation/coprecipitation equilibra. Geochimica et Cosmochimica Acta, 59 (20): 4113-4123.

BRUNO, J.; DURO, L.; DE PABLO, J.; CASAS, I.; AYORA, C.; DELGADO, J.;GIMENO, M.J.; PENA, J.; LINKLATER, C.; DEL VILLAR, L.P. e GOMEZ, P., 1998. Estimation of the concentrations of trace metals in natural sysytems - The application of codissolution and coprecipitation approaches to E1 berrocal (Spain) and Poços de Caldas (Brazil). Chemical Geology, v.151:14.

BUSHEE, J., 1971. Potassium-argon ages of some alkaline rocks from southern Brazil. Ph.D. Thesis, University of California at Berkeley, CA, 145pp.

CLARKE, D., 1994. Newpet 1987-1994: programa livre para microcomputador (IBM - PC e compatíveis), para cálculos petroquímicos e representações gráficas. St. John's, Memorial University of Newfoundland, Depatment of Earth Sciences.

COX, K.G.; BELL, J.D. E PANKHURST, R.J., 1979. The interpretation of igneous rock. George Allan \& Unwin. London, 450pp. 
DE PUTTER, T.; CHARLET, J.M. E QUINIF, Y., 1999. Ree, Y and U concentration at the luid-iron oxide interface in late cenozoic cryptodolines from Southern Belgium. Chemical Geology, v. 153: 1-4.

DYCK, W., 1978. The mobility and concentration of uranium and its decay products in temperate surficial environments. In: Uranium Deposits, Their Mineralogy and Origin. Short Course Handbook, vol.3. Univ. Toronto: 57-100.

EDGHILL, R., 1991. Selective phase extraction analyses on four rock samples from the Osamu Utsumi mine site, Poços de Caldas, Brazil. Poços de Caldas Project Technical Report 90-11: 225-247.

ELLERT, R., 1959. Contribuição à geologia do Maciço Alcalino de Poços de Caldas. Bol. Fac. Fil. Ciênc. Letras, Univ. São Paulo (Geologia 18), 237: 5-63.

ELLERT, R.; BJÖRNBERG, A.J.S. e COUTINHO, J.M.V., 1959. Mapa geológico do Maciço Alcalino de Poços de Caldas, Brasil. In: R. Ellert, Contribuição à Gelogia do Maciço de Poços de Caldas. Bol. Fac. Fil. Ciênc. Letras, Univ. São Paulo (Geologia 18), 237: 5-63.

FRAENKEL, M.O.; SANTOS, R.C.; LOUREIRO, F.E.V.L. e MUNIZ, W.S., 1985. Jazida de urânio no Planalto de Poços de Caldas-Minas Gerais. Principais Depósitos Minerais do Brasil, v.1, Recursos Minerais Energéticos, MMe, DNPM e CVRD, Brasília: 89-103.

FRAYHA, R., 1962. DNPM, DFPM, Bol. 116, Rio de Janeiro: 75pp.

GARDA, G.M., 1990. A Alteração hidrotermal no contexto da evolução geológica do Maciço Alcalino de Poços de Caldas, MG-SP. Dissertação de Mestrado. IGc-USP. São Paulo: 213pp. 
GARRELS, R.M. e CHRIST, C.M., 1965. Solutions, minerals and equilibria. Harper \& Row, New York, 450 pp.

GOLDSCHMIDT, V.M., 1954. Geochemistry. Oxford. 562-567.

GOMES, C.B. e DUT'RA, C.V., 1984. Fluorescência de raios X na geologia. Técnicas analíticas aplicadas à geologia. XXXIII Congresso Bras. Geol. : 84120.

GORSKY, V. A. e GORSKY, E., 1974. Contribuição à mineralogia e petrografia do planalto de Poços de Caldas. Comissão Nacional de Energia Nuclear, bol. 13: $91 \mathrm{pp}$.

GUALDA, G. A.R. e VLACH, S.R.F., 1996. Eudialitas-eucolitas do maciço alcalino Poços de Caldas, MG: quimismo e correlações com comportamento óptico. Cong. Bras. Geol., 39. Anais. Salvador, BA, v.3: 34-36.

GUALDA, G.A.R. e VLACH, S.R.F., 1998. Controles na mineralogia acessória de rochas intermediárias a agpaíticas do Taquari - maciço alcalino de Poços de Caldas (MG-SP). Cong. Bras. Geol., 40. Anais. Belo Horizonte, MG, p.460.

HAMZA, V.M., 1982. Terrestrial heat flow in the Alkaline Intrusive Complex of Poços de Caldas, Brazil, Tectonophysics, 83 (1-2): 45-62.

HALL, A.J., BOYCE, A.J. e FALLICK, A.E. (1987); Iron Sulphides in Metasediments: Isotopic Support for a Retrogressive Pyrrhotite to Pyrite Reaction. - Chem. Geol. (Isot. Geosci.) 65: 305-310. 
HIDATA, H.; HOLLIGER, P.; SHIMIZU, H. e MASUDA, A., 1992. Lanthanide tetrad effectobserved in the Oklo and ordinary uraninites and its implication for their forming processes. Geochemical Journal, 26: 337-346.

JANASI, A.; ANDRADE, S.; ULBRICH, H.H.G.J., 1995. A correção do drift instrumental em ICP-AES com espectrômetro sequencial e análise de elementos maiores, menores e traços em rochas. Bol. IGc-Usp, série científica, v. 26: 4548.

KAWABE, I.; KITAHARA, Y. e NAITO, K., 1991. Non-chondritic yttrium/holmium ratio nad lanthanide tetrad effect observed in pre-Cenozoic limestones. Geochemical Journal, 25: 31-44.

KAWABE, I., 1992. Lanthnide tetrad effect in the Ln3+ ionic radii and refined spin-pairing energy theory. Geochemical Journal, 26: 309-315.

KAWASHITA, K.; MAHIQUES, M.M. e ULBRICH, H.H.G.J., 1984. Idades $\mathrm{Rb} / \mathrm{Sr}$ de Nefelina-sienitos do Anel Norte do Maciço Alcalino de Poços de Caldas, MG-SP. In: $33^{\circ}$ Congr. Bras. Geol., Rio de janeiro, Resumos: 345-415.

LE MAITRE, R.W., 1989. A Classification of Igneous Rocks and Glossary of Therms: Recommendations of the IUGS Subcommission on the Systhematics of Igneous Rocks. Osford, Blackwell. 193pp.

MacKENZIE, A.B.; SCOTT, R.D.; LINSALATA, P.; MIEKELEY, N.; OSMOND, J.K. e CURTIS, D.B., 1991. Natural radionuclide and stable element studies os rock samples from Osamu Utsumi mine and Morro do Ferro analogue study sites, Poços de Caldas, Brazil. Poços de Caldas Report, no. 7 , $185 \mathrm{pp}$. 
MANIAR, P.S. \& PICCOLI, P.M., 1989. Tectonic Discrimination of Granitoids. Geological Society American Bulletin, 101: 635-643.

MARTIN, R.M.; DREXEL, V.; JAHSCH, H. e WEIMER, E., 1995. Neuartiges Raster - Elektronenmikroskop setzt akzente in materialwissnschaft und biologie -- DSM 982 GEMINI. Zeiss Information mit Jenaer Rundschau 4, n.5: 14-16.

MASUDA, A.; KAWAKAMI, O.; DOHMOTO, Y. e TAKENAKA, Y., 1987. Lanthanide tetrad effect in nature: two mutually opposite types, $W$ and $M$. Geochemical Journal, 21: 119-124.

McLENNAN, S. M., 1994. Rare earth element geochemistry and the "tetrad" effect. Geochimica et Cosmochimica Acta, 58 (9): 2025-2033.

MONTES-LAUAR, C.R., 1988. Estudo paleomagnético dos maciços alcalinos de Poços de Caldas, Passa Quatro e Itatiaia. M. Sc. Thesis, Inst. Astron. e Geofis., Univ. São Paulo, 101pp.

NORDSTROM, D.K., McNUTT, R.H., PUIGDOMÈNECH, I., SMELLIE, J.A.T., WOLF, M., 1992: Ground water chemistry and geochemical modeling of water-rock interactions at the Osamu Utsumi mine and the Morro do Ferro analogue study sites, Poços de Caldas, Minas Gerais, Brazil. -- J. Geochem. Exploration, 45:249-287.

ROBINSON, B.W. e KUSAKBE, M., 1975. Quantitative Preparation of $\mathrm{SO}_{2}$ for ${ }^{34} \mathrm{~S} / 32 \mathrm{~S}$ Analyses from Sulphides by Combustion with Cuprous Oxide. - Anal. Chem. 47:1179-1181.

ROGERS, J.J.W. e ADAMS, J.A.S., 1974. Uranium. In: Handbook of geochemistry. vol.II-4, cap.92-B-O, Springer-Verlag, Berlin. 
SCHORSCHER, J.H.D., 1991. Mineral chemistry studies of rochs from Osmu Utsumi uranium mine, Poços de Caldas, Brazil. Poços de Caldas Report n². SKB Technical Report 90-11: 253-267.

SCHORSCHER, J.H.D.; GARDA, G.M.; SHEA, M.; WABER, M., 1991. Lamprophyre dykes from Osamu Utsumi uranium mine, Poços de Caldas $(\mathrm{MG})$, Brazil. Intem. Symp. Mafic Dykes (3 Congr. Bras. Geoq.; $1^{\circ}$ Cong. Geoq. Plot), São Paulo, Ed. IGc-USP. Ext. Abstr.: 116-124.

SCHORSCHER, J.H.D.; CAPOVILLA, M.M.G.M.; FALLICK, A ., 1997. $\delta^{34} \mathrm{~S}$ studies of pyrites generations related to uranium mineralization at Osamu Utsumi mine, Poços de Caldas Alkaline Complex, Brazil. South-American Symposium on Isotope Geology, Extended Abstracts: 289-290.

SCHORSCHER, J.H.D.; MONTEIRO, M.M.G.; AGUILAR, A .P.; GARDA, G.M.; BOHLAND NETO, F.; SCHULZ-DODRICK, B., 1992. Contribuição ao conhecimento da ginnettita do Complexo Alcalino de Poços de Caldas, MG. Boletim IGc-USP, 12: 105-107.

SCHORSCHER, J.H.D., MONTEIRO, M.M.G. e FALLICK, A.E., 1991. Mineralogical, geochemical and sulphur isotope studies of selected pyrite samples and pyrite generations from the Osamu Utsumi Mine Site, Poços de Caldas, Brazil. In: The Poços de Caldas Project: Natural Analogues of Processes in a Radiactive Waste Repository. SKB, Swedish Nuclear Fuel and Waste Management CO, Technical Report, 90-11: 177-247.

SCHORSCHER, J.H.D. e OSMOND, J.K., 1992. Origin and growth of pitchblende nodules at Osamu Utsumi Mine, Poços de Caldas, Brazil. In: N.A. Chapman, I.G. Mckinley, M.E. Shea and J.A.T. Smallie (Editors), The Poços 
de Caldas Project: Natural Analogues of Processes in a Radioctive Waste Repository. Journal of Geochem. Explor, 45: 159-171.

SCHORSCHER, J.H.D. e SHEA, M.E., 1992. The regional geology of the Poços de Caldas Alkaline Complex: Mineralogy and geochemistry of selected nepheline-syenites and phonolites. In: N.A. Chapman, I.G. Mckinley, M.E. Shea and J.A.T. Smallie (Editors), The Poços de Caldas Project: Natural Analogues of Processes in a Radioctive Waste Repository. Journal of Geochem. Explor., 45: 25-51.

SCHUMANN, A .S., 1994. Chemische verwitterung auf alkaligesteinen und hinweise auf hydrothermale einwirkungen seit dem ausgehenden mesozoikum, Poços de Caldas, Minas Gerais, Brasilien. Dissertation zur Erlangung des doktorgrades. Universität Hamburg, 190pp.

SHAND, S. J., 1943. The Erruptive Rocks. $-2^{\text {nd }}$ ed., Wiley, New York.

SHEA, M.E, 1992. Isotopic geochemical characterization of selected nepheline syenites and phonolites from the Poços de Caldas Alkaline Complex, Minas Gerais, Brazil. Journal of Geochem. Explor., 45: 173-214.

SPARK, K.M.; JOHSON, B.B. e WILLS, J.D., 1995. Characterizing heavymetal adsorption on oxides and oxyhydroxides. European Journal of Soil Science, 16: 621-631.

TAYLOR, G.H., 1979. Biogeochemical cycling of mineral-forming elements. Studies in Environmental Science 3, vol.3. Elsevier Scient.Publ.Co., NY: 485514.

TAYLOR , S.R. e McLENNAN, S.M., 1985. The continental crust: its composition and evolution. Blackwell ed. Oxford. 312pp. 
TERTIAN, R. e ClAISSE, F., 1982. Principles of quantitative X-ray fluorescence analysis. Wiley-Heyden, New York.

TOLBERT, G.E., 1966. The uraniferous zirconium deposits of Poços de Caldas plateau, Brazil. Part II. Eng. Min. Metal., 27 (162): 353-360.

ULBRICH, M.N.C., 1983. Aspectos mineralógicos e petrológicos de nefelina sienitos de Poços de Caldas, MG-SP. Tese de doutorado. Igc-USP. 369pp.

ULBRICH, H.H.G.J., 1984. A petrografia, a estrutura e o quimismo de nefelina-sienitos do Maciço Alcalino de Poços de Caldas, MG-SP. Tese de Livre-Docência, Inst. Geociên., Univ. São Paulo, São Paulo, 2v, 375pp.

ULBRICH, H.H.G.J e GOMES, C.B., 1981. Alkaline rocks from continental Brazil. Earth Sci. Ver. 17: 135-154.

ULBRICH, M.N.C.; GOMES, C.B. e ULBRICH, H.H.G.J., 1984. Nefelina sienitos do Maciço de Poços de Caldas, MG-SP: Caracterização Mineralógica e Petrológica. $33^{\circ}$ Congresso Bras. Geol. Rio de Janeiro, Anais, 9: 4362-4376.

VEIGA, M.M.; SCHORSCHER, J.H.D. e FYFE, W.S., 1991. Relationship of cooper with hydrous ferric oxides: Salobro, Carajás, PA, Brazil. In: Ore geology reviews, 6: 245-255.

WABER, N., 1990. Hydrothermal and supergene uranium evolution of the Osamu Utsumi Uranium Deposit and the Morro do Ferro Thorium-rare earth deposit (Minas Gerais, Brazil). PhD Thesis, Universitaet Bern. 233pp.

WABER, N.; SCHORSCHER, J.H.D. e PETERS, T. , 1991. Mineralogy, petrology and geochemistry of Poços de Caldas analoguee study sitres, Minas 
Gerais, Brazil. I. Osamu Utsumi Mine. Poços de Caldas Report n². SKB Technical Report 90m11: 1-163.

WABER, N.; SCHORSCHER, J.H.D. E PETERS, T. , 1992. Hydrothermal and supergene uranium mineralization at Osamu Utsumi Mine, Poços de Caldas, Minas Gerais, Brazil. In: N.A. Chapman, I.G. Mckinley, M.E. Shea and J.A.T. Smallie (Editors), The Poços de Caldas Project: Natural Analogues of Processes in a Radioctive Waste Repository. Journal of Geochem. Explor., 45: 53-112.

WAITE, T.D.; DAVIS, J.A.; PAYNE, T.E.; WAYCHUNAS, G.A. e XU, N., 1994. Uranium (VI) adsorption to ferrihydrite: Application of surface complexation model. Geoch. Cosmochimica Acta, v.58, 24: 5465-5478.

WILLIAMS, K.L., 1987. Introduction to X-ray spectrometry. Allen e Unwin, London.

WINCHESTER, J.A. e FLOYD, P.A., 1977. Geochemical Discrimination of Different Magma Series and their Differentiation Products Using Immobile Elements. Chemical Geology, 20: 325-343.

WITTAKER, E.J.W. E MUNTS, R., 1970. Ionic radii for use in geochemistry. Geochim. Cosmochim. Acta 34: 945-956. 
ANEXO I 
TABELA I.1 - Análises por FRX (IGc-USP) de Fonolitos da borda NW da Mina de Uránio: (ph-mi) - não a fracamente hidrotermalizados e composição Média, e (ph-mi alt) - variavel a fortemente alterados. L.D. e L.Q. - Limites de Deteç̧ão e Quantificação; ' - carbonatizaçăo fraca; ${ }^{2}$ - carbonatizaçăo forte e piritização; ${ }^{3}$ - carbonatização, fluoritização e piritizaçăo fortes; ${ }^{11}$ - sericitizaçăo forte; ${ }^{12}$ - argilizaçăo intemperica.

Amostras A1HT A4B A5 A10BH A10BT Média A1HH A1M ${ }^{2}$ A1S ${ }^{3} \quad A 6^{11} \quad A 11 N^{12}$ Rocha ph-mi ph-mi ph-mi ph-mi ph-mi ph-mi ph-mi-alt ph-mi-alt ph-mi-alt ph-mi-alt ph-mi-alt $\%$-peso

\begin{tabular}{|c|c|c|c|c|c|c|c|c|c|c|c|}
\hline$\overline{\mathrm{SiO} 2}$ & 52.52 & 54.08 & 53.26 & 53.75 & 54.94 & 53.71 & 53.37 & 50.43 & 38.84 & 58.43 & 53.71 \\
\hline $\mathrm{THO} 2$ & 0.47 & 0.42 & 0.38 & 0.40 & 0.40 & 0.41 & 0.38 & 0.39 & 0.35 & 0.42 & 0.40 \\
\hline $\mathrm{Al} 2 \mathrm{O} 3$ & 19.01 & 20.45 & 18.71 & 19.54 & 19.90 & 19.22 & 19.85 & 17.87 & 12.26 & 24.03 & 20.71 \\
\hline $\mathrm{Fe} 2 \mathrm{O} 3$ & 3.86 & 4.37 & 4.31 & 5.25 & 5.34 & 4.63 & 4.54 & 5.23 & 6.70 & 1.25 & 3.32 \\
\hline Mno & 0.38 & 0.30 & 0.31 & 0.65 & 0.62 & 0.45 & 0.48 & 1.01 & 2.26 & 0.02 & 0.07 \\
\hline $\mathrm{MgO}$ & 0.11 & 0.09 & 0.13 & 0.13 & 0.16 & 0.12 & 0.10 & 0.22 & 0.60 & 0.11 & 0.19 \\
\hline $\mathrm{CaO}$ & 4.42 & 1.16 & 1.32 & 1.88 & 1.60 & 2.08 & 1.95 & 5.15 & 19.20 & 0.02 & 0.23 \\
\hline $\mathrm{Na} 2 \mathrm{O}$ & 6.95 & 7.09 & 7.22 & 4.21 & 4.57 & 6.01 & 4.48 & 3.99 & 2.81 & 0.27 & 2.12 \\
\hline $\mathrm{K} 2 \mathrm{O}$ & 9.11 & 7.83 & 8.50 & 8.44 & 8.43 & 8.46 & 9.49 & 7.72 & 4.12 & 13.92 & 8.47 \\
\hline P2O5 & 0.05 & 0.01 & 0.00 & 0.01 & 0.01 & 0.02 & 0.02 & 0.07 & 0.24 & 0.05 & 0.01 \\
\hline LOI/PF & 2.66 & 3.33 & 1.72 & 3.75 & 3.67 & 3.03 & 1.67 & 4.28 & 9.29 & 2.15 & 4.02 \\
\hline total & 99.54 & 99.12. & 95.86 & 98.01 & 99.64 & 98.43 & 96.33 & 96.35 & 96.67 & 100.67 & 93.25 \\
\hline $\mathrm{H} 2 \mathrm{O}-$ & 0.38 & 0.66 & 0.10 & 0.65 & 0.61 & 0.48 & 0.14 & 0.62 & 1.21 & 0.41 & 1.49 \\
\hline \multicolumn{12}{|l|}{$\mathrm{ppm}$} \\
\hline $\mathrm{Ba}$ & 619 & 97 & 77 & 631 & 534 & 392 & 788 & 828 & 1183 & 741 & 678 \\
\hline \multicolumn{12}{|l|}{$\mathrm{Be}$} \\
\hline $\mathrm{Ce}$ & 982 & 303 & 129 & 422 & 360 & 439 & 404 & 1419 & 7888 & 380 & 3169 \\
\hline $\mathrm{Cl}$ & 994 & 1392 & 1115 & 51 & 0 & 710 & 419 & $\angle L D$ & $<\mathrm{LD}$ & $<\mathrm{LD}$ & $<L D$ \\
\hline Co & 2 & 2 & 5 & 3 & 3 & 3 & 3 & 3 & 1 & 2 & 3 \\
\hline $\mathrm{Cr}$ & $< \pm D$ & $<I D$ & $<L D$ & $<L D$ & $\angle L D$ & $\angle L D$ & $<L D$ & $\angle L D$ & $\angle L D$ & $<\mathrm{LD}$ & $<L D$ \\
\hline \multicolumn{12}{|l|}{ Cs } \\
\hline $\mathrm{Cu}$ & 11 & 17 & 6 & 16 & 20 & 14 & 23 & 19 & 41 & 12 & 2 \\
\hline $\mathrm{F}$ & 12035 & 3254 & 8645 & 3611 & 2750 & 6059 & 2301 & 9180 & 60656 & 1121 & 3699 \\
\hline $\mathrm{Ga}$ & 40 & 52 & 57 & 55 & 53 & 51 & 43 & 56 & 44 & 45 & 54 \\
\hline \multicolumn{12}{|l|}{$\mathrm{Hf}$} \\
\hline La & 809 & 350 & 109 & 427 & 349 & 409 & 375 & 1276 & 5067 & 405 & 12920 \\
\hline $\mathrm{Nb}$ & 230 & 260 & 236 & 258 & 254 & 248 & 231 & 254 & 213 & 211 & 241 \\
\hline $\mathrm{Nd}$ & 197 & 83 & 36 & 73 & 43 & 86 & 65 & 220 & 1021 & 123 & 2697 \\
\hline $\mathrm{Ni}$ & 5 & 0 & 6 & 0 & 4 & 3 & $<\mathrm{LD}$ & 6 & 6 & 4 & 9 \\
\hline $\mathrm{Pb}$ & 55 & 57 & 51 & 64 & 60 & 57 & 46 & 77 & 219 & 44 & 68 \\
\hline $\mathrm{Rb}$ & 185 & 125 & 137 & 510 & 588 & 309 & 311 & 323 & 291. & 298 & 142 \\
\hline$s$ & 466 & 461. & 202 & 367 & 401 & 379 & 772 & 478 & 2050 & $<L D$ & $<\mathrm{WD}$ \\
\hline $\mathrm{Sc}$ & 12 & 7 & 6 & 9 & 7 & 8 & 6 & 14 & 43 & 4 & 17 \\
\hline \multicolumn{12}{|l|}{ Sn } \\
\hline $\mathrm{Sr}$ & 5375 & 1032 & 1147 & 1495 & 1103 & 2030 & 2142 & 4374 & 11670 & 541 & 462 \\
\hline \multicolumn{12}{|l|}{$\mathrm{Ta}$} \\
\hline Th & 102 & 83 & 43 & 90 & 90 & 82 & 68 & 163 & 254 & 70 & 25 \\
\hline U & 0 & 36 & 39 & 41 & 34 & 30 & 22 & 32 & 14 & 17 & 69 \\
\hline V & 86 & 60 & 62 & 62 & 64 & 67 & 86 & 78 & 94 & 117 & 56 \\
\hline \multicolumn{12}{|l|}{ W } \\
\hline Y & 109 & 73 & 65 & 90 & 76 & 83 & 82. & 159 & 566 & 90 & 1717 \\
\hline $\mathrm{Zn}$ & 175 & 199 & 222 & 368 & 325 & 258 & 183 & 286 & 508 & 32 & 203 \\
\hline $\mathrm{Zr}$ & 425 & 1695 & 1.803 & 1781 & 1668 & 1474 & 940 & 1476 & 415 & 925 & 1775 \\
\hline
\end{tabular}


TABELA I.1 - Continuaçåo.

Amostras L.D. L.Q.

Rocha

$\%$-peso

\begin{tabular}{lrr}
\hline $\mathrm{SiO} 2$ & $<0,005$ & 0.01 \\
$\mathrm{TiO} 2$ & 0.001 & 0.003 \\
$\mathrm{Al2O} 3$ & $<0,005$ & 0.01 \\
$\mathrm{Fe} 2 \mathrm{O} 3$ & $<0,005$ & 0.01 \\
$\mathrm{MnO}$ & $<0,005$ & 0.002 \\
$\mathrm{MgO}$ & $<0,005$ & 0.01 \\
$\mathrm{CaO}$ & $<0,005$ & 0.01 \\
$\mathrm{Na2O}$ & $<0,005$ & 0.01 \\
$\mathrm{~K} 2 \mathrm{O}$ & $<0,001$ & 0.005 \\
$\mathrm{P} 2 \mathrm{O} 5$ & 0.001 & 0.002 \\
LOI/PF & & 0.1 \\
total & & \\
$\mathrm{H} 2 \mathrm{O}-$ & & 0.1
\end{tabular}

ppm

As

$\begin{array}{lll}\mathrm{Ba} & 8 & 26\end{array}$

$\mathrm{Be}$

$\mathrm{Ce} \quad 10 \quad 33$

Cl 311

Co 113

$\mathrm{Cr} \quad 2 \quad 6$

Cs

$\mathrm{Cu} \quad 2 \quad 6$

$\begin{array}{lll}F & 47 & 157\end{array}$

$\mathrm{Ga} \quad 2 \quad 5$

$\mathrm{Hf}$

La $\quad 7 \quad 22$

$\mathrm{Nb} \quad 1 \quad 3$

Nd 1.4

$\mathrm{Ni} \quad 3 \quad 21$

$\begin{array}{lll}\mathrm{Pb} & 3 & 10\end{array}$

$\mathrm{Rb} \quad<0,3 \quad 1$

$S \quad 20 \quad 60$

Sc 2

$\mathrm{Sn} \quad 1$

$\mathrm{Ta}$

$\begin{array}{lrr}T h & 3 & 10 \\ U & 2 & 8\end{array}$

$\begin{array}{lll}V & 2 & 8\end{array}$

W

$\begin{array}{lll}Y & 1 & 3\end{array}$

$\begin{array}{lll}\text { Zn } & 2 & 7\end{array}$

$\begin{array}{lll}Z r & 1 & 4\end{array}$ 
TABELA I.2 - Análises por FRX de Fonolitos da borda NW da Mina de Uránio: (ph-mi) - não a fracamente hidrotermalizados e composiçăo Média, e (ph-mi-alt) - variável a fortemente alterados, analisados no Laboratorio de FRX do Instituto de Mineralogia Aplicada e Geoquímica da T.U. Munique, Alemanha. L.D. - Limites de Deteç̧ăo; ${ }^{1}$ - carbonatização fraca; ${ }^{2}$ - carbonatação forte e piritização; ${ }^{3}$ - carbonatação, fluoritização e piritização fortes; ${ }^{11}$ - sericitização forte; ${ }^{12}$ - argilização intempérica.

\begin{tabular}{|c|c|c|c|c|c|c|c|c|c|c|}
\hline $\begin{array}{c}\text { Amostra } \\
\text { Rocha } \\
\% \text {-peso } \\
\end{array}$ & $\begin{array}{l}\text { A1HT } \\
\text { ph-mi }\end{array}$ & $\begin{array}{c}\text { A4B } \\
\text { ph-mi }\end{array}$ & $\begin{array}{c}\text { A5 } \\
\text { ph-mi }\end{array}$ & $\begin{array}{c}\text { A10BH } \\
\text { ph-mi }\end{array}$ & $\begin{array}{l}\mathrm{A} 10 \mathrm{BT} \\
\mathrm{ph}-\mathrm{mi}\end{array}$ & $\begin{array}{l}\text { Média } \\
\text { ph-mi }\end{array}$ & $\begin{array}{l}\mathrm{A} 1 \mathrm{HH}^{1} \\
\text { ph-mi-alt } \mathrm{p}\end{array}$ & $\begin{array}{c}A 1 M^{2} \\
\text { oh-mi-alt }\end{array}$ & $\begin{array}{c}\mathrm{A}^{1 \mathrm{~S}^{3}} \\
\text { ph-mi-alt }\end{array}$ & $\begin{array}{c}\text { A6 } \\
\text { ph-mi-al }\end{array}$ \\
\hline $\mathrm{SiO} 2$ & 53.30 & 53.40 & 52.70 & 54.57 & 54.92 & 53.78 & 49.50 & 50.10 & 31.50 & 58.35 \\
\hline.$T 1 \Omega ?$ & $\Omega 38$ & $\Omega A ?$ & $\Omega, 39$ & $\Omega, 37$ & $\Omega .37$ & $\Omega .39$ & $\Omega A^{\circ}$ & $\Omega A \Omega$ & $\Omega .34$ & $\Omega A \Omega$ \\
\hline $412 \Omega 2$ & $3 \Omega 7 ?_{2}$ & 2n?2 & $2 \Omega ? a$ & $2 \Omega \Omega A_{4}$ & $2 \Omega 11^{4}$ & $2 \Omega 4 \Omega$ & 19.95 & tRRAst & $1 A_{-}, A_{r}$ & $32 ? 2$ \\
\hline $\mathrm{Fe} 2 \mathrm{O} 3$ & 4.23 & 4.02 & 4.09 & 4.74 & 4.78 & 4.37 & 3.65 & 5.01 & 6.90 & 1.09 \\
\hline $\mathrm{MnO}$ & 0.49 & 0.31 & 0.33 & 0.63 & 0.61 & 0.47 & 0.41 & 1.03 & 2.29 & 0.01 \\
\hline $\mathrm{MgO}$ & 0.16 & 0.14 & 0.12 & 0.17 & 0.19 & 0.16 & 0.16 & 0.29 & 0.66 & 0.07 \\
\hline $\mathrm{CaO}$ & 2.08 & 1.34 & 1.49 & 1.81 & 1.54 & 1.65 & 4.51 & 5.15 & 16.20 & 0.20 \\
\hline $\mathrm{Na2O}$ & 5.22 & 7.94 & 8.35 & 4.89 & 4.93 & 6.27 & 7.57 & 4.71 & 3.50 & 0.30 \\
\hline $\mathrm{K} 2 \mathrm{O}$ & 10.01 & 8.25 & 9.06 & 7.93 & 7.92 & 8.63 & 9.64 & 8.00 & 4.14 & 13.58 \\
\hline P2O5 & 0.00 & 0.00 & 0.00 & 0.00 & 0.00 & 0.00 & 0.00 & 0.01 & 0.22 & 0.00 \\
\hline LOI/PF & 2.90 & 4.00 & 2.30 & 4.40 & 4.20 & 3.56 & 2.50 & 5.20 & 9.10 & 2.60 \\
\hline $\begin{array}{l}\text { total } \\
\mathrm{H} 2 \mathrm{O}-\end{array}$ & 99.49 & 100.65 & 99.12 & 99.55 & 99.57 & 99.68 & 98.38 & 98.74 & 88.99 & 99.89 \\
\hline
\end{tabular}

\begin{tabular}{|c|c|c|c|c|c|c|c|c|c|c|}
\hline \multicolumn{11}{|c|}{ ppm } \\
\hline As & 3.00 & 6.00 & 14.00 & 10.00 & 8.00 & 8.20 & 12.00 & 13.00 & 19.00 & 7.0 \\
\hline $\mathrm{Ba}$ & 797.00 & 110.00 & 69.00 & 579.00 & 559.00 & 422.80 & 617.00 & 732.00 & 1077.00 & 705.0 \\
\hline \multicolumn{11}{|c|}{ 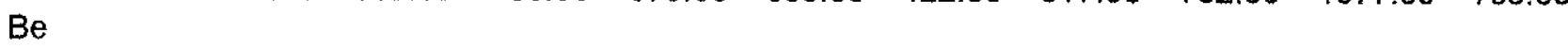 } \\
\hline $\mathrm{Ce}$ & 451.00 & 365.00 & 208.00 & 482.00 & 371.00 & 375.40 & 1067.00 & 1430.00 & 6770.00 & Nu. \\
\hline $\mathrm{Cl}$ & 194.00 & 791.00 & 808.00 & 0.00 & 0.00 & 358.60 & 776.00 & 0.00 & 0.00 & 0. \\
\hline Co & 0.00 & 4.00 & 4.00 & 0.00 & 3.00 & 2.20 & 5.00 & 0.00 & 0.00 & \\
\hline $\mathrm{Cr}$ & 30.00 & 6.00 & 7.00 & 16.00 & 19.00 & 15.60 & 12.00 & 9.00 & 7.00 & 13. \\
\hline Cs & 14.00 & 0.00 & 12.00 & 181.00 & 93.00 & 60.00 & 15.00 & 48.00 & 224.00 & 11.0 \\
\hline $\mathrm{Cu}$ & 0.00 & 0.00 & 0.00 & 0.00 & 2.00 & 0.40 & 0.00 & 0.00 & 0.00 & 2. \\
\hline$F$ & 12035.00 & 3254.00 & 8645.00 & 3611.00 & 2750.00 & 6059.00 & 2301.00 & 9180.00 & 60656.00 & 1121 \\
\hline $\mathrm{Ga}$ & 38.00 & 48.00 & 49.00 & 45.00 & 47.00 & 45.40 & 37.00 & 44.00 & 30.00 & 39.6 \\
\hline \multicolumn{11}{|l|}{$H f$} \\
\hline La & 333.00 & 345.00 & 115.00 & 430.00 & 303.00 & 305.20 & 880.00 & $\$ 456.00$ & 6536.00 & 386. \\
\hline Ib & 237.00 & 267.00 & 248.00 & 261.00 & 258.00 & 254.20 & 235.00 & 269.00 & 238.00 & 209. \\
\hline $\mathrm{Vd}$ & 93.00 & 75.00 & 59.00 & 143.00 & 14.00 & 76.80 & 244.00 & 303.00 & 1386.00 & 115.0 \\
\hline $\mathrm{Ni}$ & 5.00 & 1.00 & 3.00 & 2.00 & 4.00 & 3.00 & 0.00 & 1.00 & 7.00 & 0.0 \\
\hline $\mathrm{Pb}$ & 36.00 & 50.00 & 47.00 & 54.00 & 49.00 & 47.20 & 37.00 & 81.00 & 359.00 & $14 . C$ \\
\hline $\mathrm{Rb}$ & 342.00 & 126.00 & 141.00 & 550.00 & 626.00 & 357.00 & 191.00 & 359.00 & 342.00 & 313.0 \\
\hline$S$ & 300.00 & 0.00 & 0.00 & 0.00 & 0.00 & 60.00 & 0.00 & 0.00 & 2000.00 & 0.0 \\
\hline \multicolumn{11}{|l|}{ Sc } \\
\hline Sn & 11.00 & 0.00 & 0.00 & 4.00 & 0.00 & 3.00 & 13.00 & 0.00 & 0.00 & 0.0 \\
\hline $\mathrm{Sr}$ & 2241.00 & 1083.00 & 1202.00 & 1516.00 & 1121.00 & 1432.60 & 5637.00 & 4535.00 & 12321.00 & 539.0 \\
\hline $\mathrm{Ta}$ & 3.00 & 10.00 & 6.00 & 0.00 & 19.00 & 7.60 & 0.00 & 0.00 & 0.00 & 1.0 \\
\hline Th & 37.00 & 57.00 & 17.00 & 64.00 & 63.00 & 47.60 & 58.00 & 134.00 & 198.00 & 43.0 \\
\hline$U$ & 0.00 & 6.00 & 4.00 & 10.00 & 10.00 & 6.00 & 0.00 & 0.00 & 0.00 & 11.0 \\
\hline V & 85.00 & 70.00 & 59.00 & 59.00 & 63.00 & 67.20 & 97.00 & 86.00 & 86.00 & 133.00 \\
\hline$W$ & 0.00 & 0.00 & 0.00 & 3.00 & 0.00 & 0.60 & 0.00 & 2.00 & 20.00 & 6.00 \\
\hline Y & 45.00 & 40.00 & 32.00 & 53.00 & 45.00 & 43.00 & 84.00 & 109.00 & 457.00 & 80.00 \\
\hline $\mathrm{Zn}$ & 251.00 & 260.00 & 295.00 & 470.00 & 421.00 & 339.40 & 220.00 & 367.00 & 635.00 & 38.00 \\
\hline $\mathrm{Zr}$ & 1124.00 & 1721.00 & 1749.00 & 1728.00 & 1686.00 & 1601.60 & 1117.00 & 1809.00 & 1859.00 & 1019.00 \\
\hline
\end{tabular}


TABELA 1.2 -Continuação.

\begin{tabular}{|c|c|c|}
\hline $\begin{array}{c}\text { Amostra } \\
\text { Rocha } \\
\% \text {-peso }\end{array}$ & $\begin{array}{c}\mathrm{A} 11 \mathrm{~N}^{12} \\
\text { ph-minalt }\end{array}$ & L.D. \\
\hline $\mathrm{SiO} 2$ & 55.70 & 0.01 \\
\hline $\mathrm{TiO}_{2}$ & 0.39 & 0.00 \\
\hline $\mathrm{Al} 2 \mathrm{O} 3$ & 21.35 & 0.02 \\
\hline $\mathrm{Fe} 2 \mathrm{O} 3$ & 3.22 & 0.01 \\
\hline Mno & 0.08 & 0.00 \\
\hline MgO & 0.18 & 0.01 \\
\hline $\mathrm{CaO}$ & 0.36 & 0.01 \\
\hline $\mathrm{Na} 2 \mathrm{O}$ & 2.82 & 0.02 \\
\hline $\mathrm{K} 2 \mathrm{O}$ & 8.21 & 0.01 \\
\hline $\mathrm{P} 2 \mathrm{O} 5$ & 0.00 & 0.01 \\
\hline LOI/PF & 5.70 & 0.00 \\
\hline total & 98.01 & \\
\hline \multicolumn{3}{|l|}{$\mathrm{H} 2 \mathrm{O}$} \\
\hline \multicolumn{3}{|l|}{$\mathrm{ppm}$} \\
\hline As & 0.00 & 20.00 \\
\hline $\mathrm{Ba}$ & 241.00 & 20.00 \\
\hline \multicolumn{3}{|c|}{$-1.100-0=0$} \\
\hline $\mathrm{Ce}$ & 3112.00 & 40.00 \\
\hline $\mathrm{Cl}$ & 0.00 & 400.00 \\
\hline Co & 6.00 & 8.00 \\
\hline $\mathrm{Cr}$ & 11.00 & 6.00 \\
\hline Cs & 80.00 & 30.00 \\
\hline $\mathrm{Cu}$ & 1.00 & 8.00 \\
\hline $\mathrm{F}$ & 3699.00 & 8.00 \\
\hline $\mathrm{Ga}$ & 53.00 & 4.00 \\
\hline \multicolumn{3}{|l|}{$\mathrm{Hf}$} \\
\hline $\mathrm{La}$ & 12225.00 & 30.00 \\
\hline 16 & 282.00 & 4.00 \\
\hline$v d$ & 3109.00 & 30.00 \\
\hline $\mathrm{Ni}$ & 27.00 & 6.00 \\
\hline $\mathrm{Pb}$ & 67.00 & 10.00 \\
\hline $\mathrm{Rb}$ & 162.00 & 4.00 \\
\hline$S$ & 0.00 & 20.00 \\
\hline \multicolumn{3}{|l|}{ Sc } \\
\hline Sn & 11.00 & 30.00 \\
\hline $\mathrm{Sr}$ & 488.00 & 4.00 \\
\hline $\mathrm{Ta}$ & 0.00 & 8.00 \\
\hline Th & 36.00 & 4.00 \\
\hline$U$ & 11.00 & 6.00 \\
\hline V & 45.00 & 6.00 \\
\hline$w$ & 13.00 & 30.00 \\
\hline Y & 1413.00 & 4.00 \\
\hline $\mathrm{Zn}$ & 266.00 & 6.00 \\
\hline $\mathrm{Zr}$ & 1509.00 & 4.00 \\
\hline
\end{tabular}


Tabela I.3 -Analises por ICP-AES (IGC-USP) de Fonolitos da borda NW da Mina de Urânio: (ph-mi) - não a fracamente hidrotermalizadas e composição Média, e (ph-mi-alt) - variável a fortemente alterados. L.D. e L.Q. - limites de Deteç̧ão e Quantificação; ${ }^{1}$ - carbonatizaçăo e piritização fracas; ${ }^{2}$ - argilização intemperica.

\begin{tabular}{lrrrrrrr}
$\begin{array}{c}\text { Amostra } \\
\text { Rocha } \\
\text { \%-peso }\end{array}$ & $\begin{array}{c}\text { A4B } \\
\text { ph-mi }\end{array}$ & $\begin{array}{r}\text { A5 } \\
\text { ph-mi }\end{array}$ & $\begin{array}{r}\text { Média } \\
\text { ph-mi }\end{array}$ & $\begin{array}{c}\text { A10BH } \\
\text { ph-mi-alt }\end{array}$ & $\begin{array}{c}\text { A112 } \\
\text { ph-mi-alt }\end{array}$ & L.D. & L.Q. \\
\hline \hline SiO2 & 54.35 & 54.84 & 54.60 & 54.71 & 55.81 & 0.024 & 0.1 \\
TiO2 & 0.40 & 0.37 & 0.39 & 0.39 & 0.41 & 0.0006 & 0.003 \\
$\mathrm{Al2O} 3$ & 20.50 & 19.99 & 20.25 & 19.78 & 21.18 & 0.0006 & 0.003 \\
$\mathrm{Fe2O3}$ & 4.21 & 4.16 & 4.19 & 5.22 & 3.51 & 0.001 & 0.01 \\
$\mathrm{MnO}$ & 0.31 & 0.33 & 0.32 & 0.66 & 0.09 & 0.0001 & 0.0005 \\
$\mathrm{MgO}$ & 0.20 & 0.18 & 0.19 & 0.24 & 0.23 & 0.005 & 0.03 \\
$\mathrm{CaO}$ & 1.15 & 1.27 & 1.21 & 1.87 & 0.19 & 0.001 & 0.01 \\
$\mathrm{Na2O}$ & 7.59 & 7.96 & 7.78 & 4.86 & 2.76 & 0.006 & 0.03 \\
$\mathrm{~K} 20$ & 7.23 & 7.93 & 7.58 & 7.83 & 8.04 & 0.032 & 0.15 \\
$\mathrm{P} 2 \mathrm{O} 5$ & 0.02 & 0.02 & 0.02 & 0.03 & 0.02 & 0.009 & 0.05 \\
LO1/PF & 3.33 & 1.72 & 2.53 & 3.75 & 4.02 & 0.01 & 0.1 \\
total & 99.29 & 98.77 & 99.03 & 99.34 & 96.26 & & \\
H2O- & 0.66 & 0.10 & 0.38 & 0.65 & 1.49 & 0.01 & 0.1
\end{tabular}

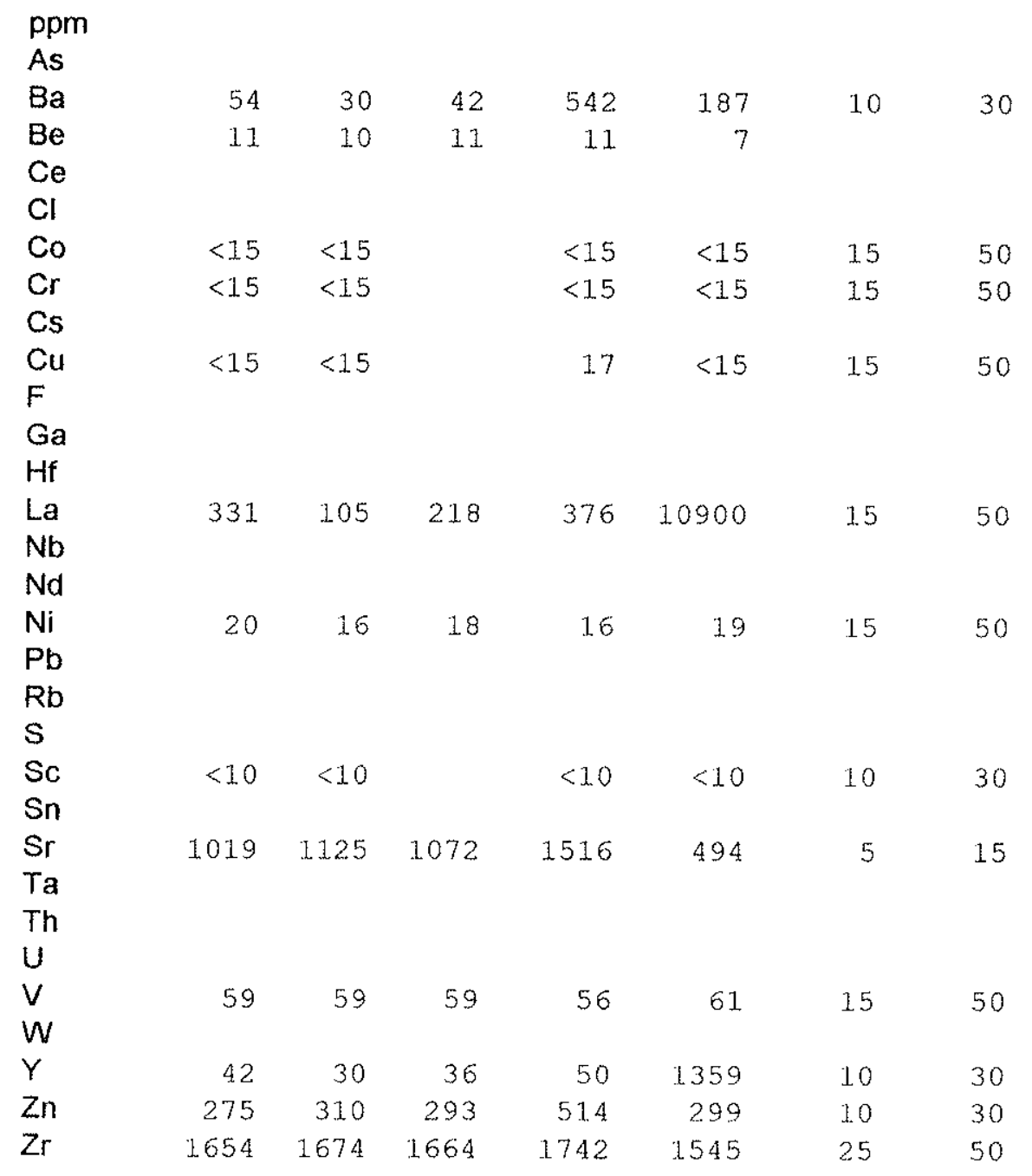


TABELA 1.4 - Dados litogeoquímicos comparativos de Fonolitos nåo-hidrotermalizados selecionados da borda NW da Mina de Uránio (ph-mi) por FRX e ICP-AES e médias (MMXRF e MMICP), assim como de fonolitos e nefelina sienitos regionais (ph-reg e ns-reg): 1-segundo Schumann (1994), 2-segundo Schorscher e Shea (1992) e respectivas médias.

Amostra A1HT A4B A5 A10BH A10BT MMFRX A4BICP A5ICP MMICP 51/13 55/15 Rocha ph-mi ph-mi ph-mi ph-mi ph-mi ph-mi ph-mi ph-mi ph-mi ns-reg1 ns-reg1 $\%$-peso

\begin{tabular}{|c|c|c|c|c|c|c|c|c|c|c|c|}
\hline$\overline{\mathrm{SiO} 2}$ & 53.30 & 53.40 & 52.70 & 54.57 & 54.92 & 53.78 & 54.35 & 54.84 & 54.60 & 51.11 & 51.28 \\
\hline $\mathrm{TiO} 2$ & 0.38 & 0.42 & 0.39 & 0.37 & 0.37 & 0.39 & 0.40 & 0.37 & 0.39 & 0.23 & 0.42 \\
\hline $\mathrm{A} 12 \mathrm{O} 3$ & 20.72 & 20.83 & 20.29 & 20.04 & 20.11 & 20.40 & 20.50 & 19.99 & 20.25 & 22.01 & 20.19 \\
\hline $\mathrm{Fe} 2 \mathrm{O} 3$ & 4.23 & 4.02 & 4.09 & 4.74 & 4.78 & 4.37 & 4.21 & 4.16 & 4.19 & 3.08 & 4.22 \\
\hline $\mathrm{MnO}$ & 0.49 & 0.31 & 0.33 & 0.63 & 0.61 & 0.47 & 0.31 & 0.33 & 0.32 & 0.22 & 0.26 \\
\hline $\mathrm{MgO}$ & 0.16 & 0.14 & 0.12 & 0.17 & 0.19 & 0.16 & 0.20 & 0.18 & 0.19 & 0.03 & 0.23 \\
\hline $\mathrm{CaO}$ & 2.08 & 1.34 & 1.49 & 1.81 & 1.54 & 1.65 & 1.15 & 1.27 & 1.21 & 0.98 & 1.59 \\
\hline $\mathrm{Na} 2 \mathrm{O}$ & 5.22 & 7.94 & 8.35 & 4.89 & 4.93 & 6.27 & 7.59 & 7.96 & 7.78 & 9.11 & 8.16 \\
\hline $\mathrm{K} 2 \mathrm{O}$ & 10.01 & 8.25 & 9.06 & 7.93 & 7.92 & 8.63 & 7.23 & 7.93 & 7.58 & 8.52 & 8.15 \\
\hline $\mathrm{P} 2 \mathrm{O} 5$ & 0.05 & 0.01 & 0.01 & 0.01 & 0.01 & 0.02 & 0.02 & 0.02 & 0.02 & 0 & 0 \\
\hline $\mathrm{LOI} / \mathrm{PF}$ & 2.90 & 4.00 & 2.30 & 4.40 & 4.20 & 3.56 & 3.33 & 1.72 & 2.53 & 2.50 & 3.00 \\
\hline total & 99.54 & 100.66 & 99.13 & 99.56 & 99.58 & 99.69 & 99.29 & 98.77 & 99.03 & 97.79 & 97.50 \\
\hline $\mathrm{H} 2 \mathrm{O}-$ & & & & & & & 0.66 & 0.10 & 0.38 & 0.26 & 0.44 \\
\hline \multicolumn{12}{|l|}{ ppm } \\
\hline As & 3 & 6 & 14 & 10 & 8 & 8 & & & & & \\
\hline $\mathrm{Ba}$ & 797 & 110 & 69 & 579 & 559 & 423 & 54 & 30 & 42 & 54 & 298 \\
\hline $\mathrm{Be}$ & & 11 & 10 & & & 10 & 11 & 10 & 11 & & \\
\hline $\mathrm{Ce}$ & 451 & 365 & 208 & 482 & 371 & 375 & & & & 403 & 254 \\
\hline $\mathrm{Cl}$ & 194 & 791 & 808 & & & 598 & & & & & \\
\hline Co & 2 & 4 & 4 & 3 & 3 & 3 & & & & 13 & 7 \\
\hline $\mathrm{Cr}$ & 30 & 6 & 7 & 16 & 19 & 16 & & & & 13 & 16 \\
\hline Cs & 14 & 5 & 12 & 181 & 93 & 61 & & & & & \\
\hline $\mathrm{Cu}$ & 11 & 17 & 6 & 16 & 2 & 10 & & & & 0 & 4 \\
\hline$F$ & 12035 & 3254 & 8645 & 3611 & 2750 & 6059 & & & & & \\
\hline $\mathrm{Ga}$ & 38 & 48 & 49 & 45 & 47 & 45 & & & & 43 & 44 \\
\hline \multicolumn{12}{|l|}{$\mathrm{Hf}$} \\
\hline $\mathrm{La}$ & 333 & 345 & 115 & 430 & 303 & 305 & 331 & 105 & 218 & 285 & 191 \\
\hline $\mathrm{Nb}$ & 237 & 267 & 248 & 261 & 258 & 254 & & & & 202 & 180 \\
\hline $\mathrm{Nd}$ & 93 & 75 & 59 & 1.43 & 14 & 77 & & & & 83 & 48 \\
\hline $\mathrm{Ni}$ & 5 & 1 & 3 & 2 & 4 & 3 & 20 & 16 & 1.8 & 0 & 0 \\
\hline $\mathrm{Pb}$ & 36 & 50 & 47 & 54 & 49 & 47 & & & & 35 & 59 \\
\hline $\mathrm{Rb}$ & 342 & 126 & 141 & 550 & 626 & 357 & & & & 183 & 195 \\
\hline$s$ & 300 & 461. & 202 & 367 & 401 & 346 & & & & 120 & 200 \\
\hline Sc & 12 & 7 & 6 & 9 & 7 & 8 & & & & & \\
\hline Sn & 11 & 1 & 1 & 4 & 1. & 4 & & & & & \\
\hline $\mathrm{Sr}$ & 2241 & 1083 & 1202 & 1516 & 1121 & 1433 & 1019 & 1125 & 1072 & 532 & 1471 \\
\hline Ta & 3 & 10 & 6 & 1 & 19 & 8 & & & & & \\
\hline Th & 37 & 57 & 17 & 64 & 63 & 48 & & & & 24 & 28 \\
\hline $\mathrm{U}$ & 1 & 6 & 4 & 10 & 10 & 6 & & & & 11 & 0 \\
\hline V & 85 & 70 & 59 & 59 & 63 & 67 & 59 & 59 & 59 & 50 & 62 \\
\hline$w$ & 1 & 1 & 1 & 3 & 1 & 1 & & & & & \\
\hline$Y$ & 45 & 40 & 32 & 53 & 45 & 43 & 42 & 30 & 36 & 41 & 38 \\
\hline $\mathrm{Zn}$ & 251. & 260 & 295 & 470 & 421 & 339 & 275 & 31.0 & 293 & 150 & 262 \\
\hline $\mathrm{Zr}$ & 1124 & 1721 & 1749 & 1728 & 1686 & 1602 & 1654 & 1674 & 1664 & 754 & 1294 \\
\hline
\end{tabular}


TABELA I.4 - Continuação.

\begin{tabular}{|c|c|c|c|c|c|c|c|c|c|c|}
\hline $\begin{array}{c}\text { Amostra } \\
\text { Rocha } \\
\% \text {-peso }\end{array}$ & $\begin{array}{c}56 / 16 \\
\text { ns-reg1 }\end{array}$ & $\begin{array}{c}61 / 18 \\
\text { ns-reg1 }\end{array}$ & $\begin{array}{l}61 \mathrm{~b} / 20 \\
\text { ns-reg1 }\end{array}$ & $\begin{array}{c}66 / 22 \\
\text { ns-reg1 }\end{array}$ & $\begin{array}{c}99 / 33 \\
\text { ns-reg1 }\end{array}$ & $\begin{array}{c}\text { MedNS1 } \\
\text { ns-reg1 }\end{array}$ & $\begin{array}{l}44 / 8 \text { ph } \\
\text { ph-reg1 }\end{array}$ & $\begin{array}{c}44 \mathrm{a} / 9 \mathrm{ph} \\
\text { ph-reg1 }\end{array}$ & $\begin{array}{l}70 a / 24 \\
\text { ph-reg1 }\end{array}$ & $\begin{array}{l}71 \mathrm{a} / 25 \\
\text { ph-reg1 }\end{array}$ \\
\hline $\mathrm{SiO} 2$ & 51.72 & 51.24 & 52.55 & 53.16 & 52.63 & 96 & $=$ & 2.12 & 52.12 & 53.3 \\
\hline $\mathrm{TIO} 2$ & 0.44 & 38 & 33 & 0.41 & 0.38 & & & & & 0.51 \\
\hline $\mathrm{A} 12 \mathrm{O} 3$ & 20.14 & 22.32 & 21.63 & 1.8 .81 & 20.38 & 20.78 & & 19.63 & 16 & 21.03 \\
\hline $\mathrm{Fe} 2 \mathrm{O} 3$ & 3.87 & 2.43 & 2.51 & 5.83 & 4.34 & .75 & & 43 & 7 & 4.07 \\
\hline $\mathrm{MnO}$ & 0.23 & 0.13 & 0.14 & 0.21 & 3 & 0.21 & 0 & 0.22 & 22 & 0.19 \\
\hline $\mathrm{MgO}$ & 0.25 & 0.15 & 0 & 0.25 & 2 & 0.16 & 0. & 0.25 & 0.3 & 0.17 \\
\hline $\mathrm{CaO}$ & 1. & 0.91 & 0.96 & 1.92 & 1.4 & 34 & 1. & 3 & 1.8 & 1.92 \\
\hline $\mathrm{Na2O}$ & 8.76 & 6.9 & 7.3 & 7.25 & .28 & 7 & 1.42 & 0.2 & 7.8 & 8.42 \\
\hline $\mathrm{K} 2 \mathrm{O}$ & 8.29 & 11.07 & 10.52 & 7.99 & 55 & 87 & 8.3 & .61 & 8.48 & 8.52 \\
\hline P2O5 & 0 & 0 & 0 & 0 & - & 00 & 0.03 & 0 & 0.03 & 0.03 \\
\hline LOI/PF & 2.43 & 1.83 & 91 & 1.6 & 27 & 2.22 & 1.55 & .19 & 2.49 & 1.09 \\
\hline total & 97.76 & 97.36 & 98.85 & 97.43 & 96.73 & 97.63 & 99.15 & 99.10 & 98.24 & 99.26 \\
\hline $\mathrm{H} 2 \mathrm{O}$ & 0.23 & 0.41 & 0.35 & 0.32 & 1.34 & 0.48 & 0.19 & 0.13 & 0.6 & 0.18 \\
\hline
\end{tabular}

ppm

As

$\begin{array}{lrrrrrrrrrr}\mathrm{Ba} & 251 & 67 & 88 & 134 & 127 & 146 & 436 & 428 & 420 & 451 \\ \mathrm{Be} & & & & & & & & & & \\ \mathrm{Ce} & 291 & 161 & 191 & 1081 & 309 & 384 & 337 & 372 & 337 & 337 \\ \mathrm{Cl} & & & & & & & & & & \\ \mathrm{Co} & 14 & 7 & 3 & 19 & 28 & 13 & 1 & 21 & 13 & 15 \\ \mathrm{Cr} & 21 & 15 & 20 & 21 & 18 & 18 & 9 & 10 & 23 & 12 \\ \mathrm{Cs} & & & & & & & & & & \\ \mathrm{Cu} & 1 & 2 & 10 & 0 & 0 & 2 & 12 & 4 & 4 & 0 \\ \mathrm{~F} & & & & & & & & & & \\ \mathrm{Ga} & 42 & 39 & 33 & 45 & 44 & 41 & 38 & 42 & 31 & 33 \\ \mathrm{Hf} & & & & & & & & & & \\ \mathrm{La} & 221 & 82 & 110 & 750 & 227 & 267 & 185 & 198 & 173 & 146 \\ \mathrm{Nb} & 192 & 214 & 146 & 275 & 202 & 202 & 160 & 176 & 177 & 1.46 \\ \mathrm{Nd} & 74 & 31 & 39 & 168 & 62 & 72 & 77 & 85 & 74 & 99 \\ \mathrm{Ni} & 0 & 1 & 2 & 0 & 0 & 0 & 0 & 0 & 0 & 0 \\ \mathrm{~Pb} & 57 & 63 & 38 & 11 & 66 & 47 & 46 & 33 & 43 & 31 \\ \mathrm{Rb} & 202 & 526 & 275 & 120 & 197 & 243 & 167 & 190 & 175 & 172 \\ \mathrm{~S} & 360 & 1001 & 1762 & 0 & 120 & 509 & 280 & 481 & 320 & 280 \\ \mathrm{Sc} & & & & & & & & & & \\ \mathrm{Sn} & & & & & & & & & & \\ \mathrm{Sr} & 1384 & 295 & 542 & 1674 & 1324 & 1032 & 1989 & 2128 & 2077 & 2115 \\ \mathrm{Ta} & & & & & & & & & \\ \mathrm{Th} & 38 & 16 & 31 & 79 & 48 & 38 & 4 & 25 & 19 & 11 \\ \mathrm{U} & 1 & 47 & 0 & 8 & 0 & 10 & 0 & 0 & 0 & 0 \\ \mathrm{~V} & 43 & 43 & 16 & 111 & 64 & 56 & 76 & 58 & 69 & 85 \\ \mathrm{~W} & & & & & & & & & & \\ \mathrm{Y} & 43 & 29 & 27 & 226 & 14 & 60 & 37 & 48 & 53 & 34 \\ \mathrm{Zn} & 213 & 74 & 72 & 119 & 265 & 165 & 164 & 180 & 163 & 112 \\ \mathrm{Zr} & 1284 & 1337 & 722 & 781 & 1659 & 1119 & 918 & 1005 & 905 & 746 \\ & & & & & & & & & & \end{array}$


TABELA 1.4 - Continuação.

$\begin{array}{llllllll}\text { Amostra } & 77 a / 27 & 74 / 28 & 84 a / 30 & 126 a / 38 & 127 a / 39 & 1271 / 40 & \text { MedFon1 NS-1 NS-4 NS-6 }\end{array}$ Rocha ph-reg1 ph-reg1 ph-reg1 ph-reg1 ph-reg1 ph-reg1 ph-reg1 ns-reg2 ns-reg2 ns-reg2 $\%$-peso

\begin{tabular}{|c|c|c|c|c|c|c|c|c|c|c|}
\hline $\mathrm{SiO} 2$ & 53.11 & 52.4 & 53.91 & 51.55 & 53.02 & 52.76 & 52.54 & 54.78 & 54.83 & 54.52 \\
\hline TiO2 & 0.52 & 0.55 & 0.52 & 0.51 & 0.5 & 0.52 & 0.52 & 0.79 & 0.87 & 0.91 \\
\hline $\mathrm{Al} 2 \mathrm{O} 3$ & 20.25 & 19.93 & 20.9 & 20.58 & 21.37 & 20.76 & 20.46 & 19.93 & 2.0 .2 & 20.17 \\
\hline $\mathrm{Fe} 2 \mathrm{O} 3$ & 4.18 & 4.65 & 3.74 & 4.23 & 4.3 & 3.69 & 4.18 & 4.43 & 4.34 & 4.35 \\
\hline Mno & 0.21 & 0.24 & 0.23 & 0.21 & 0.21 & 0.24 & 0.22 & 0.28 & 0.25 & 0.27 \\
\hline $\mathrm{MgO}$ & 0.2 & 0.19 & 0.35 & 0.52 & 0.24 & 0.31 & 0.26 & 0.44 & 0.51 & 0.52 \\
\hline $\mathrm{CaO}$ & 1.81 & 1.93 & 1.59 & 2.18 & 2.08 & 1.65 & 1.87 & 1.99 & 1.99 & 1.9 \\
\hline $\mathrm{Na} 2 \mathrm{O}$ & 8.14 & 8.06 & 8.21 & 7.76 & 5.19 & 8.94 & 8.41 & 6.48 & 6.48 & 5.66 \\
\hline K2O & 8.23 & 8.12 & 8.28 & 8.8 & 8.57 & 8.03 & 8.39 & 8.26 & 8.23 & 7.95 \\
\hline P2O5 & 0 & 0 & 0.03 & 0.07 & 0.05 & 0.03 & 0.03 & 0.12 & 0.13 & 0.14 \\
\hline LOI/PF & 1.68 & 1.29 & 0.97 & 1.36 & 2.77 & 0.54 & 1.49 & 1.23 & 1.88 & 3.46 \\
\hline total & 98.33 & 97.36 & 98.73 & 97.77 & 98.30 & 97.47 & 98.37 & 98.73 & 99.71 & 99.85 \\
\hline $\mathrm{H} 2 \mathrm{O}-$ & 0.31 & 0.29 & 0.16 & 0.2 & 0.35 & 0.21 & 0.26 & & & \\
\hline \multicolumn{11}{|l|}{ ppm } \\
\hline $\mathrm{Ba}$ & 420 & 392 & 54 & 378 & 412 & 47 & 344 & 261. & 479 & 502 \\
\hline \multicolumn{11}{|l|}{$\mathrm{Be}$} \\
\hline $\mathrm{Ce}$ & 327 & 813 & 388 & 293 & 325 & 415 & 394 & 422 & 357 & 335 \\
\hline \multicolumn{11}{|l|}{$\mathrm{Cl}$} \\
\hline Co & 25 & 3 & 19 & 0 & 11 & 11 & 12 & 7 & 11 & 8 \\
\hline $\mathrm{Cr}$ & 10 & 18 & 9 & 23 & 24 & 14 & 15 & $<I d$ & $<1 d$ & $<1 d$ \\
\hline \multicolumn{11}{|l|}{ Cs } \\
\hline $\mathrm{Cu}$ & 4 & 0 & 5 & 8 & 11 & 7 & 6 & $<1 d$ & $<1 d$ & $<I d$ \\
\hline$F$ & & & & & & & & 2670 & 1766 & 1216 \\
\hline $\mathrm{Ga}$ & 34 & 33 & 40 & 39 & 30 & 36 & 36 & & & \\
\hline $\mathrm{Hf}$ & & & & & & & & $<1 d$ & $<1 d$ & $<1 d$ \\
\hline La & 190 & 234 & 228 & 189 & 198 & 240 & 198 & 320 & 265 & 245 \\
\hline $\mathrm{Nb}$ & 165 & 206 & 224 & 156 & 167 & 231 & 181 & 287 & 239 & 260 \\
\hline Nd & 71 & 91 & 99 & 86 & 73 & 127 & 88 & 125 & 110 & 93 \\
\hline $\mathrm{Ni}$ & 0 & 0 & 1 & 0 & 5 & 3 & 1 & $<l d$ & $<1 d$ & $<1 d$ \\
\hline $\mathrm{Pb}$ & 34 & 43 & 49 & 49 & 55 & 33 & 42 & 8 & 6 & 12 \\
\hline $\mathrm{Rb}$ & 170 & 175 & 171 & 217 & 204 & 168 & 181 & 148 & 146 & 138 \\
\hline$S$ & 120 & 200 & 2.00 & 921 & 1722 & 280 & 481 & 987 & 764 & 878 \\
\hline Sc & & & & & & & & $<1 d$ & $<l d$ & $<1 d$ \\
\hline \multicolumn{11}{|l|}{ Sn } \\
\hline $\mathrm{Sr}$ & 2090 & 2091 & 1391 & 2116 & 1988 & 1306 & 1929 & 2019 & 2709 & 2750 \\
\hline \multicolumn{11}{|l|}{$\mathrm{Ta}$} \\
\hline Th & 3 & 32 & 13 & 46 & 19 & 3 & 18 & 14 & 9 & 17 \\
\hline U & 0 & 0 & 0 & 0 & 0 & 0 & 0 & $<l d$ & $<1 d$ & $<1 d$ \\
\hline V & 64 & 74 & 63 & 62 & 85 & 76 & 71 & 69 & 72 & 51 \\
\hline \multicolumn{11}{|c|}{$W$} \\
\hline Y & 35 & 44 & 44 & 30 & 41 & 52 & 42 & 53 & 44 & 44 \\
\hline $\mathrm{Zn}$ & 160 & 193 & 182 & 166 & 170 & 184 & 167 & 181 & 165 & 180 \\
\hline $\mathrm{Zr}$ & 885 & 1120 & 893 & 944 & 542 & 954 & 891 & 1112 & 932 & 1156 \\
\hline
\end{tabular}


TABELA I.4 - Continuaçåo.

Amostra NS-7 MedNS2 ph02a ph-02b ph-03 ph-05 ph-08 ph-09b MedFon2 MedNSR Rocha ns-reg2 ns-reg2 ph-reg2 ph-reg2 ph-reg2 ph-reg2 ph-reg2 ph-reg2 ph-reg2 ns-reg $\%$-peso

\begin{tabular}{|c|c|c|c|c|c|c|c|c|c|c|}
\hline$\overline{\mathrm{SiO} 2}$ & 52.58 & 54.18 & 53.13 & 54.96 & 55.61 & 53.21 & 53.92 & 53.8 & 54.11 & 52.76 \\
\hline $\mathrm{TiO} 2$ & 0.7 & 0.82 & 0.51 & 0.56 & 0.58 & 0.55 & 0.59 & 0.57 & 0.56 & 0.53 \\
\hline $\mathrm{Al} 2 \mathrm{O} 3$ & 19.66 & 19.99 & 19.84 & 20.21 & 20.63 & 19.75 & 19.83 & 19.78 & 20.01 & 20.49 \\
\hline $\mathrm{Fe} 2 \mathrm{O} 3$ & 3.77 & 4.22 & 4.09 & 4.25 & 3.88 & 3.72 & 3.81 & 3.78 & 3.92 & 3.92 \\
\hline Mno & 0.26 & 0.27 & 0.21 & 0.26 & 0.24 & 0.24 & 0.24 & 0.25 & 0.24 & 0.23 \\
\hline $\mathrm{MgO}$ & 0.27 & 0.44 & 0.19 & 0.24 & 0.31 & 0.21 & 0.24 & 0.22 & 0.24 & 0.26 \\
\hline $\mathrm{CaO}$ & 1.46 & 1.84 & 1.78 & 1.82 & 1.57 & 1.52 & 1.58 & 1.57 & 1.64 & 1.52 \\
\hline $\mathrm{Na} 2 \mathrm{O}$ & 7.6 & 6.56 & 7.77 & 6.95 & 6.87 & 8 & 7.3 & 7.4 & 7.38 & 7.45 \\
\hline $\mathrm{K} 2 \mathrm{O}$ & 7.73 & 8.04 & 8.54 & 8.43 & 8.41 & 7.94 & 8.53 & 8.4 & 8.38 & 8.57 \\
\hline P2O5 & 0.08 & 0.12 & 0.06 & 0.06 & 0.06 & 0.06 & 0.06 & 0.06 & 0.06 & 0.04 \\
\hline LOI/PF & 3.17 & 2.44 & 1.06 & 1.89 & 1.36 & 1.82 & 0.96 & 1.2 & 1.38 & 2.30 \\
\hline $\begin{array}{l}\text { total } \\
\mathrm{H} 2 \mathrm{O}\end{array}$ & 97.28 & 98.89 & 97.18 & 99.63 & 99.52 & 97.02 & 97.06 & 97.03 & 97.91 & $\begin{array}{r}98.09 \\
0.48\end{array}$ \\
\hline \multicolumn{11}{|l|}{ ppm } \\
\hline $\begin{array}{l}\mathrm{Ba} \\
\mathrm{Be}\end{array}$ & 339 & 395 & 371 & 217 & 44 & 45 & 60 & 50 & 131 & 236 \\
\hline $\begin{array}{l}\mathrm{Ce} \\
\mathrm{Cl}\end{array}$ & 341 & 364 & 275 & 266 & 355 & 369 & 400 & 391 & 343 & 377 \\
\hline Co & 6 & 8 & 9 & 9 & 7 & 8 & 13 & 9 & 9 & 11 \\
\hline $\begin{array}{l}\mathrm{Cr} \\
\mathrm{Cs}\end{array}$ & $<l d$ & & $<1 d$ & 9 & $<1 d$ & $<l d$ & $<1 d$ & $<I d$ & 9 & 18 \\
\hline $\mathrm{Cu}$ & $<1 d$ & & $<\mathrm{ld}$ & $<l d$ & $<1 d$ & $<l d$ & $<1 \mathrm{~d}$ & $<I d$ & & 2 \\
\hline$F$ & 1335 & 1747 & 2199 & na & 1578 & 1490 & 1703 & 1472 & 1688 & 1747 \\
\hline $\mathrm{Ga}$ & & & & & & & & & & 41 \\
\hline $\mathrm{Hf}$ & $<l d$ & & $<1 d$ & $<\mathrm{ld}$ & $<\mathrm{ld}$ & $<1 d$ & 1 & $<1 d$ & 1 & \\
\hline La & 245 & 269 & 235 & 172 & 257 & 266 & 310 & 284 & 254 & 267 \\
\hline $\mathrm{Nb}$ & 290 & 269 & 185 & 195 & 251 & 262 & 267 & 262 & 237 & 226 \\
\hline $\mathrm{Nd}$ & 86 & 104 & 53 & 77 & 99 & 99 & 108 & 93 & 88 & 84 \\
\hline $\mathrm{Ni}$ & $<\mathrm{ld}$ & & $<l d$ & 3 & $<1 d$ & $<1 d$ & $<1 . d$ & $<1 d$ & 3 & 0 \\
\hline $\mathrm{Pb}$ & 12 & 10 & 3 & 23 & $<l d$ & 4 & 2 & 1 & 7 & 33 \\
\hline $\mathrm{Rb}$ & 147 & 145 & 173 & 175 & 143 & 147 & 165 & 161 & 161 & 207 \\
\hline$S$ & 545 & 794 & 1689 & 1496 & 1288 & 630 & 782 & 651 & 1089 & 613 \\
\hline $\begin{array}{l}\text { Sc } \\
\text { Sn }\end{array}$ & $<1 d$ & & $<I d$ & $<l d$ & $<1 d$ & $<1 \mathrm{~d}$ & $<I d$ & $<1 d$ & & \\
\hline $\begin{array}{l}\mathrm{Sr} \\
\mathrm{Ta}\end{array}$ & 2096 & 2394 & 1944 & 1974 & 1252 & 1265 & 1607 & 1559 & 1600 & 1527 \\
\hline Th & 22 & 16 & 6 & 30 & 1 & 7 & 6 & 4 & 9 & 30 \\
\hline U & $<1 d$ & & $<1 d$ & 6 & $<1 d$ & $<l d$ & $<1 d$ & $<I d$ & 6 & 10 \\
\hline$V$ & 40 & 58 & 72 & 71 & 63 & 61 & 78 & 84 & 72 & 56 \\
\hline $\begin{array}{l}W \\
Y\end{array}$ & 52 & 48 & 27 & 39 & 37 & & & & & 56 \\
\hline $\mathrm{Zn}$ & 20.1 & $\begin{array}{l}180 \\
182 .\end{array}$ & 140 & $\begin{array}{r}39 \\
195\end{array}$ & $\begin{array}{r}37 \\
162\end{array}$ & $\begin{array}{r}42 \\
1.69\end{array}$ & $\begin{array}{r}44 \\
165\end{array}$ & $\begin{array}{r}39 \\
164\end{array}$ & $\begin{array}{r}38 \\
166\end{array}$ & 1.71 . \\
\hline $\mathrm{Zr}$ & 1208 & 1102 & 827 & 1004 & 931 & 891 & 859 & 858 & 895 & 1113 \\
\hline
\end{tabular}


TABELA I.4 - Continuaçăo.

\begin{tabular}{lrr}
$\begin{array}{c}\text { Amostra } \\
\text { Rocha } \\
\% \text {-peso }\end{array}$ & $\begin{array}{c}\text { MedPhR } \\
\text { ph-reg }\end{array}$ & $\begin{array}{c}\text { MedAlcR } \\
\text { alc-reg }\end{array}$ \\
\hline $\mathrm{SiO2}$ & 53.12 & 52.98 \\
$\mathrm{TiO} 2$ & 0.54 & 0.54 \\
$\mathrm{Al2O} 3$ & 20.29 & 20.37 \\
$\mathrm{Fe} 2 \mathrm{O} 3$ & 4.08 & 4.02 \\
$\mathrm{MnO}$ & 0.23 & 0.23 \\
$\mathrm{MgO}$ & 0.25 & 0.25 \\
$\mathrm{CaO}$ & 1.79 & 1.68 \\
$\mathrm{Na2O}$ & 8.03 & 7.79 \\
$\mathrm{~K} 2 \mathrm{O}$ & 8.39 & 8.46 \\
$\mathrm{P} 2 \mathrm{O} 5$ & 0.04 & 0.04 \\
$\mathrm{LOl} / \mathrm{PF}$ & 1.45 & 1.80 \\
total & 98.20 & 98.15 \\
$\mathrm{H} 2 \mathrm{O}-$ & 0.26 & 0.35
\end{tabular}

$\begin{array}{lrr}\mathrm{ppm} & & \\ \mathrm{As} & & \\ \mathrm{Ba} & 264 & 253 \\ \mathrm{Be} & & \\ \mathrm{Ce} & 375 & 376 \\ \mathrm{Cl} & & \\ \mathrm{Co} & 11 & 11 \\ \mathrm{Cr} & 15 & 16 \\ \mathrm{Cs} & & \\ \mathrm{Cu} & 6 & 4 \\ \mathrm{~F} & 1688 & 1714 \\ \mathrm{Ga} & 36 & 38 \\ \mathrm{Hf} & 1 & 1 \\ \mathrm{La} & 21.9 & 239 \\ \mathrm{Nb} & 202 & 212 \\ \mathrm{Nd} & 88 & 86 \\ \mathrm{Ni} & 1 & 1 \\ \mathrm{~Pb} & 30 & 31 \\ \mathrm{Rb} & 173 & 187 \\ \mathrm{~S} & 709 & 670 \\ \mathrm{Sc} & & \\ \mathrm{Sn} & & \\ \mathrm{Sr} & 1806 & 1692 \\ \mathrm{Ta} & & \\ \mathrm{Th} & 14 & 21 \\ \mathrm{U} & 1 & 4 \\ \mathrm{~V} & 71 & 65 \\ \mathrm{~W} & 40 & 47 \\ \mathrm{Y} & 167 & 169 \\ \mathrm{Zn} & 893 & 982 \\ \mathrm{Zr} & & \end{array}$


TABELA 1.5 - Indice de alcalinidade/agpaicidade de Fonolitos não-hidrotermalizados selecionados da borda NW da Mina de Uranio (ph-mi) por FRX e ICP-AES e médias (MMXRF e MMICP), assim como de fonolitos e nefelina sienitos regionais (ph-reg e ns-reg): 1-segundo Schumann (1994), 2-segundo Schorscher e Shea (1992) e respectivas médias.

\begin{tabular}{|c|c|c|c|c|c|c|c|}
\hline \multirow{2}{*}{$\frac{\text { Amostra }}{126 a / 38 p h}$} & \multirow{2}{*}{$\frac{\text { Rocha }}{\text { ph-regl }}$} & \multirow[t]{2}{*}{ ACNK } & ANK & $\mathrm{Fe} 203$ & $\mathrm{FeO}$ & \multicolumn{2}{|c|}{$\begin{array}{l}(\mathrm{Na} 2 \mathrm{O}+\mathrm{K} 2 \mathrm{O}) / \\
\mathrm{Al} 2 \mathrm{O} 3 \text { (molar) }\end{array}$} \\
\hline & & & 0.78 & 0.92 & 2.20 & 1.98 & 1.08 \\
\hline $1271 / 40 \mathrm{ph}$ & ph-reg1 & & 0.79 & 0.89 & 1.91 & 1.72 & 1.13 \\
\hline 127a/39ph & ph-regt & & 0.99 & 1.20 & 2.26 & 2.03 & 0.83 \\
\hline $44 / 8 \mathrm{ph}$ & ph-reg1 & & 0.64 & 0.72 & 2.16 & 1.94 & 1.30 \\
\hline $44 a 0 p h$ & ph-regl & & 0.66 & 0.75 & 2.27 & 2.04 & 1.33 \\
\hline $51 / 1$ औs & ns-reg1 & & 0.85 & 0.91 & 1.62 & 1.46 & 1.10 \\
\hline $55 / 15 \mathrm{~ns}$ & ns-reg1 & & 0.80 & 0.91 & 2.24 & 2.01 & 1.10 \\
\hline $56 / 16$ ns & ns-reg1 & & 0.76 & 0.86 & 2.03 & 1.83 & 1.16 \\
\hline $61 / 48$ ns & ns-reg1 & & 0.89 & 0.96 & 1.27 & 1.15 & 1.05 \\
\hline $61 \mathrm{~b} / 20 \mathrm{~ns}$ & ns-reg1 & & 0.86 & 0.92 & 1.31 & 1.18 & 1.08 \\
\hline $66 / 22 n s$ & ns-reg1 & & 0.78 & 0.91 & 3.05 & 2.75 & 1.09 \\
\hline $70 \mathrm{a} / 24 \mathrm{ph}$ & ph-reg1 & & 0.80 & 0.92 & 2.23 & 2.01 & 1.09 \\
\hline $71 \mathrm{a} / 25 \mathrm{ph}$ & ph-reg1 & & 0.79 & 0.91 & 2.08 & 1.87 & 1.10 \\
\hline 7/2asph & phregl & & 8.78 & 8.99 & 2.43 & 2.18 & $1: 10$ \\
\hline $84 a / 30 \mathrm{ph}$ & ph-reg1 & & 0.82 & 0.93 & 1.92 & 1.72 & 1.07 \\
\hline $99 / 33$ ns & ns-reg1 & & 0.84 & 0.94 & 2.28 & 2.05 & 1.07 \\
\hline $\mathrm{A} 10 \mathrm{BH}$ & ph-mi & & 1.01 & 1.21 & 2.50 & 2.25 & 0.83 \\
\hline A1OBT & ph-mi & & 1.03 & 1.21 & 2.51 & 2.26 & 0.83 \\
\hline ÂHT & ph-mi & & 0.89 & 1.07 & 2.19 & 1.97 & 0.94 \\
\hline$A 4 B$ & $\mathrm{ph}-\mathrm{mi}$ & & 0.85 & 0.95 & 2.08 & 1.87 & 1.06 \\
\hline A4BICP & ph-mi & & 0.91 & 1.01 & 2.20 & 1.98 & 0.99 \\
\hline A5 & ph-mi & & 0.77 & 0.86 & 2.12 & 1.90 & 1.16 \\
\hline $\mathrm{A} 5 \mathrm{ICP}$ & ph-mi & & 0.83 & 0.92 & 2.15 & 1.93 & 1.08 \\
\hline MedAlc & akcreg & & 0.81 & 0.93 & 2.09 & 1.88 & 1.08 \\
\hline MedFon1 & ph-red1 & & 0.78 & 0.89 & 2.16 & 1.94 & 1.12 \\
\hline MedFon2 & ph-reg2 & & 0.83 & 0.94 & 2.04 & 1.83 & 1.06 \\
\hline MedNS1ns & ns-reg1 & & 0.83 & 0.92 & 1.97 & 1.77 & 1.09 \\
\hline MedNS2 & ns-reg2 & & 0.88 & 1.03 & 2.19 & 1.97 & 0.98 \\
\hline MMedFon & ph-mi & & 0.79 & 0.91 & 2.11 & 1.90 & 1.10 \\
\hline MMICP & ph-mi & & 0.87 & 0.96 & 2.17 & 1.96 & 1.04 \\
\hline MMXRF & phmmi & & 0.90 & 1.04 & 2.28 & 2.05 & 0.96 \\
\hline NS2-1 & กs-reg2 & & 0.86 & 1.02 & 2.28 & 2.05 & 0.98 \\
\hline NS2-4 & ns-reg2 & & 0.87 & 1.03 & 2.22 & 2.00 & 0.97 \\
\hline NS2-6 & ns-reg2 & & 0.94 & 1.12 & 2.26 & 2.00 & 0.89 \\
\hline NS2-7 & ns-reg2 & & 0.84 & 0.94 & 2.01 & 1.81 & 1.06 \\
\hline$p h 2.02 a$ & ph-reg2 & & 0.79 & 0.90 & 2.13 & 1.92 & 1.11 \\
\hline $\mathrm{ph} 2-02 \mathrm{~b}$ & ph-reg2 & & 0.85 & 0.98 & 2.18 & 1.96 & 1.02 \\
\hline ph2-03 & ph-reg2 & & 0.89 & 1.01 & 1.98 & 1.78 & 0.99 \\
\hline ph 2.05 & pth-reg2 & & 0.81 & 0.91 & 1.96 & 1.76 & 1.10 \\
\hline ph2-08 & ph-reg2 & & 0.82 & 0.93 & 1.99 & 1.79 & 1.07 \\
\hline ph $2-00 b$ & ph-reg2 & & 0.82 & 0.93 & 1.98 & 1.78 & 1.08 \\
\hline
\end{tabular}


Tabela I.6 A: Análises por FRX de rochas reduzidas (hidrotermalitos reduzidos) com pirita da mina de U Osamu Utsumi, Complexo Alcalino de Poços de Caldas (Projeto Internacional Po-ços de Caldas; dados extraídos de Waber et al., 1991; 1992).

\begin{tabular}{|c|c|c|c|c|c|c|c|c|c|c|}
\hline $\begin{array}{c}\text { Amostra } \\
\text { Furo } \\
\text { Litotipo } \\
\end{array}$ & $\begin{array}{r}39-1 \mathrm{~A} \\
\mathrm{~F} 1 \\
\mathrm{red} . \\
\end{array}$ & $\begin{array}{r}41-1 \mathrm{~A} \\
\mathrm{~F} 1 \\
\text { red. } \\
\end{array}$ & $\begin{array}{r}68-1 \mathrm{~A} \\
\mathrm{~F} 1 \\
\mathrm{red} . \\
\end{array}$ & $\begin{array}{r}68-1 \mathrm{AA} \\
\mathrm{F} 1 \\
\mathrm{red} \\
\end{array}$ & $\begin{array}{r}68-1 A B \\
F 1 \\
\text { red. } \\
\end{array}$ & $\begin{array}{r}68-1 \mathrm{AC} \\
\mathrm{F1} \\
\mathrm{red}\end{array}$ & $\begin{array}{r}69-1 \mathrm{~B} \\
\mathrm{~F} 1 \\
\text { red. } \\
\end{array}$ & $\begin{array}{r}71-1 \mathrm{~A} \\
\mathrm{~F} 1 \\
\text { red. } \\
\end{array}$ & $\begin{array}{r}71-1 \mathrm{~B} \\
\mathrm{~F} 1 \\
\mathrm{red} \\
\end{array}$ & $\begin{array}{r}4-1 A \\
F 1 \\
\text { red. }\end{array}$ \\
\hline \multicolumn{11}{|l|}{$\%$-peso } \\
\hline $\mathrm{SiO}_{2}$ & 56.77 & 58.28 & 54.10 & 55.22 & 55.50 & 54.13 & 55.68 & 57.19 & 58.23 & 53.5 \\
\hline $\mathrm{THO}_{2}$ & 0.36 & 0.17 & 0.52 & 0.50 & 0.52 & 0.52 & 0.46 & 0.24 & 0.24 & 0.3 \\
\hline $\mathrm{Al} 2 \mathrm{O} 3$ & 24.70 & 22.88 & 21.46 & 22.64 & 22.14 & 21.77 & 22.29 & 24.11 & 21.54 & 19.4 \\
\hline Fe203tot & 0.92 & 0.88 & 4.07 & 3.81 & 3.76 & 3.72 & 3.65 & 0.80 & 1.73 & 4.4 \\
\hline $\mathrm{MnO}$ & 0.10 & 0.01 & 0.01 & 0.10 & 0.10 & 0.10 & 0.10 & 10 & 0.10 & 0.0 \\
\hline $\mathrm{MgO}$ & 0.03 & 0.02 & 0.11 & 0.09 & 0.12 & 0.10 & 0.10 & 0.06 & 0.03 & 0.2 \\
\hline $\mathrm{CaO}$ & 0.10 & 0.10 & 0.10 & 0.10 & 0.01 & 0.10 & 0.10 & 0.10 & 0.10 & 0.5 \\
\hline $\mathrm{Na} 2 \mathrm{O}$ & 0.28 & 1.00 & 1.31 & 0.24 & 0.25 & 0.18 & 0.20 & 0.16 & 0.42 & 0.3 \\
\hline $\mathrm{K} 2 \mathrm{O}$ & 11.99 & 14.20 & 12.96 & 13.20 & 13.28 & 13.06 & 13.44 & 13.07 & 13.25 & 12.3 \\
\hline P2O5 & 0.05 & 0.05 & 0.05 & 0.05 & 0.05 & 0.05 & 0.05 & 5 & 0.05 & 0.0 \\
\hline LOI/PF & 4.10 & 2.44 & 4.84 & 3.99 & 3.94 & 4.29 & 3.79 & 3.68 & 3.14 & 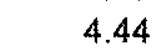 \\
\hline \multicolumn{11}{|l|}{$\mathrm{CO} 2$} \\
\hline $\begin{array}{l}\text { Total } \\
\text { ppm }\end{array}$ & 99.40 & 100.03 & 99.53 & 99.94 & 9.67 & 98.02 & 99.86 & 99.56 & 98.83 & 95.7 \\
\hline As & & & 10.00 & & & & & & & \\
\hline $\mathrm{Ba}$ & 418.00 & 553.00 & 383.00 & 310.00 & 298.00 & 00 & 345.00 & 457.00 & 17.00 & 33.0 \\
\hline $\mathrm{Ce}$ & 746.00 & 468.00 & 188.00 & 178.00 & 157.00 & 00 & 82.00 & 221.00 & $\$ 79.00$ & $\$ 272.00$ \\
\hline Co & 7.00 & 1.00 & 1.00 & 1.00 & 1.00 & 1.00 & 1.00 & 1.00 & 1.00 & 1.00 \\
\hline $\mathrm{Cu}$ & 1.00 & 4.00 & 1.00 & 1.00 & 1.00 & 1.00 & 1.00 & 1.00 & 4.00 & 6.0 \\
\hline $\mathrm{Cr}$ & 1.00 & 1.00 & 14.00 & 1.00 & 1.00 & 1.00 & 1.00 & 1.00 & 1.00 & 46. \\
\hline$F$ & & & & 1091.00 & 1220.00 & 883.00 & 953.00 & 1003.00 & & \\
\hline Ga & 29.00 & 34.00 & 47.00 & & & & & & 39.00 & 45.0 \\
\hline $\mathrm{Hf}$ & & & & 15.00 & 7.00 & 2.00 & 6.00 & 0.00 & & \\
\hline La & 28.00 & 556.00 & 213.00 & 233.00 & 229.00 & 20 & 260.00 & 291.00 & 337.00 & 6843.0 \\
\hline $\mathrm{Nb}$ & .00 & 00 & 306.00 & 244.00 & 00 & 00 & 249.00 & 395 & 445.00 & 240.0 \\
\hline $\mathrm{Nd}$ & 4.00 & 128.00 & 46.00 & 33.00 & 25.00 & 16.00 & 31.00 & 43.00 & 145.00 & 1854.0 \\
\hline $\mathrm{Ni}$ & .00 & 7.00 & 6.00 & 1.00 & 1.00 & 1.00 & 1.00 & 1.00 & 10.00 & 47.0 \\
\hline $\mathrm{Pb}$ & .00 & 00 & 22.00 & 15.00 & 13.00 & 1.00 & 1.00 & 1.00 & 1.00 & 27.0 \\
\hline $\mathrm{Rb}$ & 9.00 & 347.00 & 309.00 & 299.00 & 295.00 & 77.00 & 296.00 & 299.00 & 316.00 & 273.0 \\
\hline$S$ & 83.00 & 2545.00 & 1414.00 & 1527.00 & 7384.00 & 7115 & 5821.00 & 2164.00 & 6785.00 & 18153.00 \\
\hline Sc & 2.00 & & & 5.00 & 4.00 & 3.00 & 4.00 & 4.00 & 1.00 & 1.0 \\
\hline $\mathrm{Sr}$ & 80.00 & & 0 & 192.00 & 00 & 148.00 & 132.00 & 109.00 & 97.00 & 183.0 \\
\hline Th & .00 & .00 & & 9.00 & 12.00 & 8.00 & 14.00 & 13.00 & 31.00 & 6.0 \\
\hline $\mathrm{U}$ & 29.00 & .00 & .00 & 61.00 & 45.00 & 25.00 & 86.00 & 206.00 & 89.00 & 17.0 \\
\hline V & 65.00 & 109.00 & 318.00 & 259.00 & 244.00 & 251.00 & 231.00 & 134.00 & 72.00 & $\$ 16.00$ \\
\hline$Y$ & 92.00 & & 38.00 & 48.00 & 39.00 & 23.00 & 43.00 & 22.00 & 50.00 & 461.0 \\
\hline $\mathrm{Zn}$ & 1.00 & 22.00 & 21.00 & 11.00 & 11.00 & 13.00 & 16.00 & 2.00 & 9.00 & 714.0 \\
\hline $\mathrm{Zr}$ & 333.00 & 251.00 & 826.00 & 1425.00 & 1004.00 & 588.00 & 806.00 & 198.00 & 2222.00 & 1109.0 \\
\hline
\end{tabular}


Tabela I.6 A : Continuação.

\begin{tabular}{|c|c|c|c|c|c|c|c|c|c|c|}
\hline $\begin{array}{c}\text { Amostra } \\
\text { Furo } \\
\text { Litotipo }\end{array}$ & $\begin{array}{r}75-1 \mathrm{BA} \\
\mathrm{F} 1 \\
\mathrm{red} .\end{array}$ & $\begin{array}{r}\text { 75-1BB } \\
\mathrm{F} 1 \\
\text { red. }\end{array}$ & $\begin{array}{r}77-1 \mathrm{~A} \\
\mathrm{~F} 1 \\
\text { red. }\end{array}$ & $\begin{array}{r}77-1 B \\
F 1 \\
\text { red. }\end{array}$ & $\begin{array}{r}78-1 \mathrm{~A} \\
\mathrm{~F} 1 \\
\text { red. }\end{array}$ & $\begin{array}{r}81-1 \mathrm{~A} \\
\mathrm{~F} 1 \\
\text { red. }\end{array}$ & $\begin{array}{r}\text { 85-1A } \\
F 1 \\
\text { red. }\end{array}$ & $\begin{array}{r}90-1 \mathrm{~B} \\
\mathrm{~F} 1 \\
\text { red. }\end{array}$ & $\begin{array}{r}91-1 A \\
F 1 \\
\text { red. }\end{array}$ & $\begin{array}{r}95-1 A \\
F 1 \\
\text { red. }\end{array}$ \\
\hline \multicolumn{11}{|l|}{$\%$-peso } \\
\hline $\mathrm{SiO}_{2}$ & 55.82 & 56.53 & 56.51 & 56.59 & 56.70 & 56.10 & 51.82 & 56.01 & 56.52 & 57.71 \\
\hline $\mathrm{TiO} 2$ & 0.47 & 0.45 & 0.44 & 0.46 & 0.43 & 0.46 & 0.42 & 0.47 & 0.46 & 0.57 \\
\hline $\mathrm{Al} 2 \mathrm{O} 3$ & 21.60 & 21.77 & 21.90 & 21.71 & 21.51 & 21.69 & 20.59 & 21.73 & 22.12 & 23.23 \\
\hline $\mathrm{Fe} 2 \mathrm{O} 3$ tot & 3.28 & 3.18 & 2.83 & 2.96 & 3.51 & 3.28 & 6.41 & 3.41 & 2.63 & 0.90 \\
\hline Mno & 0.01 & 0.10 & 0.10 & 0.10 & 0.10 & 0.01 & 1.48 & 0.10 & 0.01 & 0.01 \\
\hline $\mathrm{MgO}$ & 0.04 & 0.10 & 0.06 & 0.09 & 0.10 & 0.02 & 0.24 & 0.07 & 0.01 & 0.01 \\
\hline $\mathrm{CaO}$ & 0.23 & 0.22 & 0.03 & 0.30 & 0.09 & 0.01 & 0.21 & 0.01 & 0.01 & 0.01 \\
\hline $\mathrm{Na} 2 \mathrm{O}$ & 0.58 & 0.33 & 0.43 & 0.36 & 0.29 & 0.33 & 0.49 & 0.68 & 0.30 & 0.38 \\
\hline $\mathrm{K} 2 \mathrm{O}$ & 13.70 & 13.76 & 13.96 & 13.86 & 14.04 & 14.04 & 11.39 & 13.01 & 13.06 & 14.49 \\
\hline P2O5 & 0.03 & 0.03 & 0.04 & 0.04 & 0.05 & 0.04 & 0.05 & 0.03 & 0.05 & 0.06 \\
\hline LOI/PF & 3.32 & 3.03 & 3.10 & 3.09 & 3.10 & 2.96 & 6.13 & 3.77 & 3.59 & 1.73 \\
\hline \multicolumn{11}{|l|}{$\mathrm{CO} 2$} \\
\hline $\begin{array}{l}\text { Total } \\
\text { ppm }\end{array}$ & 99.08 & 99.50 & 99.40 & 99.56 & 99.92 & 98.94 & 99.23 & 99.29 & 98.76 & 99.10 \\
\hline AS & & & & & & & & & 7.00 & \\
\hline $\mathrm{Ba}$ & 375.00 & 415.00 & 445.00 & 477.00 & 451.00 & 477.00 & 973.00 & 1668.00 & 631.00 & 710.00 \\
\hline $\mathrm{Ce}$ & 335.00 & 208.00 & 278.00 & 205.00 & 141.00 & 203.00 & 362.00 & 308.00 & 351.00 & 398.00 \\
\hline Co & 1.00 & 1.00 & 1.00 & 1.00 & 1.00 & 1.00 & 1.00 & 1.00 & 1.00 & 1.00 \\
\hline $\mathrm{Cu}$ & 4.00 & 1.00 & 4.00 & 1.00 & 1.00 & 4.00 & 4.00 & 4.00 & 4.00 & 4.00 \\
\hline $\mathrm{Cr}$ & 1.00 & 1.00 & 1.00 & 1.00 & 1.00 & 1.00 & 1.00 & 1.00 & 1.00 & 1.00 \\
\hline $\mathrm{F}$ & & 2660.00 & & 2888.00 & 1527.00 & & & & & \\
\hline $\mathrm{Ga}$ & 38.00 & & 32.00 & & & 34.00 & 31.00 & 28.00 & 26.00 & 40.00 \\
\hline $\mathrm{Hf}$ & & 4.00 & & 4.00 & 5.00 & & & & & \\
\hline $\mathrm{La}$ & 272.00 & 281.00 & 226.00 & 248.00 & 170.00 & 00 & 232.00 & 20 & 241.00 & 327.00 \\
\hline $\mathrm{Nb}$ & 211.00 & 234.00 & 235.00 & 207.00 & 222.00 & 243.00 & 247.00 & 20 & 241.00 & 241.00 \\
\hline $\mathrm{Nd}$ & 85.00 & 31.00 & 69.00 & 29.00 & 12.00 & 49.00 & 76.00 & 52.00 & 78.00 & 89.00 \\
\hline $\mathrm{Ni}$ & .00 & & 0 & 1.00 & .00 & 5.00 & 6.00 & 5.00 & 6.00 & 5.00 \\
\hline $\mathrm{Pb}$ & 1.00 & 1.00 & 1.00 & .00 & 00 & 00 & .00 & .00 & 1.00 & 1.00 \\
\hline$R b$ & 01.00 & 283.00 & 302.00 & 299.00 & 300.00 & 15.00 & 64.00 & 86.00 & 02.00 & 342.00 \\
\hline$S$ & 4074.00 & 1024.00 & 1477.00 & 9447.00 & 8004.00 & 3139.00 & 9126.00 & 9120.00 & 12576.00 & 890.00 \\
\hline Sc & 1.00 & 4.00 & 1.00 & 4.00 & 4.00 & 1.00 & 1.00 & 1.00 & 1.00 & 1.00 \\
\hline $\mathrm{Sr}$ & 216.00 & 307.00 & 122.00 & 167.00 & 171.00 & 112.00 & 174.00 & 96.00 & 121.00 & 170.00 \\
\hline Th & 5.00 & 1.00 & 21.00 & 1.00 & 5.00 & 21.00 & 41.00 & 14.00 & 22.00 & 26.00 \\
\hline U & 20.00 & 5.00 & 17.00 & 3.00 & 30.00 & 30.00 & 37.00 & 25.00 & 14.00 & 13.00 \\
\hline $\mathrm{V}$ & 142.00 & 161.00 & 113.00 & 153.00 & 262.00 & 111.00 & 82.00 & 102.00 & 96.00 & 299.00 \\
\hline$Y$ & 34.00 & 29.00 & 38.00 & 30.00 & 19.00 & 23.00 & 39.00 & 32.00 & 35.00 & 54.00 \\
\hline $\mathrm{Zn}$ & 753.00 & 843.00 & 299.00 & 413.00 & 311.00 & 93.00 & 520.00 & 123.00 & 432.00 & 25.00 \\
\hline $\mathrm{Zr}$ & 706.00 & 655.00 & 544.00 & 767.00 & 851.00 & 667.00 & 645.00 & 1218.00 & 894.00 & 453.00 \\
\hline
\end{tabular}


Tabela I.6 A : Continuação.

\begin{tabular}{|c|c|c|c|c|c|c|c|c|c|}
\hline $\begin{array}{c}\text { Amostra } \\
\text { Furo } \\
\text { Litotipo }\end{array}$ & $\begin{array}{r}101-1 \mathrm{~A} \\
\mathrm{~F} 1 \\
\text { red. } \\
\end{array}$ & $\begin{array}{r}\text { 104-1A } \\
\mathrm{F} 1 \\
\mathrm{red} \\
\end{array}$ & $\begin{array}{r}\text { 105-1A } \\
\mathrm{F} 1 \\
\text { red. } \\
\end{array}$ & $\begin{array}{r}106-1 \mathrm{~A} \\
\mathrm{~F} 1 \\
\text { red. }\end{array}$ & $\begin{array}{r}107-1 \mathrm{~A} \\
\mathrm{~F} 1 \\
\text { red. } \\
\end{array}$ & $\begin{array}{r}109-1 \mathrm{~A} \\
\mathrm{~F} 1 \\
\text { red. } \\
\end{array}$ & $\begin{array}{r}109-1 \mathrm{~B} \\
\mathrm{~F} 1 \\
\text { red. } \\
\end{array}$ & $\begin{array}{r}111-1 \mathrm{~A} \\
\mathrm{~F} 1 \\
\text { red. } \\
\end{array}$ & $\begin{array}{r}112-1 \mathrm{~A} \\
\mathrm{~F} 1 \\
\mathrm{red} \\
\end{array}$ \\
\hline \multicolumn{10}{|l|}{$\%$-peso } \\
\hline $\mathrm{SiO} 2$ & 55.33 & 56.71 & 48.40 & 56.20 & 56.96 & 51.20 & 56.88 & 56.09 & 55.97 \\
\hline $\mathrm{TiO} 2$ & 52 & 0.55 & 0.37 & 0.48 & 0.52 & 0.72 & 0.51 & 0.48 & 0.56 \\
\hline $\mathrm{Al} 2 \mathrm{O} 3$ & 21.95 & 21.73 & 20.48 & 21.66 & 21.92 & 25.54 & 22.25 & 22.18 & 18.51 \\
\hline Fe203tot & 3.75 & 2.38 & 1.56 & 3.20 & 2.56 & 3.84 & 2.28 & 3.12 & 5.64 \\
\hline MnO & 0.10 & 0.01 & 0.10 & 0.10 & 0.01 & 0.03 & 0.10 & 0.10 & 0.10 \\
\hline $\mathrm{MgO}$ & 0.01 & 0.04 & 0.01 & 0.02 & 0.04 & 0.07 & 0.06 & 0.03 & 0.02 \\
\hline $\mathrm{CaO}$ & 0.01 & 0.01 & 0.09 & 0.01 & 0.01 & 0.46 & 0.01 & 0.01 & 0.01 \\
\hline $\mathrm{Na} 2 \mathrm{O}$ & 0.35 & 0.13 & 0.49 & 0.86 & 0.07 & 0.36 & 0.23 & 0.43 & 0.54 \\
\hline $\mathrm{K} 2 \mathrm{O}$ & 13.48 & 13.40 & 10.40 & 13.86 & 13.61 & 8.23 & 13.51 & 13.96 & 13.85 \\
\hline P2O5 & .03 & 0.11 & 0.68 & 0.10 & 0.06 & 0.09 & 0.09 & 0.05 & 0.04 \\
\hline LOI/PF & 3.55 & 3.34 & 5.33 & 3.13 & 3.24 & 7.50 & 3.47 & 2.99 & 3.70 \\
\hline \multicolumn{10}{|l|}{$\mathrm{CO} 2$} \\
\hline $\begin{array}{l}\text { Total } \\
\text { ppm }\end{array}$ & 99.08 & 98.41 & 87.91 & 99.62 & 99.00 & 98.04 & 99.39 & 99.44 & 8.94 \\
\hline \multicolumn{10}{|l|}{ As } \\
\hline $\mathrm{Ba}$ & 607.00 & 1095.00 & 937.00 & 779.00 & 719.00 & 446.00 & 891.00 & 89.00 & 376.00 \\
\hline $\mathrm{Ce}$ & 339.00 & 258.00 & 22807.00 & 435.00 & 240.00 & 446.00 & 243.00 & 371.00 & 572.00 \\
\hline Co & 1.00 & 1.00 & 9.00 & 1.00 & 1.00 & 1.00 & 1.00 & 1.00 & 1.00 \\
\hline $\mathrm{Cu}$ & 4.00 & 1.00 & 21.00 & 4.00 & 1.00 & 1.00 & 1.00 & 4.00 & 4.00 \\
\hline $\mathrm{Cr}$ & 1.00 & 1.00 & 102.00 & 1.00 & 1.00 & 1.00 & 1.00 & 1.00 & 1.00 \\
\hline$F$ & & & & & \multicolumn{5}{|c|}{1102.00} \\
\hline $\mathrm{Ga}$ & 36.00 & 56.00 & 34.00 & 41.00 & 42.00 & 37.00 & & 36.00 & 41.00 \\
\hline $\mathrm{Hf}$ & & & & & & & 8.00 & & \\
\hline La & 264.00 & 168.00 & 14204.00 & 276.00 & 155.00 & 259.00 & 308.00 & 259.00 & 322.00 \\
\hline $\mathrm{Nb}$ & 248.00 & 202.00 & .00 & 225.00 & 229.00 & 336.00 & 205.00 & 286.00 & 507.00 \\
\hline $\mathrm{Nd}$ & 71.00 & 22.00 & 5578.00 & 97.00 & 41.00 & 65.00 & 41.00 & 88.00 & 187.00 \\
\hline $\mathrm{Ni}$ & 7.00 & 1.00 & 93.00 & 12.00 & 1.00 & 1.00 & 1.00 & 6.00 & 15.00 \\
\hline $\mathrm{Pb}$ & 1.00 & 7.00 & 1202.00 & 9.00 & 1.00 & 1.00 & 1.00 & 48.00 & 2.00 \\
\hline $\mathrm{Rb}$ & 292.00 & 16.00 & 151.00 & 292.00 & 331.00 & 197.00 & 286.00 & 304.00 & 290.00 \\
\hline$S$ & 17483.00 & 10081.00 & 7548.00 & 14482.00 & 10079.00 & 15148.00 & 842.00 & 11823.00 & 29553.00 \\
\hline Sc & 1.00 & 7.00 & 8.00 & 1.00 & 7.00 & 4.00 & 4.00 & 1.00 & 1.00 \\
\hline $\mathrm{Sr}$ & 109 & 480.00 & 689.00 & 453.00 & 255.00 & 112.00 & 421.00 & 237.00 & 289.00 \\
\hline Th & 0 & 127.00 & 3651.00 & 91.00 & 29.00 & 12.00 & 83.00 & 59.00 & 45.00 \\
\hline$U$ & 31.00 & 18.00 & 210.00 & 51.00 & 25.00 & 94.00 & 10.00 & 24.00 & 24.00 \\
\hline V & 208.00 & 592.00 & 247.00 & 258.00 & 311.00 & 90.00 & 408.00 & 176.00 & 185.00 \\
\hline Y & 48.00 & 89.00 & 970.00 & 127.00 & 67.00 & 77.00 & 68.00 & 59.00 & 110.00 \\
\hline $\mathrm{Zn}$ & 213.00 & 139.00 & 4424.00 & 145.00 & 107.00 & 119.00 & 151.00 & 83.00 & 188.00 \\
\hline $\mathrm{Zr}$ & 970.00 & 2323.00 & 405.00 & 1559.00 & 1754.00 & 2084.00 & 898.00 & 855.00 & 2785.00 \\
\hline
\end{tabular}


Tabela I.6 A : Continuação.

\begin{tabular}{|c|c|c|c|c|c|c|c|c|c|}
\hline $\begin{array}{l}\text { Amostra } \\
\text { Furo } \\
\text { Litotipo }\end{array}$ & $\begin{array}{r}112-1 \mathrm{AD} \\
\mathrm{F} 1 \\
\mathrm{red} \\
\end{array}$ & $\begin{array}{r}113-1 A \\
F 1 \\
\text { red. } \\
\end{array}$ & $\begin{array}{r}113-1 \mathrm{~B} \\
\mathrm{~F} 1 \\
\text { red. } \\
\end{array}$ & $\begin{array}{r}115-1 \mathrm{~A} \\
\mathrm{~F} 1 \\
\text { red. }\end{array}$ & $\begin{array}{r}117-1 \mathrm{~A} \\
\mathrm{~F} 1 \\
\mathrm{red} \\
\end{array}$ & $\begin{array}{r}118-1 \mathrm{~A} \\
\mathrm{F1} \\
\text { red. } \\
\end{array}$ & $\begin{array}{r}119-1 \mathrm{~A} \\
\mathrm{~F} 1 \\
\text { red. } \\
\end{array}$ & $\begin{array}{r}121-1 \mathrm{~A} \\
\mathrm{~F} 1 \\
\mathrm{red} \\
\end{array}$ & $\begin{array}{r}126-1 \mathrm{~A} \\
\mathrm{~F} 1 \\
\mathrm{red} \\
\end{array}$ \\
\hline \multicolumn{10}{|l|}{$\%$-peso } \\
\hline $\mathrm{SiO} 2$ & 56.36 & 59.03 & 59.51 & 55.46 & 55.73 & 56.86 & 56.15 & 61.54 & 56.09 \\
\hline TiO2 & 0.41 & 0.08 & 0.39 & 0.47 & 0.55 & 0.32 & 0.49 & 0.08 & 0.45 \\
\hline $\mathrm{Al} 2 \mathrm{O} 3$ & 21.71 & 22.18 & 21.63 & 18.43 & 22.44 & 21.76 & 22.66 & 19.12 & 22.10 \\
\hline Fe2O3tot & 3.09 & 0.73 & 0.99 & 3.49 & 3.34 & 2.75 & 2.44 & 0.84 & 1.83 \\
\hline $\mathrm{MnO}$ & 0.10 & 0.01 & 0.10 & 0.02 & 0.10 & 0.02 & 0.02 & 0.01 & 0.13 \\
\hline $\mathrm{MgO}$ & 0.08 & 0.02 & 0.05 & 0.01 & 0.07 & 0.04 & 0.02 & 0.01 & 0.02 \\
\hline $\mathrm{CaO}$ & 0.01 & 0.50 & 0.28 & 0.54 & 0.13 & 0.02 & 0.06 & 0.24 & 1.09 \\
\hline $\mathrm{Na} 2 \mathrm{O}$ & 0.36 & 0.05 & 0.21 & 0.11 & 0.39 & 0.28 & 0.44 & 0.60 & 0.32 \\
\hline $\mathrm{K} 2 \mathrm{O}$ & 13.60 & 14.13 & 14.42 & 14.23 & 12.64 & 13.24 & 12.86 & 15.02 & 13.25 \\
\hline P2O5 & 0.04 & 0.07 & 0.06 & 0.05 & 0.06 & 0.09 & 0.07 & 0.05 & 0.05 \\
\hline LOI/PF & 3.25 & 2.17 & 2.21 & 3.12 & 4.11 & 3.58 & 3.70 & 1.25 & 3.50 \\
\hline \multicolumn{10}{|l|}{$\mathrm{CO} 2$} \\
\hline $\begin{array}{l}\text { Total } \\
\text { ppm }\end{array}$ & 99.01 & 98.97 & 99.85 & 95.93 & 99.56 & 98.96 & 98.91 & 98.76 & 98.83 \\
\hline As & & & & & & & 7.00 & & 17.00 \\
\hline $\mathrm{Ba}$ & 634.00 & 882.00 & 761.00 & 620.00 & 660.00 & 786.00 & 783.00 & 715.00 & 750.00 \\
\hline $\mathrm{Ce}$ & 535.00 & 341.00 & 374.00 & 263.00 & 230.00 & 293.00 & 321.00 & 310.00 & 355.00 \\
\hline Co & 1.00 & 1.00 & 1.00 & 1.00 & 1.00 & 1.00 & 1.00 & 1.00 & 1.00 \\
\hline $\mathrm{Cu}$ & 1.00 & 1.00 & 1.00 & 1.00 & 1.00 & 1.00 & 4.00 & 4.00 & 4.00 \\
\hline $\mathrm{Cr}$ & 1.00 & 1.00 & 1.00 & 1.00 & 1.00 & 1.00 & 1.00 & 1.00 & 1.00 \\
\hline$F$ & 1331.00 & & 2343.00 & & 1098.00 & & & & \\
\hline Ga & & 40.00 & & 43.00 & & 43.00 & 31.00 & 29.00 & 37.00 \\
\hline $\mathrm{Hf}$ & 38.00 & & 6.00 & & 23.00 & & & & \\
\hline La & 504.00 & 193.00 & 417.00 & 140.00 & 259.00 & 167.00 & 227.00 & 233.00 & 301.00 \\
\hline $\mathrm{Nb}$ & 224.00 & 17.00 & 91.00 & 332.00 & 303.00 & 76.00 & 338.00 & 83.00 & 97.00 \\
\hline $\mathrm{Nd}$ & 127.00 & 60.00 & 68.00 & 44.00 & 47.00 & 41.00 & 69.00 & 65.00 & 82.00 \\
\hline $\mathrm{Ni}$ & 1.00 & 1.00 & 1.00 & 1.00 & 1.00 & 1.00 & 1.00 & 1.00 & 1.00 \\
\hline $\mathrm{Pb}$ & 11.00 & 2.00 & 2.00 & 2.00 & 2.00 & 2.00 & 2.00 & 2.00 & 2.00 \\
\hline $\mathrm{Rb}$ & 305.00 & 345.00 & 331.00 & 331.00 & 284.00 & 305.00 & 286.00 & 379.00 & 301.00 \\
\hline$S$ & 4191.00 & 2459.00 & 3831.00 & 14668.00 & 3743.00 & 11741.00 & 1914.00 & 2366.00 & 5273.00 \\
\hline Sc & 4.00 & 7.00 & 4.00 & 7.00 & 4.00 & 6.00 & 1.00 & 1.00 & 1.00 \\
\hline $\mathrm{Sr}$ & 180.00 & 240.00 & 188.00 & 134.00 & 155.00 & 100.00 & 128.00 & 130.00 & 206.00 \\
\hline Th & 35.00 & 52.00 & 22.00 & 21.00 & 13.00 & 26.00 & 51.00 & 40.00 & 14.00 \\
\hline U & 1.00 & 17.00 & 1.00 & 80.00 & 79.00 & 12.00 & 42.00 & 10.00 & 7.00 \\
\hline V & 247.00 & 257.00 & 218.00 & 155.00 & 231.00 & 155.00 & 97.00 & 36.00 & 232.00 \\
\hline$Y$ & 91.00 & 88.00 & 59.00 & 73.00 & 72.00 & 51.00 & 46.00 & 43.00 & 55.00 \\
\hline $\mathrm{Zn}$ & 81.00 & 81.00 & 144.00 & 89.00 & 494.00 & 42.00 & 109.00 & 19.00 & 132.00 \\
\hline $\mathrm{Zr}$ & 2790.00 & 1735.00 & 740.00 & 2139.00 & 2068.00 & 733.00 & 431.00 & 258.00 & 248.00 \\
\hline
\end{tabular}


Tabela 1.6 A: Continuação.

\begin{tabular}{|c|c|c|c|c|c|c|c|c|}
\hline $\begin{array}{l}\text { Amostra } \\
\text { Furo } \\
\text { Litotipo } \\
\end{array}$ & $\begin{array}{r}26-1 \mathrm{AA} \\
\mathrm{F} 1 \\
\text { red. } \\
\end{array}$ & $\begin{array}{r}126-1 \mathrm{~B} \\
\mathrm{~F} 1 \\
\text { red. } \\
\end{array}$ & $\begin{array}{r}91-1 \mathrm{~B} \\
\mathrm{~F} 4 \\
\text { red. } \\
\end{array}$ & $\begin{array}{r}107-1 \mathrm{~A} \\
\mathrm{~F} 4 \\
\text { red. } \\
\end{array}$ & $\begin{array}{r}123-1 \mathrm{~A} \\
\mathrm{~F} 4 \\
\text { red. } \\
\end{array}$ & $\begin{array}{r}129-1 \mathrm{~A} \\
\mathrm{~F} 4 \\
\mathrm{red} \\
\end{array}$ & $\begin{array}{r}265-1 A-B \\
F 4 \\
r e d . \\
\end{array}$ & $\begin{array}{r}\text { Média } \\
\text { todas rs. } \\
\text { reduzidas }\end{array}$ \\
\hline \multicolumn{9}{|l|}{$\%$ - peso } \\
\hline $\mathrm{SiO} 2$ & 56.56 & 55.72 & 52.60 & 54.16 & 55.18 & 52.48 & 50.45 & 55.85 \\
\hline TiO2 & 0.53 & 0.69 & 0.56 & 0.50 & 0.44 & 0.41 & 0.49 & 0.44 \\
\hline $\mathrm{Al} 2 \mathrm{O} 3$ & 22.03 & 21.41 & 22.49 & 23.07 & 20.11 & 18.64 & 22.98 & 21.80 \\
\hline Fe2O3tot & 2.36 & 2.83 & 3.16 & 2.99 & 3.57 & 3.89 & 4.32 & 2.96 \\
\hline $\mathrm{MnO}$ & 0.11 & 0.44 & 0.10 & 0.16 & 0.40 & 0.91 & 0.07 & 0.14 \\
\hline $\mathrm{gO}$ & 0.06 & 0.07 & 0.17 & 0.19 & 0.10 & 0.15 & 0.34 & 0.07 \\
\hline $\mathrm{aO}$ & 0.28 & 0.4 & 1.63 & 1.32 & 1.19 & 2.49 & 0.60 & 0.31 \\
\hline $\mathrm{a} 2 \mathrm{O}$ & 0.31 & 0.4 & 0.80 & 1.90 & 0.55 & 0.53 & 0.62 & 0.44 \\
\hline 20 & 13.62 & 13.2 & 12.77 & 9.46 & 13.27 & 12.24 & 11.30 & 13.16 \\
\hline 205 & 0.06 & 0. & 9 & 0.11 & 0.05 & 0.18 & 0.32 & 0.06 \\
\hline LOI/PF & 3.46 & 3.93 & 3.90 & 4.07 & 2.53 & 3.68 & 4.51 & 3.56 \\
\hline $\mathrm{CO} 2$ & & & 0.19 & 0.44 & 0.69 & 1.42 & & 0.55 \\
\hline $\begin{array}{l}\text { Total } \\
\mathrm{ppm}\end{array}$ & 99.38 & 99.28 & 98.46 & 98.37 & 98.08 & 97.02 & 96.00 & 98.64 \\
\hline . & & & & & & & & 10.25 \\
\hline $\mathrm{Ba}$ & 863.00 & 824.00 & 787.00 & 677.00 & 780.00 & 444.00 & 1135.00 & 648.69 \\
\hline $\mathrm{Ce}$ & 302.00 & 430.0 & 538.00 & 396.00 & 189.00 & 2253.00 & 309.00 & 403.77 \\
\hline$o$ & 1.00 & 1.0 & 4.00 & 5.00 & 5.00 & 9.00 & 5.00 & 1.67 \\
\hline $\mathrm{Cu}$ & 1.00 & 1.0 & 1.00 & 1.00 & 1.00 & 1.00 & 1.00 & 2.23 \\
\hline $\mathrm{Cr}$ & 1.00 & 1.00 & 1.00 & 1.00 & 1.00 & 12.00 & 1.00 & 2.60 \\
\hline$F$ & 2100.00 & 2733.00 & 8101.00 & 5946.00 & 6989,00 & 11579.00 & 3665.00 & 3116.42 \\
\hline $\mathrm{Ga}$ & & & & & & & & 37.27 \\
\hline$H f$ & 0.00 & 1.00 & 1.00 & 1.00 & 25.00 & 57.00 & 63.00 & 14.00 \\
\hline La & 352.00 & 457.00 & 479.00 & 395.00 & 186.00 & .00 & 6.00 & 507.51 \\
\hline $\mathrm{Nb}$ & 100.00 & 131. & 215.00 & 276.00 & 148.00 & .00 & 8.00 & 225.80 \\
\hline $\mathrm{Nd}$ & 49.00 & 71.00 & 108.00 & 70.00 & 35.00 & 41.00 & 312.00 & 126.14 \\
\hline $\mathrm{N}$ & 1.00 & 1.00 & 1.00 & 1.00 & 1.00 & 1.00 & 1.00 & 4.19 \\
\hline $\mathrm{Pb}$ & 2.00 & 2.00 & 5.00 & 51.00 & 11.00 & 9.00 & 43.00 & 8.79 \\
\hline $\mathrm{Rb}$ & 296.00 & 291.00 & 15.00 & 239.00 & 00 & .00 & 77.00 & 298.56 \\
\hline$S$ & 9303.00 & 7972.00 & 18134.00 & 5498.00 & 13441.00 & 22781.00 & 21098.00 & 9316.00 \\
\hline Sc & 5.00 & 6.00 & 3.00 & 1.00 & 4.00 & 3.00 & 5.00 & 3.24 \\
\hline $\mathrm{Sr}$ & 132.00 & 131.00 & 335.00 & 387.00 & 176.00 & 577.00 & 55.00 & 198.28 \\
\hline Th & 10.00 & 5.00 & 28.00 & 17.00 & 17.00 & 62.00 & 214.00 & 31.14 \\
\hline U & 1.00 & 1.00 & .00 & 364.00 & 78.00 & 184.00 & 81.00 & 51.95 \\
\hline V & 471.00 & 393.00 & 345.00 & 336.00 & 192.00 & 146.00 & 279.00 & 213.00 \\
\hline Y & 33.00 & 44.00 & 35.00 & 32.00 & 62.00 & 105.00 & 320.00 & 69.00 \\
\hline $\mathrm{Zn}$ & 77.00 & 139.00 & 37.00 & 79.00 & 6.00 & 68.00 & 506.00 & 185.84 \\
\hline $\mathrm{Zr}$ & 403.00 & 532.00 & 645.00 & 383.00 & 2082.00 & 4529.00 & 4621.00 & 1202.93 \\
\hline
\end{tabular}


Tabela I.6B: Análises por FRX de rochas oxidadas (hidrotermalitos oxidados) com OHF da mina de $U$ Osamu Utsumi, Complexo Alcalino de Poços de Caldas (Projeto Internacional Poços de

Caldas; dados extraídos de Waber et al. 1991; 1992).

\begin{tabular}{|c|c|c|c|c|c|c|c|c|c|c|c|}
\hline $\begin{array}{c}\text { Amostra } \\
\text { Furo } \\
\text { Litotipo } \\
\end{array}$ & $\begin{array}{r}1-1 \mathrm{~B} \\
\mathrm{~F} 1 \\
0 \times \mathrm{O} \\
\end{array}$ & $\begin{array}{r}10-1 \mathrm{~A} \\
\mathrm{~F} 1 \\
\mathrm{oxi} \\
\end{array}$ & $\begin{array}{r}14-1 \mathrm{~A} \\
\mathrm{~F} 1 \\
0 \times i . \\
\end{array}$ & $\begin{array}{r}16-1 \mathrm{~A} \\
\mathrm{~F} 1 \\
0 \times \mathrm{i} \\
\end{array}$ & $\begin{array}{r}20-1 \mathrm{~A} \\
\mathrm{~F} 1 \\
\text { oxi. } \\
\end{array}$ & $\begin{array}{r}20-1 B \\
F 1 \\
0 \times i . \\
\end{array}$ & $\begin{array}{r}23-1 \mathrm{~A} \\
\mathrm{~F} 1 \\
0 \times \mathrm{xi} \\
\end{array}$ & $\begin{array}{r}26-1 A \\
F 1 \\
\text { oxi. } \\
\end{array}$ & $\begin{array}{r}31-1 \mathrm{~A} \\
\mathrm{~F} 1 \\
0 \times 1 \\
\end{array}$ & $\begin{array}{r}3-1 A \\
F 1 \\
\text { oxi. }\end{array}$ & $\begin{array}{r}45-1 A \\
F 1\end{array}$ \\
\hline \multicolumn{12}{|l|}{$\%$ - peso } \\
\hline $\mathrm{SiO} 2$ & 54.49 & 56.05 & 55.51 & 57.30 & 57.04 & 56.02 & 58.32 & 53.67 & 56.67 & 58.61 & 54.5 \\
\hline $\mathrm{O} 2$ & 0.49 & 0.40 & 0.47 & 0.22 & 0.52 & 0.52 & 0.38 & 0.49 & 0.45 & 0.50 & 0.5 \\
\hline 1203 & 24.05 & 23.14 & 23.09 & 22.37 & 23.84 & 22.71 & 21.69 & 23.10 & 24.17 & 21.41 & 23.5 \\
\hline e203tot & 3.65 & 3.50 & 3.57 & 0.70 & 1.18 & 3.30 & 2.03 & 3.56 & 1.46 & .49 & 4.0 \\
\hline ino & 0.01 & 0.01 & 0.01 & 0.01 & 0.01 & 0.01 & 0.01 & 0.01 & 0.01 & .01 & 0.0 \\
\hline$g O$ & 0.02 & 0.01 & 0.04 & 0.05 & 0.04 & 0.02 & 0.06 & 0.05 & 0.03 & 0.04 & $0 . c$ \\
\hline $\mathrm{aO}$ & 0.01 & 0.01 & 0.01 & 0.01 & 0.01 & 0.01 & 0.01 & 0.01 & 0.01 & 0.01 & 0.0 \\
\hline 20 & 0.35 & 0.27 & 0.39 & 3.03 & 0.27 & 0.26 & 0.30 & 2.19 & 0.48 & 0.34 & 0. \\
\hline 20 & 12.33 & 13.64 & 13.62 & 13.53 & 13.42 & 13.58 & 14.33 & 11.76 & 13.10 & 13.81 & 13.1 \\
\hline 205 & 07 & 02 & 0.03 & 0.05 & .05 & .03 & 33 & 0.05 & 0.05 & 0.05 & 0. \\
\hline DI/PF & 3.37 & 2.36 & 2.47 & 2.44 & 3.04 & 2.39 & 1.85 & 3.96 & 2.91 & 2.23 & 2. \\
\hline \multicolumn{12}{|l|}{02} \\
\hline $\begin{array}{l}\text { otal } \\
\text { pm }\end{array}$ & 84 & .41 & 99.21 & 99.71 & 99.42 & 98.85 & 01 & 8.85 & 9.34 & 8.50 & 9. \\
\hline s & & & & 5.00 & & & & 21.00 & & 5.00 & 17.6 \\
\hline a & 7.00 & 568.00 & 618.00 & 767.00 & 650.00 & 626.00 & 733.00 & 4585.00 & .00 & 1497.00 & 510.0 \\
\hline & 5.00 & .00 & 393.00 & 268.00 & 1606.00 & 574.00 & $127 t$ & & 36.00 & 37.00 & 772.0 \\
\hline & 00 & 00 & 00 & 00 & 00 & 1.00 & 30 & 00 & 00 & .00 & 1.0 \\
\hline & 00 & 00 & 1.00 & 17.00 & 00 & 20 & & & .00 & .00 & 4.8 \\
\hline & 10.00 & 0.00 & 10.00 & 14.00 & .00 & 0.00 & 30 & .00 & 10.00 & 10.00 & 12. \\
\hline & & & & & 1100.00 & & 08.00 & & & & \\
\hline $\mathrm{Ba}$ & 7.00 & 35.00 & 42.00 & 42.00 & & 35.00 & 00 & 1.00 & 37.00 & 30.00 & 41. \\
\hline If & & & & & 00 & & 00 & & & & \\
\hline$a$ & .00 & 00 & .00 & .00 & 30 & 1 & 14 & & & 20.00 & 250. \\
\hline & & 12 & 0 & 0 & & 1 & & 00 & .00 & 146.00 & 324.0 \\
\hline id & 00 & .00 & 00 & 71.00 & 0 & 00 & 288.00 & 00 & 31.00 & 22.00 & 97.0 \\
\hline & 0 & bo & 00 & 0 & 30 & 00 & 3.00 & 00 & 3.00 & 3.00 & 7.0 \\
\hline $\mathrm{b}$ & 1.00 & 3.00 & .00 & .00 & 00 & 45.00 & 20 & 00 & 3.00 & 11.00 & 7.0 \\
\hline $\mathrm{b}$ & 21.00 & 350.00 & 359.00 & 414.00 & 43.00 & 351.00 & 00 & & .00 & 3.00 & 313.0 \\
\hline & 5.00 & 5.00 & 5.00 & 00 & 00 & 5.00 & 5.00 & & 64.00 & 127.00 & $62 . c$ \\
\hline Sc & 00 & 00 & 00 & 0 & 0 & 00 & 0 & 00 & 00 & 1.00 & 1 \\
\hline $\mathrm{Sr}$ & 176.00 & 175.00 & 163.00 & 243.00 & .00 & 183.00 & 00 & .00 & .00 & 3.00 & 158. \\
\hline Th & .00 & 18.00 & 14.00 & 10 & .00 & 10 & & 00 & 00 & 217.00 & 30 \\
\hline ) & 1.00 & 3.00 & 2.00 & 00 & 3.00 & 108.00 & 00 & 00 & 00 & 41.00 & 190. \\
\hline 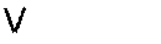 & 238.00 & 150.00 & 156.00 & 212.00 & 196.00 & 143.00 & 00 & 257.00 & 142.00 & 144.00 & 171. \\
\hline$r$ & & 37.00 & 39.00 & 00 & .00 & 55.00 & 103.00 & .00 & 53.00 & 61.00 & 59. \\
\hline $\mathrm{Zn}$ & .00 & 10.00 & 14.00 & 00 & 00 & 00 & 7.00 & 00 & 00 & 1.00 & 5 \\
\hline $\mathrm{Zr}$ & 912.00 & 567.00 & 649.00 & 403.00 & 420.00 & 892.00 & 977.00 & 345.00 & 783.00 & 702.00 & 752. \\
\hline
\end{tabular}


Tabela I.6B: Continuação.

\begin{tabular}{|c|c|c|c|c|c|c|c|c|c|c|}
\hline $\begin{array}{c}\text { Amostra } \\
\text { Furo } \\
\text { Litotipo } \\
\end{array}$ & $\begin{array}{r}47-1 A \\
F 1 \\
0 \times i . \\
\end{array}$ & $\begin{array}{r}\text { 50-1A } \\
\mathrm{F} 1 \\
\text { oxi. } \\
\end{array}$ & $\begin{array}{r}55-1 \mathrm{~A} \\
\mathrm{~F} 1 \\
\text { oxi. } \\
\end{array}$ & $\begin{array}{r}59-1 A \\
F 1 \\
\text { oxi. } \\
\end{array}$ & $\begin{array}{r}59-1 \mathrm{~B} \\
\mathrm{~F} 1 \\
\text { oxi. } \\
\end{array}$ & $\begin{array}{r}63-1 A \\
F 1 \\
0 \times i . \\
\end{array}$ & $\begin{array}{r}19-1 \mathrm{~A} \\
\mathrm{~F} 4 \\
\mathrm{Oxi} \\
\end{array}$ & $\begin{array}{r}22-1 \mathrm{~A} \\
F 4 \\
0 \times 1 . \\
\end{array}$ & $\begin{array}{r}39-1 \mathrm{~A} \\
\mathrm{~F} 4 \\
\text { oxi. } \\
\end{array}$ & $\begin{array}{r}\text { Médias } \\
\text { Todos } \\
\text { R. oxidadas } \\
\end{array}$ \\
\hline \multicolumn{11}{|l|}{$\%$-peso } \\
\hline $\mathrm{SiO}_{2}$ & 56.75 & 57.21 & 56.36 & 54.76 & 54.20 & 54.85 & 53.04 & 53.45 & 54.33 & 55.66 \\
\hline TiO2 & 0.75 & 0.38 & 0.53 & 0.46 & 0.59 & 0.49 & 0.65 & 0.70 & 0.99 & 0.53 \\
\hline $\mathrm{Al} 2 \mathrm{O} 3$ & 22.56 & 23.56 & 22.08 & 23.77 & 23.28 & 24.13 & 25.22 & 24.88 & 23.75 & 23.32 \\
\hline $\mathrm{Fe} 2 \mathrm{O} 3$ tot & 1.97 & 1.46 & 3.30 & 3.71 & 4.33 & 3.72 & 2.79 & 2.41 & 2.57 & 2.74 \\
\hline $\mathrm{MnO}$ & 0.01 & 0.01 & 0.01 & 0.01 & 0.01 & 0.01 & 0.01 & 0.17 & 0.02 & 0.02 \\
\hline $\mathrm{MgO}$ & 0.06 & 0.00 & 0.06 & 0.04 & 0.05 & 0.01 & 0.16 & 0.12 & 0.12 & 0.05 \\
\hline $\mathrm{CaO}$ & 0.01 & 0.01 & 0.01 & 0.01 & 0.01 & 0.01 & 0.04 & 0.02 & 0.02 & 0.01 \\
\hline $\mathrm{Na} 2 \mathrm{O}$ & 0.16 & 0.28 & 0.16 & 0.57 & 0.21 & 0.25 & 1.04 & 0.83 & 0.74 & 0.62 \\
\hline $\mathrm{K} 2 \mathrm{O}$ & 13.75 & 12.84 & 13.03 & 12.59 & 11.79 & 12.45 & 11.64 & 11.96 & 12.48 & 12.94 \\
\hline P2O5 & 0.09 & 0.05 & 0.08 & 0.09 & 0.10 & 0.06 & 0.17 & 0.13 & 0.14 & 0.07 \\
\hline LOl/PF & 2.95 & 3.03 & 3.98 & 3.28 & 4.97 & 3.50 & 3.79 & 3.54 & 2.92 & 3.09 \\
\hline $\mathrm{CO} 2$ & & & & & & & 0.12 & 0.15 & 0.19 & 0.02 \\
\hline $\begin{array}{l}\text { Total } \\
\text { ppm }\end{array}$ & 99.06 & 98.83 & 99.60 & 99.29 & 99.54 & 99.48 & 98.67 & 98.36 & 98.27 & 99.07 \\
\hline As & & & & 50.00 & & & & & & \\
\hline $\mathrm{Ba}$ & 702.00 & 578.00 & 524.00 & 598.00 & 528.00 & 587.00 & 679.00 & 815.00 & 1312.00 & 746.47 \\
\hline $\mathrm{Ce}$ & 2331.00 & 204.00 & 301.00 & 277.00 & 401.00 & 150.00 & 1459.00 & 1658.00 & 659.00 & 479.35 \\
\hline Co & 1.00 & 1.00 & 1.00 & 1.00 & 1.00 & 1.00 & 6.00 & 8.00 & 6.00 & 1.85 \\
\hline $\mathrm{Cu}$ & 1.00 & 4.00 & 1.00 & 4.00 & 1.00 & 4.00 & 1.00 & 1.00 & 1.00 & 3.15 \\
\hline $\mathrm{Cr}$ & 1.00 & 1.00 & 1.00 & 1.00 & 1.00 & 1.00 & 1.00 & 1.00 & 1.00 & 5.55 \\
\hline $\mathrm{F}$ & 1340.00 & & 1095.00 & & 1000.00 & & 1820.00 & 1699.00 & 1544.00 & 1388.25 \\
\hline $\mathrm{Ga}$ & & 29.00 & & 45.00 & & 43.00 & & & & 35.54 \\
\hline Hf & 13.00 & & 11.00 & & 27.00 & & 5.00 & 10.00 & 9.00 & 11.13 \\
\hline La & 412.00 & 183.00 & 428.00 & 298.00 & 361.00 & 281.00 & 1836.00 & 1230.00 & 634.00 & 447.80 \\
\hline $\mathrm{Nb}$ & 184.00 & 70.00 & 236.00 & 278.00 & 328.00 & 256.00 & 264.00 & 264.00 & 299.00 & 193.25 \\
\hline $\mathrm{Nd}$ & 85.00 & 84.00 & 79.00 & 90.00 & 71.00 & 60.00 & 448.00 & 266.00 & 142.00 & 107.30 \\
\hline $\mathrm{Ni}$ & 3.00 & 7.00 & 3.00 & 10.00 & 3.00 & 6.00 & 3.00 & 3.00 & 3.00 & 5.55 \\
\hline $\mathrm{Pb}$ & 35.00 & 3.00 & 31.00 & 29.00 & 27.00 & 59.00 & 39.00 & 313.00 & 43.00 & 28.84 \\
\hline $\mathrm{Rb}$ & 324.00 & 336.00 & 309.00 & 295.00 & 383.00 & 311.00 & 268.00 & 282.00 & 280.00 & 330.50 \\
\hline$s$ & 5.00 & 32.00 & 5.00 & 5.00 & 5.00 & 47.00 & 196.00 & 56.00 & 5.00 & 37.40 \\
\hline Sc & 5.00 & 1.00 & 6.00 & 1.00 & 6.00 & 1.00 & 4.00 & 6.00 & 6.00 & 3.70 \\
\hline $\mathrm{Sr}$ & 160.00 & 196.00 & 180.00 & 207.00 & 211.00 & 226.00 & 123.00 & 144.00 & 100.00 & 174.15 \\
\hline Th & 75.00 & 41.00 & 27.00 & 61.00 & 58.00 & 42.00 & 51.00 & 94.00 & 62.00 & 50.60 \\
\hline$u$ & 212.00 & 91.00 & 153.00 & 263.00 & 308.00 & 198.00 & 107.00 & 118.00 & 101.00 & 48.78 \\
\hline V & 400.00 & 135.00 & 170.00 & 263.00 & 269.00 & 296.00 & 268.00 & 404.00 & 418.00 & 229.85 \\
\hline Y & 68.00 & 86.00 & 66.00 & 101.00 & 141.00 & 56.00 & 83.00 & 147.00 & 120.00 & 75.50 \\
\hline $\mathrm{Zn}$ & 20.00 & 1.00 & 80.00 & 9.00 & 14.00 & 7.00 & 76.00 & 74.00 & 72.00 & 23.45 \\
\hline $\mathrm{Zr}$ & 857.00 & 3057.00 & 1101.00 & 1794.00 & 2208.00 & 596.00 & 616.00 & 1072.00 & 1167.00 & 1043.50 \\
\hline
\end{tabular}


Tabela I-7A: Geoquímica via ICP-MS dos microperfis das frentes redox nas zonas reduzidas.

\begin{tabular}{|c|c|c|c|c|c|c|c|c|c|}
\hline $\begin{array}{c}\text { AMOSTRA } \\
\text { Fd } \\
\text { ppmitipo } \\
\end{array}$ & $\begin{array}{c}\text { IARF-12 } \\
5000 \\
\text { red } \\
\end{array}$ & $\begin{array}{c}\text { AARF-12 } \\
50000 \\
\text { red }\end{array}$ & $\begin{array}{c}\text { IARF-11 } \\
5000 \\
\text { red }\end{array}$ & $\begin{array}{c}\text { IARF-11 } \\
50000 \\
\text { red }\end{array}$ & $\begin{array}{c}\text { IARF-9 } \\
5000 \\
\text { fr.red } \\
\end{array}$ & $\begin{array}{l}\text { IARF-9 } \\
50000 \\
\text { fr.red } \\
\end{array}$ & $\begin{array}{l}\text { IARF-B } \\
5000 \\
\text { fr.red } \\
\end{array}$ & $\begin{array}{l}\text { IARF-8 } \\
50000 \\
\text { fr.red }\end{array}$ & $\begin{array}{c}\text { M2c-5 } \\
5000 \\
\text { red }\end{array}$ \\
\hline As & 6.59 & 5.20 & 22.02 & 25.66 & 5.45 & 8.77 & 8.82 & 13.09 & 6.77 \\
\hline Ba & 739.30 & 902.40 & 623.30 & 736.00 & 582.60 & 806.60 & 1461.00 & 1800.00 & 658.30 \\
\hline $\mathrm{Be}$ & 5.18 & 6.74 & 5.82 & 6.56 & 4.39 & 7.88 & 15.56 & 18.13 & 3.30 \\
\hline $\mathrm{Bi}$ & 0.06 & 0.12 & 0.06 & 0.13 & 0.05 & 0.00 & 0.03 & 0.05 & 0.06 \\
\hline $\mathrm{Ca}$ & 842.30 & 883.90 & 77.40 & 900.10 & 424.10 & 0.00 & 453.20 & 239.70 & 430.90 \\
\hline $\mathrm{Cd}$ & 3.18 & 4.00 & 2.02 & 2.44 & 1.40 & 2.05 & 3.38 & 0.00 & 7.46 \\
\hline $\mathrm{Ce}$ & 372.50 & 425.60 & 328.70 & 348.00 & 133.50 & 173.80 & 130.40 & 128.20 & 738.80 \\
\hline Co & 7.85 & 9.11 & 21.12 & 24.83 & 8.67 & 12.80 & 6.03 & 7.43 & 1.65 \\
\hline $\mathrm{Cr}$ & 16.63 & 11.59 & 31.15 & 31.39 & 26.23 & 15.68 & 14.13 & 26.45 & 3.65 \\
\hline Cs & 0.52 & 0.68 & 0.57 & 0.55 & 0.39 & 0.42 & 0.42 & 0.55 & 0.51 \\
\hline $\mathrm{Cu}$ & 3.35 & 4.13 & 8.71 & 13.91 & 2.93 & 1.29 & 7.97 & 10.47 & 5.53 \\
\hline Dy & 34.36 & 33.67 & 15.37 & 16.97 & 7.74 & 8.62 & 14.06 & 14.11 & 25.98 \\
\hline Er & 25.88 & 23.37 & 9.90 & 10.96 & 4.94 & 6.09 & 10.92 & 10.16 & 12.96 \\
\hline $\mathrm{Eu}$ & 5.30 & 5.00 & 2.75 & 2.60 & 1.55 & 1.50 & 3.08 & 3.80 & 11.48 \\
\hline $\mathrm{Fe}$ & 13230.00 & 15280.00 & 33080.00 & 38970.00 & 15080.00 & 24150.00 & 24970.00 & 30720.00 & 26990.00 \\
\hline Ga & 44.40 & 50.67 & 51.39 & 59.20 & 39.67 & 60.33 & 101.20 & 125.10 & 45.59 \\
\hline Gd & 20.21 & 24.12 & 12.04 & 12.08 & 6.92 & 5.84 & 8.03 & 11.29 & 42.21 \\
\hline $\mathrm{Ge}$ & 1.58 & 2.35 & 2.43 & 0.00 & 1.27 & 2.60 & 1.99 & 7.18 & 4.08 \\
\hline $\mathrm{Hf}$ & 12.00 & 10.64 & 9.45 & 6.68 & 5.95 & 4.90 & 24.21 & 16.80 & 11.39 \\
\hline Ho & 8.48 & 8.96 & 3.52 & 3.94 & 1.75 & 2.07 & 3.49 & 3.08 & 5.08 \\
\hline La & 381.30 & 448.70 & 341.30 & 389.30 & 142.50 & 194.00 & 129.60 & 135.60 & 565.00 \\
\hline $\mathrm{Li}$ & 21.93 & 0.00 & 35.50 & 51.22 & 39.60 & 63.81 & 76.48 & 211.00 & 68.87 \\
\hline Lu & 3.56 & 3.98 & 1.14 & 1.08 & 0.62 & 0.51 & 1.67 & 1.56 & 1.27 \\
\hline $\mathrm{Mg}$ & 147.50 & 229.70 & 199.10 & 321.30 & 174.70 & 252.90 & 399.90 & 516.70 & 350.80 \\
\hline Mn & 38.45 & 42.59 & 47.69 & 50.31 & 50.89 & 75.26 & 108.30 & 130.80 & 46.25 \\
\hline Mo & 654.00 & 716.00 & 408.00 & 447.40 & 180.70 & 228.50 & 257.60 & 288.90 & 157.90 \\
\hline $\mathrm{Nb}$ & 21.62 & 19.71 & 26.31 & 18.42 & 15.55 & 19.68 & 90.12 & 75.98 & 39.15 \\
\hline $\mathrm{Nd}$ & 56.98 & 59.57 & 39.02 & 36.72 & 17.30 & 22.82 & 23.48 & 20.95 & 183.20 \\
\hline $\mathrm{Ni}$ & 2.57 & 3.87 & 9.45 & 9.09 & 51.63 & 68.20 & 1447.00 & 1861.00 & 1.96 \\
\hline $\mathrm{Pb}$ & 46.94 & 43.27 & 41.68 & 48.12 & 28.57 & 25.56 & 30.71 & 35.50 & 58.06 \\
\hline $\mathrm{Pd}$ & 18.95 & 18.92 & 8.04 & 6.59 & 5.57 & 4.03 & 6.87 & 6.22 & 9.83 \\
\hline $\operatorname{Pr}$ & 27.08 & 28.11 & 21.08 & 22.97 & 9.20 & 10.12 & 9.87 & 9.58 & 75.57 \\
\hline $\mathrm{Rb}$ & 226.50 & 254.90 & 215.90 & 230.70 & 178.10 & 240.00 & 358.20 & 425.00 & 216.30 \\
\hline s & 36810.00 & 54060.00 & 47850.00 & 64110.00 & 35210.00 & 61390.00 & 61940.00 & 120400.00 & 76990.00 \\
\hline $\mathrm{Sb}$ & 1.95 & 1.85 & 1.64 & 1.48 & 1.24 & 1.14 & 1.84 & 1.53 & 1.26 \\
\hline $\mathrm{Sc}$ & $\{2.19$ & 14.16 & 4.42 & 4.92 & 2.14 & 3.44 & 5.16 & 6.91 & 1.81 \\
\hline Se & 2.94 & 0.00 & 1.56 & 1.93 & 0.86 & 6.60 & 1.00 & 0.00 & 4.20 \\
\hline $\mathrm{Sm}$ & 11.13 & 10.40 & 5.87 & 6.10 & 2.99 & 3.35 & 5.07 & 4.14 & 28.57 \\
\hline $\mathrm{Sr}$ & 1478.00 & 1928.00 & 1502.00 & 1912.00 & 744.40 & 1059.00 & 590.70 & 715.80 & 610.50 \\
\hline Ta & 0.17 & 0.04 & 0.26 & 0.02 & 0.02 & 0.06 & 0.91 & 0.00 & 0.57 \\
\hline Tb & 4.98 & 4.40 & 2.36 & 2.20 & 1.20 & 1.32 & 1.90 & 2.68 & 5.96 \\
\hline Th & 124.40 & 141.40 & 54.42 & 55.20 & 30.50 & 31.35 & 70.64 & 71.44 & 100.30 \\
\hline $\mathrm{Ti}$ & 1280.00 & 1483.00 & 1826.00 & 2062.00 & 1113.00 & 1468.00 & 4126.00 & 4832.00 & 2708.00 \\
\hline Tm & 4.05 & 4.07 & 1.46 & 1.42 & 0.74 & 0.77 & 1.90 & 1.73 & 1.58 \\
\hline$u$ & 256.30 & 280.20 & 155.90 & 162.50 & 146.70 & 143.80 & 283.60 & 294.30 & 1257.00 \\
\hline v & 260.90 & 318.30 & 345.90 & 400.80 & 258.60 & 365.50 & 601.50 & 735.00 & 224.20 \\
\hline W & 9.28 & 7.51 & 6.46 & 6.21 & 3.97 & 4.38 & 8.96 & 7.26 & 6.80 \\
\hline Y & 291.60 & 326.10 & 125.30 & 130.60 & 57.05 & 75.04 & 122.10 & 141.40 & 158.70 \\
\hline $\mathrm{Yb}$ & 24.43 & 24.53 & 8.44 & 8.35 & 4.20 & 4.06 & 11.30 & 12.30 & 8.52 \\
\hline $\mathrm{Zn}$ & 71.91 & 93.05 & 80.95 & 124.60 & 115.40 & 119.60 & 114.00 & 125.90 & 104.70 \\
\hline $\mathrm{Zr}$ & 1195.00 & 1086.00 & 591.30 & 511.20 & 320.50 & 322.50 & 1222.00 & 1121.00 & 624.30 \\
\hline
\end{tabular}


Tabela 1-7A : Continuação.

\begin{tabular}{|c|c|c|c|c|c|c|c|c|c|}
\hline $\begin{array}{c}\text { AMOSTRA } \\
\text { Fd } \\
\text { ppmitipo } \\
\end{array}$ & $\begin{array}{r}\text { M2c-5 } \\
50000 \\
\text { red } \\
\end{array}$ & $\begin{array}{c}\mathrm{PH}-028-8 \\
5000 \\
\text { red } \\
\end{array}$ & $\begin{array}{c}\mathrm{PH}-028-8 \\
50000 \\
\text { red } \\
\end{array}$ & $\begin{array}{c}\text { PH-028-7 } \\
5000 \\
\text { red } \\
\end{array}$ & $\begin{array}{c}\text { PH-028-7 } \\
50000 \\
\text { red } \\
\end{array}$ & $\begin{array}{c}\mathrm{PH}-028-6 \\
5000 \\
\text { red } \\
\end{array}$ & $\begin{array}{c}\mathrm{PH}-028-6 \\
50000 \\
\text { red } \\
\end{array}$ & $\begin{array}{c}\text { U3c-1 } \\
5000 \\
\text { red } \\
\end{array}$ & $\begin{array}{c}\text { U3c-1 } \\
50000 \\
\text { red } \\
\end{array}$ \\
\hline As & 4.98 & 8.38 & 9.12 & 4.59 & 6.75 & 5.27 & 5.79 & 6.74 & 5.20 \\
\hline $\mathrm{Ba}$ & 793.00 & 458.20 & 549.10 & 508.40 & 682.60 & 497.40 & 594.60 & 350.90 & 443.40 \\
\hline $\mathrm{Be}$ & 3.17 & 5.99 & 11.11 & 4.41 & 3.59 & 3.22 & 3.44 & 4.96 & 5.30 \\
\hline $\mathrm{Bi}$ & 0.15 & 0.04 & 0.02 & 1.18 & 1.45 & 0.02 & 0.06 & 1.48 & 2.00 \\
\hline $\mathrm{Ca}$ & 427.50 & 445.60 & 491.90 & 443.80 & 0.00 & 164.70 & 111.60 & 431.50 & 66.46 \\
\hline $\mathrm{Cd}$ & 6.88 & 1.80 & 0.41 & 2.21 & 1.71 & 1.20 & 0.00 & 10.06 & 9.74 \\
\hline $\mathrm{Ce}$ & 929.10 & 743.90 & 842.60 & 106.50 & 128.90 & 73.90 & 84.14 & 95.32 & 113.10 \\
\hline Co & 2.00 & 4.43 & 4.99 & 20.61 & 3.16 & 1.30 & 1.84 & 0.90 & 1.00 \\
\hline $\mathrm{Cr}$ & 10.27 & 13.44 & 23.89 & 12.85 & 13.63 & 17.46 & 24.17 & 14.66 & 8.88 \\
\hline Cs & 0.59 & 0.31 & 0.43 & 1.36 & 1.81 & 0.22 & 0.27 & 0.25 & 0.32 \\
\hline $\mathrm{Cu}$ & 10.51 & 4.96 & 6.67 & 5.60 & 7.22 & 31.66 & 43.73 & 4.22 & 8.15 \\
\hline Dy & 29.50 & 40.12 & 41.95 & 3.50 & 3.39 & 4.46 & 3.81 & 7.38 & 9.91 \\
\hline $\mathrm{Er}$ & 15.15 & 20.77 & 19.69 & 2.24 & 2.30 & 3.37 & 3.17 & 5.64 & 6.75 \\
\hline Eu & 11.10 & 15.37 & 16.76 & 1.40 & 1.31 & 1.48 & 1.59 & 1.16 & 1.06 \\
\hline $\mathrm{Fe}$ & 34740.00 & 19660.00 & 23670.00 & 20120.00 & 23520.00 & 20130.00 & 24100.00 & 4921.00 & 5525.00 \\
\hline Ga & 56.61 & 55.65 & 61.54 & 52.31 & 55.98 & 42.90 & 53.07 & 42.27 & 47.91 \\
\hline $\mathrm{Gd}$ & 48.00 & 49.68 & 56.28 & 4.68 & 5.03 & 4.17 & 5.13 & 4.69 & 4.91 \\
\hline $\mathrm{Ge}$ & 6.83 & 4.76 & 6.56 & 1.82 & 2.96 & 1.51 & 3.13 & 1.29 & 0.00 \\
\hline $\mathrm{Hf}$ & 9.86 & $\$ 4.87$ & 12.13 & 9.23 & 7.69 & 13.32 & 9.60 & 7.14 & 6.92 \\
\hline Ho & 5.84 & 7.77 & 8.17 & 0.79 & 1.01 & 1.03 & 1.11 & 1.77 & 1.76 \\
\hline La & 700.60 & 460.40 & 479.50 & 88.50 & 108.80 & 73.21 & 79.82 & 74.82 & 90.05 \\
\hline أسا & 91.04 & 94.22 & 176.20 & 94.81 & 51.74 & 79.54 & 146.50 & 47.83 & 48.09 \\
\hline Lu & 1.25 & 1.85 & 2.00 & 0.36 & 0.43 & 0.55 & 0.61 & 1.04 & 1.25 \\
\hline $\mathrm{Mg}$ & 509.20 & 455.40 & 595.80 & 521.90 & 635.30 & 416.80 & 480.70 & 326.00 & 391.50 \\
\hline $\mathrm{Mn}$ & 61.29 & 56.51 & 73.67 & 52.72 & 58.11 & 27.25 & 39.27 & 20.88 & 21.74 \\
\hline Mo & 178.20 & 30.12 & 34.94 & 13.60 & 15.53 & 16.03 & 18.05 & 7.89 & 10.09 \\
\hline $\mathrm{Nb}$ & 36.22 & 34.50 & 23.44 & 25.52 & 23.46 & 39.53 & 31.27 & 22.51 & 23.23 \\
\hline $\mathrm{Nd}$ & 193.30 & 253.80 & 250.00 & 22.68 & 27.02 & 19.64 & 18.48 & 21.48 & 25.14 \\
\hline $\mathrm{Ni}$ & 4.04 & 14.60 & 17.63 & 17.96 & 20.42 & 37.65 & 50.62 & 3.22 & 5.70 \\
\hline $\mathrm{Pb}$ & 66.83 & 849.70 & 922.00 & 26.53 & 28.11 & 21.69 & 20.66 & 27.70 & 36.70 \\
\hline$P d$ & 8.93 & 14.07 & 15.87 & 1.80 & 1.40 & 2.17 & 2.26 & 3.55 & 2.50 \\
\hline $\mathrm{Pr}$ & 86.36 & 87.05 & 90.80 & 8.69 & 9.73 & 6.38 & 6.41 & 9.90 & 12.21 \\
\hline $\mathrm{Rb}$ & 239.30 & 239.10 & 290.20 & 270.40 & 282.00 & 244.30 & 292.60 & 217.50 & 233.60 \\
\hline$S$ & 83520.00 & 57140.00 & 118200.00 & 89540.00 & 0.00 & 61580.00 & 111400.00 & 19480.00 & 0.00 \\
\hline $\mathrm{Sb}$ & 0.95 & 0.87 & 0.84 & 1.98 & 2.23 & 0.69 & 0.71 & 0.41 & 0.40 \\
\hline Sc & 1.34 & 1.80 & 1.81 & 1.58 & 0.23 & 0.94 & 0.00 & 0.94 & 0.43 \\
\hline $\mathrm{Se}$ & 0.00 & 2.88 & 4.83 & 0.86 & 2.11 & 6.09 & 6.84 & 1.14 & 12.65 \\
\hline $\mathrm{Sm}$ & 29.80 & 44.14 & 46.73 & 3.55 & 3.97 & 3.46 & 4.06 & 2.88 & 2.92 \\
\hline $\mathrm{Sr}$ & 684.20 & 245.60 & 308.10 & 216.30 & 238.70 & 179.70 & 223.40 & 244.80 & 269.10 \\
\hline $\mathrm{Ta}$ & 0.35 & 0.33 & 0.72 & 0.33 & 0.13 & 0.73 & 0.77 & 9.34 & 0.24 \\
\hline Tb & 5.99 & 7.78 & 8.85 & 0.68 & 1.03 & 0.73 & 0.74 & 0.98 & 1.05 \\
\hline Th & 116.20 & 53.65 & 49.53 & 13.57 & 15.38 & 16.04 & 14.99 & 25.35 & 29.60 \\
\hline $\mathrm{Ti}$ & 3081.00 & 1737.00 & 1956.00 & 2113.00 & 2193.00 & 2434.00 & 2903.00 & 1923.00 & 2044.00 \\
\hline $\mathrm{Tm}$ & 1.68 & 2.40 & 2.57 & 0.40 & 0.47 & 0.55 & 0.47 & 1.01 & 1.11 \\
\hline U & 1582.00 & & 5495.00 & 278.90 & 380.30 & 341.80 & 300.90 & 1677.00 & 2522.00 \\
\hline V & 275.60 & 270.60 & 303.50 & 257.90 & 268.20 & 223.40 & 267.30 & 157.60 & 167.80 \\
\hline$W$ & 6.04 & 3.49 & 2.23 & 2.51 & 2.75 & 3.37 & 2.59 & 9.08 & 9.47 \\
\hline$Y$ & 162.90 & 237.80 & 279.10 & 29.99 & 32.59 & 34.87 & 39.74 & 55.44 & 60.34 \\
\hline Yb & 9.41 & 12.95 & 14.18 & 3.61 & 4.68 & 3.48 & 3.65 & 6.30 & 8.28 \\
\hline $\mathrm{Zn}$ & 181.00 & 86.62 & 99.66 & 37.76 & 39.84 & 68.67 & 123.60 & 69.73 & 83.99 \\
\hline $\mathrm{Zr}$ & 547.30 & 890.00 & 835.50 & 518.90 & 496.00 & 794.40 & 791.00 & 364.40 & 334.00 \\
\hline
\end{tabular}


Tabela 1-7A : Continuação.

\begin{tabular}{|c|c|c|c|c|c|c|c|c|c|}
\hline $\begin{array}{c}\text { AMOSTRA } \\
\text { Fo } \\
\text { ppmitipo } \\
\end{array}$ & $\begin{array}{l}\text { U3c-2 } \\
5000 \\
\text { fr.red } \\
\end{array}$ & $\begin{array}{l}\text { U3c-2 } \\
50000 \\
\text { fr.red } \\
\end{array}$ & $\begin{array}{r}\text { U3c-3 } \\
5000 \\
\text { fr.red } \\
\end{array}$ & $\begin{array}{l}\text { U3c-3 } \\
50000 \\
\text { fr.red } \\
\end{array}$ & $\begin{array}{r}\text { U3c-7 } \\
5000 \\
\text { red } \\
\end{array}$ & $\begin{array}{r}\text { U3c-7 } \\
50000 \\
\text { red } \\
\end{array}$ & $\begin{array}{c}\text { SN/15-1 } \\
5000 \\
\text { red } \\
\end{array}$ & $\begin{array}{c}\text { SN/15-1 } \\
50000 \\
\text { red } \\
\end{array}$ & $\begin{array}{c}04 / 02-5 \\
5000 \\
\text { red } \\
\end{array}$ \\
\hline As & 4.04 & 3.30 & 5.02 & 10.09 & 2.23 & 2.64 & 15.97 & 24.61 & 9.75 \\
\hline $\mathrm{Ba}$ & 265.40 & 348.00 & 369.20 & 549.20 & 338.00 & 455.20 & 539.40 & 793.60 & 308.10 \\
\hline $\mathrm{Be}$ & 3.54 & 0.53 & 3.72 & 11.16 & 1.45 & 0.00 & 2.26 & 5.78 & 4.77 \\
\hline $\mathrm{Bi}$ & 0.11 & 0.19 & 0.07 & 0.13 & 0.09 & 0.12 & 0.53 & 0.64 & 0.03 \\
\hline $\mathrm{Ca}$ & 378.00 & 339.80 & 68.79 & 0.00 & 414.60 & 374.60 & 1293.00 & 1161.00 & 309.00 \\
\hline $\mathrm{Cd}$ & 5.60 & 4.68 & 2.55 & 2.76 & 5.51 & 8.05 & 1.72 & 2.19 & 5.06 \\
\hline $\mathrm{Ce}$ & 74.70 & 81.82 & 51.31 & 63.75 & 93.52 & 119.50 & 73.81 & 90.45 & 174.30 \\
\hline $\mathrm{Co}$ & 0.61 & 0.84 & 0.58 & 0.55 & 1.23 & 1.15 & 0.54 & 1.04 & 1.99 \\
\hline $\mathrm{Cr}$ & 7.21 & 18.85 & 25.77 & 38.00 & 12.39 & 6.94 & 32.60 & 48.75 & 10.72 \\
\hline Cs & 0.26 & 0.34 & 0.25 & 0.29 & 0.29 & 0.40 & 0.29 & 0.29 & 0.14 \\
\hline $\mathrm{Cu}$ & 4.38 & 3.89 & 4.06 & 5.17 & 65.01 & 86.01 & 10.24 & 12.41 & 7.06 \\
\hline Dy & 3.79 & 4.19 & 7.21 & 8.22 & 4.19 & 6.62 & 3.11 & 3.48 & 9.50 \\
\hline Er & 2.91 & 2.71 & 6.32 & 7.51 & 3.65 & 4.05 & 1.79 & 1.91 & 5.75 \\
\hline Eu & 0.62 & 0.78 & 0.73 & 0.79 & 0.95 & 1.02 & 0.80 & 0.80 & 1.47 \\
\hline $\mathrm{Fe}$ & 5615.00 & 6583.00 & 8785.00 & 13970.00 & 12860.00 & 15430.00 & 4309.00 & 6589.00 & 5932.00 \\
\hline $\mathrm{Ga}$ & 43.11 & 49.44 & 40.12 & 58.33 & 20.88 & 24.24 & 36.98 & 52.28 & 32.65 \\
\hline $\mathrm{Gd}$ & 2.64 & 2.65 & 3.21 & 4.29 & 3.39 & 4.70 & 3.49 & 2.75 & 9.27 \\
\hline $\mathrm{Ge}$ & 0.88 & 1.55 & 1.09 & 0.24 & 1.49 & 0.00 & 1.01 & 1.48 & 0.97 \\
\hline $\mathrm{Hf}$ & 3.85 & 4.45 & 7.74 & 7.38 & 6.67 & 5.86 & 1.81 & 1.58 & 4.27 \\
\hline Ho & 0.88 & 1.00 & 2.00 & 1.92 & 1.03 & 1.31 & 0.68 & 0.66 & 2.03 \\
\hline La & 65.48 & 64.74 & 51.75 & 63.78 & 80.34 & 100.40 & 42.62 & 90.37 & 167.10 \\
\hline أ & 38.25 & 109.60 & 35.31 & 118.20 & 10.58 & 0.00 & 35.12 & 146.70 & 31.80 \\
\hline Lu & 0.56 & 0.61 & 1.08 & 1.42 & 0.67 & 0.72 & 0.28 & 0.34 & 0.52 \\
\hline $\mathrm{Mg}$ & 240.60 & 289.30 & 259.10 & 216.60 & 97.00 & 107.00 & 360.20 & 466.90 & 162.30 \\
\hline $\mathrm{Mn}$ & 14.46 & 21.58 & 39.08 & 57.23 & 71.78 & 82.67 & 28.50 & 34.11 & 68.41 \\
\hline Mo & 6.00 & 6.41 & 10.79 & 14.84 & 6.54 & 8.53 & 10.96 & 13.33 & 225.40 \\
\hline $\mathrm{Nb}$ & 20.34 & 21.83 & 19.29 & 25.76 & 37.45 & 32.49 & 15.60 & 21.46 & 18.75 \\
\hline $\mathrm{Nd}$ & 14.48 & 13.91 & 9.00 & 10.89 & 16.90 & 21.80 & 11.54 & 15.86 & 34.33 \\
\hline $\mathrm{Ni}$ & 1.95 & 4.93 & 9.91 & 11.32 & 10.01 & 10.18 & 41.86 & 54.82 & 249.60 \\
\hline $\mathrm{Pb}$ & 43.20 & 46.41 & 111.90 & 120.00 & 34.70 & 46.75 & 23.39 & 22.15 & 31.99 \\
\hline $\mathrm{Pd}$ & 2.13 & 1.96 & 5.27 & 4.16 & 2.53 & 2.59 & 1.97 & 0.20 & 6.14 \\
\hline $\mathrm{Pr}$ & 6.70 & 7.07 & 4.53 & 5.08 & 7.76 & 10.42 & 5.62 & 7.19 & 14.86 \\
\hline $\mathrm{Rb}$ & 206.50 & 243.80 & 212.40 & 276.60 & 229.50 & 273.20 & 229.40 & 301.00 & 120.90 \\
\hline$S$ & 18000.00 & 16000.00 & 17410.00 & 78370.00 & 6647.00 & 0.00 & 12200.00 & 46930.00 & 15380.00 \\
\hline $\mathrm{Sb}$ & 0.28 & 0.20 & 0.25 & 0.59 & 0.31 & 0.31 & 0.40 & 0.42 & 0.68 \\
\hline Sc & 0.25 & 1.36 & 0.68 & 1.55 & 0.68 & 0.00 & 0.28 & 0.73 & 0.50 \\
\hline $\mathrm{Se}$ & 0.54 & 1.85 & 1.34 & 3.30 & 1.09 & 0.00 & 0.77 & 0.00 & 2.38 \\
\hline $\mathrm{Sm}$ & 1.51 & 1.18 & 1.27 & 1.22 & 1.81 & 2.11 & 1.23 & 1.53 & 3.78 \\
\hline $\mathrm{Sr}$ & 285.00 & 332.30 & 294.40 & 407.90 & 292.60 & 358.10 & 267.30 & 365.40 & 897.30 \\
\hline Ta & 0.06 & 0.02 & 0.02 & 0.08 & 0.47 & 0.26 & 0.15 & 1.08 & 0.12 \\
\hline Tb & 0.53 & 0.56 & 0.76 & 1.01 & 0.65 & 0.71 & 0.50 & 0.57 & 1.46 \\
\hline Th & 12.86 & 12.71 & 24.21 & 23.52 & 39.20 & 50.47 & 26.21 & 32.50 & 32.99 \\
\hline $\mathrm{Ti}$ & 1286.00 & 1485.00 & 1448.00 & 1905.00 & 2403.00 & 2561.00 & 1096.00 & 1476.00 & 1199.00 \\
\hline $\mathrm{Tm}$ & 0.52 & 0.59 & 1.11 & 1.22 & 0.69 & 0.70 & 0.30 & 0.53 & 0.71 \\
\hline U & 890.50 & 1014.00 & 412.80 & 416.80 & 769.80 & 1023.00 & 262.60 & 280.70 & 1089.00 \\
\hline V & 136.70 & 154.00 & 163.50 & 215.00 & 63.41 & 69.77 & 194.60 & 242.40 & 167.20 \\
\hline$W$ & 8.24 & 7.86 & 18.68 & 17.00 & 29.23 & 30.66 & 3.84 & 4.19 & 4.12 \\
\hline$Y$ & 29.80 & 33.57 & 54.74 & 75.62 & 38.97 & 41.65 & 19.65 & 26.19 & 61.23 \\
\hline $\mathrm{Yb}$ & 3.28 & 3.24 & 7.59 & 6.85 & 4.05 & 5.22 & 1.89 & 1.78 & 3.98 \\
\hline $\mathrm{Zn}$ & 78.40 & 89.13 & 70.91 & 124.10 & 25.80 & 42.54 & 66.86 & 42.66 & 4307.00 \\
\hline $\mathrm{Zr}$ & 160.90 & 140.40 & 338.70 & 364.30 & 261.80 & 258.30 & 61.70 & 71.42 & 173.30 \\
\hline
\end{tabular}


Tabela 1-7A : Continuaçäo.

\begin{tabular}{|c|c|c|c|c|c|c|c|c|c|}
\hline $\begin{array}{c}\text { AMOSTRA } \\
\text { Fd } \\
\text { ppmitipo } \\
\end{array}$ & $\begin{array}{c}04 / 02-5 \\
50000 \\
\text { red } \\
\end{array}$ & $\begin{array}{c}04 / 02-4 \\
5000 \\
\text { red } \\
\end{array}$ & $\begin{array}{c}04 / 02-4 \\
50000 \\
\text { red } \\
\end{array}$ & $\begin{array}{c}\text { M2b-1 } \\
5000 \\
\text { red } \\
\end{array}$ & $\begin{array}{c}\text { M2b-1 } \\
50000 \\
\text { red }\end{array}$ & $\begin{array}{c}\text { M2b-2 } \\
5000 \\
\text { red } \\
\end{array}$ & $\begin{array}{c}\text { M2b-2 } \\
50000 \\
\text { red } \\
\end{array}$ & $\begin{array}{c}\text { M2b-7 } \\
5000 \\
\text { red } \\
\end{array}$ & $\begin{array}{c}\text { M2b-7 } \\
50000 \\
\text { red }\end{array}$ \\
\hline As & 11.07 & 31.54 & 35.39 & 30.60 & 35.67 & 53.92 & 61.63 & 34.41 & 32.52 \\
\hline $\mathrm{Ba}$ & 415.40 & 517.50 & 559.30 & 809.30 & 1057.00 & 951.40 & 1252.00 & 805.90 & 1003.00 \\
\hline $\mathrm{Be}$ & 6.62 & 5.70 & 3.65 & 1.39 & 0.52 & 4.60 & 4.34 & 4.23 & 3.31 \\
\hline $\mathrm{Bi}$ & 0.03 & 0.24 & 0.45 & 0.07 & 0.00 & 0.19 & 0.20 & 0.13 & 0.25 \\
\hline $\mathrm{Ca}$ & 228.50 & 608.80 & 560.70 & 301.90 & 791.50 & 607.50 & 578.30 & 404.80 & 375.10 \\
\hline $\mathrm{Cd}$ & 5.48 & 8.11 & 10.95 & 4.10 & 3.61 & 3.81 & 3.06 & 3.47 & 2.36 \\
\hline $\mathrm{Ce}$ & 248.20 & 288.80 & 336.90 & 230.80 & 238.10 & 92.79 & 99.09 & 59.63 & 63.81 \\
\hline Co & 1.74 & 4.26 & 4.35 & 9.09 & 11.04 & 3.79 & 4.57 & 2.74 & 2.58 \\
\hline $\mathrm{Cr}$ & 1.32 & 12.66 & 27.58 & 16.12 & 25.99 & $\$ 7.90$ & 37.31 & 12.91 & 16.25 \\
\hline Cs & 0.12 & 0.44 & 0.40 & 0.21 & 0.31 & 0.23 & 0.29 & 0.24 & 0.21 \\
\hline $\mathrm{Cu}$ & 10.60 & 7.47 & 8.01 & 2.52 & 8.11 & 4.44 & 5.04 & 9.19 & 13.45 \\
\hline Dy & 11.02 & 36.99 & 46.07 & 8.29 & 8.31 & 20.71 & 23.22 & 25.12 & 28.01 \\
\hline $\mathrm{Er}$ & 6.87 & 23.58 & 28.78 & 5.30 & 5.63 & 15.14 & 15.57 & 19.84 & 21.27 \\
\hline $\mathrm{Eu}$ & 1.37 & 3.35 & 3.40 & 2.35 & 2.60 & 2.69 & 3.38 & 2.96 & 3.49 \\
\hline $\mathrm{Fe}$ & 8031.00 & 18380.00 & 21320.00 & 12520.00 & 15310.00 & 16260.00 & 18120.00 & 8606.00 & 9750.00 \\
\hline $\mathrm{Ga}$ & 43.18 & 54.38 & 57.49 & 33.09 & 34.58 & 30.75 & 34.08 & 49.67 & 51.53 \\
\hline $\mathrm{Gd}$ & 8.23 & 16.43 & 17.38 & 8.36 & 9.67 & 7.88 & 9.01 & 8.93 & 9.03 \\
\hline Ge & 0.00 & 1.74 & 2.32 & 1.44 & 1.97 & 1.28 & 2.03 & 1.21 & 0.63 \\
\hline $\mathrm{Hf}$ & 4.16 & 14.07 & 11.56 & 10.73 & 9.51 & 22.21 & 14.49 & 28.70 & 20.08 \\
\hline Ho & 2.38 & 8.61 & 10.22 & 1.73 & 2.14 & 5.07 & 5.46 & 6.61 & 7.35 \\
\hline La & 212.10 & 253.80 & 282.70 & 148.60 & 152.30 & 72.12 & 78.74 & 45.06 & 45.49 \\
\hline u & 9.94 & 45.43 & 0.00 & 18.21 & 81.46 & 17.01 & 57.26 & 38.78 & 1.99 \\
\hline Lu & 0.71 & 3.31 & 3.00 & 0.73 & 0.68 & 2.21 & 2.14 & 2.92 & 3.31 \\
\hline $\mathrm{Mg}$ & 246.90 & 255.20 & 342.50 & 200.80 & 247.50 & 241.70 & 259.80 & 302.20 & 451.00 \\
\hline$M n$ & 81.21 & 115.30 & 133.70 & 14.87 & 24.10 & 18.29 & 27.08 & 22.32 & 22.21 \\
\hline Mo & 283.40 & 208.20 & 249.00 & 180.20 & 203.50 & 1256.00 & 1451.00 & 771.60 & 850.40 \\
\hline $\mathrm{Nb}$ & 16.22 & 21.05 & 17.81 & 23.00 & 22.17 & 41.84 & 26.90 & 41.58 & 36.18 \\
\hline $\mathrm{Nd}$ & 41.41 & 54.72 & 56.26 & 50.25 & 53.06 & 20.33 & 21.43 & 16.60 & 15.11 \\
\hline $\mathrm{Ni}$ & 334.80 & 405.60 & 466.50 & 3.41 & 5.34 & 3.49 & 5.01 & 2.79 & 3.30 \\
\hline $\mathrm{Pb}$ & 33.67 & 40.64 & 45.62 & 25.26 & 28.83 & 62.68 & 68.72 & 24.11 & 25.70 \\
\hline $\mathrm{Pd}$ & 4.71 & 16.70 & 13.77 & 3.05 & 3.06 & 9.28 & 7.79 & 11.72 & 11.69 \\
\hline $\operatorname{Pr}$ & 18.88 & 23.64 & 27.70 & 19.80 & 21.05 & 7.29 & 7.59 & 5.45 & 5.91 \\
\hline$R b$ & 142.70 & 236.50 & 251.20 & 214.70 & 268.20 & 216.40 & 258.40 & 244.10 & 252.10 \\
\hline$S$ & 0.00 & 47740.00 & 109100.00 & 39830.00 & 88010.00 & 53360.00 & 112300.00 & 24740.00 & 0.00 \\
\hline $\mathrm{Sb}$ & 0.69 & 1.25 & 1.46 & 0.56 & 1.05 & 3.05 & 3.65 & 2.06 & 2.05 \\
\hline Sc & 0.00 & 4.22 & 3.25 & 1.10 & 1.43 & 3.84 & 4.47 & 5.37 & 4.05 \\
\hline $\mathrm{Se}$ & 0.00 & 5.00 & 1.79 & 0.00 & 0.00 & 2.24 & 3.24 & 1.05 & 0.00 \\
\hline $\mathrm{Sm}$ & 3.96 & 7.85 & 7.21 & 6.09 & 6.63 & 5.21 & 4.70 & 5.63 & 5.39 \\
\hline $\mathrm{Sr}$ & 1226.00 & 1086.00 & 1301.00 & 327.30 & 412.80 & 413.70 & 510.70 & 299.00 & 306.10 \\
\hline $\mathrm{Ta}$ & 0.17 & 0.21 & 0.00 & 0.11 & 0.00 & 0.95 & 0.30 & 0.61 & 0.25 \\
\hline $\mathrm{Tb}$ & 1.40 & 4.98 & 5.47 & 1.28 & 1.51 & 2.40 & 2.14 & 2.98 & 2.49 \\
\hline$T h$ & 33.17 & 100.00 & 100.70 & 33.55 & 34.30 & 74.99 & 81.18 & 92.38 & 94.59 \\
\hline $\mathrm{Ti}$ & 1583.00 & 1878.00 & 2152.00 & 2501.00 & 2738.00 & 2067.00 & 2252.00 & 2884.00 & 3237.00 \\
\hline $\mathrm{Tm}$ & 0.68 & 3.80 & 3.88 & 0.77 & 0.97 & 2.25 & 2.59 & 3.28 & 3.28 \\
\hline $\mathrm{U}$ & 1531.00 & 556.70 & 671.10 & 41.48 & 41.77 & 182.10 & 185.10 & 240.50 & 278.40 \\
\hline V & 214.60 & 249.70 & 280.40 & 214.20 & 239.00 & 208.50 & 227.00 & 368.70 & 427.90 \\
\hline$W$ & 4.31 & 6.04 & 5.01 & 5.66 & 6.07 & 8.83 & 9.24 & 9.04 & 7.38 \\
\hline$Y$ & 73.89 & 272.60 & 294.70 & 55.27 & 62.60 & 165.80 & 182.70 & 219.40 & 229.00 \\
\hline$Y b$ & 4.39 & 21.12 & 22.94 & 4.86 & 6.00 & 14.39 & 14.40 & 18.87 & 23.13 \\
\hline $\mathrm{Zn}$ & 64.20 & 108.40 & 144.40 & 21.92 & 72.44 & 59.32 & 76.76 & 44.11 & 103.00 \\
\hline $\mathrm{Zr}$ & 190.70 & 929.20 & 794.80 & 443.50 & 404.20 & 1148.00 & 1007.00 & 1467.00 & 1412.00 \\
\hline
\end{tabular}


Tabela 1-7A : Continuação.

\begin{tabular}{|c|c|c|}
\hline $\begin{array}{c}\text { AMOSTRA } \\
\text { Fd } \\
\text { ppmltipo } \\
\end{array}$ & $\begin{array}{c}\text { M2b-3 } \\
5000 \\
\text { zona brca }\end{array}$ & $\begin{array}{c}\text { M2b-3 } \\
50000 \\
\text { zona brca }\end{array}$ \\
\hline As & 8.43 & 16.05 \\
\hline $\mathrm{Ba}$ & 966.40 & 1467.00 \\
\hline $\mathrm{Be}$ & 4.27 & 7.29 \\
\hline $\mathrm{Bi}$ & 0.31 & 0.30 \\
\hline $\mathrm{Ca}$ & 1553.00 & 1688.00 \\
\hline $\mathrm{Cd}$ & 0.89 & 0.52 \\
\hline $\mathrm{Ce}$ & 265.10 & 349.60 \\
\hline Co & 1.22 & 1.67 \\
\hline $\mathrm{Cr}$ & 28.82 & 13.96 \\
\hline $\mathrm{Cs}$ & 0.32 & 0.27 \\
\hline $\mathrm{Cu}$ & 21.96 & 32.39 \\
\hline Dy & 10.90 & 13.49 \\
\hline $\mathrm{Er}$ & 7.85 & 9.01 \\
\hline Eu & 2.99 & 3.99 \\
\hline $\mathrm{Fe}$ & 21430.00 & 34210.00 \\
\hline $\mathrm{Ga}$ & 37.36 & 57.15 \\
\hline $\mathrm{Gd}$ & 14.60 & 13.29 \\
\hline $\mathrm{Ge}$ & 2.27 & 4.52 \\
\hline $\mathrm{Hf}$ & 4.35 & 5.12 \\
\hline Ho & 2.69 & 3.49 \\
\hline $\mathrm{La}$ & 184.70 & 257.50 \\
\hline Li & 27.65 & 87.92 \\
\hline $\mathrm{Lu}$ & 0.95 & 1.07 \\
\hline $\mathrm{Mg}$ & 348.20 & 589.80 \\
\hline $\mathrm{Mn}$ & 127.60 & 203.60 \\
\hline Mo & 151.70 & 208.10 \\
\hline $\mathrm{Nb}$ & 11.79 & 19.13 \\
\hline $\mathrm{Nd}$ & 57.42 & 68.53 \\
\hline $\mathrm{Ni}$ & 8.21 & 8.77 \\
\hline $\mathrm{Pb}$ & 81.62 & 87.41 \\
\hline $\mathrm{Pd}$ & 7.41 & 4.93 \\
\hline $\mathrm{Pr}$ & 22.18 & 26.14 \\
\hline $\mathrm{Rb}$ & 190.80 & 254.80 \\
\hline$S$ & 14970.00 & 57320.00 \\
\hline $\mathrm{Sb}$ & 1.20 & 1.19 \\
\hline Sc & 1.47 & 2766.00 \\
\hline $\mathrm{Se}$ & 1.11 & 7.77 \\
\hline $\mathrm{Sm}$ & 7.98 & 9.75 \\
\hline $\mathrm{Sr}$ & 487.80 & 701.20 \\
\hline $\mathrm{Ta}$ & 0.10 & 0.10 \\
\hline $\mathrm{Tb}$ & 1.92 & 2.16 \\
\hline Th & 48.19 & 56.20 \\
\hline $\mathrm{Ti}$ & 1529.00 & 1999.00 \\
\hline Tm & 1.10 & 1.49 \\
\hline$U$ & 60.22 & 64.01 \\
\hline 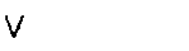 & 302.90 & 404.40 \\
\hline W & 111.20 & 133.00 \\
\hline$Y$ & 78.26 & 108.50 \\
\hline$Y b$ & 6.96 & 6.67 \\
\hline $\mathrm{Zn}$ & 144.50 & 184.30 \\
\hline $\mathrm{Zr}$ & 331.00 & 416.50 \\
\hline
\end{tabular}


Tabela 1-7B: Geoquímica via ICP-MS dos microperfis das frentes redox nas zonas oxidadas.

\begin{tabular}{|c|c|c|c|c|c|c|c|c|c|}
\hline $\begin{array}{c}\text { AMOSTRA } \\
F d \\
\text { ppmltipo } \\
\end{array}$ & $\begin{array}{c}\text { IARF-10 } \\
5000 \\
\text { Oxi } \\
\end{array}$ & $\begin{array}{c}\text { IARF-10 } \\
50000 \\
\text { oxi } \\
\end{array}$ & $\begin{array}{c}\text { IARF-7 } \\
5000 \\
\text { fr.oxi } \\
\end{array}$ & $\begin{array}{r}\text { IARF-7 } \\
50000 \\
\text { fr. } 0 \times 1 \\
\end{array}$ & $\begin{array}{c}\text { IARF-5 } \\
5000 \\
0 \times 1 \\
\end{array}$ & $\begin{array}{c}\text { IARF-5 } \\
50000 \\
0 \times 1 \\
\end{array}$ & $\begin{array}{c}\text { IARF-3 } \\
5000 \\
0 \times 1 \\
\end{array}$ & $\begin{array}{c}\text { IARF-3 } \\
50000 \\
0 \times 1 \\
\end{array}$ & $\begin{array}{c}\text { IARF-2 } \\
5000 \\
\text { oxi } \\
\end{array}$ \\
\hline As & 8.62 & 12.06 & 10.00 & 7.49 & 6.83 & 13.26 & 17.50 & 23.12 & 14.14 \\
\hline $\mathrm{Ba}$ & 450.70 & 591.70 & 879.60 & 1162.00 & 499.30 & 727.50 & 474.90 & 592.80 & 517.00 \\
\hline $\mathrm{Be}$ & 3.68 & 3.98 & 12.79 & 8.46 & 5.11 & 7.71 & 5.20 & 3.52 & 4.98 \\
\hline $\mathrm{Bi}$ & 0.06 & 0.00 & 0.00 & 105.60 & 0.02 & 0.01 & 0.03 & 0.13 & 0.04 \\
\hline $\mathrm{Ca}$ & 1525.00 & 1473.00 & 302.50 & 0.00 & 58.67 & 0.00 & 176.40 & 49.17 & 839.20 \\
\hline $\mathrm{Cd}$ & 1.80 & 1.86 & 1.83 & 2.62 & 0.72 & 0.83 & 0.66 & 0.84 & 1.38 \\
\hline $\mathrm{Ce}$ & 388.70 & 480.50 & 93.29 & 102.90 & 71.61 & 86.41 & 760.30 & 1062.00 & 77.80 \\
\hline Co & 40.39 & 54.69 & 9.51 & 10.79 & 3.45 & 4.73 & 0.15 & 0.08 & 0.60 \\
\hline $\mathrm{Cr}$ & 60.80 & 25.50 & 78.13 & 52.62 & 82.56 & 104.80 & 10.53 & 14.27 & 7.30 \\
\hline $\mathrm{Cs}$ & 0.55 & 0. & 0.23 & 0.27 & 0.34 & 0.40 & 0.28 & 0.28 & 0.93 \\
\hline $\mathrm{Cu}$ & 17.21 & 22.80 & 3.10 & 5.61 & 7.26 & 9.42 & 0.56 & 3.11 & 4.93 \\
\hline Dy & 20.65 & 25.55 & 10.03 & 12.30 & 5.06 & 5.41 & 39.93 & 42.00 & 4.53 \\
\hline Er & 12.94 & 12.45 & 7.07 & 7.90 & 3.93 & 4.39 & 15.61 & 17.95 & 3.19 \\
\hline Eu & 3.60 & 3.40 & 1.96 & 1.87 & 1.12 & 0.98 & 13.37 & 14.90 & 1.22 \\
\hline $\mathrm{Fe}$ & 42510.00 & 72060.00 & 47370.00 & 58730.00 & 10980.00 & 16960.00 & 27550.00 & 39380.00 & 77670.00 \\
\hline Ga & 25.78 & 33.33 & 78.38 & 79.87 & 33.27 & 48.10 & 32.60 & 42.91 & 30.77 \\
\hline Gd & 19.93 & 17.09 & 5.76 & 6.55 & 4.32 & 3.91 & 61.76 & 5682.00 & 3.99 \\
\hline $\mathrm{Ge}$ & 3.10 & 5.95 & 2.98 & 4.69 & 1.91 & 3.80 & 4.24 & 3.80 & 3.60 \\
\hline$-1 f$ & 0.90 & 0.65 & 16.19 & 14.76 & 8.14 & 6.33 & 5.84 & 4.49 & 4.82 \\
\hline Ho & 4.72 & 4.74 & 2.36 & 2.85 & 1.36 & 1.10 & 6.68 & 7.43 & 1.08 \\
\hline La & 338.20 & 434.10 & 110.40 & 124.40 & 89.30 & 112.80 & 454.00 & 604.10 & 88.19 \\
\hline $\mathrm{Li}$ & 13.88 & 210.90 & 69.42 & 44.86 & 40.59 & 131.00 & 37.56 & 5.50 & 22.99 \\
\hline Lu & 1.42 & 1.36 & 1.13 & 1.15 & 0.57 & 0.49 & 1.05 & 1.10 & 0.40 \\
\hline $\mathrm{Mg}$ & 140.20 & 145.60 & 257.60 & 309.50 & 138.00 & 130.90 & 112.90 & 198.30 & 213.80 \\
\hline $\mathrm{Mn}$ & 81.46 & 129.50 & 92.26 & 101.90 & 36.68 & 53.26 & 40.31 & 42.70 & 55.06 \\
\hline Mo & 294.20 & 371.90 & 217.80 & 236.80 & 53.31 & 70.46 & 151.00 & 176.80 & 327.40 \\
\hline b & 10.06 & 12.97 & 20.75 & 18.14 & 17.60 & 21.62 & 17.29 & 21.73 & 21.90 \\
\hline d & 50.34 & 60.72 & 16.77 & 17.83 & 11.71 & 12.85 & 195.50 & 248.90 & 12.71 \\
\hline & 6.98 & 5.48 & 2529.00 & 2956.00 & 901.80 & 1245.00 & 13.93 & 18.73 & 12.03 \\
\hline b & 37.38 & 29.75 & 16.14 & 0.00 & 17.33 & 11.93 & 26.17 & 27.84 & 35.39 \\
\hline d & 17.79 & 8.94 & 4.90 & 4.64 & 5 & 2.12 & 13 & 7.81 & 2.44 \\
\hline $\mathrm{Pr}$ & 23.05 & 28.40 & 7.64 & 8.49 & 5.30 & 5.79 & 80.16 & 98.31 & 6.01 \\
\hline $\mathrm{Rb}$ & 150.00 & 190.40 & 228.20 & 229.20 & 192.10 & 250.10 & 179.50 & 213.40 & 197.80 \\
\hline$s$ & 25360.00 & 0.00 & 15150.00 & 0.00 & 18350.00 & 0.00 & 6814.00 & 0.00 & 9264.00 \\
\hline $\mathrm{Sb}$ & 0.62 & 0.78 & 1.44 & 1.62 & 0.39 & 0.40 & 0.71 & 1.09 & 1.15 \\
\hline Sc & 4.63 & 6.21 & 4.19 & 3.25 & 1.62 & 3.35 & 2.92 & 2.33 & 1.67 \\
\hline Se & 2.71 & 0.00 & 0.75 & 0.00 & 1. & 1.99 & 3.04 & 0.00 & 5397.00 \\
\hline $\mathrm{Sm}$ & 8.83 & 8.24 & 3.67 & 3.25 & 1.82 & 1.60 & 3.46 & 38.95 & 2.31 \\
\hline $\mathrm{sr}$ & 1592.00 & 2414.00 & 507.00 & 550.20 & 482.30 & 712.80 & 423.10 & 508.00 & 424.60 \\
\hline Ta & 0.10 & 0.11 & 0.12 & 0.08 & 0.05 & 0.17 & 0.11 & 0.08 & 0.11 \\
\hline$T b$ & 3.06 & 3.33 & 1.43 & 1.54 & 0.74 & 0.63 & 8.37 & 8.55 & 0.73 \\
\hline Th & 93.34 & 83.95 & 108.10 & 321.90 & 30.73 & 32.79 & 55.26 & 66.34 & 33.43 \\
\hline $\mathrm{Ti}$ & 1558.00 & 1868.00 & 1993.00 & 2078.00 & 1819.00 & 2181.00 & 1549.00 & 1867.00 & 1704.00 \\
\hline $\operatorname{Tm}$ & 1.85 & 1.90 & 1.19 & 1.33 & 0.61 & 0.56 & 1.67 & 1.51 & 0.48 \\
\hline 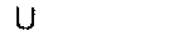 & 563.90 & 523.70 & 323.30 & & 91.57 & 74.78 & 199.50 & 213.70 & 133.30 \\
\hline v & 165.40 & 184.50 & 452.60 & 491.10 & 210.30 & 247.10 & 216.20 & 247.20 & 180.30 \\
\hline W & 4.70 & 5.59 & 3.88 & 4.05 & 2.84 & 3.20 & 4.67 & 5.72 & 3.93 \\
\hline$Y$ & 144.80 & 180.60 & 85.22 & 89.83 & 39.38 & 55.39 & 146.30 & 167.60 & 39.33 \\
\hline$Y_{b}$ & 10.31 & 10.07 & 7.49 & 8.93 & 3.83 & 3.20 & 8.43 & 8.58 & 2.89 \\
\hline $\mathrm{Zn}$ & 286.10 & 332.40 & 100.80 & 108.00 & 60.62 & 63.59 & 84.48 & 163.20 & 253.90 \\
\hline $\mathrm{zr}$ & 51.09 & 74.70 & 823.40 & 729.40 & 296.70 & 339.00 & 201.80 & 199.50 & 183.40 \\
\hline
\end{tabular}


Tabela 1-7B: Continuação.

\begin{tabular}{|c|c|c|c|c|c|c|c|c|c|}
\hline $\begin{array}{c}\text { AMOSTRA } \\
\text { Fd } \\
\text { ppmltipo } \\
\end{array}$ & $\begin{array}{c}\text { IARF-2 } \\
50000 \\
\text { oxi } \\
\end{array}$ & $\begin{array}{c}\text { IARF-4 } \\
5000 \\
\text { OXi } \\
\end{array}$ & $\begin{array}{c}\text { IARF-4 } \\
50000 \\
0 \times 1 \\
\end{array}$ & $\begin{array}{c}\text { IARF-6 } \\
5000 \\
0 \times 1 \\
\end{array}$ & $\begin{array}{c}\text { IARF-6 } \\
50000 \\
\text { oxi } \\
\end{array}$ & $\begin{array}{c}\text { IARF-1 } \\
5000 \\
\text { oxi } \\
\end{array}$ & $\begin{array}{c}\text { IARF-1 } \\
50000 \\
0 \times 1 \\
\end{array}$ & $\begin{array}{c}\text { M2c-4 } \\
5000 \\
0 \times i \\
\end{array}$ & $\begin{array}{c}M 2 c-4 \\
50000 \\
0 \times i \\
\end{array}$ \\
\hline As & 12.78 & 25.83 & 27.68 & 27.15 & 42.26 & 78.24 & 86.00 & 10.99 & 17 \\
\hline $8 a$ & 675.90 & 372.80 & 462.80 & 427.10 & 685.40 & 567.50 & 676.20 & 599.80 & 827 \\
\hline $\mathrm{Be}$ & 4.58 & 7.14 & 10.10 & 1.93 & 5.98 & 3.63 & 8.92 & 2.13 & 5 \\
\hline $\mathrm{Bi}$ & 0.04 & 0.03 & 0.07 & 0.04 & 0.04 & 0.11 & 0.15 & 0.05 & 0.04 \\
\hline $\mathrm{Ca}$ & 660.40 & 712.40 & 600.70 & 423.90 & 0.00 & 670.10 & 805.70 & 86.75 & 0.00 \\
\hline $\mathrm{Cd}$ & 1.36 & 1.16 & 2.20 & 2.26 & 3.26 & 2.42 & 1.18 & 1.75 & 2. \\
\hline $\mathrm{Ce}$ & 84.42 & 47.66 & 55.19 & 69.16 & 92.94 & 1017.00 & 1389.00 & 189.10 & 230. \\
\hline Co & 0.69 & 1.52 & 1.99 & 0.37 & 0.58 & 1.06 & 1.83 & 0.59 & 0. \\
\hline $\mathrm{Cr}$ & 0.00 & 10.43 & 20.28 & 22.21 & 0.17 & 53.37 & 44.55 & 33.34 & 0. \\
\hline Cs & 1.05 & 0.46 & 0.36 & 0.69 & 0.90 & 0.39 & 0.51 & 0.40 & 0. \\
\hline $\mathrm{Cu}$ & 5.85 & 14.26 & 22.47 & 0.00 & 0.00 & 9.32 & 12.54 & 0.00 & 0. \\
\hline Dy & 6.18 & 4.87 & 5.70 & 10.11 & 13.36 & 54.08 & 58.66 & 11.87 & 13.72 \\
\hline Er & 3.77 & 3.56 & 2.94 & 6.79 & 8.04 & 21.45 & 23.67 & 6.56 & 7.03 \\
\hline Eu & 1.39 & 1.01 & 0.78 & 2.05 & 2.08 & 19.73 & 21.20 & 3.87 & 4.44 \\
\hline $\mathrm{Fe}$ & 99390.00 & 64500.00 & 86350.00 & 66260.00 & 138100.00 & 62580.00 & 82200.00 & 11900.00 & 18430.00 \\
\hline $\mathrm{Ga}$ & 32.43 & 49.82 & 55.65 & 32.52 & 47.33 & 44.83 & 51.50 & 33.45 & 42.41 \\
\hline Gd & 3.99 & 3.22 & 3.61 & 8.03 & 8.32 & 66.98 & 77.74 & 16.20 & 13.97 \\
\hline $\mathrm{Ge}$ & 3.99 & 3.27 & 2.56 & 3.46 & 5.37 & 7.32 & 10.96 & 2.19 & 3.24 \\
\hline $\mathrm{Hf}$ & 4.43 & 7.79 & 6.54 & 9.20 & 8.12 & 12.12 & 9.91 & 8.36 & 7.49 \\
\hline Ho & 1.29 & 1.17 & 1.23 & 2.28 & 2.88 & 8.97 & 10.57 & 2.41 & 2.67 \\
\hline La & 96.94 & 57.15 & 66.24 & 80.61 & 115.80 & 714.20 & 865.60 & 221.20 & 263.30 \\
\hline i & 0.00 & 77.07 & 118.50 & 58.12 & 147.80 & 45.99 & 150.90 & 60.20 & 227.50 \\
\hline Lu & 0.51 & 0.51 & 0.54 & 0.98 & 0.88 & 1.80 & 1.91 & 0.69 & 0.43 \\
\hline $\mathrm{Mg}$ & 267.30 & 301.40 & 410.50 & 218.40 & 366.60 & 210.90 & 294.30 & 280.30 & 363.20 \\
\hline Mn & 53.80 & 44.53 & 57.59 & 54.92 & 91.65 & 117.30 & 133.70 & 50.81 & 72.96 \\
\hline Mo & 354.90 & 284.70 & 312.00 & 263.90 & 343.00 & 325.90 & 358.30 & 163.00 & 198.40 \\
\hline $\mathrm{Nb}$ & 13.71 & 24.36 & 21.72 & 16.08 & 21.68 & 17.35 & 13.00 & 15.45 & 19.16 \\
\hline $\mathrm{Nd}$ & 15.10 & 1 & 12.63 & 20.49 & 24.79 & 293.60 & 275.80 & 51.47 & 64.82 \\
\hline $\mathrm{Ni}$ & 11.64 & 314.90 & 355.80 & 9.74 & 12.04 & 65.72 & 77.07 & 0.27 & 0.0 \\
\hline $\mathrm{Pb}$ & 4 & 33.78 & 41.8 & 33.66 & 32. & 52.67 & 6 & 21.71 & 14.43 \\
\hline $\mathrm{Pd}$ & 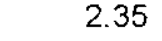 & 2.41 & 25 & 7.39 & 3.79 & 14.63 & 11.45 & 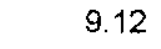 & 4.05 \\
\hline Pr & 7.01 & 4.68 & 4.96 & 8.49 & 10.11 & 116.00 & 118.90 & 20.61 & 22.62 \\
\hline $\mathrm{Rb}$ & 204.70 & 189.60 & 213.80 & 162.10 & 228.90 & 203.40 & 246.40 & 188.80 & 240.00 \\
\hline$s$ & 0.00 & 5407.00 & 229.50 & 14060.00 & 0.00 & 5400.00 & 0.00 & 23030.00 & 0.00 \\
\hline $\mathrm{Sb}$ & 1.46 & 1.21 & 0.81 & 0.41 & 0.54 & 2.39 & 2.41 & 0.38 & 0.34 \\
\hline $\mathrm{Sc}$ & 0.54 & 2.36 & 1.2 & 2.67 & 4.22 & 5.88 & 7.63 & 1.06 & 2.80 \\
\hline $\mathrm{Se}$ & 0.00 & 0.71 & 0.0 & 0.78 & 4.01 & 4.21 & 2.59 & 3.31 & 18.48 \\
\hline $\mathrm{Sm}$ & 2.11 & 1.88 & 2.23 & 4.20 & 3.74 & 48.98 & 52.35 & 9.76 & 11.40 \\
\hline $\mathrm{Sr}$ & 456.40 & 19.10 & 363.50 & 491.10 & 729.40 & 1097.00 & $\{517.00$ & 469.70 & 617.80 \\
\hline Ta & 0.03 & 2993.00 & 0.55 & 0.15 & 0.10 & 0.33 & 0.13 & 0.05 & 0.08 \\
\hline $\mathrm{Tb}$ & 0.71 & 0.70 & 0.67 & 1.59 & 1.93 & 10.88 & 12.69 & 2.29 & 2.26 \\
\hline Th & 38.00 & 31.13 & 38.50 & 36.20 & 39.70 & 130.10 & 126.30 & 33.65 & 36.10 \\
\hline Ti & 1726.00 & 2514.00 & 2764.00 & 2072.00 & 2719.00 & 1128.00 & 1381.00 & 1292.00 & 1528.00 \\
\hline $\operatorname{Tm}$ & 0.60 & 0.60 & 0.69 & 0.98 & 0.95 & 2.43 & 2.98 & 0.91 & 0.71 \\
\hline U & 165.00 & 265.30 & 335.90 & 196.30 & 214.40 & 520.10 & 533.30 & 1105.00 & 1123,00 \\
\hline V & 182.80 & 369.30 & 436.40 & 211.60 & 269.80 & 178.50 & 212.20 & 174.20 & 187.90 \\
\hline W & 3.32 & 1.81 & 2.35 & 2.13 & 5.50 & 29.93 & 32.64 & 3.43 & 3.41 \\
\hline Y & 39.89 & 40.29 & 44.66 & 70.34 & 101.40 & 232.70 & 272.60 & 73.89 & 91.21 \\
\hline$Y_{b}$ & 3.73 & 3.33 & 3.52 & 6.55 & 7.11 & 12.71 & 14.81 & 5.01 & 4.66 \\
\hline $\mathrm{Zn}$ & 296.50 & 201.30 & 54.60 & 79.00 & 319.00 & 80.80 & 10.20 & 29.41 & 55.49 \\
\hline $\mathrm{Zr}$ & 159.80 & 294.80 & 317.70 & 56.10 & 457.10 & 43.00 & 469.80 & 393.30 & 435.30 \\
\hline
\end{tabular}


Tabela 1-7B: Continuação.

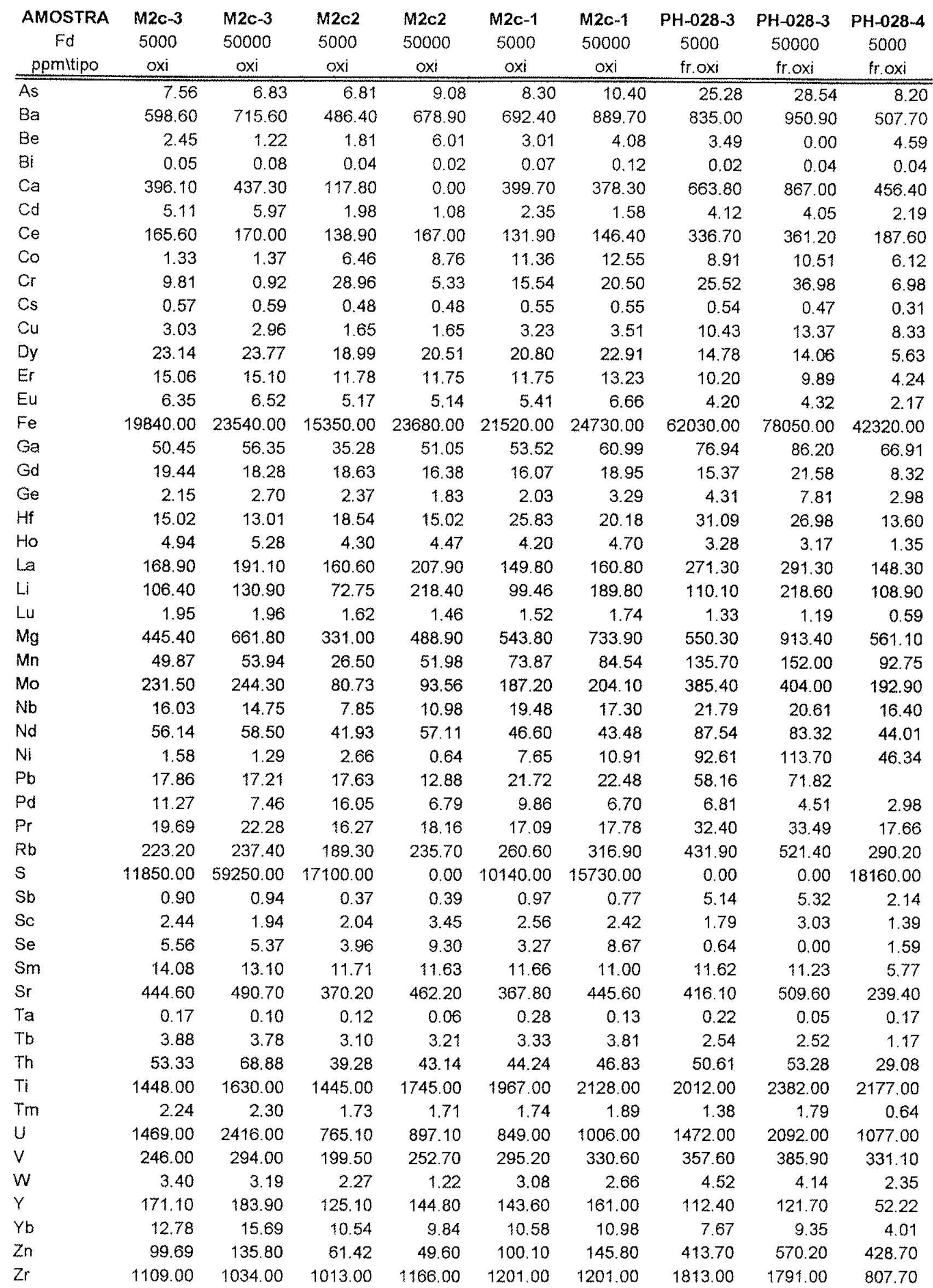


Tabela 1-7B: Continuaçåo.

\begin{tabular}{|c|c|c|c|c|c|c|c|c|}
\hline $\begin{array}{c}\text { AMOSTRA } \\
\text { Fd } \\
\text { ppmitipo }\end{array}$ & $\begin{array}{c}\text { PH-028-4 } \\
50000 \\
\text { fr.oxi }\end{array}$ & $\begin{array}{c}\text { PH-028-5 } \\
5000 \\
\text { fr.oxi } \\
\end{array}$ & $\begin{array}{c}\text { PH-028-5 } \\
50000 \\
\text { fr.oxi } \\
\end{array}$ & $\begin{array}{c}\text { PH-028-1 } \\
5000 \\
\text { Oxi } \\
\end{array}$ & $\begin{array}{c}\text { PH-028-1 } \\
50000 \\
\text { oxi } \\
\end{array}$ & $\begin{array}{c}\mathrm{PH}-028-2 \\
5000 \\
\text { oxi } \\
\end{array}$ & $\begin{array}{c}\text { PH-028-2 } \\
50000 \\
0 \times i \\
\end{array}$ & $\begin{array}{r}\text { U3c-4 } \\
5000 \\
\text { fr. oxi }\end{array}$ \\
\hline As & 8.33 & 14.62 & 16.21 & 23.84 & 24.49 & 10.73 & 17.55 & 3.78 \\
\hline $\mathrm{Ba}$ & 664.60 & 497.60 & 624.20 & 700.00 & 892.00 & 518.40 & 718.60 & 303.20 \\
\hline $\mathrm{Be}$ & 0.00 & 1.27 & 0.00 & 2.89 & 2.63 & 2.24 & 4.52 & 3.00 \\
\hline $\mathrm{Bi}$ & 0.12 & 0.08 & 0.05 & 0.03 & 0.08 & 0.03 & 0.00 & 0.11 \\
\hline $\mathrm{Ca}$ & 160.20 & 270.90 & 140.80 & 384.70 & 656.70 & 70.75 & 0.00 & 524.30 \\
\hline $\mathrm{Cd}$ & 2.58 & 2.88 & 2.66 & 1.66 & 1.46 & 2.41 & 2.21 & 2.07 \\
\hline $\mathrm{Ce}$ & 233.90 & 382.60 & 434.40 & 361.70 & 385.10 & 125.00 & 147.50 & 60.55 \\
\hline Co & 6.70 & 9.03 & 9.18 & 2.19 & 2.58 & 1.71 & 2.31 & 4568.00 \\
\hline $\mathrm{Cr}$ & 7.44 & 13.26 & 15.07 & 28.37 & 42.35 & 42.79 & 30.81 & 18.17 \\
\hline $\mathrm{Cs}$ & 0.31 & 0.36 & 0.27 & 0.35 & 0.41 & 0.32 & 0.31 & 0.26 \\
\hline $\mathrm{Cu}$ & 9.89 & 7.38 & 6.94 & 5.14 & 6.81 & 122.60 & 195.20 & 6.03 \\
\hline Dy & 7.34 & 12.61 & 13.33 & 7.25 & 7.77 & 7.01 & 8.04 & 2.80 \\
\hline $\mathrm{Er}$ & 6.00 & 8.89 & 10.01 & 4.75 & 5.41 & 5.37 & 5.93 & 2.45 \\
\hline Eu & 2.23 & 4.08 & 4.09 & 2.80 & 2.46 & 2.27 & 2.14 & 0.52 \\
\hline $\mathrm{Fe}$ & 49090.00 & 47230.00 & 58980.00 & 28350.00 & 34920.00 & 28650.00 & 45470.00 & 8026.00 \\
\hline $\mathrm{Ga}$ & 72.52 & 26.17 & 28.39 & 43.89 & 53.51 & 43.84 & 60.38 & 36.76 \\
\hline $\mathrm{Gd}$ & 8.20 & 17.07 & 15.67 & 12.82 & 11.18 & 9.83 & 8.77 & 2.20 \\
\hline Ge & 1.27 & 3.85 & 1.68 & 2.19 & 2.08 & 3.17 & 2.09 & 1.15 \\
\hline$H f$ & 10.30 & 19.28 & 14.46 & 14.71 & 10.96 & 17.75 & 15.64 & 2.66 \\
\hline Ho & 1.59 & 2.94 & 3.05 & 1.56 & 1.73 & 1.70 & 1.73 & 0.70 \\
\hline La & 185.70 & 264.70 & 307.30 & 266.30 & 283.10 & 99.75 & 122.50 & 58.18 \\
\hline $\mathrm{Li}$ & 114.20 & 23.88 & 0.00 & 67.43 & 49.65 & 69.98 & 270.90 & 24.73 \\
\hline Lu & 0.65 & 1.21 & 1.58 & 0.56 & 0.68 & 0.73 & 0.63 & 0.36 \\
\hline $\mathrm{Mg}$ & 683.20 & 151.40 & 177.90 & 260.90 & 461.20 & 357.10 & 570.70 & 186.10 \\
\hline $\mathrm{Mn}$ & 88.90 & 96.46 & 100.90 & 48.35 & 54.49 & 54.63 & 81.59 & 23.49 \\
\hline Mo & 218.00 & 254.90 & 274.10 & 182.00 & 201.30 & 180.40 & 214.30 & 62.90 \\
\hline $\mathrm{Nb}$ & 17.84 & 50.02 & 27.50 & $\uparrow 3.00$ & 13.65 & 18.79 & 27.86 & 11.28 \\
\hline $\mathrm{Nd}$ & 48.28 & 91.36 & 85.04 & 76.54 & 79.69 & 32.88 & 37.53 & 11.10 \\
\hline $\mathrm{Ni}$ & 50.57 & 15.11 & 17.92 & 342.20 & 417.40 & 38.93 & 47.07 & 3.70 \\
\hline $\mathrm{Pb}$ & 34.94 & 152.40 & 190.60 & 89.53 & 84.48 & 33.54 & 35.82 & 50.11 \\
\hline $\mathrm{Pd}$ & 1.96 & 6.60 & 5.09 & 3.38 & 3.12 & 5.99 & 3.51 & 1.37 \\
\hline $\mathrm{Pr}$ & 19.16 & 36.69 & 40.83 & 32.54 & 33.52 & 11.71 & 13.56 & 5.03 \\
\hline $\mathrm{Rb}$ & 291.50 & 234.00 & 229.00 & 274.30 & 290.50 & 242.60 & 332.90 & 206.60 \\
\hline$S$ & 0.00 & 11310.00 & 0.00 & 1583.00 & 99570.00 & 20910.00 & 0.00 & 11900.00 \\
\hline $\mathrm{Sb}$ & 1.90 & 2.98 & 2.65 & 3.32 & 2.99 & 2.28 & 3.30 & 0.72 \\
\hline Sc & 0.00 & 2.07 & 0.46 & 1.39 & 2.43 & 1.47 & 3.55 & 0.31 \\
\hline $\mathrm{Se}$ & 0.00 & 1.75 & 5.84 & 1.13 & 0.00 & 1.32 & 1.08 & 1.06 \\
\hline $\mathrm{Sm}$ & 5.85 & 11.84 & 12.36 & 7.59 & 7.11 & 5.97 & 5.08 & 1.06 \\
\hline $\mathrm{Sr}$ & 239.20 & 257.50 & 263.50 & 310.40 & 332.80 & 210.80 & 282.10 & 339.10 \\
\hline Ta & 0.07 & 0.88 & 0.32 & 0.08 & 0.10 & 0.09 & 0.06 & 0.03 \\
\hline $\mathrm{Tb}$ & 1.12 & 2.32 & 2.26 & 1.50 & 1.31 & 1.28 & 1.17 & 0.39 \\
\hline Th & 35.53 & 59.93 & 69.02 & 25.28 & 28.64 & 21.20 & 24.10 & 42.16 \\
\hline $\mathrm{Ti}$ & 2274.00 & 2552.00 & 2672.00 & 809.50 & 973.80 & 3136.00 & 4142.00 & 602.40 \\
\hline $\mathrm{Tm}$ & 0.66 & 1.45 & 1.60 & 0.65 & 0.62 & 0.84 & 0.86 & 0.37 \\
\hline U & 1655.00 & 1608.00 & 2743.00 & 278.90 & 360.60 & 436.70 & 395.10 & 392.00 \\
\hline V & 363.70 & 132.60 & 144.90 & 178.60 & 221.70 & 263.70 & 327.00 & 112.30 \\
\hline W & 2.48 & 6.08 & 4.70 & 2.24 & 1.15 & 2.49 & 1.85 & 15.54 \\
\hline Y & 57.25 & 105.60 & 113.60 & 55.50 & 60.00 & 53.67 & 70.86 & 21.69 \\
\hline Yb & 4.79 & 8.16 & 8.74 & 3.97 & 3.92 & 5.48 & 4.94 & 2.44 \\
\hline $\mathrm{Zn}$ & 523.70 & 327.60 & 392.10 & 157.40 & 200.60 & 245.40 & 360.60 & 54.59 \\
\hline $\mathrm{Zr}$ & 784.60 & 1281.00 & 1158.00 & 1030.00 & 987.60 & 1034.00 & 1263.00 & 103.00 \\
\hline
\end{tabular}


Tabela 1-7B: Continuação.

\begin{tabular}{|c|c|c|c|c|c|c|c|c|c|}
\hline $\begin{array}{c}\text { AMOSTRA } \\
\text { Fd } \\
\text { ppmitipo } \\
\end{array}$ & $\begin{array}{r}\text { U3c-4 } \\
50000 \\
\text { fr.oxi } \\
\end{array}$ & $\begin{array}{l}\text { U3c-5 } \\
5000 \\
\text { fr.oxi } \\
\end{array}$ & $\begin{array}{c}\text { U3c-5 } \\
50000 \\
\text { fr.oxi } \\
\end{array}$ & $\begin{array}{r}\text { U3c-6 } \\
5000 \\
\text { fr.oxi } \\
\end{array}$ & $\begin{array}{c}\text { U3c-6 } \\
50000 \\
\text { fr.oxi } \\
\end{array}$ & $\begin{array}{c}\text { SN/15-1 } \\
5000 \\
\text { oxi } \\
\end{array}$ & $\begin{array}{c}\text { SN/15-1 } \\
50000 \\
\text { oxi } \\
\end{array}$ & $\begin{array}{c}\text { SN/15-2 } \\
5000 \\
\text { oxi } \\
\end{array}$ & $\begin{array}{c}\text { SN/15-2 } \\
50000 \\
\text { oxi } \\
\end{array}$ \\
\hline As & 4.81 & 5.18 & 3.02 & 3.23 & 5.70 & 15.97 & 24.61 & 12.66 & 25.87 \\
\hline $\mathrm{Ba}$ & 399.70 & 380.80 & 507.50 & 387.10 & 479.10 & 539.40 & 793.60 & 522.80 & 792.60 \\
\hline $\mathrm{Be}$ & 2.64 & 5.01 & 4.65 & 3.56 & 10.21 & 2.26 & 5.78 & 1.42 & 6.77 \\
\hline $\mathrm{Bi}$ & 0.00 & 0.07 & 0.15 & 0.14 & 0.23 & 0.53 & 0.64 & 0.26 & 0.05 \\
\hline $\mathrm{Ca}$ & 403.70 & 316.80 & 98.89 & 24.92 & 0.00 & 1293.00 & 1161.00 & 333.40 & 0.00 \\
\hline $\mathrm{Cd}$ & 1.74 & 2.43 & 2.25 & 9.79 & 10.61 & 1.72 & 2.19 & 1.43 & 1.36 \\
\hline $\mathrm{Ce}$ & 62.06 & 70.05 & 77.06 & 82.35 & 90.76 & 73.81 & 90.45 & 77.42 & 96.04 \\
\hline Co & 0.96 & 0.90 & 1.29 & 1.88 & 2.87 & 0.54 & 1.04 & 0.44 & 0.00 \\
\hline $\mathrm{Cr}$ & 23.00 & 28.39 & 21.32 & 30.61 & 38.64 & 32.60 & 48.75 & 13.22 & 60.89 \\
\hline Cs & 0.37 & 0.25 & 0.28 & 0.17 & 0.22 & 0.29 & 0.29 & 0.28 & 0.32 \\
\hline $\mathrm{Cu}$ & 9.22 & 9.57 & 18.04 & 16.36 & 24.61 & 10.24 & 12.41 & 5.94 & 7.45 \\
\hline Dy & 3.08 & 4.86 & 6.39 & 4.44 & 5.55 & 3.11 & 3.48 & 3.01 & 4.12 \\
\hline Er & 2.75 & 4.05 & 4.55 & 3.58 & 3.72 & 1.79 & 1.91 & 1.92 & 2.17 \\
\hline $\mathrm{Eu}$ & 0.61 & 0.79 & 0.77 & 0.85 & 1.23 & 0.80 & 0.80 & 0.66 & 0.87 \\
\hline $\mathrm{Fe}$ & 9892.00 & 11540.00 & 13810.00 & 14230.00 & 22920.00 & 4309.00 & 6589.00 & 20430.00 & 4900.00 \\
\hline Ga & 41.30 & 44.76 & 51.27 & 76.59 & 108.60 & 36.98 & 52.28 & 41.25 & 61.20 \\
\hline Gd & 3.22 & 3.02 & 2.77 & 4.17 & 3.21 & 3.49 & 2.75 & 3.43 & 3.60 \\
\hline $\mathrm{Ge}$ & 1.63 & 1.03 & 2.76 & 1.34 & 0.00 & 1.01 & 1.48 & 2056.00 & 3.64 \\
\hline $\mathrm{Hif}$ & 3.13 & 5.49 & 4.13 & 4.72 & 3.42 & 1.81 & 1.58 & 1.28 & 0.90 \\
\hline Ho & 0.56 & 1.31 & 1.56 & 1.02 & 1.29 & 0.68 & 0.66 & 0.71 & 1.03 \\
\hline La & 63.25 & 62.80 & 73.63 & 59.06 & 70.16 & 42.62 & 90.37 & 76.80 & 96.15 \\
\hline $\mathrm{Li}$ & 138.40 & 38.31 & 0.00 & 70.52 & 126.40 & 35.12 & 146.70 & 35.59 & 145.20 \\
\hline Lu & 0.43 & 0.74 & 0.88 & 0.64 & 0.56 & 0.28 & 0.34 & 0.28 & 0.26 \\
\hline $\mathrm{Mg}$ & 277.20 & 191.70 & 232.20 & 151.00 & 205.70 & 360.20 & 466.90 & 199.10 & 243.50 \\
\hline $\mathrm{Mn}$ & 33.71 & 52.02 & 57.85 & 97.30 & 136.10 & 28.50 & 34.11 & 27.03 & 33.27 \\
\hline Mo & 63.68 & 13.65 & 14.99 & 8.65 & 7.53 & 10.96 & 13.33 & 22.23 & 26.89 \\
\hline $\mathrm{Nb}$ & 12.56 & 16.84 & 17.00 & 16.99 & 20.81 & 15.60 & 21.46 & 14.71 & 18.97 \\
\hline $\mathrm{Nd}$ & 10.27 & 13.10 & 14.56 & 16.91 & 21.80 & 11.54 & 15.86 & 12.29 & 14.54 \\
\hline $\mathrm{Ni}$ & 5.59 & 6.81 & 10.80 & 13.16 & 15.68 & 41.86 & 54.82 & 22.86 & 32.03 \\
\hline $\mathrm{Pb}$ & 48.06 & 39.99 & 48.48 & 168.20 & 185.40 & 23.39 & 22.15 & 37.33 & 38.08 \\
\hline $\mathrm{Pd}$ & 1.29 & 2.77 & 2.27 & 2.36 & 2.11 & 1.97 & 0.20 & 2.23 & 1.80 \\
\hline $\mathrm{Pr}$ & 4.97 & 6.15 & 6.70 & 8.36 & 9.22 & 5.62 & 7.19 & 5.88 & 7.41 \\
\hline $\mathrm{Rb}$ & 258.50 & 224.30 & 242.80 & 169.10 & 228.20 & 229.40 & 301.00 & 239.20 & 324.40 \\
\hline$S$ & 7603.00 & 9382.00 & 0.00 & 7155.00 & 0.00 & 12200.00 & 46930.00 & 15480.00 & 0.00 \\
\hline $\mathrm{Sb}$ & 0.80 & 0.34 & 0.23 & 0.63 & 0.77 & 0.40 & 0.42 & 0.33 & 0.27 \\
\hline Sc & 0.25 & 0.87 & 0.00 & 0.65 & 2.90 & 0.28 & 0.73 & 0.59 & 2.67 \\
\hline $\mathrm{Se}$ & 4.59 & 1.31 & 0.00 & 1.90 & 4.56 & 0.77 & 0.00 & 3.24 & 21.08 \\
\hline $\mathrm{Sm}$ & 1.11 & 1.51 & 1.43 & 1.96 & 2.50 & 1.23 & 1.53 & 1.13 & 0.97 \\
\hline $\mathrm{Sr}$ & 432.50 & 328.60 & 374.90 & 106.50 & 135.70 & 267.30 & 365.40 & 292.10 & 391.80 \\
\hline $\mathrm{Ta}$ & 0.02 & 0.12 & 0.01 & 0.05 & 0.04 & 0.15 & 1.08 & 0.05 & 0.00 \\
\hline $\mathrm{Tb}$ & 0.44 & 0.62 & 0.50 & 0.75 & 0.78 & 0.50 & 0.57 & 0.53 & 0.52 \\
\hline$T h$ & 41.64 & 44.35 & 57.44 & 36.57 & 42.54 & 26.21 & 32.50 & 74.78 & 83.04 \\
\hline $\mathrm{Ti}$ & 656.00 & 1357.00 & 1468.00 & 1022.00 & 330.00 & 1096.00 & 1476.00 & 987.20 & 1250.00 \\
\hline Tm & 0.43 & 0.70 & 0.79 & 0.59 & 0.50 & 0.30 & 0.53 & 0.28 & 0.21 \\
\hline$U$ & 412.20 & 492.80 & 662.30 & 2076.00 & 3180.00 & 262.60 & 280.70 & 360.20 & 346.10 \\
\hline 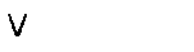 & 126.40 & 153.10 & 167.00 & 235.70 & 317.10 & 194.60 & 242.40 & 226.50 & 286.50 \\
\hline W & 15.44 & 29.85 & 30.20 & 75.01 & 69.16 & 3.84 & 4.19 & 3.64 & 4.11 \\
\hline Y & 26.42 & 44.90 & 47.05 & 29.99 & 36.11 & 19.65 & 26.19 & 20.49 & 26.92 \\
\hline Yb & 2.92 & 4.84 & 5.37 & 4.14 & 4.82 & 1.89 & 1.78 & 1.61 & 2.13 \\
\hline $\mathrm{Zn}$ & 49.74 & 86.69 & 12.30 & 9.47 & 102.70 & 66.86 & 42.66 & 95.86 & 101.90 \\
\hline $\mathrm{Zr}$ & 98.21 & 254.70 & 210.20 & 180.10 & 166.80 & 61.70 & 71.42 & 54.28 & 63.76 \\
\hline
\end{tabular}


Tabela 1-7B: Continuação.

\begin{tabular}{|c|c|c|c|c|c|c|c|c|c|}
\hline $\begin{array}{c}\text { AMOSTRA } \\
\text { Fd } \\
\text { ppmltipo }\end{array}$ & $\begin{array}{c}\text { SN/15-3 } \\
5000 \\
\text { fr.oxi } \\
\end{array}$ & $\begin{array}{c}\text { SN/15-3 } \\
50000 \\
\text { fr.oxi } \\
\end{array}$ & $\begin{array}{c}\text { SN/15-4 } \\
5000 \\
\text { oxi } \\
\end{array}$ & $\begin{array}{c}\text { SN/15-4 } \\
50000 \\
0 \times i \\
\end{array}$ & $\begin{array}{c}\text { SN/15-5 } \\
5000 \\
0 \times 1 \\
\end{array}$ & $\begin{array}{c}\text { SN/15-5 } \\
50000 \\
0 \times 1 \\
\end{array}$ & $\begin{array}{c}04 / 02-3 \\
5000 \\
\text { fr.oxi } \\
\end{array}$ & $\begin{array}{l}04 / 02-3 \\
50000 \\
\text { fr.oxi }\end{array}$ & $\begin{array}{c}04 / 02-1 \\
5000 \\
0 \times i \\
\end{array}$ \\
\hline As & 5.30 & 10.26 & 7.10 & 0.43 & 2.75 & $\overline{8.41}$ & 83.44 & 90.77 & 51.96 \\
\hline $\mathrm{Ba}$ & 428.60 & 634.30 & 430.80 & 619.30 & 471.20 & 605.60 & 501.30 & 619.30 & 476.70 \\
\hline $\mathrm{Be}$ & 2.03 & 3.31 & 2.34 & 6.06 & 0.58 & 1.84 & 5.28 & 6.34 & 7.83 \\
\hline $\mathrm{Bi}$ & 0.21 & 0.30 & 0.07 & 0.19 & 0.07 & 0.06 & 0.16 & 0.09 & 0.07 \\
\hline $\mathrm{Ca}$ & 74.23 & 0.00 & 225.60 & 0.00 & 82.11 & 0.00 & 497.50 & 407.80 & 785.70 \\
\hline $\mathrm{Cd}$ & 1.22 & 0.93 & 1.83 & 2.80 & 0.96 & 1.05 & 8.26 & 9.64 & 7.20 \\
\hline $\mathrm{Ce}$ & 66.69 & 82.06 & 88.49 & 94.47 & 52.55 & 61.82 & 268.70 & 359.30 & 209.80 \\
\hline Co & 0.34 & 0.64 & 0.70 & 0.58 & 0.46 & 0.51 & 2.87 & 3.43 & 2.32 \\
\hline $\mathrm{Cr}$ & 23.67 & 0.00 & 12.94 & 8.01 & 14.51 & 0.00 & 21.10 & 26.22 & 3.72 \\
\hline Cs & 0.21 & 0.27 & 0.28 & 0.34 & 0.22 & 0.22 & 0.26 & 0.37 & 0.30 \\
\hline $\mathrm{Cu}$ & 1.76 & 2.04 & 1.55 & 3.24 & 2.16 & 1.28 & 4.36 & 9.62 & 38.45 \\
\hline Dy & 4.27 & 4.77 & 2.96 & 2.91 & 5.99 & 6.62 & 106.60 & 118.60 & 12.53 \\
\hline Er & 0.72 & 3.17 & 1.77 & 2.10 & 4.37 & 4.84 & 66.60 & 76.56 & 7.85 \\
\hline Eu & 0.75 & 0.51 & 0.72 & 0.74 & 0.75 & 0.80 & 6.20 & 7.10 & 1.82 \\
\hline $\mathrm{Fe}$ & 18270.00 & 30830.00 & 32420.00 & 39020.00 & 6594.00 & 10110.00 & 17570.00 & 21210.00 & 18850.00 \\
\hline $\mathrm{Ga}$ & 26.38 & 38.87 & 34.51 & 39.34 & 11.91 & 17.04 & 42.24 & 51.01 & 83.31 \\
\hline $\mathrm{Gd}$ & 3.22 & 2.69 & 3.07 & 3.01 & 3.03 & 2.80 & 30.97 & 32.92 & 8.72 \\
\hline Ge & 1.93 & 6.46 & 1.69 & 0.43 & 1.01 & 0.66 & 1.93 & 1.12 & 2.49 \\
\hline $\mathrm{Hf}$ & 2.05 & 2.99 & 1.53 & 1.07 & 4.99 & 6.03 & 23.35 & 22.57 & 10.43 \\
\hline Ho & 0.94 & 1.05 & 0.60 & 0.78 & 1.53 & 1.65 & 24.41 & 26.90 & 2.66 \\
\hline La & 71.85 & 93.60 & 84.23 & 93.57 & 49.17 & 61.51 & 220.90 & 288.10 & 180.50 \\
\hline $\mathrm{Li}$ & 17.82 & 56.13 & 23.95 & 0.00 & 13.79 & 87.05 & 41.93 & 0.00 & 88.60 \\
\hline Lu & 0.34 & 0.38 & 0.24 & 0.28 & 0.69 & 0.74 & 9.28 & 11.44 & 0.96 \\
\hline $\mathrm{Mg}$ & 54.71 & 26.32 & 122.20 & 171.10 & 57.45 & 16.56 & 203.30 & 306.60 & 450.00 \\
\hline $\mathrm{Mn}$ & 12.30 & 17.09 & 19.35 & 23.20 & 15.71 & 18.31 & 05 & 134.90 & 147.60 \\
\hline Mo & 22.68 & 28.70 & 0.02 & 52.01 & 12.48 & 14.34 & 848 & 1032.00 & 538.20 \\
\hline $\mathrm{Nb}$ & 19.06 & 4.93 & 13.13 & 14.02 & 18.29 & 25.56 & 9 & 18.70 & 52.65 \\
\hline Nd & 9.45 & 3.10 & 14.81 & 15.30 & 8.21 & 9.49 & 8 & 68.81 & 37.78 \\
\hline $\mathrm{Ni}$ & 16.31 & 21.29 & 7.17 & 10.08 & 14.14 & 16.73 & 45 & 592.70 & 20.24 \\
\hline $\mathrm{Pb}$ & 38.76 & 39.59 & 33.31 & 37.57 & 15.44 & 10.96 & ) & 46.52 & 44.35 \\
\hline $\mathrm{Pd}$ & 3.46 & 2.33 & 0.0 & 1.0 & 4.13 & 1.90 & ) & 7.25 & 6.13 \\
\hline Pr & 4.72 & 5.7 & 7.1 & 7.40 & 3.95 & 4.76 & 7 & 28.62 & 17.41 \\
\hline $\mathrm{Rb}$ & 203.70 & 289.30 & 30. & 32.70 & 03.10 & & & 70 & 46.40 \\
\hline s & 19110.00 & 0.00 & 0.00 & 0.00 & 20.00 & 67.00 & 7862.00 & 0.00 & 15200.00 \\
\hline$s b$ & 0.31 & 0.67 & 0.36 & 0.61 & 0.16 & 0.24 & 0.61 & 0.35 & 8225.00 \\
\hline $\mathrm{Sc}$ & 0.58 & 1.41 & 0.70 & 0.00 & 0.95 & 1.61 & 9.52 & 10.05 & 1.68 \\
\hline $\mathrm{Se}$ & 5.22 & 9.9 & 2. & 0.00 & 1.03 & 8 & 0 & 4.14 & 4.47 \\
\hline $\mathrm{Sm}$ & 1.10 & 1.48 & 1.50 & 93 & 1.32 & 37 & 3.83 & 15.28 & 4.33 \\
\hline $\mathrm{Sr}$ & 351.20 & 518.40 & 74.30 & 288.10 & 98.90 & 267.10 & 969.50 & 1265.00 & 861.60 \\
\hline Ta & 0.12 & 0.13 & 0.11 & 0.03 & 0.06 & 0.44 & 0.34 & 0.34 & 0.74 \\
\hline Tb & 0.64 & 0.76 & 0.50 & 0.52 & 0.68 & 0.69 & 12.10 & 13.25 & 1.80 \\
\hline Th & 75.96 & 91.88 & 75.38 & 82.04 & 70.58 & 74.97 & 237.20 & 275.60 & 53.24 \\
\hline $\mathrm{Ti}$ & 1753.00 & 2259.00 & 996.60 & 1076.00 & 1125.00 & 1427.00 & 2623.00 & 29.31 & 3587.00 \\
\hline $\mathrm{Tm}$ & 0.42 & 0.46 & 0.26 & 0.28 & 0.73 & 0.73 & 9.17 & 11.52 & 1.10 \\
\hline U & 262.80 & 311.00 & 5.80 & 8.90 & 156.40 & 149.90 & 899.70 & 1119.00 & 439.70 \\
\hline V & 147.40 & 185.90 & 153.40 & 161.10 & 40.36 & 48.43 & 244.10 & 292.40 & 425.90 \\
\hline W & 3.57 & 4.16 & 3.16 & 3.26 & 3.16 & 2.87 & 5.80 & 6.03 & 6.01 \\
\hline Y & 29.80 & 41.79 & 22.01 & 20.80 & 41.29 & 52.20 & 593.30 & 774.40 & 95.53 \\
\hline$Y b$ & 2.73 & 2.22 & 1.61 & 1.72 & 4.41 & 4.27 & 57.78 & 73.95 & 5.90 \\
\hline $\mathrm{Zn}$ & 93.11 & 83.85 & 150.70 & 187.80 & 31.76 & 9.09 & 157.00 & 230.20 & 157.50 \\
\hline $\mathrm{Zr}$ & 81.58 & 91.98 & 61.58 & 50.14 & 199.70 & 214.50 & 1741.00 & 2156.00 & 476.50 \\
\hline
\end{tabular}


Tabela 1-7B: Continuação.

\begin{tabular}{|c|c|c|c|c|c|c|c|}
\hline AMOSTRA & $04 / 02-1$ & $04 / 02-2$ & $04 / 02-2$ & $M 2 b-5$ & $M 2 b-5$ & $M 2 b-6$ & $M 2 b-6$ \\
\hline$F d$ & 50000 & 5000 & 50000 & 5000 & 50000 & 5000 & 50000 \\
\hline ppmitipo & oxi & oxi & $o x i$ & fr.oxi & fr.oxi & oxi & oxi \\
\hline As & 54.42 & 6.81 & 9.08 & 111.00 & 164.50 & 68.03 & 71.25 \\
\hline $\mathrm{Ba}$ & 634.40 & 486.40 & 678.90 & 1845.00 & 3483.00 & 996.80 & 1327.00 \\
\hline $\mathrm{Be}$ & 10.77 & 1.81 & 6.01 & 8.79 & 11.47 & 4.68 & 4.52 \\
\hline $\mathrm{Bi}$ & 0.09 & 0.04 & 0.02 & 0.14 & 0.14 & 0.09 & 0.28 \\
\hline $\mathrm{Ca}$ & 524.30 & 117.80 & 0.00 & 263.90 & 0.00 & 376.20 & 400.70 \\
\hline $\mathrm{Cd}$ & 6.72 & 1.98 & 1.08 & 4.03 & 3.01 & 3.58 & 3.64 \\
\hline $\mathrm{Ce}$ & 252.40 & 138.90 & 167.00 & 104.60 & 128.40 & 109.00 & 125.00 \\
\hline Co & 2.54 & 6.46 & 8.76 & 13.58 & 20.98 & 1.04 & 1.18 \\
\hline $\mathrm{Cr}$ & 5.63 & 28.96 & 5.33 & 43.41 & 17.14 & 9.60 & 21.38 \\
\hline $\mathrm{Cs}$ & 0.30 & 0.48 & 0.48 & 0.24 & 0.20 & 0.26 & 0.23 \\
\hline $\mathrm{Cu}$ & 46.09 & 1.65 & 1.65 & 22.45 & 32.18 & 3.48 & 10.65 \\
\hline Dy & 14.28 & 18.99 & 20.51 & 44.60 & 51.65 & 33.04 & 38.79 \\
\hline $\mathrm{Er}$ & 8.00 & 11.78 & 11.75 & 31.60 & 35.19 & 26.55 & 27.06 \\
\hline Eu & 1.67 & 5.17 & 5.14 & 5.48 & 6.54 & 3.63 & 3.73 \\
\hline $\mathrm{Fe}$ & 21720.00 & 15350.00 & 23680.00 & 21920.00 & 35850.00 & 13940.00 & 14920.00 \\
\hline $\mathrm{Ga}$ & 88.65 & 35.28 & 51.05 & 26.88 & 38.66 & 71.41 & 80.52 \\
\hline Gd & 8.22 & 18.63 & 16.38 & 14.98 & 17.34 & 11.98 & 10.33 \\
\hline $\mathrm{Ge}$ & 2.50 & 2.37 & 1.83 & 2.50 & 0.94 & 1.27 & 0.00 \\
\hline $\mathrm{Hf}$ & 9.67 & 18.54 & 15.02 & 17.67 & 16.97 & 31.23 & 25.73 \\
\hline Ho & 3.26 & 4.30 & 4.47 & 11.11 & 12.93 & 8.53 & 9.38 \\
\hline La & 209.40 & 160.60 & 207.90 & 45.40 & 59.12 & 87.43 & 98.25 \\
\hline $\mathrm{Li}$ & 67.27 & 72.75 & 218.40 & 29.82 & 123.40 & 41.71 & 68.18 \\
\hline Lu & 1.34 & 1.62 & 1.46 & 4.87 & 5.48 & 4.12 & 4.68 \\
\hline $\mathrm{Mg}$ & 504.10 & 331.00 & 488.90 & 170.20 & 228.60 & 457.30 & 633.70 \\
\hline $\mathrm{Mn}$ & 154.40 & 26.50 & 51.98 & 42.80 & 65.28 & 32.06 & 33.38 \\
\hline Mo & 596.40 & 80.73 & 93.56 & 778.90 & 1050.00 & 647.60 & 684.30 \\
\hline $\mathrm{Nb}$ & 33.18 & 7.85 & 10.98 & 8.26 & 12.41 & 26.57 & 22.63 \\
\hline $\mathrm{Nd}$ & 43.55 & 41.93 & 57.11 & 23.25 & 31.84 & 25.56 & 28.77 \\
\hline $\mathrm{Ni}$ & 22.75 & 2.66 & 0.64 & 8.77 & 10.28 & 4.22 & 6.68 \\
\hline $\mathrm{Pb}$ & 56.23 & 17.63 & 12.88 & 22.42 & 16.36 & 37.37 & 45.27 \\
\hline$P d$ & 4.49 & 16.05 & 6.79 & 33.07 & 19.47 & 15.22 & 13.70 \\
\hline Pr & 19.86 & 16.27 & 18.16 & 7.16 & 8.57 & 9.31 & 10.18 \\
\hline $\mathrm{Rb}$ & 270.20 & 189.30 & 235.70 & 199.60 & 271.00 & 201.40 & 218.40 \\
\hline$S$ & 0.00 & 17100.00 & 0.00 & 19370.00 & 0.00 & 10200.00 & 45250.00 \\
\hline $\mathrm{Sb}$ & 0.57 & 0.37 & 0.39 & 0.86 & 0.79 & 1.19 & 0.97 \\
\hline Sc & 0.94 & 2.04 & 3.45 & 8.01 & 13.07 & 6.32 & 6.41 \\
\hline $\mathrm{Se}$ & 2.11 & 3.96 & 9.30 & 3.49 & 10.48 & 2.31 & 8.54 \\
\hline Sm & 4.42 & 11.71 & 11.63 & 8.96 & 9.83 & 7.25 & 7.93 \\
\hline Sr & 1029.00 & 370.20 & 462.20 & 128.90 & 172.80 & 591.30 & 636.50 \\
\hline Ta & 0.34 & 0.12 & 0.06 & 0.22 & 0.19 & 0.32 & 0.04 \\
\hline Tb & 1.98 & 3.10 & 3.21 & 5.23 & 5.64 & 3.74 & 3.41 \\
\hline Th & 64.49 & 39.28 & 43.14 & 122.60 & 139.10 & 128.50 & 140.00 \\
\hline $\mathrm{Ti}$ & 3840.00 & 1445.00 & 1745.00 & 3864.00 & 5533.00 & 2928.00 & 3233.00 \\
\hline $\mathrm{Tm}$ & 1.18 & 1.73 & 1.71 & 5.06 & 5.74 & 4.29 & 4.51 \\
\hline U & 547.50 & 765.10 & 897.10 & 405.10 & 411.30 & 265.70 & 286.50 \\
\hline V & 476.10 & 199.50 & 252.70 & 242.60 & 312.20 & 504.00 & 598.00 \\
\hline W & 6.11 & 2.27 & 1.22 & 5.11 & 5.12 & 7.29 & 6.18 \\
\hline Y & 105.80 & $\$ 25.10$ & 144.80 & 304.70 & 453.70 & 266.20 & 288.90 \\
\hline$Y_{b}$ & 7.07 & 10.54 & 9.84 & 32.18 & 35.35 & 26.64 & 26.72 \\
\hline $\mathrm{Zn}$ & 180.70 & 61.42 & 49.60 & 46.53 & 31.90 & 30.24 & 114.70 \\
\hline$Z r$ & 439.60 & 1013.00 & 1166.00 & 1252.00 & 1838.00 & 1669.00 & 1690.00 \\
\hline
\end{tabular}


Tabela 1-8: Reanálise via ICP-MS e AES* de amostras maiores das frentes redox dos microperfis.

\begin{tabular}{|c|c|c|c|c|c|c|c|c|}
\hline Amostra & iarf4 & iarf3 & iart2 & iarf1 & iarf5 & iarf7 & iarf6 & $\mathrm{m} 2 \mathrm{~b} 2$ \\
\hline $\mathrm{Fd}$ & 10000 & 10000 & 10000 & 10000 & 10000 & 10000 & 10000 & 10000 \\
\hline ppmitipo & red & red & oxi-OHF & oxi & oxi & oxi & OXI-OHF & red \\
\hline $\mathrm{Al}^{*}$ & 65000.00 & 108000.00 & 106000.00 & 116000.00 & 82000.00 & 112000.00 & 96000.00 & 136000.00 \\
\hline As & 38.27 & 37.28 & 34.65 & 32.98 & 25.69 & 21.63 & 52.58 & 90.53 \\
\hline $\mathrm{Ba}$ & 749.80 & 799.20 & 744.50 & 667.80 & 515.10 & 662.80 & 601.80 & 1198.00 \\
\hline $\mathrm{Bi}$ & 0.50 & 0.85 & 0.00 & 0.26 & 0.28 & 0.35 & 0.62 & 0.29 \\
\hline $\mathrm{Ca}$ & 624.00 & 617.50 & 488.90 & 485.80 & 334.20 & 508.40 & 455.70 & 424.20 \\
\hline $\mathrm{Ca}^{*}$ & 184.00 & 187.00 & 213.00 & 109.00 & 113.00 & 133.00 & 134.00 & 100.00 \\
\hline $\mathrm{Cd}$ & 3.83 & 1.05 & 7.79 & 1.77 & 6.25 & 0.91 & 2.20 & 7.97 \\
\hline $\mathrm{Ce}$ & 339.80 & 395.90 & 315.80 & 181.20 & 134.20 & 233.90 & 85.47 & 119.50 \\
\hline Co & 1.07 & 1.41 & 0.41 & 0.61 & 0.62 & 0.32 & 0.13 & 0.79 \\
\hline $\mathrm{Cr}$ & 1.38 & 0.57 & 0.00 & 1.38 & 0.11 & 1.04 & 1.29 & 0.00 \\
\hline $\mathrm{Cs}$ & 0.78 & 0.81 & 0.68 & 0.50 & 0.63 & 0.46 & 0.92 & 0.38 \\
\hline $\mathrm{Cu}$ & 1.66 & 2.78 & 1.01 & 2.92 & 1.08 & 9.81 & 3.45 & 4.08 \\
\hline Dy & 15.57 & 21.95 & 23.11 & 14.80 & 14.01 & 12.90 & 10.82 & 9.46 \\
\hline $\mathrm{Er}$ & 9.61 & 13.03 & 15.18 & 10.05 & 12.31 & 7.15 & 7.74 & 7.53 \\
\hline Eu & 5.25 & 6.26 & 3.15 & 2.99 & 2.09 & 3.31 & 1.75 & 1.44 \\
\hline $\mathrm{Fe}^{*}$ & 20000.00 & 23000.00 & 64000.00 & 30000.00 & 18000.00 & 15000.00 & 122000.00 & 20000.00 \\
\hline $\mathrm{Ga}$ & 54.29 & 47.61 & 42.09 & 54.46 & 40.51 & 46.49 & 45.65 & 67.08 \\
\hline $\mathrm{Gd}$ & 19.87 & 23.38 & 15.06 & 12.60 & 8.39 & 14.96 & 7.80 & 5.39 \\
\hline $\mathrm{Ge}$ & 3.40 & 3.62 & 6.24 & 3.67 & 2.23 & 4.54 & 9.15 & 3.15 \\
\hline $\mathrm{Hf}$ & 36.06 & 16.55 & 56.05 & 21.45 & 50.60 & 13.74 & 13.07 & 16.96 \\
\hline Ho & 3.47 & 4.27 & 5.21 & 3.33 & 3.97 & 2.64 & 2.51 & 2.28 \\
\hline La & 313.90 & 341.10 & 345.40 & 166.50 & 138.10 & 188.60 & 94.90 & 99.09 \\
\hline Lu & 1.01 & 1.44 & 2.12 & 1.33 & 1.94 & 0.87 & 1.04 & 0.94 \\
\hline $\mathrm{Mg}^{\star}$ & 116.00 & 118.00 & 173.00 & 292.00 & 188.00 & 167.00 & 224.00 & 259.00 \\
\hline $\mathrm{Mn}$ & 40.78 & 36.60 & 42.61 & 60.85 & 84.14 & 49.35 & 70.76 & 18.74 \\
\hline $\mathrm{Mn}^{\star}$ & 35.00 & 33.00 & 47.00 & 51.00 & 69.00 & 42.00 & 69.00 & 19.00 \\
\hline Mo & 355.30 & 204.10 & 418.20 & 176.20 & 217.20 & 129.60 & 356.60 & 116.20 \\
\hline $\mathrm{Nb}$ & 244.60 & 241.40 & 271.00 & 230.00 & 217.40 & 259.70 & 195.90 & 162.20 \\
\hline $\mathrm{Nd}$ & 72.04 & 75.45 & 39.21 & 35.33 & 20.66 & 48.68 & 21.73 & 20.45 \\
\hline $\mathrm{Ni}$ & 0.55 & 0.23 & 0.95 & 0.00 & 0.41 & 2.10 & 0.00 & 1.79 \\
\hline $\mathrm{Pb}$ & 57.18 & 65.51 & 51.34 & 33.80 & 28.61 & 24.57 & 41.38 & 29.61 \\
\hline $\mathrm{Pd}$ & 4.87 & 5.69 & 7.48 & 3.26 & 5.92 & 3.16 & 2.12 & 3.63 \\
\hline Pr & 29.51 & 32.29 & 18.52 & 14.68 & 8.60 & 19.35 & 7.64 & 7.19 \\
\hline Pt & 0.52 & 0.16 & 0.81 & 0.36 & 0.45 & 0.21 & 0.13 & 0.31 \\
\hline $\mathrm{Rb}$ & 281.00 & 251.20 & 243.90 & 292.30 & 268.00 & 258.20 & 243.50 & 348.00 \\
\hline$S$ & 85120.00 & 112500.00 & 0.00 & 9585.00 & 0.00 & 0.00 & 0.00 & 10230.00 \\
\hline $\mathrm{Sb}$ & 2.41 & 2.15 & 3.99 & 2.03 & 2.22 & 0.95 & 1.60 & 1.10 \\
\hline $\mathrm{Se}$ & 5.89 & 3.57 & 2.20 & 6.47 & 6.03 & 7.90 & 5.52 & 0.53 \\
\hline $\mathrm{Sm}$ & 15.11 & 16.26 & 7.47 & 6.88 & 4.97 & 8.49 & 4.41 & 3.63 \\
\hline $\mathrm{Sr}$ & 1178.00 & 1471.00 & 1546.00 & 711.40 & 513.10 & 599.10 & 521.10 & 714.00 \\
\hline $\mathrm{Ta}$ & 3.22 & 5.22 & 4.48 & 9.07 & 3.38 & 4.92 & 5.27 & 3.52 \\
\hline $\mathrm{Tb}$ & 2.45 & 3.46 & 2.77 & 2.05 & 1.79 & 2.11 & 1.38 & 1.01 \\
\hline Th & 106.60 & 76.47 & 151.80 & 63.90 & 77.13 & 46.81 & 43.22 & 53.14 \\
\hline $\mathrm{Ti}$ & 2724.00 & 2554.00 & 2898.00 & 2954.00 & 2317.00 & 3010.00 & 2245.00 & 2640.00 \\
\hline $\mathrm{Ti}^{*}$ & 2600.00 & 2600.00 & 3100.00 & 2800.00 & 2400.00 & 3100.00 & 2200.00 & 2600.00 \\
\hline $\mathrm{Tm}$ & 1.23 & 1.72 & 2.30 & 1.53 & 1.98 & 0.96 & 1.05 & 1.04 \\
\hline $\mathrm{U}$ & 140.10 & 143.20 & 551.80 & 149.10 & 203.60 & 84.76 & 163.00 & 77.81 \\
\hline V & 375.80 & 362.90 & 341.90 & 416.80 & 255.90 & 364.80 & 336.10 & 600.80 \\
\hline$w$ & 16.48 & 14.41 & 20.61 & 11.14 & 19.39 & 9.68 & 5.91 & 10.04 \\
\hline$Y$ & 125.40 & 139.20 & 193.40 & 86.51 & 147.00 & 76.52 & 73.38 & 97.96 \\
\hline$Y_{b}$ & 6.94 & 10.07 & 13.83 & 8.52 & 12.67 & 5.86 & 6.75 & 6.43 \\
\hline $\mathrm{Zn}$ & 0.00 & 132.80 & 41.40 & 127.90 & 0.00 & 107.80 & 484.90 & 90.19 \\
\hline $\mathrm{Zr}$ & 3023.00 & 982.40 & 5901.00 & 1076.00 & 5178.00 & 641.60 & 568.00 & 1244.00 \\
\hline
\end{tabular}


Tabela 1-8: Coninuação.

\begin{tabular}{|c|c|c|c|c|c|c|c|c|}
\hline $\begin{array}{c}\text { Amostra } \\
\text { Fd } \\
\text { ppmltipo } \\
\end{array}$ & $\begin{array}{c}\mathrm{m} 2 \mathrm{~b} 1 \\
10000 \\
\text { red }\end{array}$ & $\begin{array}{l}\mathrm{m} 2 \mathrm{~b} 3 \\
10000 \\
z . \mathrm{brca} \\
\end{array}$ & $\begin{array}{c}\text { m2b4 } \\
10000 \\
\text { oxi } \\
\end{array}$ & $\begin{array}{c}m 2 c 4 \\
10000 \\
\text { red } \\
\end{array}$ & $\begin{array}{c}\mathrm{m} 2 \mathrm{c} 2 \\
10000 \\
\text { red } \\
\end{array}$ & $\begin{array}{c}m 2 c 1 \\
10000 \\
\text { oxi } \\
\end{array}$ & $\begin{array}{c}\mathrm{m} 2 \mathrm{c} 3 \\
10000 \\
\mathrm{oxi} \\
\end{array}$ & $\begin{array}{c}\text { sn/15-1 } \\
10000 \\
\text { red }\end{array}$ \\
\hline$\overline{A l^{*}}$ & 114000.00 & 108000.00 & 118000.00 & 124000.00 & 114000.00 & 118000.00 & 113000.00 & 96000.00 \\
\hline As & 55.49 & 23.63 & 185.10 & 17.73 & 15.09 & 14.13 & 12.80 & 4.07 \\
\hline $\mathrm{Ba}$ & 1054.00 & 1085.00 & 2544.00 & 1039.00 & 793.10 & 811.60 & 864.20 & 603.90 \\
\hline $\mathrm{Bi}$ & 0.35 & 0.18 & 0.92 & 0.31 & 0.80 & 0.31 & 0.30 & 0.00 \\
\hline $\mathrm{Ca}$ & 536.10 & 559.40 & 744.10 & 481.70 & 542.80 & 345.50 & 421.60 & 295.40 \\
\hline $\mathrm{Ca}^{*}$ & 76.00 & 16.00 & 132.00 & 132.00 & 103.00 & 108.00 & 144.00 & 47.00 \\
\hline $\mathrm{Cd}$ & 9.15 & 0.98 & 3.00 & 2.93 & 5.80 & 2.87 & 1.84 & 1.17 \\
\hline $\mathrm{Ce}$ & 71.78 & 216.70 & 162.30 & 547.40 & 130.00 & 121.80 & 92.57 & 77.60 \\
\hline Co & 0.51 & 0.89 & 0.63 & 0.70 & 0.90 & 1.86 & 1.09 & 1.09 \\
\hline $\mathrm{Cr}$ & 0.00 & 8.84 & 0.00 & 0.00 & 0.00 & 0.00 & 0.00 & 0.00 \\
\hline Cs & 0.38 & 0.29 & 0.32 & 0.56 & 0.73 & 0.62 & 0.74 & 0.36 \\
\hline $\mathrm{Cu}$ & 8.84 & 19.06 & 2.92 & 5.74 & 3.04 & 0.02 & 23.51 & 1.97 \\
\hline Dy & 11.97 & 10.81 & 15.08 & 19.36 & 9.89 & 11.17 & 14.11 & 4.32 \\
\hline Er & 9.89 & 8.04 & 11.33 & 9.46 & 6.64 & 7.31 & 8.64 & 2.79 \\
\hline $\mathrm{Eu}$ & 1.16 & 2.07 & 2.50 & 7.73 & 2.43 & 2.77 & 3.37 & 0.57 \\
\hline $\mathrm{Fe}^{\star}$ & 15000.00 & 8200.00 & 22000.00 & 17000.00 & 19000.00 & 18000.00 & 21000.00 & 4200.00 \\
\hline $\mathrm{Ga}$ & 54.95 & 44.23 & 46.53 & 446.20 & 50.68 & 49.85 & 43.34 & 27.83 \\
\hline $\mathrm{Gd}$ & 5.30 & 8.04 & 8.27 & 30.65 & 8.96 & 10.49 & 11.65 & 2.66 \\
\hline Ge & 2.79 & 1.63 & 3.27 & 2.49 & 3.51 & 2.60 & 2.81 & 1.64 \\
\hline $\mathrm{Hf}$ & 22.80 & 16.65 & 18.61 & 16.70 & 16.04 & 17.58 & 18.77 & 2.69 \\
\hline Ho & 3.36 & 2.90 & 3.74 & 3.80 & 2.22 & 2.71 & 3.17 & 1.01 \\
\hline La & 67.63 & 163.80 & 142.00 & 389.80 & 124.90 & 148.30 & 132.80 & 91.89 \\
\hline Lu & 1.35 & 1.10 & 1.56 & 1.14 & 0.91 & 0.91 & 0.99 & 0.33 \\
\hline $\mathrm{Mg}^{\star}$ & 0.25 & 196.00 & 236.00 & 230.00 & 247.00 & 312.00 & 378.00 & 27.00 \\
\hline $\mathrm{Mn}$ & 20.11 & 30.45 & 22.78 & 32.43 & 73.50 & 46.44 & 56.96 & 11.04 \\
\hline $\mathrm{Mn}^{\star}$ & 19.00 & 29.00 & 22.00 & 30.00 & 59.00 & 44.00 & 51.00 & 11.00 \\
\hline Mo & 61.21 & 92.94 & 892.90 & 191.60 & 109.40 & 155.10 & 126.80 & 7.73 \\
\hline $\mathrm{Nb}$ & 105.50 & 163.20 & 199.20 & 183.30 & 170.60 & 174.60 & 1610.00 & 231.30 \\
\hline $\mathrm{Nd}$ & 13.39 & 33.00 & 28.59 & 126.40 & 28.13 & 31.34 & 28.83 & 10.23 \\
\hline $\mathrm{Ni}$ & 1.94 & 9.73 & 1.74 & 2.15 & 1.41 & 1.49 & 2.89 & 4.19 \\
\hline $\mathrm{Pb}$ & 14.46 & 24.07 & 39.16 & 73.46 & 37.08 & 22.08 & 20.65 & 34.53 \\
\hline $\mathrm{Pd}$ & 4.74 & 4.28 & 5.23 & 4.86 & 3.23 & 4.01 & 5.67 & 1.31 \\
\hline $\mathrm{Pr}$ & 4.97 & 14.52 & 11.03 & 50.5 & 9.45 & 10.73 & 10.12 & 4.94 \\
\hline Pt & 0.30 & 0.34 & 0.14 & 0.12 & 0.11 & 0.20 & 0.21 & 0.37 \\
\hline $\mathrm{Rb}$ & 309.30 & 277.80 & 304.10 & 331.80 & 296.30 & 304.70 & 285.90 & 273.30 \\
\hline$s$ & 76140.00 & 11370.00 & 25500.00 & 64660.00 & 94010.00 & 0.00 & 21440.00 & 12940.00 \\
\hline $\mathrm{Sb}$ & 1.24 & 1.87 & 2.93 & 6.79 & 0.89 & 1.24 & 1.13 & 0.50 \\
\hline $\mathrm{Se}$ & 0.00 & 0.00 & 3.49 & 11.92 & 3.18 & 0.00 & 6.74 & 0.00 \\
\hline$S m$ & 3.41 & 5.59 & 6.12 & 19.73 & 5.74 & 7.01 & 8.02 & 1.43 \\
\hline Sr & 500.10 & 699.80 & 791.30 & 524.30 & 456.50 & 457.40 & 398.30 & 558.80 \\
\hline Ta & 5.25 & 4.39 & 3.90 & 3.36 & 3.27 & 3.38 & 3.24 & 3.78 \\
\hline $\mathrm{Tb}$ & 1.31 & 1.37 & 1.67 & 3.65 & 1.38 & 1.80 & 2.08 & 0.57 \\
\hline Th & 50.30 & 59.73 & 92.50 & 59.46 & 34.59 & 37.51 & 39.56 & 22.49 \\
\hline $\mathrm{Ti}$ & 1630.00 & 2292.00 & 2468.00 & 2613.00 & 2552.00 & 2442.00 & 2520.00 & 1716.00 \\
\hline$T_{i}^{*}$ & 1600.00 & 2600.00 & 2500.00 & 2600.00 & 2500.00 & 2500.00 & 2600.00 & 1700.00 \\
\hline$T m$ & 1.48 & 1.25 & 1.59 & 1.28 & 0.94 & 1.10 & 1.18 & 0.40 \\
\hline$u$ & 94.42 & 70.57 & 107.60 & 1532.00 & 1358.00 & 1102.00 & 691.30 & 150.70 \\
\hline V & 498.60 & 383.90 & 413.20 & 257.00 & 305.30 & 335.00 & 304.80 & 153.00 \\
\hline W & 7.80 & 55.00 & 14.74 & 14.24 & 13.86 & 10.42 & 10.52 & 12.31 \\
\hline Y & 122.40 & 109.00 & 147.70 & 133.30 & 89.45 & 100.00 & 121.20 & 34.60 \\
\hline $\mathrm{Yb}$ & 9.51 & 7.46 & 10.29 & 7.31 & 5.70 & 6.21 & 7.12 & 2.23 \\
\hline $\mathrm{Zn}$ & 96.60 & 45.29 & 80.76 & 172.90 & 50.29 & 70.22 & 82.79 & 218.30 \\
\hline $\mathrm{Zr}$ & 1697.00 & 1115.00 & 1396.00 & 1376.00 & 1264.00 & 1155.00 & 1496.00 & 172.70 \\
\hline
\end{tabular}


Tabela 1-8: Coninuação.

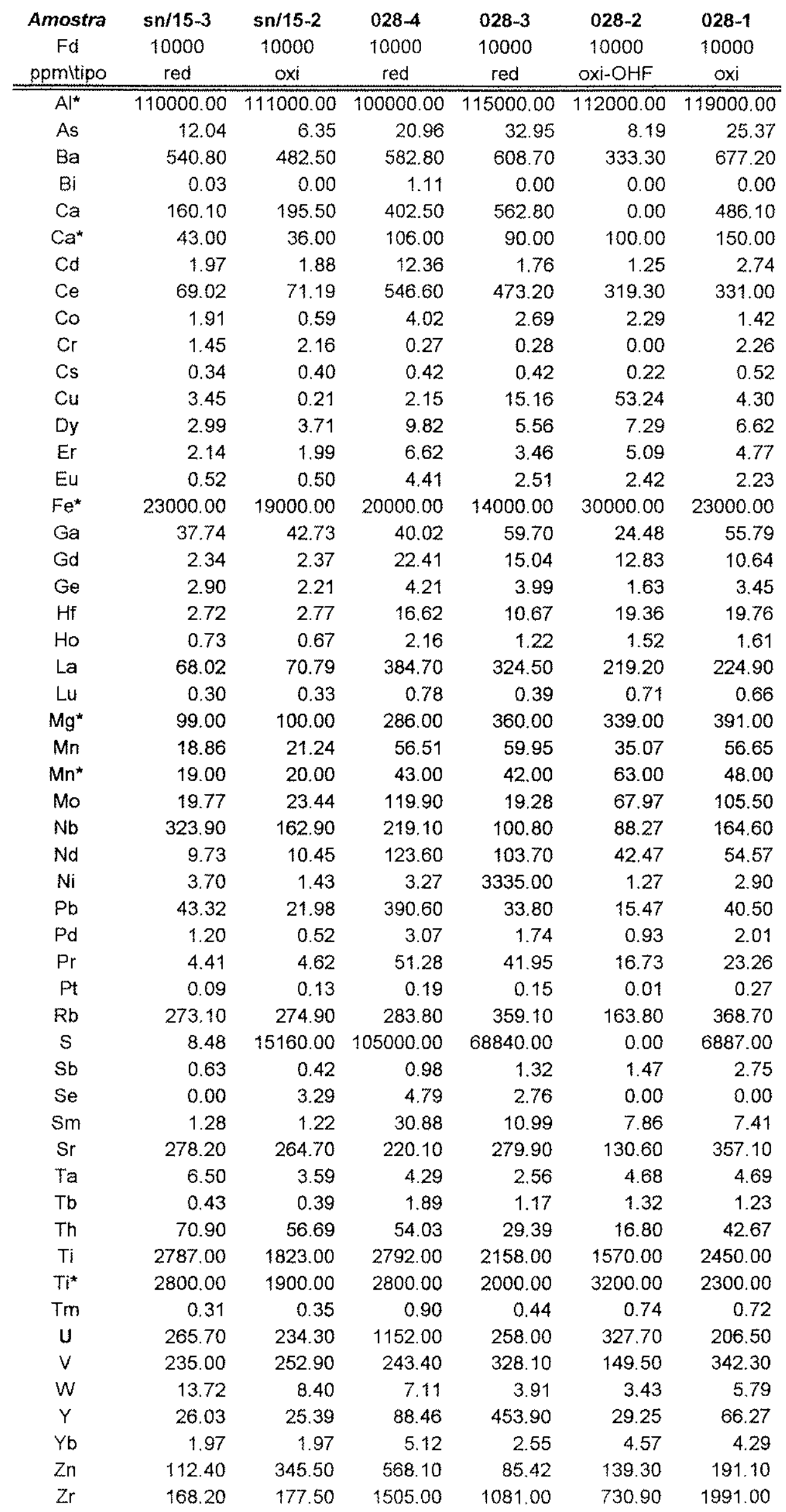


ANEXO II 
TABELA II-1: LISTAGEM DAS AMOSTRAS

*: Schumann, 1994; **: Schorscher e Shea, 1992, **: Waber et at., 1992

Legenda: Ph-fonolito; NeS-nefeltna sientto; Bf-brecha; FRX-fluorescencta de raios X. MSO- microssonda eletronic-a;ICP-AES- espectrometria de emissao atomica com fonte de ptasme induthamente acoplado; KCPMS- espectrometria de massa com fonte de plasma indutivamente acoptado; ESOHF- extraçăo selettua de oxb-hkdróxdos de ferTo; MEV- microscopla eletronka do varredura

\begin{tabular}{|c|c|c|c|}
\hline No da Amostra & Locellzaçio & Descriçäo & Análises \\
\hline A1M & mina Osamu Utsumi & Ph com hidrotermaksmo incipiente & FRX, MSO \\
\hline AIHH & mina Osamu Utsumi & Ph nao hidnotermalizado & FRX, MSO \\
\hline $\mathrm{A} 1 \mathrm{HT}$ & mina Osamu Utsum & Ph nao hidrotermalizado & FRX, MSO \\
\hline A1s & mina Osamu Utsumi & Ph com hidrotermalismo inclpiente e voio sulf. & FRX, MSO \\
\hline$A 2$ & mina Osamu Utsumi & Ph com hidrotermalismo inictal inctplente & MSO \\
\hline$A 4 B$ & mina Osamu Utsumi & Ph năo hidrotermalizado & FRX, ICP-AES,MSO \\
\hline A5 & mbra Osamt Utsum! & Ph năo hlorotermalkzado & FRX, ICP-AES, MSO \\
\hline A6 & mona Osamu Utsumt & Ph pouco hidrotermalizado & FRX, MSO \\
\hline A10BH & mine Osamu Utsuml & Ph nao hidrotermalizado & FRX, ICP-AES, MSO \\
\hline A10BT & mina Osamu Utsuml & Ph nao hidrotermalizado & FRX, MSO \\
\hline At1N & mina Osamu Utsumi & Ph Intemperkado & FRX, ICP.AES, MSO \\
\hline IARF & mina Osamu Ưtsumi & Frente redox & FRX, ICP-MS, ICP-AES, ESOHF \\
\hline M2b & mina Osamu Utsuml & Frente redox & FRX, ICP-MS, ICP-AES, ESOHF \\
\hline $\mathrm{M} 2 \mathrm{c}$ & mina Osamu Utsuml & Frente redox & FRX, ICP-MS, ICP-AES, ESOHF \\
\hline PDC-PH-028 & mina Osamu Utsumi & Frente redox & FRX, ICP-MS, ICP-AES, ESOHF \\
\hline SN/15 & mina Osama Utsumi & Frente redox & ICP-MS \\
\hline $\mathrm{U} 3 \mathrm{c}$ & mina Osamu Utsumt & Frente redox & ICP-MS \\
\hline $04 / 02$ & mina Osamu Utsumi & Frente redax & ICP-MS, IsOS \\
\hline IRF & mhra Osamu Ufsuml & Frente redox & FRX, ICP-MS, ICP-AES, ESOHF \\
\hline Vilt & mina Osamu Utsum & Frente redox & FRX, ICP-MS, ICP.AES, ESOHF \\
\hline RF III & mina Osamu Utsumi & Frente redox & FRX \\
\hline RF IV & mina Osamu Utsumi & Fremte redox & FRX \\
\hline SN/24-1 & mina Osamu Utsumi & $\begin{array}{l}\text { Frente redox } \\
\text { Nóduio maciço de } \mathrm{U}\end{array}$ & $\begin{array}{l}\text { FRX } \\
\text { isos }\end{array}$ \\
\hline SN/24-2 & mina Osamu Utsumi & Nodulo maciço de $\mathrm{U}$ & $\begin{array}{l}\text { isos } \\
\text { isos }\end{array}$ \\
\hline SN/24-3 & mina Osamu Utsum & Nódulo maciço de U & $\begin{array}{l}\text { Isos } \\
\text { isos }\end{array}$ \\
\hline SN/24-4 & mina Osamu Utsumf & Nơduto maclço de U & $\begin{array}{l}\text { isos } \\
\text { isas }\end{array}$ \\
\hline SN2,4-5 & mina Osamu Utsumi & Nodulo mackpo de U & $\begin{array}{l}\text { isas } \\
\text { Isos }\end{array}$ \\
\hline KU-3-1 & mina Osamu Utsumi & Nodulo maclço de U & $\begin{array}{l}\text { Isos } \\
\text { Isas }\end{array}$ \\
\hline KU-3-2 & mina Osamu Utsuml & Nodulo mackso de U & $\begin{array}{l}\text { Isas } \\
\text { Isos }\end{array}$ \\
\hline KU-6-1 & mina Osamu Utsumt & Noduk maciço de U & $\begin{array}{l}\text { Isos } \\
\text { Isos }\end{array}$ \\
\hline KU-6-1.1 & mina Osamu Utsumi & Noduto mackpo de U & $\begin{array}{l}\text { Isos } \\
\text { isos }\end{array}$ \\
\hline $\mathrm{KU}-6-1.2$ & mina Osamu Utsumi & Noduto macko de U & $\begin{array}{l}\text { isos } \\
180 \mathrm{~S}\end{array}$ \\
\hline VI-1.1 & mina Osamu Utsumb & Nodulo mactço de U & $\begin{array}{l}180 S \\
\text { Isos }\end{array}$ \\
\hline vil-1.2 & mina Osamu Utsumi & Nodulo macicio de U & $\begin{array}{l}\text { Isos } \\
\text { Isos }\end{array}$ \\
\hline vit-2 & mina Osamu Utsumi & Nodulo macko de U & $\begin{array}{l}\text { Isos } \\
1805\end{array}$ \\
\hline VII-3 & mina Osamu Uisumi & $\begin{array}{l}\text { Nodulo mackjo de U } \\
\text { Nodulo mackpo de U }\end{array}$ & $\begin{array}{l}1805 \\
\text { isos }\end{array}$ \\
\hline$M-1$ & mina Osamu Utsum! & $\begin{array}{l}\text { Nodulo mackio de } 0 \\
\text { Ph reduzido com mineralizaça do Mo }\end{array}$ & $\begin{array}{l}\text { isos } \\
\text { IsoS }\end{array}$ \\
\hline U-1A & mira Osamu Utsumi & $\begin{array}{l}\text { Ph reduzido com mineralizacia oo wo } \\
\text { Br reduzida }\end{array}$ & $\begin{array}{l}\text { Isos } \\
\text { Isos }\end{array}$ \\
\hline U4A & mina Osamu Utsumt & $\begin{array}{l}\text { Br recuzida } \\
\text { Ph reduzido com mineralkaçao de Mo }\end{array}$ & $\begin{array}{l}\text { Isos } \\
\text { Isos }\end{array}$ \\
\hline U4-B & mina Osamu Utsum! & $\begin{array}{l}\text { Ph reduzkdo } \\
\text { Phe }\end{array}$ & $\begin{array}{l}\text { Isos } \\
\text { isos }\end{array}$ \\
\hline U4D & mina Osamu Utsumi & $\begin{array}{l}\text { Pn reduzkio } \\
\text { Ph reduzido }\end{array}$ & $\begin{array}{l}\text { isos } \\
\text { isos }\end{array}$ \\
\hline U-7E & mina Osamu Utsumi & $\begin{array}{l}\text { Ph reduzido } \\
\text { Ph reduzido em frente redox com } \mathrm{min} \text {. } U\end{array}$ & $\begin{array}{l}\text { isos } \\
\text { isos }\end{array}$ \\
\hline U7-G & mina Osamu Utsuml & Pt reduzido em frente redox com min. U & $\begin{array}{l}\text { isos } \\
\text { Isos }\end{array}$ \\
\hline OUM-102 & mina Osamu Utsumi & 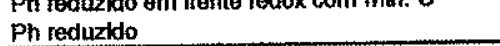 & $\begin{array}{l}\text { Isos } \\
\text { Isos }\end{array}$ \\
\hline $44 a / 9^{\star}$ & Barreta (CBA) - ba, fig. 2 & Ph reduzkdo & $\frac{\text { Isos }}{\text { FRX }}$ \\
\hline $51 / 13^{*}$ & Campo dos Bezerros (Tognt S/A) -cb, fig. 2 & Nes regkonal náthidrotermakzado & $\begin{array}{l}\text { FRX } \\
\text { FRX }\end{array}$ \\
\hline $55 / 15^{*}$ & Campo do Leme (Min. Curimbaba) - cl, fig. 2 & Nes regional nao-hidrotermalkado & $\begin{array}{l}\text { FRX } \\
\text { FRX }\end{array}$ \\
\hline $56 / 16^{*}$ & Campo do Leme (Min. Curimbaba) - c1, fig.2 & NoS rogional nao-hidrotemalzado & $\begin{array}{l}\text { FRX } \\
\text { FRX }\end{array}$ \\
\hline $61 / 18^{*}$ & Barro Preto (Min. Curimbaba) - bp, fag. 2 & NoS regional nao-hidrotemaltzado & $\begin{array}{l}\text { FRX } \\
\text { FRX }\end{array}$ \\
\hline $61 / 20 b^{*}$ & Barro Preto (Min. Cutmbaba) - bp, fig. 2 & $\begin{array}{l}\text { Nos regional nao-hidiotematizzado } \\
\text { Nes reglonal nao-hidrotermalizado }\end{array}$ & \\
\hline $66 / 22^{*}$ & 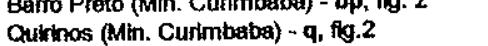 & $\begin{array}{l}\text { Nes reglonal nao-niarotermalizado } \\
\text { Nes regional nao-tidrotemalizado }\end{array}$ & FRX \\
\hline $70 a / 24^{\star}$ & 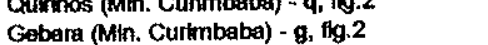 & $\begin{array}{l}\text { Nes regional nao-fidrotemalizado } \\
\text { Ph regional noo- hikrotermalizado }\end{array}$ & FRX \\
\hline $71 \mathrm{a} / 25^{\star}$ & 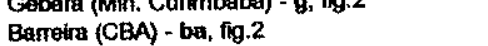 & $\begin{array}{l}\text { Ph reglonal năo- hilirotermalizado } \\
\text { Ph reglonal nao-hidrotermallzado }\end{array}$ & FRX \\
\hline $72 \mathrm{a} / 27^{*}$ & $\begin{array}{l}\text { Barretra (CEAA) - ba, lig. } \\
\text { Barreka (CBA) - ba, fig.2 }\end{array}$ & $\begin{array}{l}\text { Ph reglonal nao- hidrotermallzado } \\
\text { Ph regional nao hidrotermalzzado }\end{array}$ & FRX \\
\hline $74 / 28^{*}$ & $\begin{array}{l}\text { Barreka (CBA) - ba, } 13.2 \\
\text { Barreira (CAA) - ba, fig.2 }\end{array}$ & $\begin{array}{l}\text { Ph regional nao hidrotermaltzado } \\
\text { Ph reglonal náo- hldrotermaltzado }\end{array}$ & FRX \\
\hline $84 a / 30^{*}$ & Senta Rosália (Akoa) - sr, fig.2 & & FRX \\
\hline $99 / 33^{*}$ & Plcada (CBA) - p, fig.2 & & FRX \\
\hline $126 \mathrm{a} / 38^{*}$ & Bameira (CBA) - ba, fig.2 & & FRX \\
\hline $127 \cup 40^{*}$ & Plcadta Maranhao (CBA) - pm, fig.2 & & FRX \\
\hline ph02an & ver Figura 2 & Ph regional năo-hdrotermallzado & FRX \\
\hline pho2b & wor Figura 2 & & FRX \\
\hline ph03 & ver Figura 2 & & FRX \\
\hline phostith & ver Figura 2 & & FRX \\
\hline phos** & $\begin{array}{l}\text { ver Figura } 2 \\
\text { ver Figura } 2\end{array}$ & $\begin{array}{l}\text { Ph regional nao- hidrotermalkado } \\
\text { Ph regional nao- hidrotermattzado }\end{array}$ & FRX \\
\hline phogb & $\begin{array}{l}\text { ver Figura } 2 \\
\text { ver Figura } 2\end{array}$ & $\begin{array}{l}\text { Ph reglonal nuo- hidrotermatzzado } \\
\text { Ph reglonal noo- hidrotermaltzado }\end{array}$ & FRX \\
\hline NS-1* & $\begin{array}{l}\text { ver Figura } 2 \\
\text { ver Figura } 2\end{array}$ & $\begin{array}{l}\text { Ph reglonal nao- hidrotermaltzado } \\
\text { Nes regional nto-hidrotermalizzado }\end{array}$ & FRX \\
\hline NS $-4^{k *}$ & $\begin{array}{l}\text { ver Figura } 2 \\
\text { ver Figura } 2\end{array}$ & NeS regional noto-hidrotermaikzado & FRX \\
\hline NS-6*n & $\begin{array}{l}\text { ver Figura } 2 \\
\text { ver Figura } 2\end{array}$ & & FRX \\
\hline NS- $7^{\text {*t }}$ & $\begin{array}{l}\text { ver Figura } 2 \\
\text { ver Figura } 2\end{array}$ & $\begin{array}{l}\text { NeS regional nao-hidrotermatkzado } \\
\text { NaS regional nao-hldrotermalizado }\end{array}$ & FRX \\
\hline \multirow{2}{*}{\multicolumn{4}{|c|}{$\begin{array}{l}\text { NS-7 } \\
\text { Furo sondagem F1 ver Figura } 2\end{array}$}} \\
\hline $1-1 B^{n+*}$ & mina Osarnu Utsuml & & \\
\hline $1-1 C^{* * *}$ & $\begin{array}{l}\text { mina Osamu Utsumi } \\
\text { mina Osamu Utsumi }\end{array}$ & $\begin{array}{l}\text { Ph oxddado } \\
\text { Ph oxidado }\end{array}$ & $\begin{array}{l}\text { FRX } \\
\text { FRX }\end{array}$ \\
\hline $10-1 A^{* * *}$ & $\begin{array}{l}\text { mina Osanu Utsumi } \\
\text { mkra Osamu Utsumi }\end{array}$ & $\begin{array}{l}\text { Ph oxidado } \\
\text { Ph oxkdado }\end{array}$ & $\begin{array}{l}\text { FRX } \\
\text { FRXX }\end{array}$ \\
\hline $14-1 A^{* * *}$ & $\begin{array}{l}\text { mara Osamu Utsum| } \\
\text { mina Osamu Utsumt }\end{array}$ & Ph oxidado & FRX \\
\hline
\end{tabular}




\begin{tabular}{|c|c|c|c|}
\hline No da Amostre & Locellixacta & Descrictio & andilsea \\
\hline $16-1 A^{x+1+2 n}$ & mina Osame Utsuml & Ph oxidado & $F$ \\
\hline $20-1 A^{\text {nan }}$ & mina Osamu Utsumt & Ph oxidado & FRX \\
\hline $20-18^{\text {man }}$ & mina Osamu Utsumt & Pho oddado & FRX \\
\hline $23-1 A^{\text {nath }}$ & mina Osams Utsuml & Ph oxddado & FRX \\
\hline $26-1 A^{*+1}$ & mina Osamu Utsumi & Ph oxidado & $\mathrm{FRX}$ \\
\hline $31-1 A^{*+\cdots}$ & mina Osamu Utsumt & Ph oxidado & FRX \\
\hline $33-1 A^{* n+k}$ & mina Osamu Utsuml & Ph oxtiado & $\mathrm{FRX}$ \\
\hline $45-1 A^{* * n}$ & mina Osamu Utsumi & Ph oxidado & FRX \\
\hline $47-1 A^{\text {*n+k }}$ & mina Osamu Utsumf & Ph oxddado & FRX \\
\hline $50-1 A^{*}$ & mina Osamu Utsumt & Ph oxddado & FRX \\
\hline $55-1 A^{* n *}$ & mira Osamu Utsumt & Ph oxdado & FRX \\
\hline $59-1 A^{\operatorname{man}}$ & mina Osamu Utsuml & Ph oxdado & $\mathrm{FRX}$ \\
\hline $59-1 \mathrm{~B}^{*+* *}$ & mlng Osamu Utsum & Ph oxdado & $\mathrm{FRX}$ \\
\hline $63-1 A^{\text {mat }}$ & mina Osamu Utsumi & Ph oxidado & $F R X$ \\
\hline $39-1 A^{* * * *}$ & mina Osamu Utsumt & Ph roduzido & FRX \\
\hline $4 t-1 A^{*+* k}$ & mira Osamu Utsumt & Ph reduzido & FRX \\
\hline $68-1 A^{*+2 *}$ & mina Osamu Utsumi & Ph reduzido & FRX \\
\hline $68-1 A A^{*+4 k}$ & mina Osamu Utsumi & Ph reduzido & FRX \\
\hline $68-1 A B^{\star \star *}$ & mine Osarnu Utsumi & $\mathrm{Ph}$ reduzido & FRX \\
\hline 68-1AC & mina Osamu Ltsumi & Ph reduzzldo & FRX \\
\hline $89-10^{* * *}$ & mina Osamu Utsumi & Ph reduzido & FRX \\
\hline $70-1 C-1$ & mina Osamu Utsuml & Ph reduzido & Isos \\
\hline $70-1 \mathrm{C}-2$ & mina Osamu Utsumi & $\mathrm{Ph}$ reduzido & Isas \\
\hline $70-1 \mathrm{C}-3$ & mina Osamu Utsumi & Ph reduzido & isos \\
\hline $7 t-1 A^{*+\cdots+1}$ & mina Osamu Utsuml & $\mathrm{Ph}$ reduzkdo & FRX \\
\hline $71-1 B^{*+\infty}$ & mina Osamu Utsumi & $\mathrm{Ph}$ reduzddo & FRX \\
\hline $74-1 A^{\star * * *}$ & mina Osamu Utsuml & Ph reduzldio & FRX \\
\hline $75-1 A^{* * * *}$ & mkra Osamu Utsumi & Ph reduzido & FRX, MSO \\
\hline $75-1 B^{*+*}$ & mitra Osamu Utsumi & Ph reduzido & $\mathrm{FRX}$ \\
\hline $77-1 A^{* * 4 *}$ & mina Osamu Utsumi & Ph reduzido & FRX \\
\hline $77-1 B^{*+1}$ & mina Osamu Utsumt & Ph reduzido & FRX \\
\hline $78-1 A^{\text {*** }}$ & mina Osamu Utsumi & Ph reduzido & $\mathrm{FRX}$ \\
\hline $81-1 A^{+\infty n+k}$ & mine Osamu Utsumt & Ph reduzido & FRX, MSO \\
\hline $85-1 A^{+\infty=0}$ & mina Osamu Utsumi & Ph reduzldo & FRX \\
\hline $90-1 B^{*+* *}$ & mina Osamu Utsumt & Ph reduzido & FRX \\
\hline $91-1 A^{-1}$ & mina Osamu Utsumi & $\mathrm{Ph}$ reduzkdo & FRX \\
\hline $95-1 A^{\text {tank }}$ & mina Osanu Utsumt & Ph reduzldo & FRX \\
\hline $101-1 A^{* * *}$ & mina Osamu Utsum! & Ph redtzido & FRX \\
\hline $104-1 A^{* * *}$ & mpra Osamu Utsumf & Ph reduzido & FRX \\
\hline $105-1 A^{\text {name }}$ & mina Osamu Utsumi & Ph redizzido & FRX \\
\hline $106-1 A^{\text {thth }}$ & mina Oramu Utsumi & Ph redizzido & FRX \\
\hline $107-1 A^{4}$ & mina Osamu Utsumi & Ph reduzido & FRX \\
\hline $109-1 A^{\text {natk }}$ & mina Osamu Utsumb & Ph reduzido & $F R X$ \\
\hline $108-1 B^{\star * 10}$ & mina Osamu Utsermi & Ph reduzido & FRX \\
\hline $111-1 A^{n+* * *}$ & mina Osamu Utsumi & Ph reduzido & FRX \\
\hline $110-1 A^{*+1+1}$ & mina Osamu Utsumi & Pth reduzido & MSO \\
\hline $112-1 A^{* n * *}$ & mina Osamu Utsumi & Ph rediuzido & $F R X$ \\
\hline $112-1 A D^{*+*}$ & mina Osamu Utsumi & Ph reduzido & FRX \\
\hline $113-1 A^{* \star *}$ & mina Osamu Utsumi & Ph reduzido & FRX \\
\hline $113-1 B^{n * * *}$ & mina Osamu Utsumi & Ph roduzido & FRX \\
\hline 114-1A-1 & mina Osamu Utsum & Ph redizzido & Isos \\
\hline $114-1 A-2$ & mina Osamu Utsumi & Ph reduzkdo & Isos \\
\hline $115-1 A^{*+1+4}$ & mina Osamu Utsumi & Ph reduzido & FRX \\
\hline $117-1 A^{\text {thit }}$ & mine Osamu Utsumi & Ph reduzido & FRX \\
\hline $118-1 A^{\text {t+m }}$ & mina Osamu Utsumi & Ph reduzido & FRX \\
\hline $119-1 A^{*+\infty+1}$ & mina Osamu Utsumi & Ph reduzido & FRX \\
\hline $121-1 A^{* * * *}$ & mine Osamu Utsumi & Ph reduzido & FRX \\
\hline $126-1 A^{* \pi+4}$ & mina Osamu Utsumi & Ph reduzido & FRX, isos \\
\hline 126-1AA & mine Osamu Utsumi & Ph reduzido & FRX \\
\hline $128-1 \mathrm{~B}^{n * \pi}$ & mina Osamu Utsumi & Ph foduzido & FRX \\
\hline Furo sondagem $\mathrm{F}_{4}$ & & & \\
\hline $19-1 A^{* A A}$ & mina Osamu Utsumi & Ph oxidado & $\operatorname{FRX}$ \\
\hline $22-1 A^{* * *+1}$ & mtra Osamu Utsumi & Nes oxkiado & FRX \\
\hline $39-1 A^{+\infty n+\infty}$ & mina Osamu Utsuml & Ph oxkdado & FRX \\
\hline $91-1 B^{* n+4}$ & mina Osemu Utsumi & NaS radizikto & FRX \\
\hline $107-1 A^{* * *}$ & mina Osamu Utsumi & Nas roduzzdo & FRX \\
\hline $123-1 A^{n * * *}$ & mana Osamu Utsumi & NeS reduzkdo & FRX \\
\hline $129-1 A^{\text {*na }}$ & mina Osamu Utsuml & Ph reduzido & FRX \\
\hline 243-1A & mima Osamu Utsum! & Br reduzida & MEV, isos \\
\hline $243 \cdot A 3$ & mina Osamu Utsuml & Br reduzida & FRX \\
\hline $265-1 A-B^{\star \star \star \star}$ & mina Osamu Utsumi & Nes reduzido & FRX \\
\hline 277-1A-1 & mina Osamu Utsumi & fratura hidrotemal, porçato reduzlda & Isos \\
\hline $383-1 A-1$ & mika Osamu Utsumi & fratura hidrotermal em be redtuzida & isos \\
\hline 383-1A-2 & mina Osamu Utsumi & fratura hidrotermal em br reduzkda & isos \\
\hline $38 B-1 A-1$ & mina Osamu Utsumi & fratura hidroformal em br reduzida & Isos \\
\hline $386-1 A-1.1$ & mina Osamu Utsumi & fratura hldrotermal em br reduzida & Isos \\
\hline $386-1 A-1.2$ & mine Osamu Utsuml & fretura hidrotermat em br reduzida & isos \\
\hline $386-1 \mathrm{~A}-2$ & mina Osamu Utsumi & fratura hidrotermal om br reduzida & isos \\
\hline $386-1 A-2.1$ & mina Osamu Utsumi & fratura hidrotermal em br reduzida & Isas \\
\hline $386-1 A-3$ & mina Osamu Utsumi & fratura hidrotermal om br reduzida & isos \\
\hline $388-1 \mathrm{~A}-4$ & mina Osamu Utsuml & fratura hidrotermal em br reduzida & isos \\
\hline $394-1 A-1$ & mina Osamu Utsumi & Fratura fiddrotermal em NoS reduzkdo & tsos \\
\hline
\end{tabular}




\begin{tabular}{|c|c|c|}
\hline No de Amostro Locellzecto & Descricifo & Ansllises \\
\hline 394-1A-2 mina Osamu Utsuml & Fratura hidrotermal em NoS reduzkdo & Tsos \\
\hline 397-1A-1 mine Osamu utsum & Fragmento de Ph reduztdo & lsos \\
\hline 397-1A-2 mina Osamu Utsumi & Fragmento de Ph reduzldo & Isos \\
\hline 397-1A-3 mkn Osamu Utsumi & Fragmento de Ph reduzido & isos \\
\hline 397-1A-4 mina Osamu Utsumb & Fragmento de Ph rexuztdo & 1sos \\
\hline 408-1A-1 mina Osamu Ltsumi & Fragmento de Ph reduzido & isos \\
\hline 408-1A-2 mina Osamu Utsuml & Fragmento de Ph reduzido & Isos \\
\hline 413-1A-A ${ }^{* * \hbar}$ mina Osamu Utsuml & NeS reduzido & FRX \\
\hline 413-1A-B $B^{n+4}$ mina Osamu Utsumi & NeS rectizido & FRX \\
\hline 413-1A-C mina Osamu Utsuml & Nes reduzido & FRX \\
\hline $413-1 A-D^{* *}$ mina Osamu Utstımi & Nes reduzido & FRX \\
\hline 413-1A-C mina Osamu Utsumi & NeS redtuzido & FRX \\
\hline 414-1B-1 mina Csamu Utsumi & Br reduzida & isos \\
\hline 414-1B-2 mina Osamu Utsumi & Br reduzida & Isos \\
\hline 414-1B-3 mina Osamu tUtsumi & Br reduzida & 180s \\
\hline 414-1B-4 mina Osamu Utsumi & Br reduzicia & tsos \\
\hline 414-1B-5 mina Osamu Utsumi & Br reduzida & Isos \\
\hline 414-18-6 mina Osamu Utsumi & Br reduzida & isos \\
\hline
\end{tabular}


ANEXO III 
FELDSPATOS ALCALINOS

\begin{tabular}{|c|c|c|c|c|}
\hline AMOSTRA & A1H-h & A1+1-h & $A 1+H-h$ & At+hth \\
\hline Localbaçfo & $\begin{array}{l}P .1 / \mathrm{c} 2 \\
\text { borda }\end{array}$ & $\begin{array}{l}\text { P.2/c2 } \\
\text { borda }\end{array}$ & $\begin{array}{l}\text { P.8/c4 } \\
\text { borda }\end{array}$ & $\begin{array}{l}\text { P.6/c2 } \\
\text { borda }\end{array}$ \\
\hline$\longdiv { \mathrm { SiO } 2 }$ & 63.1 & 63.0 & 64.1 & 63.9 \\
\hline TiO2 & 0.0 & 0.1 & 0.0 & 0.1 \\
\hline $\mathrm{Al} 203$ & 19.2 & 19.3 & 18.3 & 18.3 \\
\hline $\mathrm{Fe} 2 \mathrm{O3}$ & 0.3 & 0.3 & 0.2 & 0.5 \\
\hline $\mathrm{MnO}$ & 0.0 & 0.0 & 0.0 & 0.0 \\
\hline $\mathrm{CaO}$ & 0.1 & 0.1 & 0.0 & 0.0 \\
\hline Sro & 1.4 & 1.5 & 0.2 & 0.6 \\
\hline $\mathrm{BaO}$ & 0.7 & 1.1 & 0.2 & 0.1 \\
\hline $\mathrm{Na2O}$ & 1.9 & 1.8 & 0.7 & 1.4 \\
\hline $\mathrm{K} 2 \mathrm{O}$ & 13.1 & 13.0 & 15.6 & 14.5 \\
\hline $\mathrm{MgO}$ & 0.0 & 0.0 & 0.0 & 0.0 \\
\hline$F$ & 0.0 & 0.1 & 0.1 & 0.0 \\
\hline $\mathrm{Cl}$ & 0.0 & 0.0 & 0.0 & 0.0 \\
\hline soma & 99.7 & 100.2 & 99.3 & 99.2 \\
\hline
\end{tabular}

\begin{tabular}{|c|c|c|c|}
\hline $\begin{array}{l}\text { ANOSTRA } \\
\text { Localbagto }\end{array}$ & $\begin{array}{l}\text { A1-Hh } \\
\text { P. } 3 / \mathrm{c} 2 \\
\text { centro } \\
\end{array}$ & $\begin{array}{l}\text { A1-Hh } \\
\text { P.7/c4 } \\
\text { centro } \\
\end{array}$ & $\begin{array}{l}\text { A1-H-h } \\
\text { P.5/c2 } \\
\text { centro }\end{array}$ \\
\hline $\mathrm{SiO} 2$ & 63.3 & 61.8 & 65.1 \\
\hline $\mathrm{TiO} 2$ & 0.0 & 0.0 & 0.0 \\
\hline $\mathrm{Al} 2 \mathrm{O} 3$ & 18.9 & 17.9 & 18.4 \\
\hline $\mathrm{Fe} 2 \mathrm{O} 3$ & 0.3 & 2.5 & 0.4 \\
\hline MnO & 0.0 & 0.7 & 0.0 \\
\hline $\mathrm{CaO}$ & 0.1 & 0.2 & 0.0 \\
\hline Sro & 1.4 & 0.8 & 0.6 \\
\hline $\mathrm{BaO}$ & 0.6 & 0.2 & 0.0 \\
\hline $\mathrm{Na} 2 \mathrm{O}$ & 2.1 & 1.6 & 1.9 \\
\hline $\mathrm{K} 20$ & 12.8 & 13.3 & 14.1 \\
\hline $\mathrm{MgO}$ & 0.0 & 0.0 & 0.0 \\
\hline$F$ & 0.0 & 0.0 & 0.0 \\
\hline $\mathrm{Cl}$ & 0.0 & 0.0 & 0.0 \\
\hline soma & 99.5 & 99.0 & 100.5 \\
\hline
\end{tabular}

\begin{tabular}{|c|c|c|c|c|c|}
\hline $\begin{array}{l}\text { AMOSTRA } \\
\text { Locallzaçá }\end{array}$ & $\begin{array}{l}\text { A1+H-h } \\
\text { P29/c2 } \\
\text { Matriz }\end{array}$ & $\begin{array}{c}\text { A1-H-h } \\
\text { P.30/c2 } \\
\text { Matriz }\end{array}$ & $\begin{array}{l}\text { A1-H-h } \\
\text { P.33/c3 } \\
\text { Matriz }\end{array}$ & $\begin{array}{l}\text { A1-HAh } \\
\text { P.34/C3 } \\
\text { Matriz }\end{array}$ & $\begin{array}{l}\text { At-Heh } \\
\text { P.35/c6 } \\
\text { Matriz }\end{array}$ \\
\hline $\mathrm{SiO} 2$ & 65.5 & 65.1 & 64.8 & 65.4 & 65.2 \\
\hline TIO2. & 0.1 & 0.0 & 0.0 & 0.0 & 0.0 \\
\hline$A 1203$ & 18.0 & 18.2 & 17.8 & 18.1 & 18.0 \\
\hline $\mathrm{Fe} 2 \mathrm{O} 3$ & 0.7 & 0.6 & 0.6 & 0.8 & 0.7 \\
\hline MnO & 0.0 & 0.0 & 0.0 & 0.0 & 0.0 \\
\hline $\mathrm{CaO}$ & 0.0 & 0.0 & 0.0 & 0.0 & 0.0 \\
\hline Sro & 0.1 & 0.2 & 0.1 & 0.1 & 0.1 \\
\hline $\mathrm{BaO}$ & 0.0 & 0.1 & 0.0 & 0.2 & 0.0 \\
\hline $\mathrm{Na} 2 \mathrm{O}$ & 1.3 & 1.1 & 1.0 & 1.5 & 1.4 \\
\hline $\mathrm{K} 2 \mathrm{O}$ & 15.0 & 15.2 & 15.3 & 14.6 & 14.8 \\
\hline $\mathrm{MgO}$ & 0.0 & 0.0 & 0.0 & 0.0 & 0.0 \\
\hline$F$ & 0.0 & 0.0 & - & 0.0 & 0.1 \\
\hline $\mathrm{Cl}$ & 0.0 & 0.0 & 0.0 & 0.0 & 0.0 \\
\hline soma & 100.7 & 100.5 & 99.8 & 100.7 & 100.3 \\
\hline
\end{tabular}

Análises de microssonda eletrônica por WDS de feldspatos puros 
FELDSPATOS ALCALINOS

\begin{tabular}{|c|c|c|c|c|c|c|c|}
\hline $\begin{array}{l}\text { AMOSTRA } \\
\text { Localkaçá }\end{array}$ & $\begin{array}{c}\text { A2 } \\
\text { P.14/c6 } \\
\text { borda }\end{array}$ & $\begin{array}{c}\text { A2 } \\
\text { P.10/c1 } \\
\text { borda }\end{array}$ & $\begin{array}{c}\text { A2 } \\
\text { P.54/c1 } \\
\text { inclusáo }\end{array}$ & $\begin{array}{c}\text { A2 } \\
\text { P.12/c2 } \\
\text { borda }\end{array}$ & $\begin{array}{c}\text { A2 } \\
\text { P.16/c8 } \\
\text { borda }\end{array}$ & $\begin{array}{c}\text { A2 } \\
\text { P.17/c8 } \\
\text { borda/borda }\end{array}$ & $\begin{array}{c}\text { A2 } \\
\text { P. } 19 / 108 \\
\text { borda }\end{array}$ \\
\hline $\mathrm{SiO} 2$ & 65.1 & 65.4 & 65.4 & 64.6 & 65.5 & 66.0 & 65.4 \\
\hline $\mathrm{TiO} 2$ & 0.1 & 0.0 & 0.0 & 0.0 & 0.0 & 0.0 & 0.0 \\
\hline Al2O3 & 18.4 & 18.6 & 18.5 & 18.4 & 18.5 & 18.2 & 18.8 \\
\hline $\mathrm{Fe} 203$ & 0.4 & 0.4 & 0.4 & 0.3 & 0.3 & 0.5 & 0.4 \\
\hline $\mathrm{MnO}$ & 0.0 & 0.0 & 0.0 & 0.1 & 0.0 & 0.0 & 0.0 \\
\hline $\mathrm{CaO}$ & 0.0 & 0.0 & 0.0 & 0.0 & 0.0 & 0.0 & 0.0 \\
\hline Sro & 0.4 & 0.4 & 0.3 & 0.4 & 0.3 & 0.0 & 0.3 \\
\hline $\mathrm{BaO}$ & 0.0 & 0.0 & 0.0 & 0.1 & 0.1 & 0.0 & 0.0 \\
\hline $\mathrm{Na2O}$ & 3.0 & 3.1 & 3.1 & 3.0 & 2.6 & 2.7 & 2.7 \\
\hline $\mathrm{K} 2 \mathrm{O}$ & 12.3 & 12.3 & 12.2 & 12.4 & 13.1 & 12.9 & 12.7 \\
\hline $\mathrm{MgO}$ & 0.0 & 0.0 & 0.0 & 0.0 & 0.0 & 0.0 & 0.0 \\
\hline$F$ & 0.0 & 0.0 & & 0.0 & 0.1 & 0.0 & 0.1 \\
\hline $\mathrm{Cl}$ & 0.0 & 0.0 & & 0.0 & 0.0 & 0.0 & 0.0 \\
\hline soma & $99.7 \mid$ & 100.4 & 100.0 & 100.8 & 100.6 & 100.4 & 100.5 \\
\hline
\end{tabular}

\begin{tabular}{|c|c|c|c|c|c|c|}
\hline $\begin{array}{l}\text { AMOSTRA } \\
\text { Localkaça }\end{array}$ & $\begin{array}{c}A 2 \\
\text { P.13/c6 } \\
\text { centro }\end{array}$ & $\begin{array}{c}\text { A2 } \\
P .9 / c 1 \\
\text { centro }\end{array}$ & $\begin{array}{c}A 2 \\
P .11 / c 2 \\
\text { centro }\end{array}$ & $\begin{array}{c}\text { A2 } \\
\text { P.15/C8 } \\
\text { centro }\end{array}$ & $\begin{array}{c}\text { A2 } \\
\text { P.18/C8 } \\
\text { centro }\end{array}$ & $\begin{array}{c}\text { A2 } \\
\text { P.56/c1 } \\
\text { contro }\end{array}$ \\
\hline $\mathrm{SiO} 2$ & 65.9 & 65.8 & 65.5 & 65.0 & 65.1 & 67.6 \\
\hline $\mathrm{TiO} 2$ & 0.0 & 0.0 & 0.0 & 0.0 & 0.0 & 0.1 \\
\hline A|2O3 & 18.6 & 18.5 & 18.6 & 18.2 & 18.4 & 19.0 \\
\hline $\mathrm{Fe} 203$ & 0.3 & 0.4 & 0.3 & 0.4 & 0.3 & 0.2 \\
\hline Mno & 0.0 & 0.0 & 0.0 & 0.0 & 0.0 & 0.0 \\
\hline $\mathrm{CaO}$ & 0.0 & 0.0 & 0.0 & 0.0 & 0.0 & 0.0 \\
\hline Sro & 0.2 & 0.4 & 0.4 & 0.1 & 0.3 & 0.1 \\
\hline $\mathrm{BaO}$ & 0.2 & 0.1 & 0.0 & 0.0 & 0.0 & 0.0 \\
\hline $\mathrm{Na} 2 \mathrm{O}$ & 3.1 & 3.2 & 2.9 & 1.7 & 1.9 & 10.5 \\
\hline$K 20$ & 12.4 & 12.2 & 12.4 & 14.2 & 13.9 & 1.8 \\
\hline MgO & 0.0 & 0.0 & 0.0 & 0.0 & 0.0 & 0.0 \\
\hline$F$ & 0.1 & 0.1 & 0.0 & 0.0 & 0.0 & \\
\hline $\mathrm{Cl}$ & 0.0 & 0.0 & 0.0 & 0.0 & 0.0 & \\
\hline soma & 100.8 & 100.7 & 100.5 & 99.7 & 100.0 & 99.3 \\
\hline
\end{tabular}

\begin{tabular}{|c|c|c|c|c|c|c|c|}
\hline $\begin{array}{l}\text { AMOSTRA } \\
\text { Localkacto }\end{array}$ & $\begin{array}{c}\text { A2 } \\
\text { P.38/c5 } \\
\text { Matriz }\end{array}$ & $\begin{array}{c}\text { A2 } \\
\text { P.39/c5 } \\
\text { Matriz }\end{array}$ & $\begin{array}{c}\text { A2 } \\
\text { P.4O/c6 } \\
\text { Marb }\end{array}$ & $\begin{array}{c}\text { A2 } \\
\text { P. } 41 / c 8 \\
\text { Matriz }\end{array}$ & $\begin{array}{c}\text { A2 } \\
\text { P.42/c8 } \\
\text { Matrìz }\end{array}$ & $\begin{array}{c}\text { A2 } \\
\text { P.361C1 } \\
\text { Matriz }\end{array}$ & $\begin{array}{c}\text { A2 } \\
\text { P.37/c1 } \\
\text { Matriz }\end{array}$ \\
\hline $\mathrm{SiO} 2$ & 65.3 & 65.8 & 66.0 & 65.9 & 65.2 & 65.9 & 65.4 \\
\hline $\mathrm{TiO} 2$ & 0.0 & 0.1 & 0.0 & 0.0 & 0.0 & 0.0 & 0.0 \\
\hline$A 1203$ & 17.8 & 18.1 & 18.0 & 17.9 & 18.3 & 18.1 & 17.9 \\
\hline $\mathrm{Fe} 203$ & 0.8 & 1.0 & 0.8 & 0.8 & 0.3 & 0.4 & 0.8 \\
\hline Mno & 0.0 & 0.0 & 0.0 & 0.0 & 0.0 & 0.0 & 0.0 \\
\hline $\mathrm{CaO}$ & 0.0 & 0.0 & 0.0 & 0.0 & 0.0 & 0.0 & 0.0 \\
\hline Sro & 0,0 & 0.0 & 0.0 & 0.0 & 0.0 & 0.0 & 0.0 \\
\hline $\mathrm{BaO}$ & 0.0 & 0.1 & 0.0 & 0.1 & 0.2 & 0.0 & 0.0 \\
\hline $\mathrm{Na}_{2} \mathrm{O}$ & 2.1 & 2.1 & 2.8 & 2.8 & 1.3 & 2.9 & 2.4 \\
\hline $\mathrm{K} 2 \mathrm{O}$ & 13.8 & 13.7 & 12.7 & 12.9 & 14.7 & 12.9 & 13.4 \\
\hline $\mathrm{MgO}$ & 0.0 & 0.0 & 0.0 & 0.0 & 0.0 & 0.0 & 0.0 \\
\hline$F$ & 0.0 & 0.0 & 0.0 & 0.0 & 0.0 & 0.0 & 0.0 \\
\hline Cl & 0.0 & 0.0 & 0.0 & 0.0 & 0.0 & 0.0 & 0.0 \\
\hline soma & $\% 9$ & 101.0 & 100.3 & 100.5 & 100.0 & 100.1 & 99.9 \\
\hline
\end{tabular}


FELDSPATOS ALCALINOS

\begin{tabular}{|c|c|c|c|c|}
\hline $\begin{array}{l}\text { AMOSTRA } \\
\text { LocalthaçÁ }\end{array}$ & $\begin{array}{c}\text { AA-B } \\
\text { P.21/c1 } \\
\text { borda }\end{array}$ & $\begin{array}{c}\text { AA-B } \\
\text { P23/c1 } \\
\text { borda } \\
\end{array}$ & $\begin{array}{c}\text { A4-B } \\
\text { P25/c4 } \\
\text { borda } \\
\end{array}$ & $\begin{array}{c}\text { Aa-B } \\
\text { P28/c6 } \\
\text { borda } \\
\end{array}$ \\
\hline $\mathrm{SiO2}$ & 65.6 & 66.5 & 63.9 & 64.8 \\
\hline $\mathrm{TiO}_{2}$ & 0.1 & 0.0 & 0.0 & 0. \\
\hline Al2O3 & 18.4 & 18.5 & 19.3 & 15 \\
\hline $\mathrm{Fe} 2 \mathrm{O} 3$ & 0.3 & 0.4 & 0.4 & 0. \\
\hline $\mathrm{MnO}$ & 0.0 & 0.0 & 0.0 & 0. \\
\hline $\mathrm{CaO}$ & 0.0 & 0.0 & 0.0 & 0. \\
\hline Sro & 0.4 & 0.4 & 0.3 & 0. \\
\hline $\mathrm{BaO}$ & 0.0 & 0.1 & 0.2 & 0. \\
\hline $\mathrm{Na2O}$ & 2.4 & 2.8 & 3.5 & \\
\hline K2O & 13.3 & 12.8 & 12.5 & 11. \\
\hline $\mathrm{MgO}$ & 0.0 & 0.0 & 0.0 & 0 \\
\hline$F$ & 0.0 & 0.0 & 0.1 & 0. \\
\hline $\mathrm{cl}$ & 0.0 & 0.0 & 0.2 & 0.0 \\
\hline soma & 100.5 & 100.4 & 100.3 & 99.9 \\
\hline
\end{tabular}

\begin{tabular}{|c|c|c|c|c|c|c|}
\hline $\begin{array}{l}\text { AMOSTRA } \\
\text { Locatkacto }\end{array}$ & $\begin{array}{c}\text { A4-B } \\
\text { P.20/c1 } \\
\text { centro }\end{array}$ & $\begin{array}{c}\text { AA-B } \\
\text { P.22/c2 } \\
\text { centro }\end{array}$ & $\begin{array}{c}A 4 B \\
P .24 / C 4 \\
\text { centro }\end{array}$ & $\left.\begin{array}{c}\text { A4-B } \\
\text { P.27/c6 } \\
\text { centro }\end{array}\right]$ & $\begin{array}{c}\text { A4B } \\
\text { P.5e/c4 } \\
\text { centro }\end{array}$ & $\begin{array}{c}\text { A4-B } \\
\text { P. } 48 / c 6 \\
\text { centro }\end{array}$ \\
\hline $\mathrm{SiO} 2$ & 65.4 & 65.9 & 66.1 & 65.4 & 65.5 & 65.3 \\
\hline $\mathrm{TIO} 2$ & 0.0 & 0.1 & 0.1 & 0.0 & 0.1 & 0.1 \\
\hline $\mathrm{A} 1203$ & 18.5 & $\{8.7$ & 18.5 & 18.6 & 18.6 & 18.7 \\
\hline $\mathrm{Fe} 203$ & 0.2 & 0.3 & 0.4 & 0.3 & 0.5 & 0.4 \\
\hline $\mathrm{MnO}$ & 0.0 & 0.0 & 0.0 & 0.0 & 0.0 & 0.0 \\
\hline $\mathrm{CaO}$ & 0.0 & 0.0 & 0.0 & 0.0 & 0.0 & 0.0 \\
\hline SrO & 0.6 & 0.5 & 0.0 & 0.5 & 0.5 & 0.4 \\
\hline $\mathrm{BaO}$ & 0.0 & 0.1 & 0.1 & 0.1 & 0.0 & 0.2 \\
\hline $\mathrm{Na} 2 \mathrm{O}$ & 2.4 & 3.0 & 2.5 & 2.4 & 3.1 & 2.7 \\
\hline $1<20$ & 13.2 & 12.4 & 13.3 & 13.1 & 12.2 & 12.6 \\
\hline $\mathrm{MgO}$ & 0.0 & 0.0 & 0.0 & 0.0 & 0.0 & 0.0 \\
\hline$F$ & 0.0 & 0.0 & 0.0 & 0.0 & - & 0.0 \\
\hline $\mathrm{Cl}$ & 0.0 & 0.0 & 0.0 & 0.0 & - & 0.0 \\
\hline soma & 100.3 & 101.1 & 100.9 & 100.6 & 100.5 & 100.4 \\
\hline
\end{tabular}

\begin{tabular}{|c|c|}
\hline $\begin{array}{l}\text { AMOSTRA } \\
\text { Localtragá }\end{array}$ & $\begin{array}{c}\text { A4-B } \\
\text { P. } 46 / c 6 \\
\text { Matriz }\end{array}$ \\
\hline $\mathrm{S} 1 \mathrm{O} 2$ & 61.0 \\
\hline $\mathrm{THO2}$ & 0.1 \\
\hline Al2O3 & 17.9 \\
\hline $\mathrm{Fe} 2 \mathrm{O}$ & 0.8 \\
\hline $\mathrm{MnO}$ & $0 . C$ \\
\hline $\mathrm{CaO}$ & 1. \\
\hline sro & 0.4 \\
\hline $\mathrm{BaO}$ & 0.0 \\
\hline $\mathrm{Na} 2 \mathrm{O}$ & 3.6 \\
\hline $\mathrm{K} 2 \mathrm{O}$ & 11.8 \\
\hline $\mathrm{MgO}$ & 0.0 \\
\hline$F$ & 0.4 \\
\hline $\mathrm{Cl}$ & 0.0 \\
\hline soma & 97.3 \\
\hline
\end{tabular}

Análises de micnossonda eletrónica por WDS de feldspatos puros 
CLINOPIROXENIOS- análises de microssonda eletronica por WDS de cpx puros

\begin{tabular}{|c|c|c|c|c|c|}
\hline $\begin{array}{l}\text { AMOSTRA } \\
\text { Localbacáto }\end{array}$ & $\begin{array}{r}\text { A1-Hh } \\
\text { P.62/C1 } \\
\text { centro } \\
\end{array}$ & & $\begin{array}{c}\text { A1-HAh } \\
\text { P.71/C3 } \\
\text { centro } \\
\end{array}$ & $\begin{array}{c}\text { A1-H-h } \\
\text { P.EDC1 } \\
\text { centro } \\
\end{array}$ & \\
\hline $\mathrm{SiO} 2$ & 47.4 & & 50.9 & 52.9 & \\
\hline $\mathrm{TiO} 2$ & 1.4 & & 0.7 & 0.4 & \\
\hline $\mathrm{Al} 2 \mathrm{O} 3$ & 4.4 & & 0.8 & 4.9 & \\
\hline $\mathrm{Cr} 2 \mathrm{O} 3$ & 0.0 & & 0.0 & 0.0 & \\
\hline $\mathrm{Fe} 2 \mathrm{O} 3$ & 16.8 & & 26.6 & 22.4 & \\
\hline $\mathrm{MnO}$ & 1.2 & & 1.7) & 1.5 & \\
\hline $\mathrm{MgO}$ & 7.4 & & 1.6 & 1.6 & \\
\hline $\mathrm{CaO}$ & 21.4 & & 8.1 & 8.5 & \\
\hline $\mathrm{Na} 2 \mathrm{O}$ & 1.5 & & 8.7 & 6.3 & \\
\hline $\mathrm{K} 2 \mathrm{O}$ & 0.0 & & 0.0 & 2.7 & \\
\hline $\mathrm{ZrO} 2$ & 0.0 & & 0.3 & 0.2 & \\
\hline $\mathrm{ZnO}$ & 0.1 & & 0.1 & 0.0 & \\
\hline $\mathrm{BaO}$ & 0.0 & & 0.0 & 0.0 & \\
\hline Sto & 0.2 & & 0.2 & 0.2 & \\
\hline soma & 101.8 & & 99.6 & 101.6 & \\
\hline $\begin{array}{l}\text { AMOSTRA } \\
\text { Localizaçá }\end{array}$ & $\begin{array}{c}\text { A1-H-h } \\
\text { P.63/C1 } \\
\text { borda }\end{array}$ & $\begin{array}{c}\text { Atrih } \\
\text { P.64/C1 } \\
\text { borda }\end{array}$ & $\begin{array}{c}\text { A1+H-h } \\
\text { P.72/C3 } \\
\text { borda } \\
\end{array}$ & & $\begin{array}{c}\text { A1-H-h } \\
\text { P.77/C6 } \\
\text { borda } \\
\end{array}$ \\
\hline $\mathrm{SiO} 2$ & 43.3 & 51.3 & 50.6 & & 50.4 \\
\hline TiO2 & 1.1 & 0.9 & 0.6 & & 0.6 \\
\hline $\mathrm{Al} 2 \mathrm{O} 3$ & 4.4 & 0.7 & 0.8 & & 0.9 \\
\hline $\mathrm{Cr} 2 \mathrm{O3}$ & 0.0 & 0.0 & 0.0 & & 0.0 \\
\hline $\mathrm{Fe} 2 \mathrm{O} 3$ & 16.6 & 26.0 & 26.0 & & 28.2 \\
\hline Mno & 2.4 & 1.6 & 1.5 & & 1.6 \\
\hline Mgo & 9.0 & 2.4 & 1.8 & & 1.5 \\
\hline $\mathrm{CaO}$ & 7.9 & B.1 & 9.2 & & 8.5 \\
\hline $\mathrm{Na2} 2 \mathrm{O}$ & 4.2 & 8.8 & 8.0 & & 8.6 \\
\hline $\mathrm{K} 2 \mathrm{O}$ & 4.1 & 0.0 & 0.0 & & 0.0 \\
\hline $\mathrm{ZrO} 2$ & 0.1 & 0.2 & 0.2 & & 0.2 \\
\hline $\mathrm{ZnO}$ & 0.0 & 0.0 & 0.1 & & 0.0 \\
\hline $\mathrm{BaO}$ & 0.1 & 0.0 & 0.0 & & 0.0 \\
\hline SrO & 1.2 & 0.0 & 0.3 & & 0.2 \\
\hline soma & 94.5 & 100.0 & 99.2 & & 100.7 \\
\hline $\begin{array}{l}\text { AMOSTRA } \\
\text { Localtzaçăo }\end{array}$ & $\begin{array}{c}\text { A1+H-h } \\
\text { P.7o/C2 } \\
\text { matriz } \\
\end{array}$ & $\begin{array}{c}\text { At Hh } \\
\text { P.74/C3 } \\
\text { matrlz } \\
\end{array}$ & & & \\
\hline $\mathrm{SiO} 2$ & 57.6 & 49.8 & & & \\
\hline $\mathrm{TiO} 2$ & 0.1 & 0.4 & & & \\
\hline$A 1203$ & 23.8 & 0.7 & & & \\
\hline $\mathrm{Cr} 203$ & 0.0 & 0.0 & & & \\
\hline $\mathrm{Fe} 203$ & 1.0 & 25.4 & & & \\
\hline $\mathrm{MnO}$ & 0.0 & 1.7 & & & \\
\hline $\mathrm{MgO}$ & 0.0 & 2.0 & & & \\
\hline $\mathrm{CaO}$ & 1.5 & 10.1 & & & \\
\hline $\mathrm{Na} 2 \mathrm{O}$ & 3.8 & 7.6 & & & \\
\hline $\mathrm{K} 2 \mathrm{O}$ & 11.1 & 0.1 & & & \\
\hline $\mathrm{ZrO} 2$ & 0.0 & 0.2 & & & \\
\hline $\mathrm{ZnO}$ & 0.0 & 0.0 & & & \\
\hline $\mathrm{BaO}$ & 0.1 & 0.0 & & & \\
\hline Sro & 0.2 & 0.2 & & & \\
\hline soma & 99.3 & 98.3 & & & \\
\hline
\end{tabular}


CLINOPIROXENNIOS- análises de microssonda eletronica por WDS de cpx puros

\begin{tabular}{|c|c|c|c|c|}
\hline $\begin{array}{l}\text { ANOSTRA } \\
\text { Localhacto }\end{array}$ & $\begin{array}{c}\mathrm{A} 2 \\
\text { P.eorcs } \\
\text { centro } \\
\end{array}$ & $\begin{array}{c}\mathrm{A} 2 \\
\mathrm{P} .83 / \mathrm{C5} \\
\text { centro } \\
\end{array}$ & $\begin{array}{c}\text { A4B } \\
\text { P.91/C9 } \\
\text { centro }\end{array}$ & $\begin{array}{c}\mathrm{A}-10-\mathrm{B} 1 \\
\mathrm{P} .130 \mathrm{C} 4 \\
\text { centro }\end{array}$ \\
\hline S1O2 & 52.3 & 52.2 & 50.4 & 52.7 \\
\hline TIO2 & 1.2 & 1.4 & 0.8 & 0.8 \\
\hline$A \mid 203$ & 0.8 & 0.8 & 0.8 & 2.9 \\
\hline $\mathrm{Cr} 203$ & 0.0 & 0.0 & 0.0 & 0.0 \\
\hline $\mathrm{Fe} 2 \mathrm{O3}$ & 27.5 & 27.5 & 23.7 & 24.3 \\
\hline Mno & 1.4 & 1.3 & 1.2 & 1.3 \\
\hline $\mathrm{MgO}$ & 1.7 & 1.7 & 3.3 & 1.3 \\
\hline $\mathrm{CaO}$ & 5.4 & 5.4 & 10.4 & 4.5 \\
\hline $\mathrm{Na} 2 \mathrm{O}$ & 10.7) & 10.4 & 7.6 & 9.6 \\
\hline $\mathrm{K} 20$ & 0.0 & 0.0 & 0.0 & 1.3 \\
\hline $\mathrm{ZrO} 2$ & 0.4 & 0.3 & 0.4 & 0.3 \\
\hline $\mathrm{ZnO}$ & 0.1 & 0.1 & 0.0 & 0.1 \\
\hline $\mathrm{BaO}$ & 0.0 & 0.0 & 0.0 & 0.0 \\
\hline Sro & 0.0 & 0.0 & 0.1 & 0.0 \\
\hline soma & 101.5 & 101.1 & 98.6 & 99.1 \\
\hline $\begin{array}{l}\text { AMOSTRA } \\
\text { Localtracto }\end{array}$ & $\begin{array}{c}\text { A2 } \\
\text { P.81/C5 } \\
\text { borda }\end{array}$ & $\begin{array}{c}\mathrm{A} 2 \\
\text { P.82/C5 } \\
\text { borda }\end{array}$ & & \\
\hline $\mathrm{SiO} 2$ & 52.4 & 52.1 & & \\
\hline T102 & 1.2 & 1.2 & & \\
\hline$A \mid 203$ & 0.8 & 0.9 & & \\
\hline $\mathrm{Cr} 203$ & 0.0 & 0.0 & & \\
\hline $\mathrm{Fe} 2 \mathrm{O} 3$ & 27.2 & 27.3 & & \\
\hline $\mathrm{MnO}$ & 1.4 & 1.4 & & \\
\hline $\mathrm{MgO}$ & 1.7 & 1.6 & & \\
\hline $\mathrm{CaO}$ & 5.4 & 4.6 & & \\
\hline $\mathrm{Na} 2 \mathrm{O}$ & 10.6 & 11.2 & & \\
\hline $\mathrm{K} 2 \mathrm{O}$ & 0.0 & 0.0 & & \\
\hline $\mathrm{ZrO} 2$ & 0.3 & 0.3 & & \\
\hline $\mathrm{ZnO}$ & 0.0 & 0.0 & & \\
\hline $\mathrm{BaO}$ & 0.0 & 0.2 & & \\
\hline Sro & 0.0 & 0.0 & & \\
\hline soma & $\infty .2$ & 0.0 & & \\
\hline $\begin{array}{l}\text { AMOSTRA } \\
\text { Localtxacto }\end{array}$ & $\begin{array}{c}\text { A2 } \\
\text { P.85/C5 } \\
\text { matriz } \\
\end{array}$ & $\begin{array}{c}\text { A2 } \\
\text { P.86/C6 } \\
\text { matriz }\end{array}$ & $\begin{array}{c}\text { A2 } \\
\text { P.80/C6 } \\
\text { matritz }\end{array}$ & $\begin{array}{c}\mathrm{A} 2 \\
\text { P.90/C6 } \\
\text { matriz }\end{array}$ \\
\hline $5 \mathrm{SiO2}$ & 56.2 & 51.5 & 51.7 & 51.3 \\
\hline TiO2 & 0.7 & 1.0 & 1.1 & 1.0 \\
\hline $\mathrm{Al} 203$ & 9.7 & 0.8 & 0.9 & 0.8 \\
\hline $\mathrm{Cr} 203$ & 0.0 & 0.0 & 0.0 & 0.0 \\
\hline $\mathrm{Fe} 203$ & 15.0 & 27.6 & 27.8 & 26.7 \\
\hline Mno & 0.6 & 1.2 & 1.1 & 1.4 \\
\hline $\mathrm{MgO}$ & 0.6 & 1.4 & 1,4 & 1.6 \\
\hline $\mathrm{CaO}$ & 2.0 & 4.6 & 4.3 & 5.1 \\
\hline $\mathrm{Na} 2 \mathrm{O}$ & 6.4 & 11.4 & 11.2 & 10.8 \\
\hline $\mathrm{K} 2 \mathrm{O}$ & 7.0 & 0.0 & 0.0 & 0.0 \\
\hline $\mathrm{ZrO} 2$ & 0.1 & 0.3 & 0.2 & 0.3 \\
\hline $\mathrm{ZnO}$ & 0.0 & 0.0 & 0.1 & 0.1 \\
\hline $\mathrm{BaO}$ & 0.0 & 0.0 & 0.0 & 0.0 \\
\hline sro & 0.0 & 0.0 & 0.2 & 0.0 \\
\hline soma & 98.3 & 99.9 & 99.9 & 99.1 \\
\hline
\end{tabular}


CLINOPIROXENIOS- análises de microssonda eletronica por WDS de cpx puros

\begin{tabular}{|c|c|c|}
\hline $\begin{array}{l}\text { AMOSTRA } \\
\text { Locallzaçáo }\end{array}$ & $\begin{array}{c}\mathrm{AS} \\
\text { P.11A/C1 } \\
\text { centro }\end{array}$ & $\begin{array}{c}\text { A5 } \\
\text { P.116/C1 } \\
\text { centro }\end{array}$ \\
\hline $\mathrm{SiO2}$ & 52.5 & 52.2 \\
\hline TiO2 & 0.8 & 0.6 \\
\hline Al2O3 & 0.9 & 1.0 \\
\hline Cr.2O3 & 0.0 & 0.0 \\
\hline $\mathrm{Fe} 2 \mathrm{O}$ & 30.9 & 31.3 \\
\hline $\mathrm{MnO}$ & 0.6 & 0.4 \\
\hline Mgo & 0.4 & 0.2 \\
\hline $\mathrm{CaO}$ & 1.1) & 0.7 \\
\hline $\mathrm{Na} 2 \mathrm{O}$ & 13.0 & 13.2 \\
\hline K2O & 0.0 & 0.0 \\
\hline $2 \mathrm{rO} 2$ & 0.6 & 0.3 \\
\hline $\mathrm{ZnO}$ & 0.0 & 0.0 \\
\hline $\mathrm{BaO}$ & 0.0 & 0.0 \\
\hline sro & 0.0 & 0.0 \\
\hline soma & 100.7 & 99.9 \\
\hline $\begin{array}{l}\text { AMOSTRA } \\
\text { Localizaçáto }\end{array}$ & $\begin{array}{c}\text { A5 } \\
\text { P.115/c1 } \\
\text { borda }\end{array}$ & \\
\hline $\mathrm{S1O2}$ & 52.3 & \\
\hline $\mathrm{TiO} 2$ & 0.5 & \\
\hline A|203 & 1.4 & \\
\hline $\mathrm{Cr} 2 \mathrm{O} 3$ & 0.0 & \\
\hline $\mathrm{Fe} 2 \mathrm{O}$ & 30.7 & \\
\hline MnO & 0.6 & \\
\hline Mgo & 0.7 & \\
\hline $\mathrm{CaO}$ & 0.8 & \\
\hline $\mathrm{Na} 2 \mathrm{O}$ & 12.8 & \\
\hline K2O & 0.3 & \\
\hline $\mathrm{ZrO2}$ & 0.4 & \\
\hline $\mathrm{ZnO}$ & 0.0 & \\
\hline $\mathrm{BaO}$ & 0.1 & \\
\hline sro & 0.0 & \\
\hline soma & 100.6 & \\
\hline AMOSTRA & A5 & A5 \\
\hline Localfzaçáo & $\begin{array}{c}\text { P.113/C1 } \\
\text { matrz }\end{array}$ & $\begin{array}{c}\text { P.117/C1 } \\
\text { matriz }\end{array}$ \\
\hline $\mathrm{SiO} 2$ & 51.5 & 52.9 \\
\hline $\mathrm{THO} 2$ & 0.9 & 0.5 \\
\hline A12O3 & 3.2 & 1.0 \\
\hline $\mathrm{cr} 203$ & 0.0 & 0.0 \\
\hline $\mathrm{Fe} 2 \mathrm{O} 3$ & 26.3 & 31.1 \\
\hline Mno & 2.1 & 0.4 \\
\hline MgO & 3.0 & 0.2 \\
\hline $\mathrm{CaO}$ & 0.6 & 0.7 \\
\hline $\mathrm{Na} 2 \mathrm{O}$ & 10.2 & 13.1 \\
\hline $\mathrm{K} 2 \mathrm{O}$ & 1.8 & 0.0 \\
\hline $\mathrm{ZrO2}$ & 0.3 & 0.5 \\
\hline $\mathrm{ZnO}$ & 0.1 & 0.1 \\
\hline $\mathrm{BaO}$ & 0.0 & 0.1 \\
\hline Sro & 0.0 & 0.0 \\
\hline soma & 100.0 & 100.6 \\
\hline
\end{tabular}


NEFELINAS E FELDSPATOIDES - análises de microssonda eletrónica por WDS

\begin{tabular}{|c|c|c|c|c|c|c|c|c|c|}
\hline $\begin{array}{l}\text { AMOSTRA } \\
\text { Localizaça }\end{array}$ & $\begin{array}{l}\text { A1+H-h } \\
\text { P.52/c6 } \\
\text { nefelina }\end{array}$ & $\begin{array}{c}\mathbf{A 4 \mathbf { B }} \\
\text { P. } 60 / \mathrm{c} 7 \\
\text { nefelina } \\
\text { centro }\end{array}$ & $\begin{array}{c}\text { A4-B } \\
\text { P.26/c6 } \\
\text { centro } \\
\text { centro }\end{array}$ & $\begin{array}{c}\text { A4-B } \\
\text { P32/c4 } \\
\text { nefelina }\end{array}$ & $\begin{array}{c}\mathbf{A 4} \mathbf{B} \\
\text { P.50/co } \\
\text { nefelina }\end{array}$ & $\begin{array}{c}\text { AA-B } \\
\text { P.58/c1 } \\
\text { nefelina }\end{array}$ & $\begin{array}{c}\text { A4-B } \\
\text { P.47/c6 } \\
\text { nefelina }\end{array}$ & $\begin{array}{c}\text { A2 } \\
\text { P.53/c1 } \\
\text { nefelina }\end{array}$ & $\begin{array}{c}\text { A2 } \\
\text { P.5E/c1 } \\
\text { nefelina }\end{array}$ \\
\hline SIO2 & 45.5 & 44.6 & 44.1 & 43.7 & 44.3 & 46.9 & 44.6 & 44.8 & 45.6 \\
\hline T1O2 & 0.0 & 0.0 & 0.0 & 0.1 & 0.0 & 0.0 & 0.0 & 0.0 & 0. \\
\hline$A \mid 203$ & 34.9 & 33.2 & 33.0 & 33.2 & 33.1 & 31.3 & 32.1 & 37.1 & 34. \\
\hline $\mathrm{Fe} 203$ & 3.6 & 1.0 & 1.1 & 1.0 & 0.9 & 0.9 & 1.1 & 1.7 & . \\
\hline Mno & 0.1 & 0.0 & 0.0 & 0.0 & 0.0 & 0.0 & 0.0 & 0.0 & 0.0 \\
\hline $\mathrm{CaO}$ & 0.2 & 0.0 & 0.3 & 0.2 & 0.0 & 0.1 & 0.4 & 0.0 & 0.1 \\
\hline $\mathrm{MgO}$ & 0.2 & 0.0 & 0.0 & 0.0 & 0.0 & 0.0 & 0.0 & 0.2 & 0. \\
\hline $\mathrm{Na} 2 \mathrm{O}$ & 0.9 & 16.4 & 16.5 & 16.3 & 16.2 & 6.9 & 16.1 & 0.1 & 0.3 \\
\hline $\mathrm{K} 2 \mathrm{O}$ & 8.2 & 6.1 & 6.2 & 6.4 & 6.3 & 5.6 & 5.7 & 10.4 & 9.5 \\
\hline Sro & 0.1 & 0.0 & 0.0 & 0.0 & 0.0 & 0.0 & 0.0 & 0.0 & 0.0 \\
\hline $\mathrm{BaO}$ & 0.1 & 0.0 & 0.1 & 0.0 & 0.0 & 0.0 & 0.1 & 0.0 & 0.0 \\
\hline$F$ & 0.0 & 0.0 & 0.2 & 0.0 & 0.0 & 0.0 & 0.4 & 0.0 & 0.0 \\
\hline $\mathrm{Cl}$ & 0.0 & 0.0 & 0.0 & 0.0 & 0.0 & 0.0 & 0.0 & 0.0 & 0.0 \\
\hline soma & 93.9 & 101.4 & 101.5 & 100.9 & 100.8 & 91.6 & 100.5 & 94.5 & 93.0 \\
\hline
\end{tabular}

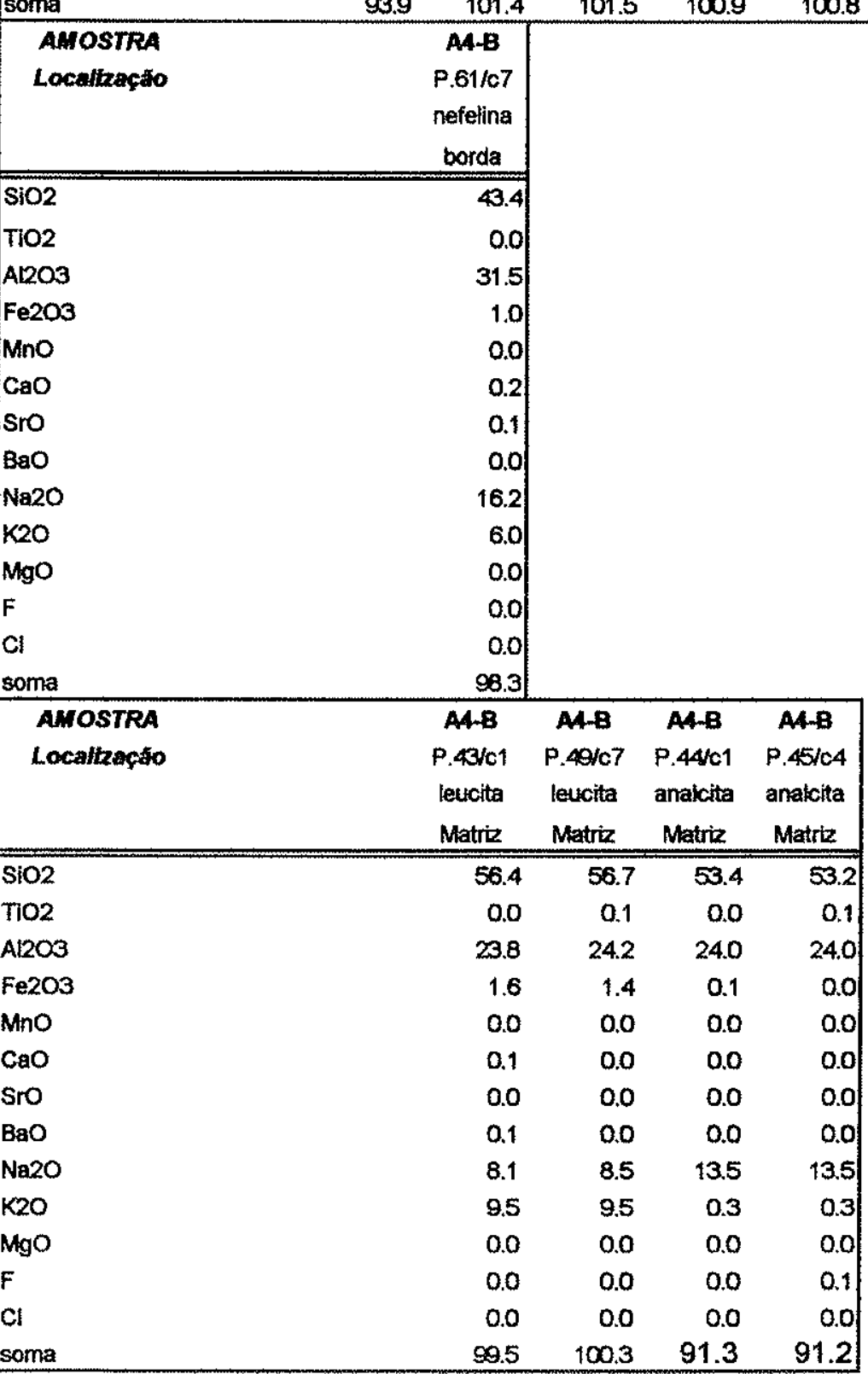


NEFELINAS E FELDSPATOIDES - análises de microssonda eletrónica por WDS

\begin{tabular}{|c|c|c|c|c|}
\hline $\begin{array}{l}\text { AMOSTRA } \\
\text { Localbagao }\end{array}$ & $\begin{array}{c}\text { A4-B } \\
\text { P.92/C9 } \\
\text { nefelina } \\
\text { bofda }\end{array}$ & $\begin{array}{c}\text { A6 } \\
\text { P.118/C5 } \\
\text { nefelina } \\
\text { centro }\end{array}$ & $\begin{array}{c}\text { A6 } \\
\text { P.124/C7 } \\
\text { nefelina } \\
\text { centro }\end{array}$ & $\begin{array}{c}\text { A6 } \\
\text { P.127/C7 } \\
\text { nefelina } \\
\text { centro }\end{array}$ \\
\hline $\mathrm{SiO} 2$ & 43.7 & 44.5 & 48.6 & 45.5 \\
\hline $\mathrm{TiO} 2$ & 0.0 & 0.0 & 0.0 & 0.0 \\
\hline Al2O3 & 35.1 & 32.3 & 33.3 & 34.6 \\
\hline $\mathrm{Fe} 2 \mathrm{O} 3$ & 1.1 & 1.9 & 2.0 & 2.9 \\
\hline $\mathrm{MnO}$ & 0.0 & 0.0 & 0.1 & 0.1 \\
\hline $\mathrm{CaO}$ & 0.3 & 0.2 & 0.0 & 0.0 \\
\hline $\mathrm{MgO}$ & 0.0 & 0.0 & 0.0 & 0.0 \\
\hline $\mathrm{Na} 2 \mathrm{O}$ & 16.4 & 17.3 & 14.5 & 15.7 \\
\hline $\mathrm{K} 2 \mathrm{O}$ & 6.1 & 5.3 & 5.6 & 5.4 \\
\hline Sro & 0.0 & 0.0 & 0.0 & 0.0 \\
\hline $\mathrm{BaO}$ & 0.0 & 0.0 & 0.0 & 0.0 \\
\hline $\mathrm{Cl}$ & 0.0 & 0.0 & 0.0 & 0.0 \\
\hline soma & 102.8 & 101.5 & 104.2 & 104.2 \\
\hline
\end{tabular}

\begin{tabular}{|c|c|c|c|c|}
\hline $\begin{array}{l}\text { AMOSTRA } \\
\text { Localtzaça }\end{array}$ & $\begin{array}{c}\text { A5 } \\
\text { P.119/C5 } \\
\text { analcita } \\
\text { borda }\end{array}$ & $\begin{array}{c}\text { A5 } \\
\text { P.125/C7 } \\
\text { nefelina } \\
\text { borda }\end{array}$ & $\begin{array}{c}\text { A6 } \\
\text { P.128/C7 } \\
\text { contaminaçao } \\
\text { borda }\end{array}$ & $\begin{array}{c}\text { A6 } \\
\text { P.121/Cto } \\
\text { nefelina } \\
\text { borda }\end{array}$ \\
\hline $\mathrm{SiO} 2$ & 54.9 & 65.7 & 23.9 & 47.6 \\
\hline $\mathrm{TOO} 2$ & 0.1 & 0.0 & 0.2 & 0.0 \\
\hline A12O3 & 25.0 & 19.4 & 2.7 & 34.2 \\
\hline $\mathrm{Fe} 203$ & 0.2 & 1.0 & 13.2 & 2.7 \\
\hline $\mathrm{MnO}$ & 0.0 & 0.0 & 0.2 & 0.0 \\
\hline $\mathrm{CaO}$ & 0.0 & 0.0 & 35.1 & 0.0 \\
\hline $\mathrm{MgO}$ & 0.0 & 0.0 & 0.1 & 0.1 \\
\hline $\mathrm{Na} 2 \mathrm{O}$ & 11.6 & 2.5 & 6.3 & 16.0 \\
\hline K2O & 1.2 & 13.3 & 0.3 & 4.6 \\
\hline sro & 0.0 & 0.1 & 3.1 & 0.0 \\
\hline $\mathrm{BaO}$ & 0.0 & 0.1 & 0.0 & 0.0 \\
\hline Cl & 0.0 & 0.0 & 0.0 & 0.0 \\
\hline $\mathrm{ZrO} 2$ & 0.1 & 0.0 & 0.2 & 0.0 \\
\hline soma & 93.0 & 102.1 & 85.1 & 105.2 \\
\hline
\end{tabular}


FELDSPATOS ALCALINOS HIDROTERIMAIS andises de microssonda detronica por WDS

\begin{tabular}{|c|c|c|c|c|c|c|}
\hline $\begin{array}{l}\text { AllOSTRA } \\
\text { Localkaça }\end{array}$ & $\begin{array}{c}\text { A6 } \\
\text { P.94/C1 } \\
\text { felds.alc. } \\
\text { centro }\end{array}$ & & $\begin{array}{c}A 6 \\
\text { P.103/C3 } \\
\text { felds.ałc. } \\
\text { centro }\end{array}$ & & & \\
\hline $\mathrm{SIO} 2$ & 63.2 & & 64.9 & & & \\
\hline 1702 & 2.3 & & 0.0 & & & \\
\hline ALO3 & 17.7 & & 17.7 & & & \\
\hline $\mathrm{Fe} 203$ & 0.2 & & 0.8 & & & \\
\hline Mno & 0.0 & & 0.0 & & & \\
\hline $\mathrm{CaO}$ & 0.0 & & 0.0 & & & \\
\hline sro & 0.0 & & 0.1 & & & \\
\hline $\mathrm{BaO}$ & 0.2 & & 0.1 & & & \\
\hline $\mathrm{Na2O}$ & 0.2 & & 1.0 & & & \\
\hline 120 & 16.1 & & 15.5 & & & \\
\hline $\mathrm{MgO}$ & 0.0 & & 0.0 & & & \\
\hline$F$ & 0.0 & & 0.0 & & & \\
\hline $\mathrm{Cl}$ & 0.0 & & 0.0 & & & \\
\hline soma & 100.0 & & 100.0 & & & \\
\hline $\begin{array}{l}\text { AMOSTRA } \\
\text { Locallzaça }\end{array}$ & $\begin{array}{c}\text { A6 } \\
\text { P.go/C1 } \\
\text { felds.alc. } \\
\text { borda }\end{array}$ & $\begin{array}{c}A 6 \\
\text { P.97/C1 } \\
\text { feloks.akc. } \\
\text { borda }\end{array}$ & $\begin{array}{c}\text { A6 } \\
\text { P.104/C3 } \\
\text { felds.alc. } \\
\text { borda }\end{array}$ & $\begin{array}{c}\mathbf{A 6} \\
\text { P.102/C3 } \\
\text { felds.alc. } \\
\text { borda }\end{array}$ & & \\
\hline $\mathrm{SiO} 2$ & 64.2 & 62.5 & 65.6 & 64.6 & & \\
\hline TIO2 & 0.1 & 0.0 & 0.0 & 0.1 & & \\
\hline At2O3 & 17.9 & 17.6 & 17.9 & 17.6 & & \\
\hline $\mathrm{Fe}_{203}$ & 0.4 & 0.4 & 0.7 & 0.6 & & \\
\hline $\mathrm{MnO}$ & 0.0 & 0.0 & 0.0 & 0.0 & & \\
\hline $\mathrm{CaO}$ & 0.0 & 0.0 & 0.0 & 0.0 & & \\
\hline sro & 0.2 & 0.1 & 0.1 & 0.1 & & \\
\hline $\mathrm{BaO}$ & 0.2 & 0.1 & 0.0 & 0.0 & & \\
\hline $\mathrm{Na}_{2} \mathrm{O}$ & 0.6 & 0.4 & 0.8 & 0.5 & & \\
\hline 1020 & 15.8 & 15.9 & 15.6 & 16.1 & & \\
\hline $\mathrm{MgO}$ & 0.0 & 0.0 & 0.0 & 0.0 & & \\
\hline$F$ & 0.0 & 0.0 & 0.0 & 0.0 & & \\
\hline $\mathrm{Cl}$ & 0.0 & 0.0 & 0.0 & 0.0 & & \\
\hline soma & 99.4 & 97.0 & 100.7 & 99.5 & & \\
\hline $\begin{array}{l}\text { AMOSTRA } \\
\text { Locallzagáo }\end{array}$ & $\begin{array}{c}\text { A6 } \\
\text { P.SB/C1 } \\
\text { felds.alc. } \\
\text { matriz }\end{array}$ & $\begin{array}{c}\text { A6 } \\
\text { P.colC2 } \\
\text { felds.alc. } \\
\text { matriz }\end{array}$ & $\begin{array}{c}\text { A6 } \\
\text { P.106/C4 } \\
\text { felds.alc. } \\
\text { matriz }\end{array}$ & $\begin{array}{c}\text { A6 } \\
\text { P.101/C2 } \\
\text { felds.alc. } \\
\text { matriz }\end{array}$ & $\begin{array}{c}\text { A6 } \\
\text { P.96/C1 } \\
\text { felds.alc. } \\
\text { matriz }\end{array}$ & $\begin{array}{c}\text { A6 } \\
\text { P.96/C1 } \\
\text { felds.alc. } \\
\text { matriz }\end{array}$ \\
\hline SIO2 & 64.1 & 64.7 & 64.9 & 64.2 & 64.6 & 64.2 \\
\hline TiO2 & 0.0 & 0.0 & 0.0 & 0.1 & $0.0^{\circ}$ & 0.0 \\
\hline ARO3 & 17.9 & 18.0 & 18.0 & 17.6 & 18.1 & 17.9 \\
\hline $\mathrm{Fe} 2 \mathrm{O} 3$ & 0.5 & 0.1 & 0.5 & 0.6 & 0.3 & 0.2 \\
\hline Mno & 0.0 & 0.0 & 0.0 & 0.0 & 0.0 & 0.0 \\
\hline $\mathrm{CaO}$ & 0.0 & 0.0 & 0.0 & 0.0 & 0.0 & 0.0 \\
\hline sro & 0.2 & 0.0 & 0.3 & 0.0 & 0.0 & 0.0 \\
\hline $\mathrm{BaO}$ & 0.0 & 0.1 & 0.0 & 0.0 & 0.1 & 0.0 \\
\hline $\mathrm{Na}_{2} \mathrm{O}$ & 0.5 & 0.2 & 0.6 & 0.4 & 0.4 & 0.3 \\
\hline$K 20$ & 15.8 & 16.7 & 15.7 & 16.2 & 16.1 & 16.0 \\
\hline $\mathrm{MgO}$ & 0.0 & 0.0 & 0.0 & 0.0 & 0.0 & 0.0 \\
\hline$F$ & 0.0 & 0.0 & 0.0 & 0.0 & 0.0 & 0.0 \\
\hline $\mathrm{Ci}$ & 0.0 & 0.0 & 0.0 & 0.0 & 0.0 & 0.0 \\
\hline soma & $\infty .2$ & 90.9 & 100.0 & 99.1 & 99.7 & 98.7 \\
\hline
\end{tabular}


SERICITAS HIDROTERMAIS - andeses de microssonde eletronica por WDS

\begin{tabular}{|c|c|c|c|c|}
\hline $\begin{array}{l}\text { AMOSTRA } \\
\text { Locallzaçáo }\end{array}$ & $\begin{array}{c}\text { A3 } \\
\text { P.107/C1 } \\
\text { sericitas } \\
\text { centro }\end{array}$ & $\begin{array}{c}\text { A3 } \\
\text { P.109/C1 } \\
\text { sericitas } \\
\text { centro }\end{array}$ & $\begin{array}{c}A 3 \\
\text { P.110/C4 } \\
\text { sericitas } \\
\text { centro }\end{array}$ & \\
\hline $\mathrm{SiO} 2$ & 44.5 & 45.4 & 44.6 & \\
\hline Tio2 & 0.1 & 0.2 & 0.1 & \\
\hline $\mathrm{Al} 203$ & 37.1 & 36.8 & 35.2 & \\
\hline $\mathrm{Fe} 2 \mathrm{O} 3$ & 2.0 & 2.1 & 3.2 & \\
\hline Mno & 0.1 & 0.0 & 0.1 & \\
\hline $\mathrm{CaO}$ & 0.0 & 0.0 & 0.0 & \\
\hline Sro & 0.0 & 0.0 & 0.0 & \\
\hline $\mathrm{BaO}$ & 0.0 & 0.0 & 0.0 & \\
\hline $\mathrm{Na} 2 \mathrm{O}$ & 0.4 & 0.4 & 0.2 & \\
\hline $\mathrm{K} 20$ & 10.4 & 10.4 & 10.7 & \\
\hline $\mathrm{MgO}$ & 0.1 & 0.1 & 0.2 & \\
\hline$F$ & 0.1 & 0.1 & 0.2 & \\
\hline $\mathrm{Cl}$ & 0.0 & 0.0 & 0.0 & \\
\hline soma & 94.8 & 96.5 & 94.5 & \\
\hline $\begin{array}{l}\text { ANIOSTRA } \\
\text { Localltacáo }\end{array}$ & $\begin{array}{c}\text { A3 } \\
\text { P.1081c1 } \\
\text { sericitas } \\
\text { borda }\end{array}$ & & & \\
\hline $\mathrm{SiO} 2$ & 46.1 & & & \\
\hline $\mathrm{THO}_{2}$ & 0.1 & & & \\
\hline Al2O3 & 37.1 & & & \\
\hline $\mathrm{Fe} 2 \mathrm{O} 3$ & 1.9 & & & \\
\hline Mno & 0.0 & & & \\
\hline $\mathrm{CaO}$ & 0.0 & & & \\
\hline Sro & 0.1 & & & \\
\hline $\mathrm{BaO}$ & 0.1 & & & \\
\hline $\mathrm{Na} 2 \mathrm{O}$ & 0.4 & & & \\
\hline $\mathrm{K} 20$ & 10.4 & & & \\
\hline $\mathrm{MgO}$ & 0.1 & & & \\
\hline$F$ & 0.0 & & & \\
\hline $\mathrm{Cl}$ & 0.0 & & & \\
\hline soma & 95.2 & & & \\
\hline $\begin{array}{l}\text { ANOSTRA } \\
\text { Localfraçto }\end{array}$ & $\begin{array}{c}\text { A6 } \\
\text { P.100/C2 } \\
\text { sericitas } \\
\text { matriz }\end{array}$ & $\begin{array}{c}\text { A6 } \\
\text { P.105/C3 } \\
\text { sericitas } \\
\text { matriz }\end{array}$ & $\begin{array}{c}\mathbf{A 6} \\
\mathrm{P} .105 / \mathrm{C} 4 \\
\text { sericitas } \\
\text { matriz }\end{array}$ & $\begin{array}{c}\text { A6 } \\
\text { P.106/C4 } \\
\text { sericitas } \\
\text { matriz }\end{array}$ \\
\hline 9102 & 48.3 & 45.0 & 48.6 & 47.4 \\
\hline TrO2 & 0.1 & 0.5 & 0.1 & 1.1 \\
\hline $\mathrm{A} 1203$ & 39.0 & 32.8 & 35.3 & 226 \\
\hline $\mathrm{Fe} 2 \mathrm{O} 3$ & 0.8 & 3.9 & 1.8 & 1.6 \\
\hline Mno & 0.0 & 0.0 & 0.0 & 0.0 \\
\hline $\mathrm{CaO}$ & 0.1 & 0.0 & 0.0 & 0.0 \\
\hline Sro & 0.0 & 0.0 & 0.0 & 0.0 \\
\hline $\mathrm{BaO}$ & 0.1 & 0.0 & 0.0 & 0.0 \\
\hline $\mathrm{Na} 2 \mathrm{O}$ & 0.0 & 0.1 & 0.2 & 0.1 \\
\hline $\mathrm{K} 2 \mathrm{O}$ & 13.0 & 10.7 & 12.0 & 11.3 \\
\hline $\mathrm{MgO}$ & 0.2 & 0.5 & 0.2 & 0.2 \\
\hline$F$ & 0.1 & 0.3 & 0.1 & 0.2 \\
\hline $\mathrm{Cl}$ & 0.0 & 0.0 & 0.0 & 0.1 \\
\hline soma & 101.5 & 93.7 & 98.2 & 84.5 \\
\hline
\end{tabular}




\begin{tabular}{|c|c|c|c|c|c|c|c|}
\hline $\begin{array}{l}\text { AMOSTRA } \\
\text { Localtaraçao }\end{array}$ & $\begin{array}{c}75-1 B \\
755-k 001 \\
\text { caotred }\end{array}$ & $\begin{array}{c}75-1 B \\
755-k 002 \\
\text { caol-red }\end{array}$ & $\begin{array}{c}75-1 \mathrm{~B} \\
755-\mathrm{ko00} \\
\text { caol-red }\end{array}$ & $\begin{array}{c}75-1 B \\
75 \sqrt{5}-\mathrm{koO} 4 \\
\text { caol-red }\end{array}$ & $\begin{array}{c}75-1 B \\
75 \sqrt{5}-k 005 \\
\text { caotred }\end{array}$ & $\begin{array}{c}76-1 B \\
75 \sqrt{5-k 006} \\
\text { caol-red }\end{array}$ & $\begin{array}{c}\text { 76-1B } \\
755-k 007 \\
\text { caot-red }\end{array}$ \\
\hline $\mathrm{SIO} 2$ & 43.88 & 45.2 & 47.59 & 47.96 & 47.49 & 47.5 & 47.48 \\
\hline $\mathrm{FeO}$ & 0 & 0 & 0 & 0.64 & 0.44 & 0 & 0.51 \\
\hline $\mathrm{Na2O}$ & 0 & 0 & 0 & 0.05 & 0.06 & 0 & $0 . \infty$ \\
\hline $\mathrm{MgO}$ & 0 & 0 & 0 & 0 & 0 & 0 & 0 \\
\hline $\mathrm{K} 20$ & 0 & 0 & 0 & 0.73 & 0 & 0 & 0 \\
\hline $\mathrm{A} / 203$ & 36.54 & 37.87 & 30.32 & 39.37 & 40.17 & 39.86 & 39 \\
\hline $\mathrm{UO2}$ & 0 & 0 & 0 & 0 & 0 & 0 & 0 \\
\hline ThO2 & 0 & 0 & 0 & 0 & 0 & 0 & 0 \\
\hline $\mathrm{ZrO} 2$ & 0 & 0 & 0 & 0 & 0 & 0 & 0 \\
\hline $\mathrm{Ce} 2 \mathrm{O}_{3}$ & 0 & 0 & 0 & 0 & 0 & 0 & 0 \\
\hline $\operatorname{La2} 203$ & 0 & 0 & 0 & 0 & 0 & 0 & 0 \\
\hline $\mathrm{Y} 203$ & 0 & 0 & 0 & 0 & 0 & 0 & 0 \\
\hline $\mathrm{Yb} 203$ & 0 & 0 & 0 & 0 & 0 & 0 & 0 \\
\hline HFO2 & 0 & 0 & 0 & 0 & 0 & 0 & 0 \\
\hline soma & 80.42 & 83.07 & 86.91 & 88.75 & 88.16 & 87.36 & 87.08 \\
\hline
\end{tabular}

\begin{tabular}{|c|c|c|c|c|c|c|c|}
\hline $\begin{array}{l}\text { AMOSTRA } \\
\text { Localtatato }\end{array}$ & $\begin{array}{c}78-1 A \\
78 / 6-204 \\
\text { zircsio-red } \\
\text { centro }\end{array}$ & $\begin{array}{c}78-1 A \\
78 \ldots-z 06 a \\
\text { zircto-red } \\
\text { centro }\end{array}$ & $\begin{array}{c}\text { 78-1A } \\
78 / 6-208 \\
\text { zirca-red } \\
\text { interm. }\end{array}$ & $\begin{array}{c}\text { 78-1A } \\
78 / 6-z 03 \\
\text { zircăo-red } \\
\text { borda }\end{array}$ & $\begin{array}{c}78-1 A \\
7816-209 \\
\text { zirca-red } \\
\text { borda }\end{array}$ & $\begin{array}{c}78-1 A \\
786-Z 11 \\
\text { zirclio-red } \\
\text { centro }\end{array}$ & $\begin{array}{c}\text { 78-1A } \\
78 / 6-Z 10 a \\
\text { zircdo-red } \\
\text { borda }\end{array}$ \\
\hline $\mathrm{SiO} 2$ & 32.77 & 33.34 & 33.23 & 32.9 & 33.57 & 33.2 & 32.33 \\
\hline $\mathrm{FeO}$ & 0 & 0 & 0 & 0 & 0 & 0 & 0 \\
\hline $\mathrm{Na}_{2} \mathrm{O}$ & 0.1 & 0.1 & 0.11 & 0.15 & 0.07 & 0.08 & 0.13 \\
\hline $\mathrm{MgO}$ & 0 & 0 & 0 & 0 & 0 & 0 & 0 \\
\hline UO2 & 0 & 0 & 0 & 0 & 0 & 0 & 0 \\
\hline ThO2 & 0 & 0 & 0 & 0 & 0 & 0 & 0 \\
\hline $\mathrm{ZrO2}$ & 67.43 & 66.77 & 66.86 & 66.11 & 67.2 & 66.36 & 65.04 \\
\hline $\mathrm{Yb} 203$ & 0 & 0 & 0.12 & 0.16 & 0.12 & 0.12 & 0.12 \\
\hline $\mathrm{Ce} 203$ & 0.07 & 0.17 & 0.19 & 0.11 & 0.11 & 0.1 & 0.09 \\
\hline$Y 203$ & 0.39 & 0.23 & 0.36 & 0.29 & 0.33 & 0.62 & 0.68 \\
\hline $1 \mathrm{~K} 20$ & 0 & 0 & 0 & 0 & 0 & 0 & 0 \\
\hline A12O3 & 0 & 0 & 0 & 0 & 0 & 0 & 0 \\
\hline La203 & 0 & 0 & 0 & 0 & 0 & 0 & 0 \\
\hline $\mathrm{HFO} 2$ & 0.47 & 0.72 & 0.79 & 0.7 & 0 & 0.79 & 0.39 \\
\hline soma & 101.23 & 101.33 & 101.66 & 100.42 & 101.4 & 101.27 & 98.78 \\
\hline
\end{tabular}

\begin{tabular}{|c|c|c|c|c|c|c|c|}
\hline $\begin{array}{l}\text { Allostra } \\
\text { Localtzaçá }\end{array}$ & $\begin{array}{c}78-1 \mathrm{~A} \\
78 / 6-F 116 \\
\text { fluor. red }\end{array}$ & $\begin{array}{c}78-1 \mathrm{~A} \\
78-6-\mathrm{F} 117 \\
\text { fluor.-red }\end{array}$ & $\begin{array}{c}78-1 \mathrm{~A} \\
78 / 6-F 118 \\
\text { fluor.-red }\end{array}$ & $\begin{array}{c}78-1 \mathrm{~A} \\
78 / 6-\mathrm{F} 119 \\
\text { fluor.-red }\end{array}$ & $\begin{array}{c}78-1 \mathrm{~A} \\
78 / 4 \mathrm{~F} 101 \\
\text { fluor, } \mathrm{red}\end{array}$ & $\begin{array}{c}78-1 \mathrm{~A} \\
78 / 4 \mathrm{~F} 102 \\
\text { fluor.-red }\end{array}$ & $\begin{array}{c}78-1 \mathrm{~A} \\
78 / 4-\mathrm{F} 103 \\
\text { fluor.-red }\end{array}$ \\
\hline 5102 & 0 & 0 & $\overline{0}$ & 0 & 0 & 0 & 0 \\
\hline Feo & 0 & 0 & 0 & 0 & 0 & 0 & 0 \\
\hline $\mathrm{Na} 2 \mathrm{O}$ & 0.06 & 0.07 & 0.00 & 0.06 & 0 & 0 & 0 \\
\hline $\mathrm{MgO}$ & 0 & 0 & 0 & 0 & 0 & 0 & 0 \\
\hline UO2 & 0 & 0 & 0 & 0 & 0 & 0 & 0 \\
\hline ThO2 & 0 & 0 & 0 & 0 & 0 & 0 & 0 \\
\hline $\mathrm{ZrO} 2$ & 0 & 0 & 0 & 0 & 0 & 0 & 0 \\
\hline $\mathrm{rb} 203$ & 0 & 0 & 0 & 0 & 0 & 0 & 0 \\
\hline $\mathrm{Ce} 2 \mathrm{OS}$ & 0 & 0 & 0 & 0 & 0 & 0 & 0 \\
\hline 1203 & 0 & 0 & 0 & 0.07 & 0.12 & 0.15 & 0 \\
\hline 1120 & 0.98 & 0.7 & 0.79 & 0.83 & 0.76 & 0.96 & 0.87 \\
\hline A1203 & 0 & 0 & 0 & 0 & 0 & 0 & 0 \\
\hline $\operatorname{La2O3}$ & 0 & 0 & 0 & 0 & 0 & 0 & 0 \\
\hline $\mathrm{HFO}$ & 0 & 0 & 0 & 0 & 0 & 0 & 0 \\
\hline$F \in O$ & 48.67 & 48.67 & 48.67 & 48.67 & 48.67 & 48.67 & 48.67 \\
\hline $\mathrm{CaO}$ & 50.51 & 50.7 & 50.62 & 50.54 & 50.6 & 50.42 & 50.61 \\
\hline soma & 100.17 & 0.77 & 100.17 & 100.17 & 100.15 & 100.2 & 100.15 \\
\hline
\end{tabular}




\begin{tabular}{|c|c|c|c|c|c|c|c|}
\hline $\begin{array}{l}\text { AMOSTRA } \\
\text { Localkaçä́o }\end{array}$ & $\begin{array}{l}\text { SN/24 } \\
\text { SN/24-1 rus } \\
\text { rutilo } \\
\end{array}$ & $\begin{array}{l}\text { SN/24 } \\
\text { SN/24-1ru6 } \\
\text { rutilo }\end{array}$ & $\begin{array}{c}\text { SN/24 } \\
\text { SN/24-2ru2 } \\
\text { rutilo }\end{array}$ & $\begin{array}{c}\text { SN/24 } \\
\text { SN/24-2rLB } \\
\text { rutilo }\end{array}$ & $\begin{array}{c}110-1 A \\
110 / 1 \text { ru4 } \\
\text { rutilo }\end{array}$ & $\begin{array}{c}110-1 \mathrm{~A} \\
110 / 1 \mathrm{n} 5 \\
\text { rutilo }\end{array}$ & $\begin{array}{c}110-1 A \\
110 / 1 \text { ru6 } \\
\text { rutilo }\end{array}$ \\
\hline $\mathrm{TIO} 2$ & 95.42 & 95.44 & 94.22 & 95.85 & 87.91 & 91 & 91.62 \\
\hline Mno & 0 & 0 & 0 & 0 & 0 & 0 & 0 \\
\hline $\mathrm{FeO}$ & 0 & 1.95 & 1.02 & 1.67 & 4.77 & 4.50 & 2.89 \\
\hline Al2O3 & 0.76 & 0.81 & 1.1 & 0.68 & 0.68 & 0.64 & 0.66 \\
\hline $\mathrm{SiO} 2$ & 0.76 & 1.04 & 1.11 & 0.6 & 1.34 & 0.57 & 0.6 \\
\hline $\mathrm{CaO}$ & 0 & 0 & 0 & 0 & 0 & 0 & 0 \\
\hline $\mathrm{K} 20$ & 0 & 0 & 0 & 0 & 0.38 & 0 & 0 \\
\hline $\mathrm{Nb} 2 \mathrm{O} 3$ & 0.5 & 0 & 0.47 & 0.24 & 2.07 & 1.08 & 1.96 \\
\hline UO2 & 0 & 0 & 0 & 0 & 0 & 0 & 0 \\
\hline ThO2 & 0 & 0 & 0.21 & 0 & 0 & 0 & 0 \\
\hline$Y 203$ & 0 & 0.1 & 0.15 & 0.31 & 0.46 & 0 & 0 \\
\hline $\mathrm{Ce} 2 \mathrm{O}$ & 0 & 0 & 0 & 0 & 0 & 0 & 0 \\
\hline La203 & 0 & 0 & 0 & 0 & 0 & 0 & 0 \\
\hline $\mathrm{Yb} 203$ & 0 & 0 & 0 & 0 & 0 & 0 & 0 \\
\hline soma & 97.44 & 99.34 & 98.28 & 99.35 & 97.61 & 97.88 & 97.73 \\
\hline $\begin{array}{l}\text { AMOSTRA } \\
\text { Localthayá }\end{array}$ & $\begin{array}{c}110-1 \mathrm{~A} \\
110 / 1-p y 54 \\
\text { pirita }\end{array}$ & $\begin{array}{c}110-1 A \\
110 / 1-p y 55 \\
\text { pirita }\end{array}$ & $\begin{array}{c}110-1 A \\
1101-p y 58 \\
\text { pirita } \\
\end{array}$ & $\begin{array}{c}110-1 A \\
110 / 1-p y 60 \\
\text { pirita }\end{array}$ & $\begin{array}{c}110-1 A \\
110 / 1-p y o s \\
\text { pinita }\end{array}$ & $\begin{array}{c}110-1 A \\
110 / 1-p y 64 \\
\text { pirita } \\
\end{array}$ & $\begin{array}{l}110-1 \mathrm{~A} \\
110 / \text { py } \\
\text { pirita }\end{array}$ \\
\hline $\mathrm{Fe}$ & 46.23 & 45.2 & 44.93 & 46.4 & 45.97 & 46.29 & 46.62 \\
\hline s & 53.2 & 52.77 & 51.83 & 52.96 & 53.01 & 53.36 & 52.52 \\
\hline $\mathrm{Pb}$ & 0.67 & 0.94 & 0.69 & 0 & 0 & 0 & 1.13 \\
\hline As & 0.12 & 0.17 & 0.17 & 0 & 0 & 0 & o \\
\hline Mo & 0.7 & 0.57 & 0.74 & 0.6 & 0.57 & 0.56 & 0.57 \\
\hline $\mathrm{Ag}$ & 0 & 0.16 & 0 & 0 & 0 & 0 & 0 \\
\hline soma & 100.92 & 99.65 & 98.56 & 99.96 & 99.55 & 100.21 & 100.84 \\
\hline AMOSTRA & SN/24 & SN/24 & SN/2A & SN/24 & Sinnd & SN124 & SNIA4 \\
\hline Localfzacto & $\begin{array}{l}\text { SN24-1U1 } \\
\text { Ox. Uranio }\end{array}$ & $\begin{array}{l}\text { SN2A1U2 } \\
\text { Ox. Uranio }\end{array}$ & $\begin{array}{l}\text { SN24-1U3 } \\
\text { Ox. Uranio }\end{array}$ & $\begin{array}{l}\text { SN24-1U4 } \\
\text { Ox. Uranio }\end{array}$ & $\begin{array}{l}\text { SN24-1U7 } \\
\text { Ox. Uranio }\end{array}$ & $\begin{array}{l}\text { SN241U9 } \\
\text { Ox. Uranio }\end{array}$ & $\begin{array}{l}\text { SN24-1U11 } \\
\text { Ox. Uranio }\end{array}$ \\
\hline $\mathrm{FeO}$ & 0 & 0 & 0 & 0 & 0 & 0 & 0 \\
\hline $\mathrm{CaO}$ & 0 & 0 & 0 & 0 & 0 & 0 & o \\
\hline $\mathrm{SIO} 2$ & 2.42 & 2.15 & 2.23 & 2.09 & 2.13 & 2.96 & 2.50 \\
\hline$A 1203$ & 0.29 & 0.15 & 0 & 0.2 & 0.18 & 0.53 & 0.39 \\
\hline $\mathrm{TiO} 2$ & 0 & 0 & 0 & 0 & 0 & 0 & 야 \\
\hline Mno & 0 & 0 & 0 & 0 & 0 & 0 & 0 \\
\hline $\mathrm{K} 2 \mathrm{O}$ & 1.39 & 1.16 & 1.01 & 0.94 & 0.86 & 0.84 & 1.16 \\
\hline $\mathrm{Nb} 2 \mathrm{O}$ & 0 & 0 & 0 & 0 & 0 & 0 & of \\
\hline $\mathrm{Yb} 2 \mathrm{O}$ & 0 & 0 & 0 & 0 & 0 & 0 & 이 \\
\hline UO2 & 87.17 & 82.8 & 82.32 & 82.66 & 84.06 & 84.89 & 82.16 \\
\hline Y203 & 0.42 & 0 & 0.3 & 0.07 & 0 & 0.14 & of \\
\hline $\mathrm{Ce} 2 \mathrm{O3}$ & 0.32 & 0 & 0 & 0 & 0 & 0.3 & of \\
\hline La2O3 & 0 & 0 & 0 & 0 & 0 & 0 & ol \\
\hline ThO2 & 0 & 0 & 0 & 0 & 0 & 0 & 이 \\
\hline soma & 92.01 & 86.26 & 85.86 & 85.96 & 87.23 & 89.66 & 86.3 \\
\hline AMOSTRA & SN/24 & SNR4 & SN/24 & SN/24 & SN/24 & SN/24 & SN/24 \\
\hline Localkayato & $\begin{array}{r}\text { SN24-2U5 } \\
\text { matrtz }\end{array}$ & $\begin{array}{r}\text { SN24-1U2 } \\
\text { matrz } \\
\end{array}$ & $\begin{array}{r}\text { SN24-1U3 } \\
\text { matriz } \\
\end{array}$ & $\begin{array}{r}\text { SN241U4 } \\
\text { matrzz } \\
\end{array}$ & $\begin{array}{r}\text { SN24-1U7 } \\
\text { matriz } \\
\end{array}$ & $\begin{array}{r}\text { SN24-1U9 } \\
\text { matriz }\end{array}$ & $\begin{array}{c}\text { SN24-1U11 } \\
\text { matriz }\end{array}$ \\
\hline FeO & 0 & $\overline{0}$ & $\overline{0}$ & 0 & 0 & 0 & 이 \\
\hline $\mathrm{CaO}$ & 0 & 0 & 0 & 0 & 0 & 0 & 아 \\
\hline $\mathrm{SiO} 2$ & 3 & 2.15 & 2.23 & 2.09 & 2.13 & 2.96 & 2.59 \\
\hline $\mathrm{A} \mid 2 \mathrm{O3}$ & 0.29 & 0.15 & 0 & 0.2 & 0.18 & 0.53 & 0.39 \\
\hline $\mathrm{TiO} 2$ & 0 & 0 & 0 & 0 & 0 & 0 & o. \\
\hline Mno & 0 & 0 & 0 & 0 & 0 & 0 & of \\
\hline $\mathrm{K} 2 \mathrm{O}$ & 1.39 & 1.16 & 1.01 & 0.94 & 0.86 & 0.84 & 1.16 \\
\hline $\mathrm{Nb} 2 \mathrm{O}$ & 0 & 0 & 0 & 0 & 0 & 0 & 이 \\
\hline Yb2O & 0 & 0 & 0 & 0 & 0 & 0 & of \\
\hline $\mathrm{UO2}$ & 87.17 & 82.8 & 82.32 & 82.66 & 84.06 & 84.89 & 82.16 \\
\hline Y2O3 & 0.42 & 0 & 0.3 & 0.07 & 0 & 0.14 & of \\
\hline $\mathrm{Ce} 203$ & 0.32 & 0 & 0 & 0 & 0 & 0.3 & o \\
\hline $\mathrm{La203}$ & 0 & 0 & 0 & 0 & 0 & 0 & 0 \\
\hline ThO2 & 0 & 0 & 0 & 0 & 0 & 0 & o \\
\hline soma & 92.59 & 86.26 & 85.86 & 85.96 & 87.23 & 89.66 & 86.3 \\
\hline
\end{tabular}

